\title{
Informatie, toestemming en geheimhouding bij erfelijkheidsadvisering : een gezondheidsrechtelijk onderzoek
}

Citation for published version (APA):

Kieboom, W. (2003). Informatie, toestemming en geheimhouding bij erfelijkheidsadvisering : een gezondheidsrechtelijk onderzoek. [Doctoral Thesis, Maastricht University]. Koninklijke Vermande. https://doi.org/10.26481/dis.20030131wk

Document status and date:

Published: 01/01/2003

DOI:

10.26481/dis.20030131wk

Document Version:

Publisher's PDF, also known as Version of record

Please check the document version of this publication:

- A submitted manuscript is the version of the article upon submission and before peer-review. There can be important differences between the submitted version and the official published version of record.

People interested in the research are advised to contact the author for the final version of the publication, or visit the DOI to the publisher's website.

- The final author version and the galley proof are versions of the publication after peer review.

- The final published version features the final layout of the paper including the volume, issue and page numbers.

Link to publication

\footnotetext{
General rights rights.

- You may freely distribute the URL identifying the publication in the public portal. please follow below link for the End User Agreement:

www.umlib.nl/taverne-license

Take down policy

If you believe that this document breaches copyright please contact us at:

repository@maastrichtuniversity.nl

providing details and we will investigate your claim.
}

Copyright and moral rights for the publications made accessible in the public portal are retained by the authors and/or other copyright owners and it is a condition of accessing publications that users recognise and abide by the legal requirements associated with these

- Users may download and print one copy of any publication from the public portal for the purpose of private study or research.

- You may not further distribute the material or use it for any profit-making activity or commercial gain

If the publication is distributed under the terms of Article 25fa of the Dutch Copyright Act, indicated by the "Taverne" license above, 
INFORMATIE, TOESTEMMING EN GEHEIMHOUDING

BIJ ERFELI]KHEIOSADVISERING

EEN GEZONDHEIDSRECHTELIJK ONDERZOEK 
Dit onderzoek werd mogelijk gemaakt door een projectsubsidie van de Nederlandse Organisatie voor Wetenschappelijk Onderzoek (NWO) in het kader van het nationale stimuleringsprogramma Ethiek \& Beleid. 


\title{
INFORMATIE, TOESTEMMING EN GEHEIMHOUDING BIJ ERFELIJKHEIDSADVISERING EEN GEZONDHEIDSRECHTELIJK ONDERZOEK
}

\author{
PROFFSCHRIY' \\ ter verkrigging van de graad van doctor a an de \\ Universiteit Maastricht, op gezag van de \\ Rector Magnificus \\ prof.dr. A.C. Nieuwenhuijzen-Kruseman
}

volgens het besluit van het College van Decanen

in het openbaar te verdedigen op vrijdag 31 januari 2003 om 16.00 uur door

Wendy Kieboom 
promotor:

(io-promotor:

Beoordelingscommissic:
Prof. mr. F.C.B. van Wijmen

Mr. (tr. J.C.). Dute

Prof. dr. J.A. Knotherus (vooryitter)

l'rof. mr. J.K.M. (ievers (linversiteit van Amsterdam)

Prof. (r. L.P. (en Kalte (Vrije Universileit Amsterdam)

Prof. clr. H. Nys

Prof. dr. (i.M.W.R. de Wert 
Voor mijn ouders 


\section{INHOUDSOPGAVE}

\section{Woord vooraf}

\section{Gebruikte afkortingen}

$\begin{array}{llr}\text { 1. } & \text { Verkenning } & 1 \\ 1.1 & \text { Inleiding } & 1 \\ 1.2 & \text { Probleemstelling } & 4 \\ \text { 1.3 } & \text { Ontstaan en ontwikkeling van de klinische genetische centra } & 5 \\ 1.3 .1 & \text { Ontstaan van de klinisch genetische centra } & 6 \\ 1.3 .2 & \text { Huidig functioneren van de klinisch genetische centra } & 9 \\ 1.4 & \text { Erfelijkheidsadvisering } & 13 \\ 1.4 .1 & \text { Wat is erfelijkheidsadvisering? } & 13 \\ 1.4 .2 & \text { Huidig doel erfelijkheidsadvisering } & 17 \\ 1.4 .3 & \text { Gang van zaken bij erfelijkheidsadvisering } & 18 \\ 1.5 & \text { Begrippenverheldering } & 18 \\ 1.5 .1 & \text { Opbouw en werking van ons erfelijkheidsmateriaal } & 20 \\ 1.5 .2 & \text { Klassieke wijzen van overerving } & 22 \\ 1.5 .3 & \text { Oorzaak van de aandoening } & 24 \\ 1.5 .4 & \text { Typen erfelijkheidsonderzoek } & 25 \\ 1.6 & \text { Samenvatting }\end{array}$

2. Verantwoording uitgangspunten en gehanteerde methoden 27

$2.1 \quad$ Inleiding 27

2.2 Juridisch onderzoek $\quad 27$

2.2.1 Normatief juridisch kader 28

$\begin{array}{ll}2.2 .2 & \text { Verhouding tot de praktijk } \\ 2.3 & 28\end{array}$

2.3 Opzet en verantwoording empirisch kwalitatief onderzoek 30

2.3.1 De aard van het onderzoek 31

2.3.2 Dataverzameling 32

2.3.2.1 Opzet interviews 34

2.3.2.2 Opzet observatie $\quad 35$

2.3.3 Reikwijdte en representativiteit van het empirisch onderzoek 36

$\begin{array}{lll}2.3 .4 & \text { Data-analyse } & 38\end{array}$

2.4 Samenvatting 38

3. Zelfbeschikking en erfelijkheidsadvisering 41

$3.1 \quad$ Inleiding 41

3.2 Het zelfbeschikkingsrecht als rechtsbeginsel 41

3.3 Ontwikkeling van het zelfbeschikkingsrecht 42 
3.4 De betekenis van het zelfbeschikkingsrecht voor de erfelijkheidsadvisering

3.5 Zelfbeschikking in de maatschappelijke context

3.6 Samenvatting

4. Erfelijkheidsadvisering, informatie en toestemming 55

4.1 Inleiding 55

4.2 Het recht op informatie 57

4.3 Informatie en erfelijkheidsadvisering 60

4.3.1 Het informeren van de adviesvrager 60

4.3.2 Hogere eisen aan informatieplicht bij erfelijkheidsadvisering? 68

4.3.3 De therapeutische exceptie $\quad 72$

4.3.3.1 De therapeutische exceptie en erfelijkheidsadvisering 75

4.3.4 Non-directieve erfelijkheidsadvisering? $\quad 79$

4.4 Het toestemmingsvereiste 91

4.5 Toestemming en erfelijkheidsadvisering 93

4.6 Samenvatting 95

5. Het recht op weten $\quad 99$

5.1 Inleiding 99

5.2 Het recht op weten jegens de overheid 100

5.3 Het recht op weten jegens familieleden 107

5.3.1 Een recht op weten jegens degene die voor zichzelf een 108 erfelijkheidsonderzoek heeft laten verrichten?

5.3.2 Een recht op weten jegens degene die ten behoeve van eiser een 116 erfelijkheidsonderzoek heeft laten verrichten?

5.4 Een waarschuwingsplicht voor genetici jegens familieleden? 117

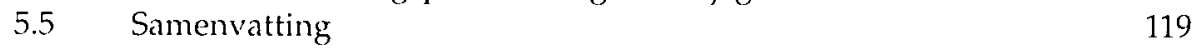

6. Erfelijkheidsadvisering en het recht op niet weten 123

$\begin{array}{lll}6.1 & 123\end{array}$

6.2 Het recht op niet weten in het positieve recht 123

$\begin{array}{lll}6.3 & \text { Het recht op niet weten en zelfbeschikking } & 125\end{array}$

$\begin{array}{ll}6.4 & \text { Het recht op niet weten } \\ 6.5 & 128\end{array}$

6.5 Het recht op niet weten en erfelijkheidsadvisering $\quad 130$

6.5.1 Het recht om informatie betreffende de gezondheid niet tot stand 130 te doen komen

6.5.1.1 Het recht om bestaande informatie over de gezondheid 133 niet te ontvangen

6.5.1.2 Uitzonderingen 138

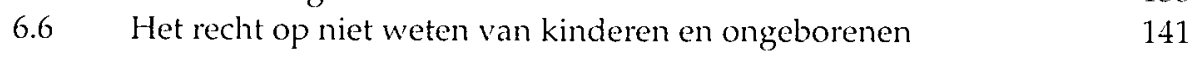

6.6.1 Het recht op niet weten van kinderen 143

6.6.2 Het recht op niet weten van ongeborenen 152

$\begin{array}{ll}6.7 & \text { Samenvatting } \\ & 162\end{array}$ 
7. Erfelijkheidsadvisering en geheimhouding

7.1 Inleiding

7.2 De geheimhoudingsplicht

7.3 Erfelijkheidsadvisering en de geheimhoudingsplicht

7.3.1 Het benaderen van familieleden

7.3.2 De situatie warin ten gevolge van de geheimhoudingsplicht

7.3.3 Alternatieven voor een conflict van plichten?

7.3.4 De situatie warin ten gevolge van de geheimhoudingsplicht geen

7.4 Samenvatting

8. Erfelijkheidsadvisering, informatie en toestemming in de praktijk 195

8.1 Inleiding

8.2 Houding klinisch genetici ten opzichte van patiëntenrechten

8.3 Het recht op informatic

8.3.1 Het informeren bij erfelijkheidsadvisering

8.3.1.1 Informatic bij voorspellend onderzoek naar aandoeningen bij de adviesvrager

8.3.1.2 Informatie bij voorspellend onderzoek om het risico op een aandoening voor nageslacht of andere bloedverwanten vast te stellen

8.3.1.3 Informatie bij diagnostisch onderzock

8.3.2 Het bespreken van de consequenties voor familieleden

8.3.3 Onverwachte bevindingen

8.3.4 De wijze van informeren over de uitslag

8.3.5 Het recht op informatie versus het recht op niet weten 209

$\begin{array}{lll}8.4 & \text { De therapeutische exceptie } 210\end{array}$

$8.5 \quad$ Een non-directicve houding? 215

8.6 Het toestemmingsvereiste 216

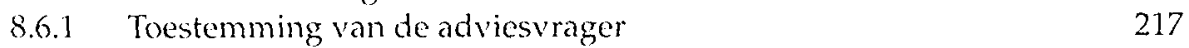

$\begin{array}{ll}\text { 8.6.2 Toestemming van familieleden } & 218\end{array}$

8.6.3 Toestemming voor het verrichten van nader onderzoek 219

$\begin{array}{lll}8.7 & \text { Slotbeschouwing } & 220\end{array}$

9. Erfelijkheidsadvisering en het recht op niet weten in de praktijk 225

9.1 Inleiding 225

9.2 Het informeren over het recht op niet weten 225

9.3 Het besluit om niet te willen weten 228

9.4 Een erfelijkheidsonderzoek zonder vooraf geïnformeerd te zijn 232

9.5 Het recht op niet weten van kinderen en ongeborenen 235

$\begin{array}{lll}9.6 & \text { Slotbeschouwing } & 237\end{array}$ 
10. Erfelijkheidsadvisering en geheimhouding in de praktijk

10.1 Inleiding

10.2 Het benaderen van familieleden

10.3 De geheimhoudingsplicht

10.4 Het conflict van plichten

10.5 De geheimhoudingsplicht na de dood

10.6 Slotbeschouwing

11. Conclusies en aanbevelingen

11.1 Inleiding 263

11.2 Het recht op informatie en het toestemmingsvereiste 263

11.2.1 Het recht op informatie 263

11.2.2 De therapeutische exceptie 266

$\begin{array}{lll}11.2 .3 & \text { Non-directiviteit } & 268\end{array}$

$\begin{array}{ll}\text { 11.2.4 Het toestemmingsvereiste } & 269\end{array}$

$\begin{array}{lll}11.3 & \text { Het recht op weten } & 270\end{array}$

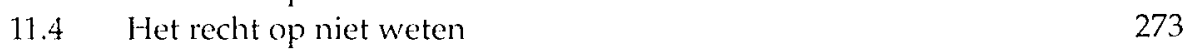

$\begin{array}{ll}11.5 & \text { De geheimhoudingsplicht } \\ 11.6 & 278\end{array}$

11.6 De Wgbo of een status aparte voor de overeenkomst tussen 286 klinisch geneticus en adviesvrager?

11.7 Erfelijkheidsadvisering in de toekomst 288

$\begin{array}{ll}\text { Samenvatting } & 293\end{array}$

$\begin{array}{ll}\text { Summary } & 301\end{array}$

$\begin{array}{lr}\text { Geraadpleegde literatuur } & 309\end{array}$

$\begin{array}{ll}\text { Curriculum Vitae } & 325\end{array}$ 


\section{WOORD VOORAF}

Dit proefschrift is tot stand gekomen met de hulp van aantal mensen die ik op deze plaats graag wil bedanken. Op de eerste plaats dank ik mijn promotor Frans van Wijmen voor de opbouwende en positieve wijze waarop hij zich de afgelopen jaren heeft opgesteld. Ten tweede, mijn co-promotor Jos Dute voor de onvermoeibare wijze waarop hij al mijn teksten nauwgezet las en van deskundig commentaar voorzag. Voorts is dank verschuldigd an Christine de Die-Smulders die mij vakkundig de genetica heeft binnengeleid. Het enthousiasme waarmee ik door haar werd begeleid was bijzonder. Guido de Wert wil ik bedanken voor zijn goede begeleiding. Zijn grote deskundigheid en scherpe commentaar hebben een grote bijdrage geleverd aan het onderliggend resultaat. Ook bedank ik Anja Krumeich. Zij wist altijd alle empirische en kwalitatieve knopen snel en helder te ontwarren. Een woord van dank gaat tevens uit naar Joep Geraedts voor zijn waardevolle commentaar gedurende de gehele onderzoeksperiode. Daarnaast bedank ik alle medewerkers van de klinisch genetische centra in Maastricht en Leiden. Dankzij hun gastvrijheid heb ik het empirisch onderzoek uit kunnen voeren. Ook de klinisch genetici en de adviesvragers die ik heb mogen interviewen wil ik hiervoor bedanken. Margreet Sluiter wil ik bedanken voor haar onmisbare hulp bij de Engelse vertaling van de samenvatting. Isolde Vaessen bedank ik voor haar onverstoorbare hulp bij het opmaken van dit proefschrift. Mijn paranimfen, Mireille van den Dungen-Wijnen en Sissel Pemmelaar, hebben op verschillende manieren een belangrijke bijdrage geleverd aan de zogenaamde laatste loodjes, waarvoor mijn dank groot is. Mijn zus Carola dank ik voor het kritisch lezen van een aantal teksten. Tot slot, bedankt lieve Wouter. Je gaf ook de afgelopen jaren aan alles vorm, inhoud en kleur. Dit proefschrift draag ik op aan mijn ouders voor hun onvermoeibare liefde en steun in alle mogelijke vormen.

Maastricht, november 2002 


\section{GEBRUIKTE AFKORTINGEN}

art. artikel

BW Burgerlijk Wetbock

CF Cystische Fibrose

CMT Centraal Medisch Tuchtcollege

EHRM Europees Hof voor de Rechten van de Mens

EVRM Europees Verdrag tot bescherming van de Rechten van de Mens en de fundamentele vrijheden

Gr.w. Grondwet

GW Grondwet

HR Hoge Raad

IVBPR Internationaal Verdrag inzake Burgerrechten en Politieke Rechten

KG Kort Geding

KNMG Koninklijke Nederlandsche Maatschappij tot bevordering der Geneeskunst

LOG Landelijk Overleg Genetic Counselors

MT Medisch Tuchtcollege

NJ Nederlandse Jurisprudentie

NJB Nederlands Juristenblad

PGD Preïmplantatie Genetische Diagnostiek

Pr. President

Rb. Rechtbank

RZA Rechtspraak Ziekenfondswet en Awbz

SKG Stichtingen Klinische Genetica

Stcrt Staatscourant

TvGr Tijdschrift voor Gezondheidsrecht

VGKN Vereniging Klinische Genetica Nederland

VSOP Vereniging Samenwerkende Ouder- en Patiëntenorganisaties

Wbmv Wet op bijzondere medische verrichtingen

Wbp Wet bescherming persoonsgegevens

Wgbo Wet op de geneeskundige behandelingsovereenkomst

WHO World Health Organisation

WvSr Wetboek van Strafrecht 


\section{VERKENNING}

\subsection{Inleiding}

Genetisch onderzoek en de toekomstige mogelijkheden ervan staan sterk in de belangstelling. De volgorde van het menselijk DNA is grotendeels bepaald. De volledige functie en werking ervan vaststellen is de volgende stap. Voor enkele honderden aandoeningen is momenteel bekend welke genetische afwijkingen tot de ziekte leiden. ${ }^{1}$ Voor die aandoeningen is diagnostiek mogelijk. In de nabije toekomst zal het aantal ziekten waarbij door middel van erfelijkheidsonderzoek een diagnose kan worden gesteld sterk uitbreiden. Het is aannemelijk dat bij de meeste aandoeningen genetische aspecten mede een rol spelen. Bovendien wordt het door de voortschrijdende ontwikkelingen, onder andere in de DNA-chiptechnologie, in de toekomst wellicht mogelijk om door middel van één onderzoek op vele erfelijke aandoeningen te testen.2 Dit leidt tot de verwachting dat "op termijn steeds gedetailleerdere genetische profielen van mensen kumnen worden vastgesteld met de mogelijkheid (bij voorspellend genetisch onderzoek) om op tijd preventieve maatregelen te kunnen nemen of, na het constateren van een eventuele aandoening of ziekte, de medicatie of andere vormen van behandeling (zoals bestraling) op dit profiel af te kunnen stemmen".3

Wanneer binnen een familie een (mogelijk) erfelijke aandoening speelt, kan men zich wenden tot de huisarts. Ook een behandeld specialist kan vaak vragen betreffende de erfelijkheid van een aandoening beantwoorden. Wanneer echter een erfelijkheidsonderzoek of complexe erfelijkheidsadvisering geindiceerd is, zal men zich, na verwijzing, tot een klinisch genetisch centrum wenden. "Hierbij kan gedacht worden aan de vraag naar het risico op een kind met een verstandelijke handicap wanneer in de familie van het paar met een kinderwens verstandelijke handicaps voorkomen. Of de vraag naar het risico op borstkanker wanneer verschillende familieleden aan borstkanker lijden of hebben geleden. Ook met de vraag naar prenatale diagnostiek gericht op chromosoomafwijkingen, afwijkingen in de genen of afwijkingen in de stofwisseling van de foetus, richt men zich tot een klinisch genetisch centrum. Hoe is de relatie tussen een adviesvrager (iemand die zich tot een klinische geneticus wendt voor een erfelijkheidsadvies) en een klinisch geneticus echter juridisch geregeld?

De relatie adviesvrager-klinisch geneticus wordt gereguleerd door de Wet op de geneeskundige behandelingsovereenkomst (Wgbo). Deze op 1 april 1995 in werking getreden wet heeft betrekking op alle typen medische hulpverlening in de gezondheidszorg. De algemene bepalingen over informatie, toestemming, de

1 De begrippen aandoening en ziekte worden in deze studie door elkaar gebruikt.

Ministerie van Volksgezondheid, Welzijn en Sport 2000, p. 11-12.

Ministerie van Volksgezondheid, Welzijn en Sport 2000, p. 10.

De verschillende functies van de klinisch genetische centra worden in paragraaf 1.3 .2 besproken. 
therapeutische exceptie, het recht op niet weten en het beroepsgeheim zijn dus van toepassing op erfelijkheidsadvisering.

In artikel 7:448 van het Burgerlijk Wetboek (de Wgbo is geincorporeerd in het Burgerlijk Wetboek) is geregeld dat de hulpverlener de patiënt op duidelijke wijze inlicht over het voorgenomen onderzoek, de voorgestelde behandeling en over de ontwikkelingen omtrent het onderzoek, de behandeling en de gezondheidstoestand van de patiënt. Onder de informatieplicht van de hulpverlener vallen inlichtingen over de aard en het doel van het onderzoek of behandeling die de arts noodzakelijk acht en over de uit te voeren verrichtingen. Daarnaast vallen de te verwachten gevolgen en risico's daarvan voor de patiënt er onder. Ten slotte behoort de patiënt te worden ingelicht over eventuele andere methoden van onderzoek of behandeling die in aanmerking komen en over de staat van en de vooruitzichten voor wat betreft het terrein van het onderzoek of de behandeling. De toestemming die de patiënt geeft voor een onderzoek of behandeling behoort gebaseerd te zijn op de door de hulpverlener daaraan vooraf gegeven informatie waarbij de genoemde punten aan de orde moeten zijn geweest. Het geven van toestemming na voorafgaande duidelijke informatie wordt informed consent genoemd.

In genoemd artikel is ook de therapeutische exceptie geregeld. Deze houdt in dat de hulpverlener de patiënt de informatie mag onthouden indien deze de patiënt kennelijk ernstig nadeel zou opleveren. Als het belang van de patiënt dit vereist licht de hulpverlener een ander dan de patiënt in. Hierbij zou men kunnen denken aan de partner of een familielid. De hulpverlener is wel verplicht om alvorens hij besluit om zijn patiënt bepaalde informatie te onthouden, hierover een andere hulpverlener te raadplegen.

Artikel 7:449 BW regelt het recht op niet weten. Als de patiënt te kennen heeft gegeven geen informatie te willen ontvangen, dan verstrekt een hulpverlener deze ook niet, tenzij het belang van de patiënt niet opweegt tegen het nadeel dat uit het niet geven van informatie voor de patiënt of anderen kan voortvloeien.

Het beroepsgeheim is onder andere in artikel 7:457 BW geregeld. De hulpverlener draagt er zorg voor dat aan anderen dan de patiënt geen inlichtingen over de patiënt, dan wel inzage in of afschrift van de bescheiden van de patiënt, worden verstrekt dan met toestemming van de patiënt, tenzij het bij of krachtens de wet bepaalde daartoe verplicht. Onder anderen dan de patiënt zijn niet begrepen degenen die rechtstreeks betrokken zijn bij de uitvoering van de behandelingsovereenkomst en degene die optreedt als vervanger van de hulpverlener.

De vraag die het bovenstaande oproept is op welke wijze deze patiëntenrechten in de relatie adviesvrager-klinisch geneticus toegepast moeten worden. Erfelijkheidsinformatie heeft namelijk een aantal specifieke kenmerken, waardoor de relatie adviesvrager-klinisch geneticus in enkele opzichten afwijkt van de reguliere

Voor de leesbaarheid wordt de hij-vorm gebruikt. Telkens wanneer er over hij wordt gesproken moet er echter gelezen worden hij of zij, tenzij uit de tekst anders blijkt. 
patiënt-hulpverlener relatie. Ten eerste is voor het verwerven van gegevens in het kader van erfelijkheidsonderzoek vaak informatie over bloed- en aanverwanten vereist. Dit kan informatie zijn uit eerder gedaan onderzoek, echter het kan ook zo zijn dat het voor een juiste diagnose noodzakelijk is dat een familielid een erfelijkheidsonderzoek ondergaat.

Ten tweede kan erfelijkheidsinformatie niet alleen van belang zijn voor de adviesvrager zelf, maar ook voor zijn bloed- en aanverwanten. Het risico dat nageslacht van een adviesvrager aan een erfelijke aandoening gaat lijden of lijdt kan voor broers en zussen van de adviesvrager bijvoorbeeld even groot zijn.

Ten derde heeft erfelijkheidsinformatie een duurzaam en (althans gedurende een aantal generaties) vaak onveranderlijk karakter. Dit in tegenstelling tot de vaak vlottende ${ }^{7}$ reguliere medische informatie.

Ten vierde heeft erfelijkheidsinformatie een voorspellende waarde. Deze voorspellende waarde kan eruit bestaan dat de adviesvrager weet dat zich in de toekomst een ziekte bij hem of zijn nageslacht zal openbaren. Het is echter ook mogelijk, en dit komt veel vaker voor, dat er een verhoogd risico is op een ziekte. Dit voor de genetica kenmerkende, specifieke en wezenlijke aspect ${ }^{8}$ verdient enige nuancering in die zin dat er ook vele onvoorspelbare omgevingsfactoren meespelen. ${ }^{9}$ Bovendien is men vaak niet in staat om te voorspellen wanneer en in welke mate een aandoening zich zal openbaren. ${ }^{10}$ Deze onzekerheden kunnen de keus van de adviesvrager om wel of geen erfelijkheidsonderzoek te laten verrichten bemoeilijken. De kennis die een uitslag van een erfelijkheidsonderzoek brengt is immers omgeven met veel onzekerheden.

Dit onveranderlijke karakter en de voorspellende waarde van erfelijkheidsinformatie kunnen grote gevolgen hebben voor het leven van de adviesvrager en diens naasten. Deze kennis kan een bestaande aandoening betreffen bij de adviesvragers zelf of diens ongeboren kind of een aandoening die zich in de toekomst (waarschijnlijk of mogelijk) zal openbaren. Deze gevolgen kunnen bestaan uit consequenties voor de partnerkeuze, de beroepskeuze, het afbreken van een zwangerschap, de keuze om al dan niet kinderen te krijgen, al dan niet kinderen te adopteren of al dan niet gebruik te maken van een kunstmatige voortplantingsmethode. Genoemde gevolgen betreffen het maken van ingrijpende keuzes. Erfelijkheidsinformatie brengt echter

- Callens wijst er terecht op dat het onveranderlijke karakter van de informatie alleen opgaat voor het genetische materiaal op zich en niet voor bijvoorbeeld informatie over de gezondheidstoestand van een adviesvrager. Hij noemt het voorbeeld van een persoon die eerst drager is van een gemuteerd gen en een aantal jaren later lijdt aan de ziekte waarvoor het betreffend gen muteerde. Callens 1995, p. 133.

- De term is van Sutorius.

$s$ Dit kenmerkende en wezenlijke aspect is niet een uniek aspect. Er zijn veel onderzoeken die een (zekere) voorspellende waarde hebben. Zo voorspelt een HIV-test of de ziekte AIDS zich zal opbaren.

$9 \quad$ Sutorius 1993, p. 154-155.

$10 \quad$ Zie ook Callens 1995, p. 131-132. 
ook psychische, sociale en matschappelijke gevolgen met zich mee. De wetenschap dat men aan een erfelijke aandoening lijdt of (waarschijnlijk) zal gaan lijden eist vaak een herinrichting van het eigen leven. Prioriteiten kunnen anders komen te liggen. De nieuwe wetenschap kan schuld- en, angstgevoelens met zich mee brengen. Bij erfelijkheidsinformatie kunnen ten slotte ook matschappelijke belangen in het geding zijn. Werkgevers (aanstellingskeuringen), hypotheekverstrekkers en verzekeraars (met name bij levensverzekeringen) hebben er belang bij te weten of de toekomstige werk-, hypotheck-, verzekeringsnemer in de toekomst (mogelijk) aan een erfelijke aandoening zal gaan lijden.

\subsection{Probleemstelling}

De relatie adviesvrager-klinisch geneticus is juridisch geregeld in de Wet op de geneeskundige behandelingsovereenkomst. Dit algemeen wettelijk kader is van toepassing op elke behandelingsovereenkomst tussen een patiënt en een hulpverlener. De specifieke kenmerken die erfelijkheidsinformatie heeft en het specialistische karakter van de erfelijkheidsadvisering maken de relatie adviesvrager-klinisch geneticus tot een complexe hulpverleningsrelatie. Aan de zijde van de adviesvrager is bovendien de familie vaak betrokken bij de hulpvraag en aan de andere zijde wordt hulp niet alleen door de klinisch geneticus verleend, maar ook door genetisch consulenten, psychologen en maatschappelijk werkenden. In deze studie staat de relatie adviesvrager-klinisch geneticus centraal. Erfelijkheidsadvisering door andere hulpverleners wordt niet in deze studie betrokken. Bij andere hulpverleners zal het geven van een erfelijkheidsadvies een onderdeel van de dagelijkse werkzaamheden zijn. Voor een klinisch geneticus is het echter zijn primaire taak.

De kernvraag van deze studie is:

Wat is het gewenste juridisch kader voor informatie, toestemming en geheimhouding bij erfelijkheidsadvisering in de klinisch genetische centra?

Het gaat er in deze studie om een kader uit te werken waarin de toepassing van genetische kennis door de klinisch geneticus gestalte kan krijgen. ${ }^{11} \mathrm{Om}$ hiertoe te kunnen komen zullen eerst twee deelvragen aan de orde komen, te weten:

$11 \quad$ Het kader ziet op de behandelingsovereenkomst tussen een klinisch geneticus en een adviesvrager. Derhalve zal geen aandacht besteed worden aan de Wet bevolkingsonderzoek. Het uitwerken van het gewenste juridisch kader voor informatie zal gericht zijn op de informatieplicht uit artikel 7:448 BW. Onderwerpen die hiermee verband houden, zoals de verplichting voor de hulpverlener een dossier in te richten en dit minimaal tien jaar te bewaren, het recht op inzage, afschrift, alsmede het recht gegevens te laten vernietigen zullen, gezien de noodzaak het onderzoek af te bakenen, buiten beschouwing worden gelaten. 
Wat is het juridisch kader inzake informatic, toestemming en geheimhouding bij 'rfelijkheidsadoisering in de klinische genetische centrn?

En

hoe wordt in de praktijk van de erfelijkheidsadvisering bimnen de klinisch genetische centra met (knelpunten e'n dilemma's rond) informatie, toestemming en geheimhouding omgegann?

Dit onderzoek bestaat uit vier delen. Onderhavig verkennend hoofdstuk vormt samen met het tweede hoofdstuk, waar de opzet nader wordt uitgewerkt, de inleiding. De eerste deelvraag zal in het tweede deel worden beantwoord door middel van een juridische analyse van relevante rechtsbronnen. De tweede deelvraag was het voorwerp van een empirisch onderzoek naar de omgang met informatie, toestemming en geheimhouding in de praktijk. Dit wordt in het derde deel behandeld. De normatieve en praktische bevindingen moeten leiden tot een juridisch kader voor informatie, toestemming en geheimhouding bij erfelijkheidsadvisering binnen de klinisch genetische centra. Dit komt in het laatste deel aan de orde.

Het doel van deze studie is om een bijdrage te leveren aan verantwoorde zorg in de klinisch genetische centra. Voor klinisch genetici zou de winst kunnen zijn dat er meer duidelijkheid is in de vorm van een op hun situatie toegesneden invulling van de algemene verplichtingen voor hulpverleners zoals deze zijn neergelegd in de Wgbo. Voor adviesvragers kan meer duidelijkheid voor de hulpverlening een patiëntvriendelijkere zorgverlening bewerkstelligen. Het nader uitwerken en toespitsen van de behandelingsovereenkomst tussen klinisch genetici en adviesvragers bevordert bovendien de rechtsgelijkheid en rechtszekerheid. Het kan wellicht mede dienen als voorbeeld voor vergelijkbare hulpverleningssituaties.

De opzet van de studie zal, zoals opgemerkt, in hoofdstuk 2 nader worden uitgewerkt. Daar wordt een verantwoording gegeven van de gebruikte onderzoeksmethoden. In dit hoofdstuk wordt nader ingegaan op de genetica, de leer der erfelijkheid. Om te beginnen worden het ontstaan en het huidige functioneren van de klinisch genetische centra geschetst. Vervolgens wordt de erfelijkheidsadvisering nader uitgewerkt. Dit wordt gevolgd door een basale uitleg van enkele voor de klinische genetica relevante begrippen en onderscheiden. Het hoofdstuk wordt afgesloten met een samenvatting.

\subsection{Ontstaan en ontwikkeling van de klinische genetische centra}

Sinds 1979 wordt er in Nederland door klinisch genetische centra erfelijkheidsonderzoek verricht en erfelijkheidsadvies gegeven. In 1997 werden er een kleine 10.000 erfelijkheidsadviezen gegeven door de centra. De verwachting is dat dit aantal adviezen in de periode $1998-2003$ met $15 \%$ zal toenemen. ${ }^{12}$

12 Gezondheidsraad 1999, p. 20. 


\subsubsection{Ontstan van de klinisch genetische centra}

De genetica is als onderzoeksgebied ongeveer een eeuw oud. De wetmatigheden van de erfelijkheid, zoals deze in 1865 door Mendel zijn gepostuleerd, werden rond 1900 herontdekt. ${ }^{13}$ Aan het begin van de vorige eeuw werd in vijf van de zes medische faculteiten die ons land destijds kende een leerstoel ingesteld voor de erfelijkheidsleer van de mens. De onderzoekers richtten zich met name op de overervingpatronen van algemene kenmerken van de mens, zoals lengte, schedelomvang en huidskleur.4 De genetica was indertijd vooral een aandachtsgebied binnen de biologie. Na de tweede wereldoorlog en met name vanaf de jaren zestig werd erfelijkheidsleer van groter belang voor de geneeskunde. ${ }^{15}$ In 1944 werd de ontdekking gedaan dat het erfelijk materiaal uit DNA bestaat, gevolgd in 1953 door de opheldering van de structuur van DNA. In 1956 is vastgesteld dat menselijke cellen 46 chromosomen per celkern bevatten. De genetische code, de code die het DNA bevat voor de cellulaire bouwstenen, is in 1966 opgehelderd.16 De erfelijkheidsadviezen berustten echter tot ver in de tweede helft van de vorige eeuw nog "op klinisch onderzoek van de patiënt, waarbij het erfelijke karakter moest worden vastgesteld aan de hand van familie- en stamboomonderzoek. Voor aandoeningen waarvan het overervingpatroon bekend was (dominant, recessief of geslachtsgebonden) ${ }^{17}$ konden, aan de hand van stamboomonderzoek, overervingpatronen binnen één familie worden bestudeerd. Op basis van deze overervingpatronen werd het herhalingsrisico op een aandoening bij een volgende zwangerschap bepaald." 18

In de jaren zeventig van de vorige eeuw nam de aandacht voor erfelijkheidsadvies en -diagnostiek snel toe. Nelis schetst drie met elkaar samenhangende ontwikkelingen die hieraan hebben bijgedragen. Ten eerste het feit dat klinici vanuit verschillende academische ziekenhuizen zich bewust werden van het feit dat ze niet de enige waren die zich met overervingpatronen en de oorzaak van aandoeningen bezighielden. Dit bewustzijn leidde tot geformaliseerde overlegstructuren waar men leerde van elkaars ervaring en kennis. Daarnaast verbeterden de technieken om chromosoomkaarten te maken. Het werd mogelijk om individuele chromosomen en

13 Mannens en De Boer 1999, p. 31. Een andere stimulans aan de genetica als onderzoeksgebied werd gegeven door de eugenetica. Dit begrip werd door zijn grondlegger Galton gedefinieerd als: "de wetenschap die zich bezighoudt met alle invloeden die de erfelijke eigenschappen van een ras verbeteren." Het verbeteren van een ras was te bereiken door een wetenschappelijk geplande voortplanting. Door middel van positieve eugenetica wordt gepoogd de frequentie van wenselijke genen toe te laten nemen en door middel van negatieve eugenetica wordt het voorkómen van onwenselijke individuen of schadelijk geachte genen beoogd. Dierickx 1999, hoofdstuk 3.

$14 \quad$ Nelis 1998, p. 56-57.

15 Van der Weele 1987, p. 36-43.

16 Mannens en De Boer 1999, hoofdstuk 2.

$17 \quad$ Zie hiervoor paragraaf 1.5 .2 .

Nelis 1998, p. 57. 
onderdelen daarvan te identificeren. En ten derde nam de ontwikkeling van prenatale diagnostiek een hoge vlucht. Het werd nu mogelijk om bepaalde aandoeningen bij de foetus zelf te diagnosticeren, wat voor aanstaande ouders de optie met zich meebracht, om een abortus provocatus te laten verrichten indien de foetus de betreffende aandoening bleek te hebben. ${ }^{19}$ Deze toegenomen aandacht leidde tot een verdere organisatie van de praktijk. Verschillende academische ziekenhuizen boden erfelijkheidsadvies en -diagnostiek aan. De financiering hiervan was een probleem aangezien de kosten van advies en diagnostiek niet door de zorgverzekeraars vergoed werden. De kosten werden uit onderzoeksbudgetten en andere fondsen betaald. ${ }^{20}$

Niet alleen in de medische wereld groeide de belangstelling voor erfelijkheidsadvies en -diagnostiek. In 1975 werd tijdens een bijeenkomst van ouders- en patiëntenorganisaties besloten de Vereniging Samenwerkende Ouder- en Patiëntenorganisaties (VSOP) op te richten, met als doel het voorkómen van aangeboren en erfelijke aandoeningen. ${ }^{21}$ De VSOP hoopte onder andere door het uitgeven van brochures een bijdrage te leveren aan de voorlichting omtrent aangeboren of erfelijke afwijkingen opdat deze vroegtijdig onderkend zouden worden. ${ }^{22}$ Ook de media besteedden aandacht aan de nieuwe mogelijkheden op het gebied van erfelijkheidsadvisering en -diagnostiek. Vooral de prenatale diagnostiek en daaraan gekoppeld de nieuwe mogelijkheden van preventie trokken de aandacht.23 De toegenomen aandacht voor de organisatie van de erfelijkheidsadvisering en -diagnostiek leidde tot het instellen door de Gezondheidsraad in 1973 van een adviescommissie, de zogeheten commissie Genetic Counseling. ${ }^{24}$ De commissie werd gevraagd advies uit te brengen "inzake de in Nederland bestaande behoefte aan genetic counseling en prenatale diagnostiek van aangeboren afwijkingen, alsmede inzake de structuur en de faciliteiten die dienen te worden gecreëerd om in deze behoefte te voorzien". ${ }^{25}$ In 1977 bracht de commissie haar advies inzake genetic counseling uit. In het advies werden vijf aanbevelingen gedaan.

19 Nelis 1998, p. 59-63.

20 Nelis 1998, p. 63-64.

21 In 1979 is de VSOP een vereniging geworden, daarvoor was sprake van een samenwerkingsverband. Deze doelstelling is inmiddels verlaten. De VSOP stelt zich tegenwoordig ten doel de gemeenschappelijke belangen van de bij haar aangesioten organisaties te behartigen door middel van het belangstelling wekken voor de vraagstukken rondom erfelijke ziekten en aangeboren aandoeningen. Zij ziet hierbij als één van haar taken "het bevorderen van een klimaat van maatschappelijke solidariteit ten aanzien van mensen met een (verhoogd risico op een) al dan niet erfelijke aangeboren aandoening en hun familieleden". VSOP 2001, p. 5.

$22 \quad$ Nelis 1998, p. 66.

$2.3 \quad$ Nelis 1998, p. 67.

24 In deze studie wordt niet de term genetic counseling, maar de term erfelijkheidsadvisering gehanteerd.

25 Gezondheidsraad 1977, p. 1. 
Ten eerste diende volgens de commissie de vroegtijdige onderkenning van lichamelijke en/of geestelijke ontwikkelingsstoornissen, waarvan een belangrijk gedeelte op aangeboren afwijkingen berust, te worden verbeterd. Ten tweede diende bij elke patiënt met een lichamelijke en/of geestelijke handicap, die mogelijk op een aangeboren afwijking berust, op een zo vroeg mogelijk tijdstip een volledig diagnostisch onderzoek te worden verricht om de identiteit van de aandoening vast te stellen. Ten derde moest genetic counseling op grotere schaal worden gegeven en de kwaliteit diende te verbeteren. De vierde aanbeveling stelde dat er een zodanige situatie diende te worden geschapen dat elke echtpaar, dat op grond van een verhoogde kans op afwijkend nageslacht voor prenataal vruchtwater(cel)onderzoek in aanmerking kwam, dit onderzoek ook kon ondergaan. Als laatste beval de commissie aan dat er meer aandacht aan de medische genetica zou worden besteed door onder andere de medische faculteiten, samen met een veranderende organisatiestructuur en voldoende steunverlening aan de daarvoor in aanmerking komende instanties en instituten op het terrein van de zuigelingen-, kleuter-, jeugd-, en gehandicaptenzorg. ${ }^{26}$

Om de aanbevelingen gerealiseerd te krijgen, pleitte de commissie voor een regionale concentratie van het chromosoomonderzoek en de klinische en moleculaire diagnostiek van erfelijke (stofwisselings)ziekten in de universitaire centra. Met het oog op de kwaliteit, de continuiteit, een efficiënte bedrijfsvoering en de aanwezigheid van voldoende contacten met het wetenschappelijk werk op het terrein van chromosoomonderzoek stelde de commissie voor het chromosoomonderzoek uitsluitend in de universitaire centra te doen plaatsvinden. Voor de concentratie van het biochemisch onderzoek naar erfelijke stofwisselingsziekten pleitte volgens de commissie het feit dat men in universitaire centra beschikt over voldoende vergelijkingsmateriaal en de noodzakelijke samenwerkingsverbanden met verschillende gespecialiseerde laboratoria. Wegens het feit dat ten tijde van het advies van de commissie nauwelijks sprake was van formeel aanwezige faciliteiten voor genetic counseling en het feit dat er in de eerste en de tweede lijn nauwelijks deskundigen beschikbaar waren, adviseerde de Gezondheidsraad om op een zo kort mogelijke termijn multidisciplinaire teams voor erfelijkheidsadvisering in alle Nederlandse universitaire centra op te zetten. Behalve gebrek aan deskundigheid was er ook nauwelijks financiering voor de verschillende vormen van erfelijkheidsonderzoek. De Gezondheidsraad pleitte daarom voor overleg met de ziekenfondsen. Bovendien achtte hij het van belang dat er, om de via het ziekenfonds beschikbaar komende middelen op hun juiste bestemming terecht te laten komen, dat schriftelijke overeenkomsten met academische ziekenhuizen zouden worden gesloten, of dat de verschillende vormen van erfelijkheidsonderzoek in aparte stichtingen zouden worden ondergebracht. In de jaren 1979 en 1980 is dit laatste ook daadwerkelijk gebeurd. Door alle universiteiten werden stichtingen voor klinisch genetisch onderzoek in het leven geroepen, waarin de verschillende universitaire vakgroepen, betrokken bij erfelijkheidsonderzoek, bij elkaar werden 
gebracht. 27 Sinds 4 mei 1987 is de klinische genetica officieel erkend als medische specialisme.

\subsubsection{Huidig functioneren onn de klinisch genetische centra}

Er zijn in Nederland momenteel zeven Stichtingen voor Klinische Genetica, ${ }^{28}$ te weten:

- Stichting voor erfelijkheidsvoorlichting te Groningen;

- Stichting Klinisch Genetisch Centrum Nijmegen e/o;

- Stichting Klinisch Genetisch Centrum Utrecht;

- Stichting Klinische Genetica Amsterdam;

- Stichting Klinisch Genetisch Centrum Leiden;

- Stichting Klinische Genetica regio Rotterdam;

- Stichting Klinische Genetica Zuid-Oost Nederland.

De door de klinisch genetische centra verrichte functies vallen onder de vergunningsregeling die thans gebaseerd is op artikel 2 van de Wet bijzondere medische verrichtingen (Wbmv). De vergumningsregeling heeft in 1994 tot de huidige Regeling Klinisch Genetisch Onderzoek en Erfelijkheidsadvisering geleid. ${ }^{29}$ Hierin worden voor de Stichtingen voor Klinische Genetica de volgende functies onderscheiden: 30

- afname van foetaal materiaal ten behoeve van prenataal onderzoek;

- prenataal chromosoom-, biochemisch en DNA-onderzoek van tijdens de zwangerschap afgenomen (foetaal) materiaal voor het vaststellen van aangeboren en erfelijke afwijkingen;

- geavanceerd prenataal ultrageluidonderzoek naar structurele foetale afwijkingen dat wordt uitgevoerd in verband met van tevoren bekend verhoogd risico op, of een vermoeden van foetale misvormingen;

27 Rutten c.a. 1998, bijlage 1

2s Inmiddels zijn bijna alle klinisch genetische centra geïntegreerd in de academische ziekenhuizen. Verwacht wordt dat in 2002 de integratie zal worden afgerond. Kamerstukken II 2001/02, 27 543, nr. 5, p. 6. Voor deze integratie heeft de minister drie redenen opgegeven. Ten eerste is een afzonderlijke positie om de ontwikkeling te sturen niet meer nodig omdat de klinische genetica zich inmiddels een vaste plaats heeft verworven in de gezondheidszorg. Ten tweede omdat integratie voor elk medisch specialisme in de academische ziekenhuizen van steeds groter belang zal worden. Het kan bijdragen aan de noodzakelijke verdergaande multidisciplinaire benadering en afstemming van de academische ziekenhuiszorg. Ten derde omdat met integratie kan worden bevorderd dat academische ziekenhuizen steeds meer de rol van wetenschappelijke kenniscentra gaan vervullen. Ministerie van Volksgezondheid, Welzijn en Sport 2000, p. 50.

29 Een nieuwe regeling wordt in 2002 verwacht. Kamerstukken II 2001/02, 27 543, nr. 5, p. 5.

30 Stcrt. 1994, 68. 
- postnataal chromosoom- en DNA-onderzoek ten behoeve van de diagnostiek van aangeboren en erfelijke afwijkingen, dragerschap en van stoornissen in de geslachtelijke ontwikkeling en functie;

- postnataal biochemisch onderzoek (van complexe aard) gericht op vroegtijdige opsporing en behandeling van erfelijke stofwisselingsziekten en om dragerschap vast te stellen;

- postnataal chromosoomonderzoek ten behoeve van de diagnostiek en prognose van proliferatieve stoornissen van beenmerg;

- erfelijkheidsadvisering van complexe aard, dat wil zeggen het informatieproces dat nodig is om mensen tot begrip en tot een voor hen juiste besluitvorming te laten komen ten aanzien van erfelijke of aangeboren afwijkingen.

Op elk van deze functies ga ik kort in: ${ }^{31}$

- afname van foetaal materiaal

De afname van foetaal materiaal vindt plaats ten behoeve van prenatale diagnostiek. Met dit materiaal wordt vervolgens prenataal chromosoom-, biochemisch of DNA-onderzoek verricht (zie hieronder). De afname van foetaal materiaal vindt plaats door middel van een vlokkentest, een vruchtwaterpunctie of een navelstrengpunctie. Afhankelijk van de mate waarin de zwangerschap is gevorderd wordt voor één van de methoden gekozen. ${ }^{32}$

- prenataal onderzoek

Prenataal onderzoek is onder te verdelen in prenataal chromosoomonderzoek, prenataal DNA-onderzoek en prenataal biochemisch onderzoek:

- prenataal chromosoomonderzoek: dit onderzoek is gericht op de vroegtijdige opsporing van erfelijke en aangeboren chromosoomafwijkingen van de ongeborene. Het kunnen afwijkingen in het aantal en/of in de structuur van de chromosomen betreffen;

- prenataal DNA-onderzoek: dit onderzoek is gericht op de vroegtijdige opsporing van erfelijke en aangeboren afwijkingen in de genen van de ongeborene;

- prenataal biochemisch onderzoek: dit onderzoek is gericht op de analyse van foetaal materiaal met het doel om vroegtijdig erfelijke stofwisselingsziekten bij de ongeborene te constateren. Dit laatste onderzoek is alleen voorbehouden aan de Stichting Klinische Genetica regio Rotterdam. ${ }^{33}$

Op de functie postnataal chromosoomonderzoek ten behoeve van de diagnostiek en prognose van proliferatieve stoomissen van beenmerg zal niet nader worden ingegaan, daar deze vorm van chromosoomonderzoek geen erfelijke achtergrond heeft. De reden dat zij toch is voorbehouden aan de klinisch genetische centra is gelegen in het feit dat de expertise voor dit soort onderzoek in de laboratoria van de klinisch genetische centra aanwezig is. 
De beroepsgroep voert een beleid wat betreft de toepassing van prenataal onderzoek. ${ }^{34}$ Afspraken over een indicatiestelling (binnen de beroepsgroep en tussen de beroepsgroep en verzekeraars) kunnen echter slechts globaal van aard zijn en zijn dit ook. ${ }^{35}$

- geavanceerd ultrageluidonderzoek

Dit onderzoek is gericht op het opsporen van structurele en functionele afwijkingen bij de ongeborene. Het gaat hierbij om een zeer gedetailleerd onderzoek naar alle orgaanstructuren van de ongeborene, dit in tegenstelling tot het eenvoudige ultrageluidonderzoek, dat gericht is op de bepaling van de zwangerschapsduur, de detectie van meerlingen en het meten van de groei van de ongeborene. ${ }^{36}$

- postnataal onderzoek

Postnataal onderzoek is net als prenataal onderzoek onder te verdelen in postnataal chromosoomonderzoek, postnataal DNA-onderzoek en postnataal biochemisch onderzoek:

- postnataal chromosoomonderzoek: dit onderzoek betreft de diagnostiek van erfelijke of aangeboren afwijkingen in het aantal en/of in de hoedanigheid van de chromosomen;

- postnataal DNA-onderzoek: "het onderzoek naar veranderingen en varianten in het lichaamseigen DNA die geassocieerd zijn met het ontstaan van, het risico op en het verloop van bepaalde ziektebeelden of met de reactie op bepaalde medische handelingen". ${ }^{37}$ Door middel van dit onderzoek kunnen erfelijke of aangeboren afwijkingen en dragerschap van een erfelijke aanleg worden vastgesteld of uitgesloten;

- postnataal biochemisch onderzoek: dit onderzoek betreft de diagnostiek van erfelijke ziekten of dragerschap door middel van onderzoek van metabolieten of het aantonen van een enzymdeficiënties/defecten of eiwitdefecten. ${ }^{38}$

- Erfelijkheidsadvisering van complexe aard.

Erfelijkheidsvoorlichting van complexe aard omvat: voorlichting, advies, diagnostiek en (psychosociale) begeleiding bij a) het maken van keuzen die samenhangen met de kans op het krijgen van kinderen met erfelijke of aangeboren afwijkingen of b) een persoonlijk risico dat zich in de toekomst een erfelijke ziekte openbaart.

Van complexiteit is sprake als:

- een professionele stamboomanalyse moet worden gemaakt of;

- onderzoek van meerdere familieleden moet plaats vinden of;

- complexe kansberekeningen moeten worden gemaakt of;

- de genetische heterogeniteit nader diagnostisch onderzoek noodzakelijk maakt.

In hoofdstuk 4 wordt hierop nader ingegaan.

Ministerie van Volksgezondheid, Welzijn en Sport 2000, p. 49.

Rutten e.a. 1998, p. 23.

Gezondheidsraad 1998, p. 39.

Rutten e.a. 1998, p. 23. 
Sinds 1996 is erfelijkheidsadvisering van complexe aard verdeeld in twee typen, te weten het enkelvoudig consult en de complexe erfelijkheidsadvisering. Onder een enkelvoudig consult wordt erfelijkheidsvoorlichting verstaan die in één afspraak tussen de klinisch geneticus en de adviesvrager wordt afgerond. Bij complexe erfelijkheidsadvisering vergt de beantwoording van de vraagstelling meer tijd. ${ }^{39}$ Op landelijk niveau opereert het Landelijk Overleg Genetic Counselors (LOG). Eén van de belangrijkste doelstellingen van het LOG is "de handhaving van de hoogwaardige patiëntenzorg die op genetisch gebied in Nederland wordt geboden" ${ }^{40}$ Door middel van controle op de kwaliteit en efficiëntie van het onderzoek alsmede het ontwikkelen van nieuwe protocollen tracht men dit te bewerkstelligen. Momenteel bestaat er geen algemeen landelijk protocol wat betreft erfelijkheidsadvisering. Per klinisch genetisch centrum werkt men vaak wel met specifieke, op één aandoening gerichte, protocollen, met name bij voorspellend onderzoek.

De laatstgenoemde functie, erfelijkheidsadvisering van complexe aard, van de Stichtingen voor Klinische Genetica, staat centraal in dit onderzoek. In de volgende paragraaf wordt hier nader op ingegaan.

Een aantal van de genoemde functies vindt ook (zonder vergunning) buiten de klinisch genetische centra plaats. Dit geldt met name voor DNA-onderzock. Bij het onderzoek buiten de centra staat de erfelijkheidsvraag niet steeds centraal. DNAonderzoek kan ook leiden tot beter inzicht in de aard van de afwijking van de patiënt. Het is dan vaak in de plats gekomen van biochemisch onderzoek vanwege de hogere betrouwbaarheid en sensitiviteit. ${ }^{11}$

In de Regeling klinisch genetisch onderzoek en erfelijkheidsadvisering wordt preimplantatie genetische diagnostiek (PGD) niet als functie genoemd. De regeling is hier echter wel in beginsel op van toepassing. ${ }^{42}$ Preimplantatie genetische diagnostiek is een methode waarmee erfelijke aandoeningen bij preimplantatieembryo's (0-14 dagen oud) kunnen worden aangetoond. De in-vitro tot stand gebrachte preïmplantatie-embryo's worden op een specifieke erfelijke afwijking onderzocht met als doel om alleen de preïmplantatie-embryo's waarbij de desbetreffende afwijking niet wordt gevonden in de baarmoeder van de vrouw te plaatsen. PGD kan als een alternatief voor prenataal onderzoek gelden. Het wordt toegepast bij paren die een vastgesteld risico hebben op een kind met een erfelijke afwijking en die daaraan de voorkeur geven boven prenataal onderzoek. Het toepassingsgebied sluit in beginsel aan bij de indicaties voor prenatale diagnostiek. PGD verkeert vooralsnog in het stadium van medisch-wetenschappelijk onderzoek en wordt vooralsnog alleen in Maastricht uitgevoerd. 43

\footnotetext{
34 Rutten e.a. 1998 , p. 23-24.

to Rutten e.a. 1998, p. 17.

4 Rutten e.a. 1998 , p. 37.

42 Ministerie van Volksgezondheid, Welzijn en Sport 2000, p. 49.

43 Ministerie van Volksgezondheid, Welzijn en Sport 2000, p. 13.
} 
Bij de klinisch genetische centra zijn de volgende deskundigen werkzaam op het gebied van de erfelijkheidsadvisering:

- klinisch genetici en artsen al dan niet in opleiding tot klinisch geneticus;

- genetisch consulenten;

- maatschappelijk werkenden, sociaal verpleegkundigen of psychologen (of cen combinatie) voor de psychosociale begeleiding;

- een genealoog voor het verrichten van complex stamboom- en familieonderzoek.74

De in paragraaf 1.3.1 genoemde Vereniging Samenwerkende Ouder- en Patiëntenorganisaties is inmiddels uitgegroeid tot een samenwerkingsverband van 56 organisaties. Tezamen vertegenwoordigen deze organisaties 150.000 mensen die te maken hebben met erfelijke en/of aangeboren aandoeningen. ${ }^{45}$ Recentelijk is het ERFO-centrum opgericht (centrum voor voorlichting en documentatie op het gebied van erfelijke aandoeningen). ${ }^{46} \mathrm{Er}$ is een nauwe (bestuurlijke) band tussen de genetische centra en de VSOP. De VSOP is in alle, met uitzondering van het klinisch genetisch centrum Nijmegen, besturen van de stichtingen vertegenwoordigd door een bestuurslid. ${ }^{77}$ In het bestuur van het erfocentrum is zowel de Vereniging van Stichtingen Klinische Genetica (SKG) als de Vereniging Klinische Genetica Nederland (VKGN) vertegenwoordigd.

\subsection{Erfelijkheidsadvisering}

Hieronder zal worden omschreven wat in deze studie onder erfelijkheidsadvisering wordt verstaan. In de klinische genetica is het gebruikelijk om de persoon die zich tot een klinisch genetisch centrum wendt voor erfelijkheidsadvies aan te duiden als adviesvrager. De hulpverlener die erfelijkheidsadvies verleent is de adviesgever, meestal een klinisch geneticus. In dit onderzoek zal deze terminologie gevolgd worden.

\subsubsection{Wat is erfelijkheidsadvisering?}

De Gezondheidsraad hanteert de volgende, van de American Society of Human Genetics afkomstige, vertaalde omschrijving:

"Erfelijkheidsadvisering is een communicatieproces betreffende de menselijke problemen die voortkomen uit het optreden, of uit de kans van het optreden, van een erfelijke afwijking in de familie. Dit communicatieproces houdt in een poging door een of meer darvoor opgeleide personen, de betrokken persoon of de familie te helpen bij:

it Leschot en Brunner 1998, p. 1. Momenteel werken nog twee centra met een genealoog. Door de komst van DNA-diagnostiek, waarmee genmutaties kunnen worden opgespoord, is er minder behoefte aan complex stamboom- en familieonderzoek.

4 www.vsop.n].

to www.erfocentrum.nl.

*7 Rutten e.a. 1998, p. 17. 
- het verkrijgen van inzicht in de medische gegevens, omvattende de diagnose, het waarschijnlijke verloop van de aandoening en de beschikbare mogelijkheden van therapie en/of begeleiding;

- het verkrijgen van begrip omtrent erfelijke factoren die mogelijk bij de betreffende aandoening een rol spelen en omtrent het risico van herhaling bij bepaalde familieleden;

- het verkrijgen van inzicht in de maatregelen die genomen kunnen worden in verband met het herhalingsrisico;

- de keuze van die gedragslijn die de adviesvragers passend schijnt in verband met hun risico, hun gezinsopbouw, hun ethische en religieuze opvattingen, alsmede bij het handelen overeenkomstig hum beslissing;

- de zo goed mogelijke aanpassing aan het bestaan van een erfelijk defect bij een betrokken familielid en/of aan het risico van het opnieuw zich manifesteren van die afwijking." 48

Leschot en Brunner stellen: "erfelijkheidsadvies is het verstrekken van informatie over genetische aspecten van een aandoening of ziekte. Deze informatie stelt de adviesvragers in staat keuzes te maken omtrent zichzelf, hun kinderen, of de beslissing om kinderen te krijgen." $49 \mathrm{Zij}$ splitsen het erfelijkheidsadvies op in diagnostiek en advies:

"Gang van zaken bij erfelijkheidsadvisering

Erfelijkheidsadvies

genetiscle dingnostiek

1 wat is de medische diagnose?

2 is dit een geheel of gedeeltelijk genetische aandoening?

- stamboomonderzoek

- literatuurgegevens

3 wat is het risico? Indien onbekend, welk aanvullend onderzoek is nodig?

4 aanvullend genetisch onderzoek

- klinisch onderzoek

- DNA-onderzoek

- stofwisselingsonderzoek

- chromosomenonderzoek

genetisch advies

5 bespreken van de diagnose

6 bespreken van het risico

7 bespreken van de opties

8 kiezen van een bij de adviesvragers passende gedragslijn

9 follow-up" 50

Volgens Leschot en Brunner omvat het begrip erfelijkheidsadvies dus ook genetische diagnostiek. ${ }^{51}$ In deze studie zal hier ook vanuit worden gegaan. Met uitzondering

48 Gezondheidsraad 1989, p. 75. Aldus ook Gezondheidsraad 1980, p. 13-14.

49 Leschot en Brunner 1998, p. 2.

50 Leschot en Brunner 1998, p. 2. 
van stap vier, worden alle stappen ook verricht door een klinisch geneticus. In de literatuur wordt ook de term genetic counseling gebezigd. De Engelse term zou de lading beter dekken dan de term erfelijkheidsadvisering omdat in deze laatste term de adviescompent een te actieve rol van de klinisch geneticus zou indiceren en de voorlichtende en begeleidende taken hier niet in tot uitdrukking komen. ${ }^{52}$ Aangezien de term erfelijkheidsadvisering (zij het vaak in verschillende betekenissen) meer gangbaar is, zal deze hier gevolgd worden. Hoe actief de rol van de klinisch geneticus vanuit het oogpunt van zijn goed hulpverlenerschap tijdens het proces van de erfelijkheidsadvisering behoort te zijn komt in hoofdstuk 4 aan de orde. Wanneer in het vervolg over erfelijkheidsonderzoek of erfelijkheidsdiagnostiek wordt gesproken, dan wordt hiermee een specifiek onderdeel van de erfelijkheidsadvisering bedoeld. Wanneer er over erfelijkheidsadvisering wordt gesproken, dan worden daar alle aspecten uit het schema mee bedoeld.

In het Planningsbesluit van de Regeling Klinisch Genetisch Onderzoek en Erfelijkheidsadvisering (zie paragraaf 1.3.2) wordt de hierboven bedoelde erfelijkheidsadvisering, erfelijkheidsadvisering van complexe aard genoemd. Eenvoudige erfelijkheidsadvisering, erfelijkheidsadvies dat ook gegeven kan worden door de huisarts of de behandelend specialist, valt buiten het bestek van dit onderzoek.

\subsubsection{Huidig doel erfelijkheidsadvisering}

Het Planningsbesluit noemt erfelijkheidsadvisering het informatieproces dat nodig is om mensen tot begrip en tot een voor hen juiste besluitvorming te komen ten aanzien van erfelijke of aangeboren afwijkingen. ${ }^{53}$ De Gezondheidsraad gaat hier nader op in. Hij onderscheidt drie aspecten van de hulpverlenende taak van adviesgevers.

Ten eerste de taak om adviesvragers te informeren. Het belangrijkste doel is "de adviesvrager(s) door het verstrekken van informatie in staat te stellen tot het doen van een keuze die past bij zijn (hun) opvattingen en situatie".54 Het geven van goede informatie is tijdrovend en zij moet door de adviesvrager begrepen worden. Bovendien dient, aldus de Gezondheidsraad, de gegeven informatie schriftelijk, in begrijpelijke taal te worden vastgelegd. Dit is ook van belang in verband met het

51 De definitie die Leschot en Brunner van erfelijkheidsadvies geven sluit echter slechts aan bij de punten 5 tot en met 9 .

52 Sutorius 1993, p. 156-157.

53 Stcrt. 1994, 68. Zie ook Van de Kamp, XVI Vakinhoudelijke aspecten, hoofdstuk 1, paragraaf 1.1. Van de Kamp noemt het primaire doel "(aanstaande) ouders voldoende inzicht te geven om het voor hen bestaande erfelijkheidsprobleem te integreren in hun bestaan".

5. Gezondheidsraad 1989, p. 76. In haar advies uit 1977 wordt erop gewezen dat erfelijkheidsadvisering (in het advies genetic counseling genoemd) ertoe bijdraagt dat de geboorte van kinderen met een aangeboren afwijking wordt voorkómen. In haar advies uit 1980 wordt het voorkomen van erfelijke aandoeningen nog als maatschappelijk belang genoemd. 
informeren van familieleden. Wat betreft de verwerking van de informatie na het erfelijkheidsadvies, ziet de Gezondheidsraad een taak weggelegd voor de behandelend arts die de adviesvrager heeft doorverwezen. .55

Ten tweede heeft de adviesgever een adviserende taak. Uit het doel van de erfelijkheidsvoorlichting, adviesvragers in staat te stellen een voor hen passende keuze te maken, vloeit voort dat de advisering non-directief van aard is. Respect voor de eigen levensbeschouwelijke en morele opvattingen van de adviesvrager en voor zijn zelfbeschikkingsrecht vereist dat de adviesgever de adviesvrager in de gelegenheid stelt om zelf op basis van alle ontvangen informatie keuzes te maken. Dit wordt wel genuanceerd door het besef dat absolute non-directiviteit in de praktijk niet haalbaar is. Het is een streven..$^{56}$

Ten derde de taak om adviesvragers te begeleiden. Het ontvangen van erfelijkheidsadvies is voor veel adviesvragers een ingrijpende gebeurtenis. Zo ontvangt men medisch-genetische informatie waarmee men vaak onbekend is, die bovendien (onterechte) schuld- en minderwaardigheidsgevoelens alsmede onverwerkte emoties kunnen oproepen. Door erfelijkheidsadvies kunnen ook ernstige gewetensconflicten ontstaan, zoals bijvoorbeeld de vraag of men een familielid moet informeren over een mogelijk erfelijk risico. De keuzes waarvoor een adviesvrager zich geplaatst ziet, kunnen voor een dilemma zorgen, alsmede verschillende zienswijzen van partners of familieleden. Eén en ander legt een grote verantwoordelijkheid bij de adviesgever voor een adequate begeleiding. Deze begeleiding kan ook worden gegeven door de genetisch consulent, psycholoog of maatschappelijk werkende van het klinisch genetisch centrum, alsmede door een hulpverlener werkzaam buiten het klinisch genetisch centrum. Ook het in contact brengen van adviesvragers met ouder- en patiëntorganisaties is een vorm van begeleiding. De Raad wijst tevens op het belang van een goede begeleiding alvorens tot aanvullend erfelijkheidsonderzoek wordt overgegaan. Dit geldt met name voor voorspellend onderzoek. Wanneer erfelijkheidsonderzoek (toekomstige) gegevens over de gezondheid van de adviesvrager en/of diens kinderen en familie aan het licht kan brengen, vereist dit een goede begeleiding. De adviesgever dient zich ervan te vergewissen dat de adviesvrager weten echt prefereert boven niet weten en dient te wijzen op de mogelijke psychische en maatschappelijke gevolgen die het aantonen van een mutatie met zich mee kan brengen. Bovendien dient de adviesvrager in vrijheid om erfelijkheidsadvies te vragen. ${ }^{57}$

\footnotetext{
55 Gezondheidsraad 1989, p. 75-77.

56 Gezondheidsraad 1989, p. 77. In hoofdstuk 4 wordt verder ingegaan op de nondirectieve aard van de erfelijkheidsadvisering.

57 Gezondheidsraad 1989, p.79-80.
} 


\subsubsection{Gang van zaken bij erfelijkheidsadvisering}

Bij het eerste gesprek, het intakegesprek, zal de klinisch geneticus helder moeten krijgen wat de erfelijkheidsvraag van de adviesvrager is. Naar aanleiding van de vraag zal hij een genetische diagnose moeten stellen. Dit gebeurt, afhankelijk van de vraag, op basis van een persoonlijke en een familieanamnese, stamboomonderzoek, literatuurgegevens en het opvragen van gegevens van de adviesvrager of diens bloedverwanten bij andere artsen. Vaak zal ook aanvullend genetisch onderzoek noodzakelijk zijn, te weten; klinisch onderzoek,58 DNA-onderzoek, chromosomenonderzoek, stofwisselingsonderzoek, of een combinatie daarvan. Vervolgens, dit kan tijdens het eerste gesprek zijn, maar meestal zal dit tijdens een tweede of een derde gesprek zijn, zal een genetisch advies gegeven worden, bestaande uit de punten 5 tot en met 9 van het schema in paragraaf 1.4.1.

Dit betreft allereerst het bespreken van de diagnose. Daarbij zijn er drie mogelijkheden. Er is sprake van een genetische afwijking in de familie. De adviesvrager zelf heeft deze afwijking of niet. Het dragen van die afwijking kan weer verschillende gevolgen met zich mee brengen. Ten tweede kan het zo zijn dat de afwijking niet-genetisch van aard is. Tot slot is het mogelijk dat er geen diagnose is gesteld. Men heeft geen oorzaak kunnen vinden voor het (mogelijke) erfelijkheidsprobleem. ${ }^{59} \mathrm{Bij}$ het bespreken van de diagnose zal ook, voor zover relevant en mogelijk, informatie worden gegeven over de aard en het verloop van de aandoening.

Vervolgens zullen de risico's besproken worden. Het gaat dan in veel gevallen over herhalingsrisico's voor het nageslacht. Dit risico hangt uiteraard af van de wijze van overerving. Zie hiervoor paragraaf 1.5 . Ook de keuzemogelijkheden zullen, indien daarvan sprake is, aan bod komen.

Bij een verhoogd risico op een kind met een erfelijke aandoening zijn er de volgende mogelijkheden:

- het risico accepteren en verder geen maatregelen nemen;

- afzien van nageslacht;

- bij een zwangerschap gebruik maken van prenatale diagnostiek;

- gebruik maken van donorsperma of donoreicellen;

- gebruik maken van pre-implantatiediagnostiek.

Wanneer er sprake is van een verhoogd risico op een erfelijke aandoening bij de adviesvrager zelf zullen de mogelijke preventieve gezondheidsmaatregelen aan bod komen (zoals bijvoorbeeld regelmatig onderzoek laten verrichten, het volgen van een dieet of het laten verwijderen van de borsten).

58 Dit kan ook door een andere specialist worden uitgevoerd.

59 Dit betekent overigens niet dat het stellen van een diagnose altijd inhoudt dat daarmee ook de oorzaak is vastgesteld. Een aandoening kan bijvoorbeeld op grond van een klinisch beeld worden vastgesteld zonder dat de erfelijke oorzaak is opgespoord. 
De klinisch geneticus zal de adviesvragers helpen bij het maken van een keuze die voor de adviesvrager zelf de juiste keuze is. Zie paragraaf 1.4.2. Soms vindt na het eindgesprek met de klinisch geneticus een follow-upcontact plaats met de psychosociaal medewerker van het klinisch genetisch centrum.

Na afloop van de erfelijkheidsadvisering wordt de adviesvrager een schriftelijke samenvatting toegezonden van hetgeen besproken en geconcludeerd is. De verwijzende arts en de huisarts ontvangen, indien de adviesvrager hier geen bezwaar tegen heeft, een kopie van deze brief of een eigen verslaglegging. ${ }^{60}$

\subsection{Begrippenverheldering}

In deze paragraal zal nader in worden gegaan op de opbouw en werking van ons erfelijkheidsmateriaal, de verschillende vormen van overerving, de verschillende oorzaken van erfelijke of aangeboren afwijkingen en de verschillende soorten van onderzoek. Het is nadrukkelijk niet de bedoeling om een uitputtende beschrijving te geven. De hier volgende paragrafen dienen om de niet medisch geschoolde lezer enige basiskennis en achtergrondinformatie te verschaffen voor een goed begrip van hetgeen in de volgende hoofdstukken aan de orde komt.

\subsubsection{Opboutv en werking van ons erfelijkheidsmaterinal}

Elke lichaamscel van de mens bevat in zijn kern 46 chromosomen, die te rangschikken zijn in 22 homologe (overeenkomstige) paren die volgens grootte zijn genummerd. Het 23e paar zijn de geslachtschromosomen. Bij een vrouw bestaat het $23^{e}$ par uit twee zogeheten $X$-chromosomen en bij de man uit een $X$ - en een $Y$ chromosoom. In de zaad- en eicellen, de zogeheten kiemcellen, komt een enkel stel van 23 chromosomen voor. Deze kiemcellen vormen bij de bevruchting een nieuwe cel met een dubbel stel chromosomen, bestaande uit 23 chromosomen van vader en 23 chromosomen van moeder. Ieder mens erft dus de helft van zijn erfelijk materiaal van zijn vader en de andere helft van zijn moeder.

Het genetisch materiaal dat zich op de chromosomen bevindt is opgebouwd uit DNA-moleculen. Het DNA bevat de erfelijkheidsinformatie voor de aanmaak van de eiwitten die de ontwikkeling, regulering en het beëindigen van alle celfuncties verzorgen. Een stukje DNA dat de code bevat voor de vorming van een eiwit en dus drager is van een bepaalde eigenschap heet een gen. Er zijn 30.000 tot 40.000 menselijke genen. Elk gen ligt op een specifiek stukje van een chromosoom. De plaats waar het gen ligt wordt locus genoemd. Op de eerste 22 chromosomenparen zijn de genen dubbel aanwezig, één van vader en één van moeder. Van veel genen bestaan echter verschillende varianten. Per individu, maar ook per apart chromosoom kunnen op hetzelfde locus verschillende vormen aangetroffen worden. Elk van de alternatieve vormen die een gen op een bepaald locus kan aannemen, wordt een allel

Liebaers en Hamel 1999, p. 287-293. Aldus ook Leschot en Brunner 1998, p. 2. 
genoemd. Een individu kan per gen dus twee allelen hebben, maar binnen een populatie kunnen er veel meer allelen voorkomen.

Alle genen van cén individu worden tezamen zijn genotype genoemd. Het genotype van een individu zegt dus alleen iets over zijn genetische aanleg. Hoe een mens eruit ziet, wat zijn eigenschappen en kenmerken zijn, wordt niet alleen door het genotype bepaald, maar ook door talloze milieufactoren. De samenwerking tussen genotype en milieu bepaalt uiteindelijk de verschijningsvorm van een mens. Dit resultaat wordt het fenotype genoemd.

Wanneer één persoon twee allelen bezit die identiek zijn, is hij homozygoot voor die eigenschap. Indien de allelen onderling verschillen is die persoon heterozygoot voor die eigenschap. Welke fenotype dit tot gevolg heeft is afhankelijk van de invloed van de beide allelen. In paragraaf 1.4.2 wordt hier verder op ingegaan. Van de genen die bij de man op het $X$-chromosoom liggen is er maar één allel. In dat geval is een persoon hemizygoot voor die eigenschap.

Het totaal aan DNA-moleculen waarover de mens beschikt heet het genoom. Slechts 2 à 3 procent hiervan bestaat uit genen en ongeveer 22 procent uit niet-coderende delen van de genen. Van de functie van het overige DNA is weinig tot niets bekend. Dit wordt ook wel junk-DNA genoemd.

Er treden regelmatig veranderingen op in de chemische structuur van het DNA. Dit kan gebeuren tijdens de vorming van kiemcellen, bij de gewone celdeling of door externe invloeden. Deze veranderingen worden mutaties genoemd. Wanneer de verandering beperkt blijft tot één gen spreekt men van een genmutatie. Indien de verandering betrekking heeft op een stuk van een chromosoom dat vele genen bevat, spreekt men van een chromosoommutatie. Ook kan het totale aantal chromosomen veranderd zijn. Dit wordt een genoommutatie genoemd.61 Slechts wanneer een mutatie plaatsvindt in de voortplantingscellen, kan de mutatie overgedragen worden op het nageslacht. Dit wordt een erfelijke mutatie genoemd. Wanneer de mutatic optreedt in de gewone cellen, spreekt men van een somamutatie. Somamutaties worden dus niet doorgegeven aan nakomelingen. Somamutaties spelen onder andere een rol bij het ontstaan van kanker. Sommige veranderingen kunnen tot een aandoening leiden, of zijn daarmee geassocieerd. Andere mutaties kunnen juist een beschermende werking hebben en het risico op een bepaalde aandoening door de aanwezige mutatie verminderen. De relatie tussen de aanwezigheid van een mutatie en het zich voordoen van een aandoening wordt de penetrantie van die mutatie genoemd. 62

Een aangeboren aandoening kan zowel genetisch als verworven zijn. Dit laatste is bijvoorbeeld het geval bij een prenatale rode hond-infectie. Wanneer een aandoening

61 De term genoom verwijst zoals opgemerkt naar het totaal aantal DNA-moleculen. In deze context wordt er echter alleen het aantal chromosomen mee bedoeld.

62 Gezondheidsraad 1998, p. 39-40. Aldus ook Cokelaere en Craeynest 1998, p. 80-90 en p. 175. 
genetisch is kan deze zowel erfelijk als niet erfelijk (de genetische oorzaak kan niet worden doorgegeven) zijn. Een erfelijke is aandoening altijd aangeboren en genetisch. De aandoening hoeft zich echter niet gelijk bij de geboorte te openbaren. Een erfelijke aandoening kan ook op latere (kinder)leeftijd tot expressie komen. ${ }^{63}$

\subsubsection{Klassieke zijzen van overerving}

Een afwijking in de chromosomen of in de genen kan op verschillende manieren worden overgeërfd. Hieronder zullen de klassieke wijzen van overerving besproken worden. Opgemerkt dient te worden dat de oude Mendeliaanse opvatting, als zou er een strikte relatie bestaan tussen een eigenschap en een gen, te beperkt is. Met andere woorden: de relatie tussen het genotype en het fenotype is niet zo eenduidig dat zij enkel door de wetten van Mendel verklaard zou kunnen worden. Zo kan het zijn dat één eigenschap pas door een veelheid van genen tot stand komt en/of door verschillende genencombinaties tot stand kan komen. Voor het doel van dit onderzoek kan echter volstaan worden met een opsomming van de klassieke monogene overervingpatronen.

\section{De verschillende overervingwijzen zijn:}

- autosomaal dominante overerving

Autosomaal betekent niet geslachtsgebonden. Het betreft dus de overerving van het erfelijk materiaal gelegen op één van de tweeëntwintig homologe chromosoomparen. Bij een heterozygote samenstelling van twee allelen is het fenotype afhankelijk van de invloed van beide allelen. Wanneer de invloed van het ene allel sterker is dan van het andere, zal in principe alleen de invloed van het sterkste allel tot uiting komen. De expressie van dat allel is in dat geval dominant. 64 Indien één van de ouders dus lijdt aan een door een dominante mutatie veroorzaakte ziekte, dan is het risico voor nageslacht op deze ziekte 50 procent. De kans dat vader of moeder de mutatie doorgeeft is namelijk 50 procent en de expressie van de mutatie is dominant.

- autosomaal recessieve overerving

Bij een heterozygote samenstelling van twee allelen, wordt het allel dat overheerst wordt door het dominante allel, het recessieve allel genoemd. Dit allel kan alleen in homozygote toestand tot uiting komen, dus wanneer een personen twee dezelfde allelen heeft op een chromosomenpaar.65 Indien één van de ouders drager is van een recessieve mutatie in één van de genen, dan is de kans voor nageslacht op de ziekte waartoe de mutatie leidt en waarvan één van de ouders drager is 0 procent. De kans dat vader of moeder de mutatie doorgeeft is 50 procent, maar omdat de mutatie recessief is leidt de doorgave van dit allel niet tot ziekte. Het nageslacht heeft wel 50 procent kans om net als één van de ouders

\footnotetext{
i3 Liebaers en Hamel 1999, p. 288.

(r) Cokelaere en Craeynest 1998, p. 90-91.

65 Cokelaere en Craeynest 1998, p. 90-91.
} 
drager te zijn van de recessieve mutatie (één afwijkend allel en éćn normal allel). Wanneer vader en moeder echter beide drager zijn van een recessieve mutatie in éen van de genen, dan is het risico voor nageslacht op de zickte, waarvan zowel vader als moeder drager zijn, 25 procent. Zowel de kans dat moeder als dat vader de mulatie doorgeeft is 50 procent, waardoor de kans dat ze beide de mutatie doorgeven, en het nageslacht dus zal lijden aan de ziekte, 25 procent wordt. De kans van nageslacht op dragerschap is 50 procent en de kans dat het nageslacht twee normalc genen erft is, net als de kans op twee afwijkende genen, 25 procent.

- geslachtsgebonden overerving

Er zijn maar weinig fenotypische kenmerken bekend die veroorzaakt worden door een allel op het $Y$-chromosoom van de man. Daarentegen zijn er juist veel kenmerken bekend die van het $X$-chromosoom afkomstig zijn. Daarom is het nauwkeuriger om te spreken over $X$-gebonden overerving. ${ }^{66}$

- X-gebonden recessieve overerving

Een man is omdat hij slechts één X-chromosoom heeft hemizygoot voor alle kenmerken die zich op het $X$-chromosoom bevinden. Bij een recessief allel komt de ziekte dus toch tot uiting. Het gen is altijd van de moeder afkomstig omdat zij één van haar $X$-chromosomen doorgeeft. Een vrouw kan veelal de door de afwijking veroorzaakte aandoening niet krijgen, omdat op haar andere $X$-chromosoom het normale gen ligt dat er voor zorgt dat ze in principe de aandoening niet krijgt. Ze kan alleen draagster van het gen zijn. ${ }^{67}$ Mannelijk nageslacht heeft dan vervolgens 50 procent kans het gemuteerde gen te erven en dus de aandoening te krijgen. Zelf kunnen aangedane mannen de aandoening niet doorgeven. Aan mannelijk nageslacht geven zij hun normale Y-chromosoom door en aan vrouwelijk nageslacht geven zij wel het $X$-chromosoom door met het gemuteerde gen, echter dit vrouwelijk nageslacht ontvangt een normaal $X$-chromosoom van moeder, tenzij de moeder draagster is en het gemuteerde gen doorgeeft. ${ }^{68}$

- X-gebonden dominante overerving

Dominante kenmerken komen tot uiting, ongeacht of ze enkelvoudig of dubbel aanwezig zijn op de chromosomen. Hier is er dus geen verschil tussen mannen en vrouwen omdat een afwijking veroorzakende mutatie zowel bij mannen (in een hemizygote toestand) als vrouwen (zowel in een heterozygote als in een homozygote combinatie) in dit geval manifest wordt. Uit de literatuur is echter bekend dat van de meeste genen op het $X$-chromosoom de normale vorm meestal dominant is. Om die reden zijn het meestal mannen die lijden aan een $X$-gebonden afwijking/ziekte.69

\footnotetext{
wo Cokelaere en Craeynest 1998, p. 94.

67 Cokelaere en Craeynest 1998, p. 95.

68 Dit verandert indien het defecte gen in homozygote toestand aanwezig is, dus wanneer een vrouw ook van moeders zijde een defect gen erft.

69 Cokelaere en Craeynest 1998, p. 96.
} 


\subsubsection{Oorzank wan de andoening}

Erfelijke aandoeningen kunnen verschillende afwijkingen in het erfelijk materiaal als oorzaak hebben. Hieronder worden de belangrijkste oorzaken kort besproken:

- chromosomale afwijkingen

Bij een chromosomale afwijking is de oorzaak van de aandoening gelegen in het aantal chromosomen, oftewel een numerieke afwijking of in de hoedanigheid van de chromosomen, oftewel een structurele afwijking. Slechts bij ongeveer 4 procent van de chromosoomafwijkingen is de afwijking van één van de ouders geërfd. De ouder is dan meestal drager van een afwijkende chromosoomrangschikking zonder dat dit gevolgen heeft voor zijn gezondheid. De meeste afwijkingen ontstaan echter tijdens de vorming van de geslachtscellen of bij de eerste delingen van de bevruchte eicel. De kans op afwijkingen neemt toe met de leeftijd van de vrouw en onder invloed van schadelijke uitwendige factoren. Bij de geboorte heeft ruim één op de tweehonderd kinderen $(0,6 \%)$ een herkenbare numerieke of structurele chromosoomafwijking. Het overgrote deel van de vruchten met een numerieke chromosoomafwijking sterft al vroeg in de zwangerschap. ${ }^{70}$

- numerieke chromosoomafwijkingen

Bij numerieke chromosoomafwijkingen is de aandoening te wijten aan een afwijkend aantal chromosomen. Wanneer er één chromosoom te veel aanwezig is, spreekt men van een trisomie. Enkel een trisomie van de chromosomen 13, 18, 21 of de geslachtschromosomen is levensvatbaar. Hiervan is trisomie-21, oftewel het syndroom van Down, het bekendst en het meest vóórkomend. Trisomie-13 veroorzaakt het syndroom van Patau en trisomie-18 veroorzaakt het syndroom van Edwards. Het hebben van drie $X$-chromosomen wordt het triple $X$-syndroom genoemd. I let hebben van twee $X$-chromosomen en een $Y$ chromosoom veroorzaakt het Klinefeltersyndroom. De aanwezigheid ten slotte van twee $Y$-chromosomen en één $X$-chromosoom staat bekend als het XYYsyndroom. Ook is het mogelijk dat er één chromosoom ontbreekt. Dit wordt een monosomie genoemd. Alleen het ontbreken van éen X-chromosoom is met het leven verenigbaar. Vrouwen met een dergelijke afwijking lijden aan het Turnersyndroom.

- structurele chromosoomafwijkingen

Bij structurele chromosoomafwijkingen is de aandoening te wijten aan de hoedanigheid, de vorm van één of meer chromosomen. Indien er een stukje van een chromosoom ontbreekt, noemt men dit een deletie of partiële monosomie. Wanneer een stukje chromosoom dubbel aanwezig is, is sprake van een duplicatie of partiële trisomie. Bij een translocatie zijn stukjes chromosoom van plaats verwisseld. Wanneer daarbij geen erfelijk materiaal verloren gaat, spreekt men van een gebalanceerde translocatie, in het andere geval van een ongebalanceerde translocatie. Gebalanceerde translocaties kunnen voor nageslacht ongebalanceerde translocaties tot gevolg hebben, bestaande uit een 
partiële trisomie of monosomie. ${ }^{71}$ De gevolgen van structurele chromosoomafwijkingen zijn zeer verschillend en sterk afhankelijk van de vraag of er erfelijkheidsinformatie verloren gaat, en zo ja, hoeveel. ${ }^{2}$ Het syndroom van Prader-Willi en het syndroom van Angelman zijn voorbeelden van syndromen die veroorzaakt worden door structurele chromosoomafwijkingen..$^{73}$

- monogene afwijkingen

Bij een monogene afwijking is de oorzaak van de aandoening gelegen in een erfelijke mutatie van één bepaald gen. De penetrantie van zo'n mutatie is bijna honderd procent: de aanwezigheid van één afwijkend gen leidt in principe tot de aandoening. Het aantonen van de mutatie leidt daarom tot de wetenschap dat de ziekte waarmee het gemuteerde gen in verband is gebracht zich vrijwel zeker in de toekomst zal openbaren. Dit hoeft echter niet te betekenen dat steeds hetzelfde gen, of hetzelfde gedeelte van dat gen, verantwoordelijk is voor de aandoening. Identieke aandoeningen kunnen dus door verschillende genen veroorzaakt worden. Een voorbeeld van een monogene autosomale dominante aandoening is de ziekte van Huntington. Een voorbceld van een monogene autosomale recessieve aandoening is Cystische Fibrose.

- multifactoriële afwijkingen

Een multifactoriële afwijking wordt niet alleen bepaald door een erfelijke mutatie in een bepaald gen, maar zoals de naam al aangeeft door een complexe interactie van diverse genetische en omgevingsfactoren. Eén of verschillende mutaties leiden niet rechtstreeks tot een bepaalde aandoening, zij kunnen echter wel het risico op een multifactoriele afwijking verhogen. In zo'n geval is een mutatie een genetische risicofactor. Het aantal bij een bepaalde ziekte betrokken genen kan sterk variëren. Voor het type 1-diabetes zijn bijvoorbeeld al veertien geassocieerde mutaties beschreven, waarvan er één juist een beschermende werking heeft.74 Bekende volksziekten, zoals hart- en vaatziekten en kanker, zijn multifactoriële aandoeningen.

- monogene variant van multifactoriële afwijkingen

Men spreekt van een monogene variant van een multifactoriële afwijking indien de aanwezigheid van een erfelijke mutatie in een gen een zo overheersende factor is, dat men haast kan spreken van een monogene afwijking. De penetrantie van zo'n gen is niet, zoals bij een monogene afwijking, volledig, maar kan oplopen tot meer dan 80 procent. Deze monogene varianten doen zich vaak slechts bij 5 tot 10

7 Cokelaere en Craeynest 1998, p. 199-202.

i2 Cokelaere en Craeynest 1998, p. 196.

73. Beide syndromen zijn het gevolg van een kleine deletie op chromosoom 15 . Bij het syndroom van Prader-Willi is het vaderlijk chromosoom 15 beschadigd en bij het syndroom van Angelman het moederlijk chromosoom 15. Cokelaere en Craeynest 1998, p. 170-171.

74 Gezondheidsraad 1998, p. 43. 
procent van het totaal aantal mensen met de aandoening voor. ${ }^{55}$ Zo'n aandoening zal dus meestal andere oorzaken hebben. Een bekend voorbeeld is erfelijke borstkanker.

\subsubsection{Typen erfelijkheidsonderzoek}

Er zijn twee soorten erfelijkheidsonderzoek te onderscheiden: diagnostisch en voorspellend onderzoek. Bij diagnostisch onderzoek wordt getracht door middel van erfelijkheidsonderzoek een diagnose te stellen of te bevestigen. Naar aanleiding van het onderzoek wordt vastgesteld of de persoon aan de betreffende aandoening lijdt. Het kan mede dienen om een individuele prognose te geven. Bij het zoeken naar een diagnose betreft het vaak de etiologie van verstandelijke handicaps.

Bij voorspellend genetisch onderzoek wordt het risico vastgesteld dat de adviesvrager of zijn nageslacht aan een erfelijke aandoening gaat lijden. Binnen het voorspellend onderzoek zijn er verschillende soorten onderzoeken mogelijk:76

- Voorspellend onderzoek naar dragerschap van een mutatie die leidt tot:

- een autosomale dominant of recessief overervende monogene ziekte bij de adviesvrager of een;

- een geslachtsgebonden overervende monogene ziekte bij de adviesvrager.

Bij dit type onderzoek wordt gezocht naar de aanwezigheid van een mutatie bij een gezond persoon. Deze persoon vertoont nog geen symptomen van de aandoening. Indien deze mutatie wordt gevonden, weet de onderzochte persoon dat bij hem in de toekomst de monogene aandoening waarmee de mutatie is geassocieerd zich zal openbaren.

- Voorspellend onderzoek naar dragerschap van een mutatie die kan leiden tot:

- een autosomale mulifactoriële ziekte bij de adviesvrager of een;

- een geslachtgebonden mulifactoriële ziekte bij de adviesvrager.

Bij dit type onderzoek wordt gezocht naar de aanwezigheid bij een gezond persoon van één of verschillende mutaties die het risico op een multifactoriële aandoening verhogen. Indien deze mutatie wordt gevonden weet de onderzochte persoon dat hij cen verhoogde kans heeft op de aandoening waarmee de mutatie is geassocieerd. De kans op de aandoening voor het nageslacht is vaak moeilijk te bepalen. ${ }^{77}$

Zowel voorspellend onderzoek naar dragerschap van een mutatie die leidt tot een monogene ziekte als onderzoek naar dragerschap van een mutatie die kan leiden tot een multifactoriële ziekte, wordt ook wel presymptomatisch onderzoek genoemd. De

7 Gezondheidsraad 1998, p. 44.

76. De Wert spreekt hier van een continuüm met aan de ene kant van het spectrum monogene ziekten en aan de andere kant multifactoriële ziekten. De Wert 1999, p. 272.

$\pi$ Gezondheidsraad 1998, p. 45-46. 
adviesvrager vertoont geen symptomen van de ziekte warvan het dragerschap wordt onderzocht.

- Voorspellend onderzoek naar dragerschap van een mutatie of een chromosoomafwijking die kan leiden tot een erfelijke aandoening bij nageslacht van de adviesvrager.

Bij een dergelijk onderzoek wordt gezocht naar de aanwezigheid van een mutatie of een chromosoomafwijking bij een gezond persoon. De adviesvrager zal de aandoening waarmee de mutatie of afwijking toe kan leiden, maar wel aan zijn nageslacht doorgeven.

In dit onderzoek zal het voorspellend erfelijkheidsonderzoek aangeduid worden als voorspellend of predictief onderzoek. Indien wordt gedoeld op onderzoek waarbij het risico onderzocht wordt dat de adviesvrager heeft dat hij zal gaan lijden aan een erfelijke aandoening, wordt de term presymptomatisch onderzoek gebruikt. Voor wat betreft de voorspellende waarde is er een verschil tussen de onderzoeken die met de term voorspellend onderzoek worden aangeduid. Men zou kunnen zeggen dat de voorspellende waarde afneemt bij onderzoek naar een multifactoriële aandoening en nog meer bij onderzoek naar dragerschap van een mutatic of chromosoomafwijking die alleen bij het nageslacht kan leiden tot een erfelijke aandoening. Bij het laatste type onderzoek betreft de voorspelling niet de gezondheid van de adviesvrager. Omdat echter bij alle drie de soorten onderzoek het een gezonde adviesvrager betreft die een erfelijkheidsadvies wil betreffende toekomstige risico's op een ziekte voor zichzelf of zijn nageslacht, worden ze met dezelfde term aangeduid. Onderzoek dat dient om een diagnose te bevestigen of mogelijk te stellen zal worden aangeduid als diagnostisch onderzoek.

\subsection{Samenvatting}

In dit hoofdstuk is het onderwerp van deze studie verkend. De kernvraag van dit proefschrift luidt: Wat is het gewenste juridisch kader voor informatie, toestemming en geheimhouding bij erfelijkheidsadvisering in de klinisch genetische centra. Door middel van een juridisch en een empirisch onderzoek zal deze vraag worden beantwoord. Het doel hiervan is om een bijdrage te leveren aan verantwoorde zorg in de klinisch genetische centra. In paragraaf 1.3 is de totstandkoming van de klinisch genetische centra geschetst. Tevens is ingegaan op het huidige functioneren van die centra. Daarbij is aandacht besteed aan de Regeling Klinisch Genetisch Onderzoek en Erfelijkheidsadvisering. Vervolgens is in paragraaf 1.4 het onderdeel van de genetica waar het in deze studie om draait, de erfelijkheidsadvisering, nader omschreven. Het begrip erfelijkheidsadvies is omschreven. Daarnaast is ingegaan op het doel en de gang van zaken bij erfelijkheidsadvisering. Ten slotte zijn in paragraaf 1.5 ter verheldering enige relevante begrippen en onderscheiden aan de orde geweest. Hierbij is aandacht besteed aan de opbouw en werking van ons erfelijkheidsmateriaal en aan de klassieke wijzen van overerving. 
In het volgende hoofdstuk zal de opzet van de studie uiteen worden gezet. Tevens zal een verantwoording van de gebruikte onderzoeksmethoden worden gegeven. Hoofdstuk 3 zal ingaan op het zelfbeschikkingsrecht. Het recht op informatie, het toestemmingsvereiste, het recht op weten en niet weten en de geheimhoudingsplicht zijn op dit rechtsbeginsel gebaseerd. Hoofdstuk 4 behandelt het recht op informatie en het toestemmingsvereiste. In hoofdstuk $5 \mathrm{komt}$ het recht op weten aan bod. Dit recht is als zodanig niet gepositiveerd, maar is af te leiden uit het recht op respect voor de persoonlijke levenssfeer. Hoofdstuk 6 besteedt aandacht aan het recht op niet weten. In hoofdstuk 7 wordt ingegaan op de geheimhoudingsplicht. Genoemde rechten zullen alle worden geanalyseerd in relatie to de erfelijkheidsadvisering. In de hoofdstukken 8, 9 en 10 worden de resultaten van het empirisch onderzoek beschreven en geanalyseerd. Ten slotte worden in hoofdstuk 11 conclusies getrokken en aanbevelingen gedaan. 


\section{VERANTWOORDING UITGANGSPUNTEN EN GEHANTEERDE METHODEN}

\subsection{Inleiding}

In dit hoofdstuk zal een verantwoording worden gegeven van de in dit proefschrift gehanteerde uitgangspunten en methoden. In paragraaf 2.2 worden de uitgangspunten van het juridisch onderzoek besproken. Daarnaast wordt aangegeven op welke wijze de praktijk een bijdrage levert aan de juridische normering van de relatie tussen de adviesvrager en de klinisch geneticus. Paragraaf 2.3 handelt over het empirisch onderzoek. De beschrijving daarvan maakt duidelijk dat een kwalitatieve aanpak de meest geschikte vorm was voor het empirisch onderzoek. Hierop volgt een verantwoording en concrete beschrijving van de gehanteerde onderzoeksmethoden, te weten interviews en observatie. Vervolgens wordt ingegaan op de reikwijdte en representativiteit van het empirisch onderzoek. Ten slotte wordt aandacht besteed aan de data-analyse. Paragraaf 2.4 vat één en ander samen en biedt een korte vooruitblik.

\subsection{Juridisch onderzoek}

De probleemstelling, zoals deze in hoofdstuk 1 nader is toegelicht, luidt als volgt:

Wat is het gezvenste juridisch kader voor informatie, toestemming en gehemhouding bij erfelijkheidsadvisering in de klinisch genetische centra?

Om deze vraag in hoofdstuk 11 te kunnen beantwoorden staat in het juridisch betoog de volgende vraag centraal:

Wat is het juridisch kader inzake informatie, toestemming en geheimhouding bij erfelijkheidsadvisering in de klinisch genetische centra?

In het empirisch onderzoek wordt de volgende vraag gesteld:

Hoe wordt in de praktijk wan de erfelijkheidsadvisering binnen de klinisch genetisch centra met (knelpunten en dilemma's rond) informatie, toestemming en geheimhouding omgegann?

Hieronder wordt beschreven welke methoden zijn gebruikt om de deelvragen te kunnen beantwoorden. Allereerst komt het juridisch betoog aan de orde. Vervolgens de verhouding hiervan tot het empirisch onderzoek. In paragraaf 2.3 wordt ingegaan op de gehanteerde methoden in het empirisch onderzoek. 


\subsubsection{Normatief juridisch kader}

Aan elk juridisch betoog, in casu een betoog over het gezondheidsrechtelijk kader inzake informatie, toestemming en geheimhouding in de klinische genetica, ligt (impliciet) een opvatting ten grondslag over de aard van het recht. In het onderhavig onderzoek wordt ervan uitgegaan dat het recht nomatief van aard is en dat er om die reden altijd een mensbeeld ten grondslag ligt aan het recht. Dit zal niet bij elk rechtsgebied even sterk naar voren komen. In het gezondheidsrecht ontkomt men echter vaak niet aan een normstelling met duidelijke vooronderstellingen. Hierbij valt bijvoorbeeld te denken aan de discussie over de aanvaardbaarheid en de juridische grondslag van euthanasie.

Aan dit onderzoek ligt het beeld ten grondslag van de mens als een vrij en autonoom persoon wiens waardigheid inherent is aan zijn mens-zijn. Op grond van zijn waardigheid dient hij met respect benaderd en behandeld te worden. ${ }^{1}$ Daarnaast wordt ervan uitgegaan dat de mens verantwoordelijkheid draagt en gedwongen is normatieve standpunten in te nemen. In het volgende hoofdstuk wordt hier op teruggekomen.

De vraag naar het juridisch kader inzake informatic, toestemming en geheimhouding bij erfelijkheidsadvisering in de klinisch genetische centra is onderwerp van het juridisch betoog. De beantwoording van deze vraag zal resulteren in een normatief gezondheidsrechtelijk kader voor de erfelijkheidsadvisering in de klinische genetica. Iet zelfbeschikkingsrecht wordt daarbij gezien als leidend rechtsbeginsel. Als uitgangspunt voor het betoog zullen dienen het recht op informatie, de therapeutische exceptie, het recht op niet weten, het toestemmingsvereiste en de geheimhoudingsplicht. Deze rechten en plichten zijn in de Wgbo algemeen omschreven en van toepassing op behandelingsovereenkomsten tussen een hulpverlener en zijn patiënt. Ze zullen worden onderzocht en toegepast op de juridische relatie tussen de klinisch geneticus en de adviesvrager. Hierbij zal blijken dat het goed hulpverlenerschap een belangrijke rol speelt bij de interpretatie en invulling van genoemde rechten en plichten.

\subsubsection{Verhouding tot de praktijk}

Deze studie bevat een juridische en een empirische component. Het verrichten van dergelijk onderzoek veronderstelt een positief antwoord op de vraag of de praktijk een zinvolle bijdrage kan bieden aan de juridische normering van de relatie klinisch geneticus-adviesvrager. Hieronder wordt ingegaan op de wijze waarop de praktijk deze bijdrage levert.

Het uitgangspunt van dit juridisch-empirisch onderzoek is dat er geen strikt en noodzakelijk onderscheid bestaat tussen feiten en normen. De beschrijving van een praktijk en de theorievorming daarover zijn niet strikt van elkaar te scheiden. De

Leenen 2000, p. 33. 
beschrijving van een praktijk is niet een neutrale beschrijving van feiten, maar noodzakelijk een interpretatie ran de praktijk en deswege een normatief geladen beschrijuing.

Deze benadering is in de wetenschaps- en rechtsfilosofie terug te vinden. In de wetenschapsfilosofie wordt niet meer uitgegaan van de objectiviteit van feiten. De wetenschapsfilosoof Popper heeft er in de jaren dertig van de vorige eeuw op gewezen dat warnemingsuitspraken altijd interpretaties zijn van de feiten in het licht van een impliciete dan wel expliciete theorie. Wetenschappelijke kennis is volgens Popper feilbaar van aard. Feiten worden gë̈nterpreteerd vanuit een bepaald gezichtspunt en zijn verbonden met bepaalde verwachtingen. ${ }^{2}$ De objectiviteit van de opgedane kennis bestaat uit het feit dat zij intersubjectief getoetst kan worden. ${ }^{3}$

Volgens de hermeneutische rechtsfilosofie is het recht op te vatten als de interpretatie van een praktijk. Hiemee wordt bedoeld dat de vraag wat het recht is, nooit los gezien kan worden van de normatieve vraag naar wat het recht behoort te zijn. Beschrijvingen van het recht kumnen daarom niet neutraal zijn, alleen in meer of mindere mate normatief. Volgens de hermeneutiek bestaat er dus geen scheiding tussen beschrijvende en warderende rechtswetenschap.

Het juridisch betoog en de normatieve beschrijving van de praktijk zijn evenmin duidelijk van elkaar te scheiden, in tegenstelling tot wat de separate behandeling wellicht suggereert. Ten eerste zijn de Wgbo en de daarin beschreven rechten gebaseerd op de praktijk. Een wet staat nooit los van de praktijk, maar is juist gemaakt om een bepaalde praktijk te reguleren volgens een bepaald ideaal. Ten tweede is het juridisch betoog niet los te zien van de in het empirisch onderzoek opgedane kennis van de praktijk. Hierop wordt hieronder nog teruggekomen. Ten derde hebben klinisch genetici en adviesvragers enige juridische kennis en handelen zij mede op basis daarvan.

Onderhavig onderzoek is een juridisch-empirisch onderzoek. Het doel is enerzijds om door bestudering van de praktijk de wijze waarop met (dilemma's en knelpunten rond) informatie, toestemming en geheimhouding binnen de klinisch genetische centra word omgegaan te identificeren en te beschrijven, en anderzijds om met deze inzichten tot een verdieping van het juridisch kader te komen. Het primaat ligt bij de juridische invulling van het gezondheidsrechtelijke kader van de relatie klinisch geneticus-adviesvrager. De inzichten in de praktijk zullen op verschillende wijzen worden aangewend.

Ten eerste worden in het juridisch betoog de praktijkinzichten verwerkt in die zin dat de in de praktijk van de erfelijkheidsadvisering opgedane kennis, juridische vragen oproept die in het juridisch betoog worden beantwoord. In de juridische literatuur over erfelijkheidsadvisering worden weliswaar ook veel vragen belicht. Bestudering van de praktijk laat echter een diversiteit aan vragen en knelpunten

De Vries 1995, hoofdstuk 2.

De Vries 1995, p. 93. 
zien, welke niet allemaal achter de studeertafel bedacht hadden kunnen worden. Het nut hiervan voor het juridisch betoog is heel concreet merkbaar. Het verbreedt en verdiept het juridisch betoog doordat het vragen toevoegt die anders wellicht niet gesteld en behandeld waren. Bovendien voorkomt de in de praktijk opgedane kennis het stellen van irrelevante vragen.

Ten tweede biedt kennis van de praktijk de mogelijkheid om vanuit het juridisch perspectief hier kritisch op te reflecteren. Hiertoe worden 5 stappen gezet:

- In de empirische hoofdstukken wordt ten eerste beschreven hoe klinisch genetici en adviesvragers omgaan met informatie, toestemming en geheimhouding.

- Ten tweede wordt nagegaan of klinisch genetici en adviesvragers zich kunnen vinden in de uitgangspunten van het juridisch betoog.

- Ten derde wordt onderzocht welke dilemma's en knelpunten klinisch genetici en adviesvragers tegenkomen en hoe zij hiermee omgaan.

- Hierop volgt een beschouwing. Daarin wordt, ten vierde, nagegaan of de wijze waarop klinisch genetici en adviesvragers omgaan met informatie, toestemming en geheimhouding overeenstemt met de wijze waarop hier in het juridisch betoog invulling aan is gegeven. Daarbij wordt ook aandacht besteed aan wat klinisch genetici en adviesvragers daarvan vinden.

- Ten vijfde volgt er op basis van het juridische betoog een kritische reflectie op de wijze waarop klinisch genetici en adviesvragers invulling geven aan het recht op informatie, het toestemmingsvereiste en de geheimhoudingsplicht. In de slotbeschouwing van elk empirisch hoofdstuk worden dan de volgende vragen beantwoord:

- Zijn klinisch genetici en adviesvragers op de hoogte van het recht dat in dat hoofdstuk aan de orde is?

- Delen zij de uitgangspunten van de juridische invulling?

- Wordt het recht dat in dat hoofdstuk aan de orde is toegepast conform de juridische invulling die daaraan is gegeven en wat vinden klinisch genetici en adviesvragers van die invulling?

- Wat zijn daarbij de dilemma's en knelpunten en hoe zijn deze eventueel op te lossen?

\subsection{Opzet en verantwoording empirisch kwalitatief onderzoek}

In het empirisch onderzoek is onderzocht hoe in de praktijk van de klinische genetica met (dilemma's en knelpunten rond) informatie, toestemming en geheimhouding wordt omgegaan. Dit is gedaan met behulp van kwalitatieve onderzoeksmethoden. Het juridisch betoog vormde het theoretisch-normatieve uitgangspunt voor het empirisch onderzoek. Alvorens in te gaan op de wijze van dataverzameling en dataanalyse zal ook hier aandacht worden besteed aan de aard van het onderzoek. 


\subsubsection{De and wan het onderzoek}

Het empirisch onderzock is een kwalitatief onderzoek. Maar wat is kwalitatief onderzoek? Maso en Smaling omschrijven kwalitatief onderzoek als "een vorm van empirisch onderzoek die zich laat typeren aan de hand van de manier van informatie verzamelen, het soort analyse, de onderzoeksopzet, het onderwerp van onderzoek en de rol van de onderzoeker"."

De manier van informatie verzamelen kenmerkt zich door openheid en flexibiliteit. $\mathrm{Er}$ is ruimte voor onvoorziene en ongeplande verschijnselen en een sterke voorstructurering wordt vermeden. Hierbij past een onderzoeksopzet die niet kwantificerend is, maar waarbij verzamelen en analyseren elkaar afwisselen en die gericht is op direct contact met de te onderzoeken werkelijkheid.

Het onderwerp van onderzoek wordt benaderd vanuit de opvatting dat menselijk gedrag voor een niet onbelangrijk deel verklaard kan worden door de betekenisverleningen aan hun omgeving in het dagelijks leven. Het gaat voornamelijk om alledaagse betekenisgeving en om alledaagse betekenisrelaties tussen verschijnselen zoals die tot uiting komen in het alledaagse taalgebruik. De analyse gebeurt niet met behulp van een kunstmatige, numerieke taal, maar wordt beschreven in de alledaagse taal. Deze taal is echter niet dezelfde taal als die van de onderzochten; getracht wordt de werkelijkheid in begrippen te objectiveren. Door de cyclus van verzameling, analyse, reflectie en toetsing verschillende malen te doorlopen en gebruik te maken van verschiliende onderzoeksmethoden wordt deze objectivering mogelijk gemaakt.

Voor de onderzoeker betekent dit dat hij zich meestal als persoon moet inzetten om inzicht te krijgen in de leefwereld (althans in dat gedeelte dat de onderzoeker wil onderzoeken) van de onderzochten. Een centrale gedachte in de kwalitatieve methodologie is de verstehende methode. De onderzoeker moet de omgeving zien zoals de onderzochten die zien. Hij kan zich niet verschuilen achter een onderzoeksinstrument. De onderzoeker is als zijn eigen instrument te beschouwen. Een goede relatie met de onderzochten is dan ook van cruciaal belang.

Kwalitatief onderzoek wordt vaak als subjectief onderzoek getypeerd. Dit is juist als daarmee wordt bedoeld dat het onderzoek zich richt op de betekenisgeving aan en de beleving van de onderzochte aspecten door de onderzochte subjecten. Ook is het juist dat de subjectiviteit van de onderzoeker een grote rol speelt. De onderzoeker moet zich immers kunnen inleven in de belevingswereld van de onderzochte subjecten en is zelf zijn eigen instrument. Kwalitatief onderzoek is niet subjectief in die zin dat er geen methodologische eisen/standaarden aan dergelijk onderzoek gesteld zouden worden. Wel is het zo dat er geen consensus bestaat over de wijze waarop de aan het onderzoek gestelde eisen ingevuld moeten worden. ${ }^{5}$

Maso en Smaling 1998, p. 9.

Maso en Smaling 1990, p. 13. 
Evenals in het juridisch betoog, wordt er bij het empirisch kwalitatief onderzoek vanuit gegaan dat het kennen van de objectieve werkelijkheid een illusie is en dat het maximaal haalbare bestaat uit intersubjectieve consensus over de juistheid van de interpretatie van het onderzoeksveld. Hiermee wordt bedoeld dat de onderzoeksresultaten dezelfde zouden zijn geweest indien een andere onderzoeker het onderzoek had uitgevoerd. Dit zal praktisch niet mogelijk zijn. De onderzoeksresultaten zijn niet los van de onderzoeker te zien. Wel er wordt naar gestreefd dat de onderzoeksresultaten zo min mogelijk worden medebepaald door specifieke eigenaardigheden van de onderzoeker. Er zijn twee standaardmiddelen om de kans op overeenstemming te vergroten, namelijk explicitering van de resultaten en de tussenstappen die genomen zijn om tot die resultaten te komen en standaardisering van instrumenten en procedures. ${ }^{6}$ Voorliggend empirisch onderzoek is voornamelijk op de eerste standaardmethode gebaseerd. Objectiviteit is op drie manieren nagestreefd. Ten eerste in de houding van onderzoeker, te weten het streven naar evenwicht tussen betrokkenheid en distantie. Ten tweede wat betreft de handelwijze, dat wil zeggen de gekozen onderzoeksmethoden en de wijze van uitvoering. Ten derde zal naar objectiviteit worden gestreefd voor wat betreft de onderzoeksresultaten door explicitering van de onderzoeksresultaten en van de tussenstappen die daarvoor genomen zijn. ${ }^{7}$ Op die manier wordt getracht recht te doen aan het object van studie. Bij de beschrijving van de dataverzameling en analyse zal ik in concreto aangeven en inzichtelijk proberen te maken hoe naar methodologische objectiviteit is gestreefd.

I-let bovenstaande laat zien dat kwalitatief onderzoek een vorm van empirisch onderzoek is die de onderzochte werkelijkheid tracht te onderzoeken door de betekenissen te achterhalen die onderzoekssubjecten aan de onderzochte verschijnselen toekennen; door de werkelijkheid te zien zoals de onderzochten deze zien. Dit type onderzoek is geschikt om de vraagstelling te beantwoorden. Kwalitatief onderzoek is naar zijn aard onderzoek dat de manier waarop iets gebeurt wil beschrijven. De vraag hoe in de praktijk met informatie, toestemming en geheimhouding wordt omgegaan, vereist een kwalitatieve onderzoeksbenadering die de betekenis kan beschrijven die klinisch genetici en adviesvragers verlenen aan de onderzochte (juridische) begrippen en kan weergeven hoe daarmee om wordt gegaan. Deze benadering heeft bestaan uit semi-gestructureerde interviews met zowel klinisch genetici als adviesvragers en participerende observatie van gesprekken tussen klinisch genetici en adviesvragers.

\subsubsection{Dataverzameling}

Alvorens is gestart met het verzamelen van de data is een oordeel gevraagd voor het empirisch onderzoek aan de Medisch Ethische Toetsingscommissie van het academisch ziekenhuis Maastricht. Het empirisch onderzoek viel echter niet onder de Wet medisch-wetenschappelijk onderzoek met mensen, daar er geen personen

Swanborn 1990, p. 53 en p. 59.

Smaling 1990, p. 33-35. 
aan handelingen worden onderworpen of personen een bepaalde gedragswijze wordt opgelegd, zoals omschreven in artikel 1 van bedoelde wet. Deswege heeft de Medisch Ethische Toetsingscommissie geen oordeel gegeven over het onderzoek.

De data zijn verzameld door middel van semi-gestructureerde interviews en observatie. Deze dataverzameling is geschied vanuit het juridisch kader. Hier wordt mee bedoeld dat de vragen in de interviews en de aandachtspunten in de participerende observatie gestoeld waren op het juridische perspectief en als vertrekpunt dienden voor het empirisch onderzoek.

De interviews die zijn afgenomen met klinisch genetici waren primair op een tweetal zaken gericht. Ten eerste is aan genetici gevraagd hoe gesprekken met adviesvragers in het algemeen verlopen en welke aspecten daarbij aan de orde worden gesteld. Ten tweede is gevraagd welke knelpunten men daarbij tegenkomt of wat als problematisch wordt ervaren in de praktijk. Door middel van de interviews is getracht om drie vragen te beantwoorden die hiervoor reeds aan de orde zijn geweest. Ten eerste hoe klinisch genetici omgaan met informatie, toestemming en geheimhouding. Ten tweede of klinisch genetici zich kunnen vinden in de uitgangspunten van het juridisch betoog. En ten derde welke dilemma's en knelpunten klinisch genetici tegenkomen en hoe zij hiermee omgaan.

De interviews met adviesvragers waren gericht op hun ervaringen met de praktijk van de erfelijkheidsadvisering. Dit is enerzijds gedaan om het perspectief van de adviesvragers te belichten en anderzijds om de interviews met de adviesvragers te vergelijken met die van klinisch genetici. Aan adviesvragers is gevraagd hoe het gesprek of de gesprekken met de klinisch geneticus verliepen, en wat men daarvan vond. Ook door middel van deze interviews is getracht om de hiervoor genoemde vragen te beantwoorden, maar dan vanuit het perspectief van de adviesvragers. Ten eerste de vraag hoe adviesvragers omgaan met informatie, toestemming en geheimhouding. Ten tweede of adviesvragers zich kunnen vinden in de uitgangspunten van het juridisch betoog. En ten derde welke dilemma's en knelpunten adviesvragers tegenkomen en hoe zij hiermee omgaan. Uit de interviews bleek dat hun ervaringen met de praktijk van de erfelijkheidsadvisering zich voornamelijk richten op de wijze waarop zij werden bejegend en de wijze waarop zij werden geïnformeerd. Daarom zal in de empirische hoofdstukken de aandacht voornamelijk uitgaan naar de klinisch genetici.

Ook de participerende observatie was op genoemde vragen gericht. De participerende observatie bood de mogelijkheid om het beeld van de praktijk dat uit de interviews met klinisch genetici en adviesvragers naar voren kwam te vergelijken met het beeld dat door de observatie werd gevormd. Onderzocht is ten eerste hoe klinisch genetici en adviesvragers omgaan met informatie, toestemming en geheimhouding. Ten tweede of klinisch genetici en adviesvragers zich kunnen vinden in de uitgangspunten van het juridisch betoog. En ten derde welke dilemma's en knelpunten klinisch genetici en adviesvragers zijn tegenkomen en hoe zij hiermee omgaan. 
Door de triangulatie van interviews met klinisch genetici, interviews met adviesvragers en de participerende observatie, wordt de praktijk van de erfelijkheidsadvisering in de klinisch genetische centra driemaal belicht, met als doel intersubjectieve consensus te bereiken over de juistheid van de interpretatie van het onderzoeksveld. Bovendien boden de interviews verschillende perspectieven zodat tevens kon worden nagegaan wat klinisch genetici en adviesvragers vinden van de praktijk van de erfelijkheidsadvisering. Hieronder zal nader worden ingegaan op de wijze waarop de data zijn verkregen.

\subsubsection{Opzet interviews}

De interviews waren semi-gestructureerd. Er is gewerkt met een lijst van onderwerpen, een zogenaamde topiclijst. De vragen stonden niet bij voorbaat vast, evenmin als de volgorde van de onderwerpen die aan bod kwamen. De volgorde van de vragen en de mate warin werd doorgevraagd over een onderwerp was afhankelijk van het gespreksverloop. De vergelijkbaarheid van de verschillende interviews werd gerealiseerd doordat in elk interview dezelfde aspecten aan de orde zijn geweest. ${ }^{8}$

\section{Interviews genetici}

Er zijn in totaal 16 klinisch genetici, al dan niet in opleiding, dan wel basisartsen en 1 genetisch consulente geïnterviewd, dus in totaal 17 interviews. Deze genetisch consulente verricht, onder supervisie, dezelfde werkzaamheden als de klinisch geneticus. Om de leesbaarheid te bevorderen zullen in het vervolg genetici in opleiding, basisartsen en de genetisch consulente als geneticus of klinisch geneticus worden aangeduid. Deze genetici werken verspreid over de acht klinisch genetische centra in Nederland. In Maastricht zijn er drie genetici geinterviewd en in de overige zeven centra twee genetici per centrum. Naar alle genetische centra is een brief gestuurd, waarin het doel van het onderzoek is uitgelegd en is gevraagd of twee klinisch genetici bereid waren mee te werken aan een interview. Alle centra hebben zich hiertoe bereid verklaard. Vervolgens hebben de interviews plaatsgevonden. De interviews zijn op band opgenomen en integraal uitgetypt.

\section{Interviezus adviesoragers}

In totaal zijn 16 adviesvragers geïnterviewd. Aan de genetici werkzaam bij het klinisch genetisch centrum te Maastricht is een brief verstrekt waarin ze werden verzocht adviesvragers te benaderen met de vraag of ze in principe wilden meewerken aan een interview. Na één à twee weken werden ze vervolgens benaderd met de vraag of ze definitief mee wilden werken. Alle adviesvragers kozen ervoor om het interview thuis plaats te laten vinden. Het alternatief was een interview op het klinisch genetisch centrum in Maastricht. Aan de genetici was verzocht adviesvragers te benaderen die één of meer malen het klinisch genetisch centrum hadden bezocht en die in principe nog eenmaal terug zouden komen voor een uitslag of een gesprek waarin meer informatie zou worden verstrekt. Hiervoor waren twee redenen. Ten eerste werd er vanuit gegaan dat adviesvragers die het contact met de geneticus nog niet hadden afgesloten een verse mening over dit contact hadden en

Wester 1995, p. 86. 
dat men zich nog veel kon herinneren van het gesprek. Ten tweede kon het contact nict beïnvloed kon zijn door een positieve, dan wel negatieve uitslag over een erfelijke aanleg. De veronderstelling was dat men eerder geneigd is tot een positief oordeel bij een gunstige uitslag en vice versa. Daar kwam nog bij dat in het geval van een ongunstige uitslag een interview erg belastend kon zijn. ${ }^{9}$ Adviesvragers die voor een eenmalig gesprek een klinisch geneticus hebben geconsulteerd zijn niet benaderd. Hiervoor waren twee redenen aan te voeren. Ten eerste vielen de adviesvragers die na een gesprek besloten hadden geen nader erfelijkheidsonderzoek te ondergaan buiten het bestek van dit onderzoek. De vraag waarom mensen daartoe besluiten is zeker een interessante vraag, maar is niet het voorwerp van dit onderzoek. Ten tweede bevinden zich onder de groep adviesvragers die een cenmalig gesprek hebben, adviesvragers die helemaal geen erfelijkheidsvraag blijken te hebben. Deze adviesvragers zijn bijvoorbeeld doorverwezen door de behandelend arts, zonder dat is stil gestaan bij de vraag of deze mensen wel een erfelijkheidsadvies willen ontvangen. De vooronderstelling was bovendien dat de erfelijkheidsadvisering waarbij met één gesprek wordt volstaan niet wezenlijk verschilt van de erfelijkheidsadvisering waarvoor meerdere gesprekken vereist zijn, zodat het verantwoord leek om alleen adviesvragers te interviewen bij wie de erfelijkheidsadvisering nog niet was afgerond. De aandoening waarop de erfelijkheidsvraag betrekking had was voor de selectie van adviesvragers niet van belang. Centraal stonden de ervaringen en het contact met de klinisch geneticus. De interviews zijn op band opgenomen en integraal uitgetypt.

\subsubsection{Opzet observatic}

Tijdens de participerende observatie zijn 71 gesprekken geobserveerd. Getracht is om gesprekken van zo veel mogelijk verschillende hulpverleners bij te wonen. Vooraf is geen selectie gemaakt. De gesprekken betroffen dus uiteenlopende erfelijkheidsvragen, die zowel een informatief als een afsluitend karakter konden hebben. In de maanden april en mei 2000 zijn er 37 gesprekken van 10 verschillende hulpverleners geobserveerd in het klinisch genetisch centrum in Maastricht en in de maand september 2000 zijn er 34 gesprekken van twaalf verschillende hulpverleners in het klinisch genetisch centrum in Leiden geobserveerd. Voorafgaand aan de gesprekken werd door de hulpverlener aan de adviesvrager uitgelegd wat het doel was van de observatie, dat hetgeen besproken werd uiteraard geheimgehouden zou worden en dat de onderzoeker zelf niet actief deel zou nemen aan het gesprek. Vervolgens werd mondeling toestemming gevraagd. Het is eenmaal voorgekomen dat een adviesvrager toestemming weigerde. De reden hiervoor was niet duidelijk. Tijdens de gesprekken is ervoor gekozen op de achtergrond te blijven door, waar dat mogelijk was, plaats te nemen in een hoek van de onderzoekskamer of aan de zijkant van de tafel. Dit om de indruk te vermijden dat de onderzoeker ook een soort behandelaar was waar adviesvragers zich ook op moesten richten. Door een positie op de achtergrond in te nemen is geprobeerd het gesprek zo min mogelijk te beïnvloeden. Wanneer een hulpverlener de spreekkamer verliet om te overleggen

Hierbij is primair gedacht aan een ongunstige uitslag van een voorspellend erfelijkheidsonderzoek van een ernstige ongeneeslijke of moeilijk te genezen zickte, maar ook andere ongunstige berichten zijn natuurlijk denkbaar. 
met een andere hulpverlener, liep onderzoeker mee, om ook hier getuige van te zijn. Indien de hulpverlener het gesprek om een andere reden onderbrak, bleef onderzoeker achter met de adviesvrager(s). Soms werd dan gevraagd naar het onderzoek, meestal ging het gesprekje echter over koetjes en kalfjes. Een enkele keer werd hulp verleend bij een medisch(e) onderzock of handeling. I-Herbij moet gedacht worden aan het noteren van gegevens. Na afloop van elk gesprek is zo gedetailleerd mogelijk opgeschreven wat had plaatsgevonden tijdens het gesprek.

\subsubsection{Reikwijdte en representativiteit on het empirisch onderzoek}

Het empirisch onderzoek heeft een beperkte omvang gehad. Er zijn zestien adviesvragers en zeventien klinisch genetici geinterviewd. Daarnaast zijn 71 gesprekken tussen klinisch genetici en adviesvragers geobserveerd. De geinterviewde adviesvragers waren allen voor een consult naar het klinisch genetisch centrum in Maastricht geweest en spraken dus over hun ervaringen met dat specifieke centrum. Bovendien betrof het adviesvragers die nog (minstens) eenmal een consult zouden hebben met een klinisch geneticus. Het interview was daardoor beperkt tot hun ervaringen tot dan toe. De genetici werkten verspreid over de acht genetische centra die Nederland momenteel kent. De observatie heeft zich beperkt tot het observeren van consulten die in een bepaalde periode plaatsvonden in twee genetische centra; het klinisch genetisch centrum in Maastricht en het klinisch genetisch centrum in Leiden. De vraag die hier aan de orde is, is die naar de reikwijdte en representativiteit van de onderzoeksresultaten. Wat is met andere woorden de waarde van de bevindingen buiten het aantal adviesvragers en genetici dat is geinterviewd en buiten de geobserveerde consulten in de centra in Maastricht en Leiden? Gelden de resultaten ook voor niet geïnterviewde adviesvragers? Wat zijn de ervaringen van niet geïnterviewde genetici? Hoe informeren niet geobserveerde genetici? Hoe zien gesprekken er in Groningen bijvoorbeeld uit? Dergelijke vragen tonen de kwetsbaarheid van het onderzoek aan. Mogelijk gelden de onderzoeksresultaten alleen voor de geïnterviewde adviesvragers en genetici en de geobserveerde consulten. We weten dan wel, en dat is op zich al waardevol, hoe er in een bepaalde setting invulling wordt gegeven aan de informatieverstrekking, het geven van toestemming en de geheimhoudingsplicht. De ambities strekten echter verder. De vraag was hoe er in de praktijk van de klinische genetische centra mee omgegaan wordt.

Toch is er meer te zeggen over de resultaten. Op grond van hieronder te noemen redenen, moet het op een aantal punten mogelijk zijn om onderbouwde uitspraken te kunnen doen over de praktijk van de klinisch genetische centra in Nederland.

Ten eerste zijn per klinisch genetisch centrum twee klinisch genetici geïnterviewd. Op die manier is de praktijk van elk centrum vanuit het perspectief van twee genetici belicht. Na ongeveer 12 interviews werd een zeker verzadigingspunt bereikt en 
boden de interviews geen nieuwe gezichtspunten. ${ }^{10}$ We veronderstellen dan ook dat interviews met andere klinisch genetici dit evenmin zullen bieden en deswege geen grote verschillen aan het licht zullen brengen.

Ten tweede werd ook bij de interviews met de adviesvragers na ongeveer 12 gesprekken een verzadigingspunt bereikt, waardoor het aantal geinterviewden ons inziens verantwoord was. Het is wel een feit dat de geinterviewden allen het klinisch genetisch centrum in Maastricht hadden bezocht. De voornaamste reden hiervoor was een praktische. Het cmpirisch onderzoek had een beperkte omvang en de interviews met de adviesvragers vormden daar zeker niet de kern van. In de hoofdstukken waarin het empirisch materiaal besproken wordt komt dit interviewmateriaal slechts zeer summier aan de orde. Bovendien blijkt uit het interviewmateriaal dat, hoewel we niet met zekerheid kunnen vaststellen dat de geinterviewde adviesvragers een representatieve groep vormen, de zaken die de adviesvragers naar voren brengen, zoals wat adviesvragers van belang vinden met betrekking tot de informatieverstrekking, een vrij algemeen karakter hebben. Ze bleken niel samen te hangen met de specifieke werkwijze van het klinisch genetisch centrum in Maastricht. Daarom hebben we het materiaal uit deze interviews toch een (zeer bescheiden) plaats gegeven in dit onderzoeksverslag. We gaan er vanuit dat het interviewmateriaal van de adviesvragers slechts een aantal cerste inzichten oplevert met betrekking tot de ervaringen van adviesvragers met de praktijk van de erfelijkheidsadvisering. Het is zeker mogelijk dat interviews met adviesvragers die andere centra hebben bezocht nog aanvullende informatie zou kunnen geven.

De participerende observatie is in twee centra uitgevoerd. Hierbij werd na ongeveer 50 gesprekken een verzadigingspunt bereikt, waardoor het aantal geobserveerde gesprekken, 71 in totaal, ons inziens verantwoord was. Door het feit dat in twee centra is geobserveerd zonder dat dit wezenlijke verschillende toonde, alsmede het aantal gesprekken waarbij is geobserveerd en het aantal klinisch genetici dat tijdens de observaties is geobserveerd, tweeëntwintig in totaal, verwachten we geen wezenlijke verschillen wanneer tevens in andere centra was geobserveerd. Ook hier is echter voorzichtigheid geboden. Observaties in meer centra zouden andere uitkomsten kunnen geven.

Ten vierde zijn de resultaten van het empirisch onderzoek voorgelegd aan klinisch genetici die werkzaam zijn bij het klinisch genetisch centrum in Maastricht als een vorm van memberchecking. Dit leidde tot herkenning, wat een aanwijzing oplevert dat de resultaten breder zijn te interpreteren.

Het blijft echter een feit dat het een onderzoek van beperkte omvang betreft met een verkennend karakter.

10 Van een verzadigingspunt is sprake wanneer er door de onderzoeker geen nieuwe informatie meer wordt verkregen uit het onderzoeksmateriaal. Maso en Smaling 1998, p. 75. Zie ook Bertaux 1983. 


\subsubsection{Data-analyse}

Het juridisch kader is het referentiepunt voor de data-analyse. Eerst is nagegaan hoe in de praktijk met informatie, toestemming en geheimhouding wordt omgegaan. Vervolgens zijn de resultaten van het empirisch onderzoek in een beschouwing geconfronteerd met de uitkomsten van het juridisch betoog. Daarin is nagegaan of de wijze waarop klinisch genetici en adviesvragers omgaan met informatie, toestemming en geheimhouding overeenstemt met de wijze warop hier in het juridisch betoog invulling aan is gegeven. Daarbij is ook aandacht besteed aan wat klinisch genetici en adviesvragers daarvan vinden. Vervolgens is er vanuit het juridisch betoog kritisch gereflecteerd op de wijze waarop klinisch genetici en adviesvragers invulling geven aan het recht op informatie, het toestemmingsvereiste en de geheimhoudingsplicht.

De analyse is cyclisch uitgevoerd. Het verzamelde materiaal is in de zoektocht naar antwoorden geordend en bewerkt. Deze tussentijdse reflectie riep telkens andere vagen op waardoor de cyclus van gegevens verzamelen, analyse en reflectie, van inhoud veranderde." De cyclus werd als voltooid beschouwd toen er geen nieuwe informatie meer werd verkregen. Zoals eerder aangegeven was dit punt bij de interviews na ongeveer 12 gesprekken bereikt. Bij de geobserveerde gesprekken lag dit punt rond de 50 gesprekken. De uitgetypte interviews en uitgeschreven consulten zijn herhaaldelijk nauwgezet doorgelezen. Daarbij zijn in de marge opmerkingen en steekwoorden geplaatst. Vervolgens zijn er samenvattingen gemaakt per hoofdonderwerp. De interviews konden op die manier per hoofdonderwerp met elkaar worden vergeleken. Ook de geobserveerde gesprekken zijn op die manier verwerkt. Per onderwerp is een ordenende en interpreterende samenvatting geschreven. Deze samenvattingen vormen de basis voor de empirische hoofdstukken.

\subsection{Samenvatting}

In dit hoofdstuk zijn de in dit onderzoek gehanteerde uitgangspunten en methoden verantwoord. Paragraaf 2.2 beschrijft de uitgangspunten van het juridisch betoog en de wijze waarop dit zich verhoudt tot het empirisch onderzoek. In paragraaf 2.3 is ingegaan op het empirisch onderzoek. Ten ecrste is de keus voor kwalitatief onderzoek verantwoord. Ten tweede is de dataverzameling aan de orde geweest. In subparagrafen is angegeven hoe de interviews en observatie zijn opgezet. Ten derde is de reikwijdte en representativiteit van het empirisch onderzoek beschreven. Ten slotte is ingegaan op de data-analyse. 
In het volgende hoofdstuk zal het zelfbeschikkingsrecht aan de orde komen. Het zal gepresenteerd worden als het rechtsbeginsel dat de achtergrond vormt van de verdere uitwerking van de rechtsnormen rond informatie, toestemming en geheimhouding in relatie tot de erfelijkheidsadvisering. 



\section{ZELFBESCHIKKING EN ERFELIJKHEIDSADVISERING}

\subsection{Inleiding}

Aan zelfbeschikking wordt in westerse samenlevingen grote waarde gehecht. Mensen willen zelf kunnen beslissen hoe ze hun leven inrichten. In de klinische genetica speelt, meer nog dan bij de specialismen waarbij het curatieve element op de voorgrond staat, zelfbeschikking een grote rol. Bij erfelijkheidsonderzoek speelt de vraag of de adviesvrager wel wil weten welk risico hij loopt om in de toekomst aan een erfelijke zickte te gaan leiden een belangrijke rol. Het belang dat een adviesvrager heeft bij weten kan echter botsen met het belang van een verwant bij niet wit'n. Bij de bespreking van het recht op informatie, de therapeutische exceptie, het recht op weten, het recht op niet weten, het toestemmingsvereiste en de geheimhoudingsplicht zal blijken dat het zelfbeschikkingsrecht van de adviesvrager steeds het uitgangspunt is. In dit hoofdstuk zal nader ingegaan worden op het zelfbeschikkingsrecht zelf. Het wordt in dit onderzoek beschouwd als een rechtsbeginsel dat ten grondslag ligt aan het patiëntenrecht en dus ook aan de in dit proefschrift centraal staande rechten. Het begrip en de functies van rechtsbeginselen worden in paragraaf 3.2 kort toegelicht. In paragraaf 3.3 wordt de ontwikkeling van het zelfbeschikkingsrecht geschetst. Paragraaf 3.4 besteedt aandacht aan de betekenis van het zelfbeschikkingsrecht voor de erfelijkheidsadvisering. Tevens komen de bezwaren aan de orde die tegen het zelfbeschikkingsrecht worden aangevoerd. In paragraaf 3.5 wordt ingegaan op de maatschappelijke context waarin adviesvragers hun zelfbeschikkingsrecht uitoefenen. Het hoofdstuk wordt afgesloten met een samenvatting.

\subsection{Het zelfbeschikkingsrecht als rechtsbeginsel}

Het recht op informatie, de therapeutische exceptie, het recht op niet weten, het toestemmingsvereiste en de geheimhoudingsplicht zijn onderdelen van het gezondheidsrecht. Het gezondheidsrecht is vanaf de jaren vijftig van de vorige eeuw als discipline binnen het recht tot ontwikkeling gekomen. "Het eigen object van het gezondheidsrecht is het geheel van rechtsregels dat op de gezondheid is gericht. Dat geheel is van grondwettelijke en internationaal verdragsrechtelijke, civiel-, bestuursen strafrechtrechtelijke aard." 1 Het is dus een horizontaal specialisme waarbij het onderwerp van de rechtsregels, de zorg voor de gezondheid in brede zin, de bindende factor is. Hierbij moet niet alleen aan wettelijke rechtsregels worden gedacht. Met name het rechtersrecht en de zelfregulering spelen in het gezondheidsrecht ook een belangrijke rol. Daarnaast spelen binnen het gezondheidsrecht, evenals in andere rechtsgebieden en in het recht in het algemeen, rechtsbeginselen een rol. Van der Mijn stelt:

1

Leenen 2000, p. 19. 


\begin{abstract}
"Rechtsbeginselen, $z o$ is in het algemeen de opvatting, zijn grondgedachten die in en achter elk rechtssysteem zitten en die zozeer de waarde en de waardigheid van de mens raken dat ook de overheid deze dient te eerbiedigen en niet mag schenden zonder aan haar eigen macht elke zedelijke grondslag te ontnemen. Rechtsbeginselen zijn ongeschreven maar vinden hun uitwerking in wettelijke bepalingen en rechterlijke beslissingen. Zij hebben als het ware een dubbelfunctie: enerzijds vormen $z$ ij het fundament van cen positiefrechtelijk systeem, anderzijds zijn zij een kritische toetssteen tegenover een positiefrechtelijk systeem."2
\end{abstract}

Daar kan men nog aan toevoegen dat rechtsbeginselen ook een legitimerende en rechtsvormende functie hebben. Rechtsbeginselen kunnen gezien worden als het "zenuwstelsel van het recht". Zij hebben een gewetensfunctie. ${ }^{3}$ Rechtsbeginselen hebben "intern normatieve kracht zonder een exact meetbare werking te hebben"."

Een voor het gezondheidsrecht, en met name voor het patiëntenrecht, belangrijk rechtsbeginsel is het zelfbeschikkingsrecht. ${ }^{5}$ Het patiëntenrecht, waar het recht op informatie, het toestemmingsvereiste en de geheimhoudingsplicht een onderdeel van zijn, is in zijn totaliteit te zien als een uitdrukking van het zelfbeschikkingsrecht. In het patiëntenrecht fungeert het zelfbeschikkingsrecht als het normatieve kader waarbinnen de patiëntenrechten gestalte krijgen.

Het zelfbeschikkingsrecht is geen statisch beginsel met een onveranderlijke inhoud. Het is aan verandering onderhevig en groeit mee met de ontwikkeling van de samenleving. Het is in de twintigste eeuw een steeds grotere rol gaan spelen in het westerse mensbeeld, het recht en specifiek ook het gezondheidsrecht. ${ }^{6}$ Om die reden zal hieronder een korte beschrijving worden gegeven van de ontwikkeling van het zelfbeschikkingsrecht in het gezondheidsrecht.

\title{
3.3 Ontwikkeling van het zelfbeschikkingsrecht
}

Bij de ontwikkeling van het gezondheidsrecht speelde de uitwerking van de rechten van de mens na de Tweede Wereldoorlog een rol. ${ }^{7}$ Bij deze uitwerking speelde het zelfbeschikkingsrecht als rechtsbeginsel een belangrijke rol. Zo bevatten de Universal

Van der Mijn 1990, p. 122.

Kelk 1990, p. 111.

Kclk 1990, p. 111.

5 Het woord recht moet hier gezien worden in zijn algemene normatieve betekenis en niet als een juridische regel. Leenen 2000, p. 32.

- De wortels van het zelfbeschikkingsrecht liggen in de periode van de Verlichting (17021789). Van belang hierbij is het gedachtegoed van Hume, Kant en Rousseau geweest. Het is echter vooral Mill geweest die grote invloed heeft uitgeoefend op het huidige zelfbeschikkinsconcept. In zijn visie is vrijheid op te vatten als het gevrijwaard worden van dwang en inmenging door anderen in het leven van het individu. Ten Have, Ter Meulen en Van Leeuwen 1998, p. 104. Overigens is het recht op respect voor de persoonlijke levenssfeer in deze opvatting reeds te herkennen. Leenen 2000, p. 14. 
Declaration of Human Rights uit 1948, als de International Covenant on Civil and Political Rights uit 1966 en de European Convention for the Protection of Human Rights and Fundamental Freedoms uit 1950 artikelen met voor het zelfbeschikkingsrecht relevante grondrechten. 8

Leenen wijst erop dat ontwikkelingen in de gezondheidszorg steeds meer raken aan de menselijke zelfbeschikking. Hij stelt dat wetenschap en techniek leiden tot steeds dieper gaande ingrepen in de mens en dat de gezondheidszorg meer en meer een groot, ingewikkeld en bureaucratisch apparaat geworden is, waaraan de patiënt ondergeschikt raakt. Ook buiten de gezondheidszorg kan het zelfbeschikkingsrecht onder druk komen te staan. Hierbij valt te denken aan medische keuringen. ${ }^{9}$ Met name de dieper gaande ingrepen waartoe wetenschap en techniek leiden, raken in de klinische genetica aan de zelfbeschikking van de adviesvrager en diens familie. Hierop wordt in de volgende paragraaf teruggekomen.

In het gezondheidsrecht zelf hebben veranderde opvattingen geleid tot kritische geluiden betreffende de rechtspositie van de patiënt. In de jaren zeventig van de vorige eeuw werd allereerst de rechtspositie van psychiatrische patiënten aan de orde gesteld. In de rechtspraak werden de juridische normen voor een gedwongen opname aangescherpt. Ippel merkt hierover op dat:

\begin{abstract}
"klaarblijkelijk een in brede lagen van de samenleving levend bewustzijn was gegroeid, dat de vrijheid en het burgerschap van psychiatrische - en andere - patiënten bedreigd $x$ ijn en dat ter wille van behoud of herwinning van zelfbeschikking actie is geboden. (...) Deze verschuiving manifesteerde zich ook op andere terreinen. Het was immers de episode waarin vrouwen het zelfbeschikkingsrecht over abortus voor zich opeisten. Het debat over de aanvardbaarheid van euthanasie kwam sterk in het teken te staan van 'het recht om menswaardig te sterven'."10
\end{abstract}

In 1973 introduceert Rang in zijn oratie de term patiëntenrecht. ${ }^{11}$ Hij constateert dat de positie van de patiënt niet, op een negatieve of op een indirecte wijze in het Nederlandse recht naar voren komt. Deze negatieve of indirecte bescherming heeft bovendien een bevoogdend karakter. Hierover merkt hij op:

"Voor deze verouderde benadering is geen plaats meer nu er sprake is van persoonlijkheidsrechten, rechten waarover de mens moet kunnen beschikken om zich te ontplooien, om waarachtig mens te zijn, zoals het recht op leven, het recht op het eigen lichaam, het recht op erkenning en eerbiediging van de lichamelijke en geestelijke integriteit, het recht ook op sterven. (...) Het belang van deze persoonlijkheidsrechten neemt toe naarmate de mens in een meer kwetsbare en

s Voor de Universal Declaration of Human Rights zijn dat de artikelen 3, 5, 12 en 18. Voor de International Convenant on Civil and Political Rights betreffen dat de artikelen $6,7,9,10,17$ en 18. En voor de European Convention for the Protection of Human Rights and Fundamental Freedoms gaat het om de artikelen 2, 3, 5, 8 en 9.

$9 \quad$ Leenen 2000, p. 34.

$10 \quad$ Ippel 1994, p. 39.

11 Rang 1973, p. 14-15. 
afhankelijke positie komt te verkeren. Vandaar ook dat het zinvol is te spreken over een patiëntenrecht dat mede op de persoonlijkheidsrechten is gebaseerd."1?

Het woord zelfbeschikking wordt als zodanig niet grenoemd. Duidelijk is echter dat Rang dit op het oog heeft wanneer hij spreekt over ontplooiing en waarachtig mens zijn. In 1978 besteedt Leenen in zijn gezondheidsrechtelijke studie uitgebreid aandacht aan het zelfbeschikkingsrecht en wijst hij op de relatie met de rechten van de patiënt. ${ }^{13}$ In de rechtspraak en literatuur heeft deze gedachte onder meer geleid tot het erkennen van een informatieplicht van de arts, waarbij het onder omstandigheden niet informeren van die patiënt aan steeds strengere normen is gebonden. I. Volgens de huidige opvattingen is de patiënt degene die zijn eigen individuele normen stelt. De arts stelt bij een klacht vast welke behandeling of welke onderzoek op medische gronden gëndiceerd is, maar de patiënt beslist vervolgens hoe dit gezondheidsbelang in verhouding staat tot zijn andere belangen. Vaak zullen deze belangen overeenkomen. In onze cultuur wordt immers grote waarde gehecht aan een zogenaande goede gezondheid. Vanzelfsprekend is dit echter niet meer. In de klinische genetica is niet altijd sprake van een voor de hand liggende medische optie. Aan de gevolgen hiervan voor de informatieplicht wordt in het volgende hoofdstuk aandacht besteed.

Het zelfbeschikkingsrecht is niet gepositiveerd in de Grondwet. ${ }^{15}$ Wel zijn daar sinds 1983 in de artikelen 10 en 11 het recht op privacy en het recht op lichamelijke integriteit in opgenomen die als een partiële positivering van het zelfbeschikkingsrecht worden gezien. Het belang van het beginsel is in de jaren negentig van de vorige eeuw, behalve in de Wgbo, ook tot uiting gekomen in een groot aantal wetten waarbij het zelfbeschikkingsrecht in de vorm van patiëntenrechten een rol speelt. ${ }^{16}$

Op de gezondheidszorg toegesneden documenten met voor het zelfbeschikkingsrecht relevante bepalingen betreffen de Declaration on the Promotion of Patient's rights in Europe, het Verdrag inzake Mensenrechten en Biogeneeskunde en verschillende resoluties van het Europees Parlement. In het eerstgenoemde document wordt het zelfbeschikkingsrecht expliciet genoemd in artikel $1.2 .{ }^{17}$

$12 \quad$ Rang 1973, p. 14.

13 Leenen 1978, p. 29.

1.4 In hoofdstuk 4 wordt hier meer aandacht aan besteed.

15 Dekkers pleitte daar in zijn proefschrift wel voor. Hij stelde de volgende formulering voor: "Ieder heeft het recht de eigen persoonlijkheid te ontplooien en aan te wenden naar eigen inzicht, voorzover hij daarmee niet rechten en vrijheid van anderen schendt en behoudens ieders verantwoordelijkheid voor de wet." Dekkers 1979, p. 18.

16 Hierbij valt onder andere te denken aan de Wet bijzondere opnemingen in psychiatrische ziekenhuizen, de Wet klachtrecht cliënten zorgsector, de Wet orgaandonatie, de Wet medereggenschap cliënten zorginstellingen en de Wet medischwetenschappelijk onderzoek met mensen.

17 Leenen 2000, p. 40-41. 


\subsection{De betekenis van het zelfbeschikkingsrecht voor de erfelijkheidsadvisering}

De grondslag van het zelfbeschikkingsrecht is het beeld van de mens als een vrij en autonoom persoon wiens waardigheid inherent is aan zijn mens-zijn. Op grond van zijn waardigheid dient hij met respect benaderd en behandeld te worden. ${ }^{18}$ Scheltens noemt de inherente waardigheid van de mens het allesbeheersende beginsel. ${ }^{19}$ De mens is een lichamelijk en geestelijk wezen dat boven het enkel biologische uitstijgt. Dit betekent dat hij kan denken en handelen. Op grond daarvan is de mens verantwoordelijk en moet hij keuzes maken. Een mens is gedwongen normatieve standpunten in te nemen. De keus voor een neutraal standpunt is ook een keus. Als deze keus een afwijking inhoudt van de gangbare normen en waarden, dan dient dit gerespecteerd te worden. Dat een mens het recht heeft om over zijn eigen leven te beschikken wil niet zeggen dat hij dat feitelijk ook altijd kan. Er zijn verschillende factoren die onze autonomic kunnen beperken. Het ontbreken van zelfbepaling als eigenschap tast het rechtsbeginsel als waarde echter niet aan. Het is bij uitstek de taak van het recht om zo veel mogelijk ruimte en mogelijkheden te bieden voor de uitoefening van het zelfbeschikkingsrecht. ${ }^{20}$ Het zelfbeschikkingsrecht is naar zijn aard een individueel rechtsbeginsel. Iedereen kan er aanspraak op maken dat dit vrijheidsrecht niet wordt geschonden. Het is met andere woorden een negatief claimrecht. Het geeft niet aan hoe invulling moet worden gegeven aan de keuzes die het zelfbeschikkingsrecht met zich mee brengt. ${ }^{21}$

Kenmerkend voor een rechtsbeginsel is dat de precieze inhoud niet exact is aan te geven, dat deze inhoud in de tijd verandert en afhangt van de omstandigheden. Kelk noemt het zelfbeschikkingsrecht open-ended en stelt dat het in verschillende situaties een eigen betekenis, frequentie en intensiteit van toepasselijkheid heeft.22 Wel zijn er grenzen aan te stellen. Daar het echter een rechtsbeginsel betreft dat uitdrukking geeft aan ons mensbeeld waarbij wij aan de mens inherente waarde toekennen en op grond daarvan vinden dat hij zo veel mogelijk naar eigen beslissing moet kunnen leven, moeten zware eisen aan beperkingen worden gesteld. Leenen noemt vier grenzen aan het zelfbeschikkingsrecht. Ten eerste wordt het zelfbeschikkingsrecht begrensd door datzelfde recht van anderen. Ten tweede mag de uitoefening van het zelfbeschikkingsrecht niet tot schade bij anderen lciden. Deze grens omvat zowel

is Leenen 2000 , p. 33.

19 Scheltens 1981, p. 58. In 1948 is dit beginsel in de Universal Declaration of Human Rights crkend.

20) Dute 1994, p. 127.

21 Deze invulling grijpt terug op het liberale gedachtegoed van Mill. De ethiek kan hier $w \mathrm{cl}$ een invulling aangeven. Zo werkt Bolt in haar dissertatie een concept tuit van autonomie voor de praktijk van de erfelijkheidsadvisering. Daartoe hanteert zij een inclusief rationaliteitsbegrip warin zij ervan uitgaat dat het welzijn van de adviesvrager verbonden is met het welzijn van anderen. Het inclusieve rationaliteitsbegrip vereist dat de uniciteit en het welzijn van de ander in het handelen wordt inbegrepen. Met behulp van dit begrip kan in de erfelijkheidsadvisering worden afgewogen of een adviesvrager al dan niet goede redenen heeft voor zijn keuze. Bolt 1997, hoofdstuk 4 .

$22 \quad$ Kelk 1990, p. 114 . 
schade aan een ander persoon als schade aan de collectiviteit. Een derde grens is te vinden in het algemeen belang. Ten slotte kan het zelfbeschikkingsrecht begrensd worden door een bestaande ongerechtvaardigde ongelijkheid tussen mensen of om machtsverhoudingen te reguleren. ${ }^{23}$

Met name de eerst genoemde grens is voor de erfelijkheidsadvisering van belang. Het zelfbeschikkingsrecht van de adviesvrager wordt begrensd door hetzelfde recht van zijn verwanten. De volgende situaties zijn hierbij denkbaar.

Ten eerste brengt kennis van de adviesvrager over zijn genetische constitutie kennis met zich mee over die van familieleden. Deze kennis zal in de meeste gevallen bestaan uit de wetenschap dat verwanten een verhoogd risico lopen op een erfelijke aandoening. De kennis kan echter zo ver gaan dat de adviesvrager weet dat één van zijn ouders drager is van een genmutatie die lijdt tot een bepaalde aandoening of een verhoogd risico daarop geeft. Dit is het geval wanneer een ziekte van een grootouder de aanleiding was voor een erfelijkheidsonderzoek. Het aantonen van een mutatie leidt tot de wetenschap dat de mutatie is doorgegeven door de ouder, die zelf dus tevens drager ervan is. Het is echter de vraag of familieleden over die kennis willen beschikken.

Ten tweede is om erfelijkheidsonderzoek te kunnen verrichten, in veel gevallen de medewerking van een familielid noodzakelijk. Dit familielid hecft echter het recht om hier niet aan mee te werken. Daarnaast kan ook hier de vraag spelen of het familielid wel over bepaalde kennis wil beschikken. Het familielid moet immers op de hoogte worden gesteld van het voornemen van de adviesvrager en, indien hij dit nog niet wist, van het feit dat de aandoening waaraan de index-persoon lijdt of heeft geleden (mogelijk) een erfelijke aandoening is. Het feit dat een bepaalde aandoening erfelijk is, kan bovendien medische consequenties hebben. Zo is bij erfelijke borstkanker de kans dat de kanker terugkomt, hoger dan bij de niet erfelijke vorm.

Ten derde kan het uitoefenen van het zelfbeschikkingrecht door ouders botsen met het toekomstige zelfbeschikkingsrecht van hun kind. Het betreft dan niet het recht om over erfelijkheidsinformatie betreffende de eigen gezondheid te beschikken, maar het recht van ouders om informatie over hun kind te vergaren. Dit kan botsen met het recht van het kind om in de toekomst zelf te kunnen beslissen of het wil weten of het een risico heeft op een bepaalde aandoening dan wel of zich een ziekte bij hem zal openbaren. Ook kan het zelfbeschikkingsrecht van ouders botsen met te beschermen belangen van hun toekomstige kind. In hoofdstuk 6 wordt hierop teruggekomen.

De vraag is telken male wanneer een inbreuk op het zelfbeschikkingsrecht van verwanten toelaatbaar is. Op deze vraag is geen eenduidig antwoord te geven. Veel zal afhangen van de specifieke omstandigheden van de adviesvrager en diens familieleden. De volgende relevante factoren kunnen worden genoemd. Een belangrijke factor is de kans dat de erfelijke aandoening tot gezondheidsschade zal

23 Leenen 2000, p. 36 . 
leiden alsmede de mogelijkheden om deze te voorkómen of te reduceren. Een tweede factor zijn de persoonlijke omstandigheden van zowel de adviesvrager als diens familieleden. Met name de psychische draagkracht is hierbij van belang. Van belang is voorts de kans dat verwanten op de hongte raken van de uitslag van het erfelijkheidsonderzoek. Een andere factor die van belang kan zijn, is de vraag hoeveel personen willen beschikken over bepaalde informatie en hoeveel personen van deze informatie verschoond willen blijven. In de volgende hoofdstukken zal bij de nadere uitwerking van de verschillende rechten van de adviesvrager en diens bloedverwanten hierop terug worden gekomen.

Door verschillende auteurs zijn bezwaren aangevoerd tegen de grote nadruk die in het gezondheidsrecht op rechtsbeginselen als het zelfbeschikkingsrecht wordt gelegd.24 Ook de relatie tussen patiëntenrechten en het zelfbeschikkingsrecht wordt door sommigen ontkend. De vraag of en door welke rechtsbeginselen het gezondheidsrecht wordt gedragen is in deze studie niet aan de orde. Evenmin de vraag of het gezondheidsrecht als discipline meer dan andere disciplines door rechtsbeginselen en grondrechten wordt genormeerd. De ontkenning van het zelfbeschikkingsrecht als rechtsbeginsel is hier wel van belang, alsmede de kritiek waarin het verband tussen het zelfbeschikkingsrecht en het patiëntenrecht wordt ontkend. De kritiek houdt onder meer de volgende punten in.

Ten eerste wordt het zelfbeschikkingrecht als zodanig ontkend, en dus ook de relatie tussen dit beginsel en de Wgbo, door hen die geloven in een hogere macht. Zo ontkenden tijdens de behandeling van de Wgbo in de Tweede Kamer de confessionele partijen een verband tussen het zelfbeschikkingsrecht en de artikelen 10 en 11 in de Grondwet en het verband tussen het zelfbeschikkingsrecht en de Wgbo. ${ }^{25}$ Juist in het zelfbeschikkingsrecht wordt echter de nadruk gelegd op het leven volgens de eigen normen en waarden en doet daarmee recht aan de morele pluriformiteit. Dit kan een keuze zijn om de normen en waarden van hogerhand opgelegd te krijgen, welke respect verdient. Het aanhangen van een geloof is dan ook een vorm en uiting van zelfbeschikking. ${ }^{26}$ Het is waarschijnlijk eerder de voor sommigen negatieve connotatie van het woord zelfbeschikking die zoveel verzet oproept. Het wordt geassocieerd met "doorgeschoten individualisme, het verwerpen van traditionele gezagsverhoudingen binnen het gezin en - meer algemeen - gebrek aan overkoepelend normbesef".27 Dit betreffen echter allemaal verwerpingen van mogelijke gevolgen van invullingen van het zelfbeschikkingsrecht. Er wordt met andere woorden geprotesteerd tegen bepaalde normen en waarden, niet tegen het zelfbeschikkingsrecht als zodanig.

Kritiek van hele andere orde is de onbepaaldheid van het beginsel, de geringe juridische kracht en het vermeende gebrek aan meerwaarde ten opzichte van de

24 Zie bijvoorbeeld Sluijters 1985, Van der Burg en Oevermans 1994, p. 187-202 en Engberts 1997.

25 Engberts 1997, p. 251-253.

$26 \quad$ Leenen 2000, p. 38.

$27 \quad$ Engberts 1997, p. 252. 
artikelen 10 en 11 Grondwet.28 Ik noem deze drie kritiekpunten tezamen omdat zij alledrie de eigen functie van een rechtsbeginsel miskennen. Het kan naar zijn aard niet exact en uitputtend beschreven worden. Evenmin is het een afdwingbaar recht. Het zelfbeschikkingsrecht is een rechtsfilosofisch idee en als zodanig onderdeel van het juridisch gedachtegoed. Zo bezien is de vraag of het een meerwaarde heeft irrelevant. Het heeft een andere functie.

Ten slotte wordt benadrukt dat patiëntenrechten zich als civielrechtelijke verhoudingen manifesteren. Sluijters zegt hier over:

"Bij patientenrechten, bijvoorbeeld, gaat het voomamelijk om rechten van de patiënten ten opzichte van artsen, andere beroepsbeofenaren en instellingen. Dat zijn civielrechtelijke verhoudingen. (...) Het is niet nodig en ongewenst, om, zoals zo vaak gebeurt, deze rechten juist in de eerste plats op de grondrechten te baseren." 29

Sluijters stelt terecht dat de rechten van patiënten ten opzichte van artsen civielrechtelijk ingekaderd zijn. Het feit dat ervoor is gekozen om patiëntenrechten in het civiele rechtsgebied op to nemen, welke keus ook anders uit had kunnen vallen, ${ }^{30}$ levert echter geen doorslaggevend argument op om een achterliggend rechtsbeginsel noch de relatie met de artikelen 10 en 11 Grondwet te ontkennen. Zo is het verband tussen artikel 11 Grondwet en het toestemmingsvereiste toch evident. Het geven van toestemming voor een behandeling of onderzoek voorkomt een schending van de lichamelijke integriteit van de patient. Zijn toestemming of weigering daarvan is een duidelijke vorm van zelfbeschikking.

\subsection{Zelfbeschikking in de maatschappelijke context}

Het zelfbeschikkingsrecht is het rechtsbeginsel dat ten grondslag ligt aan het recht op informatie, het recht op niet weten, de therapeutische exceptie, het toestemmingsvereiste en de geheimhoudingsplicht van de klinisch geneticus. Het moet tezamen met de genoemde rechten waarborgen dat de adviesvrager autonome, vrije geïnformeerde keuzen kan maken met betrekking tot de erfelijkheidsadvisering. Kenmerkend voor het zelfbeschikkingsrecht is, zoals aangegeven, dat de precieze inhoud niet exact aan te geven is. Wel is het mogelijk om een beeld te schetsen van de bredere maatschappelijke context waarin adviesvragers dit zelfbeschikkingsrecht uitoefenen.

Het vertrouwen en geloof in de wetenschap en techniek zijn in onze maatschappij groot. Het is als de moderne levensvisie te beschouwen. Deze visie is zo ingeburgerd geraakt dat zij als zodanig vaak niet eens herkend wordt. Een publiek debat wordt

28 Zie bijvoorbeeld Visser 't Hooft 1979, p. 181-189, Sluijters 1985 en Engberts 1997, paragraaf 16.

29 Sluijters 1985, p. 24.

30 In Finland bijvoorbeeld is de hulpverlener-patiënt relatie administratiefrechtelijk geregeld. 
gevoerd in algemene termen. Levensbeschouwelijke overtuigingen zijn privé en horen daar niet in thuis. Het is echter niet zo dat alleen argumenten met een religieuze achtergrond blijk geven van vooropgezette overtuigingen. Een ieder heeft een levensvisie. Het geloof in de wetenschap en techniek is ook een levensvisie. ${ }^{31}$

Dit geloof in de wetenschap is begrijpelijk tegen de achtergrond van de risicocultuur die zich in Nederland in de vorige eeuw ontwikkeld heeft. Het spreken in termen van risico's om onze toekomstige gezondheidstoestand in te schatten is tegenwoordig vrij vanzelfsprekend. Het begrip risico verwijst echter naar een stijl van redeneren die afkomstig is uit de wetenschap. Het begrip gezondheidsrisico heeft zich ontwikkeld in relatie tot de epidemiologie. De epidemiologie heeft een geprivilegieerde positie ingenomen, waarbij de representaties van risico's als feiten zijn gaan gelden. Dit heeft met zich meegebracht dat wetenschappelijke inzichten in risico's en de norm van beheersing van ziekte en sterfte samen gaan. Het idee is ontstaan dat ziekte en gezondheid tot op grote hoogte maakbaar en beheersbaar zijn en moeten zijn. Zaken die ons kunnen overkomen worden niet als lot maar als risico gedefinieerd. Dat de beheersing van risico's als een goede zaak wordt gezien blijkt uit de vanzelfsprekende verbinding tussen onderzoek naar gezondheidsrisico's en pleidooien voor preventie. Voorbeelden zijn de voorlichtingscampagnes die wijzen op de gevaren van roken en vet eten en aangeven dat dit de kans op kanker en hartinfarcten vergroot. ${ }^{32}$

Bovendien is er sprake van een vermaatschappelijking van de geneeskunde. Enerzijds is de geneeskunde zich steeds meer met de samenleving gaan bemoeien. Artsen zijn een steeds belangrijkere rol gaan spelen bij de coördinatie van maatschappelijke afhankelijkheidsverhoudingen, bijvoorbeeld bij de advisering over sociale en private verzekeringen, en als poortwachter voor sociale voorzieningen. Anderzijds is de samenleving zich steeds meer met de geneeskunde gaan bemoeien. Een arts functioneert te midden van een uitgebreid netwerk van regelingen en toezichthouders. Te denken valt aan de Inspectie voor de Volksgezondheid, verzekeraars en ziekenhuisdirecties. Aan dit proces van vermaatschappelijking van de geneeskunde levert de voorspellende, niet klachtgebonden, maar risicogeoriënteerde, geneeskunde een grote bijdrage. Men wendt zich tot een arts voor voorlichting over gezondheidsrisico's op basis van gezondheidsproblemen in de familie, voorlichting door de media of door professionals. Het initiatief kan ook liggen bij een gezondheidszorginstantie die individuen oproept op grond van algemene kennis over risico's die mensen lopen. Een groot aantal actoren is aldus betrokken bij de relatie tussen de hulpverlener en hulpvrager. ${ }^{33}$

Binnen dit geheel, waar onze gezondheid veelal in termen van risico's wordt gedefinieerd, krijgt de genetica grote aandacht. De toepassingsmogelijkheden en vooral mogelijke tockomstige toepassingen spreken tot de verbeelding. Daarnaast is de maatschappelijke invloed van de genetica duidelijk waarneembaar. Zo verandert

Jochemsen 1999.

Horstman, De Vries en Haveman 1999, paragraaf 2.3.

Horstman, De Vries, en Haveman 1999, paragraaf 2.2. 
de definitie van ziekte. Ten Have wijst erop dat burgers in feite worden behandeld alsof ze een ziekte hebben wanneer de kans bestaat om de aanleg voor een ziekte door te geven. Hij gebruikt de term geneticalisering om de toenemende invloed van de genetica op de maatschappij aan te geven. In de geneeskunde zelf is bovendien ook de neiging ontstaan om vrijwel alle ziekten op genetisch niveau te verklaren en te behandelen. Dit genetisch paradigma maakt volgens Ten Have andere perspectieven ondergeschikt aan de genetische benadering. ${ }^{34}$ Een groot geloof in de mogelijkheden van de genetica en daarbij het beheersen van risico's waar dat mogelijk is als vanzelfsprekend uitgangspunt van verantwoord handelen, maken het welhaast vanzelfsprekend om een erfelijkheidsonderzoek te laten verrichten.

In dat licht is de uitkomst van een door het Nederlands Huisartsen Genootschap ingesteld onderzoek niet verwonderlijk: van de bevolking meent $87 \%$ dat beter 1000 mensen voor niets onderzocht kunnen worden dan dat bij 1 persoon een ernstige aandoening over het hoofd wordt gezien. ${ }^{35}$ Onderzoek wijst in dezelfde richting. Veel jonge moeders zullen hun pasgeboren baby 24 uur naar een screeningskliniek brengen indien zij daarmee het risico van 1 op 90.000 op een ernstige ziekte kunnen uitsluiten. Van de bloeddonors zou $49 \%$ zich zorgen maken wanneer dit een risico van 1 op 5 miljoen op het AIDS-virus met zich mee zou brengen. ${ }^{36}$ De verklaring voor dit, gezien de risico's sterk irrationele, gedrag wordt gezocht in de geneigdheid van mensen tot binair denken. Men laat zich niet leiden door de omvang van een risico, maar door het feit dat er een risico is. Wanneer er een risico is, wordt dit beleefd als een risico van 1 op 2, hoe klein dit risico feitelijk ook is. Daarnaast is er het aspect van de geanticipeerde beslissingsspijt. Men wil voorkomen achteraf spijt te krijgen van de beslissing om geen medisch onderzoek te laten verrichten. ${ }^{37}$

Het voorgaande zou tot de conclusie kunnen leiden dat in een maatschappij waar het geloof in de mogelijkheden van de genetica groot is en de geneeskunde een belangrijke positie inneemt, mensen alles willen laten onderzoeken wat technisch mogelijk is. Hier staat echter het volgende tegenover. Ten eerste heeft onderzoek naar de ziekte van Huntington uitgewezen dat sinds de beschikbaarheid van de test niet meer dan 1 op de 10 risicodragers een voorspellend erfelijkheidsonderzoek ondergaat. ${ }^{38} \mathrm{Bij}$ andere neurodegeneratieve aandoeningen ligt de vraag nog lager ${ }^{39}$ Een hoog risico op een erfelijke onbehandelbare neurodegeneratieve aandoening leidt dus in de overgrote meerderheid van de gevallen niet tot het ondergaan van een presymptomatisch voorspellend onderzoek, ook al heeft de adviesvrager een risico van 50 procent dat hij drager is. Ten tweede laat, bij ziekten waarvoor preventieve behandelingsopties bestaan, ongeveer 60 procent van de mogelijke mutatiedragers zich testen. ${ }^{40}$ Zelfs het bestaan van preventieve opties maakt kennelijk dat slechts een

\footnotetext{
34 Ten Have 1999.

35. Van der Voort, Grundmeijer en Hendrick 1995, p. 351-354.

36 Tijmstra en Bajema 1990, p. 1884-1885.

37 Tijmstra 1999.

3s Tibben 2000 , p. 6. Zie ook Tibben e.a. 1997, p. 20-35.

39 Tibben 2000, p. 6. Zie ook Lannfelt e.a. 1995, p. 332-335.

40 Gezondheidsraad 1998, p. 101.
} 
kleine meerderheid een erfelijkheidsonderzoek ondergaat. Ten derde blijkt uit onderzoek dat bij de vraag of men een erfelijkheidsonderzoek wil ondergaan, niet het feit dat men een risico loopt, of de grootte van het risico op een aandoening, de belangrijkste determinant bij de te nemen beslissing is. De eigen ervaring met een ziekte of handicap in het gezin en de aan- of afwezigheid van een gezond kind zijn belangrijker factoren bij de beslissing al dan niet een erfelijkheidsonderzoek te ondergaan. "Geanticipeerde beslissingsspijt speelt hier geen rol.

Het geloof in de mogelijkheden van de klinische genetica leidt er dus niet toe dat men alles wil onderzoeken wat technisch mogelijk is. Bovendien is niet alleen het feit dat men een risico loopt op een erfelijke aandoening van belang bij de beslissing om een erfelijkheidsonderzoek te ondergaan. Het feit dat enerzijds er een klimaat heerst waarin er een groot greloof is in de mogelijkheden van de klinische genetica en anderzijds blijkt dat we grotendeels denken in termen van gezondheidsrisico's die beheerst moeten worden, werpt wel een ander licht op het zelfbeschikkingsrecht als eigenschap die we adviesvragers toedichten. Dit recht wordt uitgeoefend vanuit een matschappelijk kader dat ons als het ware voorprogrammeert. De geneigdheid van mensen tot binair denken is hierbij een complicerende factor, zeker wanneer men bedenkt dat veruit de meeste aandoeningen multifactorieel van aard zijn. Men heeft dan een verhoogd risico op een aandoening, waarbij in veel gevallen dit risico slechts globaal aan te geven is. Dit maakt het erg moeilijk om een uitslag van erfelijkheidsonderzoek te interpreteren, zeker wanneer over de andere factoren die de aandoening doen ontstaan nagenoeg niets bekend is. Het betreft geen ja of nee situaties zoals bij monogene aandoeningen. Ook bij monogene aandoeningen is er echter nog veel onzekerheid. De enige zekerheid is vaak dat men aan de aandoening zal gaan lijden. Men weet niet wanneer en ook niet in welke mate. Preventieve maatregelen geven evenmin garanties. Dit roept de vraag op in welke beslissituaties adviesvragers mogen worden geplaatst. ${ }^{2}$ Van belang hierbij is het bewustzijn dat wanneer adviesvragers eenmaal in beslissituaties zijn geraakt, zij beschikken tegen een maatschappelijke achtergrond waar de invloed van de genetica groot is en waar risicomijdend gedrag als vanzelfsprekend wordt beschouwd. Een adviesvrager komt niet als een tabula masa de spreekkamer binnen. Dit doet niet af aan de waarde van het zelfbeschikkingsrecht als normerend rechtsbeginsel in diezelfde spreekkamer. Het maatschappelijk klimaat toont echter wel het perspectief van waaruit de adviesvrager zijn geinformeerde beslissing zal maken. Een klinisch geneticus dient zich hiervan bewust te zijn, zodat hij de adviesvrager zo goed mogelijk kan begeleiden bij het maken van een keuze om een erfelijkheidsonderzoek te ondergaan en eventueel bij het interpreteren van de uitslag daarvan. Van groot belang hierbij is uiteraard dat de mentaliteit en het handelen van klinisch genetici door het zelfbeschikkingsrecht worden gestuurd. ${ }^{43} \mathrm{Zij}$ zijn het die de relevantie informatie moeten verstrekken, die aan moeten geven dat deze informatie niet behoeft te worden verstrekt, die de adviesvragers moeten begeleiden en wijzen op de consequenties van de verschillende keuzemogelijkheden, die de uitslag van cen

4 Gezondheidsraad 1998, p. 101.

42 Tijmstra 1997, p. 1578-1581.

43 Leenen 2000, p. 35. 
erfelijkheidsonderzoek moeten meedelen en moeten zorgen dat waar nodig psychosociale nazorg wordt verleend.

\subsection{Samenvatting}

Het zelfbeschikkingsrecht van de adviesvrager stond in dit hoofdstuk centraal. Het werd gezien als een rechtsbeginsel dat ten grondslag ligt aan het patiëntenrecht en dus ook aan de in de volgende hoofdstukken te bespreken rechten. In het gezondheidsrecht kreeg het zelfbeschikkingsrecht met name aandacht in relatie tot de rechtspositie van de patiënt. Het is niet gepositiveerd in de Grondwet. Wel worden het recht op privacy en het recht op lichamelijke integriteit als een partiële positivering van het zelfbeschikkingsrecht gezien.

De grondslag van het zelfbeschikkingsrecht is het beeld van de mens als een vrij en autonoom persoon wiens waardigheid inherent is aan zijn mens-zijn. Het zelfbeschikkingsrecht is naar zijn aard een individueel rechtsbeginsel. Iedereen kan er aanspraak op maken dat dit vrijheidsrecht niet wordt geschonden. Het geeft niet aan hoe invulling moet worden gegeven aan de keuzes die het zelfbeschikkingsrecht met zich mee brengt. Kenmerkend voor een rechtsbeginsel is bovendien dat de precieze inhoud niet exact is aan te geven, dat deze inhoud in de tijd verandert en afhangt van de omstandigheden. Wel zijn er grenzen aan te stellen. Met name het feit dat het zelfbeschikkingsrecht van de adviesvrager wordt begrensd door hetzelfde recht van zijn verwanten is voor de erfelijkheidsadvisering van belang. Of en wanneer een inbreuk op het zelfbeschikkingsrecht van een adviesvrager toelaatbaar is, is afhankelijk van verschillende factoren. Een belangrijke factor daarbij is de kans dat de erfelijke aandoening tot gezondheidsschade zal leiden alsmede de mogelijkheden om deze schade te voorkómen of te reduceren.

Voorts is ingegaan op de bezwaren die tegen het zelfbeschikkingsrecht worden aangevoerd. Ten eerste wordt het zelfbeschikkingsrecht ontkend door hen die geloven in een hogere macht. Het geloven in een hogere macht is echter ook een uiting van zelfbeschikking welke door het zelfbeschikkingsrecht wordt gerespecteerd. Ten tweede wordt het beginsel zijn onbepaaldheid, de geringe juridische kracht en het vermeende gebrek aan meerwaarde ten opzichte van de artikelen 10 en 11 Grondwet verweten. Hierbij wordt echter de functie van het rechtsbeginsel miskend. Het is naar zijn aard niet exact en uitputtend te beschrijven en heeft tevens een andere functie dan grondrechten.

In de vorige paragraaf is een beeld geschetst van de bredere maatschappelijke context waarin adviesvragers hun zelfbeschikkingsrecht uitoefenen. Ingegaan is op het grote vertrouwen en geloof in wetenschap en techniek, welke begrijpelijk is tegen de achtergrond van de risicocultuur die zich in Nederland in de $20^{\circ}$ eeuw heeft ontwikkeld. Ook het geloof in de mogelijkheden van de klinische genetica is groot. Dit heeft er echter niet toe geleid dat adviesvragers alles willen laten onderzoeken wat technisch mogelijk is. Bovendien is niet alleen het feit dat men een risico loopt op een erfelijke aandoening van belang bij de beslissing om een erfelijkheidsonderzoek 
te ondergaan. Het feit dat er enerzijds een klimaat heerst waarin er een groot geloof is in de mogelijkheden van de klinische genetica en anderzijds blijkt dat we grotendeels denken in termen van gezondheidsrisico's die beheerst moeten worden, werpt wel een licht op het perspectief van waaruit de adviesvrager zijn geïnformeerde keus maakt. De klinisch geneticus dient zich hiervan bewust te zijn, zodat hij de adviesvrager zo goed mogelijk kan begeleiden bij het maken van een keuze om een erfelijkheidsonderzoek te ondergaan en eventueel bij het interpreteren van de uitslag daarvan.

In de volgende hoofdstukken zullen het recht op informatie en het toestemmingsvereiste, de therapeutische exceptie, het recht op niet weten, en de geheimhoudingsplicht verder uitgewerkt worden. Ook het recht op weten zal besproken worden. 


\section{ERFELIJKHEIDSADVISERING, INFORMATIE EN TOESTEMMING}

\subsection{Inleiding}

In dit hoofdstuk staan het recht op informatie en het toestemmingsvereiste in de relatie klinisch geneticus-adviesvager centraal. Hoewel nauw met elkaar verbonden zullen zij in aparte paragrafen worden besproken. Allereerst wordt ingegaan op het recht op informatie zoals dit in artikel 7:448 lid 1 en 2 BW is geregeld. Vervolgens spitst het betoog zich toe op het recht op informatie van de adviesvrager ten opzichte van de klinisch geneticus. Bij de behandeling daarvan komen eerst de onderwerpen aan bod warover de klinisch geneticus de adviesvrager zal moeten informeren. In paragraaf 4.3.2 wordt de vraag gesteld of er hogere eisen moeten worden gesteld aan de informaticplicht van de klinisch geneticus dan aan die van andere hulpverleners. De daarop volgende paragraal richt zich op artikel 7:448 lid 3 BW, alwaar de therapeutische exceptie is geregeld. Vervolgens wordt ingegaan op de wijze waarop de klinisch geneticus zou moeten informeren. Verschillende vormen van nondirectieve erfelijkheidsadvisering krijgen daarbij aandacht. De laatste twee paragrafen gaan in op het toestemmingsvereiste. Het hoofdstuk wordt afgesloten met een samenvatting.

Alvorens met de bespreking van het recht op informatie te starten wordt aandacht besteed an twee essentiële begrippen uit de Wgbo, te weten de behandelingsovereenkomst en het goed hulpverlenerschap.

\section{Behandelingsovereenkomst en goed hulpverlenerschap}

Artikel 7:446 BW definieert de behandelingsovereenkomst. ${ }^{1}$ Er is sprake van een opdrachtrelatie. In de praktijk van de klinisch genetische centra zal één van de 8 stichtingen de opdrachtnemer zijn. De opdrachtgever, in de Wgbo aangeduid als de patiënt, zal de adviesvrager zijn. De werknemer, de klinisch geneticus, zal namens

Artikel 7:446 BW luidt:

"1. De overeenkomst inzake geneeskundige behandeling - in deze afdeling verder aangeduid als de behandelingsovereenkomst - is de overeenkomst waarbij een natuurlijke persoon of een rechtspersoon, de hulpverlener, zich in de uitoefening van een geneeskundig beroep of bedrijf tegenover een ander, de opdrachtgever, verbindt tot het verrichten van handelingen op het gebied van de geneeskunst, rechtstreeks betrekking hebbende op de persoon van de opdrachtgever of van een bepaalde derde. Degene op wiens persoon de handelingen rechtstreeks betrekking hebben wordt verder aangeduid als de patiënt.

2. Onder handelingen op het gebied van de geneeskunst worden verstaan:

a. alle verrichtingen - het onderzoek en het geven van raad daaronder begrepen rechtstreeks betrekking hebbende op een persoon en ertoe strekkende hem van een ziekte te genezen, hem voor het ontstaan van een ziekte te behoeden of zijn gezondheidstoestand te beoordelen, dan wel deze verloskundige bijstand te verlenen; b. andere dan de onder a bedoelde handelingen, rechtstreeks betrekking hebbende op een persoon, die worden verricht door een arts of tandarts in die hoedanigheid." 
zijn werkgever de behandelingsovereenkomst met de adviesvrager aangaan. De geneticus zal primair de verantwoording dragen voor de geneeskundige behandeling van de adviesvrager. De handelingen op het gebied van de geneeskunst die de geneticus in het kader van de behandelingsovereenkomst verricht zullen zich voornamelijk concentreren op het beoordelen van de (toekomstige) gezondheidstoustand van de adviesvrager.

Artikel 7:453 BW regelt het goed hulpverlenerschap.? Dit is éćn van de kermbepalingen van de Wgbo en is gedurende de grehele behandelingsovereenkomst van belang. ${ }^{3}$ Het artikel stelt enerzijds een norm voor het handelen van de klinisch geneticus en anderzijds de grens van dit handelen. De klinisch geneticus moet een door de adviesvrager gewenste handeling namelijk weigeren wanneer hij daardoor niet volgens de professionele standaard zou werken. Binnen het kader van de professionele standaard behoudt de klinisch geneticus zijn professionele autonomie.t

De norm die wordt gesteld voor het handelen van de hulpverlener is algemeen en maakt niet zonder meer duidelijk hoe in een concreet geval gehandeld dient te worden. De bepaling biedt een juridisch aanknopingspunt voor situaties die in de wet niet of onvoldoende geregeld zijn en geeft de hulpverlener ruimte om de Wgbobepalingen toe te passen op een manier die voor de individuele patiënt het meest geëigend is. Gezien het feit dat veel Wgbo-bepalingen globaal zijn geformuleerd, zal de hulpverlener bovendien in veel situaties waarvoor wel een regeling bestaat, zijn handelen moeten verantwoorden op grond van zijn goed hulpverlenerschap. Dit betreft zowel de inhoud van de bepaling als de wijze warop deze in individuele situaties moet worden loegepast. ${ }^{5}$ Over de omvang van de norm van goed hulpverlenerschap stelt de regering:

"De rechter zal bij de toetsing van de in [art. 7:453] neergelegde norm, regels en normen die op het gebied van de hulpverlening in de gezondheidszorg gelden, gebruiken als bouwstenen voor zijn oordeel. Zo zullen ter zake van het handelen van

Artikel 7:453 BW luidt:

"De hulpverlener moet bij zijn werkzaamheden de zorg van een goed hulpverlener in acht nemen en handelt daarbij in overeenstemming met de op hem rustende verantwoordelijkheid, voortvloeiende uit de voor hulpverleners geldende professionele standaard." In artikel 4 van het Verdrag inzake Mensenrechten en Biogeneeskunde is tevens een bepaling opgenomen betreffende de professionele standaard. Artikel 4 van het Verdag inzake Mensenrechten en Biogeneeskunde: "Any intervention in the health field, including research, must be carried out in accordance with relevant professional obligations and standards." Nys 1998, p. 188. Van Wijmen spreekt over de kunst van het goed hulpverlenerschap. Van Wijmen 1996, p. 10. Legemaate beschouwt het als de basisnorm van de Wgbo. Legemaate 1995, p. 14. Van Lomwel en Van Veen 1999, p. 23-27. Zie ook Legemaate 1994, p. 34-35.

Legemaate 1995, p. 15-16. Leenen daarentegen interpreteert de norm minder ruim. Volgens hem wordt met het goed hulpverlenerschap in de Wgbo het voldoen aan de medisch-professionele standaard bedoeld, welke hij opvat als het medisch handelen volgens de inzichten van medische wetenschap en ervaring. Leenen 2000, p. 187. 
een individucle beroepsbeofenaar gedragsregels die worden gehanteerd door de desbetreffende beroepsorganisatie van een belang kunnen zijn (...)."

De regels en normen van de beroepsgroep worden dus via artikel 7:453 BW indirect onderdeel van de behandelingsovereenkomst. Dat is zeker voor de klinische genetica, waar veel vragen bestaan waar de beroepsgroep een antwoord op moet formuleren, een belangrijk gegeven. Deze vragen kunnen de toegang tot erfelijkheidsonderzoek betreffen, zoals bijvoorbeeld de vraag of voorspellend prenataal onderzoek naar erfelijke borstkanker toelaatbaar is. Echter ook de houding ten opzichte van bloedverwanten roept vragen op die om bezinning van de beroepsgroep vragen. De mogelijk verstrekkende gevolgen van de kennis van erfelijkheidsinformatie voor de adviesvrager en zijn familie vragen van de beroepsgroep een doordacht en uniform beleid, waar ruimte is voor de individuele merites van elke behandelingsovereenkomst.

Het in acht nemen van de zorg van een goed hulpverlener is een algemene formulering en behoeft deswege in individuele situaties interpretatie. In situaties die wettelijk niet geregeld zijn of waar de wettelijke regels geen pasklare oplossing bieden kan het goed hulpverlenerschap, zoals opgemerkt, een aanknopingspunt bieden voor de oplossing van een juridisch vraagstuk. Bij de bespreking van de problematiek rond erfelijkheidsadvisering zal blijken dat een beroep op het goed hulpverlenerschap in enkele situaties (mede) als juridische basis kan dienen en ook zal moeten dienen, daar waar een meer gedetailleerde norm ontbreekt.

\subsection{Het recht op informatie}

De informatieplicht is vastgelegd in artikel 7:448 BW lid 1 en lid 2:

1. "De hulpverlener licht de patiënt op duidelijke wijze, en desgevraagd schriftelijk in over het voorgenomen onderzoek en de voorgestelde behandeling en over de ontwikkelingen omtrent het onderzoek, de behandeling en de gezondheidstoestand van de patient. De hulpverlener licht een patiënt die de leeftijd van twaalf jaren nog niet heeft bereikt op zodanige wijze in ais past bij zijn bevattingsvermogen.

2. Bij het uitvoeren van de in lid 1 neergelegde verplichting laat de hulpverlener zich leiden door hetgeen de patiënt redelijkerwijze dient te weten ten aanzien van:

a. de aard en het doel van het onderzoek of de behandeling die hij noodzakelijk acht en van de uit te voeren verrichtingen;

b. de te verwachten gevolgen en risico's daarvan voor de gezondheid van de patiënt;

c. andere methoden van onderzock of behandeling die in aanmerking komen;

d. de staat van en de vooruitzichten met betrekking tot diens gezondheid voor wat betreft het terrein van het onderzoek of de behandeling."

Het recht op informatie zoals dat in de Wgbo is neergelegd is een codificatie van reeds bestaand recht. In Nederland verschijnen vanaf de tweede helft van de jaren

Kamerstukken II 1990/91, 21561, nr. 6, p. 60. 
zestig van de vorig eeuw publicaties warin een recht op informatie aan de orde wordt gesteld. ${ }^{7}$ In 1979 verschijnt het proefschrift van Dekkers dat aan de patiënt en het recht op informatie is gewijd. ${ }^{8}$ Daamaast is zowel in de tuchtrechtspraak als in de civielrechtelijke jurisprudentie vanaf 1970 een omslag te bespeuren. Voor die tijd werd het geheel aan de arts overgelaten of hij de patiënt informeerde." Geleidelijk wordt er van een informatieplicht gesproken waarvan een arts niet zomaar mag afwijken. In een uitspraak van het CMT van 19 maart $1981^{10}$ worden de grenzen van de informatieplicht nader omschreven. ${ }^{11}$ De ruimte voor uitzonderingen wordt in de jaren negentig verder ingeperkt. ${ }^{12}$ Zo laat de therapeutische exceptie alleen in uitzonderingsgevallen het achterhouden van informatie toe. Zie hiervoor paragraaf 4.3.3.

Op 1 april 1995 is de Wgbo in werking getreden en daarmee was het recht op informatie wettelijk geregeld.13 Het staat centraal in de rechten van de patiënt, aldus Leenen. ${ }^{14}$ Het is een voorwaarde voor het kunnen uitoefenen van het zelfbeschikkingsrecht. Daamaast heeft het een sterk symbolische waarde. Het geeft uitdrukking aan het feit dat de patiënt serieus genomen wordt. Het overdragen van informatie door de hulpverlener verkleint het kennisverschil tussen beide, maar accentueert daarmee wel tevens de afhankelijkheid van de patiënt van goede informatie en dus van de hulpverlener.

Uit artikel 7:448 lid 1 en 2 BW blijkt dat met name de volgende drie aspecten van belang zijn. Ten eerste dient een patiënt op basis van de verstrekte informatie een weloverwogen besluit te kunnen nemen ten aanzien van het eventueel ondergaan van een erfelijkheidsonderzoek. Ten tweede dient de patiënt te weten welke conclusies de hulpverlener heeft kunnen trekken met betrekking tot zijn gezondheidstoestand. Ten derde bevordert het verstrekken van duidelijke en

Zie onder andere Marley 1966, Maeijer 1968 en Dekkers 1979.

Dekkers 1979.

" Alleen wanneer het evident was dat het oordeel van de arts niet te rechtvaardigen was in het licht van de omstandigheden, werd het niet-informeren als een tuchtrechtelijk relevante nalatigheid beschouwd. Gevers en Van Aalst 1998, p. 169.

10 CMT 19 maart 1981, TvGr 1981, 28.

" "Wat nu in het bijzonder de plicht om informatie te geven vóór de aanvang van de behandeling betreft, moet als criterium gelden, dat de patiënt een beschrijving moet krijgen van de te behandelen kwaal, inzicht van de behandeling die de arts zich voorstelt te geven en in de redelijkerwijs te verwachten gevolgen waarbij de nadruk moet vallen op gevolgen, die voor de patiënt van ingrijpend karakter kunnen zijn, een en ander met inachtneming van de bovenomschreven beperkingen. Wanneer de patiënt zulks wenst behoort tevens medegedeeld te worden, wat de gevolgen zijn van het nalaten van de behandeling en welke alternatieve behandeling mogelijk is. Is de behandeling aangevangen dan moet, indien de bevindingen anders zijn dan bij de aanvankelijke inlichtingen werd aangenomen, de mededeling gedaan worden welke consequenties dit kan hebben."

12 Gevers en Van Aalst 1998, p. 169.

13 Van Wijmen 1995, p. 411-412.

14 Leenen 2000, p. 191. 
begrijpelijke inlichtingen dat de patiënt optimaal kan meewerken aan de bevordering of het herstel van zijn gezondheidstoestand. De informatie moet zo veel mogelijk in voor de patiënt begrijpelijke bewoordingen worden gegeven. De toevoeging redelijkerwijze in lid 2 zorgt ervoor dat een patiënt op maat wordt geïnormeerd, rekening houdend met zijn specifieke informatiebehoefte op grond van zijn persoonlijke omstandigheden. ${ }^{15}$ Deze gë̈ndividualiseerde informatie zorgt ervoor dat de gegeven informatie zijn doel niet voorbij schiet. Een overmat aan informatie zou eigen inzicht in en herstel of bevordering van de gezondheidstoestand, alsmede het maken van weloverwogen keuzen kunnen belemmeren. De hulpverlener moet zich ervan vergewissen dat de patiënt de informatie voldoende heeft begrepen. ${ }^{16}$ Een patiënt behoeft niet geinformeerd te worden over alle mogelijke risico's die verbonden zijn aan erfelijkheidsonderzoek. Dit zal afhangen van de specifieke omstandigheden. Belangrijke indicatoren zullen de aard van het risico en het incidentiepercentage $z \mathrm{ijn}$. Bij het verstrekken van informatie kunnen de normen van de beroepsgroep voor de hulpverlener als leidraad fungeren. ${ }^{17}$

Het recht op informatie is ook op Europees niveau geregeld ${ }^{18}$. In het Verdrag inzake Mensenrechten en Biogenceskunde van de Raad van Europa, is in artikel 5 te lezen:

\footnotetext{
"An intervention in the health field may only be carried out after the person concerned has given free and informed consent to it.

This person shall beforehand be given appropriate information as to the purpose and nature of the intervention as well as on its consequences and risks.

The person concerned may freely withdraw consent at any time." 19
}

Informatie en toestemming worden hier in één artikel geregeld. Het recht op informed consent is ook af te leiden uit artikel 8 EVRM (het recht op eerbiediging van privé-leven, familie- en gezinsleven). Artikel 5 van het Verdrag inzake Mensenrechten en Biogeneeskunde kan als een nadere invulling van artikel 8 EVRM worden gezien. ${ }^{20}$ Dit is een belangrijke constatering. Het recht op informatie buiten een behandelingsovereenkomst is niet geregeld. Voor bloedverwanten van de

15 Internationaal wordt uitgegaan van standards of disclosure. Bovenstaande norm is een combinatie van the reasonable person standard en the subjective standard. Bij the reasonable person standard wordt uitgegaan van de hypothetische redelijke persoon. Bij the subjective standard is de omvang on inhoud van de informatieverplichting afhankelijk van de specifieke informatiebehoeften van de individuele persoon. Een andere standard of disclosure is the professional practice standard. Hierbij bepaalt de beroepsgroep de omvang en inhoud van de informatieverplichting. Beauchamp en Childress 1994, p. 146-150.

16 MT Den Haag 23 oktober 1985, TvGr 1986, 48; Hof Amsterdam 18 juli 1996, TvGr 1998, 19; Rb Zwolle 10 juli 1996, Tv Gr 1997, 30.

17 Sluijters e.a. 1999, p. 415-417.

is Zie bijvoorbeeld de Declaration on the Promotion of Patients' Rights in Europe van de WHO. Leenen 1994, p. 275-281.

19 Nys 1998, p. 188-189.

20 Gevers 1994, p. 456-464. Zie ook Roscam Abbing 1994b, p. 313-314. 
adviesvrager zou artikel 8 EVRM als juridische basis kunnen dienen voor een zeker recht op informatie. In het volgende hoofdstuk wordt hier verder op ingegaan.

\subsection{Informatie en erfelijkheidsadvisering}

De relatie klinisch geneticus-adviesvrager heeft, zoals in hoofdstuk 1 aangegeven, een aantal specifieke kenmerken. In deze paragraaf zullen de juridische gevolgen hiervan voor het recht op informatie van de adviesvrager worden onderzocht. Het informeren van bloedverwanten van de adviesvrager komt in hoofdstuk 7 aan de orde.

In 1991 heeft de Vereniging voor Gezondheidsrecht onder de titel Wat mag en moet bij 'rfelijkheidsonderzoek? richtlijnen voor erfelijkheidsonderzoek gepubliceerd. ${ }^{21}$ Het doel was om enerzijds de praktijk een handreiking te bieden en anderzijds een bijdrage te leveren aan de rechtsontwikkeling op het terrein van de erfelijkheidsadvisering. De informatieplicht is daarin als volgt uitgewerkt:

"De arts licht de cliënt op duidelijke wijze, en desgevraagd schriftelijk, in over de aard en de inhoud van het onderzoek, over de mogelijke resultaten en gevolgen ervan en over de beschikbare alternatieven. (...) Voor zover voorzienbaar vertelt hij bovendien dat de medewerking van bloedverwanten gewenst is, en dat het onderzoek resultaten kan opleveren die voor die bloedverwanten van groot belang zijn."22

De informatieplicht is gebaseerd op (het destijds nog niet in werking getreden) artikel 7:448 BW. Het vult artikel 7:448 BW bovendien aan door te stellen dat de adviesvrager ingelicht moet worden over de eventuele vereiste medewerking van bloedverwanten en over het mogelijk grote belang van de uitslag van erfelijkheidsonderzoek voor die bloedverwanten.

\subsubsection{Het informeren van de adviesvrnger}

Lid 1 van artikel 7:448 BW legt de verplichting op de geneticus om informatie te verstrekken voor de aanvang van een onderzoek of behandeling en informatie tijdens of na het onderzoek of de behandeling. In navolging van het verslag van de evaluatie van de Wgbo, zal ik hier spreken van vóórinformatie en voortgangsinformatie. ${ }^{23}$ De informatie kan desgevraagd schriftelijk worden gegeven. Bij erfelijkheidsadvisering is het gebruikelijk om na afloop van de

21 Vereniging voor Gezondheidsrecht 1991, p. 481-488. De richtlijnen zijn voorbereid door de Werkgroep Erfelijkheidsrichtlijnen van de Vereniging voor Gezondheidsrecht. De Werkgroep, onder voorzitterschap van prof. mr. F.C.B. van Wijmen, bestond uit leden van de Vereniging, aangevuld met drie personen die afgevaardigd waren door het Landelijk Overleg Genetic Counseling. Ze zullen in het vervolg aangeduid worden als erfelijkheidsrichtlijnen.

22 Vereniging voor Gezondheidsrecht 1991, p. 483.

23 Dute e.a. 2000, p. 45. 
behandelingsovereenkomst een samenvattende brief aan de adviesvrager te verstrekken. In dezelfde trant zijn ook de erfelijkheidsrichtlijnen:

"De arts zorgt ervoor dat de cliënt de informatie kan begrijpen en vergewist zich ervan dat de cliënt de informatie inderdaad begrepen heeft. Als de cliënt erom vraagt verzorgt de arts een schriftelijke samenvatting."

Over deze schriftelijke samenvatting merkt de Vereniging op dat het verstandig is de adviesvrager erop te wijzen dat hij niet verplicht is de samenvatting aan wie dan ook te verstrekken.

Lid 2 ziet voornamelijk op de vóórinformatie. In sub a wordt gesproken over het noodzakelijk onderzoek. Bij diagnostisch erfelijkheidsonderzoek zal onderzoek vaak noodzakelijk zijn om cen diagnose te kunnen stellen. Voorspellend erfelijkheidsonderzoek is medisch niet-noodzakelijk onderzoek. Uit de volgende paragraaf zal blijken dat het belang van duidelijke vóórinformatie bij dergelijk onderzoek groot is. Sub b spreekt over de te verwachten gevolgen en risico's van onderzoek of behandeling voor de gezondheid van de patiënt. Bij de vóórinformatie dienen echter ook de gevolgen en risico's voor bloedverwanten aan de orde te komen. ${ }^{25}$ Deze gevolgen en risico's vloeien voort uit de aard van het onderzoek. De plicht is aldus te baseren op lid 2, sub a, alsmede op de zorg van een goed hulpverlener. Ook mogelijke maatschappelijke gevolgen, die uit de aard van het onderzoek kunnen voortvloeien, dienen aan de orde te komen. ${ }^{26}$ De plicht hiertoe lijkt me moeilijk af te bakenen. Mogelijke problemen bij de toegang tot werk en verzekeringen vallen er in ieder geval onder. Dit zijn direct aan het onderzoek te relateren gevolgen die kort genoemd kunnen worden en waarover voorlichtingsmateriaal verstrekt kan worden.

Alvorens erfelijkheidsonderzoek wordt verricht zal de geneticus ook de mogelijkheden om preventieve matregelen te nemen bij een ongunstige uitslag aan de orde moeten stellen. Dan weet de adviesvrager dat hij te zijner tijd voor de keuze kan komen te staan of, en zo ja, welke preventieve maatregelen hij zal kunnen treffen om de ziekte te voorkomen, het risico op de ziekte te verkleinen of het verloop ervan gunstig te beinvloeden. Bij een ongunstige uitslag zullen de preventieve opties uitvoerig aan de orde moeten komen. De voor- en nadelen zullen op een rijtje moeten worden gezet, zodat de adviesvrager ook op dat punt een weloverwogen beslissing kan nemen.

Bij voorspellende erfelijkheidsadvisering valt, indien in casu relevant, binnen de fase van de vóórinformatie ook het maken van afspraken met de adviesvrager omtrent de vraag of en de wijze warop de informatie na een voorspellend onderzoek wordt

$24 \quad$ Vereniging voor Gezondheidsrecht 1991, p. 484.

25. Zie de gecitecrde informatieplicht van de crfelijkheidsrichtlijnen van de Vereniging voor Gezondheidsrecht.

20 Gevers 1996, p. 19. Zie ook Vereniging voor Gezondheidsrecht 1991, richtlijn A1, Leenen 2000, p. 79 en Gezondheidsraad 1989, p. 96. 
verstrekt aan de adviesvager zelf, aan zijn bloedverwanten en aan andere hulpverleners. Een dergelijke handelwijze doet, wanneer dit op een non-directieve wijze gebeurt, ${ }^{27}$ recht aan het zelfbeschikkingsrecht van de adviesvrager. ${ }^{25}$

Met de adviesvrager moeten afspraken worden gemaakt over de termijn waarop de uitslag wordt meegedeeld. Meestal zal dit kort na het bekend worden van de uitslag van het erfelijkheidsonderzoek zijn. Het kan echter ook zo zijn dat de adviesvrager voor het onderzoek aangeeft dat hij er prijs op stelt de uitslag pas te vernemen op een van tevoren bepaald tijdstip, geruime tijd nadat deze bekend geworden is. ${ }^{29}$ Ook de wijze waarop de uitslag zal worden meegedeeld kan van tevoren worden besproken. Het komt in de praktijk regelmatig voor dat familieleden tegelijk een erfelijkheidsonderzoek ondergaan en dan gezamenlijk de vóórinformatie ontvangen en bespreken met de klinisch geneticus. Er zullen dan afspraken moeten worden gemaakt over het ontvangen van de uitslag. Dudok de Wit stelt voor wat betreft presymptomatisch DNA-onderzoek naar later in het leven optredende ziekten hierover:

"Concerning the test result, it is very important to discuss whether they want to be with relatives at the department of Clinical Genetics, or not. When various relatives want to recieve their test result at the same time, multiple rooms should be reserved i.e. a separate room for each of them to receive their own result. After everybody has received his/her own testresult they can meet together if they so wish." 30

Goed hulpverlenerschap impliceert dat zeker bij dergelijk DNA-onderzoek de uitslag aan elke adviesvrager separaat wordt verstrekt. De uitslag moet individueel verwerkt kumnen worden, zodat de implicaties voor de adviesvrager en zijn directe omgeving een voorlopige plaats kunnen krijgen alvorens de implicaties voor familieleden aan de orde komen. Zeker wanneer één adviesvrager een gunstige en de ander een ongunstige uitslag te horen krijgt. Op die manier is er bijvoorbeeld ruimte om blij te kunnen zijn zonder schuldgevoel ten opzichte van het familielid dat een ongunstige uitslag krijgt.

Voor wat betreft andere erfelijkheidsonderzoeken zal veel afhangen van de individuele omstandigheden. Een richtlijn hierbij zou kunnen zijn dat naarmate de gevolgen van het onderzoek ingrijpender kunnen zijn, het raadzamer is om de uitslag aan adviesvragers apart te verstrekken.

Tevens zal aan de orde moeten komen of de uitslag telefonisch gegeven kan worden. Het goed hulpverlenerschap impliceert hier dat naarmate de gevolgen van het

27 De non-directiviteit van de erfelijkheidsadvisering wordt in paragraaf 4.3.1.4 besproken.

28 Leenen 2000 , p. 80.

29 Uit de praktijk is mij een casus bekend waarin de adviesvrager in het buitenland woonde en eenmal per jaar naar Nederland kwam. Deze adviesvrager vroeg om een voorspellend onderzoek en wilde de uitslag een jaar later bij zijn volgende bezoek aan Nederland te horen krijgen. Dudok de Wit 1997, p. 72. 
onderzoek ingrijpender kumnen zijn, het sterk af te raden is om de uitslag dáárvan telefonisch te geven.

\section{Het informeren wan familieleden}

De vragen of en zo ja, op welke wijze en welke familieleden zullen worden ingelicht over het erfelijkheidsonderzoek en de uitkomsten daarvan, zullen aan de orde moeten komen alvorens onderzoek wordt verricht. ${ }^{31}$ Het belang hiervan neemt toe naarmate het risico op een aandoening hoger is, het een ernstige aandoening betreft en de mogelijkheden van preventieve matregelen toenemen. Het inlichten van verwanten is een eigen verantwoordelijkheid van de adviesvrager, waarbij de klinisch geneticus eventueel kan helpen. In hoofdstuk 7 wordt verder ingegaan op het informeren van bloedverwanten van de adviesvrager. De vraag of onder omstandigheden een juridische plicht rust op de klinisch geneticus om de familieleden van de adviesvrager te informeren, komt in het volgende hoofdstuk aan de orde.

Het is zoals reeds opgemerkt de taak van de klinisch geneticus om de adviesvrager te wijzen op de consequenties van erfelijkheidsonderzoek voor zijn familieleden. Het familiaire aspect dient echter niet centraal te staan bij de informatieverstrekking. Dudok de Wit stelt over de relatie adviesvrager-klinisch geneticus het volgende:

"Attention is focused on the needs of the individual who has the appointment. Counsellors should be aware not to be seduced into discussing the implications of the genetic status of family members (such as whether a family member made the right decision etc.). However the impact of the ongoing events in the family on the particular participants may be adressed. (...) Taking the test, or not, should be an enterprise of the person at-risk and the respective partner and not a family enterprise." 32

De klinisch geneticus kan de adviesvrager helpen bij het inlichten van familieleden. Zo kan hij een brief opstellen, waarin wordt uitgelegd dat de familie een verhoogd risico loopt op een bepaalde aandoening, die de adviesvrager vervolgens onder zijn familieleden verspreidt. Zeker wanneer de familie nog onbekend is met de erfelijke aandoening en de adviesvrager veel complexe informatie door moet geven, kan dit uitkomst bieden. In hoofdstuk 7 wordt hier verder aandacht aan besteed.

\section{Het informeren van andere hulpuerleners}

De voortgangsinformatie wordt in de medische wereld veelal met veronderstelde toestemming ook aan behandelende specialisten en de huisarts meegedeeld. In de klinische genetica is deze toestemming minder vanzelfsprekend omdat er niet altijd een direct medisch belang is om andere hulpverleners in te lichten. Een voorbeeld is onderzoek naar onbehandelbare aandoeningen waarvoor preventieve maatregelen niet aan de orde zijn. Adviesvragers kunnen goede redenen hebben om de uitslag van dergelijk onderzoek voor zichzelf te houden. Ook bij erfelijkheidsonderzoek dat uitsluitend in het belang van anderen wordt verricht, is er geen medisch belang om

\footnotetext{
31 Vereniging voor Gezondheidsrecht 1991, richtlijn $A 1$

32 Dudok de Wit 1997, p. 72.
} 
andere hulpverleners hiervan op de hoogte te stellen. De functie van de huisarts van adviesvragers ligt voornamelijk in de begeleidende sfeer. Ifij is vaak het best op de hoogte van de familierclaties. Het ligt dan voor de hand om de huisarts wel op de hoogte te stellen van de uitkomsten van erfelijkheidsonderzock. Uit onderzock naar opvattingen van adviesvragers hieromtrent bij presymptomatisch onderzoek naar de zickte van Huntington bleek echter het volgende:

"Prior studies have adrocated involving the patient's GP in predictive testing, and have shown the increasing willingness of GPs to become involved in such programs (...). It was therefore noteworthy that almost $25 \%$ of patients indicated that their GP should not be routinely involved in the predictive testing process. "33

Het verdient daarom de voorkeur als de klinisch geneticus bij erfelijkheidsonderzoek waarbij geen medisch belang is om andere hulpverleners in te lichten tijdens de vórinformatie aan de adviesvrager vraagt of hij er prijs op stelt dat de huisarts en eventueel andere hulpverleners op de hoogte worden gesteld van de uitslag van het erfelijkheidsonderzoek. ${ }^{3 \cdot 4}$

\section{Onverwachte bevindingen}

Er wordt in lid 1 of 2 van artikel 7:448 BW niet gerept over onverwachte bevindingen bij onderzoek. Is de klinisch geneticus verplicht om mogelijk onverwachte bevindingen aan de orde te stellen, alvorens tot onderzoek over te gaan? Hierbij is ook het recht op niet weten in het geding (zie hiervoor hoofdstuk 6). Met name bij het bespreken van de familieanamnese en chromosomenonderzoek kan meer erfelijkheidsinformatie worden gegenereerd dan waar de erfelijkheidsvraag op gericht was. ${ }^{35}$ Het vermelden van deze mogelijkheid hoort daarom dan ook tot de standaard te verstrekken informatie wanneer dergelijk onderzoek wordt verricht. Zeker gezien het feit dat veel vrouwen ervan uitgaan dat prenataal chromosomenonderzoek alleen uitsluitsel geeft over het al dan niet aanwezig zijn van het syndroom van Down, ${ }^{36}$ is het van belang dat adviesvragers zich bewust zijn van mogelijke onverwachte bevindingen. Ook het recht op niet weten wordt beschermd wanneer de adviesvrager in de gelegenheid wordt gesteld aan te geven wat hij wel en niet wil weten. Het is daarom van groot belang om voorafgaand aan een erfelijkheidsonderzoek zo duidelijk mogelijke afspraken te maken over de vraag of en hoe eventuele onverwachte bevindingen meegedeeld zullen worden. ${ }^{37}$ In dezelfde zin ook de erfelijkheidsrichtlijnen:

33 Copley e.a. 1995 , p. 59-69.

34 Aldus ook De Wert 1999, p. 253.

35 Bij het bespreken van de familieanamnese wordt gevraagd naar in de familie voorkomende aandoeningen, naar het vóórkomen van miskramen en naar voorkomende ontwikkelingsproblemen. Hierbij kan blijken dat in de familie mogelijk meer of andere erfelijke aandoeningen een rol spelen dan waar de hulpvraag op gericht is. Bij chromosoomonderzoek kunnen chromosomale afwijkingen aan het licht komen.

37 Zie ook Gevers 1996, p. 18-19. 
"De arts vraagt de cliënt of hij volledig geinformeerd wil worden over de resultaten van het erfelijkheidsonderzoek, ook over eventuele onverwachte bevindingen." 3.

Hiermee is overigens niet gezegd dat dit eenvoudig is. De Gezondheidsraad wijst erop dat het praktisch onmogelijk is alle eventualiteiten voorafgaand aan een chromosomenonderzoek met de adviesvrager te bespreken. ${ }^{39}$

Een uitzondering op het respecteren van de wens van de adviesvrager om niet geinformeerd te worden over onverwachte bevindingen is aan de orde wanneer de niet gewenste bevindingen medisch relevant kunnen zijn.4) De Wert verwijst hierbij naar het voorbeeld van Van de Kamp,"1 warbij een echtpaar prenataal onderzoek laat verrichten met de intentie om de foetus te laten aborteren wanneer het een jongetje blijkt te zijn, omdat er een risico van $50 \%$ bestaat dat het jongetje lijdt aan een ernstige $X$-gebonden aandoening. Indien nu het prenataal onderzoek een $X X Y$ chromosomenpatroon laat zien, is dit een extra bevinding. Het jongetje zou bij zijn geboorte lijden aan het Klinefelter-syndroom. Dit is een milde chromosomale afwijking, die in de praktijk vaak niet lijdt tot een abortus provocatus. Dit extra $X$ chromosoom maakt de kans op de $X$-gebonden aandoening echter wel aanmerkelijk kleiner, omdat waarschijnlijk is dat het extra $X$-chromosoom het gendefect op het andere chromosoom compenseert. Deze kennis is voor de aanstaande ouders medisch zeer relevant omdat, nu het jongetje waarschijnlijk niet aan de gevreesde aandoening zal gaan leiden, het hen ervan zou kunnen weerhouden om een abortus te laten verrichten.

Betreft de plicht om, wanneer de adviesvrager aangeeft hiervan op de hoogte te willen worden gesteld, onverwachte bevindingen mede te delen ook het meedelen van niet medische informatie? De informatieplicht van de klinisch geneticus ziet op informatie omtrent de gezondheidstoestand. Bovendien moet de informatie relevant zijn. Het moet informatie zijn die de adviesvrager redelijkerwijze dient te weten ten aanzien van zijn gezondheid voor wat betreft het terrein van het erfelijkheidsonderzoek. Niet-medische informatie valt hier niet onder. Bij het verrichten van een erfelijkheidsonderzoek is het mogelijk dat uit onderzoek blijkt dat de vader niet de biologische vader van de adviesvrager blijkt te zijn of dat de adviesvrager niet de biologische vader van zijn kind blijkt te zijn. Wanneer de nonpaterniteit niet rechtstreeks verband houdt met de gezondheidstoestand van de adviesvrager, is een verplichting om de adviesvrager daarover in te lichten niet aanwezig.

Anders ligt de situatie wanneer de non-paterniteit wel enig verband houdt met de gezondheidstoestand. Dit is bijvoorbeeld het geval wanneer een echtpaar een kind met een erfelijke ziekte heeft en ze willen weten hoe het groot het risico is dat een volgend kind de ziekte ook heeft. Indien dit risico nihil blijkt te zijn omdat de man

\footnotetext{
38 Vereniging voor Gezondheidsrecht 1991, p. 484.

39 Gezondheidsraad 2001, p. 132.

40 De Wert, XVI Ethische aspecten, hoofdstuk 2, paragraaf 2.4.1.

${ }^{41}$ Van de Kamp, XVI Vakinhoudelijke aspecten, hoofdstuk 2, paragraaf 2.2.2.
} 
geen mutatiedrager is en dus ook niet de biologische vader kan zijn van zijn kind, dient dit uitgelegd te worden. Van de geneticus kan niet verlangd worden dat hij een leugen vertelt.

\section{Begeleiding na de uitslag}

De gevolgen van, met name voorspellend, erfelijkheidsonderzoek zijn vaak ingrijpend voor de adviesvrager en diens directe familieleden. De zorgverplichting eindigt dan ook niet bij het meedelen van de uitslag van het erfelijkheidsonderzoek. Een goede psychosociale begeleiding van de adviesvrager en diens verwanten is van groot belang. ${ }^{42}$ De klinisch geneticus dient er zorg voor te dragen dat de adviesvrager deze begeleiding ook krijgt. De dynamiek binnen een familie beinvloedt op vele niveaus en vele manieren de reacties van de adviesvrager die aan een erfelijke aandoening lijdt of zal gaan lijden. ${ }^{43}$ Verder is uit onderzoek gebleken dat een goede begeleiding ook van belang kan zijn bij een gunstige uitslag van voorspellend genetisch onderzoek. ${ }^{44}$

\section{Het recht op informatie versus het recht op niet weten}

Een adviesvrager heeft op grond van artikel 7:448 lid 1 en 2 BW recht op informatie. Dit recht kan echter botsen met de wens van een familielid om verschoond te blijven van erfelijkheidsinformatie. Dit probleem doet zich bijvoorbeeld voor wanneer een adviesvrager wil laten onderzoeken of hij drager is van een mutatie die tot dezelfde erfelijke ziekte leidt of kan leiden als waaraan één van zijn grootouders lijdt of heeft geleden. ${ }^{45}$ Gebleken dragerschap bij de adviesvrager toont aan dat de ouder die zoon of dochter is van de grootouder, ook drager moet zijn van de mutatie die tot de erfelijke ziekte lijdt. Indien deze ouder niet wil weten of hij drager is, maar de adviesvrager wel, ontstaat er een dilemma. ${ }^{46}$ In de ethiek bestaat voor dit probleem

42 Over het belang van een goede begeleiding van de verwanten van de adviesvrager stellen Bloch e.a. het volgende: "The decision to take the test or not must ultimately be made by the person at risk. However, the effects of his decision are not isolated but have a ripple effect throughout the family. The nontested spouse receives information about his/her partner as well as a change in the risk of his/her children and possibly grandchildren. It is this spouse who may later be the primary caregiver for this at risk individual and this person's hopes for the future may also be drastically affected by the test result. Similarly the children of the candidate are simultaneously receiving an alteration in their risk status. Counselling should also be available for relatives as part of any predictive testing program to alleviate some of these potential adverse events." Bloch e.a. 1992, p. 499-507.

43 Kessler 1988, p. 617-621.

4t Tibben 1993, met name hoofdstuk 2. Zie ook Tibben 2000, p. 10-11, Bleiker e.a. 1997, p. 107-116 en Huggins e.a. 1992, p. 508-515.

45 Dit probleem kan zich ook voordoen wanneer de adviesvrager een eeneiige tweelingbroer of -zus heeft.

40 In sommige situaties kan de zogenaande exclusietest uitkomst bieden. Door middel van een indirect DNA-onderzoek kan men vaststellen of de adviesvrager geen drager is van de mutatie, dan wel net als zijn ouder een risico van $50 \%$ heeft op de mutatie. De ouder kan door dit onderzoek nooit te horen krijgen dat hij aan een erfelijke ziekte zal gaan leiden. Indien de adviesvrager geen drager blijkt te $z$ ijn, is er geen dilemma meer. Wanneer echter wordt vastgesteld dat de adviesvrager een risico heeft van $50 \%$ op de 
geen eenduidige oplossing. De Wert geeft laat zien dat een eenduidige richtlijn waarschijnlijk onvoldoende recht doet aan het karakter van de te maken afweging in afzonderlijke situaties. Zowel het laten verrichten van het erfelijkheidsonderzoek als het blokkeren van de toegang tot dat onderzoek kon volgens hem onder omstandigheden gerechtvaardigd zijn. Relevante factoren bij het maken van de afweging zijn met name de persoonlijke omstandigheden en psychische draagkracht van de adviesvrager en het betreffende familielid en de grootte van het risico dat het familielid ongewild op de hoogte raakt van een eventuele ongunstige uitslag van het erfelijkheidsonderzoek bij de adviesvrager. Situaties warin het recht op informatie en de wens om niet geinformeerd te zijn botsen acht De Wert minder problematisch wanneer het gaat voorspellend DNA-onderzoek naar later in het leven optredende ziekten waarvoor waarschijnlijk preventieve opties beschikbaar zijn. Als vuistregel moet bij de beoordeling van dergelijke situaties volgens de auteur gelden dat het morele gewicht van de wens van het betreffende familielid om niet te weten afneemt naarmate de mogelijkheden van dragers tot primaire en/of secundaire preventie toenemen. 47

Gevers merkt op dat vanuit juridisch oogpunt het belang, mits dit zwaarwegend is, van de adviesvrager zal moeten prevaleren. Aan het uitgangspunt van gelijke toegang tot de gezondheidszorg dient alleen in uitzonderlijke situaties afbreuk te worden gedaan, aldus Gevers. ${ }^{4}$ Hieraan zou men het formele argument kunnen toevoegen dat de klinisch geneticus een behandelingsovereenkomst is aangegaan met de adviesvrager en niet met het betrokken familielid. De adviesvrager heeft een wettelijk recht op informatie. Het familielid daarentegen heeft de wens om niet op de hoogte te raken.

Gezien het feit dat Gevers aangeeft dat het belang van de adviesvrager wel zwaarwegend moet zijn, lijken de standpunten van De Wert en Gevers niet ver uit elkaar te liggen. Uitgaande van de veronderstelling dat zowel de adviesvrager als het familielid in concrete situaties zwaarwegende belangen zullen hebben, zal een

erfelijke ziekte, zal hij nog steeds een voorspellend onderzoek willen laten verrichten om vast te kunnen stellen of hij drager is of niet. De exclusietest wordt uitgevoerd door het DNA van de grootouders, alsmede van de ouder die niet verwant is met de grootouders te bekijken. Daarbij blijft buiten beschouwing op welk van de beide chromosomen de mutatie is gelegen van de aangedane grootouder. Wanneer de kleinzoon geen chromosoom van zijn aangedane grootouder heeft geërfd, is hij geen mutatiedrager. Wanneer dit wel zo is, heeft hij een risico van $50 \%$ dat hij de mutatie heeft geërfd. Zie voor een duidelijke uitleg De Wert, XVI Ethische aspecten, hoofdstuk 1, paragraaf 1.3 .2

4 De Wert 1998, p. 43-52. Zie ook De Wert, XVI Ethische aspecten, hoofdstuk 1, paragraaf 1.3.2. De KNMG heeft dit standpunt overgenomen. KNMG Achtergrondstudie Commissie Medische Ethick 1998, p. 40-41.

48 Gevers 1999, p. 46. In zijn preadvies uit 1996 stelt hij: "Dat het kunnen weten door het recht beschermd wordt, betekent overigens niet dat het absoluut karakter heeft, ook niet als men aanvaardt dat het om een fundamentele vrijheid gaat. In de eerste plaats is het mogelijk, dat het soms moet wijken voor andere belangen. Zo kan het in bepaalde gevallen botsen met het recht op niet weten van een ander. Gevers 1996, p. 15. 
belangenafweging moeten uitmaken wat goed hulpverlenerschap in concrete situaties inhoudt. Dit zal in ieder geval bestaan uit intensief contact van de zijde van de klinisch geneticus met zowel de adviesvrager als met het betrokken familielid. De Wert heeft, zoals aangegeven, een aantal relevante factoren genoemd die van belang zijn bij het maken van een afweging. Daarnaast heeft hij er terecht opgewezen dat de wens om niet te worden geinformeerd minder snel gerespecteerd dient te worden wanneer er voor de adviesvrager preventieve opties zijn.

\subsubsection{Hogere eisen ann informatieplicht bij erfelijkheidsadvisering?}

In hoofdstuk 1 is aangegeven dat de relatie adviesvrager-klinisch geneticus in enkele opzichten afwijkt van de reguliere patient-hulpverlener relatie. Daar is opgemerkt dat om een erfelijkheidsonderzoek te kunnen verrichten vaak informatie over bloedverwanten vereist is. Bovendien kan informatie die uit erfelijkheidsonderzoek naar voren is gekomen, van belang zijn voor familieleden van de adviesvrager. Ook het duurzame en vaak onveranderlijke karakter van erfelijkheidsinformatie is genoemd. Ten slotte is gewezen op het meest wezenlijke aspect van de erfelijkheidsinformatie, te weten het voorspellende karakter ervan. Hebben deze aspecten ook gevolgen voor de eisen die aan de erfelijkheidsadvisering moeten worden gesteld?

\section{Voorspellend erfelijkheidsonderzoek is medisch niet noodzakelijk}

In veel hulpverleningssituaties richt een patiënt zich tot zijn arts met een klacht, hopend dat de arts een diagnose kan stellen en hem vervolgens van de klacht af kan helpen. In veel gevallen zal een medisch onderzoek voor de hand liggen om een diagnose te kunnen stellen. In de genetica wordt ook diagnostisch onderzoek verricht. Daarbij is de vraag overigens zelden of nooit gericht op het verhelpen van de aandoening. Enerzijds omdat de geneticus niet de behandelend arts is en hem gevraagd is de klinisch reeds gestelde of vermoede diagnose door middel van erfelijkheidsonderzoek te bevestigen, anderzijds omdat de adviesvrager lijdt aan een mogelijk erfelijk syndroom en een klinisch geneticus niet veel meer kan doen dan te proberen een diagnose te stellen. Bij voorspellend genetisch onderzoek is de keus voor een medisch onderzoek, in concreto een erfelijkheidsonderzoek, minder vanzelfsprekend. Het betreft immers gezonde adviesvragers die willen weten of zij zullen gaan lijden aan een erfelijke ziekte, dan wel of zij, of hun nageslacht, een verhoogd risico hebben op een (deels) erfelijke ziekte. Heeft dit feit gevolgen voor de informatieplicht van de klinisch geneticus?

Hier dient een onderscheid gemaakt te worden tussen enerzijds het begrip medische indicatie en anderzijds noodzakelijk onderzoek. De beroepsgroep stelt vast of een erfelijkheidsonderzoek medisch geindiceerd is. Bij voorspellend erfelijkheidsonderzoek zal dit afhangen van het feit of de adviesvrager een verhoogd risico heeft op een (toekomstige) erfelijke aandoening. Noodzakelijk onderzoek zou ik willen definiëren als onderzoek dat noodzakelijk is om een diagnose te kunnen stellen en/of om mogelijke gezondheidsschade te voorkomen. Voorspellend erfelijkheidsonderzoek is volgens deze definitie niet altijd noodzakelijk onderzoek. 
Het betreft in veel gevallen dus medisch geïndiceerd niet-noodzakelijk onderzoek. Hiermee wordt overigens geenszins het belang van erfelijkheidsonderzoek ontkend of onderschat. Artikel 7:448 lid 2, sub a, BW stelt dat de hulpverlener zich laat leiden door hetgeen de patiënt redelijkerwijze dient te weten ten aanzien van de aard en het dol van het onderzoek of de behandeling die hij noodzakelijk acht. Omgekeerd legt dit mijns inziens de verplichting op de klinisch geneticus om, indien dit aan de orde is, duidelijk aan te geven dat het voorspellend genetisch onderzoek niet noodzakelijk is, in die zin dat de adviesvrager gezondheidsschade op zou kunnen lopen wanneer hij besluit het onderzoek niet te laten verrichten. Hij dient duidelijk te maken dat het onderzoek, gezien de aard, te weten onderzoek betreffende toekomstige aandoeningen of de risico's daarop, dient om kennis te vergaren omtrent die toekomstige aandoeningen of die risico's daarop, met als, niet medisch, doel van de erfelijkheidsadvisering: het informatieproces dat nodig is om adviesvragers tot begrip en tot een voor hen juiste besluitvorming te komen ten aanzien van erfelijke aandoeningen. $\$ 9$ Het voorspellende karakter van de informatie dient dus duidelijk naar voren te worden gebracht.

De voorspellend aard stelt hoge eisen an de erfelijkheidsadvisering

Voor wat betreft de aard van het voorspellende erfelijkheidsonderzoek het volgende. De voorspellende waarde kan eruit bestaan dat de adviesvrager weet dat zich in de toekomst een ziekte bij hem of zijn nageslacht zal openbaren. Het is echter ook mogelijk, en dit komt veel vaker voor, dat er een verhoogd risico is op een ziekte. Dit voor de genetica kenmerkende, specifieke en wezenlijke aspect verdient enige nuancering in die zin dat er ook vele onvoorspelbare omgevingsfactoren meespelen. Bovendien is men vaak niet in staat om te voorspellen wanneer en in welke mate een aandoening zich zal openbaren. Dit onveranderlijke karakter en de voorspellende waarde van erfelijkheidsinformatie kunnen grote gevolgen hebben voor het leven van de adviesvrager en diens naasten. Deze kennis kan een bestaande aandoening betreffen bij de adviesvragers zelf of diens ongeboren kind of een aandoening die zich in de toekomst (waarschijnlijk of mogelijk) zal openbaren. Deze gevolgen kumnen bestaan uit consequenties voor de partnerkeuze, de beroepskeuze, het afbreken van een zwangerschap, de keuze om al dan niet kinderen te krijgen, al dan niet kinderen te adopteren of al dan niet gebruik te maken van een kunstmatige voortplantingsmethode. Genoemde gevolgen betroffen het maken van ingrijpende keuzes. Erfelijkheidsinformatie brengt ook psychische, sociale en maatschappelijke gevolgen met zich mee. De wetenschap dat men aan een erfelijke aandoening lijdt, of (waarschijnlijk) zal gaan lijden, vereist vaak een herinrichting van het eigen leven. Prioriteiten kunnen anders komen te liggen. De nieuwe wetenschap kan schuld- en, angstgevoelens met zich mee brengen. Bij erfelijkheidsinformatie kunnen ten slotte ook maatschappelijke belangen in het geding zijn. Werkgevers (aanstellingskeuringen), hypotheekverstrekkers en verzekeraars (met name bij levensverzekeringen) hebben er belang bij te weten of de toekomstige werk-, hypotheek-, verzekeringsnemer in de toekomst (mogelijk) aan een erfelijke aandoening zal gaan lijden. De voorspellende aard van het onderzoek en met name 
de genoemde mogelijke gevolgen en matschappelijke belangen, stellen hoge eisen an de erfelijkheidsadvisering.

\section{Jurisprudentie}

Uit de jurisprudentie is nar voren gekomen dat "naarmate de informatie van groter gewicht is, moet de arts zich meer moeite getroosten om de informatie goed over te dragen en zich ervan te verzekeren, dat de informatie door de patiënt is begrepen". 50 $\mathrm{Bij}$ voorspellend medisch onderzoek is de uit onderzoek beschikbaar komende informatie voor de adviesvrager, en vaak ook voor bloedverwanten, van groot gewicht, hetgeen een grote verantwoordelijkheid legt bij de geneticus. De klinisch geneticus moet de informatie daarom duidelijk en zorgvuldig overdragen en zich ervan verzekeren dat de adviesvrager zowel de informatie begrepen heeft als de consequenties voor hem en zijn bloedverwanten overziet. Ook de zorg van een goed hulpverlener brengt deze verantwoordelijkheid met zich mee.

Daarnaast is in de rechtspraak de norm ontwikkeld dat aan de informatieplicht van de arts zeer strenge eisen worden gesteld wanneer het medisch niet-noodzakelijke ingrepen betreffen. ${ }^{51}$ Deze norm komt naar voren in de rechtspraak rond esthetische chirurgie en sterilisatie. In een arrest van 29 september 1992 bepaalt het hof in Arnhem dat:

"juist in een situatic waarin (...) het gaat om een esthetische, dus beslist niet noodzakelijke, operatie de informatieplicht van de arts zeer ver gaat." 52

De rechtbank in Dordrecht stelt in zijn vonnis van 21 juni 1995 inzake een mislukte sterilisatie het volgende:

"Duidelijk is dat cen sterilisatie in het algemeen geen noodzakelijke behandeling is, aangezien er alternatieven voor geboortebeperking zijn, en dat een ongeplande zwangerschap als gevolg van een mislukte sterilisatie in het algemeen als ingrijpend gevolg moet worden aangemerkt. Dit zijn redenen om hogere eisen aan de informatieverstrekking bij een sterilisatie dan bij een willekeurige medische behandeling te stellen." 5.3

De jurisprudentie dateert uit de periode voor de inwerkingtreding van de Wgbo. Daar de Wgbo juist een codificatie is van de ontwikkelingen in de jurisprudentie mag aangenomen worden dat genoemde jurisprudentie ook momenteel dient als een richtsnoer voor rechterlijke beslissingen. Belangrijk is wel te bedenken dat elke zaak een individuele zaak is en dat men voorzichtig moet zijn met het afleiden van algemene normen uit de jurisprudentie. Bovendien betreffen de uitspraken esthetische chirurgie en een mislukte sterilisatie. Beide hebben echter met voorspellend genetisch onderzoek gemeen dat het niet-noodzakelijke ingrepen betreffen. Het lijkt om die reden aannemelijk dat de rechter ook bij voorspellend

50 Gevers en Van Aalst 1998, p. 152.

\$1 Kastelein 1995, p. 336-339. Zie ook Hulst 1995 en Legemaate 1997, p. 202-207.

52 Hof Arnhem, 29 september 1992, Tथ Gr 1993, 65.

$53 \quad$ Rb. Dordrecht, 21 juni 1995, Tv Gr 1996, 11. 
medisch onderzoek strengere eisen zal stellen aan de informatieverplichting van de klinisch geneticus. De rechtbank in Dordrecht wees er daamaast op dat een ongeplande zwangerschap in het algemeen als een ingrijpend gevolg van een mislukte sterilisatie moet worden aangemerkt. De gevolgen van voorspellend erfelijkheidsonderzoek zijn weliswaar niet ingrijpend wanneer dergelijk onderzoek zou mislukken, echter de gevolgen die voortvloeien uit de informatie die beschikbaar komt ten gevolge van voorspellend erfelijkheidsonderzoek kunnen wel als ingrijpend worden bestempeld. Ook in de jurisprudentie zijn dus aanwijzingen te vinden om hoge eisen te stellen aan de informatieplicht van de klinisch geneticus. Dit leidt tot de veronderstelling dat een klinisch geneticus bij voorspellend erfelijkheidsonderzoek eerder aansprakelijk zal worden gehouden voor het niet voldoen aan de informatieplicht dan bij diagnostisch erfelijkheidsonderzoek.

\section{Conclusic}

Samenvattend kan het volgende worden gesteld. Ten eerste werd opgemerkt dat voorspellend erfelijkheidsonderzoek geen medisch noodzakelijk onderzoek betreft. Dit makt de keus om dergelijk onderzoek te ondergaan minder vanzelfsprekend. Uit de jurisprudentie bleek dat bij medisch nict-noodzakelijk onderzoek hoge eisen worden gesteld aan de informatieplicht. Van groter belang voor de eisen die aan de informatieplicht gesteld moeten worden, is mijns inziens de voorspellende aard van het onderzoek en de mogelijke gevolgen daarvan voor zowel de adviesvrager als zijn familieleden. Uit de jurisprudentie volgt de norm dat naarmate de informatie van groter gewicht is, de hulpverlener zich meer moeite moet getroosten om de informatie goed over te dragen en zich ervan te verzekeren, dat de informatie door de patiënt is begrepen. Het gewicht van de informatie en de mogelijke gevolgen rechtvaardigen hoge eisen voor wat betreft de informatieplicht van de klinisch geneticus. Hij moet zich meer moeite getroosten om de informatie duidelijk en helder over te dragen en zich ervan vergewissen dat de informatie begrepen wordt door de adviesvrager. Dit legt een grote verantwoordelijkheid op de schouders van een klinisch geneticus. Daar komt nog bij dat vaak heel veel complexe medische informatie moet worden verstrekt, waarbij nog veel zaken onzeker en onduidelijk zijn. Bij voorspellend onderzoek wordt vaak de ene onzekerheid ingeruild voor de andere. ${ }^{54}$ De onzekerheid over de vraag of een genmutatie zal worden gevonden maakt plaats voor onzekerheid over de openbaring van de ziekte, onzekerheid over de vraag wanneer en in welke mate, en onzekerheid over de effecten van preventieve matregelen.

Het gevaar bij een grote hoeveelheid informatie is dat het voor de adviesvrager contraproductief werkt en dat zijn keuze om een voorspellend erfelijkheidsonderzoek te ondergaan geen weloverwogen en geinformeerde keuze meer kan worden genoemd. Het is daarom van groot belang dat de informatie goed gedoseerd wordt gegeven, aangepast aan het vermogen van de adviesvrager om deze te verwerken. Dit zal vaak inhouden dat er meerdere gesprekken voorafgaan aan een onderzoek. Daarnaast moet een geneticus zich ervan vergewissen dat de adviesvrager alle informatie begrijpt. Een bevestigend antwoord van de adviesvrager

De Wert 1999, p. 251. 
op de vraag of hij de informatie begrijpt, is daartoe niet voldoende. In de praktijk zal uit vragen van de adviesvrager zelf vaak blijken in hoeverre de informatie is begrepen.

\title{
4.3.3 De therapentische exceptie
}

Een uitzondering op de informatieplicht is de therapentische exceptie, welke is greregeld in artikel 7:448 lid $3 \mathrm{BW}$ :

\begin{abstract}
"De hulpverlener mag de patiënt bedoelde inlichtingen slechts onthouden voor zover het verstrekken ervan kennelijk emstig nadeel voor de patiënt zou opleveren. Indien het belang van de patient dit vereist, dient de hulpverlener de desbetreffende inlichtingen aan een ander dan de patiënt te verstrekken. De inlichtingen worden de patiënt alsnog gegeven, zodra bedoeld nadeel niet meer te duchten is. De hulpverlener makt geen gebruik van zijn in de eerste volzin bedoelde bevoegdheid dan nadat hij daarover een andere hulpverlener heeft geraadpleegd."
\end{abstract}

De mogelijkheid voor de hulpverlener om onder bepaalde omstandigheden informatie niet mee te delen is een uitzondering op het recht op informatie van de patiënt. Van deze mogelijkheid kan hij alleen gebruik maken wanneer er sprake is van kennelijk ernstig nadeel. Deze formulering is geobjectiveerd zodat de beslissing om geen inlichtingen te verstrekken een toetsbare is. De hulpverlener zal derhalve een zorgvuldige afweging moeten maken van de in het geding zijnde belangen alvorens hij besluit gebruik te maken van de therapeutische exceptie. Bij deze afweging gaat het om de verhouding tussen de aard van de informatie enerzijds en het vermogen van de patiënt om deze informatie te verwerken anderzijds. In de Memorie van Toelichting wordt als voorbeeld genoemd de situatie waarin te verwachten valt dat het meedelen van een zeer ongunstige prognose aan een patiënt die in een labiele psychische toestand verkeert, zal kunnen leiden tot een ernstige psychische crisis, tot uitdrukking komend in een poging tot zelfdoding.

Het vermoeden dat het meedelen van de informatie zal leiden tot een ernstige psychische crisis moet een gegrond vermoeden zijn. Dit kan bijvoorbeeld blijken uit een eerder ondernomen poging tot zelfdoding. Een te verwachten minder gunstig verloop van het genezingsproces is op zich niet nog voldoende voor een beroep op de therapeutische exceptie. Hetzelfde geldt voor de situatie waarin de hulpverlener in onzekerheid verkeert omtrent de prognose. ${ }^{55}$ Ook de mogelijke weigering van een medische behandeling wanneer geïformeerd zou worden, levert geen grond op voor de toepassing van de therapeutische exceptie. Het recht van de patiënt om een medische behandeling te weigeren zou hierdoor anders uitgehold worden. ${ }^{56}$ 1993, TvGr 1994, 9. 
Het Amsterdamse Hof oordeelde dat het niet informeren over complicaties die kumnen optreden op grond van het feit dat het beleid is om patiënten met een levercirrose niet over de complicaties en over de opvattingen elders in te lichten, geen grond opleverde om de informatie aan patient te onthouden. Patiënt had recht op informatie omtrent zijn zickte en de complicaties die daaruit kumnen voortvloeien, met name omdat men er in medische kring klaarblijkelijk vanuit ging dat in geval van levercirrose een verhoogde kans op het ontstaan van slokdarmspataderen bestond. Die complicatie kan een ernstige bedreiging voor de gezondheid van de patiënt gaan vormen, zeker wanneer onwetendheid omtrent een dergelijk complicatie tot gevolg kan hebben dat de patiënt zich bij een bloeding niet direct van adequate medische hulp voorziet. Ook had de pationt recht op informatie over de verschillende opvattingen omtrent het nut van eventuele behandelingsvormen van slokdarmspataderen, zodat hij de keus zou hebben gehad om elders een second opinion te vragen, dan wel te opteren voor een behandelingsmethode, aldus het Hof. Omtrent de geleden immateriële schade overwoog het Hor:

"Bovendien is A. door het achterhouden van de hier bedoelde informatie in zijn zelfbeschikkingsrecht en daardoor in zijn persoon aangetast."s?

Het feit dat een patiënt door het achterhouden van informatie in zijn zelfbeschikkingsrecht en daardoor in zijn persoon kan worden aangetast toont mijns inziens het belang van een restrictieve interpretatie van de therapeutische exceptie. Slechts kennelijk ernstig nadeel voor de patiënt rechtvaardigt, na een zorgvuldige belangenafweging en overleg met een collega, het onthouden van informatie.

In de literatuur is gesteld dat de omschrijving kennelijk ernstig nadeel de mogelijkheid biedt voor een ruime toepassing. ${ }^{5 s}$ Volgens de Memorie van Toelichting dient de bepaling echter restrictief te worden geïnterpreteerd. Het gaat om een uitzonderingsbepaling. Verwacht wordt dat de situatie zich zelden zal voordoen. ${ }^{59}$ Bovendien heeft de hulpverlener indien het belang van de patiënt dit vereist de plicht informatic aan een ander te verstrekken. Dit zal in concrete gevallen waarschijnlijk de partner of een eerstegraads familielid zijn. Hierbij kan gedacht worden aan het geval warin het voor de genezing van de patiënt noodzakelijk is dat de partner of de kinderen die hem verzorgen of opvangen bepaalde gedragsregels in acht moeten nemen. Ook de huisarts zou kunnen worden ingelicht. De plicht om indien het belang van de patiënt dit eist informatie aan een ander te verstrekken is een uitzondering op de geheimhoudingsplicht van de hulpverlener. De uitzondering bestaat echter slechts zolang er kennelijk ernstig nadeel te duchten is van het verstrekken van informatie.60 De plicht voor de hulpverlener om een andere hulpverlener te consulteren is destijds bij amendement toegevoegd om te voorkomen dat er van de therapeutische exceptie gebruik zou worden gemaakt op grond van een

57 Hof Amsterdam 19 februari 1998, TvGr 1998, 48.

58 Leenen 2000, p. 198. Aldus ook de Nationale Raad voor de Volksgezondheid 1987, p. 27.

59 Kamerstukken II 1989/90, 21561 , nr. 3, p. 12.

(1) Kamerstukken II 1989/90, 21 561, nr. 3, p. 30-31. 
te subjectief en bevoogdend oordeel. ${ }^{61}$ Uit de evaluatie van de Wgbo blijkt dat maar weinig artsen de consultatieplicht nakomen. ${ }^{62}$

Op deze eis is in de literatuur kritiek geuit. Lagro en Van Wijmen wijzen erop dat de hulpverlener in verschillende situaties de ruimte krijgt om op grond van goed hulpverlenerschap een eigen afweging te maken. Het is vervolgens niet consistent om dan te veronderstellen dat de hulpverlener de keuze voor de therapeutische exceptie te gemakkelijk zou maken. Het is bovendien de vraag hoe de collegiale toetsing vorm moet krijgen. Wanneer een collega geraadpleegd wordt en een samenvatting van de situatic te horen krijgt, is de kans groot dat deze instemt. Een second opinion waarin een collega een eigen onafhankelijk oordeel velt is een te zwaar middel, dat de patiënt erg zou verontrusten. Dit leidt de auteurs ertoe te concluderen dat wetgever de verplichte collegiale raadpleging beter achterwege had kunnen laten.63

Roscam Abbing wijst erop dat de hulpverlener ook oog moet hebben voor de consequenties die het niet informeren voor de patiënt tot gevolg kunnen hebben. Een patiënt die niet geïnformeerd is over een infauste prognose, heeft niet de gelegenheid om tijdig zakelijke regelingen te treffen, hetgeen weer tot civicle acties kan leiden. Deswege is het van groot belang dat de therapeutische exceptie een uitzondering op de informatieplicht blijft. ${ }^{6+t}$

In de praktijk blijkt dit ook zo te zijn. Uit een NIVEL-enquête onder verschillende soorten artsen blijkt dat zij in de praktijk weinig gebruik maken van de therapeutische exceptie. De kwantitatieve betekenis van de bepaling is gering. Wanneer bovendien gebruik wordt gemaakt van de therapeutische exceptie, consulteert slechts een kleine groep artsen een collega. ${ }^{65}$

Voor zover de toestemming aan de orde is, dient voor de volledigheid te worden opgemerkt dat de toepassingsruimte van de therapeutische exceptie beperkt is door het feit dat de toestemmingseis voor ingrijpende verrichtingen niet door middel van de therapeutische exceptie kan worden omzeild. ${ }^{66}$ De wet biedt geen mogelijkheid om enerzijds gebruik te maken van de therapeutische exceptie en anderzijds een rechtsgeldige toestemming te verkrijgen voor een ingrijpende verrichting zonder de patiënt daarover te informeren. ${ }^{67}$

Kamerstukken II 1993/94, 21561, nr. 41.

Dute 2000, p. 85.

Lagro-Janssen en Van Wijmen 1998, p. 603-606.

Roscam Abbing 1995, p. 21-32.

Dute 2000, p. 85.

Roscam Abbing 1995, p. 27.

Leenen is van mening dat bij het toepassen van de therapeutische exceptie geen toestemming hoeft te worden gevraagd. Leenen 2000, p. 205. 


\subsubsection{De therapeutische exceptie en erfelijkheidsadvisering}

In de erfelijkheidsrichtlijnen wordt ook uitgegaan van de mogelijkheid dat een geneticus informatie onthoudt aan de adviesvrager wanneer die informatie kennelijk ernstig nadeel oplevert:

"Informatie die kennelijk ernstig nadeel voor de cliënt zou opleveren, wordt door de arts (nog) niet gegeven."

De toelichting hierop luidt:

"Bij erfelijkheidsonderzoek zal de cliënt waarschijnlijk meer dan bij andere medische handelingen voorbereid zijn op informatie over ernstige risico's. Daarom zal deze (vaak tijdelijke) uitzondering op de informatieplicht extra terughoudend moeten worden toegepast."68

Het is inderdaad zo dat een adviesvrager alvorens hij erfelijkheidsonderzoek ondergaat goed ingelicht zal zijn over de mogelijke uitkomsten, of dit althans behoort te zijn. Hoe beter hij voorbereid is op de uitkomsten, des te minder ruimte is er voor de toepassing van de therapeutische exceptie. De belangenafweging die de geneticus moet maken wanneer hij de therapeutische exceptie overweegt zal afhangen van de verhouding tussen de aard van de informatie enerzijds en het vermogen van de adviesvrager om deze informatie te verwerken anderzijds. De ingrijpende aard van de informatie zal van tevoren aan bod zijn gekomen evenals het vermogen van de adviesvrager om de uitkomsten te verwerken. Wanneer dat vermogen niet toereikend lijkt, zou het erfelijkheidsonderzoek in samenspraak met de adviesvrager uitgesteld kunnen worden, of zou daar zelfs vanaf gezien kunnen worden. Een mogelijkheid om de voorbereiding op een genetisch onderzoek te optimaliseren is bijvoorbeeld psychosociale hulpverlening door een deskundige. ${ }^{69}$ Indien vervolgens door de adviesvrager weloverwogen wordt gekozen om een erfelijkheidsonderzoek te ondergaan, is het niet aannemelijk dat het verstrekken van de uitslag kennelijk ernstig nadeel oplevert voor de adviesvrager.

Daar staat echter tegenover dat erfelijkheidsinformatie zeer belastend en bedreigend kan zijn. Een erfelijkheidsonderzoek kan informatie genereren die de geestelijke draagkracht van de adviesvrager te boven kan gaan. ${ }^{70}$ Indien echter de mogelijke bevindingen van het onderzoek van tevoren uitvoerig zijn doorgenomen met de adviesvrager en deze tot een weloverwogen besluit is gekomen, dan is er in principe geen ruimte voor de therapeutische exceptie. Dit is wellicht anders wanneer uit het erfelijkheidsonderzoek onverwachte bevindingen naar voren komen die niet vooraf besproken konden worden, dan wel niet besproken zijn. ${ }^{71}$ Indien de klinisch geneticus gegronde redenen heeft om aan te nemen dat in de gegeven omstandigheden de informatie kennelijk ernstig nadeel voor de adviesvrager op zou leveren, dan zou hij de therapeutische exceptie kunnen toepassen. Bedoelde

is Ook Gevers is deze mening toegedaan. Gevers 1996, p. 20.

69 Zo dit niet al standaard bij de voorbereidingsprocedure hoort.

70 Aldus ook Sutorius 1993, p. 166.

$71 \quad$ Zie ook Markenstein, Gevers en Roscam Abbing 1999, p. 27 en Gevers 1999, p. 39. 
omstandigheden kumnen eruit bestaan dat er een slechte uitslag is én dat er onverwacht nog een aanleg voor een erfelijke ziekte is gevonden. ${ }^{72}$ Wanneer een adviesvrager moeilijk blijkt om te kunnen gaan met een slechte uitslag, zou de geneticus kunnen besluiten on de onverwachte bevindingen op een later tijdstip mee te delen. Uiteraard tenzij medisch ingrijpen snel geboden is. Ook veranderde omstandigheden in de privé-sfeer van de adviesvrager, die zijn vermogen om de informatie te verwerken negatief beïnvloeden, kunnen aanleiding zijn om de informatie achter te houden. Zodra geen kennelijk ernstig nadeel meer te duchten is, dient de adviesvrager alsnog geinformeerd te worden.

\section{Therapeutische exceptie oersus gedoseerd on gefaseerd informeren}

Het is overigens van belang een onderscheid te maken tussen enerzijds de toepassing van de therapeutische exceptie en anderzijds het gedoseerd en gefaseerd informeren. Wanneer uit erfelijkheidsonderzoek bijvoorbeeld blijkt dat een pasgeborene lijdt aan een syndroom, zal de klinisch geneticus vooral die informatie aan de ouders moeten verstrekken, die van belang is voor de ontwikkeling van de baby op dat moment en zal informatie met betrekking tot de ontwikkeling van de pasgeborene als kleuter of als tiener, in een later stadium gegeven kunnen worden. Te meer daar het waarschijnlijk moeilijk te voorspellen valt hoe de ontwikkeling zal verlopen. De ouders moeten de informatie immers kunnen begrijpen en verwerken en een overdosis an informatie zou contraproductief werken. Het goed hulpverlenerschap vereist een begeleiding van de ouders waarin de relevante informatie op het juiste tijdstip wordt verstrekt en waarin ruimte is voor vragen van de zijde van de adviesvragers. Het onderscheid tussen de therapeutische exceptie en het gedoseerd en gefaseerd informeren is wellicht in de praktijk niet altijd scherp te maken. Van belang hierbij lijkt dat de geneticus in ieder geval vragen van de adviesvrager goed beantwoordt en duidelijk makt dat sommige informatie niet verstrekt kán worden omdat daar pas in de toekomst met zekerheid iets over gezegd kan worden.

\section{Opvatting Gezondheidsrand}

Volgens de Gezondheidsraad kan het voor wat betreft de toepassing van de therapeutische exceptie bij erfelijkheidsadvisering soms gaan

"om informatie over de kans op een onbehandelbare aandoening, waarbij volledige openheid een schaduw zou werpen over het leven van de adviesvrager en diens gezin." 73

Deze formulering is erg ruim. Wanneer een adviesvrager een bepaald risico heeft op een onbehandelbare aandoening, dan moet dat wel een schaduw werpen op zijn leven. Dit zou betekenen dat telken male wanneer een adviesvrager een risico heeft op een onbehandelbare aandoening, de therapeutische exceptie zou kunnen worden toegepast. De Gezondheidsraad geeft echter wel aan dat de therapeutische exceptie slechts in uitzonderlijke gevallen zou moeten worden toegepast. Een beroep erop is

72 Bij gericht DNA-onderzoek zal dit overigens niet voorkomen.

73. Gezondheidsraad 1989, p. 97. 
slechts dan gerechtvaardigd wanneer het belang van de informatie niet opweegt tegen de te verwachte schade. ${ }^{7.4}$

Gen therapentische exceptie bij erfelijkheidsadvisering?

Een stap verder gaat de opvatting dat er bij erfelijkheidsadvisering nooit sprake zou kumnen zijn van de therapeutische exceptie. Capron geeft drie argumenten ten faveure van deze opvatting. Ten eerste betoogt hij dat genetici, in tegenstelling tot huisartsen, ${ }^{75}$ adviesvragers nooit echt goed kennen, waardoor zij niet kunnen weten of het in het belang is van de adviesvrager om informatie achter te houden. Ten tweede wordt door zowel interne als externe druk een juiste inschatting van wat het beste is voor de adviesvrager belemmerd. Hierbij noemt Capron "physicians' wellknown tendency to overreact to disease (...) this attitude is hardly conducive to a counselor's making a good choice for his patient". Ten slotte stelt hij dat het oordeel van de geneticus door zijn eigen waarden wordt beïnvloed. ${ }^{76}$

Het is ongetwijfeld waar dat genetici adviesvragers niet goed kennen. Ook zullen zowel interne als externe druk, alsmede eigen waarden en normen de inschatting van de opvattingen van de adviesvrager beinvloeden, waardoor de beoordeling of het achterhouden van informatie ernstig nadeel oplevert, wordt bemoeilijkt. Dit hoeft echter geenszins tot de conclusie te leiden dat om die redenen de therapeutische exceptie bij de erfelijkheidsadvisering nooit mag worden toegepast. De aard van het erfelijkheidsonderzoek maakt dat er uitgebreid geinformeerd wordt en dat er deswege weinig aanleiding is om de therapeutische exceptie toe te passen. ${ }^{77}$ Het is ook uitdrukkelijk de bedoeling van de wetgever, gegeven de achterliggende gedachte van de informatieplicht, namelijk het zelfbeschikkingsrecht van de patiënt, dat er slechts in uitzonderingsgevallen gebruik van wordt gemaakt. ${ }^{78}$ Zoals hierboven aangegeven kumnen zich echter wel situaties voordoen waarin er aanleiding is om informatie tijdelijk achter te houden. Artikel 448 lid 3 BW is ook van toepassing op klinisch genetici, ondanks de door Capron genoemde beperkingen die het inschatten van de opvattingen van de adviesvrager bemoeilijken, waardoor het moeilijk kan zijn om te bepalen of bepaalde informatie ernstig nadeel voor de adviesvrager oplevert. Bovendien zorgt de toevoeging kennelijk ervoor dat het nadeel er duimendik bovenop moet liggen zodat de beslissing geobjectiveerd wordt

74 Het advies van de Gezondheidsraad is uit 1989. Het Wgbo-wetsvoorstel is in 1990 bij de Tweede Kamer ingediend.

75 De stelling dat huisartsen hun patiënten wel goed kennen lijkt me in het algemeen onhoudbaar.

76 Capron 1973, p. 221-244.

77 Zie ook de minister in haar Beleidsnota De toepassing van genetica in de gezondheidszorg: "Voor een beroep op de zogenaamde therapeutische exceptie, (..) is vanwege de eisen die bij erfelijkheidsonderzoek aan de informatie worden gesteld om tot een weloverwogen beslissing te komen, weinig ruimte. Mogelijke negaticve gevolgen zijn immers al in de besluitvorming vooraf aan de orde geweest." Ministerie van Volksgezondheid, Welzijn en Sport 2000, p. 36. 
en toetsbaar is. Overigens lijken de genoemde beperkingen me niet specifiek van toepassing te zijn op de praktijk van de erfelijkheidsadvisering. ${ }^{79}$

Gevers merkt op dat een beroep op de therapeutische exceptie bij voorspellend erfelijkheidsonderzoek praktisch onmogelijk zal zijn wanneer de test gericht en de uitslag ondubbelzinnig is, omdat het niet meedelen van een ongunstige uitslag dan al gauw op het vertelien van onwarheid neer zal komen. ${ }^{80} \mathrm{Bij}$ de toepassing van de therapeutische exceptie is het mijns inziens onmogelijk om de waarheid te vertellen. De mededeling aan een patiënt dat er niets te zien was op de foto, terwijl er cen gezwel te zien was, is even onwaar als de mededeling dat de uitslag van het erfelijkheidsonderzoek nog niet bekend is, terwijl dit wel zo is.

\section{Conclusie}

De therapeutische exceptie kan dus ook, zij het met zeer grote terughoudendheid, door de klinisch geneticus toegepast worden. Bij een eventuele toepassing van de therapeutische exceptie zou er bovendien naar gestreefd moeten worden om de informatie slechts voor een bepaalde tijd aan de adviesvrager te onthouden. Het goed hulpverlenerschap vereist inspanningen van de klinisch geneticus om te trachten dat het alsnog informeren van de adviesvrager geen kennelijk ernstig nadeel meer oplevert. Dit zou bijvoorbeeld vorm kunnen krijgen door middel van het aanbieden van psychosociale hulpverlening. De vraag is of voor wat betreft de toepassing van de therapeutische exceptie er een onderscheid gemaakt moet worden tussen diagnostisch en voorspellend erfelijkheidsonderzoek. De erfelijkheidsrichtlijnen maken dit onderscheid niet. Ook in de literatuur is deze vraag niet gesteld. Opgemerkt is dat de aard van erfelijkheidsonderzoek met zich mee brengt dat er uitgebreid geïnformeerd wordt. Dit geldt met name voor voorspellend erfelijkheidsonderzoek. Diagnostisch onderzoek verschilt qua aard niet van diagnostisch onderzoek in andere medische disciplines. Dit leidt tot de veronderstelling dat er bij diagnostisch onderzoek eerder aanleiding zal zijn voor de toepassing van de therapeutische exceptie dan bij voorspellend onderzoek. Het blijft echter een uitzonderingsbepaling.

Ten slotte nog een opmerking over de consultatieplicht. In de vorige paragraaf is opgemerkt dat er bezwaren zijn aan te voeren tegen de plicht van een hulpverlener om een andere hulpverlener te raadplegen alvorens hij de therapeutische exceptie toepast. Op het gebied van de erfelijkheidsadvisering lijkt deze eis in ieder geval op zijn plaats. ${ }^{81}$ Ten eerste kan erfelijkheidsinformatie zeer belastend en bedreigend zijn, zeker wanneer het een onverwachte bevinding betreft. Dit maakt de beslissing om de therapeutische exceptie toe te passen alles behalve een lichtvaardige, waarbij overleg op zijn plaats is. Ten tweede lijkt het aannemelijk dat het om een belangenafweging

Overigens dient hierbij in aanmerking te worden genomen dat de stelling van Capron niet van recente datum is, en geschreven is in een tijd waarin het gebruikelijker was om in het belang van de patiint informatie achter te houden.

\$1 Zie ook Gevers 1996, p. 20. 
gaat die een klinisch geneticus bij hoge uitzondering maakt. In de praktijk blijkt ook dat er overleg gepleegd wordt. Zie hiervoor hoofdstuk 8.

\subsubsection{Non-directieve erfelijkheidsadvisering?}

Artikel 7:448 BW regelt de informatieplicht van de geneticus. In zijn algemeenheid bepaalt dat artikel welke informatie in het kader van de geneeskundige behandeling moet worden gegeven en hoe dat dient te geschieden. Gelet op het bijzondere karakter van de erfelijkheidsadvisering mogen aan de informatieverstrekking hoge eisen worden gesteld. Centraal staat daarbij de non-directiviteit, $\$ 2$ door De Wert de cardinale deugd van de hulpgever genoemd. ${ }^{83}$

In de richtlijnen van Vereniging voor Gezondheidsrecht wordt de non-directiviteit als volgt verwoord:

"De arts helpt de cliënt die om advies vraagt bij het nemen van persoonlijke beslissingen, door de mogelijke alternatieven en de voor- en nadelen daarvan met hem te bespreken. De arts laat de cliënt vrij in de keuze die hij maakt en respecteert die keuze."

De toelichting hierop stelt:

"De arts zal bij de advisering niet zijn eigen mening of overtuiging moeten opdringen. Het erfelijkheidsonderzoek is bedoeld om het zelfbeschikkingsrecht van de cliënt te vergroten of te herstellen in die zin, dat de cliënt goed geïnformeerd een eigen zelfstandige beslissing kan nemen."

In paragraaf 1.4 is reeds opgemerkt dat non-directieve erfelijkheidsadvisering feitelijk niet mogelijk is. Het is een ideaal dat nagestreefd wordt. Erfelijkheidsadvisering zal altijd, zij het meestal impliciet, directieve elementen bevatten. ${ }^{84}$ Hier wordt de vraag aan de orde gesteld hoe de norm van nondirectiviteit moet worden ingevuld, alsmede de vraag of de norm altijd van toepassing is.

De eis dat de erfelijkheidsadvisering non-directief van aard is, kan worden gezien als een uitwerking van het zelfbeschikkingsrecht. De norm is ontstaan toen de erfelijkheidsadvisering nog nagenoeg identiek was aan erfelijkheidsadvisering betreffende risico's voor de gezondheid van het nageslacht van adviesvragers,

82 Zowel binnen als buiten de beroepsgroep (met de beroepsgroep wordt bedoeld de Vereniging van Stichtingen Klinische Genetica i.o.) bestaat hier eenstemmigheid over. Zie bijvoorbeeld: Gezondheidsraad 1989, p. 77 en Raad van Europa 1992, principle 3a.

s3 De Wert 1999, p. 193.

st Een tekstanalyse van dertig counselingsgesprekken in een klinisch genetisch centrum in Nederland liet zien dat de adviesvragers op subtiele wijze door genetici werden aangespoord verder gebruik te maken van de beschikbare voorzieningen. Van Zuuren 1996. Zie ook Christiaens 1988, p. 846-848. 
oftewel reproduction counseling. 85 Waarom is deze eis zo belangrijk voor de erfelijkheidsadvisering? Hiervoor zijn verschillende redenen te geven. Ten eerste kan het uitgangspunt worden gezien als een reactie op de eugenetische praktijken die in de eerste helft van de vorige eeuw in onder andere de Verenigde Staten en Duitsland bestonden, zoals de praktijk van de gedwongen sterilisaties. Een tweede reden is de nadruk die met name in de arts-patiënt relatie gedurende de jongste decennia op het zelfbeschikkingsrecht wordt gelegd. Het recht op informatie is hier een uitdrukking van. Ten derde het feit dat de beslissingen en afwegingen war adviesvragers voor komen te staan, zoals beslissingen rond de voortplanting en de beslissing wat men wel en wat men niet wil weten met betrekking tot de eigen gezondheid, in onze cultuur gelden als een persoonlijke aangelegenheid. $s$ in

\section{Verschillemde oprattingen over directiviteit en non-directiviteit}

In de literatuur en de praktijk blijken verschillende opvattingen te leven over de inhoud van de norm dat de erfelijkheidsadvisering non-directief van aard is. Er zijn verschillende concepten te onderscheiden. De Wert onderscheidt de volgende concepten van directiviteit:

- het bekrachtigen van de eigen opvattingen en keuzen van de adviesvrager;

- het - gevraagd of ongevraagd - geven van advies;

- verkapte vormen van beinvloeding, waaronder het geven van onvolledige of gekleurde informatie;

- het hanteren van een strikt indicatiegebied voor diagnostiek;

- het stellen van voorwaarden aan de toegang tot medisch-geïndiceerde onderzoeken. ${ }^{\mathrm{s}}$

De eerste drie concepten hebben betrekking op de wijze waarop de klinisch geneticus de informatie verstrekt of bekrachtigt. De laatste twee op de wijze waarop wordt bepaald wie cen erfelijkheidsonderzoek mag ondergaan.

Daarnaast onderscheidt De Wert de volgende concepten van non-directiviteit:

- de klinisch geneticus onthoudt zich van het geven van advies;

- de klinisch geneticus moet de adviesvrager steunen in iedere keuze die hij maakt;

- de klinisch geneticus presenteert de adviesvrager alleen de feiten;

- de klinisch geneticus presenteert de adviesvrager de feiten en de (eventuele) morele dilemma's waar hij voor staat, zonder een advies te geven en de adviesvrager te vertellen wat hij moet doen. ${ }^{88}$

Deze concepten, alsmede een vijfde concept, zullen hieronder worden besproken en becommentarieerd. In dit vijfde concept presenteert de klinisch geneticus niet alleen de morele aspecten van de keuzemogelijkheden van de adviesvrager, maar brengt hij ook zijn eigen waarden en normen mee in de discussie en onderzoekt de waarden van de adviesvrager en stelt deze ter discussie

s5 $\quad$ DeWert 1999, p. 193.
so $\quad$ De Wert 1999, p. 196.
s7 $\quad$ De Wert 1999, p. 195.
ss $\quad$ De Wert 1999, p. 195.


Ten eerste wordt non-directiviteit opgevat als het zich onthouden van het geven van advies: een geneticus mag zijn eigen opvattingen niet kenbaar maken aan de adviesvrager. Dit concept geeft echter geen antwoord op de vraag op welke wijze de klinisch geneticus informatie moet verstrekken, behalve dat hij dit niet kan doen door middel van het geven van een advies. Bij het bespreken van het moral education model dat in deze paragraaf verdedigd zal worden, wordt nog ingegaan op de vraag of de klinisch geneticus zijn opvattingen kenbaar mag maken aan de adviesvrager.

Ten tweede de interpretatie dat de klinisch geneticus de adviesvrager moet steunen in elke keuze die de adviesvrager makt. Deze opvatting is niet houdbaar. Een dergelijke opvatting zou, consequent doorredenerend, neerkomen op een $u$ vraagt, wij draaien beleid. De geneticus zou alle verzoeken tot erfelijkheidsonderzoek moeten honoreren. De eis van non-directiviteit heeft als achtergrond dat de adviesvrager zelf een geïnformeerde keuze moet maken. Hij beschikt zelf. Het maken van een geinformeerde keuze geschiedt echter wel binnen het juridisch kader. Dit wordt begrensd door de medische indicatie zoals die door de klinisch geneticus als een goed hulpverlener overeenkomstig de geldende medisch-professionele standaard wordt gesteld.89 Tevens is de adviesvrager afhankelijk van de technische mogelijkheden en vaak ook van de medewerking van bloedverwanten. Het stellen van voorwaarden aan de toegang tot onderzoek heeft natuurlijk wel een directief element. De beroepsgroep stelt haar grenzen en bepaalt binmen wettelijke grenzen in feite wat men wel en wat men niet mag weten. De voorwaarden die in de praktijk worden gesteld komen verderop in deze paragraaf nog aan bod.

Het concept dat de klinisch geneticus de adviesvrager in elke keuze die hij maakt moet steunen is niet alleen niet houdbaar, het geeft ook niet aan op welke wijze de klinisch geneticus informatie moet verstrekken. Het geeft alleen aan hoe de klinisch geneticus om moet gaan met de keuze van de adviesvrager: deze moet te allen tijde gesteund worden. Het derde en vierde concept geven dit wel aan. In de derde opvatting presenteert de klinisch geneticus alleen de feiten en laat hij de morele aspecten van de verschillende opties buiten beschouwing. De vierde opvatting daarentegen gaat ervan uit dat de klinisch de adviesvrager zowel de feiten als de (eventuele) morele dilemma's presenteert waar hij voor staat, zonder evenwel een advies te geven en de adviesvrager te vertellen wat hij moet doen. Voor deze vierde opvatting pleiten verschillende argumenten.

Ten eerste kan het doel van de erfelijkheidsadvisering om "adviesvrager(s) door het verstrekken van informatie in staat te stellen tot het doen van een keuze die past bij zijn (hun) opvattingen en situatie",90 alleen, of ieder geval beter, bereikt worden wanneer ook morele aspecten worden benoemd. De geneticus kan zich niet beperken tot het opsommen van de genetische feiten. Hij moet de adviesvrager helpen en ondersteunen bij het beoordelen van deze feiten. Door de morele dimensies van de verschillende keuzen die de adviesvrager heeft aan de orde te laten komen, helpt de

89 Vereniging voor Gezondheidsrecht 1991, uitgangspunt 3.1.

90 Gezondheidsraad 1989, p. 76. 
geneticus de adviesvrager om de feiten te interpreteren en zijn eigen waarden en verwachtingen te verhelderen op een wijze die het beste bij hem past.

Een tweede argument is gelegen in het feit dat het in de genetica juist de morele aspecten van de verschillende handelingsopties zijn die pleiten voor een verantwoorde professionele erfelijkheidsadvisering. Een ongunstige uitslag plaatst de adviesvrager voor nieuwe keuzen. Hij moet bijvoorbeeld bepalen of hij wel of niet zijn familieleden inlicht en voor welke preventieve handelingsopties hij kiest. De keuze om een erfelijkheidsonderzoek te ondergaan heeft consequenties voor (toekomstig) nageslacht en familieleden. Wanneer hun medewerking aan een onderzoek vereist is, zullen zij op de hoogte raken van een voorgenomen onderzoek. Zij zullen vaak ook belang hebben bij de uitkomst van het erfelijkheidsonderzoek. Een mogelijkheid is dat zij zich verzetten tegen een voorgenomen onderzoek omdat zij niet met de uitslag geconfronteerd willen worden, omdat een uitslag hun eigen risico op de erfelijke aandoening waarnaar onderzoek wordt verricht kan verhogen. Ook derden kunnen gë̈nteresseerd zijn in de uitkomst van dergelijk onderzoek. Wanneer de adviesvrager goed geinformeerd wordt over deze kwesties, is hij in staat tot het maken van een weloverwogen keuze. De Gezondheidsraad stelt met nadruk dat erfelijkheidsadvisering meer is dan het geven van medische-technische informatie. De raad benadrukt het belang van de begeleiding." In het Verdrag inzake Mensenrechten en Biogeneeskunde wordt aan voorspellend onderzoek de eis gesteld dat dergelijk onderzoek alleen plaatsvindt na "apropriate genetic counselling". ${ }^{22}$ Dit is een additionele eis die geldt naast de algemene eis dat er sprake is van een vrije geïnformeerde toestemming. Vanuit een dergelijk perspectief bezien zou het dan ook niet getuigen van goed hulpverlenerschap wanneer de klinisch geneticus zich zou beperken tot de medisch-genetische feiten.

Ten slotte speelt het gegeven een (steeds grotere) rol dat een adviesvrager vaak met risicopercentages wordt geconfronteerd. Bij voorspellend onderzoek naar een multifactoriële aandoening geeft een mutatie een verhoogd risico op de aandoening. Het is allerminst zeker dat de aandoening zich zal openbaren. Evenmin is de ernst van de aandoening op het tijdstip waarop de aandoening zich zou kunnen openbaren aan te geven. Bij dergelijk voorspellend onderzoek ligt juist de bijdrage van de geneticus daarin dat hij de feiten interpreteert en ze in verschillende contexten plaatst, uitgaande van verschillende waarden en normen, zodat het risicopercentage voor de adviesvrager een minder abstract en meer hanteerbaar gegeven wordt. Ook dit draagt bij aan een weloverwogen en geinformeerde beslissing.

\section{Het moral education model van Arras}

Een model, waarbij de klinisch geneticus ook de verschillende morele gezichtspunten, niet alleen die van de adviesvrager, aan de orde stelt, maar waarbij de uiteindelijke keuze aan de adviesvrager wordt gelaten, wordt door Arras het 
moral education model van non-directiviteit genoemd. ${ }^{33}$ Het doel ervan omschrijft Arras als volgt:

"The goal of the education model is to clarify the client's values and expand her awareness of the moral dimensions of her choices through respectful exchanges, $(\ldots) .{ }^{\prime \prime \prime 4}$

De benadering van Arras is gebaseerd op het door Katz gemaakte onderscheid tussen autonomie tijdens het beslissingsproces en autonomie als het recht om de uiteindelijke beslissing te nemen. ${ }^{95}$ In het moral education model wordt autonomie als het recht om te beslissen wel aanvaard, autonomie tijdens het beslissingsproces niet, in die zin dat het de adviesvrager niet vrij staat de morele dimensies van de verschillende handelingsopties en de gevolgen daarvan te negeren.

Bolt hanteert in haar dissertatie het model van de inclusieve rationaliteit. 96 Volgens dit model heeft de adviesvrager niet slechts informatie nodig om tot een autonome keuze te komen, maar moet hij tevens ondersteund worden bij de vraag welke betekenis de informatie heeft voor zijn eigen unieke levensperspectief. Het autonomiebegrip is in dit model encrzijds gebaseerd op het menselijk vermogen tot kritische zelfreflectie en keuzevrijheid en anderzijds op de relationele gesitueerdheid van mensen. Dit laatste aspect komt in de genetica door de verwantschap en afhankelijkheid tussen familieleden nadrukkelijk tot uiting. Daarom is eerst sprake van een autonome keuze wanneer de relatie van de adviesvrager tot zichzelf en de ander wordt gekenmerkt door betrokkenheid en gerichtheid op het welzijn van zichzelf en anderen. Dit eist van de klinisch geneticus dat hij zich een voorstelling makt van de adviesvrager en zijn perspecticf probeert in te nemen. Op die manier wordt de uniciteit van de adviesvrager gë̈ncludeerd. Door de relationele gesitueerdheid van mensen te benadrukken komt Bolt tot een definitie van autonomie waarin dit tot uiting komt:

"Autonomic houdt in dat een persoon in staat is om zich op een kritisch beredeneerde en eigen wijze te verhouden tot zichzelf en de ander. ${ }^{\prime \prime 97}$

Het ondersteunen van de adviesvrager en het inzichtelijk maken van de consequenties van zijn keuze voor zijn levensperspectief en voor dat van anderen vraagt om een directieve houding, in de zin dat het de adviesvrager niet vrij staat de gevolgen van zijn besluit te negeren. Dit wordt door Bolt gerechtvaardigd omdat het

Arras 1990, p. 353-382. Dit model is door De Wert ingebracht in het debat over nondirectiviteit als toonbeeld van het interpreteren van non-directiviteit als het wel confronteren van een adviesvrager met de (eventuele) morele dilemma's waar hij voor staat, zonder echter advies te geven en de adviesvrager een beslissing op te leggen. De Wert 1999, p. 195. 
de adviesvrager in staat stelt inzicht te verkrijgen in zijn specifieke beweegredenen en in de betekenis van een keuze.

De invulling van het model van de inclusieve rationaliteit lijkt grotendeels overeen te komen met het moral education model van Arras. Dit blijkt ook het volgende citaat.

\begin{abstract}
"Het model van de inclusieve rationaliteit vereist dat de genetische counselor niet alleen informatie verstrekt, maar ook adviseert. Daarmee wordt bedoeld dat de adviesvrager wordt ondersteund in de problemen die hij of zij ondervindt bij het maken van keuzen in het kader van de genetische counseling. De advisering houdt in dat $z$ ij worden geholpen bij het verkrijgen van inzicht in de (onbewuste) motieven en redenen van hun keuze, de gevolgen en de morele aspecten ervan. Dit reikt verder dan een cliëntmodel van voorlichting en non-directiviteit; het kan beter als educatie-model worden gekenmerkt met als normatief uitgangspunt daarbij het levensperspectief van de betrokkene. ${ }^{\prime 98}$
\end{abstract}

Het confronteren van de adviesvrager met de verschillende morele aspecten en gevolgen van mogelijke handelingsalternatieven kan gezien worden als een beperking van het zelfbeschikkingsrecht van de adviesvrager. Het staat hem immers niet meer vrij de verschillende aspecten van zijn opties te ontkennen of negeren. Een dergelijke interpretatie miskent echter het doel van de erfelijkheidsadvisering. Juist het vergroten van de zelfbeschikking door op alle morele aspecten te wijzen, maakt een geinformeerde beslissing, passend bij de eigen opvattingen, door de adviesvrager mogelijk. Met een actieve houding van de klinisch geneticus in het besluitvormingsproces, wordt zo veel mogelijk recht gedaan aan het uitgangspunt dat de adviesvrager een eigen weloverwogen en geïnformeerde keuze moet kumnen maken. ${ }^{99}$ Zeker in de genetica, waar zoals reeds aangegeven de gevolgen ingrijpend zijn voor zowel de adviesvrager als zijn bloedverwanten en waar het verkrijgen van kennis soms niet meer inhoudt dan weten dat men een verhoogd risico heeft op een bepaalde aandoening, doet een dergelijke houding recht aan het uiteindelijke doel van de erfelijkheidsadvisering.

Een actieve houding, zoals beschreven, van de geneticus heeft mijns inziens als bijkomend voordeel dat de klinisch geneticus beter zicht heeft op de vrijwilligheid wanneer de adviesvrager het erfelijkheidsonderzoek ondergaat. Het gevaar is niet denkbeeldig dat bij erfelijkheidsonderzoek familieleden en/of de partner drang uitoefenen op de adviesvrager om dit onderzoek te laten verrichten. Onderzoek naar presymptomatisch onderzoek betreffende de ziekte van Huntington heeft dit uitgewezen. ${ }^{100}$

In het moral education model schuilt wel een gevaar. De adviesvrager kan het feit dat de klinisch geneticus verschillende gezichtspunten aan de orde stelt opvatten als een afwijzing van zijn eigen mening. De adviesvrager zal dan de neiging kunnen

Bolt 1997, p. 169-170.

De Wert 1999, p. 201.

100 European Community Huntington's Disease Collaborative Stydy Group 1993, p. 10281035. 
hebben om zijn opvattingen bij te stellen omdat de geneticus gezien zijn opleiding en ervaring het vast beter weet. Klinisch genetici moeten hier attent op zijn. Zij moeten tijdens een gesprek met een adviesvrager duidelijk aangeven dat er verschillende standpunten mogelijk zijn, maar dat de uiteindelijke keuze aan de adviesvrager is. ${ }^{101}$

Een heel ander punt is de vraag welke gezichtspunten aan de orde moeten worden gesteld.102 In een pluriforme samenleving lijkt het onmogelijk om alle in de samenleving levende opvattingen te kennen, laat staan in een gesprek te noemen. De geneticus moet dus selecteren, waardoor het gevaar bestaat dat het voornamelijk de morele visie van de klinisch geneticus is, die aan de orde wordt gesteld. Een oplossing hiervoor zou gevonden kunnen worden in een landelijke richtlijn waarin een niet-limitatieve opsomming staat van aspecten die in ieder geval aan de orde zouden moeten komen tijdens gesprekken. Een dergelijke richtlijn zou breed gedragen moeten worden door de beroepsgroep. Naast vertegenwoordigers van de beroepsgroep zou inbreng van bijvoorbeeld medisch ethici, gezondheidsjuristen en patiëntenverenigingen bij de totstandkoming ervan een optie zijn. ${ }^{103}$

\section{Het dialogische model}

Een vijfde opvatting over non-directiviteit is te vinden bij Widdershoven. Hij plaats tegenover het moral education model het dialogische model van non-directiviteit. ${ }^{10-4}$ In dit model presenteert de klinisch geneticus, in tegenstelling tot het interpretatieve model van Arras, niet alleen de morele aspecten van de keuzemogelijkheden van de adviesvrager. Hij brengt ook zijn eigen waarden en normen in de discussie in. Hij onderzoekt de waarden van de adviesvrager en stelt deze ter discussie. ${ }^{105}$ De eigen

101 Zie ook Yarborough, Scott en Dixon: "The psychological dynamics of the clinical setting can undermine the equality between client and counselor. Discussion on the part of the counselor has the potential to function as coercion in the life of the client." Yarborough, Scott en Dixon 1989, p. 139-149.

102 De Wert 1999, p. 201.

103. Een kanttekening van geheel andere aard is de ratio van het 'moral-education model'. Arras heeft gezocht naar een alternatief voor de gangbare manier van non-directieve advisering waarbij alleen de feiten werden gepresenteerd, omdat deze manier van adviseren niet altijd tot de preventie van de geboorte van ernstig gehandicapte kinderen leidde. Zijn 'moral education model' moet hier kennelijk wel toe leiden: "Indeed, the kind of personal involvement, observation, and reflection promised by this model could well prove even more effective in altering infected women's behavior". Arras 1990, p. 375. De ratio voor het model in dit onderzoek is een andere, namelijk de overtuiging dat dit model het meeste recht doet aan het doel van de erfelijkheidsadvisering, te weten de adviesvrager een geïnformeerde en weloverwogen keuze te laten maken die het beste bij hem past. De Wert 1999, p. 200.

104 Widdershoven 2000, p. 95-101. Ook White bepleit een dialogisch model. White 1999, p. 14-21.

105 Voor de arts-patiëntrelatie is dit uitgewerkt door Emanuel en Emanuel in het deliberatieve model. Zij stellen hierover: "The essence of doctoring is a fabric of knowledge, understanding, teaching, and action, in which the caring physician integrates the patient's medical condition and health-related values, makes a recommendation on the appropriate course of action, and tries to persuade the patient of the worthiness of this approach and the values it realizes. The physician with a 
waarden van de geneticus zijn hier niet de waarden die hij in zijn privé-leven nastreeft, maar betreffen zijn normatieve opvatting over wat voor de adviesvrager in diens leven relevant is. Vanuit een hermeneutisch-dialogisch perspectief impliceert moral education dat gezamenlijk wordt gedelibereerd over de adequatheid van de normatieve uitgangspunten van zowel de adviesvrager als de klinisch geneticus. Een dergelijke dialogisch model is volgens Widdershoven non-directief omdat de geneticus zijn waarden niet oplegt aan de adviesvrager, maar uitgaande van zijn eigen waarden ernaar streeft de waarden van de adviesvrager kritisch te onderzoeken en tot een gemeenschappelijk normatief gezichtspunt te komen. Het uiteindelijke normatieve standpunt wordt niet bij voorbaat door de klinisch geneticus vastgesteld, maar hij faciliteert het proces waarin het uiteindelijke gezichtspunt tot stand komt. Daarbij kan de geneticus actief bijdragen aan een verandering van de waarden van de adviesvrager. De klinisch geneticus krijgt hierdoor de rol van een goede leraar, therapeut of vriend. ${ }^{106}$ Volgens Widdershoven zou het dialogisch model impasses kunnen doorbreken waarin klinisch genetici en adviesvragers terecht kunnen komen en bevordert het morele zelfontwikkeling. De auteur stelt daarom voor dat de mogelijkheden van dialogische non-directiviteit nader worden onderzocht.

Hiervoor werd opgemerkt dat een gevaar van het moral education model van Arras schuilt in het feit dat de klinisch geneticus vooral zijn eigen morele visie aan de orde stelt, omdat hij moet selecteren uit de in de samenleving levende opvattingen. In het dialogische model lijkt het gevaar dat de klinisch geneticus zijn eigen morele visie aan de orde stelt nog groter. In dit model streeft de klinisch geneticus ernaar om, uitgaande van zijn eigen waarden over wat voor de adviesvrager een goede keus is, de waarden van de adviesvrager kritisch te onderzoeken en tot een gemeenschappelijk normatief standpunt te komen. Het gevaar hiervan is mijns inziens dat de klinisch geneticus wel degelijk zijn waarden oplegt aan de adviesvrager. Het is niet moeilijk in te zien dat de klinisch geneticus op subtiele wijze de uitkomst van de dialoog zo kan sturen dat de keuze van de adviesvrager ook zijn eigen keuze zou zijn geweest. ${ }^{107}$

Ten tweede valt niet in te zien waarom de adviesvrager en de klinisch geneticus tot een gezamenlijk standpunt moeten komen. Het vergroten van de zelfbeschikking van de adviesvrager door middel van het bevorderen van een leerproces, kan even goed bereikt worden zonder dat de adviesvrager en de klinisch geneticus een gezamenlijk normatief standpunt hebben ingenomen. Ook in andere arts-patiënt relaties is het niet gebruikelijk dat gestreefd wordt naar een gezamenlijk normatief standpunt. De arts is op grond van artikel 7:448 lid 2, sub c, BW verplicht de patiënt

caring attitude is the ideal embodied in the deliberative model, the ideal that should inform laws and policies that regulate the physician-patient interaction." Emanuel E.J. en Emanuel L.L. 1992, p. 2221-2226.

106 White 1999, p. 20.

107 Zie ook het in dit hoofdstuk in noot 84 aangehaalde onderzoek van Van Zuuren waaruit bleek dat adviesvragers door klinisch genetici op subtiele wijze werden aangespoord om verder gebruik te maken van de beschikbare voorzieningen. 
in te lichten over de verschillende methoden van onderzoek of behandeling die in aammerking komen. Het is de patiënt zelf die hierover een besluit neemt.

Tot slot veronderstelt het dialogisch model dat de klinisch geneticus weet welke waarden voor de adviesvrager zelf relevant zijn. Dit vereist een intensief contact tussen de klinisch geneticus en de adviesvrager en het is de vraag of dit in de praktijk, waar vaak één en hooguit twee gesprekken worden gevoerd, haalbaar is.

\section{Tussenconclusie}

Het moral education model van Arras, waarbij de morele aspecten van de verschillende keuzemogelijkheden die een adviesvrager heeft door de geneticus aan de orde worden gesteld, maar de keuze aan de adviesvrager is, doet het meeste recht aan het doel van de erfelijkheidsadvisering, te weten de adviesvrager een geinformeerde en weloverwogen keuze te laten maken die het beste bij hem past. Het zelfbeschikkingsrecht wordt een echt zelfbeschikkingsrecht wanneer de adviesvrager inzicht heeft in datgene waarover hij zelf beschikt. Het recht op informatie is hiermee niet beperkt tot alleen de medisch-genetische informatie, zonder dat de eis van nondirectieve erfelijkheidsadvisering wordt verlaten. De keuze is immers nog altijd aan de adviesvrager.

\section{Non-directief onder alle. omstandigheden?}

Nu de vraag beantwoord is hoe de eis van non-directiviteit ingevuld moet worden, rest de vraag of een non-directieve opstelling wel onder alle omstandigheden geboden is. In sommige situaties is een directieve attitude van de klinisch geneticus, in de zin dat hij de normen en waarden van de beroepsgroep en/of zijn eigen normen en waarden kenbaar maakt, verenigbaar met het goed hulpverlenerschap. Ten eerste is een directieve houding in bepaalde situaties te verdedigen voor wat betreft de toegang tot voorspellend genetisch onderzoek. Zo kan men bij de toegang tot voorspellend prenataal onderzoek onderscheid maken tussen drie toetsen. ${ }^{108}$

Ten eerste het object van onderzoek. Er wordt door de genetische centra alleen onderzoek verricht naar kenmerken die de gezondheid betreffen van de onderzochte. Dit is vastgelegd in de overeenkomst die de Vereniging van Stichtingen Klinische Genetica i.o. met de Zorgverzekeraars Nederland heeft gesloten. ${ }^{109}$ Zo wordt bijvoorbeeld prenataal chromosomenonderzoek, uitsluitend om het geslacht van het kind te bepalen, in Nederland niet uitgevoerd. Deze beperking, gelegen in het object van onderzoek, is logisch aangezien een klinisch geneticus een medisch specialist is en een geneeskundige behandelingsovereenkomst met de adviesvrager sluit.

Ten tweede wordt er in de praktijk door de beroepsgroep een rol toegekend aan de emst van de aandoening voor wat betreft voorspellend prenataal onderzoek. In de overeenkomst tussen de Zorgverzekeraars en de Stichtingen is geen lijst opgenomen met afwijkingen die door middel van onderzoek opgespoord mogen worden. Het

10s De Wert 1999, p. 202-210.

109 Vereniging van Stichtingen Klinische Genetica i.o. en Zorgverzekeraars Nederland 1995. 
uitgangspunt van de beroepsgroep is dat de ervaring van de adviesvrager met de aandoening zwaar weegt bij de toegang tot voorspellend onderzoek. Wel is bepaald dat prenataal DNA-onderzoek slechts wordt uitgevoerd bij zwangeren met een verhoogd risico op een monogeen overervende autosomaal dominant erfelijke, autosomaal recessief erfelijke en X-gebonden aandoeningen en bij zwangeren met een mitochrondriaal erfelijke aandoening. ${ }^{110}$ Kennelijk wordt er dus een relatie gelegd tussen de ernst van de aandoening en de penetrantie van de mutatie. Een dergelijk beleid zou men kunnen verdedigen met een beroep op de professionele standaard en in het verlengde daarvan op het goed hulpverlenerschap. Voor het bepalen van deze standaard is van belang de afweging van het risico dat aan prenataal onderzoek kleeft tegen het medisch belang van de verkregen informatie. Het medisch belang is dan gerelateerd aan de verwachte ernst van de aandoening. Zo wordt prenataal chromosomenonderzoek (in de vorm van een vlokkentest of een vruchtwaterpunctie) in Nederland slechts uitgevoerd vanaf het $36^{\circ}$ levensjaar van de vrouw, tenzij er sprake is van een familiair verhoogd risico op een kind met een aangeboren afwijking. De ratio hierbij is dat vanaf het $36^{\circ}$ levensjaar van de vrouw het risico op een kind met een genetische afwijking (het betreft hier voornamelijk het syndroom van Down) hoger is dan het risico op een miskraam veroorzaakt door prenataal onderzoek.

Het belang van een bezinning op het indicatiegebied door de beroepsgroep lijkt, gezien de groeiende mogelijkheden om afwijkingen op te sporen, alleen maar toe te nemen. Bovendien kan men ook bij het huidige beleid vraagtekens stellen. Zijn er bijvoorbeeld goede argumenten om voorspellend prenataal onderzoek naar monogene autosomal dominante aandoeningen wel te verrichten en hetzelfde onderzoek naar monogene varianten van multifacoriële aandoeningen niet? De Gezondheidsraad adviseerde in 1989 reeds op een nadere afbakening van de indicatielijst voor prenataal onderzoek.111 De Raad liet het hier echter bij. In een persbericht uit 1995 van de landelijke interdisciplinaire Werkgroep Prenatale Diagnostiek werd gesteld dat vrijwel alle direct betrokken medici het kunnen maken van individuele afwegingen verkiezen boven alternatieve oplossingen, zoals een indicatielijst waarin ernstige en minder ernstige aandoeningen zijn opgesomd die wel, respectievelijk niet, een reden zouden zijn voor prenatale diagnostiek:

"Uitgangspunt daarbij is dat wij in principe de ervaring met de betrokken afwijking van de adviesvragers zelf zwaar laten wegen bij ons eindoordeel. Dat is mede ingegeven door het feit dat het vaak om zeldzame aandoeningen gaat waarmee noch de gynaecoloog, noch de klinisch geneticus een grote crvaring heeft voor wat betreft de daadwerkelijke belasting in het dagelijkse leven." 112

110 Vereniging van Stichtingen Klinische Genetica i.o. en Zorgverzekeraars Nederland 1995, p. 9.

111 "Hoewel op dit moment in ons land geen sprake is van prenatale diagnostiek om triviale redenen, vindt de commissie nadere bezinning van de beroepsgroep op de afbakening van het indicatiegebied van belang." Gezondheidsraad 1989, p. 89.

112 Werkgroep Prenatale Diagnostiek (WPD) van de Nederlandse Vereniging voor Obstetrie en Gynaecologie (NVOG) en de Vereniging Klinische Genetica Nederland (VKGN) 1995. Zie ook Leschot 1997, p. 121-133. 
De minister van VWS deelde deze mening. Zij merkte in een brief aan de Tweede Kamer hierover op:113

"Een meer principieel bezwaar ligt mijns inziens in het feit dat met het opstellen van een lijst door de overheid zou worden bepaald welke mate van leed ernstig is. De overheid zou daarmee een oordeel hebben over de vraag welke aandoening te dragen is en welke de individuele draagkracht te boven zou kunnen gaan. Dat oordeel komt alleen de toekomstige ouders toe."

Tevens noemt zij als bezwaar het feit dat nogal wat aandoeningen een enorme variatie in expressie hebben. Toch meent zij dat er een ondergrens is: naar uitgesproken milde aandoeningen zou prenataal niet moeten worden gezocht.

De ervaring van de betrokkenen met de afwijking is een valide argument om regelgeving van bovenaf af te wijzen. Beslissingen om prenatale diagnostiek te verrichten zijn individuele beslissingen die in overeenstemming moeten zijn met de morele overtuiging en moeten passen in het leven van de adviesvrager. In dat leven bepaalt hij de ernst van zijn leed en de omvang van zijn draagkracht. Vanuit dit standpunt wekt het beleid om geen prenataal onderzoek naar monogene varianten van multifactoriële aandoeningen te verrichten enigszins bevreemding. De enorme variatie in expressie die nogal wat aandoeningen hebben, maakt het bovendien praktisch onmogelijk dergelijke aandoeningen als ernstig dan wel niet ernstig te bestempelen. Hier tegenover staat echter het goed hulpverlenerschap en de professionele standaard van de beroepsgroep. Van de beroepsgroep kan niet worden verwacht dat zij elk verzoek om prenatale diagnostiek inwilligen. Daarom is het aan te bevelen dat de beroepsgroep een lijst opstelt met aandoeningen die in ieder geval niet in aanmerking komen voor prenatale diagnostiek. Aandoeningen die hiervoor in aanmerking zouden komen zijn bijvoorbeeld de door de minister in haar brief genoemde voorbeelden: kleurenblindheid en de erfelijke aanleg voor kaalhoofdigheid.

Bij voorspellend onderzoek op kinderleeftijd wordt in de praktijk de beginleeftijd van de aandoening relevant geacht. Zo worden kinderen niet getest op aandoeningen die zich niet op kinderleeftijd openbaren en waarvoor preventie niet, althans niet op kinderleeftijd, mogelijk is. ${ }^{114}$ In hoofdstuk 6 wordt hier in het kader van de behandeling van het recht op niet weten op teruggekomen.

Een derde toets is gelegen is het voomenten dat de adviesvrager heeft betreffende hoe om te gaan met een ongunstige uitslag van prenataal onderzoek. Omdat hierbij het recht op niet weten van de vrucht in het geding is, zal deze derde toets in hoofdstuk 6 worden besproken.

113 Kamerstukken II 1995/96, 24 624, nr. 1, p. 5.

114 Voorbeelden zijn de ziekte van Huntington en erfelijke borstkanker. 
Morele bezuaren van de klinisch geneticus

Een vraag naar erfelijkheidsonderzoek kan ook stuiten op morele bezwaren bij de geneticus zelf. Dit kan leiden tot een directieve houding in de zin dat de klinisch geneticus zijn bezwaren uit. Wanneer de keuze van de adviesvrager op morele bezwaren stuit bij de klinisch geneticus, zal hij wanncer het een vraag naar erfelijkheidsonderzoek betreft dat wel wordt anngeboden, in voorkomend geval de adviesvrager naar een collega of een ander klinisch genetisch centrum moeten verwijzen. Leenen lijkt nog een stap verder te willen gaan. Naast gewetensbezwaren stelt hij dat ook wanneer een arts ernstige bezwaren heeft tegen de beslissing van zijn patiënt, niet van hem kan worden verwacht dat hij zijn mening achterhoudt. ${ }^{115}$ Het lijkt echter aannemelijk dat ernstige bezwaren altijd morele bezwaren zullen zijn.

\section{Een gevrangd advies?}

Het moral education model laat geen ruimte voor het geven van een ongevraagd advies over de waarden die de klinisch geneticus in zijn eigen leven nastreeft. Mag een geneticus een adviesvrager wel zijn mening geven wanneer daar om gevraagd wordt? De Wert stelt dat genetici in het verleden sterk tegen het geven van een gevraagd advies waren:

"Het was gebruikelijk om, in reactie op een dergelijke vraag, te benadrukken dat alleen de hulpvrager zelf kan ontdekken wat in zijn specifieke omstandigheden en gegeven zijn eigen, persoonlijke levensovertuiging de beste keuze is." 116

Uiteraard moet de adviesvrager zelf zijn keuze maken. Indien hij er echter prijs op stelt te weten wat de mening is van zijn adviesgever, dient de geneticus deze te geven. Dit zou getuigen van goed hulpverlenerschap. Van belang daarbij is wel dat hij benadrukt dat het gaat om een persoonlijke mening en dat de verantwoordelijkheid voor de uiteindelijke keuze bij de adviesvrager blijft. ${ }^{117}$ Zelfbeschikking impliceert verantwoordelijkheid. Wanneer daarover geen misverstand bestaat, staat het een adviesvrager vrij om de mening te vragen van de geneticus. Deze mening onthouden aan de adviesvrager, omdat de adviesvrager anders zelf zijn keuze niet meer zou kunnen maken, berust op de veronderstelling dat de adviesvrager aan deze mening automatisch een doorslaggevend gewicht zou toekennen en niet in staat zou zijn de ene mening los te zien van een andere.

115 Leenen 2000, p. 78.

116 De Wert 1999, p. 211.

117 Binnen de Gezondheidsraad waren de meningen hierover verdeeld. Sommige leden van de commissie wijzen een 'advies op verzoek' af, omdat $z$ ij menen dat een klinisch geneticus niet in de positie is om aan te geven welke keuze het beste past bij de opvattingen en situatie van de adviesvrager. Andere leden van de commissie sluiten niet uit dat een 'advies op verzoek' in uitzonderlijke gevallen aanvaardbaar kan zijn. Voorwaarde is dan wel dat de klinisch geneticus uitdrukkelijk vermeldt dat hij zijn persoonlijke mening geeft en dat de adviesvrager uiteindelijk zelf zijn keuze moet maken. Gezondheidsraad 1989, p. 78. 


\section{Conclusio}

Op het moral education model is dus, voor wat betreft de non-directiviteit van de houding van de klinisch geneticus, een drietal uitzonderingen gemaakt. Ten eerste voor wat betreft de toegang tot erfelijkheidsonderzoek. Er worden eisen gesteld aan het object van onderzoek en de ernst van de aandoening waarnaar een erfelijkheidsonderzoek zal worden gedaan. Ook geldt het uitgangspunt van nondirectiviteit niet wanneer ouders om een voorspellend onderzoek verzoeken voor hun kind naar aandoeningen die zich eerst op volwassen leeftijd voordoen en waarvoor preventie niet, althans niet op kinderleeftijd, mogelijk is. De belangen van het kind prevaleren dan boven die van de ouders. Exacter geformuleerd; de eis van non-directieve erfelijkheidsadvisering om een geïnformeerde keuze te kunnen maken is ondergeschikt aan het toekomstige recht van het kind om zelf te bepalen of het een erfelijkheidsonderzoek wil laten verrichten. In hoofdstuk 6 zullen de rechten en belangen van kinderen en ongeborenen nog ter sprake komen. Daar zal ook blijken dat er in sommige situaties eisen kumnen worden gesteld aan het voornemen dat de adviesvrager heeft betreffende hoe hij om zal gaan met een ongunstige uitslag. Ten tweede kan niet van een klinisch geneticus verwacht worden dat hij zijn eigen normen en waarden niet ter sprake brengt wanneer hij ernstige morele bezwaren heeft tegen een bepaalde keuze van een adviesvrager. Ten slotte is ook het geven van een gevraagd advies, mits duidelijk is dat het hier de persoonlijke normen en waarden van de klinisch geneticus betreffen, in overeenstemming met het goed hulpverlenerschap.

Wanneer de eis van non-directiviteit in genoemde omstandigheden niet geldt, moet de klinisch geneticus wel duidelijk maken dat hij een ander standpunt inneemt en waarom dat zo is. Verkapte vormen van beïnvloeding zijn onder geen enkele omstandigheid toelaatbaar.

\subsection{Het toestemmingsvereiste}

Het toestemmingsvereiste in de Wgbo kan worden gezien als een uitwerking van het zelfbeschikkingsrecht, alsmede van de artikelen 10 en 11 van de Grondwet, te weten het recht op respect voor de persoonlijke levenssfeer en het recht op onaantastbaarheid van het lichaam. Zonder rechtsgeldige toestemming kunnen geen verrichtingen ter uitvoering van de behandelingsovereenkomst plaatsvinden. De patiënt bepaalt zelf welke medische handelingen hij wel en welke hij niet wenst te ondergaan. Het toestemmingsvereiste is geregeld in artikel 7:450 lid 1 BW:

"Voor verrichtingen ter uitvoering van een behandelingsovereenkomst is de toestemming van de patiënt vereist."

Het aangaan van een behandelingsovereenkomst betekent dus niet dat de patiënt bij voorbaat instemt met de in het kader daarvan uit te voeren verrichtingen. Indien de patiënt zijn toestemming weigert, kan geen behandeling plaatsvinden. Bovendien 
"When because of an emergency situation the appropriate consent cannot be obtained, any medically necessary intervention may be carried out immediately for the benefit of the health of the individual concerned." 123

Niet ingrijpende werichtingen

De tweede uitzondering betreft de niet-ingrijpende verrichtingen. Hierbij mag de toestemming worden verondersteld. Of er sprake is van een ingrijpende verrichting hangt vooral af van de omstandigheden. Bij de afweging van de mate van ingrijpendheid zal niet alleen gekeken moeten worden naar de verrichting in de zin van de technische handeling, maar ook naar hetgeen met de verrichting wordt beoogd of het mogelijke gevolg ervan. Zo kan een eenvoudige hielprik bij een pasgeborene ingrijpende gevolgen hebben voor zowel het kind als de ouders. ${ }^{124}$ Leenen merkt terecht op dat een leek een medische behandeling eerder ingrijpend zal vinden dan een hulpverlener. Omdat bovendien de bewijslast voor verkregen toestemming op de hulpverlener rust, doet hij er goed aan toestemming van de patiënt niet te snel te veronderstellen.125 De achterliggende gedachte van deze bepaling is het voorkomen van een onnodige belasting van de praktijk met het toepassen van formele voorschriften, waar die geen redelijk belang meer dienen. Volgens de Memorie van Antwoord is dit het geval wanneer de geestelijke en lichamelijke integriteit van de patiënt, ter bescherming waarvan de eis van (uitdrukkelijke) toestemming is gesteld, niet of nauwelijks in het geding is. ${ }^{126}$ Overigens zal de grens tussen veronderstelde en expliciete toestemming niet altijd helder zijn. Expliciete toestemming kan namelijk ook uit handelingen worden vastgesteld, zoals het optillen van de arm nadat de hulpverlener heeft uitgelegd dat er bloed zal worden afgenomen. ${ }^{127}$

Informatie en toestemming hangen nauw samen. Wanneer de informatie niet voldoet aan de eisen van artikel 7:448 lid 1 en 2 BW kan er geen sprake zijn van een rechtsgeldige toestemming. De toestemming kan niet verder reiken dan waarover de door de hulpverlener gegeven informatie zich heeft uitgestrekt. De toestemming bepaalt de grenzen van het handelen van de hulpverlener. ${ }^{128}$

\subsection{Toestemming en erfelijkheidsadvisering}

Zoals in hoofdstuk $6 \mathrm{zal}$ blijken wordt één aspect van het recht op niet weten, te weten het recht om informatie betreffende de gezondheid niet tot stand te doen komen, gewaarborgd door het toestemmingsvereiste. Voor de erfelijkheidsadvisering

\footnotetext{
12.3 Nys 1998, p. 189. Dit artikel wordt door velen als overbodig en niet passend in een mensenrechtenverklaring beschouwd. Nys 1998, p. 50.

124 Kamerstukke'n II 1989/90, 21 561, nr. 3. p. 49.

125 Leenen 2000, p. 204.

126. Kamerstukke'n ll 1990/91, 21 561, nr. 6, p. 71.

127 Sluijters en Biesaart 1995, p. 161.

128 Leenen 2000, p. 202.
} 
betekent dit dat de adviesvrager zelf kan bepalen of hij een erfelijkheidsonderzoek laat verrichten. Gezien de mogelijk vérstrekkende gevolgen van erfelijkheidsonderzock voor zowel de adviesvrager als zijn familieleden, is dit een belangrijke waarborg.

Bij erfelijkheidsadvisering zal voor de veronderstelde toestemming van de adviesvrager geen ruimte zijn. Dit geldt in ieder geval voor de beslissing om een voorspellend erfelijkheidsonderzoek te laten verrichten. In paragraaf 4.3 .2 is aangegeven dat voorspellend erfelijkheidsonderzoek geen medisch noodzakelijk onderzoek betreft, wat de keus om dergelijk onderzoek te ondergaan minder vanzelfsprekend makt. In overdrachtelijke zin dient voorspellend onderzoek, gezien de mogelijk vérstrekkende gevolgen, als ingrijpend en invasief te worden beschouwd. ${ }^{129}$ Dit geldt ook wanneer de verrichting alleen bestaat uit analyse van reeds beschikbaar lichaamsmateriaal. In zo'n geval is het niet de fysieke integriteit als wel de persoonlijke levenssfeer van de adviesvrager die zich tegen veronderstelde toestemming verzet. ${ }^{30}$ Ook voor diagnostisch onderzoek zal toestemming gegeven dienen te worden. Het verrichten van een erfelijkheidsonderzoek ter vaststelling van de aan- of afwezigheid van een erfelijke aandoening kan niet worden beschouwd als een niet ingrijpende verrichting. Het dient immers ter vaststelling van een erfelijke of aangeboren aandoening.

Voor het verrichten van een diagnostisch onderzoek naar een (verstandelijke) handicap worden door de klinisch geneticus in de regel foto's of dia's gemaakt. Ook hiervoor geldt het toestemmingsvereiste. Het toestemmingsvereiste heeft niet alleen betrekking op medische handelingen, maar ook op hetgeen daaromheen gebeurt. ${ }^{131}$ Gezien de aard van de handeling, het vastleggen van fysieke kenmerken van de adviesvrager, kan de toestemming niet verondersteld worden. Bovendien dient het doel van de handeling duidelijk te zijn. Dit is vaak tweeledig. Ten eerste wordt door middel van overleg met collegae getracht een diagnose te stellen. Ten tweede kunnen foto's en dia's ten behoeve van het onderwijs gebruikt worden.

Over het toestemmingsvereiste is in de erfelijkheidsrichtlijnen het volgende geregeld:

"De arts vraagt of de cliënt instemt met het erfelijkheidsonderzoek"132

"De arts beperkt het erfelijkheidsonderzock tot onderzoek waarvoor de cliënt toestemming heeft gegeven."133

Deze laatstgenoemde richtlijn vloeit logisch voort uit het gegeven dat geen behandeling plaats kan vinden indien er geen rechtsgeldige toestemming voor is gegeven. De eerstgenoemde richtlijn gaat er terecht vanuit dat de klinisch geneticus

129 Leenen 2000, p. 79. Leenen lijkt er hierbij overigens vanuit te gaan dat elk erfelijkheidsonderzoek voorspellend is.

130 Gevers 1996, p. 19.

131 Leenen 2000, p. 205.

132 Vereniging voor Gezondheidsrecht 1991, richtlijn A 3.

133 Vereniging voor Gezondheidsrecht 1991, richtlijn A 4. 
de adviesvrager altijd expliciet toestemming vraagt voor het verrichten van een erfelijkheidsonderzoek. Over het vragen van toestemming aan familieleden van de adviesvrager wordt het volgende opgemerkt:

"De arts vraagt toestemming aan de cliënt voordat hij verwanten benadert met het verzoek erfelijkheidsonderzock te ondergaan ten behoeve van de cliënt. De arts handelt vervolgens tegenover het familielid volgens de richtlijnen onder A. De arts is er zich bij het verkrijgen van toestemming van bewust dat het initiatief voor het erfelijkheidsonderzoek niet van het familielid zelf is uitgegaan."134

In hoofdstuk 7, waar de geheimhoudingsplicht aan de orde is, wordt ingegaan op het. benaderen van familieleden van de adviesvrager. De geheimhoudingsplicht vereist dat aan de adviesvrager toestemming wordt gevraagd alvorens verwanten worden benaderd. De eis dat de klinisch geneticus zich er bij het verkrijgen van toestemming van het familielid om een erfelijkheidsonderzoek te ondergaan, van bewust is dat het initiatief voor het erfelijkheidonderzoek niet van het familielid zelf is uitgegaan, kan ook worden gelezen in de algemene eis dat de hulpverlener zich ervan gewist dat de patiënt de informatie heeft begrepen. ${ }^{135}$ Onderdeel van de informatieplicht is in dit geval het duidelijk maken aan het familielid, dat nu hij een behandelingsovereenkomst heeft met de klinisch geneticus, hij het erfelijkheidsonderzoek ondergaat ten behoeve van de initiële adviesvrager.

\subsection{Samenvatting}

Hoofdstuk 4 begint met een korte bespreking van het goed hulpverlenerschap. Dit is één van de kernbepalingen van de Wgbo. Het in acht nemen van de zorg van een goed hulpverlener is een algemene formulering die in concrete situaties invulling behoeft. Naar deze norm wordt op verschillende plaatsen in hoofdstuk 4 en volgende hoofdstukken verwezen, wanneer er voor situaties niet een duidelijk juridisch antwoord is.

Het recht op informatie is geregeld in artikel 7:448 lid 1 en 2 BW. Een adviesvrager dient op basis van de verstrekte informatie een weloverwogen besluit te kunnen nemen ten aanzien van het eventueel ondergaan van een erfelijkheidsonderzoek. Ten tweede dient de adviesvrager te weten welke conclusies de klinisch geneticus heeft kunnen trekken met betrekking tot zijn gezondheidstoestand. Ten derde bevordert het verstrekken van duidelijke en begrijpelijke inlichtingen dat de adviesvrager optimaal kan meewerken aan de bevordering of herstel van zijn gezondheidstoestand. De informatie moet zo veel mogelijk in voor de adviesvrager begrijpelijke bewoordingen worden gegeven, rekening houdend met zijn specifieke informatiebehoefte op grond van zijn persoonlijke omstandigheden. De klinisch geneticus moet zich ervan vergewissen dat de adviesvrager de informatie voldoende heeft begrepen.

134 Vereniging voor Gezondheidsrecht 1991, richtlijn B 1.

135 Zie paragraaf 4.2 . 
Erfelijkheidsonderzoek kan bestaan uit diagnostisch en uit voorspellend onderzoek. In paragraaf 4.3 .2 is geconcludeerd dat voorspellend erfelijkheidsonderzoek geen medisch noodzakelijk onderzoek betreft, waarvan het voorspellende karakter dient te worden benadrukt omdat juist dit karakter het ondergaan van dergelijk onderzoek minder vanzelfsprekend maakt. Uit de jurisprudentie bleek dat bij medisch nietnoodzakelijk onderzoek hoge eisen worden gesteld aan de informatieplicht. Daarnaast rechtvaardigen de voorspellende aard van het onderzoek en de mogelijke gevolgen van het onderzoek voor zowel de adviesvrager als zijn familieleden het stellen van hoge eisen aan de informatieplicht bij de erfelijkheidsadvisering over voorspellend onderzoek.

Er wordt in lid 1 of 2 van artikel 7:448 BW niet gerept over onverwachte bevindingen bij onderzoek. De klinisch geneticus is echter verplicht om de mogelijkheid van onverwachte bevindingen aan de orde te stellen, alvorens een erfelijkheidsonderzoek wordt verricht. Met name bij het bespreken van de familieanamnese en bij chromosomenonderzoek is het altijd mogelijk dat meer erfelijkheidsinformatie wordt gegenereerd komt dan waar de erfelijkheidsvraag op gericht was. Het vermelden van deze mogelijkheid hoort daarom dan ook tot de standaard te verstrekken informatie wanneer dergelijk onderzoek wordt verricht. Ook het recht op niet weten wordt beschermd wanneer de adviesvrager in de gelegenheid wordt gesteld aan te geven wat hij wel en niet wil weten. Het is daarom van groot belang om voorafgaand aan een erfelijkheidsonderzoek zo duidelijk mogelijke afspraken te maken over de vraag of en hoe eventuele onverwachte bevindingen meegedeeld zullen worden.

Artikel 7:448 lid 3 BW regelt de therapeutische exceptie. Deze uitzondering op de informatieplicht zal niet snel aan de orde zijn wanneer de mogelijke bevindingen en gevolgen van een erfelijkheidsonderzoek met de adviesvrager uitvoerig zijn doorgenomen en er sprake is van een weloverwogen besluit om een erfelijkheidsonderzoek te ondergaan. Dit ligt anders bij onverwachte bevindingen. Indien de klinisch geneticus in het geval van onverwachte bevindingen gegronde redenen heeft om aan te nemen dat de gevonden informatie kennelijk ernstig nadeel voor de adviesvrager op zou leveren, is er ruimte om de therapeutische exceptie toe te passen. Het is voorts van belang een onderscheid te maken tussen enerzijds de toepassing van de therapeutische exceptie en het gedoseerd en gefaseerd informeren. Het goed hulpverlenerschap vereist dat relevante informatie op het juiste tijdstip aan de adviesvrager wordt verstrekt, zodat hij de informatie begrijpt.

Op welke wijze moet de adviesvrager geïnformeerd worden? Het uitgangspunt van de erfelijkheidsadvisering is dat deze non-directief van aard is. In paragraaf 4.3 .4 is het moral education model van Arras verdedigd. Dit model, waarbij de morele aspecten van de verschillende keuzemogelijkheden die een adviesvrager heeft door de geneticus aan de orde worden gesteld, maar de keuze aan de adviesvrager is, doet het meeste recht aan het doel van de erfelijkheidsadvisering, te weten de adviesvrager een geïformeerde en weloverwogen keuze te laten maken die het beste bij hem past. Het zelfbeschikkingsrecht wordt een echt zelfbeschikkingsrecht wanneer de adviesvrager inzicht heeft in hetgeen waarover hij beschikt. Het recht op 
informatie is hiermee niet beperkt tot alleen de medisch-genetische informatie, zonder dat de eis van non-directieve erfelijkheidsadvisering wordt verlaten. De keuze is immers nog altijd aan de adviesvrager.

Vervolgens is een aantal uitzonderingen besproken op het uitgangspunt dat de erfelijkheidsadvisering non-directief van aard is. Ten eerste is een directieve houding in bepaalde situaties te verdedigen voor wat betreft de toegang tot voorspellend genetisch onderzoek. Ten tweede kan niet van een klinisch geneticus verwacht worden dat hij zijn eigen normen en waarden niet ter sprake brengt wanneer hij ernstige morele bezwaren heeft tegen een bepaalde keuze van een adviesvrager. Ten derde is ook het geven van een gevraagd advies, mits duidelijk is dat het hier de persoonlijke normen en waarden van de klinisch geneticus betreffen, in overeenstemming met het gocd hulpverlenerschap.

Ten slotte is het toestemmingsvereiste besproken. Voor verrichtingen ter uitvoering van de behandelingsovereenkomst is de toestemming van de adviesvrager vereist. Voor de veronderstelde toestemming van de adviesvrager is bij de erfelijkheidsadvisering geen ruimte.

In dit hoofdstuk stonden het recht op informatie en het toestemmingsvereiste centraal. Kan er ook van een recht op informatie buiten het kader van de behandelingsovereenkomst worden gesproken? Deze vraag wordt beantwoord in het volgende hoofdstuk. Onderzocht zal worden of er een recht is om erfelijkheidsinformatie te vergaren en of een recht op kennisname van bestaande erfelijkheidsinformatie bestaat. Daarnaast zal worden bekeken of de klinisch geneticus een waarschuwingsplicht jegens familieleden heeft. 



\section{HET RECHT OP WETEN}

\subsection{Inleiding}

Het recht op informatie binnen de behandelingsovereenkomst roept de vraag op of er buiten de behandelingsovereenkomst van een zelfde recht kan worden gesproken. Of wat breder geformuleerd; bestaat er zoiets als een recht op weten? Naarmate de medisch-wetenschappelijk kennis en de technische mogelijkheden op het gebied van de genetica toenemen zal deze vraag aan belang winnen. Het weten of niet weten wordt als gronddilemma van voorspellend onderzoek gezien.1 Waar zou een recht op weten echter uit af te leiden zijn en wat is de aard van een dergelijk recht? Ten opzichte van wie zou men een recht op weten kunnen laten gelden? Deze vragen zullen in dit hoofdstuk aan de orde komen.

De vraag of er cen recht op weten is, is nauwelijks aan de orde geweest in de Nederlandse rechtsliteratuur. Gevers vormt hier een uitzondering op. In zijn preadvies uit 1996 oordeelt Gevers dat het gaat om een door het recht te beschermen belang waarvoor aansluiting gezocht kan worden bij het recht op privacy, opgevat in de ruime zin, als het recht op een vrije sfeer waarin men zijn leven naar eigen inzicht vorm kan geven. Dit belang biedt zijns inziens geen zelfstandige grondslag voor aanspraken, maar zou in samenhang met andere rechten, met name het recht op gezondheidszorg, wel tot aanspraken kunnen leiden. ${ }^{2}$

Het recht op weten is, wanneer het wordt toegespitst op de genetica, te omschrijven als het recht om kennis te vergaren betreffende de eigen genetische constitutie. Het betreft hier zowel het recht om informatie betreffende de genetische constitutie door middel van het ondergaan van een erfelijkheidsonderzoek te vergaren als het recht op kennisname van reeds bestaande informatie waarover een ander dan de hulpverlener in het kader van de behandelingsovereenkomst beschikt. ${ }^{3}$ Hieronder zal worden nagegaan of een recht op weten afgeleid zou kunnen worden uit het recht op privacy. Allereerst zal in paragraaf 5.2 onderzocht worden of het recht om informatie betreffende de eigen genetische constitutie door middel van het ondergaan van een erfelijkheidsonderzoek te vergaren is af te leiden uit het recht op privacy. Indien dit zo is, schept dit verplichtingen voor de overheid. Op grond van artikel 22 Grondwet, het recht op gezondheidszorg, is zij immers belast met de zorg voor de beschikbaarheid van de noodzakelijke gezondheidsvoorzieningen. In paragraaf $5.3 \mathrm{zal}$ worden bekeken of het recht op kennisname van reeds bestaande informatie betreffende de eigen constitutie afleidbaar is uit het recht op privacy. De aanname hiervan zou kunnen leiden tot aanspraken op kennisname van informatie die familieleden uit genetisch onderzoek hebben verkregen. In paragraaf 5.4 is de vraag aan de orde of de klinisch geneticus, los van de vraag of er sprake is van een

Gevers 1996, p. 9.

Gevers 1996, p. 13-16.

Gevers maakt dit onderscheid wel wanneer hij het recht op niet weten bespreekt, maar niet wanneer hij het recht op weten bespreekt. 
recht op weten, jegens familieleden van de adviesvrager een algemene waarschuwingsplicht, dan wel een waarschuwingsplicht onder specifieke omstandigheden, heeft. Het hoofdstuk wordt afgesloten met een samenvatting.

\subsection{Het recht op weten jegens de overheid}

In 1890 verscheen er in de Harvard Law Review een artikel van Warren en Brandeis waarin voor het eerst van een recht op privacy wordt gesproken." Warren en Brandeis omschreven dit recht als the right to be let alone. ${ }^{5}$ Deze omschrijving dient nog steeds als de grondslag van het huidige recht op respect voor de persoonlijke levenssfeer.

Het recht op privacy is onder meer geregeld in artikel 10 Grondwet, artikel 8 EVRM en in artikel 10 lid 1 van het Verdrag inzake Mensenrechten en Biogeneeskunde. ${ }^{7}$

De kern van het privacybegrip wordt gevormd door het recht dat men heeft om de persoonlijke levenssfeer te beschermen tegen betrekkingen met de buitenwereld. Deze kern bestaat uit twee delen. Enerzijds is er het toepassingsbereik van het recht

4 De wortels van het begrip zijn echter een stuk ouder. Met name het gedachtegoed van Mill is voor de ontwikkeling van het privacy-begrip van belang geweest. Hij pleit voor bescherming van de individuele vrijheid en tegen inmenging van de overheid, instellingen en andere burgers. Het domein dat beschermd moet worden is volgens hem het innerlijke domein van het geweten, overtuigingen en gevoelens. Mill 1859.

5 Ernst en Schwartz 1962. Het artikel wordt in hoofdstuk drie geciteerd.

- In de literatuur worden de begrippen persoonlijke levenssfeer, privacy, privé-leven en privé-sfeer als synoniemen gebruikt.

7 Artikel 10 Grondwet luidt: "1. Ieder heeft, behoudens bij of krachtens de wet te stellen beperkingen, recht op eerbiediging van zijn persoonlijke levenssfeer.

2. De wet stelt regels ter bescherming van de persoonlijke levenssfeer in verband met het vastleggen en verstrekken van persoonsgegevens.

3. De wet stelt regels inzake de aanspraken van personen op kennisneming van over hen vastgelegde gegevens en van het gebruik dat daarvan wordt gemaakt, alsmede op verbetering van zodanige gegevens."

Artikel 8 EVRM luidt: "1. Een ieder heeft recht op respect voor zijn privé leven, zijn familie- en gezinsleven, zijn woning en zijn correspondentie.

2. Geen inmenging van enig openbaar gezag is toegestaan in de uitoefening van dit recht, dan voor zover bij de wet is voorzien en in een democratische samenleving noodzakelijk is in het belang van de nationale veiligheid, de openbare veiligheid of het economisch welzijn van het land, het voorkomen van wanordelijkheden en strafbare feiten, de bescherming van de gezondheid of de goede zeden of voor de bescherming van de rechten en vrijheden van anderen."

Artikel 10 van het Verdrag inzake Mensenrechten en Biogeneeskunde luidt: "1. Everyone has the right to respect for private life in relation to information about his or her health."

Het recht op privacy is tevens geregeld in artikel 17 IVBPR. Dit artikel komt overeen met artikel 8 EVRM, met dit verschil dat de bescherming van de eer en goede naam apart worden genoemd. 
op privacy. Dit recht geldt binnen een bepaalde privé-ruimte, en binnen bepaalde aspecten van een persoon. Zowel de fysieke ruimte als de intimiteit van personen wordt dus beschermd. Anderzijds is er de mate van bescherming. Deze is hoog; de privé-sfeer is in beginsel onschendbaar, ongeacht de persoon waardoor, het doel waarvoor, de middelen en zorgvuldigheid waarmee het privé-leven wordt benaderd. 8

Door het recht op privacy worden verschillende elementen van het persoonlijke leven beschermd. Verhey noemt de volgende elementen:

- "de woning als de plaats bij uitstek waar men geen inmenging van anderen behoeft te dulden;

- het eigen lichaam waarover men in beginsel zelf mag beslissen;

- het vrijelijk aangaan van relaties met anderen, waaronder het stichten en onderhouden van gezinsrelaties en/of seksuele relaties;

- het vrijelijk communiceren met anderen (schriftelijk, via de telefoon of anderszins) zonder dat anderen daarvan ongewild kennis nemen;

- het uitoefenen van invloed op registratic en gebruik van de eigen persoonsgegevens teneinde onwenselijke, onjuiste of onvolledige becldvorming bij anderen te voorkomen." ${ }^{\prime \prime}$

Valt uit deze verschillende elementen van het recht op privacy een recht op weten af te leiden? Het recht op respect voor de persoonlijke levenssfeer is een individueel grondrecht. In de klassieke betekenis bieden grondrechten een constitutionele waarborg tegen de overheid. Ze garanderen dat de staat zich van optreden onthoudt binnen de door de grondrechten beschermde gebieden. Het is een defensief grondrecht. Het gaat er vooral om wat anderen, de overheid, maar door de horizontale werking ook instellingen en particulieren, moeten nalaten. De privacy van burgers dient gerespecteerd te worden. Inmenging in het privé-leven is slechts onder voorwaarden geoorloofd, welke bij of krachtens de wet moeten zijn omschreven. Een recht op weten veronderstelt dat (mede) op basis van dat recht aanspraken zouden kunnen gelden om kennis te vergaren. Zo bezien lijkt een dergelijk recht niet goed af te leiden uit het recht op privacy, het recht om met rust gelaten te worden.

\section{Kritiek op de defensieve invulling onn het privacyconcept}

Het recht op privacy is zoals opgemerkt een defensief concept, waarvan een recht op weten niet afleidbaar lijkt. Op de defensieve invulling van het privacyconcept is echter kritiek geuit. Jackson Betts, de 'Grand Old Man' van de privacydiscussie in de Verenigde Staten, ${ }^{10}$ omschreef privacy als:

"niet alleen eenvoudigweg de afwezigheid van gegevens omtrent ons bij anderen, maar de zeggenschap die wij hebben over informatie over onszelf". ${ }^{11}$

Blok en Vedder 2000, p. 5-31.

Verhey 1992, p. 206.

Kuitenbrouwer 1991, p. 18.

Kuitenbrouwer 1991, p. 18. 
Kuitenbrouwer ziet als 'sleutel tot de rechten van mensen in het informatietijdperk':

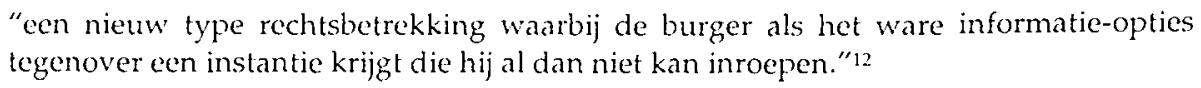

Hij werkt dit niet verder uit, maar duidelijk is dat hierbij niet de nadruk ligt op bescherming tegen inmenging in privé-zaken, maar juist op het houden van controle door burgers op hen betreffende informatie. De zeggenschap over informatie of het verkrijgen van informatie-opties veronderstelt een privacy-concept dat verder gaat dan het bieden van waarborgen tegen de overheid, instellingen en burgers. Het zou positieve verplichtingen scheppen voor de overheid om een dergelijke opvatting van de inhoud van het recht op een persoonlijke levenssfeer effectief te beschermen. Wanneer privacy wordt begrepen als een individuele zeggenschap over gegevensstromen, is er sprake van een soort informationeel zelfbeschikkingsrecht. Ook in de Amerikaanse literatuur zijn definities verschenen die het privacybegrip op een dergelijke manier invullen. Fried definieert privacy als "the control we have over information about ourselves". ${ }^{13}$ Rachel spreekt over "the ability to control who has access to us". ${ }^{14}$ Deze definities beogen individuen zelf te laten beslissen wie toegang heeft tot bestande informatie. Wanneer we echter op grond van ons recht op privacy controle hebben over onszelf betreffende informatie, is het afleiden van een recht om informatie tot stand te doen brengen over onze eigen genetische constitutie een logische volgende stap.

\section{Prizacy als een informationeel zelfbeschikkingsrecht?}

In Nederland wordt de zeggenschap van personen over de eigen gegevens niet erkend. ${ }^{15}$ De Memorie van Toelichting bij de Wet bescherming persoonsgegevens stelt dat de informationele zelfbeschikking geen onderdeel is van het in Nederland geldende recht:

"In het Nederlandse systeem geldt buiten de werkingssfeer van artikel 10, lid 1, van de Grondwet als algemeen uitgangspunt dat noch de handelingsvrijheid van degene die persoonsgegevens verwerkt, noch het recht op bescherming van de persoonlijke levenssfeer van de betrokkene in abstracto zwaarder weegt. Als in een concreet geval beide belangen dreigen te botsen, dienen zij tegen elkaar te worden afgewogen,

$12 \quad$ Kuitenbrouwer 1991, p. 181-182.

1.3 Fried 1984, p. 203-222.

$14 \quad$ Zie ook Rachels 1984, p. 290-299.

15 Dit is anders in Duitsland. Het Constitutionele Hof heeft daar in een uitspraak van 15 december 1983 een recht op informationele zelfbeschikking in de Grondwet gelezen. Uit het algemene persoonlijkheidsrecht en de menselijke waardigheid werd het beginsel afgeleid dat binnen de relatie overheid en burger een ieder zelf mag bepalen in hoeverre informatie over hem wordt gebruikt en verder bekend gemaakt. Hieraan kunnen op grond van het algemeen belang wel beperkingen worden gesteld. Kamerstukken II 1997/98, 25 892, nr. 3, p. 9. 
waarbij rekening moet worden gehouden met de bijzondere (grondwettelijke) waarde van het recht op bescherming van de persoonlijke levenssfeer."16

Erkenning van een recht op weten via de weg van een zogenaamd informationeel zelfbeschikkingsrecht is dus afgesloten. Twee uitspraken van het EHRM uit de jaren negentig van de vorige eeuw lijken wel een opening te bieden voor de erkenning van een recht on informatie tot stand te doen brengen over onze eigen genetische constitutie.

Algemeen is aanvaard dat de overheid in bepaalde opzichten een actieve rol moet vervullen om de realisering van klassieke grondrechten en dus ook het recht op privacy, te verwezenlijken. Dit geldt tevens op Europees niveau. Het is inmiddels vaste jurisprudentie van zowel de Commissie als het Hof dat de lidstaten in bepaalde gevallen verplicht zijn om door middel van wetgeving of andere maatregelen de in het EVRM opgenomen rechten te realiseren. ${ }^{17}$ Voor wat betreft artikel 8 EVRM is dit herhaaldelijk bepaald. ${ }^{18}$ Het Europese Hof stelt zich daarbij op het standpunt dat bij de bepaling of er wel of geen positieve verplichting bestaat, rekening gehouden moet worden met het bereiken van een rechtvaardig evenwicht tussen het algemeen belang van de samenleving en de belangen van het individu, de zogenaamde fair balance test. Lidstaten hebben bij het treffen van maatregelen ter bescherming van artikel 8 EVRM in beginsel een zekere beleidsvrijheid. Het is de taak van het Hof om vast te stellen of de nationale autoriteiten de maatregelen hebben getroffen die nodig zijn om het recht op respect voor privé- en familieleven te waarborgen.

Het feit dat zowel artikel 10 Grondwet en artikel 8 EVRM positieve verplichtingen met zich mee kumnen brengen voor de overheid, houdt nog niet in dat een recht op weten afgeleid kan worden uit het recht op privacy. Welk aspect van het recht op een persoonlijke levenssfeer zou geschonden moeten zijn wil een beroep hierop gehonoreerd worden? In twee uitspraken van het EHRM werd geoordeeld dat artikel 8 EVRM geschonden was omdat het welzijn van het individu was aangetast.

De eerste uitspraak betrof een zaak waarin eiseres stelde dat artikel 8 EVRM door de Spaanse autoriteiten geschonden was. ${ }^{19} \mathrm{Zij}$ stelde dat een fabriek in de directe omgeving van haar woning zorgde voor overlast door stank, damp en lawaai. Deze overlast veroorzaakte gezondheidsproblemen bij één van haar dochters. Op grond daarvan meende de eiseres dat het recht op respect voor de woning was geschonden. Het Europese Hof oordeelde dat:

"Naturally, severe environmental pollution may effect individual's well-being and prevent them from enjoying their homes in such a way as to affect their private and family life adversely".

\footnotetext{
16 Kamerstukken Il 1997/98, 25 892, nr. 3, p. 9.

17 Verhey 1992, p. 221.

is EHRM 13 juni 1979, NJ 1980, 462; EHRM 26 maart 1985, NJ 1985, 525; EHRM 17 oktober 1986, NJ 1987, 945; EHRM 18 december 1986, NJ 1989, 97; EHRM 25 maart 1992, NJ 1995, 679; EHRM 9 december 1994, NJ 1996, 506; EHRM 19 februari 1998, NJ 1999, 690. 
Hierbij hoefde geen sprake te zijn van een ernstig gevaar voor de volksgezondheid, aldus het Hof. Het Hof besliste dat de Spaanse autoriteiten er in casu niet in geslaagd waren om een billijk evenwicht te vinden tussen het economische belang van de stad Lorca en het recht van eiseres op respect voor haar woning en privé- en familieleven en concludeerde dat artikel 8 EVRM was geschonden.

Ruim drie jaar later herhaalt het Europese Hof zijn oordeel. ${ }^{20}$ Het betrof hier het feit dat klagers tot het einde van de productie van kunstmest door een nabij gelegen chemische fabriek in 1994, hadden moeten wachten op essentiële informatie van de Italiaanse autoriteiten die het hun mogelijk zou hebben gemaakt de risico's te beoordelen die zij en hun families zouden lopen als ze bleven wonen in Manfredonia. Het Hof oordeelde wederom dat:

\footnotetext{
"severe environmental pollution may affect individuals' well-being and prevent them from enjoying their homes in such a way as to affect their private and family life adversely".
}

Ook in deze zaak had de nationale overheid volgens het Hof niet aan haar verplichtingen voldaan, door niet de noodzakelijke stappen te nemen om effectieve bescherming te verzekeren van het in artikel 8 EVRM gegarandeerde recht van klagers op respect voor hun privé- en familieleven. Het Hof oordeelde dan ook dat artikel 8 EVRM was geschonden.

In beide arresten leverde een aantasting van het welzijn van het individu een schending op van artikel 8 EVRM. ${ }^{21}$ In het tweede arrest leverde het feit dat klagers lange tijd voor hen essentiële informatie was onthouden een schending op van de verplichting om het recht van klagers op respect voor hun privé- en familieleven te waarborgen. Vooral dit laatste arrest lijkt aanknopingspunten te bieden voor een eventuele klacht dat artikel 8 EVRM geschonden is op grond van het feit dat bepaalde informatie betreffende de eigen genetische constitutie van klager onthouden is doordat de staat geen mogelijkheden biedt voor het ondergaan van een erfelijkheidsonderzoek. Het lijkt goed voorstelbaar dat onwetendheid betreffende bepaalde erfelijkheidsinformatie het welzijn van een individu kan aantasten. Het Hof zou in een dergelijk geval moeten nagaan of de overheid de maatregelen heeft getroffen die nodig zijn om het recht van de eiser op respect voor zijn privé- en

20 EHRM 19 februari 1998, NJ 1999, 690.

21 In een zaak waarin militairen waren blootgesteld aan radio-actieve straling verklaarde het Hof dat het feit dat de klagers niet wisten of zij aan gevaarlijke hoeveelheden straling waren blootgesteld, makkte dat er een voldoende nauwe band is tussen hun recht op respect voor privé- en gezinsleven en hun wens om toegang te hebben tot informatie die hun vrees kon wegnemen, of die hen in staat zou stellen na te gaan aan welk gevaar zij waren blootgesteld. Artikel 8 EVRM was derhalve toepasselijk. Het was in casu echter niet geschonden omdat er een effectieve en toegankelijke procedure bestond waarmee de betrokkenen alle relevante en gepaste informatie konden verkrijgen, waarvan klagers geen gebruik hadden gemaakt. EHRM, 9 juni 1998, NJB 1998, p. 1313. 
familieleven te warborgen. In het Gaskin-arrest, waar het gebrek aan procedurele waarborgen een schending van artikel 8 EVRM opleverde, benadrukt het Europese Hof het vitale belang van informatie omtrent de eigen jeugd en vroege ontwikkeling:

"(...), persons in the situation of the applicant22 have a vital interest, protected by the Convention, in receiving the information necessary to know and to understand their childhood and early development." 23

Als dergelijke informatie beschermd wordt door het verdrag, dan lijkt informatie over de (toekomstige) gezondheid eveneens door het Verdrag beschermd te worden. Dergelijke informatie zal van vitaal belang zijn voor een individu. Hier is wel enige voorzichtigheid op zijn plaats: in het Gaskin-arrest betrof het bestaande informatie. Toch is hier de voorlopige conclusie dat een beroep op het recht op weten, in de zin van informatie tot stand te laten brengen, afgeleid van het recht op privacy, in rechte verdedigbaar lijkt. Daarbij zal in individuele gevallen bekeken moet worden of er sprake is van een schending van het welzijn van het individu. Aan het einde van deze paragraaf word hier nog op teruggekomen.

\section{Welke mantregelen moet de overheid treffen?}

De maatregelen die de overheid zou moeten treffen om het recht van het individu op zijn privé- en familieleven te waarborgen zouden in aanvulling op het recht op privacy afgeleid kunnen worden uit het recht op gezondheidszorg. Dit sociale grondrecht bepaalt dat de overheid de plicht heeft om maatregelen te treffen ter bevordering van de volksgezondheid. Deze taak wordt vaak omschreven als de zorg voor de beschikbaarheid van de noodzakelijke gezondheidsvoorzieningen. De vraag is wanneer het noodzakelijke gezondheidsvoorzieningen betreft. Leenen stelt het volgende normatieve kader voor:

a. "Het zorg dragen voor voorzieningen voor hen die wegens ziekte of gebrek niet zelfstandig kunnen bestaan.

b. Het zorg dragen voor voorzieningen waarover iedere burger voor de zorg voor zijn gezondheid moet kunnen beschikken.

c. Het zorg dragen voor extra voorzieningen voor degenen die, terwijl zij zelfstandig kunnen bestaan, door aangeboren ziekte of aandoening of door pech een ernstig medisch probleem hebben." ${ }^{24}$

Het recht op gezondheidszorg heeft in vergelijking met individuele grondrechten een zwakker juridisch karakter, omdat het afhankelijk is van de beschikbaarheid van

22 Met de situatie van de klager wordt gedoeld op het feit dat klager, Gaskin genaamd, het grootste deel van zijn jeugd heeft doorgebracht bij verschillende pleegouders. Tijdens zijn onder toezichtstelling is Gaskin volgens eigen zeggen meermalen mishandeld. Om dit te verwerken en lering te kunnen trekken uit zijn verleden wenst Gaskin informatie over degenen waarbij en de omstandigheden waaronder hij zijn jeugd heeft moeten doorbrengen.

23 EHRM 7 juli 1989, NJ 1991, 659.

24 Leenen 1995, p. 397. Zie ook Kasdorp 1988, Gezondheidsraad 1986, Nationale Raad voor de Volksgezondheid 1986 en Ziekenfondsraad 1986. 
gezondheidsvoorzieningen. Het is bovendien als een instructienorm aan de overheid geformuleerd. Aanspraak op het recht op gezondheidszorg is daarom doorgaans pas mogelijk wanneer het recht is gepositiveerd.25 De burger kan er niet rechtstreeks een beroep op doen. Wel zou het mogelijk zijn een beroep te doen op een individueel grondrecht, in casu het recht op privacy, en het recht op gezondheidszorg via de zogenaamde complementariteit van beide typen grondrechten. In dat geval moet aangetoond worden dat het recht op privacy niet gehandhaafd kan worden zonder de aanspraak op grond van het recht op gezondheidszorg. ${ }^{26}$

De matregelen die de overheid zou moeten treffen om het recht van eiser op zijn privé- en familieleven te warborgen zouden in aanvulling op het recht op privacy wellicht ook afgeleid kunnen worden uit artikel 22 lid 3 Grondwet:

"Zij schept voorwaarden voor maatschappelijke en culturele ontplooiing en voor vrijetijdsbesteding."

Nabben en Van de Luytgaarden wijzen erop dat de relatie tussen individu en samenleving veel hechter is geworden in onze tijd:

"De afhankelijkheid van de individu is (vooral door de informatisering) toegenomen en ook de persoonlijke ontplooiing van de individu is sterk afhankelijk van de erkenning en acceptatie door de maatschappelijke omgeving waarin hij leeft. Dit biedt een aanknopingspunt om het belang van privacy niet alleen te beperken tot de individu maar dit ook in een ruimer, sociaal-maatschappelijk perspectief te begrijpen." 27

Zij stellen dat privacybescherming zowel binnen als buiten de samenleving gericht is op de ontplooiing van het individu. ${ }^{28}$ Wanneer het belang van privacy in een ruimer sociaal-maatschappelijk perspectief wordt gezien als het belang van ontplooiing van het individu wordt de taak van de overheid op grond van artikel 22 lid 3 Grondwet van belang voor de bescherming van de privacy.

Hetgeen zojuist is opgemerkt over het karakter van het recht op gezondheidszorg, geldt eveneens voor de opdracht van artikel 22 lid 3 Grondwet. Wanneer op artikel 22 lid 3 Grondwet, in aanvulling op het recht op privacy, een beroep zou worden gedaan, zou aangetoond moeten worden dat het recht op privacy niet gehandhaafd kan worden zonder dat er, in casu specifieke, voorwaarden worden geschapen ter ontplooiing van het individu.

25 Dit geschiedt dan op indirecte wijze. Zie bijvoorbeeld Pr. Rb. Utrecht 29 oktober 1999, RZA 1999/192, Hof Den Bosch 2 juli 1990, TvGr 1990/81, De Geschillencommissie Dagverblijven en Gezinsvervangende Tehuizen 17 mei en 7 december 1991, TvGr 1993, 67 en Rb. Den Haag 11 maart 1992, TvGr 1993, 32.

26 Leenen 2000, hoofdstuk 2, paragraaf 1 en Leenen 1995, p. 396-406.

27 Nabben en Van de Luytgaarden 1996, p. 18.

28 Nabben en Van de Luytgaarden 1996, p. 22. 


\section{Conclusie}

Op grond van de genoemde arresten van het Europese Hof voor de Rechten van de Mens lijkt een recht om informatie te vergaren betreffende de eigen genetische constitutie door middel van het ondergaan van een erfelijkheidsonderzoek onder omstandigheden afleidbaar te zijn uit het recht op respect voor het privé- en familieleven. Dat een dergelijk recht bij de totstandkoming van artikel 8 EVRM niet aan de orde is geweest hoeft aan de erkenning ervan niet in de weg te staan. ${ }^{29}$ Volgens het Hof en Commissie voor de Rechten van de Mens is in artikel 8 EVRM geen uitputtende definitie gegeven van het begrip privéleven. ${ }^{30}$ In de genoemde arresten leveren echter bestaande overlast respectievelijk bestaande informatie een schending van artikel 8 EVRM op. Hier is de vraag aan de orde of er een recht is om informatie tot stand te brengen door middel van het afdwingen van de mogelijkheid om een erfelijkheidsonderzoek te ondergaan. Het kan natuurlijk niet zo zijn dat de overheid op grond van het recht op privacy, en daarvan afgeleid een recht op weten, verplicht zou kunnen worden om alle technische mogelijke en wetenschappelijk verantwoorde erfelijkheidsonderzoeken aan te bieden. ${ }^{31}$ Specifieke omstandigheden zouden daar in individuele gevallen wellicht wel toe kunnen leiden. Zoals aangegeven zou dan aangetoond moeten worden dat de informatie van vitaal belang is voor het individu en dat het niet verkrijgen van de informatie een aantasting van het welzijn van het individu oplevert. Dit zou het geval kunnen zijn bij een verhoogd risico op een ernstige ziekte warbij preventieve maatregelen effect kunnen sorteren wanneer deze tijdig worden getroffen.

\subsection{Het recht op weten jegens familieleden}

Is ook het andere aspect van het recht op weten, het recht op kennisname van reeds bestaande informatie betreffende de eigen genetische constitutie, af te leiden van het recht op een persoonlijke levenssfeer? Een dergelijk recht zou mogelijkheden bieden om kennis te vergaren betreffende het risico op een bepaalde aandoening, waar een bloedverwant reeds over beschikt. Hierbij moet eerst een kanttekening worden gemaakt. Het aannemen van een eventueel recht op weten ten opzichte van een familielid is alleen relevant wanneer dezelfde wetenschap niet verkregen kan worden door middel van het zelf laten verrichten van erfelijkheidsonderzoek. Dit zal het geval zijn wanneer een erfelijke aanleg door verschillende mutaties kan worden veroorzaakt en niet bekend is bij de adviesvrager of de mutatie bij een ander familielid is aangetoond en zo ja, welke mutatie het betreft. Wanneer de klinisch geneticus dit wel weet, kan zijn geheimhoudingsplicht hem in een conflict van plichten brengen. Zie hiervoor hoofdstuk 7.

\section{Gevers 1996, p. 11.}

30 Roscam Abbing 1994a, p. 107.

31 Evenmin is het zo dat de overheid op grond van het recht op privacy, en daarvan afgeleid het recht op weten, verplicht gesteld zou kunnen worden onderzoek aan te bieden dat ze eerder wegens gewichtige redenen op grond van artikel 3 van de Wet op bijzondere medische verrichtingen, gezien de ongewenste maatschappelijke, ethische of juridische aspecten, verboden heeft. 
In deze paragraaf zal een onderscheid worden gemaakt tussen de situatie waarin een bloedverwant van degene die een recht op weten claimt een erfelijkheidsonderzoek voor zichzelf heeft ondergaan en de situatie waarin er een erfelijkheidsonderzoek is verricht ten behoeve van degene die een recht op weten claimt. Begonnen zal worden met de eerstgenoemde situatie.

\subsubsection{Een recht op weten jegens degene die woor zichzelf een erfelijkheidsonderzoek heeft laten verrichten?}

Om de vraag te beantwoorden of er sprake is van een recht op kennisname van reeds bestaande informatie betreffende de eigen genetische constitutie zal worden gekeken of de jurisprudentie hiervoor aanknopingspunten biedt. Vervolgens zullen de factoren worden besproken die van belang kunnen zijn bij de beantwoording van genoemde vraag.

\section{Horizontale werking van het recht op privacy}

Het aanspraak maken op een recht op weten ten opzichte van een familielid op grond van het recht op privacy veronderstelt dat grondrechten in horizontale verhoudingen door kunnen werken. Over het feit of en in hoeverre het recht op respect voor de persoonlijke levenssfeer directe horizontale werking heeft, bestaat onduidelijkheid. 32 De algemene opvatting van de regering betreffende de horizontale werking van grondrechten houdt blijkens de Memorie van Toelichting in dat grondrechten op verschillende manieren kunnen doorwerken in private verhoudingen. ${ }^{33}$ De vraag in hoeverre de grondrechten doorwerken in civielrechtelijke verhoudingen kan per artikel, per artikelonderdeel en zelfs per categorie van gevallen, waarop het artikel betrekking heeft, verschillen, aldus de regering. In de jurisprudentie zijn twee benaderingen te onderscheiden. Ten eerste kan een grondrecht direct doorwerken. Dit is in 1987 door de Hoge Raad expliciet

32 Evenmin bestaat er eenduidigheid over de horizontale werking van artikel 8 EVRM en artikel 17 IVBPR.

3. Volgens de regering zijn er vijf manieren te onderscheiden waarop grondrechten kunnen doorwerken in horizontale verhoudingen. Ten eerste kan een grondrecht worden gezien als een opdracht aan de wetgever of de overheid om een rader geformuleerd belang of beginsel ook in civiele rechtsverhoudingen te verwezenlijken. Dit is het geval met instructienormen uit sociale grondrechten. Ten tweede kan de grondrechtsnorm zich als belangrijke waarde aan de rechter presenteren waarvan hij de invloed ondergaat bij de interpretatie van privaatrechtelijke regels of begrippen. Ten derde kan het grondrecht een zelfstandig rechtsbelang uitdrukken dat de rechter bij de afweging van belangen mede in aanmerking moet nemen. Ten vierde kan een grondrecht de uitdrukking zijn van een rechtsbeginsel waarvan de rechter slechts op zwaarwegende gronden mag afwijken. Ten slotte kan het grondrecht directe horizontale werking hebben. Kamerstukken II 1975/76, 13 873, p. 5-6. 
erkend. ${ }^{3 \cdot 4}$ Directe doorwerking speelt in jurisprudentie echter nauwelijks een rol. In de meeste uitspraken warin het recht op een persoonlijke levenssfeer aan de orde is, is er sprake van indirecte doorwerking van het recht op privacy. Het grondrecht fungeert dan als inspiratiebron bij de interpretatie van civielrechtelijke bepalingen. Tot slot zijn er talrijke uitspraken waarin de civiele rechtsvinding leidt tot bescherming van grondrechtelijke warden zonder dat deze waarden een zichtbare rol hebben gespeeld. In het laatste geval kan men echter niet meer spreken van doorwerking van grondrechten. ${ }^{35}$ De jurisprudentie inzake het recht op privacy laat zoals gezegd zien dat de rechter doorgaans geen directe werking aan het grondrecht toekent. In de meeste uitspraken speelt het recht op privacy zelfs geen expliciete rol. Vaak is slechts sprake van een zekere reflexwerking. De privacy wordt in de civiele jurisprudentie meestal beschermd door cen belangenafweging. De persoonlijke levenssfeer wordt dan afgewogen tegen andere belangen die in het geding zijn. Het betreft dan voornamelijk jurisprudentie inzake de onrechtmatige daad.

\section{Jurisprudentie}

De rechtspraak betreffende het vergaren en/of vastleggen van informatie betreft zaken waarin informatie reeds is vergaard en/of vastgelegd. Er wordt gesteld dat er een inbreuk is gepleegd op het recht op een persoonlijke levenssfeer omdat er door een derde tegen de wil van de eiser informatie is vergaard en/of vastgelegd. ${ }^{36}$

De enige zaak die hier een uitzondering op lijkt te vormen is een kort geding, waarin een vrouw had gevorderd dat de man die haar verkracht had een test zou ondergaan warin de aanwezigheid van het HIV-virus in zijn bloed zou worden onderzocht. ${ }^{37}$ In deze zaak betreft het weliswaar geen bestaande informatie, maar hij is voor de beantwoording van de in deze paragraaf centraal staande vraag interessant omdat de vraag aan de orde lijkt of een persoon jegens een ander persoon aanspraak kan maken op een recht op weten. De vrouw vreesde dat zij door de verkrachting besmet zou zijn met het HIV-virus. Ze stelde dat het voor haar emotioneel te belastend zou zijn indien zij zelf de test zou ondergaan. Ze achtte de verkrachter gehouden om deze test te ondergaan om zowel haar schade als gevolg van de verkrachting te verminderen als om haar een volgende traumatische ervaring te besparen. Wanneer haar verkrachter na een HIV-test niet seropositief zou blijken te zijn, zou eiseres de zekerheid hebben dat zij evenmin seropositief zou zijn. De President van de Rechtbank Amsterdam wees de vordering toe. Volgens hem was er sprake van:

"een botsing tussen de zowel aan $X$ als aan $M$ toekomende grondrechten als neergelegd in de artikelen 10 en 11 van de Grondwet, inhoudende het recht op eerbiediging van de persoonlijke levenssfeer en onaantastbaarheid van het lichaam en

3 HR 9 januari 1987, NJ 1987, 928. De Hoge Raad formuleerde het als volgt: "een recht op eerbiediging van de persoonlijke levenssfeer moet worden aanvaard, (...) waarvan moet worden aangenomen, dat het ook werking heeft tussen de burgers onderling."

$35 \quad$ Verhey 1992, hoofdstuk 8.

36 Zie bijvoorbeeld Hof Den Bosch 16 januari 1991, NJ 1991, 637, Pr. Rb. Maastricht 30 september 1991, KG 1991, 364 en Pr. Rb. Arnhem 8 oktober 1990, KG 1991, 14.

$37 \quad$ IIR 18 juni 1993, NJ 1994, 347. 
het hun beiden toekomende in artikel 8 EVRM neergelegde recht op eerbiediging van het privé-leven." 38

De botsing van grondrechten bracht de President tot een belangenafweging, waarbij het belang van de vrouw prevaleerde boven dat van haar verkrachter.

Het Hof in Amsterdam vernietigde het vonnis. Volgens het Hof was er geen sprake van een botsing van grondrechten. Het ging volgens het Hof om het mitigeren van de gevolgen van de schending van artikel 11 Grondwet en niet om het tegengaan van de schending zelf. Het Hof ontkende vervolgens niet dat in een dergelijk geval een inbreuk op de integriteit van het lichaam van de verkrachter gerechtvaardigd zou kunnen zijn, maar zag daar in het onderhavige geval geen aanleiding voor en ging niet over tot het opleggen van de gevraagde maatregel.

De Hoge Raad vernietigde op zijn beurt het arrest van het Hof en bekrachtigde het vonnis van de President. Hij overwoog:
"Uit de krachtens art. 1401 BW (oud) toepasselijke regels betreffende onrechtmatige daad vloeit voort dat zij er recht op had dat de gevolgen daarvan door de dader zoveel mogelijk zouden worden beperkt dan wel door een passende vorm van schadevergoeding zoveel mogelijk zouden worden goedgemaakt. Tot deze gevolgen behoorde de onzekerheid omtrent besmetting met HIV-virus. Eiseres had een zwaarwegend belang bij zo snel mogelijke beëindiging van deze onzekerheid, waarvan de aard meebracht dat zij diep in haar persoonlijk leven ingreep. Door de weigering van $X$ aan een onderzoek van zijn eigen bloed mee te werken kon eiseres de door haar verlangde zekerheid slechts verkrijgen door zelf een - nieuw - bloedonderzoek te ondergaan, waartegen zij echter voor de hand liggende, ernstige emotionele bezwaren had. Een en ander brengt met zich mee dat eiseres, zoals de president terecht heeft geoordeeld, recht had op medewerking van $X$ in de vorm van een door deze te ondergaan bloedonderzoek. (...) Het vorenoverwogene geldt ongeacht of ook aan de zijde van eiseres terecht een beroep op een grondrecht is gedaan of zou kunnen worden gedaan. In het midden kan derhalve blijven de door de president en hof in verschillende zin beantwoorde, door het middel opnieuw aan de orde gestelde vraag of de onzekerheid omtrent besmetting als na de verkrachting voortgezette aantasting van het lichaam van eiseres in de zin van art. 11 Gr.w. moet worden beschouwd."

De Hoge Raad laat hier helaas in het midden of eiseres zich op het recht op privacy kan beroepen. Wel wordt het belang dat eiseres heeft bij het ondergaan door de gedaagde van een HIV-test erkend en gestoeld op het leerstuk van de onrechtmatige daad. Op grond van de normen die het in het maatschappelijk verkeer betaamt jegens elkaar in acht te nemen, wordt de beperking van het aan de gedaagde toekomende recht op bescherming van de integriteit van zijn lichaam gerechtvaardigd. Het belang van de gedaagde dat door artikel 11 Grondwet beschermd wordt moet wijken voor het belang van eiseres dat zijn basis vind in artikel 6:162 BW. Het grondrecht prevaleert in deze horizontale rechtsverhouding niet boven het gewone recht. 
Is er hier door middel van de onrechtmatige daad-constructie een recht op weten erkend? In dit arrest is het recht op weten, al wordt het zo niet geformuleerd, van de eiseres een gevolg van een haar toekomend recht. De grondslag voor de toewijzing van de vordering van eiseres bestond uit het recht dat zij had dat de gevolgen van de verkrachting door de dader zoveel mogelijk zouden worden beperkt, dan wel door een passende vorm van schadevergoeding zoveel mogelijk zouden worden goedgemaakt. De onzekerheid omtrent besmetting met het HIV-virus behoorde tot deze gevolgen. Een recht op weten is dus niet erkend.

Daarnaast kan in deze casus nauwelijks van een, ten gevolge van een recht op beperking van de schade, recht op weten worden gesproken, eerder van een recht op beïindiging van de onzekerheid. Deze rechten zijn niet identiek. Het belang dat de eiseres had was een zo snel mogelijke beëindiging van de onzekerheid omtrent besmetting, welke onzekerheid diep in haar leven ingreep. De vraag is, als het belang van een zo snel mogelijke beëindiging van onzekerheid niet had meegespeeld, of eiseres ook dan er recht op zou hebben gehad dat haar verkrachter een HIV-test zou ondergaan. Immers, indien eiseres had kunnen leven met de onzekerheid omtrent besmetting, was er geen sprake van schade en derhalve geen grond voor het recht op beperking van de schade. Ook van een indirect recht op weten lijkt hier geen sprake.

De jurisprudentie over het weigeren van inzage in informatie inzake afstammingsgegevens lijkt meer aanknopingspunten te bieden betreffende de aanname van een recht op weten. De wet kent een recht op kennis van de afstamming noch een recht op toegang tot gegevens over de afstamming. In de zaak Valkenhorst die in 1994 voor de Hoge Raad kwam was de vraag aan de orde of een buitenechtelijk kind recht heeft op inzage in en afschrift van gegevens omtrent haar vader. De moeder leefde nog, maar weigerde toestemming tot inzage te geven in het dossier dat door de Stichting Valkenhorst was vervaardigd en waarin de gegevens omtrent de natuurlijke vader van eiseres stonden vermeld. De Stichting Valkenhorst beriep zich op de plicht tot geheimhouding van die gegevens en op het recht van de moeder op respect voor haar privé-leven.

De Hoge Raad stelde hierover het volgende:

"Uitgangspunt voor de beoordeling van het middel is dat het aan grondrechten als het recht op respect voor het privé leven, het recht op vrijheid van gedachte, geweten en godsdienst en het recht op vrijheid van meningsuiting ten grondslag liggende algemene persoonlijkheidsrecht mede omvat het recht om te weten van welke ouders men afstamt."

De Hoge Raad wees er daarbij op dat dit recht ook internationaal erkenning heeft gevonden in artikel 7 van het Verdrag inzake de rechten van het Kind. ${ }^{39}$

Artikel 7 lid 1 van het Verdrag inzake de rechten van Kind luidt: "Het kind wordt onmiddellijk na de geboorte ingeschreven en heeft vanaf de geboorte het recht op een 
Daar het geen absoluut recht betreft zal het altijd afgewogen moeten worden tegen de rechten en vrijheden van anderen. In dit arrest werd geoordeeld dat het recht van een meerderjarig natuurlijk kind om te weten door wie het is verwekt, prevaleert boven het in het recht op respect voor het privé leven besloten liggende recht van de moeder om dit tegenover haar kind verborgen te houden. De Raad overwoog hierbij:

\begin{abstract}
"Behalve door het vitaal belang van dit recht voor het kind wordt deze voorrang daardoor gewettigd dat de natuurlijke moeder in de regel mede verantwoordelijkheid draagt voor het bestaan van dat kind."
\end{abstract}

Het vitale belang van informatie betreffende de eigen jeugd en ontwikkeling is reeds in 1989 in het Gaskin-arrest door het Europese Hof aan de orde gesteld. Zie hiervoor de vorige paragraaf.

De jurisprudentie van de Hoge Raad en het Europese Hof voor de Rechten van de Mens erkent het grote belang van informatie betreffende afstamming, ontwikkeling en de eigen jeugd. Dergelijke informatie wordt vitaal genoemd. Volgens de Hoge Raad omvat het algemene persoonlijkheidsrecht mede het recht om te weten van welke ouders men afstamt. Het belang dat men heeft bij het kennen van de genetische constitutie, althans het kennen van een onderdeel daarvan lijkt een minstens zo vitaal belang. In de risicocultuur die zich in ons land in de $20^{\circ}$ eeuw heeft ontwikkeld heeft, gaan wetenschappelijke inzichten in risico's en de norm van beheersing van ziekte en sterfte samen. Het idee is ontstaan dat ziekte en gezondheid tot op grote hoogte makbaar en beheersbaar zijn en moeten zijn en de beheersing van risico's wordt als een goede zaak wordt gezien. ${ }^{40}$ Kennis omtrent verhoogde risico's op een erfelijke aandoening zal voor veel mensen om die reden van vitaal belang zijn. Deze kennis maakt mijns inziens, evenals de kennis van wie men afstamt, onderdeel uit van de identiteit." Het recht op kennisname van bestaande informatie betreffende de eigen genetische constitutie zou dan afgeleid kunnen worden uit het algemene persoonlijkheidsrecht dat onder andere ten grondslag ligt aan het recht op een persoonlijke levenssfeer. Uit de hierboven genoemde uitspraak van de Hoge Raad blijkt ook dat dit geen absoluut recht is. Het zal afgewogen moeten worden tegen rechten en vrijheden van anderen. Het zal dus afgewogen moeten worden tegen het recht op een persoonlijke levenssfeer van een bloedverwant die over informatie beschikt die zowel relevant is voor de bloedverwant als voor degene die een recht op die informatie claimt.

naam, het recht een nationaliteit te verwerven en, voor zover mogelijk, het recht zijn of haar ouders te kennen en door hen te worden verzorgd."

4 Zie hierover hoofdstuk 3, paragraaf 3.5 .

41 In de visie van Advocaat-generaal Koopmans bij het Valkenhorst-arrest maakt het recht op de eigen identiteit deel uit van het persoonlijkheidsrecht. Hij verwijst hierbij naar een uitspraak van het Duitse Bundesverfassungsgericht uit 1989 waarin werd bepaald dat het recht van een kind op kennis van de eigen afstamming kan worden afgeleid uit de door de Grundgesetz beschermde waarden, te weten het recht op vrije ontplooiing van de persoonlijkheid in combinatie met de menselijke waardigheid. 
Afweging onn beide rechten op prioncy

Het feit dat in concrete gevallen het recht op een persoonlijke levenssfeer van het familielid dat bepaalde erfelijkheidsinformatie wil weten zal botsen met hetzelfde recht van het familielid dat deze informatie niet wil prijsgeven maakt dat de omstandigheden van het geval afgewogen zullen moeten worden om vast te kunnen stellen wiens grondrecht prevaleert. ${ }^{2}$. Welke factoren zouden hierbij van belang kunnen zijn?

Ten eerste het belang dat gediend is met de inbreuk op de privacy. Degene die een recht op weten claimt, een recht op de informatie waar zijn bloedverwant over beschikt, zal het belang aan moeten tonen dat de informatie voor hem heeft. Het belang bij de wetenschap of men in de toekomst aan een bepaalde aandoening zal gaan leiden of de wetenschap of men hier een verhoogd risico op heeft kan groot en evident zijn. Het niet weten van bepaalde informatie kan een aantasting van zijn welzijn opleveren doordat aan het individu voor hem essentiële informatie wordt onthouden. Dit zal zeker het geval zijn indien primaire en/of secundaire matregelen kunnen worden genomen om het risico op de erfelijke aandoening te reduceren. Dan heeft degene die een recht op weten claimt een belang bij beëindiging van de onzekerheid rond een erfelijke aanleg, welke onzekerheid ongetwijfeld diep in zijn leven ingrijpt. Een goede gezondheid wordt in onze samenleving als een gewichtig persoonlijk goed beschouwd. Dat zal niet anders zijn voor wat betreft de kennis omtrent de toekomstige gezondheid.

Ten tweede de ernst van de inbreuk op de privacy. Wanneer de informationele privacy in het geding is, pleegt de rechter hieraan belang te hechten door te kijken naar de aard en de intimiteit van de betrokken informatie. ${ }^{43}$ Hierbij zou op de familiaire context gewezen kunnen worden. Men kan stellen dat de informatie niet persoonlijk, maar familiair van aard is. Dezelfde mutatie kan er bij het familielid dat over de erfelijkheidsinformatie wil beschikken immers verantwoordelijk voor zijn dat ook hij later in zijn leven een aandoening krijgt of een verhoogd risico daarop heeft. Bovendien zou het gebruik van de informatie beperkt blijven tot het vaststellen van het risico op de familiaire aandoening. De kring van personen waarbinnen de informatie bekend wordt blijft klein. Het gevaar van misbruik van de informatie is gering. De informatie kan, in tegenstelling tot de situatie waarin bijvoorbeeld een verzekeringsmaatschappij de gevraagde informatie tot zijn beschikking zou krijgen,

42 Verhey wijst erop dat bij botsende grondrechten "de algemene lijn is dat de rechter daarbij pragmatisch te werk gaat en de grondrechtelijke belangen tegen elkaar afweegt aan de hand van de omstandigheden van het concrete geval". Verhey 1992, p. 320. Zie bijvoorbeeld Hof Arnhem 6 maart 1990, NJ 1990, 682. Eiser zou ook kunnen stellen dat gedaagde jegens hem een onrechtmatige daad heeft gepleegd door to weigeren hem informatie te verschaffen omtrent zijn genetische constitutie. De grondslag van een dergelijke vordering zou eruit bestaan dat de weigering om informatie te verschaffen een nalaten is in strijd met hetgeen volgens ongeschreven recht in het maatschappelijk verkeer betaamt. Bron van de rechtens te beschermen belangen van eiser is dan het recht op een persoonlijke levenssfeer.

43 Verhey 1992, p. 324. Zie bijvoorbeeld HR 1 juli 1988, NJ 1988, 1000. 
niet tegen het familielid gebruikt worden. Dit alles makkt de inbreuk op de privacy gering.

Daar staat tegenover dat de aanwezigheid van een bloedband niet het intieme en persoonlijke karakter van de informatie wegneemt. Familieleden kunnen totale vreemden voor elkaar zijn. De vraag kan gesteld worden of er een principieel verschil is tussen de bescherming van de privacy jegens derden en jegens familieleden. In de gezondheidszorg wordt de bescherming van medische informatie betreffende de patiënt, en zeker van gevoelige informatie, ${ }^{4.4}$ van groot belang geacht. Het recht op privacy is mede aanleiding geweest tot verdere regeling van patiëntenrechten. ${ }^{45}$ De hulpverlener heeft een geheimhoudingsplicht die tijdens en na het leven van de patiënt van kracht is. Ook ten opzichte van derden is informatie uit erfelijkheidsonderzoek beschermd in die zin dat geen melding hoeft te worden gemaakt van reeds ondergaan erfelijkheidsonderzoek bij het aangaan van verzekeringen en arbeidsrelaties. Waarom zou deze vérgaande bescherming dan niet ook jegens het familielid gelden dat de informatie eist?

Ten slotte het subsidiariteitsbeginsel. Dit zou een rol kunnen spelen wanneer ook andere bloedverwanten over de gevorderde informatie beschikken en deze bloedverwanten deze informatie wel zouden willen delen.

\section{Conclusie}

De balans opmakend zou met betrekking tot het recht op weten het volgende gesteld kunnen worden. De vraag of er sprake is van een recht op weten is, is in de Nederlandse rechtsliteratuur, met uitzondering van Gevers, nauwelijks aan de orde geweest. Hij stelt dat het gaat om een door het recht te beschermen belang waarvoor aansluiting moet worden gezocht bij het recht op respect voor de persoonlijke levenssfeer. De uitleg van artikel 8 EVRM door het Europese Hof biedt ruimte voor een dergelijke interpretatie. Volgens vaste jurisprudentie van het Hof scheppen de in het EVRM opgenomen rechten in bepaalde gevallen positieve verplichtingen voor de lidstaten. In twee arresten oordeelde het Hof dat, doordat de overheid niet aan zijn verplichtingen had voldaan, artikel 8 EVRM was geschonden omdat het welzijn van het individu hierdoor was aangetast. Op grond van deze jurisprudentie lijkt onder omstandigheden een recht op weten uit artikel 8 EVRM af te leiden. De maatregelen die de overheid zou moeten treffen om het recht op een privé- en familieleven en daarvan afgeleid het recht op weten te waarborgen zouden in aanvulling op het recht

Zie bijvoorbeeld EHRM 25 februari 1997, NJ 1999, 516. Hier oordeelde het Hof met betrekking tot de bescherming van medische gegevens: "(..), the Court will take into account that the protection of personal data, not least medical data, is of fundamental importance to a person's enjoyment of his or her right to respect for private and family life as guaranteed by Article 8 of the Convention (art. 8). (...) The above considerations are especially valid as regards protection of the confidentiality of information about a person's HIV infection. The disclosure of such data may dramatically affect his or her private and family life, as well as social and employment situation, by exposing him or her to opprobium and the risk of ostracism."

Kamerstukken II 1990/91, 21 561, nr. 6, p. 2-3. 
op privacy afgeleid kunnen worden uit het recht op gezondheidszorg. Het betreft hier geen absoluut recht. Bij de bepaling of er een positieve verplichting bestaat voor de overheid stelt het Europese Hof stelt zich op het standpunt dat rekening gehouden moet worden met het bereiken van een rechtvaardig evenwicht tussen het algemeen belang van de samenleving en de belangen van het individu, de fair balance test. Lidstaten hebben bij het treffen van matregelen ter bescherming van artikel 8 EVRM in beginsel een zekere beleidsvrijheid. Bovendien kan het kan natuurlijk niet zo zijn dat de overheid op grond van het recht op privacy, en daarvan afgeleid een recht op weten, verplicht zou kunnen worden om alle technische mogelijke en wetenschappelijk verantwoorde erfelijkheidsonderzoeken aan te bieden. Specifieke omstandigheden zouden hier in individuele gevallen wellicht wel toe kunnen leiden. Zoals aangegeven zou dan aangetoond moeten worden dat de informatie van vitaal belang is voor het individu en dat het niet verkrijgen van de informatie een aantasting van het welzijn van het individu oplevert. Dit zou het geval kunnen zijn bij een verhoogd risico op een ernstige ziekte waarbij preventieve maatregelen effect kunnen sorteren wanneer deze tijdig worden getroffen.

Een recht op weten jegens derden zou mogelijkheden bieden om informatie te vergaren betreffende het risico op een aandoening, waarover een bloedverwant reeds beschikt. De rechtspraak betreffende het vergaren en/of vastleggen van informatie biedt voor de erkenning daarvan geen aanknopingspunten. De jurisprudentie inzake het weigeren van inzage in informatie inzake afstammingsgegevens biedt daarentegen meer ruimte. Volgens de Hoge Raad omvat het algemene persoonlijkheidsrecht dat aan grondrechten als het recht op respect voor het privé leven, het recht op vrijheid van gedachte, geweten en godsdienst en het recht op vrijheid van meningsuiting ten grondslag ligt, mede het recht om te weten van welke ouders men afstamt. Het belang dat men heeft bij het kennen van de genetische constitutie lijkt minstens zo groot als kennis omtrent de afstamming. Het lijkt daarom af te leiden uit het genoemde persoonlijkheidsrecht. Ook dit recht is geen absoluut recht. Het zal afgewogen moeten worden tegen de rechten en vrijheden van anderen. De uitkomst van deze afweging zal afhangen van de concrete omstandigheden van het geval. Van belang hierbij zijn het belang dat gediend is met de inbreuk op de privacy, de ernst van de inbreuk op de privacy en het subsidiariteitsbeginsel. Bij het belang dat gediend is met de inbreuk op de privacy zullen mijns inziens met name het risico op een erfelijke aandoening en de mogelijkheid om preventieve maatregelen te nemen een rol spelen.

Ten slotte nog een opmerking over de eventuele toekenning van een recht op weten. Het toekennen daarvan kan worden bemoeilijkt doordat voor het stellen van beperkingen op het recht op privacy noodzakelijk is dat deze krachtens het EVRM bij wet (by law) moeten worden voorzien. Het is alleen aanvaardbaar dat de beperking uit de rechtspraak voortvloeit wanneer die beperking uit de rechtspraak voldoende kenbaar en voorzienbaar is. 46 Wanneer door de rechter in de toekomst een recht op weten erkend zou worden en dit een verplichting legt op een familielid om informatie te onthullen en dus een beperking zou betekenen van zijn recht op 
privacy, zou dit een beperking zijn die niet eerder in de rechtspraak is aangenomen. Daar staat tegenover dat de Hoge Raad in het hierboven besproken arrest inzake de verplichte HIV-test concludeerde dat "die beperking met voldoende scherpte uit die normen is af te leiden". Met die normen bedoelde hij de algemene normen die voortvloeien uit artikel 6:162 BW. Bovendien blijkt uit de jurisprudentie omtrent de horizontale werking van het recht op privacy volgens Verhey dat "uiteenlopende particuliere belangen een inbreuk op de privacy rechtvaardigen. (...) Van geen enkel belang lijkt op voorhand te kunnen worden uitgesloten dat het in bepaalde omstandigheden zwaarder zou kunnen wegen dan het privacybelang". 17

\subsubsection{Een recht op weten jegens degene die ten behoeve van eiser een erfelijkheidsonderzoek} heeft laten verrichten?

Is een recht op weten in de situatie waarin een familielid ten behoeve van een ander familielid een erfelijkheidsonderzoek ondergaat, beter afdwingbaar? Wanneer een individu, op eigen initiatief, dan wel op dat van een bloedverwant, een erfelijkheidsonderzoek laat verrichten uitsluitend ten behoeve van zijn bloedverwant, zou er sprake kunnen zijn van een juridische plicht om dat familielid ook daadwerkelijk te informeren over de uitslag van het onderzoek. Het niet informeren van een familielid, terwijl het onderzoek uitsluitend ten behoeve van dat familielid werd verricht, en het familielid er belang bij heeft en ervan uit mocht gaan dat hij van de uitslag op de hoogte zou worden gesteld, zou als een onrechtmatige daad kunnen worden gezien. De aard en het gewicht van de belangen van het familielid zullen hierbij een belangrijke rol spelen. Onderzoek uitsluitend ten behoeve van een familielid, kan bijvoorbeeld plaatsvinden wanneer een individu een erfelijkheidsonderzoek ondergaat omdat het aantonen van één of meerdere mutaties inzicht geeft in de risico's van het familielid op dezelfde aandoening, terwijl dit onderzoek voor het individu niet bijdraagt aan diens prognose of behandeling. ${ }^{48} \mathrm{De}$ ratio om dergelijk onderzoek te ondergaan is gelegen in het belang van de informatie die voor zijn familielid uit het onderzoek beschikbaar kan komen. Dit brengt de verplichting mee om het familielid in kennis te stellen van de uitkomsten van het onderzoek. De inbreuk op de privacy is hier gering aangezien het onderzock juist ten behoeve van het familielid van de onderzochte is ondergaan. De plicht tot informeren geldt niet voor eventuele onverwachte bevindingen. Het erfelijkheidsonderzoek was hier niet op gericht en op dit punt ook niet ten behoeve van de bloedverwanten verricht. Zij kunnen er daarom niet vanuit gaan dat zij hiervan op de hoogte zullen worden gesteld.

$47 \quad$ Verhey 1992, p. 317.

4 Dit voorbeeld is ontleend aan het rapport DNA-diagnostiek van de Gezondheidsraad. Gezondheidsraad 1998, p. 103. 


\subsection{Een waarschuwingsplicht voor genetici jegens familieleden?}

Hiervoor was de vraag aan de orde of en wanneer er sprake kan zijn van het recht op weten. Hier is de vraag aan de orde of de klinisch geneticus jegens familieleden van de adviesvrager een algemene waarschuwingsplicht, dan wel een waarschuwingsplicht onder specifieke omstandigheden, heeft. Moet een geneticus familieleden van de adviesvrager inlichten wanneer een uitslag van een erfelijkheidsonderzoek tevens informatie met zich meebrengt over de genetische constitutie van familieleden of moet er sprake zijn van consequenties voor hun gezondheid? Jurisprudentie hiervoor ontbreekt vooralsnog. In de erfelijkheidsrichtlijnen wordt hierover het volgende opgemerkt:

"Er zal in het algemeen geen juridische plicht zijn om familieleden te informeren. Wel kan er sprake zijn van een morele verplichting voor de arts." 49

In hun beschouwing omtrent het recht op weten en niet weten stellen Markenstein, Gevers en Roscam Abbing daarentegen het volgende:

"Als het gaat om informatie die zodanig is dat een redelijk mens die per saldo zou
willen ontvangen, zal de hulpverlener voor wel informeren moeten kiezen $(. .$.$) "s0$

Dit zou impliceren dat een klinisch geneticus, wanneer het informatie betreft die een redelijk mens per saldo zou willen weten, een informatieplicht zou hebben jegens familieleden. Ze spreken immers over moeten kiezen voor informeren. Het aannemen van een algemene waarschuwingsplicht, zoals Markenstein, Gevers en Roscam Abbing aannemen, zonder het bestaan van een formele relatie, zou echter tot ongewenste medicalisering leiden.5! Het aannemen van een informatieplicht bij alle informatie die een redelijk denkend mens zou willen weten, zou betekenen dat de klinisch geneticus bij alle informatie die hem bekend is, zich af zal moeten vragen of de familie hiervan op de hoogte gesteld zou willen worden. In hoofdstuk 3 is al aangegeven dat er een groot belang wordt gehecht aan een goede gezondheid en het minimaliseren van risico's. In veel situaties zal de klinisch geneticus, wellicht ook uit angst voor aansprakelijkheid, dan waarschijnlijk tot informeren overgaan. De erfelijkheidsinformatie zou hierdoor feitelijk frmiliebezit worden, waardoor de geheimhoudingsplicht zou worden uitgehold. Een praktisch bezwaar is ten slotte dat de geneticus niet over adressen en telefoonnummers van de familieleden van de adviesvrager zal beschikken.

Leenen stelt dat een plicht voor de klinisch geneticus tot informeren wellicht aanwezig zou kunnen zijn wanneer het om een ernstige behandelbare ziekte gaat en

49 Vereniging voor Gezondheidsrecht 1991, toelichting bij richtlijn A 7.

50 Markenstein, Gevers en Roscam Abbing 1999, p. 48. Gevers drukt zich iets voorzichtiger uit. Hij stelt dat: "als redelijkerwijze moet worden aangenomen dat familieleden - indien voor de keuze gesteld - de betreffende informatie zouden willen ontvangen, is het in beginsel mogelijk dat de arts die dit nalaat, daarvoor tuchtrechtelijk of zelfs civielrechtelijk wordt aangesproken." Gevers 1999, p. 44.

Aldus ook Gevers 1999, p. 45. 
de geneticus weet dat de adviesvrager de familie niet inlicht. Het niet-informeren zou dan kunnen worden aangemerkt als een onrechtmatige daad van de klinisch geneticus ten opzichte van de betreffende familieleden of kunnen leiden tot tuchtrechtelijke aansprakelijkheid. Deze zou afhangen van de omstandigheden, zoals de redenen waarom de adviesvrager zijn familieleden niet inlicht, de aard van de aandoening en behandelbaarheid ervan, het belang van de informatie voor de procreatie en eventuele problemen met keuringen, aldus Leenen. 52 Een andere belangrijke omstandigheid zal het risico zijn dat familieleden lopen dat zij zullen gaan leiden aan de aandoening waarover de klinisch geneticus informatie heeft. Er zijn door de Nederlandse rechter echter nog geen uitspraken hieromtrent gedaan..$^{53}$ Wel heeft de Hoge Raad in 1974 bepaald:

\begin{abstract}
"dat echter van een rechtsplicht om een waargenomen gevaarssituatie voor het ontstaan waarvan men niet verantwoordelijk is, op te heffen of anderen daarvoor te waarschuwen, in het algemeen ook voor volwassenen alleen sprake kan zijn, wanneer de ernst van het gevaar dat die situatie voor anderen meebrengt tot het bewustzijn van de waarnemer is doorgedrongen $(\ldots)^{\prime \prime 54}$
\end{abstract}

In dit arrest is voor het eerst erkend dat er ook van een waarschuwingsplicht sprake kan zijn wanneer gedaagde niet verantwoordelijk is voor het gevaar dat een situatie met zich meebrengt, maar zich daar wel van bewust is. ${ }^{55}$ Het is dus niet ondenkbaar

52 Leenen 2000 , p. 83.

53 Dit in tegenstelling tot de Verenigde Staten, waar sprake is van uitvoerige rechtspraak inzake de waarschuwingsplicht van hulpverleners jegens derden at risk. Leenen $2000, p$. 83. Ratzan heeft de volgende voorwaarden geformuleerd waaraan een unsolicited medical opinion moet voldoen: "(1) physicians assess a high probability of potentially serious disease in a stranger because of information presented to them, either in the form of a communication or physical signs; (2) physicians judge this information to be latent (not readily interpretable as potentially dangerous by the stranger) and likely to remain latent prior to the onset of symptoms; (3) the physicians possess the medical knowledge appropriate to the professional interpretation of this information." Ratzan 1985, p. 147-162.

54 HR 22 november 1974, NJ 1975, 149.

55 De Hoge Raad heeft dit standpunt herhaald. Zie de volgende overweging uit het zogenaamde Veenbroei-arrest: "Degene die de zorg voor een terrein heeft, handelt in strijd met hetgeen volgens het ongeschreven recht in het maatschappelijk verkeer betaamt, wanneer hij, terwijl hij moet verwachten dat het publiek dit terrein zal betreden en weet dat zich op dit terrein een voor het publiek niet steeds waarneembaar gevaar als het onderhavige zich voordoet, dat aan het publiek niet bekend is, niettemin nalaat maatregelen te nemen zoals een ter plaatse kenbaar verbod het terrein te betreden of waarschuwing voor dit gevaar. Zulks wordt niet anders wanneer zich op dit terrein ook andere, wel aan het publiek bekende gevaren voordoen." HR 27 mei 1988, NJ 1989, 29. Deze waarschuwingsplicht, die tot aansprakelijkheid op grond van artikel 6:162 BW kan leiden, brengt Ravenschlag tot de conclusie dat er deswege voor het recht om niet ongevraagd geinformeerd te worden geen plaats is. Deze conclusie lijkt me te algemeen. Alleen in de situaties waarin er sprake is van cen waarschuwingsplicht, kan er geen gebruik gemaakt worden van het recht om niet 
dat de rechter onder omstandigheden een waarschuwingsplicht voor de klinisch geneticus aanneemt die zich bewust was van een gevaarssituatie voor een familielid of familieleden van zijn adviesvrager. Aansprakelijkheid zal afhangen van genoemde omstandigheden. Gevers merkt terecht op dat de rechtsplicht en de morele plicht hier vlak naast elkaar liggen. 56

Wanneer een klinisch geneticus besluit een familielid of meerdere familieleden te informeren kan van hem een zekere inspanning worden verwacht bij het traceren van deze verwanten, zeker wanneer door te informeren aanzienlijke gezondheidsschade kan worden voorkomen. Hij zal privaat- of tuchtrechtelijk echter niet snel aansprakelijk zijn wanneer redelijke inspanningen zijn verricht zonder dat hij erin geslaagd is familieleden te bereiken. Bij de beoordeling van de vraag of de klinisch geneticus redelijke inspanningen heeft verricht zal de verhouding tussen de inspanningen en het belang van de informatie gewogen moeten worden. ${ }^{7}$

Overigens dient de klinisch geneticus zich te realiseren dat familieleden op het moment dat zij geïnformeerd worden door de klinisch geneticus, geen gebruik meer kunnen maken van hun recht op niet weten. Dit brengt met zich mee dat er zorgvuldigheidseisen kunnen worden gesteld aan de wijze waarop familieleden worden benaderd. In hoofdstuk 7 wordt hierop teruggekomen.

\subsection{Samenvatting}

In dit hoofdstuk is het recht op weten aan de orde geweest. Het recht op informatie riep de vraag op of er ook buiten de behandelingsovereenkomst van een dergelijk recht gesproken kan worden. De vraag of er een recht op weten bestaat is nauwelijks voorwerp van onderzoek geweest in de Nederlandse rechtsliteratuur. In dit hoofdstuk is bekeken of, en zo ja, in welke omstandigheden, er sprake kan zijn van een recht om kennis te vergaren betreffende de eigen genetische constitutie. Het betrof daarbij zowel het recht om informatie betreffende de genetische constitutie door middel van het ondergaan van een erfelijkheidsonderzoek te vergaren als het recht op kennisname van reeds bestaande informatie waarover een ander dan de hulpverlener in het kader van de behandelingsovereenkomst beschikt.

Voor wat betreft het recht om informatie betreffende de genetische constitutie door middel van het ondergaan van een erfelijkheidsonderzoek te vergaren, is onderzocht of dit is af te leiden uit het recht op respect voor de persoonlijke levenssfeer. In Nederland wordt de zeggenschap van personen over de eigen gegevens via het privacybegrip niet erkend. Er is geen sprake van een zogenaamd informationeel zelfbeschikkingsrecht. Twee uitspraken van het EHRM lijken daarentegen, via de erkenning van positieve verplichtingen voor de overheid ter bescherming van het

ongevraagd geïformeerd te worden. Ravenschlag 1992, p. 129-133. In het volgende hoofdstuk zal nader op het recht op niet weten worden ingegaan.

56 Gevers 1987, p. 40.

57 Gevers 1987, p. 39. 
recht op privacy, wel een opening te bieden voor de erkenning van een recht om informatie tot stand te doen brengen over de eigen genetische constitutie. In de twee besproken uitspraken leverde een aantasting van het welzijn van het individu een schending van artikel 8 EVRM op. In de genoemde arresten leveren echter bestaande overlast respectievelijk bestaande informatie een schending van artikel 8 EVRM op. De vraag was echter of er een recht is om informatie tot stand te brengen door middel van het afdwingen van de mogelijkheid om een erfelijkheidsonderzoek te ondergaan. Het is niet aannemelijk dat de overheid op grond van het recht op privacy, en daarvan afgeleid een recht op weten, verplicht zou kunnen worden om alle technische mogelijke en wetenschappelijk verantwoorde erfelijkheidsonderzoeken aan te bieden. Specifieke omstandigheden zouden hier in individuele gevallen wellicht wel toe kunnen leiden. In zo'n geval zou aangetoond moeten worden dat de informatie van vitaal belang is voor het individu en dat het niet verkrijgen van de informatie een aantasting van het welzijn van het individu oplevert. Dit zou het geval kunnen zijn bij een verhoogd risico op een ernstige ziekte waarbij preventieve maatregelen effect kunnen sorteren, wanneer deze tijdig worden getroffen.

Om de vraag te beantwoorden of er sprake is van een recht op kennisname van reeds bestaande informatie betreffende de eigen genetische constitutie is gekeken of de jurisprudentie hiervoor aanknopingspunten biedt. De jurisprudentie van de Hoge Raad en het Europese Hof voor de Rechten van de Mens erkent het grote belang van informatie betreffende afstamming, ontwikkeling en de eigen jeugd. Volgens de Hoge Raad omvat het algemene persoonlijkheidsrecht mede het recht om te weten van welke ouders men afstamt. Het belang dat men heeft bij het kennen van de genetische constitutie, althans het kennen van een onderdeel daarvan lijkt een minstens zo vitaal belang. Het maakt mijns inziens, evenals de kennis van wie men afstamt, onderdeel uit van de identiteit. Het recht op kennisname van bestaande informatie betreffende de eigen genetische constitutie zou dan afgeleid kunnen worden uit het algemene persoonlijkheidsrecht dat onder andere ten grondslag ligt aan het recht op een persoonlijke levenssfeer. Dit is geen absoluut recht. Het zal afgewogen moeten worden tegen rechten en vrijheden van anderen. Het zal dus afgewogen moeten worden tegen het recht op een persoonlijke levenssfeer van een bloedverwant die over informatie beschikt die zowel relevant is voor de bloedverwant als voor degene die een recht op die informatie claimt. Deze uitkomst van deze afweging zal afhangen van de concrete omstandigheden van het geval. Van belang hierbij zijn het belang dat gediend is met de inbreuk op de privacy, de ernst van de inbreuk op de privacy en het subsidiariteitsbeginsel. Bij het belang dat gediend is met de inbreuk op de privacy zullen mijns inziens met name het risico op een erfelijke aandoening en de mogelijkheid om preventieve maatregelen te nemen een rol spelen.

Ten slotte is in paragraaf 5.4 de vraag aan de orde geweest of de klinisch geneticus jegens familieleden van de adviesvrager een algemene waarschuwingsplicht, dan wel een waarschuwingsplicht onder specifieke omstandigheden, heeft. Van een algemene waarschuwingsplicht kan niet worden gesproken. Wel is het mogelijk dat onder omstandigheden op de klinisch geneticus een waarschuwingsplicht rust. Er 
bestaat echter (nog) geen jurisprudentie warin van een dergelijke plicht voor een klinisch geneticus is uitgegaan.

Het volgende hoofdstuk richt zich op het recht op niet weten. Dit recht omvat het recht om zelf te bepalen of informatie tot stand wordt gebracht, het recht om geen inlichtingen te ontvangen, alsmede het recht om niet te weten of men een verhoogd risico loopt op een erfelijke aandoening. Dit laatste aspect wordt in hoofdstuk 7 besproken. Hoofdstuk 6 behandelt het eerste en tweede aspect van het recht op niet weten. Tevens zal worden ingegaan op het recht op niet weten van kinderen en ongeborenen. 



\section{ERFELIJKHEIDSADVISERING EN HET RECHT OP NIET WETEN}

\subsection{Inleiding}

In onderhavig hoofdstuk staat het recht op niet weten centraal. Het belang van dit recht lijkt voor de erfelijkheidsadvisering niet snel overschat te kunnen worden. De toenemende mogelijkheden om individuele gezondheidsinformatie te genereren, welke voor een groot deel bestaat uit voorspellingen, vraagt om een sterke bescherming van het recht om niet over deze informatie te beschikken. In paragraaf 6.2 wordt kort ingegaan op het recht op niet weten in het positieve recht. Paragraaf 6.3 handelt over de relatie tussen het recht op niet weten en het zelfbeschikkingsrecht. In de daaropvolgende paragraaf wordt ingegaan op de verschillende aspecten die het recht op niet weten omvat. In paragraaf 6.5 wordt het betoog vervolgens toegespitst op de erfelijkheidsadvisering. Het recht op niet weten van kinderen en ongeborenen is het onderwerp van paragraaf 6.6. In paragraaf 6.7 volgt ten slotte een samenvatting.

\subsection{Het recht op niet weten in het positieve recht}

Het recht op niet weten is een belangrijk recht. Het geeft uitdrukking aan het zelfbeschikkingsrecht van de patiënt. Het recht op informatie houdt niet in dat er een plicht tot het ontvangen van informatie bestaat. Een schending van het recht op niet weten zou bovendien een aantasting van het recht op een persoonlijke levenssfeer tot gevolg hebben. ${ }^{1}$

De Wgbo regelt een aspect van het recht op niet weten in artikel 7:449 BW:

"Indien de patiënt te kennen heeft gegeven geen inlichtingen te willen ontvangen, blijft het verstrekken daarvan achterwege, behoudens voor zover het belang dat de patiënt daarbij heeft niet opweegt tegen het nadeel dat daaruit voor hemzelf of anderen kan voortvloeien."

De Memorie van Toelichting bij artikel 7:449 BW is kort. Het stelt dat de hulpverlener de wens van de patiënt moet respecteren en gaat vervolgens in op de uitzonderingen. Als voorbeeld van een nadeel voor de patiënt en/of anderen, wordt genoemd het geval waarin de ziekte van de patiënt zijn rijvaardigheid beïnvloedt. In dergelijke gevallen dient een afweging te worden gemaakt tussen enerzijds het belang dat de patiënt erbij heeft, niet omtrent zijn ziekte te worden geïnformeerd, en anderzijds het belang, door zodanige informatie dergelijke risico's te verminderen of te voorkomen, aldus de Memorie van Toelichting. Het voordeel van het wel informeren moet substantieel groter zijn dan het nadeel van het niet geinformeerd worden. Bovendien moet er een redelijke mate van zekerheid zijn dat door te informeren het beoogde doel wordt bereikt. Wanneer de hulpverlener inlichtingen

Leenen 2000, p. 196. 
moet verstrekken op grond van een wettelijk voorschrift, blijft een belangenafweging achterwege en moet de patiënt worden ingelicht. ${ }^{2}$

Indien een patiënt te kennen geeft dat hij niet geinformeerd wenst te worden, betekent dit dat hij óok een goede uitslag niet wil horen. Het Medisch Tuchtcollege legde een huisarts een waarschuwing op, nadat deze zijn patiënt, ondanks diens uitdrukkelijk verzoek, toch de uitslag van een HIV-test meedeelde. De huisarts stelde dat hij dacht dat het voor zijn patiënt nog bezwarender zou zijn als hij de uitslag niet wist omdat hij uit zijn stilzwijgen dan mogelijk zou afleiden dat de uitslag niet goed zou zijn. ${ }^{3}$ Indien de hulpverlener hiertoe wel gerechtigd zou zijn, zou het recht uit artikel 7:449 BW versmallen lot het recht om geen inlichtingen te ontvangen wanneer het een 'slechte' uitslag betreft. Dit zou betekenen dat de patiënt indirect altijd op de hoogte is van de uitslag van een onderzoek en dus geen recht op niet weten heeft.

In het Verdrag inzake Mensenrechten en Biogeneeskunde wordt het recht op niet weten in artikel 10 aan de orde gesteld:

"Everyone has the right to respect for private life in relation to information about his or her health.

Everyone is entitled to know any information collected about his or her health. However, the wishes of individuals not to be so informed shall be observed.

In exceptional cases, restrictions may be placed by law on the exercise of the rights contained in paragraph 2 in the interest of the patient."

In uitzonderlijke gevallen mogen dus beperkingen in het belang van de patiënt aan zijn recht op niet weten worden gesteld. Naast deze specifieke beperkingsmogelijkheid kunnen op grond van artikel 26 lid 1 van het Verdrag inzake Mensenrechten en Biogeneeskunde algemene beperkingen worden gesteld wanneer zij bij wet zijn bepaald en in een democratische samenleving noodzakelijk zijn voor een van de volgende legitieme doeleinden: de openbare veiligheid; het voorkomen van een misdrijf; de bescherming van de volksgezondheid of de bescherming van de rechten en vrijheden van anderen.

Een verschil met artikel 7:449 BW is dat het achterwege blijven van het verstrekken van inlichtingen wanneer het belang dat de patiënt daarbij heeft niet opweegt tegen het nadeel dat daaruit voor anderen kan voortvloeien, niet wordt genoemd als uitzonderingsgrond.

De Wgbo regelt in artikel 7:449 BW het recht om tot stand gekomen inlichtingen niet te ontvangen. Het recht om geen informatie tot stand te brengen, wordt gewaarborgd door artikel 7:450 lid $1 \mathrm{BW}$, waar is geregeld dat voor verrichtingen ter uitvoering van de behandelingsovereenkomst de toestemming van de patiënt vereist is.

Kamerstukke'l II 1989/90, 21 561, nr. 3.

MT Amsterdam 14 september 1987, TvGr 1988, 25 en 26. 
Opvallend is dat in de literatuur het recht op niet weten eenzijdig benaderd wordt. Vaak wordt slechts één aspect van het recht aan de orde gesteld, t' te weten het recht om geen kennis te nemen van informatie waar de hulpverlener kennis van heeft genomen. 5 Het recht op niet weten houdt echter tevens in dat men het recht heeft om zelf te bepalen of bepaalde informatie überhaupt tot stand komt. Het recht om van reeds bestaande informatie verschoond te blijven is een logisch gevolg van het algemene recht om informatie niet tot stand te doen komen. Alvorens de omvang van dit recht en de betekenis ervan voor de erfelijkheidsadvisering nader te onderzoeken, komt eerst de vraag aan bod of een recht op niet weten wel af te leiden is uit het zelfbeschikkingsrecht. In hoofdstuk 3 is immers gesteld dat dit rechtsbeginsel ten grondslag ligt aan het recht op niet weten.

\subsection{Het recht op niet weten en zelfbeschikking}

Het recht op niet weten heeft iets paradoxaals. Het nemen van een beslissing zonder alle voor die beslissing relevante informatie maakt beslissingen minder rationeel. $6 \mathrm{Zc}$ zijn dan niel gebaseerd op alle informatie die voor een beslissing relevant is en dat belemmert het nemen van een weloverwogen besluit. Moet men om gebruik te kumen maken van het zelfbeschikkingsrecht niet weten waar men over beschikt?

Over deze vraag is door Ost en Strasser een discussie gevoerd. ${ }^{7}$ Centraal stond de grondslag van the right not to know . In de medische ethiek is de gangbare opvatting dat het recht op niet weten voortvloeit uit het recht op informatie, aldus Ost. Hij zegt hierover het volgende:

"The suggestion seems to be that, inasmuch as the right to be informed flows from the individual's status as an autonomous moral agent, so, too, does a right not to be informed. Since the health professional is obliged, in virtue of the 'contractual relationship' between them, to respect the patient's autonomy, pressing unwanted information upon that patient constitutes a prima facie violation of that patient's autonomy."s

Om na te kunnen gaan of de autonomie van de patiënt wordt geschonden wanneer hij tegen zijn wil wordt geinformeerd, onderzoekt Ost het autonomieconcept.

"In purely formal terms autonomy is that quality of entities which establishes them as p'rsons (...), i.e., bearers of rights and duties."

4 Gevers vormt hierop een uitzondering.

5 Dit geldt eveneens voor het proefschrift van Ravenschlag. Volgens Ravenschlag impliceert het recht op niet weten het de wederpartij ontslaan van de plicht tot informeren.

- Gevers 1989, p. 17-24.

$7 \quad$ Ost 1984, p. 301-312 en Strasser 1986, p. 265-278.

s Ost 1984, p. 302. 
Individuen moeten dus autonoom zijn om drager van rechten en plichten te kunnen zijn. Een essentieel onderdeel van autonomie is rationaliteit. Ost haalt hiervoor de opvattingen van Immanuel Kant en Thomas van Aquino aan. Over het recht op weten stelt hij vervolgens:

"If we can show that refusal of information is irrational, we will have shown that there is no such right. For if such refusal is irrational, and irrationality is an autonomydefeating condition, and autonomy is the basis of rights, then to refuse information is ipso facto to claim that one is not autonomous, i.e., not a bearer of rights."

\section{De brugloper}

Om dit aan te tonen neemt Ost de 'brugloper' van Mill als voorbeeld. Stel dat we een man zien die op het punt staat om een brug over te lopen, waarvan we weten dat deze brug zo gevaarlijk is, dat het leven van die man in gevaar is, wanneer hij erover loopt. In de visie van Mill mogen we deze man waarschuwen. We mogen hem echter niet tegenhouden wanneer hij toch besluit de brug over te lopen, omdat niemand anders dan de man zelf kan bepalen of hij een goed motief heeft om een risico te nemen. Volgens Ost is deze waarschuwing gerechtvaardigd omdat de waarschuwer informatie bezit die relevant is voor een rationele inschatting van het besluit om wel of niet over de brug te lopen. Relevante informatie is volgens Ost informatie die noodzakelijk is voor een rationele afweging. Welke informatie dit in concrete situaties is, hangt af van de 'redelijke persoon' standaard. Dit begrip licht Ost verder niet toe. Wanneer de brugloper de waarschuwer laat weten dat hij de informatie niet wil horen omdat geen enkele informatie relevant kan zijn voor zijn beslissing om de brug over te lopen, dan kan deze verklaring twee redenen hebben, die beide irrationeel zijn, aldus Ost. Enerzijds kunnen de intenties van de brugloper dermate gefixeerd en onveranderbaar zijn dat eigenlijk geen enkele informatie relevant voor hem kan zijn. Indien echter geen enkele informatie relevant kan zijn, dan is zijn beslissing niet gebaseerd op rationele gronden en derhalve irrationeel. Anderzijds kan de brugloper beweren dat hij reeds weet wat hij niet weten kan, namelijk de relevantie van de informatie voor zijn beslissing al dan niet over de brug te lopen, en ook dat is irrationeel. Het autonomiebeginsel kan derhalve nooit de grondslag vormen voor het recht op niet weten, aldus Ost. ${ }^{9}$

Strasser reageert hierop door te stellen dat het ten eerste onjuist is om bij de beoordeling van de vraag wat relevante informatie is, de standaard van de redelijke persoon te hanteren. We kunnen volgens hem niet stellen dat omdat een redelijk persoon gewaarschuwd wil worden wanneer hij een brug overloopt die in elkaar kan storten, de brugloper uit het voorbeeld ook gewaarschuwd wil worden.

"There might be a variety of reasons why a rational person would claim that she was willing to take a risk and not listen to certain information, especially if that information might be incorrect or if the alternative (in this case, the bridgecrossing) would no longer be viable were she to wait to hear the information. The would-be bridge-crosser

$9 \quad$ Ost bestrijdt overigens niet dat hulpverleners nooit gehoor moeten geven aan de wens van een patiënt om niet geïformeerd te worden. $\mathrm{Hij}$ bestrijdt wel dat het autonomiebeginsel de grondslag is van het recht op niet weten. 
is not claiming that she knows that the information will not be useful; rather, she is claiming that she cannot afford to take the risk that it will not be. As long as the wouldbe bridge-crosser is not exhibiting signs of mental disorder, we would not be justified in stopping her and imparting the information. Thus, the person who says, "I don't want you to tell me anything. I've already made my decision. Nothing you could say would change my mind, not even that I certainly die if I attempt to cross the bridge", may not be acting irrationaly at all. While it is true that she may be making the wrong decision, that is the risk she is taking. We are not in the position of (justifiably) overriding that decision."10

Volgens Strasser zijn we zelf degenen die op grond van onze eigen prioriteiten bepalen welke afwegingen we maken. Het niet geïnformeerd willen worden kan in bepaalde gevallen zelfs de beste manier zijn om onze autonomie te beschermen. Bijvoorbeeld wanneer onze capaciteit om beslissingen te nemen niet kan worden beïnloed door bepaalde angstaanjagende informatie, aldus Strasser."

\section{Het recht op niet weten is niet in tegensprank met het zelfoeschikkingsrecht}

Wanneer men naar de argumentaties van beide auteurs kijkt, dan blijkt dat Ost hogere eisen aan het autonomiebegrip stelt. Volgens Ost is een keuze eerst dan een autonome keuze wanneer deze rationeel is in de ogen van anderen. Indien redelijke personen bepaalde informatie wel zouden willen ontvangen, dan is een beroep op het recht op niet weten irrationeel. Strasser gaat er, net als Mill vanuit dat alleen degene die beslist bepaalde informatie niet te willen ontvangen, kan bepalen of deze beslissing gebaseerd is op alle voor hem relevante informatie. ${ }^{12}$ Strasser benadrukt derhalve terecht dat de beslissing om een risico te nemen, ook als dit erg hoog is, een weloverwogen besluit kan zijn, dat respect verdient, ook al zal een 'redelijk persoon' tot een ander besluit komen. Het is daarom de taak van het recht om waar mogelijk ruimte en mogelijkheden te bieden voor de uitoefening van het recht op niet weten. Het maken van keuzes die afwijken van de gangbare waarden en normen dient gerespecteerd te worden. Wanneer een adviesvrager wilsbekwaam is en dus als een autonoom handelend persoon beschouwd kan worden, moet zijn beslissing om gebruik te maken van het recht op niet weten, gerespecteerd worden. Hij kiest er blijkbaar voor bepaalde informatie niet te ontvangen, ondanks het feit dat dit

\section{Strasser 1986, p. 269-270.}

11 Ost reageert vervolgens op Strasser door te stellen dat het zeker mogelijk is dat de brugloper alle potentiële risico's heeft ingeschat en dat de keuze van de brugloper een autonome keuze is. Vanuit het perspectief van de waarschuwer blijft het echter irrationeel om de brug over te lopen. Omdat er wel situaties kunnen zijn waarin de keus om geen informatie te willen ontvangen een autonome keuze is stelt Ost: "I hold that they constitute conditions under which one would reasonably be excused from one's obligation to know." Ost 1986, p. 279-284.

12 Volgens Ravenschlag interpreteert Ost autonomie in antropologische zin, als een typische menselijke bestaanswijze, een vermogen en interpreteert Strasser autonomie in maatschappelijke zin, als een recht. Naar haar mening kan de grondslag van het recht op weten niet worden gevonden in het zelfbeschikkingsrecht, maar in het (ethische) principe van niet-schaden. In dit hoofdstuk wordt er wel van uitgegaan dat het zelfbeschikkingsrecht als rechtsbeginsel, alsmede het recht op respect voor de persoonlijke levenssfeer ten grondslag liggen aan het recht op niet weten. 
betekent dat beslissingen die genomen moeten worden gebaseerd zullen zijn op onvolledige informatie. Zo kan een persoon die een risico heeft van $50 \%$ op de ziekte van Huntington besluiten dat hij niet wil weten of hij gendrager is of niet. Dit geldt ook wanneer hij reeds onderzoek heeft laten verrichten naar de genmutatie, maar besluit de uitslag niet te willen weten. Beslissingen van deze persoon zullen gebaseerd zijn op onwetendheid betreffende het al dan niet drager zijn van de genmutatie die zal leiden tot Huntington. Daar kan die persoon goede argumenten voor hebben. Het zelf besluiten om niet te willen weten of zich een ziekte zal openbaren, is vanuit dit perspectief juist een autonome keuze. Het recht op niet weten is dus niet in tegenspraak met het uitgangspunt dat adviesvragers op grond van hun zelfbeschikkingsrecht er recht op hebben om tot weloverwogen keuzes te kunnen komen. Het vloeit er juist logisch uit voort.

\subsection{Het recht op niet weten}

In de inleiding is opgemerkt dat de Wgbo slechts een aspect van het recht op niet weten regelt. Indien het recht op niet weten meer omvat is vervolgens de vraag wat dan de omvang is van het recht. Alvorens deze vraag te beantwoorden zal eerst aandacht worden besteed aan de plaatsbepaling van dit recht.

Het recht op niet weten wordt door het recht op respect voor de persoonlijke levenssfeer beschermd

Het recht op niet weten als het recht om zelf te bepalen of informatie tot stand wordt gebracht is als zodanig niet gepositiveerd. Voor een plaatsbepaling dient, evenals bij het recht op weten, aansluiting gezocht te worden bij het recht op bescherming van de persoonlijke levenssfeer. ${ }^{13}$ De vrijwaring van niet gewenste kennis over gezondheidsrisico's noemt Gevers zelfs een kernelement van het recht op privacy. ${ }^{14}$ Ook auteurs die het recht op niet weten alleen bespreken als een beperking van de informatieplicht van de hulpverlener, refereren aan het recht op een persoonlijke levenssfeer. ${ }^{15}$

De aansluiting bij het recht op privacy is om de volgende redenen juist. Zoals in hoofdstuk 5 aan de orde is geweest omvat het recht op eerbiediging van de persoonlijke levenssfeer zowel de fysieke ruimte als de intimiteit van personen. In de klassieke betekenis is het een defensief concept; het biedt een waarborg tegen het optreden van de staat in het door het grondrecht beschermde gebied. Het recht om niet te hoeven weten sluit hierbij goed aan. De bescherming van de intimiteit van de persoon omvat die aspecten die zozeer met de eigen individualiteit te maken hebben, dat men geen inmenging behoeft te gedogen. ${ }^{16}$ De Gezondheidsraad stelt:

13 Gevers 1996, p. 10 en Leenen 2000, p. 77-78.

14 Gevers 1996, p. 11.

15 Sutorius 1993, p. 168-169 en Gezondheidsraad 1989, p. 98.

16 Gevers 1996, p. 11. 
"Iedereen heeft verder de vrijheid zijn leven naar eigen inzicht in te richten, een vrijheid die wordt beschermd door het grondrecht op eerbiediging van de persoonlijke levenssfeer." 17

Het recht op niet weten wordt dus door het recht op respect voor de persoonlijke levenssfeer beschermd. Informatie betreffende de eigen gezondheid, en zeker informatie betreffende de genetische constitutie, betreft zozeer de intimiteit en individualiteit van de persoon, dat deze er enerzijds recht op heeft om deze informatie niet tot stand te laten komen en anderzijds het recht heeft om deze informatie niet te ontvangen. Bovendien is de privacybescherming gericht is op de ontplooiing van het individu. ${ }^{18}$ De mogelijkheden voor een persoon om zich te ontplooien en ontwikkelen en zijn leven naar eigen inzicht vorm te geven, zouden worden gefrustreerd wanneer het individu niet gevrijwaard kan worden van ongewenste kennis betreffende zijn eigen gezondheid.

\section{Het recht op niet weten bestant uit twee elementen}

Aan het begin van deze paragraaf is opgemerkt dat artikel 7:449 BW één aspect regelt van het recht op niet weten. Welk aspect of aspecten omvat dit recht dan verder? Leenen onderscheidt bij erfelijkheidsadvisering twee elementen aan het recht op niet weten. Ten eerste het recht dat men zelf kan beslissen over het wel of niet ondergaan van genetisch onderzoek. En ten tweede het recht om desgewenst niet te worden geinformeerd over de uitkomst. ${ }^{19}$ Dit bevat ook het recht om over een gedeelte van de uitkomst niet te worden geïnformeerd. Los van de erfelijkheidsadvisering kan men spreken van een recht om zelf te bepalen of informatie betreffende de gezondheid tot stand wordt gebracht en de mogelijkheid om desgewenst van beschikbare informatie verschoond te blijven. ${ }^{20}$ Het tweede aspect vloeit voort uit het eerste. Het besluit om een erfelijkheidsonderzoek te ondergaan omvat niet de plicht voor de adviesvrager om na afloop daarvan te worden geïnformeerd over de uitkomst.

Beide elementen van het recht op niet weten zullen in de volgende paragraaf nader besproken worden. Daarbij wordt er vanuit gegaan dat het recht op niet weten een belangrijk element van het recht op eerbiediging van de persoonlijke levenssfeer is, en dat het een recht betreft dat met name bij voorspellend onderzoek, gezien de grote gevolgen die informatie over de toekomstige gezondheid kan hebben, in het geding zal zijn.

\section{Het recht om niet te weten dat men een verhoogd risico loopt op een erfelijke aandoening}

Het recht om van bepaalde informatie verschoond te blijven impliceert tevens het recht om niet te weten dat men een verhoogd risico loopt op een erfelijke aandoening. Dit aspect is moeilijk te beschermen. Wanneer een familielid van een adviesvrager benaderd wordt met de vraag of hij wil weten of hij drager is van een

\footnotetext{
17 Gezondheidsraad 1989, p. 98.

18 Nabben en Van de Luytgaarden 1996, p. 22.

19 Leenen 2000, p. 77-78.

20 Gevers 1996, p. 9.
} 
bepaalde mutatie of een verhoogd risico daarop heeft, is het voor hem niet mogelijk om te antwoorden dat hij überhaupt niet wil weten dat hij een verhoogd risico heeft op een erfelijke aandoening. Alleen de weigering om verdere informatie te krijgen, waardoor het a priori risico kan worden gewijzigd, is hier nog mogelijk. Om het familielid de keuze te laten tussen meer weten en niet meer willen weten, is de totale onwetendheid opgeofferd. Dit aspect van het recht op niet weten wordt in het volgende hoofdstuk verder uitgewerkt.

\subsection{Het recht op niet weten en erfelijkheidsadvisering}

Er zijn dus twee aspecten te onderscheiden aan het recht op niet weten. Beide aspecten zullen hier aan de orde komen. Eerst zal het recht om informatic betreffende de gezondheid niet tot stand te doen komen worden besproken. Vervolgens zal het recht om geen bestaande inlichtingen te ontvangen worden besproken.

\subsubsection{Het recht on informatie betreffende de gezondheid niet tot stand te doen komen}

Het recht om informatie betreffende de gezondheid niet tot stand te doen komen wordt allereerst beschermd door het feit dat niemand in Nederland verplicht is een erfelijkheidsonderzoek te ondergaan. ${ }^{21}$ In het kader van de behandelingsovereenkomst wordt dit recht beschermd door het toestemmingsvereiste. Dit is een belangrijke waarborg voor het recht om geen informatie betreffende de gezondheid tot stand te doen brengen. Zonder de geinformeerde toestemming van de adviesvrager komt er geen ongewenste informatie tot stand. De adviesvrager maakt zelf, na het ontvangen van de vóórinformatie van de klinisch geneticus, de afweging of hij door middel van een erfelijkheidsonderzoek informatie tot stand wil doen laten komen. Dit benadrukt wederom het belang van een juiste invulling van de informatieplicht door de klinisch geneticus en dan met name het feit dat wordt stilgestaan bij de vraag of en waarom de adviesvrager het erfelijkheidsonderzoek wil ondergaan, zodat de adviesvrager een voor hem juiste keuze maakt die gebaseerd is op alle voor hem relevante informatie. De invulling van de informatieplicht door de klinisch geneticus is besproken in hoofdstuk 4 .

Nys benadrukt dat het recht op niet weten pas werkelijk betekenis krijgt wanneer het wordt geinterpreteerd als het recht om zelf te bepalen of informatie tot stand wordt gebracht: "Het valt niet goed in te zien hoe men betere garanties zou kunnen hebben om gevrijwaard te blijven van bepaalde informatie dan door zelf te kunnen bepalen of de informatie überhaupt gegenereerd mag worden door al dan niet toe te stemmen in een medisch onderzoek." Nys 2002, p. 263-277. 
Eén van de uitgangspunten van de erfelijkheidsrichtijnen luidt:

"Ieder heeft het recht zelf te beslissen of hij erfelijkheidsonderzoek ondergaat." 22

Dit recht kan gezien worden als een uitdrukking van zowel het zelfbeschikkingsrecht als het recht op privacy. In hoofdstuk 3 werd opgemerkt dat het bij uitstek de taak van het recht is om zoveel mogelijk ruimte en mogelijkheden te bieden voor de uitoefening van het zelfbeschikkingsrecht. Het besluit om al dan niet een erfelijkheidsonderzoek te ondergaan is zo'n mogelijkheid. Er is geen sprake van gedwongen erfelijkheidsonderzoek. Er kan zich wel een aantal situaties voordoen waarin de adviesvrager een zekere drang voelt om een onderzoek te ondergaan. Kenmerk van erfelijkheidsonderzoek is dat er structureel belangen van derden, zoals bloedverwanten, kinderen en partners, aanwezig kunnen zijn. Een gevaar hiervan is dat het erfelijkheidsonderzoek mede of uitsluitend in het belang van die derden wordt ondergaan. Daamaast kan sociale druk er mede toe leiden dat een adviesvrager een erfelijkheidsonderzoek laat verrichten. ${ }^{23}{ }^{24}$ In beide situaties kan het recht om in vrijheid te beslissen tot het ondergaan van een erfelijkheidsonderzoek worden bedreigd. Deze mogelijke bedreiging leidt tot de vraag of er aanleiding is voor additionele rechtswaarborgen met betrekking tot het recht om in vrijheid tot het ondergaan van een erfelijkheidsonderzoek te beslissen. Wanneer de beslissingsvrijheid onder druk komt te staan, is sprake van een beperking van de mogelijkheden tot zelfbeschikking. Meer nog dan het recht op lichamelijke integriteit is hier bovendien ook het recht op privacy in het geding. ${ }^{25}$

Is er annleiding voor additionele rechtswarborgen?

Het is een gegeven dat de instemming met een erfelijkheidsonderzoek wellicht niet altijd als een vrije toestemming beschouwd zou kunnen worden. De hierbij in het geding zijnde waarden en beginselen verdienen om die reden juridische bescherming. De beperkingen hiervan zijn gelegen in de juridische vormgeving hiervan. Het goed hulpverlenerschap van de klinisch geneticus brengt met zich mee dat hij probeert na te gaan of de adviesvrager uit vrije wil een erfelijkheidsonderzoek wil laten verrichten. Indien blijkt dat hij het onderzoek uitsluitend in het belang van anderen ondergaat, is het van belang dat de geneticus vaststelt dat de adviesvrager zich dit realiseert. Markenstein, Gevers en Roscam Abbing opperen dat ter bescherming van de rechtspositie van het individu overwogen zou kunnen worden

\footnotetext{
22 Vereniging voor Gezondheidsrecht 1991, uitgangspunt 3.1.

23 Markenstein, Gevers en Roscam Abbing 1999, p. 31. Zie ook Roscam Abbing 1986, hoofdstuk 8 . $\mathrm{Zij}$ wijst op de bedreiging van het zelfbeschikkingsrecht door overheidsbeïnvloeding en maatschappelijke druk.

2i Ook negatieve gevolgen bij ziektekostenverzekeringen, door middel van minder gunstige polisvoorwaarden bij het niet laten verrichten van een erfelijkheidsonderzoek, zouden kunnen leiden tot drang om een erfelijkheidsonderzoek te ondergaan. Sutorius 1993 , p. 184. Sutorius bespreekt dit voorbeeld in verband met bevolkingsonderzoek. De huidige ziektekostenwetgeving laat de mogelijkheid een erfelijkheidsonderzoek van aspirant-verzekerde te eisen noch indirecte beïnvloeding door middel van premiedifferentiatie echter niet toe. Gevers 1996, p. 72. Gevers 1996, hoofdstuk 7.
} 
om tot een verbod te komen op de uitvoering van vroegopsporingsonderzoek, en dus ook van voorspellend erfelijkheidsonderzoek, uitsluitend in het belang van anderen. Een uitzondering op dat verbod zou toelaatbaar zijn indien er sprake is van een zwaarwegend belang van een derde. Hierbij kan gedacht worden aan een levensbedreigende aandoening, risico op aanzienlijke gezondheidsschade of de mogelijkheid van aanzienlijke gezondheidswinst wanneer de aandoening of het risico daarop wordt vastgesteld. Vooralsnog zijn er volgens de auteurs geen signalen dat een dergelijke wettelijke bescherming geboden is. Mocht echter in de toekomst blijken dat de vrijheid van individuen ten aanzien van het beslissen over wel of niet weten, en dus over het al dan niet ondergaan van erfelijkheidsonderzoek, in het gedrang komt, dan zou deze bescherming volgens de genoemde auteurs een te overwegen optie zijn. ${ }^{26}$

Deze optie is mijns inziens niet te overwegen. Een verbod op de uitvoering van erfelijkheidsonderzoek dat uitsluitend in het belang van anderen wordt ondergaan, zou het individuen, waarvan de beslissingsvrijheid niet in het gedrang komt, onmogelijk maken om weloverwogen dergelijk onderzoek te laten verrichten, wanneer niet voldaan zou zijn aan het uitzonderingsvereiste van een zwaarwegend belang. Het waar mogelijk voorkomen van situaties waarin het individu een zekere dwang voelt om een erfelijkheidsonderzoek te ondergaan, moet wel een continue streven zijn van met name de beroepsgroep, maar zeker ook van de samenleving, met handhaving van het uitgangspunt dat ieder het recht heeft om zelf te beslissen of hij erfelijkheidsonderzoek voor zichzelf en/of voor anderen ondergaat.

\section{Geen verplicht erfelijkheidsonderzoek in het belang van familieleden}

Het besluit om geen erfelijkheidsonderzoek te laten verrichten kan het belang dat een familielid bij die informatie heeft, schenden. In het vorige hoofdstuk is geconcludeerd dat een recht op weten jegens derden mogelijkheden zou bieden om informatie te vergaren betreffende het risico op een aandoening, waarover een bloedverwant reeds beschikt. In de jurisprudentie omtrent het weigeren van inzage in informatie inzake afstammingsgegevens werden hiervoor enige aanknopingspunten gevonden. Daar het geen absoluut recht kan betreffen zal het afgewogen moeten worden tegen de rechten en vrijheden van anderen. Van belang hierbij zijn het belang van de inbreuk op de privacy, de ernst van de inbreuk op de privacy en het subsidiariteitsbeginsel. Het belang dat een familielid heeft bij de kennisname van de informatie die door middel van een erfelijkheidsonderzoek wordt gegenereerd, kan er echter nooit toe leiden dat een individu wordt verplicht tot het ondergaan van een erfelijkheidsonderzoek. Bij onvrijwillig erfelijkheidsonderzoek, is sprake van een ernstige inbreuk op het recht op privacy van het individu, gezien het feit dat hier een belangrijk element van het grondrecht in geding is, alsmede in de meeste gevallen een inbreuk op de lichamelijke integriteit. Zeker wanneer er een alternatief is in de vorm van andere familieleden die wel willen meewerken aan een erfelijkheidsonderzoek, zal het vereiste van subsidiariteit in de weg staan aan een geoorloofde wettelijke uitzondering op genoemde 
grondrechten. ${ }^{27}$ In de literatuur betreffende preventie wordt ten aanzien van dwang een terughoudend standpunt verdedigd. Zo wordt algemeen aangenomen dat alleen het toebrengen van ernstige schade aan de gezondheid van anderen dwang in de preventieve sfeer kan rechtvaardigen. ${ }^{28}$ Kortom: van gedwongen erfelijkheidsonderzoek kan geen sprake zijn. Een ieder heeft het recht om zelf te beslissen of hij erfelijkheidsonderzoek ondergaat.

\subsubsection{Het recht om bestaande informatie over de gezondheid niet te ontvangen} In de erfelijkheidsrichtlijnen is als uitgangspunt geformuleerd:

"Ieder heeft het recht zelf te beslissen of hij over de uitkomsten van ondergaan erfelijkheidsonderzoek geïnformeerd wil worden."

Dit is nader uitgewerkt in de volgende twee richtlijnen:

"De arts vraagt de cliënt of hij volledig geinformeerd wil worden over de resultaten van het erfelijkheidsonderzoek, ook over eventuele onverwachte bevindingen.

De arts beperkt het erfelijkheidsonderzoek tot onderzoek waarvoor de cliënt toestemming heeft gegeven. Nadat het erfelijkheidsonderzoek is verricht informeert de arts de cliënt over de resultaten ervan, voor zover deze heeft aangegeven inderdaad geïnformecrd te willen worden. De arts informeert de cliënt alleen tegen diens wil, als het belang van de cliënt bij niet-weten niet opweegt tegen het nadeel dat daaruit voor hemzelf of anderen kan voortvloeien."

Ook de Universal Declaration on the Human Genome and Human Rights regelt het recht om de uitslag van erfelijkheidsonderzoek niet te ontvangen:

"The right of each individual to decide whether or not to be informed of the results of genetic examination and the resulting consequences should be respected." 29

Voor wat betreft het tijdstip in de erfelijkheidsadvisering waarop het recht op niet weten wordt besproken zeggen de richtlijnen voor erfelijkheidsonderzoek:

"Het moment waarop toestemming voor het onderzoek wordt gegeven is tevens een geschikt moment om te bespreken hoe de cliënt van zijn recht op wel/niet weten gebruik wil maken. Overigens kan deze hier later altijd op terugkomen." ${ }^{\prime \prime 0}$

Moet de adviesvrager op zijn recht om geen inlichtingen te ontvangen worden gewezen? Heeft de klinisch geneticus ook de plicht om de adviesvrager op zijn recht op niet weten te wijzen? Uit het recht op niet weten volgt niet automatisch de plicht voor de geneticus hierop te wijzen. Bij diagnostisch erfelijkheidsonderzoek komt een adviesvrager met een klacht in de hoop dat de klinisch geneticus een diagnose kan

$27 \quad$ Markenstein, Gevers en Roscam Abbing 1999, p. 35. Zie ook Gevers 1996, p. 68.

28 Nationale Raad voor de Volksgezondheid 1994, p. 16. Zie ook Dute 1994, p. 151.

29 Artikel 5c, Universal Declaration on the Human Genome and Human Rights.

Vereniging voor Gezondheidsrecht 1991, toelichting bij richtlijn A 3. 
stellen. Bij dergelijk onderzoek ligt het, evenzo als in vele andere patiënthulpverlener relaties, minder voor de hand om de adviesvrager erop te wijzen dat hij ook het recht heeft om informatie niet te ontvangen. Een plicht om in elke behandelingsovereenkomst hierop te wijzen, is daarom niet aanwezig. Het goed hulpverlenerschap vereist wel dat hier in het geval van voorspellend onderzoek op wordt gewezen en dat wordt besproken of de adviesvrager volledig geinformeerd wil worden over de resultaten. Bij voorspellend onderzoek betreft de uitslag het risico op een aandoening in de (nabije) toekomst bij de adviesvrager of een bloedverwant. Het feit dat dergelijk onderzoek om gezondheidsredenen uitgesteld kan worden, alsmede de mogelijke gevolgen ervan voor zowel de adviesvrager als familieleden, maken dat de klinisch geneticus als goed hulpverlener erop dient te wijzen dat de adviesvrager niet verplicht is om het erfelijkheidsonderzoek te ondergaan en ook niet verplicht is de informatie die wit het onderzoek komt te ontvangen.

\section{Redenen on geen inlichtingen te willen ontvangen}

De Gezondheidsraad noemt twee redenen die een adviesvrager kan hebben om geen inlichtingen te ontvangen. Ten eerste kan kennis omtrent zijn toekomstige gezondheidstoestand zéér bedreigend zijn voor de adviesvrager. Dit geldt zeker wanneer er geen preventieve en/of therapeutische mogelijkheden zijn. ${ }^{31}$ Zo heeft onderzoek onder personen die drager zijn van de mutatie die de ziekte van Huntington veroorzaakt, aangetoond aan dat deze groep "disturbed functioning, depression, suicidal behavior, or all of these" vertoonde. ${ }^{32}$

Een tweede reden die de Raad noemt is de weerslag van erfelijke gegevens op de kansen voor het vinden van werk en de mogelijk nadelige invloed op het pensioen en het aangaan van verzekeringen. ${ }^{33}$ Hier ligt een belangrijke taak voor de klinisch geneticus, te weten het informeren over de mogelijke gevolgen van tot stand gekomen informatie naar aanleiding van een erfelijkheidsonderzoek, zodat het besluit tot het al dan niet ondergaan van het onderzoek, gebaseerd is op juiste informatie.

De informatie die voorafgaand aan een erfelijkheidsonderzoek wordt gegeven is uitvoerig. Met de adviesvrager worden de mogelijke uitkomsten en consequenties daarvan doorgesproken. Bovendien is er bij presymptomatisch erfelijkheidsonderzoek in principe psychosociale begeleiding van de adviesvrager. Tijdens de fase waarin de vóórinformatie wordt verstrekt wordt de adviesvrager ruim de tijd geboden om vrijwillig een weloverwogen besluit te nemen omtrent het al dan niet ondergaan van een erfelijkheidsonderzoek. Wanneer het besluit weloverwogen genomen wordt, mag men verwachten dat de adviesvrager na het onderzoek niet snel op zijn besluit om de uitslag te vernemen terugkomt. Bij onverwachte bevindingen is er sprake van een andere situatie.

\footnotetext{
31 Gezondheidsraad 1989, p. 98.

32 Tibben e.a. 1997, p. 20-35.

33 Gezondheidsraad 1989, p. 98.
} 


\section{Onveruachte bevindingen}

In het geval van onverwachte bevindingen, kan men niet spreken van een weloverwogen besluit om deze te vernemen, in die zin dat niet van tevoren alle mogelijke onverwachte bevindingen zijn doorgenomen. In de aanbeveling van de Raad van Europa "on genetic lesting and screening for health-care purposes" zijn richtlijnen te vinden met betrekking tot het al dan niet meedelen van onverwachte bevindingen. Principle 11 stelt hieromtrent:

"In conformity with national legislation, unexpected findings may be communicated to the person tested only if they are of direct clinical importance to the person or the family." 3

De aanbeveling van de Raad van Europa inzake "the protection of medical data" geeft een aantal situaties aan waarin de mededeling van onverwachte bevindingen gerechtvaardigd kan zijn. ${ }^{35}$ Ten eerste wanneer de adviesvrager om mededeling van dergelijke informatie heeft verzocht. Ten tweede de situatie waarin van informeren geen serieuze schade is te verwachten voor de adviesvrager of diens bloedverwanten. Ten slotte de situatie warin de informatie van belang is voor behandeling of preventie van de adviesvrager.

Het recht op niet weten prevaleert hier boven het recht op informatie, in die zin dat voor het verstrekken van bijkomende bevindingen een bijzondere rechtvaardiging is vereist. Het recht op niet weten is hier het uitgangspunt. In hoofdstuk 5 is beschreven dat het recht op weten is af te leiden uit het recht op privacy. Het uitgangspunt dat onverwachte bevindingen niet worden meegedeeld schendt het recht op respect voor de persoonlijke levenssfeer. Het staat echter wel op gespannen voet met het zelfbeschikkingsrecht en hetzelfde recht op respect voor de persoonlijke levenssfeer dat garandeert dat elk individu zijn leven naar eigen inzicht kan invullen en inrichten. Het naar eigen inzicht inrichten van het leven kan betekenen dat men niet op de hoogte wil worden gesteld van bevindingen waar niet om gevraagd is. Anderzijds kan het niet meedelen van deze bevindingen inhouden dat het individu zijn leven niet naar eigen inzicht kan inrichten omdat hij niet beschikt over alle beschikbare informatie. ${ }^{36}$ Gezien het feit dat erfelijkheidsonderzoek altijd onverwachte bevindingen met zich mee kan brengen, moet hierop gewezen worden alvorens de adviesvrager een erfelijkheidsonderzoek ondergaat. ${ }^{37}$ Naar de aard van de bevindingen kan uiteraard nooit aangegeven worden, wat deze bevindingen inhouden. Wel moet zo veel mogelijk duidelijk worden gemaakt aan de adviesvrager wat hij zich erbij moet voorstellen. Het vernemen van onverwachte bevindingen is niet het beoogde doel van het onderzoek. Wanneer hier duidelijk op wordt gewezen en mogelijke onverwachte bevindingen worden doorgenomen met de adviesvrager kan hij met dit mogelijk gevolg van erfelijkheidsonderzoek rekening houden. Indien het erfelijkheidsonderzoek vervolgens een onverwachte bevinding met zich

34 Raad van Europa 1992, principle 11.

35 Raad van Europa 1997.

30 Zie ook Markenstein, Gevers en Roscam Abbing 1999, p. 44.

37 Zie ook hoofdstuk 4. 
meebrengt en de adviesvrager van tevoren heeft aangegeven hiervan op de hoogte te willen worden gesteld, vereist de zorgvuldigheid dat wordt meegedeeld dat er een onverwachte bevinding is gedaan en nogmaals wordt gevraagd of de adviesvrager hierover geinformeerd wil worden. Deze benadering doet het meeste recht aan het zelfbeschikkingsrecht en het recht om het privé-leven naar eigen inzicht in te richten en geeft de adviesvrager zowel voor als na het erfelijkheidsonderzoek de mogelijkheid een keuze tussen wel en niet weten te maken.

Het uitgangspunt hoort te zijn dat indien de adviesvrager dit aangeeft de bijkomende bevindingen worden meegedeeld, tenzij er voor de klinisch geneticus aanleiding is om van de therapeutische exceptie gebruik te maken. De wet laat hier mijns inziens geen ruimte voor een andere interpretatie. Het recht op informatie is samen met het toestemmingsvereiste het uitgangspunt van de hulpverleningsrelatie, waarvan alleen afgeweken mag worden indien het verstrekken van de informatie kennelijk ernstig nadeel oplevert. ${ }^{38}$ Wanneer de adviesvrager aangeeft geïnformeerd te willen worden is er daarom, in tegenstelling tot wat Markenstein e.a. betogen, ${ }^{39}$ geen aanleiding voor een nadere afweging van de klinisch geneticus of er wel voldoende rechtvaardiging aanwezig is voor het meedelen van de informatie.

Geen inlichtingen voorafgaand aan een erfelijkheidsonderzock willen ontvangen

Het recht op informatie houdt geen plicht in deze informatie ook te ontvangen. Vandaar dat de wetgever in artikel 7:449 BW heeft geregeld dat de patiënt niet verplicht is om inlichtingen te ontvangen. Er is daarbij geen onderscheid gemaakt tussen de soort inlichtingen. Een adviesvrager kan dus besluiten dat hij de uitslag van een erfelijkheidsonderzoek niet wil weten. Hij kan echter ook besluiten dat hij voorafgaand aan het erfelijkheidsonderzoek geen inlichtingen wil ontvangen en alleen het onderzoek wil ondergaan en daarvan de uitslag vernemen, tenzij dit voor hem of anderen kennelijk ernstig nadeel zou opleveren.

Artikel 12 van het Verdrag inzake Mensenrechten en Biogeneeskunde stelt met betrekking tot voorspellend onderzoek echter het volgende:

"Tests which are predictive of genetic diseases or which serve either to identify the subject as a carrier of a gene responsible for a disease or to detect a genetic predisposition or susceptibility to a disease may be performed only for health purposes or for scientific research linked to health purposes, and subject to appropriate genetic counselling."

"Appropriate genetic counselling" is hier een voorwaarde voor voorspellend onderzoek. De Gezondheidsraad stelt hierover dat ervan uit mag worden gegaan "dat de adviesvrager in elk geval die inlichtingen wenst te ontvangen, die nodig zijn voor een weloverwogen beslissing". ${ }^{0}$ Sutorius merkt op dat er geredelijk vanuit mag

Een andere uitzondering, die overigens voor de erfelijkheidsadvisering niet relevant is, is wanneer in het kader van een therapie een placebo wordt gebruikt. Leenen 2000, p. 197.

39 Markenstein, Gevers en Roscam Abbing 1999, p. 44.

40 Gezondheidsraad 1989, p. 98. 
worden gegaan dat de patiënt in ieder geval die inlichtingen wenst te ontvangen die nodig zijn voor het nemen van een weloverwogen beslissing. ${ }^{41}$

Wanneer een adviesvrager besluit voorafgaand aan een erfelijkheidsonderzoek geen inlichtingen te willen ontvangen, betekent dit dat hij geen weloverwogen beslissing heeft genomen in die zin dat hij niet alle inlichtingen heeft ontvangen die hem in staat stellen een weloverwogen geinformeerde beslissing te nemen. Ondanks het feit dat ervan uit mag worden gegaan 'dat de adviesvrager in ieder geval die inlichtingen wenst te ontvangen die nodig zijn voor het maken van een weloverwogen beslissing' is er geen juridische eis dat de adviesvrager die informatie ook ontvangt. De klinisch geneticus kan zich hier wel op het standpunt stellen dat het verrichten van een erfelijkheidsonderzoek zonder het verstrekken van de vóórinformatie strijdig is met de zorg van een goed hulpverlener. Deze norm onderstreept de normen en ervaringen van de beroepsgroep alsmede de eigen professionele verantwoordelijkheid van de klinisch geneticus. De norm van artikel 7:453 BW houdt volgens de regering verband met alle normen met betrekking tot behoorlijke hulpverlening. 22 De beroepsgroep zal hier met betrekking tot de verschillende soorten erfelijkheidsonderzoek moeten bepalen of het onderzoek ook zonder de vóórinformatie verricht kan worden, met ruimte voor de omstandigheden van elke afzonderlijke situatie. Criteria die hierbij gehanteerd kunnen worden zijn de vérstrekkendheid van de mogelijke consequenties van het onderzoek en de kennis hieromtrent bij de adviesvrager. Hiermee kan een 'u vraagt, wij draaien beleid' worden voorkomen. Toch bestaat er hier een zekere spanning met artikel 7:449 BW. De hulpverlener mag niet besluiten om op grond van de opvattingen binnen zijn beroepsgroep, bepaalde patiëntenrechten uit de Wgbo te negeren. ${ }^{43}$ Van de Wgbobepalingen kan niet ten nadele van de patiënt worden afgeweken. Evenmin zal in elke situatie gesteld kunnen worden dat het niet ontvangen van de vóórinformatie kennelijk ernstig nadeel voor de adviesvrager zal opleveren. Toch behoort de invulling van het goed hulpverlenerschap door de beroepsgroep mijns inziens hier de beslissende stem te hebben. Het recht om geen inlichtingen te ontvangen is een belangrijk recht dat een onderdeel is van het recht op weten en is afgeleid van het recht op privacy. Artikel 7:449 BW ziet, blijkens de uitleg uit de Memorie van Toelichting, echter op het besluit om bepaalde inlichtingen na een medisch onderzoek of een behandeling, niet te willen ontvangen. Bovendien zou het verrichte erfelijkheidonderzoek zonder rechtsgeldige toestemming zijn verricht wanneer deze niet voorafgegaan zou zijn door adequate informatie.

\section{De klinisch geneticus mag naar de reden om geen inlichtingen te willen ontvangen vragen}

Moet het besluit van een adviesvrager om gebruik te maken van zijn recht op niet weten een weloverwogen autonome beslissing zijn? Indien een adviesvrager te kennen geeft dat hij terugkomt op zijn besluit om de uitslag van het reeds ondergane erfelijkheidsonderzoek te vernemen, mag de klinisch geneticus naar de motivatie van de adviesvrager vragen? De wet stelt geen eisen wanneer de adviesvrager besluit

\footnotetext{
$41 \quad$ Sutorius 1993, p. 169.

42 Kamerstukken II 1990/91, 21 561, nr. 6, p. 60.

43 Legemaate 1995, p. 15.
} 
gebruik te maken van zijn recht op niet weten. Aan de informatieplicht uit artikel 7:448 lid 1 en 2 wordt echter de eis gesteld dat de hulpverlener zich ervan gewist dat de patiënt de informatie begrepen heeft. ${ }^{44}$ Het proces van de erfelijkheidsadvisering is erop gericht de adviesvrager in staat te stellen de voor hem juiste keuze te maken, gebaseerd op alle relevante informatie, morele gezichtspunten en inzicht in de mogelijke gevolgen. In dat licht bezien getuigt het van goed hulpverlenerschap indien de klinisch geneticus de adviesvrager naar zijn redenen vraagt wanneer hij onverwacht mededeelt dat hij de uitslag niet wil horen. Op die manier kan de geneticus zich ervan vergewissen dat ook de keuze om de uitslag niet te willen horen een weloverwogen keuze is die op de juiste informatie gebaseerd is. Het is mogelijk dat de adviesvrager de verstrekte informatie verkeerd begrepen heeft en op grond daarvan heeft besloten de uitslag niet te willen horen, terwijl hij deze wel had willen weten wanneer hij van de juiste informatie was uitgegaan. Dit kan echter nooit tot een verplichte verantwoording leiden. Indien de adviesvrager zijn keuze niet wenst toe te lichten, zal de klinisch geneticus deze moeten respecteren.

\section{Een adviesurager mag zich altijd bedenken}

De adviesvrager behoort altijd het recht te behouden om terug te komen op zijn besluit om niet geïnformeerd te willen worden. Indien de klinisch geneticus de uitslag van het erfelijkheidsonderzoek reeds tot zijn beschikking heeft, kunnen de geneticus en de adviesvrager afspreken dat de uitslag in (bijvoorbeeld een gesloten envelop) het dossier wordt opgeborgen. Zij kunnen er ook voor kiezen deze te vernietigen. Indien de adviesvrager in dat geval terug komt op zijn besluit, zal hij opnieuw een erfelijkheidsonderzoek moeten ondergaan. Wanneer het laboratorium de uitslag van het erfelijkheidsonderzoek nog niet heeft, wordt het onderzoek stopgezet. Ook dan zal de adviesvrager een nieuw onderzoek moeten laten verrichten als hij wel geïnformeerd wil worden. De Guidelines for the molecular genetics predictive test in Huntington's disease bevelen het volgende aan:

"The laboratory performing the test should not communicate the final results to the counselling team until very close to the time the results are given to the participant. ${ }^{\prime \prime 5}$

\subsubsection{Uitzonderingen}

Wat zijn de uitzonderingen voor de adviesvrager op zijn recht om tot stand gebrachte inlichtingen niet te ontvangen? Wanneer weegt het belang dat de adviesvrager daarbij heeft niet op tegen het nadeel dat daaruit voor hemzelf of anderen kan voortvloeien?

Het recht om geen inlichtingen te ontvangen heeft bij de erfelijkheidsadvisering speciaal gewicht. Met name bij voorspellend onderzoek kan het niet geïnformeerd worden voor de adviesvrager van groot belang zijn in verband met de invulling en perceptie van zijn leven.6 In haar beleidsnota De toepassing van de genetica in de

4 Zie hoofdstuk 4, paragraaf 4.2 .

45 International Huntington Association en the World Federation of Neurology Research Group on Huntington's Chorea 1994, p. 555-559, Recommendation 4.1.

46

Leenen 2000, p. 80. 
gezondheidszorg stelt de minister dat $z$ ij in principe positief staat tegenover de opvatting uit de literatuur ${ }^{-17}$ om de in de afweging van belangen vervatte discretionaire bevoegdheid van de hulpverlener te interpreteren als kennelijk crnstig nadeel. Zij voegt hieraan toe dat indien dat de algemene rechtsopvatting is in het veld en deze ook strikt wordt toegepast, het niet nodig is de wettekst van artikel 7:449 BW te preciseren. 48

\section{Nadeel voor verwanten}

Wanneer is er sprake van kennelijk ernstig nadeel? Bij erfelijkheidsadvisering zijn met name de volgende situaties denkbaar:

Ten eerste de situatie waarin de adviesvrager vérgaande maatregelen en handelingen overweegt te treffen c.q. verrichten, uitgaande van de onterechte veronderstelling dat hij in de toekomst zal gaan lijden aan een ernstige erfelijke ziekte. Hiervan kan bijvoorbeeld sprake zijn wanneer een adviesvrager depressief is en suïcidale gedachten heeft en de uitslag van het onderzoek niet wil horen uit vrees voor het slechte nieuws. Het belang van de adviesvrager, namelijk het niet hoeven aanhoren van een mogelijk slechte uitslag weegt dan niet op tegen het nadeel, bestaande uit een depressie en suïcidale gedachten. Het voordeel van het inlichten lijkt dan substantieel groter te zijn dan het nadeel van het niet geïnformeerd worden. Dit mag niet te snel worden aangenomen. Ten eerste moet worden aangenomen, gezien de uitgebreide informatieplicht van de klinisch gencticus, dat het besluit om geen inlichtingen te ontvangen, een weloverwogen genomen besluit is. De adviesvrager weet, in het geval van voorspellend erfelijkheidsonderzoek, hoe groot de kans is dat hij geen drager is. Ten tweede blijkt uit onderzoek naar adviesvragers die zich hebben laten testen op het dragen van de mutatie die leidt tot de ziekte van Huntington, dat een substantieel aantal adviesvragers dat hoort dat hij geen drager is van de mutatie niet opgelucht is, maar gevoelens tonen van somberheid, teleurstelling en verwarring, voortkomend uit wat een overlevingsschuld wordt genoemd. 49

Leenen noemt als mogelijke uitzondering het voorbeeld waarin bij ontdekking van een ernstige doch behandelbare ziekte een klinisch geneticus zich wellicht gedrongen voelt om de adviesvrager toch te informeren.50 Het feit alleen dat een ziekte

Sutorius 1993, p. 169. Zie ook Gezondheidsraad 1989, p. 99. De Raad spreekt over noodgevallen: het is alleen gerechtvaardigd wanneer de klinisch geneticus na rijp beraad concludeert dat hij bepaalde familieleden hoe dan ook moet informeren, zelfs als dat zou betekenen dat ook de adviesvrager tegen diens wil zou worden ingelicht. In dat geval zou de klinisch geneticus zich op het conflict van plichten moeten beroepen (zie hierover het volgende hoofdstuk). Gevers merkt hierover terecht op dat er geen wettelijke uitzondering op het recht op niet weten nodig is, wanneer hierop alleen in noodgevallen een beroep kan worden gedaan. In voorkomende gevallen zou kunnen worden volstaan met een beroep op het conflict van plichten. Gevers 1996, p. 21. Ministerie van Volksgezondheid, Welzijn en Sport 2000, p. 36. gepubliceerd: Tibben e.a. 1990, p. 335-553. Zie ook Hugginns e.a. 1992, p. 508-515. 
behandelbaar is, lijkt mij niet genoeg reden om een uitzondering op artikel 7:449 BW te rechtvaardigen. De adviesvrager is voorafgaand aan het onderzoek hierover uitgebreid geinformeerd en aangenomen mag worden dat de adviesvrager met deze mogelijkheid rekening heeft gehouden en de mogelijke consequenties van zijn keuze overziet. ${ }^{11}$ Dit geldt ook voor zijn tweede voorbeeld, namelijk de situatie waarin de gevolgen voor het nageslacht van iemand in de procreatieve leeftijd zodanig ernstig zijn dat de klinisch geneticus zich verplicht zou voelen de adviesvrager tegen zijn wens te informeren. ${ }^{2}$ Ook hier mag worden aangenomen dat de adviesvrager hier rekening mee houdt en de mogelijke consequenties overziet. Dit wordt in beide voorbeelden anders wanneer het onverwachte bevindingen betreft en de adviesvrager de mogelijke consequenties niet heeft (kunnen) overzien. De klinisch geneticus moet er wel van overtuigd zijn dat het voordeel van het informeren voor de adviesvrager substantieel groter is dan het nadeel van het niet geinformeerd worden.

Ten tweede de situatie waarin de adviesvrager heeft aangegeven niet te willen worden ingelicht over onverwachte bevindingen, maar op grond van zijn persoonlijke omstandigheden aangenomen mag worden dat hij over de onverwachte bevinding wel geïnormeerd wil worden. Wanneer een adviesvrager te kennen heeft gegeven dat hij niet over onverwachte bevindingen wil worden geïnformeerd, dient ook dit gerespecteerd te worden. Indien echter de adviesvrager te kennen geeft dat hij een kinderwens heeft en uit onderzoek blijkt mede dat hij onvruchtbaar is, dan mag de geneticus veronderstellen dat hij deze informatie wel wil horen. Zonder deze wetenschap zouden de adviesvrager en zijn partner, wanneer een zwangerschap uitblijft, waarschijnlijk verschillende medische onderzoeken ondergaan om de oorzaak vast te stellen van het uitblijven van de zwangerschap. Bij zijn wens om niet geïnformeerd te worden over onverwachte bevindingen, heeft de adviesvrager bij deze mogelijkheid wellicht niet stil gestaan. Het niet inlichten van de adviesvrager omtrent zijn onvruchtbaarheid zou in dit voorbeeld een schending van artikel 7:453 BW (het goed hulpverlenerschap) betekenen.

Hierboven werden uitzonderingssituaties besproken waarin de adviesvrager nadat hij een erfelijkheidsonderzoek heeft ondergaan aangeeft dat hij geen inlichtingen wil ontvangen. Indien een adviesvrager voorafgaand aan het erfelijkheidsonderzoek dat hij niet voor anderen ondergaat te kennen geeft geen informatie te willen ontvangen, is er geen aanleiding dit onderzoek te laten verrichten. ${ }^{53}$ Een dergelijk verzoek is zo onlogisch dat het mijns inziens niet voor zal komen. De klinisch geneticus is op grond van zijn professionele standaard in zo'n situatie niet verplicht hieraan zijn medewerking te verlenen. De situatie wordt anders wanneer de adviesvrager het

51 Zie ook Gevers 1996, p. 21. Hij merkt op dat er gewaakt moet worden voor te veel paternalisme. Zie ook Sutorius 1993, p. 168. "Allereerst is het de vraag of ook het nadeel dat de patiënt zelf kan betreffen, en dat hij, gë̈nformeerd door zijn arts, reeds in zijn besluitvorming heeft betrokken hier nog deel van de uitzonderingsgrond mag vormen. Doctor knows best?"

52 Leenen 2000 , p. 80-81.

53 Roscam Abbing 1995, p. 33. 
erfelijkheidsonderzoek wil ondergaan voor één of meerdere bloedverwanten. ${ }^{54}$ Dit kan bijvoorbeeld het geval zijn wanneer de adviesvrager aan een ziekte lijdt of heeft geleden en gevraagd wordt een erfelijkheidsonderzoek te ondergaan om vast te kunnen stellen of de ziekte waaraan de adviesvrager lijdt of heeft geleden erfelijk is of was. Indien de adviesvrager hier, in het belang van het familielid dat hem heeft gevraagd het onderzoek te ondergaan, gehoor aan geeft, maar daarbij aangeeft zelf niet te willen weten of het onderzoek een mutatie heeft aangetoond die erop wijst dat hij aan een erfelijke ziekte lijdt of heeft geleden, is er geen reden waarom hij zijn recht om geen inlichtingen te ontvangen in deze situatie niet zou kunnen laten gelden, tenzij het achterwege laten van de inlichtingen kennelijk ernstig nadeel oplevert voor de adviesvrager of voor anderen. .55

Sutorius wijst erop dat de geneticus voor grote problemen kan komen te staan bij de behandeling van een adviesvrager die gebruik heeft gemaakt van zijn recht op niet weten, wanneer hijzelf wel, maar de adviesvrager niet op de hoogte is van medische informatie die relevant kan zijn voor latere behandelingsbeslissingen en voegt hier aan toe dat dit in het kader van de hulpverleningsrelatie een zwaarwegend argument is. ${ }^{56}$ Dit probleem zal juist bij de erfelijkheidsadvisering niet snel aan de orde zijn. Een klinisch geneticus is geen behandelend arts. Het proces van de erfelijkheidsadvisering eindigt na het verrichten van een diagnostisch of voorspellend erfelijkheidsonderzoek en het verstrekken van de uitkomsten daarvan, of indien hiertoe niet wordt overgegaan, na het voeren van één of enkele gesprekken.

Ten slotte de situatie waarin het recht op niet weten van de adviesvrager botst met het recht op weten van één of meerdere verwanten en de klinisch geneticus zich verplicht voelt om één of meerdere verwanten in te lichten omtrent hun risico's op een erfelijke aandoening. In het volgende hoofdstuk, alwaar de geheimhoudingsplicht van de klinisch geneticus aan de orde is, zal hierop in worden gegaan. Hierbij zal ook het derde aspect van het recht op niet weten van verwanten aan de orde komen, te weten het recht om niet te weten dat er een verhoogd risico op een erfelijke aandoening bestaat.

\subsection{Het recht op niet weten van kinderen en ongeborenen}

Het onderhavige onderzoek richt zich op wilsbekwame volwassenen. Toch zal in deze paragraaf aandacht worden besteed aan het recht op niet weten van kinderen en ongeborenen. De reden hiervoor is dat dit recht kan botsen met het recht op informatie van de (aanstaande) ouders. In deze paragraaf is het recht op niet weten als het recht om geen informatie tot stand te doen komen aan de orde. Van dit recht

54 Zie ook Markenstein, Gevers en Roscam Abbing 1999, p. 41. Zij stippen deze mogelijkheid alleen aan en stellen dat wanneer het onderzoek met het oog op de belangen van anderen wordt uitgevoerd er in principe meer ruimte is voor het maken van afspraken over het niet vememen van de uitkomsten.

55 Zie ook Markenstein, Gevers en Roscam Abbing 1999, p. 43-44.

56 Sutorius 1993, p. 168-169. 
zullen jonge kinderen en ongeborenen nog geen gebruik kunnen maken. Het is echter een recht dat door de beroepsgroep in het algemeen, en in een individuele behandelingsrelatie door de klinisch geneticus, afgewogen dient te worden tegen het recht op informatie van de ouders. Hieronder zal eerst aandacht worden besteed aan het recht op niet weten van kinderen. Vervolgens zal het recht op niet weten van het toekomstige kind worden besproken. Eerst volgt echter nog een opmerking over de aard van het recht op niet weten bij kinderen en ongeborenen.

\title{
Rights-in-trust
}

Het recht op niet weten kumnen kinderen niet uitoefenen op het moment dat het in het geding is. De filosoof Feinberg heeft deze rechten daarom aangeduid als rights-intrust. Feinberg zegt hierover:

\begin{abstract}
"except that the child cannot very well exercise his free choice until later when he is more fully formed and capable. When sophisticated autonomy rights are attributed to children who are clearly not yet capable of exercising them, their names refer to rights that are to be saved for the child until he is an adult, but which can be violated "in advance," so to speak, before the child is even in a position to exercise them. The violating conduct guarantees now that when the child is an autonomous adult, certain key options will already be closed to him. His right while he is still a child is to have these future options kept open until he is a fully formed self-determining adult capable of deciding among them." 57
\end{abstract}

Deze rights-in-trust kunnen volgens Feinberg worden samengebald tot één recht, genaamd the right to an open future. ${ }^{58} \mathrm{Ze}$ anticiperen op het zelfbeschikkingsrecht als eigenschap waaraan het kind of de ongeborene vanaf zestien jaar (zie hierna) door middel van zijn eigen weloverwogen besluit tot het ondergaan van erfelijkheidsonderzoek na het ontvangen en in overweging nemen van alle relevante informatie en morele gezichtpunten, uiting kan geven. De dubbele toestemmingseis (zie hierna), die geldt bij kinderen tussen de 12 en 16 jaar, maakt dat zij ook op die leeftijd reeds hun recht op niet weten kunnen laten gelden. De Wert noemt deze rights-in-trust een aan kinderen toekomend anticiperend autonomie recht. ${ }^{59}$ Zo bezien is er bij voorspellend erfelijkheidsonderzoek naar erfelijke aandoeningen die zich pas op de volwassen leeftijd kunnen openbaren, geen grond om dergelijk onderzoek te verrichten, tenzij preventieve maatregelen in de kinderleeftijd de prognose gunstig zouden kunnen beinvloeden. Deze uitzondering is in het belang van het kind.

\section{Beschermwardige belangen}

Voor wat betreft ongeborenen geldt hetzelfde. Zij kunnen evenmin gebruik maken van een recht op niet weten, wanneer het in het geding is. De menselijke vrucht is bovendien, in tegenstelling tot kinderen, nog geen drager van rechten en plichten. Wel kan men spreken over beschermwaardige belangen. Botkin spreekt wanneer hij het heeft over fetal privacy and confidentiality daarom niet over fetal rights, maar over

is Door De Wert is vervolgens gewezen op de relevantie van de theorie van Feinberg voor het debat over het recht op niet weten van kinderen. De Wert 1999, p. 282-283. 
applicable principles. Volgens de auteur moet sommige informatie de ongeborene betreffend als privé en vertrouwelijk worden beschouwd:

"(...) there must be a concern for the basic integrity of the individual. In this case, it is the individual that the fetus will become. (...) It is appropriate to consider some information about the fetus as private and confidential."60

Gevers formuleert het als volgt:

“(...), dat de (beperkte) rechtsbescherming die de vrucht wordt toegekend, naast de fysieke integriteit mede betrekking heeft op de persoonlijke levenssfeer, en dat ook aan dit recht een zekere reflex-werking toekomt voor de geboorte."6!

Uit het feit dat in de praktijk een belangrijke rol wordt toegekend aan de verwachte ernst van de aandoening waarnaar prenataal onderzoek wordt verricht, en bijvoorbeeld geen prenataal onderzoek wordt verricht naar multifactoriële aandoeningen, 62 blijkt bovendien dat het doel van prenataal onderzoek niet alleen bestaat uit het informeren van de ouders. In dat geval zijn immers geen andere grenzen te stellen dan welke voortvloeien uit de afweging tussen het risico van het onderzoek en het nut van de verkregen informatie.63 Dit vraagt om een erkenning van de belangen van de ongeborene. Deze dienen te worden afgewogen tegen die van de ouders. Een ongeborene heeft er belang bij dat er wordt geanticipeerd op het zelfbeschikkingsrecht als eigenschap dat hem toekomt wanneer hij geboren wordt en vervolgens de leeftijd van 16 jaar bereikt. Bij de bespreking van het recht op niet weten van de ongeborene zal blijken dat dit belang in bepaalde situaties prevaleert boven het recht op informatie van de aanstaande ouders.

Wanneer in het vervolg van deze paragraaf wordt gesproken over het recht op niet weten van het kind dient hierbij bedacht te worden dat het een recht is dat het kind op dat moment niet kan uitoefenen. Indien over een recht op niet weten van de ongeborene wordt gesproken, wordt daarmee op een te beschermen belang gedoeld.

\subsubsection{Het recht op niet weten van kinderen}

Voor verrichtingen ter uitvoering van een behandelingsovereenkomst is de toestemming van de patiënt vereist, aldus artikel 7:450 lid 2 BW. In artikel 7:465 lid 1 BW wordt echter geregeld dat de verrichtingen die voor de hulpverlener uit de Wgbo jegens de patiënt voortvloeien, indien de patiënt de leeftijd van twaalf jaren nog niet heeft bereikt, door de hulpverlener worden nagekomen jegens de ouders die het gezag over de patiënt uitoefenen, dan wel jegens zijn voogd. Artikel 7:465 lid 5 BW stelt dat de ouders daarbij de zorg van goede vertegenwoordigers hebben te

$\begin{array}{ll}60 & \text { Botkin 1995, p. 32-39. } \\ 61 & \text { Gevers 1996, p. 27. } \\ 62 & \text { Zie hoofdstuk 4. } \\ 63 & \text { Gevers 1996, p. 26. }\end{array}$


betrachten en gehouden zijn het kind zo veel mogelijk bij de vervulling van hun taak te betrekken. De hulpverlener hoeft zijn verplichtingen jegens de ouders of de voogd volgens artikel 7:465 lid $4 \mathrm{BW}$, niet na te komen wanneer deze nakoming niet verenigbaar is met de zorg van een goed hulpverlener.

Voor kinderen van 12 tot 16 jaar geldt dat tevens de toestemming van de ouders die het gezag uitoefenen of van de voogd is vereist. De verrichting waarvoor zowel van het kind als van de ouders toestemming moet worden verkregen, kan evenwel zonder de toestemming van de ouders of de voogd worden uitgevoerd, indien zij kennelijk nodig is teneinde ernstig nadeel voor het kind te voorkomen, alsmede indien het kind ook na de weigering van de toestemming, de verrichting weloverwogen blijft wensen. Indien een kind, ouder dan 12 jaar, maar jonger dan 16 jaar, niet in staat kan worden geacht tot een redelijke waardering van zijn belangen ter zake, worden de verplichtingen die de hulpverlener heeft jegens het kind nagekomen jegens zijn ouders of voogd.

Kinderen van 16 jaar en ouder zijn volgens de Wgbo bekwaam tot het aangaan van een behandelingsovereenkomst en zijn dus ook degenen die toestemming geven voor de in het kader van de behandelingsovereenkomst uit te voeren verrichtingen. Daarom wordt er in deze paragraaf met de term kind, een kind tot 16 jaar bedoeld. Wanneer in deze paragraaf over ouders gesproken wordt, worden hiermee de wettelijke vertegenwoordigers van het kind bedoeld, zijnde de ouders die het gezag over het kind uitoefenen of de voogd die belast is met het gezag over het kind.

Indien ouders van een kind dat jonger is dan twaalf jaar een erfelijkheidsonderzoek bij hun kind willen laten verrichten, dienen zij hiervoor toestemming te geven. Op de klinisch geneticus rust volgens artikel 448 lid 1, laatste volzin BW, echter wel de plicht om het kind in te lichten op zodanige wijze als past bij zijn bevattingsvermogen. Deze plicht is bij amendement aan artikel 7:448 lid 1 BW toegevoegd omdat de vrees bestond dat het kind in het geheel niet zou worden geïnformeerd door hulpverleners. ${ }^{6+}$ De toelichting op het amendement luidde:

"Niet valt in te zien waarom een minderjarige jonger dan 12 geen wettelijk recht op informatie krijgt. Naast de noodzaak van een recht op informatie als voorwaarde voor het kunnen geven van toestemming, bestaat er ook nog een recht op informatie los van deze toestemmingseis. Het geven van informatie kan meerdere doelen dienen." 65

Bij kinderen tussen de 12 en 16 jaar geldt de dubbele toestemmingseis. De Memorie van Toelichting zegt hierover:

"Het vereiste is gebaseerd op de aard van de behandelingsovereenkomst, terwijl een medische verrichting waartoe zonder de toestemming van de patiënt zou worden overgegaan, een niet toelaatbare inbreuk op diens persoonlijkheidsrechten zou betekenen."66

64 Sluijters 1999 , p. 416.

65 Kamerstukken II 1993/94, 21 561, nr. 22.

6o Kamerstukken II 1989/90, 21 561, nr. 3, p. 20. 
Bij de beslissing om al dan niet genetisch onderzoek te laten verrichten bij hun kind zullen de ouders zich moeten laten leiden door het belang van hun kind. De eis dat ouders als goede vertegenwoordigers moeten handelen, eist van hun zijde een weloverwogen en zorgvuldige besluitvorming waarbij de belangen van het kind gewogen worden. ${ }^{67}$ De belangen van het kind dienen het uitgangspunt te zijn bij het nemen van de beslissing of er een erfelijkheidsonderzoek zal worden verricht. In de richtlijnen van de Vereniging voor Gezondheidsrecht wordt hierover opgemerkt:

\begin{abstract}
"Voor ouders die kiezen voor erfelijkheidsonderzoek bij hun (ongeboren of jonge) kind zal het recht op niet-weten van het kind een extra punt van overweging kunnen vormen. Het gaat dan immers om een beslissing die voor het kind (later) vergaande gevolgen kan hebben."
\end{abstract}

Bij dit uitgangspunt zijn de volgende kanttekeningen te plaatsen. Ten eerste wordt er geen onderscheid gemaakt tussen kinderen en ongeborenen, terwijl dit onderscheid wel relevant is en consequenties heeft. Wanneer ouders een erfelijkheidsonderzoek willen laten verrichten bij hun kind, is het kind echter de adviesvrager en dienen de ouders als goede vertegenwoordigers te handelen. Indien er een erfelijkheidsonderzoek bij het ongeboren kind wordt verricht, zijn de ouders de adviesvragers. Bovendien is een kind, in tegenstelling tot het ongeboren kind, een rechtssubject en deswege drager van rechten en plichten. De consequenties die uit de status van de ongeborene voortvloeien komen in de volgende paragraaf aan bod. Op deze plaats zal het betoog zich op het recht op niet weten van kinderen toespitsen.

Een tweede kanttekening is dat in de richtlijnen het belang van het kind bij het recht op niet weten wel erkend wordt, maar dat het slechts als een extra punt van overweging kan worden gezien. Bij voorspellend erfelijkheidsonderzoek is het altijd het belang van de ouders en het kind bij weten dat moet worden afgewogen tegen het belang van het kind bij niet weten. Daarbij is het dus niet een extra punt van overweging, maar het punt van overweging. ${ }^{68} \mathrm{Het}$ is een overweging die ouders als goede vertegenwoordigers dienen te maken, waarbij het belang van het kind voorop staat. Het belang van het kind kan strijdig zijn met het belang van de ouders. In dat geval kunnen ze hun rol als goede vertegenwoordigers niet goed vervullen.

Ten slotte bevat dit uitgangspunt geen handelingsaanwijzing voor de klinisch geneticus. ${ }^{69}$ Gezien het feit dat het goed hulpverlenerschap ook de verantwoordelijkheid voor de bescherming van het kind bevat, was het duidelijker geweest wanneer op deze eigen verantwoordelijkheid van de klinisch geneticus om de belangen van het kind te beschermen was gewezen. Dan was daar tevens impliciet uit gebleken dat de klinisch geneticus een verzoek van ouders om een erfelijkheidsonderzoek bij hun kind te verrichten, kan weigeren wanneer zij door

67 Gevers 1996, p. 32.

68 De Wert hierover: "Bovendien dient uitdrukkelijk te worden aangegeven dat het belang van het kind een punt van overweging moet vormen, en dat dit onder omstandigheden reden is (moet zijn) om toepassing van de test te weigeren, ook al vragen ouders daar om." De Wert 1999, p. 284.

69 De Wert 1999, p. 284. 
tegenstrijdige belangen hun rol als goede vertegenwoordigers niet kunnen vervullen en het belang van kind niet gediend is door het verrichten van een erfelijkheidsonderzoek.

\section{Belang eigen verantwoordelijkheid}

Het belang van de eigen verantwoordelijkheid van de klinisch geneticus blijkt onder meer uit het feit dat ouders geneigd zijn vooral de voordelen van een gunstige uitslag voor ogen te hebben wanneer zij verzoeken om een erfelijkheidsonderzoek bij hun kind:

"In requesting testing, parents usually" envisage the benefits of a negative test result: reduction in anxiety for themselves and the child and ability to make firm plans for the future. They are less likely to be aware of the potential harms of a positive test result. "Planning for the future," perhaps the most frequently given reason for testing, may become 'restricting the future' (and also the present) by shifting family resources away from the child with a positive diagnosis." 70

Er zijn twee gevallen bekend waarin moeders verzochten om voorspellend onderzoek bij hun kinderen naar de ziekte van Huntington, omdat zij aangaven dat zij zich alleen aan hun kind konden hechten wanneer het een laag risico op de ziekte had. In beide gevallen is het onderzoek niet verricht.71

\section{Gevolgen en impact erfelijkheidsonderzoek bij kinderen}

Onderzoek naar de gevolgen en de impact van de uitslag van erfelijkheidsonderzoek bij kinderen wijst uit dat erfelijkheidsinformatie soms significant harm kan veroorzaken. Wertz e.a. noemen onder meer de volgende punten. Ten eerste wijzen zij erop dat misverstanden bij ouders of het kind tot zogenaamde ernstige verkeerde toekomstbeelden, gebaseerd op verkeerde risico-inschattingen of het verwarren van drager-zijn met patiënt-zijn, kunnen leiden. De Wert noemt ook het interpreteren van risico's op een multifactoriële aandoening een punt van zorg: "zijn zij in staat testuitslagen te hanteren die niet aangeven dat men wel of niet risico loopt, maar een groter of kleiner risico?".72 Ten tweede is stigmatisering, waaronder lagere verwachtingen binnen de familie, een gevaar dat vaak over het hoofd wordt gezien. Ten derde maakt het korte termijn voordeel, zoals een mogelijke reductie van angst, dat ouders en genetici soms de lange termijn psychosociale nadelen niet overzien. Ten vierde kan een negatieve uitslag latente minderwaardigheidsgevoelens opwekken. Ten slotte kunnen broers en zussen die voorheen door hetzelfde risico verbonden waren, geconfronteerd worden met verschillende uitslagen, wat bij een gunstige uitslag gevoelens van overlevingsschuld kan oproepen. Bovendien kan een ongunstige uitslag bij een broer of zus er toe leiden dat de broer of zus bij wie geen erfelijkheidsonderzoek is verricht, zijn of haar risico op een erfelijke aandoening hoger inschat. ${ }^{73}$

\footnotetext{
70 Wertz, Fanos en Reilly 1994, p. 875-881.

71 Ball, Tyler en Harper 1994, p. 63-94.

72 De Wert 1999, p. 287.

73 Wertz, Fanos en Reilly 1994, p. 875-881.
} 
De mogelijk negatieve gevolgen, alsmede uiteraard de mogelijk positieve gevolgen van het verrichten van een erfelijkheidsonderzoek bij een kind, dienen met ouders die een dergelijk onderzoek wensen te worden besproken. De moeilijkheid hierbij is dat over de voor- en nadelen van erfelijkheidsonderzoek weinig bekend is. Van de genoemde negatieve gevolgen is weinig te zeggen over de grootte van het risico dat zo'n gevolg ook daadwerkelijk optreedt. Voor wat betreft onderzoek hiernaar is dit terrein grotendeels terra incognita. ${ }^{74}$ Daarnaast behoren deze mogelijke gevolgen op grond van zijn professionele verantwoordelijkheid door de klinisch geneticus zelfstandig te worden gewogen bij de afweging van de belangen van het kind.

Wanneer ouders erfelijkheidsonderzoek wensen dat niet in het belang van het kind is, verzet het goed hulpverlenerschap zich hier tegen. ${ }^{75}$ Dit omvat zoals gezegd ook verantwoordelijkheid voor de bescherming van het kind. Daarom stelt de Gezondheidsraad dat het hier, met nog meer reden dan bij volwassen adviesvragers, gewenst is dat de beroepsgroep consensus bereikt en richtlijnen ontwikkelt voor de vraag welk erfelijkheidsonderzoek nog aanvaardbaar is, gelet op de voordelen die het biedt voor het kind. ${ }^{76}$

\section{Categorieën voorspellend erfelijkheidsonderzoek bij kinderen}

Wanneer is erfelijkheidsonderzoek in het belang van het kind? De Raad van Europa stelt dat het moet gaan om een gezondheidsbelang, ${ }^{77}$ terwijl de Nuffield Council alleen spreekt over immediate benefit. ${ }^{78}$ Daarbij wordt geen onderscheid gemaakt tussen verschillende categorieën erfelijkheidsonderzoek bij kinderen. De Wert doet dit wel. Hij onderscheidt de volgende categorieën van voorspellend erfelijkheidsonderzoek bij kinderen: ${ }^{79}$

\section{Eerste categorie}

Ten eerste de situatie waarin het erfelijkheidsonderzoek van belang is omdat primaire en/of secundaire preventie mogelijk is. In zo'n situatie kan door medische interventies, zoals periodiek onderzoek, en door niet-medische aanpassingen, zoals het volgen van een dieet of het vermijden van blootstelling aan schadelijke factoren, gezondheidsschade worden voorkomen. De mogelijkheid om door middel van primaire en/of secundaire preventie, naar aanleiding van een ongunstige uitslag, maatregelen te nemen om de aandoening te voorkomen, dan wel de prognose gunstig te beinvloeden, vormt de rechtvaardiging voor dergelijk voorspellend onderzoek bij kinderen.

$74 \quad$ De Wert 1999, p. 284

75 Leenen 2000, p. 81.

76 Gezondheidsraad 1998, p. 106. Zie ook Gevers 1996, p. 30. Ook Wertz, Fanos en Reilly stellen "professional guidelines for predictive genetic testing and counseling of children" voor.

77 Raad van Europa 1992, principle 5b.

78 Nuffield Council on Bioethics 1993, hoofdstuk 4, opmerking 4.25.

79 De Wert 1999, p. 289-304. 
Ook wanneer het belang van het kind bij het erfelijkheidsonderzoek wel duidelijk is, dient echter de vraag te worden gesteld of het onderzoek niet kan worden uitgesteld tot een leeftijd waarop het kind zelf kan toestemmen, of in ieder geval mede kan toestemmen. ${ }^{80}$ Temeer daar er weinig bekend is over de effecten van voorspellend erfelijkheidsonderzoek voor wat betreft het welbevinden van kinderen. Onderzoek hiernaar is aan te bevelen. ${ }^{81}$

\section{Tweede categorie}

Ten tweede de situatie waarin het erfelijkheidsonderzoek mogelijk van belang is voor primaire en/of secundaire preventie. In deze situaties is het medische voordeel (nog) niet wetenschappelijk bewezen. Het is niet zeker of maatregelen de prognose van het kind kunnen verbeteren. Dit vereist terughoudendheid bij het verrichten van dit type onderzoek bij kinderen. De rechtvaardiging voor het onderzoek is gelegen in de verbetering van de prognose, maar het is niet zeker of dit mogelijk is. Zeker wanneer de verwachte effectiviteit van de preventieve matregel gering is en de prognose voor patiënten met de aandoening somber is, valt dergelijk onderzoek moeilijk te rechtvaardigen. Te verwachten valt bovendien dat er geen consensus zal zijn over de afweging van de voordelen van het onderzoek, waaronder de effectiviteit van de preventieve maatregel, en de nadelen ervan. In deze afweging zouden onder meer betrokken moeten worden: de ernst van de aandoening, de aard van de preventieve maatregelen (hoe ingrijpend zijn deze en zijn daar risico's aan verbonden), de penetrantie van de mutatie, met andere woorden: de grootte van het risico dat de aandoening zich openbaart, de alternatieve mogelijkheden om preventieve maatregelen te nemen alsmede de psychosociale risico's van het onderzoek. ${ }^{82}$

Ten slotte moet ook bij dit type onderzoek de vraag gesteld worden of het onderzoek niet kan worden uitgesteld. Wanneer de mogelijke voordelen ook kunnen worden behaald bij uitstel van het onderzoek, is er, gezien het feit dat het niet evident is dat de preventieve maatregelen de prognose van de erfelijke aandoening verbeteren, geen rechtvaardiging om het recht op niet weten te schenden indien de aandoening eerst op volwassen leeftijd tot uiting komt. Gezien de andere mogelijke nadelen is er, bij de mogelijkheid tot uitstel, ook geen aanleiding om voorspellend erfelijkheidsonderzoek te verrichten naar aandoeningen die niet in de kinderleeftijd tot uiting komen.

\section{Derde categorie}

Ten derde de situatie waarin primaire en/of secundaire preventie niet mogelijk is, althans niet op kinderleeftijd. ${ }^{83}$ Er zijn geen maatregelen mogelijk om de prognose te

80 Gezondheidsraad 1998, p. 106.

81 Zie ook Report of a Working Party of the Clinical Genetics Society 1994, p. 785-797 en De Wert 1999, p. 296.

82 De Wert 1999, p. 303.

83 De Wert maakt de toevoeging "althans niet op kinderleeftijd" niet. Ik neem aan dat hij dit wel bedoelt, aangezien de argumenten die hij noemt ook gelden voor op volwassen leeftijd optredende ziekten waarbij preventieve maatregelen pas op volwassen leeftijd aan de orde zijn, zoals bijvoorbeeld erfelijke borstkanker. 
verbeteren. Het erfelijkheidsonderzoek kan de ouders informeren omtrent het dragerschap van hun kind. In deze situatie kan nog een nader onderscheid gemaakt worden tussen aandoeningen die op jeugdige leeftijd optreden en aandoeningen die op volwassen leeftijd optreden.

Voor wat betreft aandoeningen die op volwassen leeftijd optreden het volgende. Het belang van het kind is niet gediend wanneer ouders onderzoek willen laten verrichten naar in het volwassen leven (mogelijk) optredende ziekten. ${ }^{84}$ Het recht van het kind om later zelf te kunnen beslissen of het erfelijkheidsonderzoek wil ondergaan zou worden geschonden, terwijl er geen medisch belang is dat een onderzoek kan rechtvaardigen. De slechte prognose in aanmerking genomen, valt er weinig bat te verwachten van vroege wetenschap bij een ongunstige uitslag. De informatie is bovendien onomkeerbaar, terwijl de weigering een erfelijkheidsonderzoek te verrichten een voorlopige weigering is; vanaf 16 jaar kan de minderjarige zelfstandig een erfelijkheidsonderzoek ondergaan. ${ }^{85}$ Het zelfbeschikkingsrecht als leidend rechtsbeginsel eist dat het toekomstige recht op niet weten van het kind wordt gerespecteerd. Daarom wordt algemeen aangenomen dat het kind wanneer het volwassen is, zelf moet kunnen beslissen of het wel of niet wil weten of het drager is van een erfelijke mutatie die een erfelijke ziekte veroorzaakt of daar een verhoogd risico op geeft. ${ }^{86}$

Bij zowel toestemming van de ouders als van het kind, wanneer het tussen de 12 en 16 jaar oud is, is voorspellend onderzoek naar later in het leven optredende ziekten

8. Leenen 2000, p. 81.

85 De Wert 1999, p. 291.

86 Dit wordt nationaal en internationaal aanvaard. Zie bijvoorbeeld Gezondheidsraad 1998, p. 106, Commissie Medische Ethiek van de KNMG 1998, p. 30, Report of a Working Party of the Clinical Genetics Society en The American Society of Human Genetics Board of Directors and The American College of Medical Genetics Board of Directors 1995, p. 1233-1241. De Amerikaanse jurist Sharpe heeft kritiek geuit op deze opstelling. Zowel het verrichten van erfelijkheidsonderzoek bij kinderen naar dragerschap van het Huntington-gen als het niet verrichten daarvan hebben in zijn visie voor- en nadelen. Het is volgens hem daarom onjuist om op voorhand voor alle situaties te bepalen dat dergelijk onderzoek niet wordt uitgevoerd. Sharpe 1993, p. 250253. De Wert voert hiertegen onder meer de volgende argumenten aan. Ten eerste gaat Sharpe gaat volledig voorbij aan het recht van het kind om, wanneer het volwassen is, zelf te kunnen beslissen of het wel of niet wil weten of het drager is van een erfelijke mutatie die een erfelijke ziekte veroorzaakt. Ten tweede is niet goed in te zien, gezien de uiterst sombere vooruitzichten voor dragers, hoe het kind baat zou kunnen hebben bij wetenschap op kinderleeftijd. Een ongunstige uitslag is irreversibel. De weigering daarentegen is voorlopig. Hij geldt alleen zolang het kind niet minderjarig is, of in het Nederlandse geval, zolang het kind de leeftijd van 16 jaren nog niet heeft bereikt. Ten slotte is voor de ouders het voordeel van een erfelijkheidsonderzoek gelegen in het feit dat hun ongerustheid wordt weggenomen bij een gunstige uitslag. Bij een ongunstige uitslag daarentegen leert de ervaring dat ouders deze mogelijkheid negeren, terwijl het risico hierop $50 \%$ is. (Zie hiervoor het artikel van Wertz e.a. waaraan eerder in dit hoofdstuk is gerefereerd.) De Wert stelt dat counseling daarom eerder aangewezen is dan een presymptomatisch erfelijkheidsonderzoek. De Wert 1999, p. 290-291. 
waarvoor geen preventie mogelijk is, in principe juridisch mogelijk. Wat is echter goed hulpverlenerschap van de klinisch geneticus bij een dergelijk verzoek? Ten eerste kan men daarbij de vraag stellen of er in de leeftijd van 12 tot 16 jaar met betrekking tot dergelijke verzoeken, waarbij de gevolgen van onderzoek zéér ingrijpend kunnen zijn, niet vanuit moet worden gegaan dat kinderen terzake niet in staat zijn tot een redelijke waardering van hun belangen. In dat geval beslissen de ouders. In zo'n situatie moet de klinisch geneticus zijn medewerking aan het erfelijkheidsonderzoek weigeren, op grond van zijn eigen verantwoordelijkheid voor de belangen van het kind. Indien in een individueel geval niet kan worden gezegd dat de minderjarige niet in staat is tot een redelijke waardering van zijn belangen terzake, zal de klinisch geneticus op grond van zijn professionele verantwoordelijkheid moeten beslissen of hij op een dergelijk verzoek ingaat. Gezien het nationale en internationale standpunt hierover is aan te nemen dat hij hier niet op in zal gaan.

Ook bij 16- en 17-jarigen zal bij een verzoek om erfelijkheidsonderzoek zorgvuldig dienen te worden nagegaan of het verzoek een weloverwogen verzoek is en of de minderjarige in staat is de mogelijke gevolgen te overzien. ${ }^{87}$

De vraag of erfelijkheidsonderzoek bij kinderen naar ziekten die op kinderleeftijd tot uiting komen, waarvoor geen preventie mogelijk is, plaats mag vinden is voor deze paragraaf niet relevant in zoverre dat het recht op niet weten hierbij niet aan de orde is. ${ }^{88}$ Dit gezien het feit dat wanneer het kind hier zelf over kan beslissen, de ziekte, bij gebleken dragerschap van de mutatie, al tot uiting is gekomen en daardoor de vraag naar wel of niet weten irrelevant is geworden. Er zijn echter ook aandoeningen met een variabele beginleeftijd: aandoeningen die zich meestal op de kinderleeftijd openbaren, maar die ook pas op volwassen leeftijd tot uiting kunnen komen. Dit

87 De internationale richtlijnen van de International Huntington Association en de World Federation of Neurology hanteren als inclusiecriterium de grens van de meerderjarigheid, wat erop neer zou komen dat voorspellend erfelijkheidsonderzoek naar de ziekte van Huntington aan 16- en 17-jarigen zou dienen te worden geweigerd. Dit is gezien artikel 7:447 lid 1 BW, in Nederland niet houdbaar. International Huntington Association and the World Federation of Neurology Research Group on Huntington's Chorea 1994, p. 555-559. Aldus ook De Wert 1999, p. 294-295.

Over de vraag of dergelijk onderzoek moet worden toegestaan zijn de meningen verdeeld. Zo stelt de werkgroep van de Clinical Genetics Society dat de ethische en praktische bezwaren die zich voordoen bij erfelijkheidsonderzoek naar aandoeningen die op volwassen leeftijd optreden, ontbreken bij erfelijkheidsonderzoek naar aandoeningen die zich op de kinderleeftijd manifesteren. De Committee on Assessing Genetic Risks van het Institute of Medicine stelt echter dat dit soort onderzoek alleen verantwoord is wanneer er curatieve of preventieve behandelingen mogelijk zijn. De Wert vindt beide stellingnamen te absoluut. Hij ziet zowel voor- als nadelen aan deze vorm van onderzoek. Hij stelt daarom voor dat de klinisch geneticus en zijn team in samenspraak met de ouders per situatie de voor- en nadelen afwegen. In het algemeen is dit type onderzock volgens de auteur eerder verantwoord naarmate de aandoening waarnaar men onderzoek wil gaan doen, zich op jongere leeftijd manifesteert. Andrews e.a. 1994, p. 10 en De Wert 1999, p. 300-302. 
betekent dat een inbreuk op het recht op niet weten hierbij mogelijk is. De Wert stelt dat hier een grotere terughoudendheid op zijn plaats is dan ten aanzien van erfelijkheidsonderzoek naar aandoeningen die zich altijd op kinderleeftijd manifesteren. ${ }^{89}$ Dit is terecht. Naast andere te beschermen belangen van het kind, is hier een mogelijke inbreuk op het recht op niet weten, een belang dat meegewogen dient te worden.

Kunmen belangen van derden annleiding zijn voor erfelijkheidsonderzoek bij kinderen?

Hiervoor werd telken-male nagegaan of en wanneer een erfelijkheidsonderzoek in het belang van kind zou kunnen zijn. Kan het onder omstandigheden ook geoorloofd zijn om een erfelijkheidsonderzoek te verrichten wanneer alleen de belangen van derden aanleiding zijn voor het onderzoek? Gevers stelt dat wanneer het onderzoek niet mede in het belang van het kind kan worden geacht, dit niet te rechtvaardigen is, gelet op de inbreuk op het recht op niet weten van het kind, tenzij er een zo zwaarwegend belang is van familieleden, dat dit prevaleert boven het recht op privacy van het kind. Waar zou dit zwaarwegend belang uit moeten bestaan? In een noot noemt Gevers de situatie waarin een erfelijkheidsonderzoek bij een kind nodig is ten behoeve de diagnostiek bij een familielid van een ernstige aandoening waarbij preventie mogelijk is en geen uitstel lijdt. ${ }^{90}$ Volgens de Gezondheidsraad is dergelijk onderzoek niet aanvaardbaar, tenzij het belang van de adviesvrager heel zwaar weegt en niet op andere wijze kan worden gediend. ${ }^{91}$ De Raad gaat verder niet in op het zwaarwegende belang, maar noemt wel het subsidiariteitsvereiste. De Raad van Europa stelt over onderzoek bij kinderen in het belang van anderen:

"Testing of these persons for diagnostic purposes should be permitted only when this is necessary for their own health or if the information is imperatively needed to diagnose the existence of a genetic disease in family members ${ }^{\prime \prime 2}$

De Raad stelt niet de eis dat de erfelijke ziekte een ernstige ziekte moet zijn waarbij preventie mogelijk is en geen uitstel kan lijden. Dit kan echter wel gelezen worden in de woorden imperatively needed..$^{93}$

Zoals bij erfelijke aandoeningen bij kinderen waarvoor preventie mogelijk is, het verbeteren van de prognose de rechtvaardiging vormt voor het verrichten van erfelijkheidsonderzoek, is hier de verbetering van de prognose van het familielid kennelijk de rechtvaardiging voor het verrichten van voorspellend erfelijkheidsonderzoek uitsluitend in het belang van een familielid. Hieraan dienen wel extra eisen te worden gesteld. Ten eerste, zoals de Gezondheidsraad ook stelde, het subsidiariteitsvereiste: het zwaarwegende belang van het familielid kan op geen enkele ander wijze, bijvoorbeeld door een ander familielid te benaderen, worden

59 De Wert 1999, p. 302.

90 Gevers 1996, p. 31. Zie ook Leenen 2000, p. 82.

91 Gezondheidsraad 1989, p. 103-104.

92 Raad van Europa 1992, principle 5b.

93 De Nuffield Council on Bioethics stelt hierover: "An exception may be where testing of the child is essential for the diagnosis of a family member". Nuffield Council on Bioethics 1993, hoofdstuk 4, opmerking 4.25. 
gediend. Ten tweede de eis van de proportionaliteit, dat wil zeggen dat het tegemoetkomen aan het zwaarwegende belang van het familielid niet onevenredig de belangen van het kind schaadt. Een andere eis die het proportionaliteitsvereiste met zich meebrengt is dat aan de aard van het zwaarwegende belang de eis moet worden gesteld, gelijk het voorbeeld van Gevers, dat voor de betreffende aandoening preventiemogelijkheden beschikbaar zijn die geen uitstel kunnen lijden.94 Indien dit niet het geval is, is, gezien de voorspellende aard van het onderzoek en de mogelijk negatieve gevolgen van de uitslag, het belang van het familielid disproportioneel ten opzichte van dat van het kind.

\title{
Belang richtlijnen beroepsgroep
}

Tot slot wil ik nogmaals het belang benadrukken dat de beroepsgroep hierover richtlijnen opstelt. Markenstein, Gevers en Roscam Abbing zeggen hierover:

\begin{abstract}
"Zulke richtlijnen vormen een onmisbare steun voor de hulpverlener om in concreto te beoordelen of het ingaan op een verzoek van ouders/vertegenwoordigers om vroegopsporingsonderzoek al dan niet verenigbaar is met 'de zorg van een goed hulpverlener'." 95
\end{abstract}

De mogelijk botsende belangen van de ouders en het kind nopen tot een duidelijk standpunt van de beroepsgroep. Terughoudendheid en een zorgvuldige weging van de mogelijke voordelen tegen de nadelen, waaronder het belang van het kind om in de toekomst zelf te kunnen beslissen of het een erfelijkheidsonderzoek wil ondergaan, zijn hier geboden.

\subsubsection{Het recht op niet weten van ongeborenen}

Kan er bij ongeborenen ook sprake zijn van een recht op niet weten? Hiervoor is reeds aangegeven dat de rechtvaardiging hiervan erin gelegen is dat voor de geboorte aan een ongeborene een zekere reflex-werking toekomt van zijn toekomstige recht op respect voor een persoonlijke levenssfeer en hiervan afgeleid zijn recht op niet weten. Het in de vorige paragraaf geciteerde uitgangspunt van de richtlijnen van de Vereniging voor Gezondheidsrecht, waarin werd gesteld dat het recht op niet weten van het ongeboren kind een extra punt van overweging kan vormen voor de ouders die kiezen voor een erfelijkheidsonderzoek bij hun ongeboren kind, is om die reden onjuist geformuleerd.

Het te beschermen belang dat de ongeborene heeft om in de toekomst verschoond te blijven van bepaalde informatie kan enerzijds beschermd worden door bij prenataal onderzoek alleen te informeren over het feit of de vrucht al dan niet aangedaan is en niet over dragerschap van een recessieve mutatie of een gebalanceerde translocatie en anderzijds door het stellen van voorwaarden aan de toegang tot prenatale diagnostiek. Beide wijzen van bescherming zullen in deze paragraaf aan bod komen.

95 Markenstein, Gevers en Roscam Abbing 1999, p. 38. 


\section{Informeren over dragerschap?}

Ten eerste de situatie waarin aanstaande ouders een prenataal onderzoek laten verrichten bij de ongeborene naar de aanwezigheid van een autosomaal overervende monogene recessieve aandoening. ${ }^{96}$ Bij dit onderzoek zijn er drie uitslagen mogelijk. De foetus kan de ziekte hebben (een risico van 25\%), hij kan drager zijn, maar de ziekte niet hebben (een risico van $50 \%$ ), waardoor in de toekomst zijn nageslacht een verhoogde kans op de aandoening heeft, en hij kan ziek noch drager zijn (een kans van $25 \%$ ). De vraag is hier of de ouders alleen geinformeerd moeten worden over het feit of de vrucht wel of niet aangedaan is, of dat de ouders ook geinformeerd moeten worden of de vrucht wanneer hij niet aangedaan is, wel of geen drager is. Voorop gesteld dient te worden dat het onmogelijk is onderzoek te verrichten zonder dat het mogelijke dragerschap wordt vastgesteld.

Is er wanneer dragerschap wordt vastgesteld sprake van een onverwachte bevinding? Dit is moeilijk te verdedigen. Voor het onderzoek wordt verricht staat namelijk al vast dat de vrucht een risico van $50 \%$ heeft om drager te zijn. Het uitgangspunt bij onverwachte bevindingen is dat de adviesvrager recht op informatie heeft.97 In deze situatie zou ik echter willen spreken van een te verwachten, maar niet gezochte bevinding. Dit heeft juridische consequenties.

Dute stelt, met verwijzing naar artikel 7:448 BW, dat de geneticus zich met betrekking tot de vraag of prenataal gevonden dragerschap aan ouders meegedeeld dient te worden, moet laten leiden door hetgeen de ouders redelijkerwijs dienen te weten. Omdat men hier van mening over kan verschillen stelt hij het volgende voor:

"Alles bijeengenomen zou ik als vaste gedragslijn voorstellen dat aan de ouders
duidelijk wordt gemaakt dat het prenatale onderzoek niet alleen leidt tot de uitslag wel
of geen chromosoomafwijking, maar dat ook eventueel dragerschap wordt vastgesteld.
Daarbij dient te worden verteld wat de betekenis van dragerschap is voor de
gezondheid van het kind en welke voor- en nadelen er aan kleven om hiervan als
ouders (en als kind) op de hoogte te zijn. Vervolgens dient de arts met de ouders af te
spreken of zij al dan niet over het dragerschap willen worden geïformeerd." ${ }^{8}$

Een dergelijke benadering legt een te eenzijdige nadruk op het recht op informatie van de ouders. Aan de belangen van de ongeborene wordt alleen indirect aandacht besteed, door de eis dat ouders goed voorgelicht worden over de betekenis en gevolgen van dragerschap. Het gaat hier echter niet om onverwachte bevindingen die ook onder het recht op informatie vallen. Het gaat om te verwachten bevindingen waar de erfelijkheidsvraag niet op gericht is. De vraag is immers of het kind aan de betreffende ziekte zal gaan lijden. Daarom is niet vol te houden dat het informatie betreft die de ouders redelijkerwijs dienen te weten. Een verplichting om de te verwachte bevinding, waar het onderzoek niet op gericht is mee te delen, volgt deswege niet uit de Wgbo. Evenmin is zij vanzelfsprekend. 
Bij de beantwoording van de vraag of ouders ook geïnformeerd moeten worden over dragerschap van de vrucht, ligt het voor de hand om aansluiting te zoeken bij soortgelijke kwesties. Ten eerste is van belang dat prenataal onderzoek, uitsluitend om dragerschap aan te tonen, algemeen wordt afgewezen. ${ }^{99}$ Ten tweede wordt ook bij kinderen geen dragerschapsonderzoek verricht. De ratio is dat wanneer er geen medische aanleiding is voor het onderzoek aan kinderen de keus moet worden gelaten, wanneer zij 16 jaar oud zijn, of zij willen weten of zij drager zijn of niet. Zoals opgemerkt is de menselijke vrucht nog geen drager van rechten en plichten, maar is er wel sprake van beschermwaardige belangen die afgewogen moeten worden tegen die van de aanstaande ouders. Gezien de afwezigheid van gezondheidsredenen om geïnformeerd te worden over dragerschap en de aanwezigheid van het belang om zelf in de toekomst een keuze te kunnen maken, is hier een restrictief beleid gerechtvaardigd. De privacy en het recht op niet weten van het toekomstige kind dienen hier te worden beschermd. Een additioneel argument vormen hier de mogelijk negatieve effecten van aangetoond dragerschap. Ten Kate sluit nadelige effecten voor de psychosociale ontwikkeling niet uit. ${ }^{100}$ Het is aan te bevelen dat hier onderzoek naar wordt verricht.

Deze benadering is niet paternalistisch. De reden om geen mededelingen te doen over dragerschap is niet gelegen in de overtuiging dat ouders geen goede belangenbehartigers zouden zijn voor hun kind. De ratio is dat voor het ongeboren kind de mogelijkheid open wordt gehouden, om wanneer het 16 jaar oud is, zelf te bepalen of het geïnformeerd wil worden over eventueel dragerschap. In hoofdstuk 3 is verdedigd dat het zelfbeschikkingsrecht als rechtsbeginsel ten grondslag ligt aan onder andere het recht op niet weten. Tevens is op verschillende plaatsen het belang van een autonome en weloverwogen beslissing benadrukt om een erfelijkheidsonderzoek te ondergaan. Tegen deze achtergrond, ligt het eens te meer voor de hand om, wanneer de erfelijkheidsvraag van de ouders er niet op was gericht en er geen gezondheidsbelangen mee gemoeid zijn, de keus om geïnformeerd te worden over dragerschap in de toekomst over te laten aan het ongeboren kind, wanneer het leeftijd van 16 jaar heeft bereikt. Het gaat ten slotte om zijn erfelijk patroon en de consequenties die dat patroon voor hem en zijn eventueel nageslacht heeft.

De logische consequentie van de constatering dat geen mededelingen worden gedaan over dragerschap, is dat het laboratorium in de uitslagbrief alleen vermeldt of de vrucht aangedaan is of niet. Geredeneerd vanuit de opvatting dat informatie over dragerschap pas door het kind wanneer het 16 is, moet kunnen worden opgevraagd, is er wanneer de vraag van de ouders zich alleen richt op de aan- of afwezigheid van een erfelijke aandoening, immers geen aanleiding voor de klinisch geneticus om op de hoogte te zijn van dragerschap. Bijkomstig voordeel hiervan is dat op die manier de geneticus via het inzagerecht niet gedwongen kan worden alsnog mededelingen te doen over de aan- of afwezigheid van dragerschap. 
Grenzen aan de toegang tot prenatale diagnostiek?

Welke grenzen moeten worden getrokken bij de toegang tot prenatale diagnostiek om het recht op niet weten van de ongeborene te beschermen? En hoe verhoudt deze voorwaardelijke toegang zich tot de Wet afbreking zwangerschap? Bij de beslissing of zij prenataal onderzoek verrichten moeten klinisch genetici zich laten leiden door hun professionele standaard. Mogen er, om het recht op niet weten van de foetus te beschermen, voorwaarden gesteld worden, en zo ja, welke, aan de toegang tot voorspellend genetisch onderzoek? In hoofdstuk vier is aangegeven dat men bij toegang tot voorspellend onderzoek onderscheid kan maken tussen drie toetsen. In dat hoofdstuk zijn aan de orde gekomen de voorwaarden met betrekking tot het object van het onderzoek en voorwaarden met betrekking tot de ernst van de aandoening. Het recht op niet weten van de ongeborene is aan de orde wanneer aanstaande ouders, ongeacht de uitslag van het prenatale onderzoek, voornemens zijn de zwangerschap te continueren. Daarom is een derde toets gelegen in het voomemen dat de adviesvrager heeft betreffende hoe om te gaan met een ongunstige uitslag van prenataal onderzoek. ${ }^{101}$ Mogen hier voorwaarden aan worden gesteld en zo ja, hoe verhouden deze zich tot de ernst van de aandoening?

Deze derde toets is controversieel en dat is in het licht van het doel van de erfelijkheidsadvisering begrijpelijk. Wanneer deze erop gericht is om het maken van een vrije geïnformeerde keuze mogelijk te maken, lijkt het ondenkbaar dat voorafgaand aan een onderzoek eisen zouden kunnen worden gesteld aan de conclusie die men aan de uitslag van het erfelijkheidsonderzoek wil gaan verbinden. Concreter gesteld: kan het toelaatbaar zijn om een adviesvrager de toegang tot prenatale diagnostiek te weigeren wanneer deze bij voorbaat de mogelijkheid van een abortus bij een ongunstige uitslag afwijst?

De Gezondheidsraad wijst dit af. De Raad wijst er daarbij op dat het doel van prenatale diagnostiek niet zwangerschapsafbreking is, maar "het informeren van de zwangere vrouw en haar eventuele partner" ${ }^{102}$ Het ontzeggen van de toegang tot prenataal onderzoek aan vrouwen die een abortus bij voorbaat afwijzen, zou tot rechtsongelijkheid leiden en zou kunnen leiden tot onaanvaardbare drang, aldus de Raad. In een aanbeveling van de Raad van Europa valt te lezen:

"There should be equality of access to genetic testing, without financial considerations and without preconditions concerning eventual personal choices." 103

101 De Wert 1999, p. 203.

102 Gezondheidsraad 1989, p. 90. Gevers sluit zich hierbij aan. Gevers 1996, p. 70.

103 Raad van Europa 1992, principle 4a. 
Het eerste uitgangspunt van de erfelijkheidsrichtlijnen luidt als volgt:

"Ieder heeft het recht zelf te beslissen of hij erfelijkheidsonderzoek ondergaat. (...) Dit uitgangspunt betekent tevens dat de arts aan het verrichten van erfelijkheidsonderzoek geen bijzondere voorwaarden mag stellen, zoals de bereidheid een abortus te ondergaan bij een gebleken positieve uitslag van prenataal onderzoek."104

Er zijn verschillende argumenten genoemd om voorwaarden te stellen aan de toegang tot prenataal onderzoek, wanneer daar geen consequenties aan worden verbonden. ${ }^{105}$ Ten eerste een medisch argument. Invasieve vormen van prenatale onderzoek brengen een risico op een miskraam met zich mee (0.2-0.5\%). Het nemen van een risico, terwijl men geen consequenties verbindt aan een ongunstige uitslag, wordt onaanvaardbaar gevonden. Ten tweede zou een ongunstige uitslag de aanstaande ouders erg belasten. Ten derde een financieel argument. Prenataal onderzoek is kostbaar en schaars en zou niet aanvaardbaar zijn, wanneer van tevoren reeds duidelijk is, dat er geen consequenties aan een ongunstige uitslag worden verbonden.

Geen van de argumenten overtuigen. 106 Het is aan de adviesvragers zelf om, weloverwogen en geinformeerd, af te wegen of zij een medisch risico willen lopen. Bovendien zijn aan praktisch elk medisch onderzoek risico's verbonden. Het feit dat het onderzoek belastende informatie op zou kunnen leveren, is waarschijnlijk juist voor adviesvragers die een abortus afwijzen, de reden om toch voor prenataal onderzoek te kiezen. Mocht de uitslag ongunstig zijn, dan kunnen zij aan die wetenschap wennen en zich voorbereiden op een kind met een aandoening. Een financieel argument mag ten slotte nooit de doorslag geven om een beleid te voeren dat leidt tot rechtsongelijkheid en dat adviesvragers geen vrije keuze laat in hun handelen.

Het niet toelaten van een adviesvrager tot prenatale diagnostiek omdat zij bij voorbaat het afbreken van zwangerschap afwijst, wordt nationaal en internationaal afgewezen. De hierboven genoemde argumenten om vrouwen geen prenatale diagnostiek aan te bieden, wanneer daar geen consequenties aan worden verbonden, overtuigen niet. Toch kunnen er in bepaalde situaties voorwaarden worden gesteld aan de toegang tot prenataal onderzoek voor wat betreft de conclusies die men voornemens is aan de uitslag van prenataal onderzoek te verbinden.

\section{Eerste grens}

Erfelijkheidsadvisering die non-directief van aard is, waarvan de grondslag ligt in het zelfbeschikkingsrecht van de adviesvrager en die ten doel heeft de adviesvrager in staat te stellen een vrije en geïnformeerde keuze te maken, vindt haar grenzen voor wat betreft die non-directiviteit in het zelfbeschikkingsrecht van anderen dan de adviesvrager. Die anderen zijn bloedverwanten en (toekomstig) nageslacht. Hoe het

104 Vereniging voor Gezondheidsrecht 1991, uitgangspunt 3.1.

105 Gezondheidsraad 1989, p. 89-90 en De Wert 1999, p. 203-204.

106 Gezondheidsraad 1989, p. 89-90 en De Wert 1999, p. 203-204. 
zelfbeschikkingsrecht van de adviesvrager kan botsen met dat van zijn bloedverwanten, komt in hoofdstuk 5 en in hoofdstuk 7 aan de orde. In hoofdstuk 7 zal blijken dat het soms de plicht van de klinisch geneticus kan zijn om zich directief om te stellen. Hier is aan de orde of het toekomstige zelfbeschikkingsrecht en recht op niet weten van het ongeboren kind van de adviesvrager een voorwaardelijke toegang tot prenataal onderzoek zouden kunnen rechtvaardigen. Deze vraag is met name aan de orde bij later in het leven optredende monogene onbehandelbare aandoeningen, zoals bijvoorbeeld de ziekte van Huntington. Wanneer de uitslag van het prenatale onderzoek ongunstig is, wordt het kind ongevraagd geconfronteerd met de zeer belastende wetenschap dat het later in zijn leven (ongeveer tussen het 35e en 50 e levensjaar) gaat leiden aan een onbehandelbare, zowel geestelijk als fysieke, degeneratieve ziekte die onvermijdelijk eindigt met de dood. De Gezondheidsraad spreekt hier van een "onoplosbaar conflict tussen het belang van de ouders bij informatie en het belang van het toekomstige kind bij 'niet weten" ${ }^{107}$ Gevers merkt op dat de Gezondheidsraad terecht over een onoplosbaar conflict spreekt. Hieraan voorafgaand merkt hij echter op:

"Nog afgezien van het feit, dat dat laatste nimmer is af te dwingen, 108 is het naar mijn
mening ook onjuist een dergelijke toegangsvoorwaarde te stellen. (...) Dit betekent dat
er kinderen geboren zullen worden die niet hebben kunnen beslissen over
totstandkoming van hen betreffende informatie over toekomstige
gezondheidsrisico's." 109

Voor Gevers prevaleert, wanneer hij opmerkt dat het onjuist is om een dergelijke toegangsvoorwaarde te stellen, kennelijk het belang van de adviesvragers en is er dus geen sprake van een onoplosbaar conflict. Hij motiveert dit verder niet. ${ }^{110}$ Ook Leenen spreekt zich over deze kwestie niet uit. Hij volstaat met de constatering dat prenataal onderzoek het toekomstige kind kan confronteren "met een bijna ondraaglijke kennis die het waarschijnlijk niet zou willen hebben bezitten". ${ }^{11}$

De Wert stelt echter dat er overtuigende argumenten om het belang van het toekomstige kind te laten prevaleren wanneer ouders verzoeken om prenataal onderzoek naar later in het leven optredende ernstige ziekten, waar geen behandeling voor bestaat.112 Van belang in dit verband is dat internationaal en nationaal wordt aanvaard dat bij kinderen geen presymptomatisch onderzoek wordt uitgevoerd naar later in het leven (mogelijk) optredende onbehandelbare aandoeningen. Zoals in de vorige paragraaf bleek, is daarbij het recht van het kind om niet te weten in het geding en vormt dit de grondslag voor de afwijzing van dergelijk onderzoek. Indien toekomstige ouders van plan zijn de zwangerschap, ongeacht de uitslag van prenataal onderzoek, te continueren, zou in feite voorspellend onderzoek worden verricht. De Wert hierover:

\footnotetext{
107 Gezondheidsraad 1989, p. 91

105 Gevers doelt hier op een abortus provocatus.

109 Gevers 1996, p. 28.

110 De Wert 1999, p. 229, noot 36.

111 Leenen 2000, p. 150.

112 De Wert 1999, p. 204-206.
} 
"Of het presymptomatisch onderzoek nu voor of na de geboorte plaatsvindt is redenerend vanuit de belangen en rechten van het opgroeiende kind niet van belang: 'the timing of harm is irrelevant'."113

De timing van het voorspellende onderzoek is redenerend vanuit een juridisch oogpunt wel van belang. Een ongeborene is, zoals meermalen is opgemerkt, geen rechtssubject en deswege geen drager van rechten en plichten. Er kan alleen sprake zijn van gerechtvaardigde belangen van de vrucht. Daarnaast is er voor wat betreft de 'timing' van het onderzoek het verschil dat bij erfelijkheidsonderzoek bij een kind, het kind zelf de adviesvrager is wiens belangen door de ouders worden waargenomen en dat bij erfelijkheidsonderzoek bij de vrucht, de ouders de adviesvragers zijn. Dit verschil in rechtspositie neemt niet weg dat wanneer aanstaande ouders hun keuze reeds hebben gemaakt en hun nog ongeboren kind ter wereld willen brengen, zij het toekomstige zelfbeschikkingsrecht en recht op niet weten van hun ongeboren kind zouden moeten respecteren. ${ }^{114}$ Van belang hierbij is, dat de kennis om in de toekomst aan een onbehandelbare ziekte te gaan lijden, welhaast ondraaglijk moet zijn. De toekomstige ouders daarentegen hebben hun keuze reeds gemaakt. De erfelijkheidsadvisering is in dit geval niet gericht op het mogelijk maken van een geinformeerde en weloverwogen keuze. Hun belang bestaat uit het ontvangen van informatie die mogelijk geruststellend is. Dit is niet een ondeugdelijk belang, maar wel een minder zwaar belang dan het toekomstige belang om zelf te kunnen beslissen of men wil weten of zich in de toekomst een onbehandelbare ziekte zal openbaren.

Dit leidt tot de volgende stellingname. ${ }^{115}$ Indien ouders verzoeken om een prenataal onderzoek naar later in het leven optredende onbehandelbare aandoeningen, terwijl de keus om het kind geboren te laten worden reeds gemaakt is door de aanstaande ouders, is de klinisch geneticus verplicht, op grond van zijn goed hulpverlenerschap, om aan te geven dat het belang van de ouders bij een dergelijk verzoek minder zwaar weegt dan het belang van de vrucht om in de toekomst zelf te kunnen beslissen of hij wil weten of zich in de toekomst een onbehandelbare ziekte zal openbaren. Wanneer de ouders volharden in hun verzoek, rest de klinisch geneticus de mogelijkheid om het verzoek op grond van zijn professionele standaard te weigeren.

Hier is geen sprake van rechtsongelijkheid ten aanzien van aanstaande ouders die een prenataal onderzoek wensen met de bedoeling de vrucht te aborteren, bij gebleken dragerschap van het gen dat voor de ziekte van Huntington muteert, aangezien het om twee geheel verschillende zaken gaat. Wanneer een abortus niet aan de orde is, gaat het uitsluitend om het vergaren van informatie betreffende het ongeboren kind. Het kind zal geboren worden en moet in de toekomst zelf een recht op niet weten moeten kunnen uitoefenen. In het andere geval zal de zwangerschap

113 De Wert 1999, p. 205.

114 Zie ook De Wert, XVI Ethische aspecten, hoofdstuk 2, paragraaf 2.5.2.

115 Hierbij wordt doorgeredeneerd op het genoemde standpunt van De Wert. 
worden afgebroken indien de foetus gendrager blijkt te zijn. Zijn belangen zullen zich in de toekomst niet verwezenlijken.

In de praktijk vindt dergelijk onderzoek ook slechts plaats wanneer toekomstige ouders voornemens zijn om bij een ongunstige uitslag de vrucht te aborteren. ${ }^{116}$ In de Guidelines for the molecular genetics predictive test in Huntington's disease valt het volgende te lezen:

"The couple requesting prenatal testing must be clearly informed that if they intend to complete the pregnancy if the fetus is a carrier of the gene defect, there is no valid reason for performing the test." 117

Aan het bovenstaande moet echter niet de consequentie verbonden worden dat toekomstige ouders zich niet mogen bedenken voor wat betreft de consequenties die aan de uitslag van prenataal onderzoek verbonden worden. $\mathrm{Zij}$ behouden te allen tijde het wettelijk recht om, ook na een ongunstige uitslag, de zwangerschap te continueren. Het goed hulpverlenerschap vereist echter dat aanstaande ouders worden gewezen op de beschermwaardige belangen van de vrucht en dat er geen valid reason is voor prenataal onderzoek wanneer de zwangerschap zeker gecontinueerd wordt. Het is van groot belang dat de beroepsgroep terzake richtlijnen opstelt.

\section{Tiveede grens}

Zijn er nog andere situaties denkbaar waarin er sprake zou moeten zijn van voorwaardelijke toegang tot prenataal onderzoek? In een boeiend betoog schetst De Wert de hypothetische situatie waarin de toekomstige ouders prenataal onderzoek laten verrichten met als doel de foetus zonder erfelijke afwijkingen te aborteren en dus alleen de aangedane vrucht ter wereld te laten komen. ${ }^{118}$ Deze situatie heeft zich in Nederland nog niet voorgedaan, maar is geenszins denkbeeldig, aldus de Wert. Als voorbeeld noemt hij een echtpaar waarvan zowel de man als de vrouw lijden aan een erfelijke vorm van doofheid die geen deel uitmaakt van een samenstel van afwijkingen, de zogeheten non-syndromic doofheid. De ervaring wijst uit dat deze echtparen zowel met een horend als een doof kind blij zijn. Sommige echtparen hebben echter een voorkeur voor een doof kind. Zij zien doofheid niet als een handicap en voelen zich bedreigd en onzeker door het vooruitzicht dat zij een horend kind krijgen. Moet aan een dergelijke wens tegemoet gekomen worden?119 Zijn bij een dysgenetische toepassing de grenzen van de non-directieve erfelijkheidsadvisering en het zelfbeschikkingsrecht in zicht of is het de uiterste consequentie ervan die we moeten aanvaarden? ${ }^{120}$ Een aangedaan kind past immers het best bij de subcultuur en de waarden en normen van het echtpaar. De Wert

\footnotetext{
116 De Wert 1999, p. 204.

117 International Huntington Association en the World Federation of Neurology Research Group on Huntington's Chorea 1994, p. 555-559, Recommendation 7.2.

118 De Wert 1999, p. 206-209.

119 In Engeland heeft een doof echtpaar een dergelijk verzoek gedaan. Plasterk 2001.

120 Nance noemt deze situatie: "the ultimate test of nondirective counseling". Nance 1993.
} 
meent dat het verzoek om prenataal onderzoek in dergelijk gevallen geweigerd zou moeten worden. De ouders gaan er bij een dergelijk verzoek kennelijk vanuit dat doofheid niet als een handicap, maar "gewoon een variatie op het spectrum der normaliteit is". ${ }^{21}$ Doofheid is echter wel degelijk een handicap en leidt op veel gebieden tot minder kansen en mogelijkheden. Wat zegt het afwijzen van het verzoek tot prenataal onderzoek over het doel en de grondslag van de erfelijkheidsadvisering? Het doel was het mogelijk maken van een geinformeerde keuze om zo recht te doen aan het zelfbeschikkingsrecht van adviesvragers en niet het voorkómen van kinderen met een aangeboren of erfelijke afwijking. De Wert stelt dat de grondslag en het doel overeind kumnen blijven, zij het dat enige precisering op zijn plaats is.

"De taak van de genetic counselor (vaak kortheidshalve gedefinieerd als helpen bij de realisering van de 'parental goals' van de cliënt) is en blijft gericht op het bevorderen van geinformeerde keuzen die passen bij de eigen waarden van de cliënt, met dien verstande dat de beschikbare genetische technieken niet mogen worden toegepast om te selecteren tegen normale kenmerken of gezondheid. "

Deze precisering, of, negatief geformuleerd, deze inperking is te verdedigen met een beroep op de professionele standaard van de beroepsgroep. De rechtvaardiging om een dergelijk verzoek af te wijzen zou ook gevonden kunnen worden in het toekomstige zelfbeschikkingsrecht. Door bewust voor een doof kind te kiezen worden het kind kansen en mogelijkheden onthouden. Het gaat er hier niet om het kind in de toekomst een keuze tussen weten en niet weten te kunnen laten maken, maar om het openhouden van mogelijkheden voor het kind om zich te ontplooien. ${ }^{123}$ Verplichte kennisgeving van gegevens uit erfelijkheidsonderzoek aan zestienjarigen?

Het feit dat aanstaande ouders te allen tijde het recht houden een zwangerschap te continueren betekent dat er kinderen worden geboren waarover informatie betreffende toekomstige gezondheidsrisico's bekend is. Hoe dient hiermee om te worden gegaan? Roscam Abbing heeft de vraag gesteld of verplichte kennisgeving van de opslag van medische persoonsgegevens vanaf de leeftijd van zestien jaar

121 De Wert 1999, p. 208.

122 De Wert 1999, p. 208.

123 Davis besteedt ook aandacht aan de situatie waarin een doof echtpaar aangeeft de voorkeur te geven aan een doof kind. Zij rechtvaardigt de afwijzing hiervan met een beroep op het toekomstige zelfbeschikkingsrecht en het van Feinberg afkomstige recht op een open toekomst van de ongeborene: "A decision, made before a child is even born, that confines her forever to a narrow group of people and a limited choice of careers, so violates the child's right to an open future that no genetic counseling team should acquiesce in it. The very value of autonomy that grounds the ethics of genetic counseling should preclude assisting parents in a project that so dramatically narrows the autonomy of the child to be." Davis 1997, p. 7-15. 
geboden is. ${ }^{124}$ Dit kan informatie betreffen uit prenataal onderzoek, maar ook informatie uit een erfelijkheidsonderzoek bij een kind onder de 12 jaar. ${ }^{125}$

Binnen een behandelingsovereenkomst bestaat het recht op informatie van de adviesvrager en de plicht tot informeren van de klinisch geneticus. Bij prenatale diagnostiek zijn de ouders de adviesvragers en heeft de klinisch geneticus jegens hen een informatieplicht. Er bestaat geen informatieplicht van de klinisch geneticus ten opzichte van het kind bij wie, in het foetale stadium, prenataal onderzoek is verricht. Evenmin heeft de geneticus een informatieplicht ten opzichte van het kind waarbij toen het jonger was dan 12 jaar cen erfelijkheidsonderzoek is uitgevoerd. De ouders zijn destijds over de uitslag geinformeerd. ${ }^{26}$ Wanneer deze plicht wel bestond zou de klinisch geneticus verplicht zijn elk kind bij wie hij onderzoek heeft verricht en dat inmiddels 16 jaar is geworden te informeren over het feit dat er destijds onderzoek is verricht en dat hij desgewenst de resultaten hiervan kan inzien. Dit is een vergaande plicht die een grote verantwoordelijkheid van de klinisch geneticus veronderstelt. Afgezien nog van de praktisch-organisatorische bezwaren die een dergelijke plicht zou oproepen, is bovendien aannemelijk dat niet alle informatie uit ondergaan erfelijkheidsonderzoek voor 16-jarigen van belang is.

Welke informatie is van belang voor het 16-jarige kind? Hiervoor is onderscheid gemaakt tussen drie categorieën erfelijkheidsonderzoek bij kinderen. In de eerste categorie was preventie mogelijk. Hierbij kan men ervan uitgaan dat het kind op de hoogte is van de uitslag van het erfelijkheidsonderzoek, gezien de maatregelen die bij een ongunstige uitslag zullen zijn genomen. De tweede categorie betrof onderzoek waarbij preventieve maatregelen de prognose wellicht konden verbeteren. Ook bij deze categorie zullen bij een ongunstige uitslag preventieve maatregelen worden getroffen, gezien het feit dat deze de prognose positief zouden kunnen beïnvloeden. Men mag er daarom vanuit gaan dat het kind op de hoogte is van de uitslag. De derde categorie betrof aandoeningen waarvoor geen preventie mogelijk is. Wanneer deze eerst op volwassen leeftijd tot uiting kunnen komen zal hiernaar geen erfelijkheidsonderzoek worden gedaan. Voor aandoeningen met een variabele beginleeftijd is dit anders. Wanneer hiernaar onderzoek is gedaan en gebleken is dat het kind de mutatie draagt, maar deze niet op kinderleeftijd tot uiting is gekomen, kan deze informatie van groot belang zijn voor de 16-jarige.

Bij prenataal DNA-onderzoek is het zo dat alleen onderzoek wordt uitgevoerd naar monogene autosomaal dominant erfelijke, autosomaal recessief erfelijke en Xgebonden aandoeningen. Er bestaat geen lijst waarin de afwijkingen staan

124 Roscam Abbing 1994c, p. 7-8.

125. Gevers pleit hiervoor, voor wat betreft beschikbare informatie verkregen uit prenataal onderzoek. Hij gaat er daarbij vanuit dat de informatie medisch van belang is, als hij zo lang bewaard is. Gevers 1996, p. 28.

126 Hierbij ga ik ervan uit dat het kind het kind destijds niet is geïformeerd omdat te verwachten is dat het destijds niet paste bij zijn bevattingsvermogen om geïformeerd te worden over de uitslag. Zie artikel 7:448 lid 1 BW, laatste volzin. 
opgenomen die door middel van prenataal onderzoek worden opgespoord. ${ }^{127}$ Voor kinderen, waarbij in het foetale stadium onderzoek is verricht, is vooral die informatie van belang die uitwijst dat zij mutatiedrager zijn van een gen dat op volwassen leeftijd tot een aandoening zal leiden alsmede gebleken dragerschap van een recessieve mutatie of een gebalanceerde translocatie. Deze mutatie of translocatie kan een verhoogd risico mee zich brengen op kinderen met een erfelijke aandoening. Alleen deze informatie en de informatie verkregen uit onderzoek bij een kind naar een aandoening die zich nog zal manifesteren, is mijns inziens van belang voor 16jarigen.

Genoemde informatie die uit erfelijkheidsonderzoek bij kinderen of door middel van prenatale diagnostiek is verkregen betreft het kind zelf en kan voor hem van groot belang zijn. Dit rechtvaardigt dat, in de situaties waarin sprake is van beschikbare informatie uit in het verleden ondergaan erfelijkheidsonderzoek die van belang kan zijn voor een 16-jarige, sprake is van een recht op weten van het kind dat 16 jaar of ouder is. ${ }^{128}$ De informatieplicht impliceert tevens een bewaarplicht. ${ }^{129}$ De gegevens verkregen uit onderzoek die voor het kind van belang kunnen zijn, dienen bewaard te blijven zodat het kind wanneer het 16 is, en er een beroep op doet, deze in kan zien. Deze plicht valt bovendien reeds af te leiden uit artikel 7:454 lid 3 BW dat bepaalt:

"Onverminderd het bepaalde in artikel 455, bewaart de hulpverlener de bescheiden, bedoeld in de vorige leden, gedurende tien jaren, te rekenen vanaf het tijdstip waarop zij zijn vervaardigd, of zoveel langer als redelijkerwijs uit de zorg van een goed hulpverlener voortvloeit."

\subsection{Samenvatting}

In dit hoofdstuk stond het recht op niet weten centraal. Allereerst is de vraag aan de orde geweest of dit recht niet strijdig is met het zelfbeschikkingsrecht. Ervan uitgaande dat alleen een adviesvrager zelf kan bepalen of het besluit om bepaalde informatie niet te willen ontvangen, gebaseerd is op alle voor hem relevante

\section{Zie hoofdstuk 4.}

128 In de "Beleidsnota De toepassing van genetica in de gezondheidszorg" geeft de minister aan dat zij het pleidooi in de gezondheidsrechtelijke literatuur onderschrijft om kinderen vanaf 16 jaar het recht te geven zich te informeren omtrent het bestaan van op hen betrekking hebbende eerder verzamelde gegevens. Zij geeft aan de beroepsgroep te vragen hiervoor nadere praktijkregels op te stellen. Ministerie van Volksgezondheid, Welzijn en Sport 2000, p. 40. Aldus ook Kamerstukken II 2001/02, 27 543, nr. 5, p. 4.

129 Deze bewaarplicht geldt voor de klinisch geneticus uiteraard alleen wanneer hij over de genoemde informatie beschikt. Indien het laboratorium, zoals voorgesteld, in de uitslagbrief alleen vermeldt of de vrucht zal gaan leiden aan een erfelijke aandoening en niet vermeldt of sprake is van dragerschap van een mutatie of een gebalanceerde translocatie, heeft de klinisch geneticus niet de beschikking over deze gegevens. 
informatie, is een besluit om geen informatie te willen ontvangen juist een autonome keuze. Niet geldt de eis dat de keuze rationeel is in de ogen van anderen.

Vervolgens is aangegeven dat het recht op niet weten uit drie aspecten bestaat, te weten het recht om zelf te bepalen of informatie tot stand word gebracht en daarmee het recht om zelf te beslissen omtrent het wel of niet ondergaan van een erfelijkheidsonderzoek. Ten tweede het recht om bestaande informatie niet te ontvangen. Dit aspect wordt geregeld in artikel 7:449 BW. Ten derde het recht om niet te weten of men een verhoogd risico loopt op een erfelijke aandoening. Dit aspect wordt in het volgende hoofdstuk besproken.

Het recht om zelf te bepalen of informatie betreffende de gezondheid tot stand wordt gebracht is af te leiden uit en wordt beschermd door het recht op respect voor de persoonlijke levenssfeer. Dit recht leidt ertoe dat niemand verplicht is een erfelijkheidsonderzoek te ondergaan. De adviesvrager moet hiermee zelf instemmen. Er kan zich evenwel een aantal situaties voordoen waarin de adviesvrager een zeker dwang voelt om een erfelijkheidsonderzoek te ondergaan. Door de structurele aanwezigheid van belangen van verwanten, bestaat het gevaar dat men tot een erfelijkheidonderzoek besluit uitsluitend of voornamelijk in het belang van anderen. Ook sociale druk kan aanleiding zijn voor een erfelijkheidsonderzoek. Het goed hulpverlenerschap brengt met zich mee dat de klinisch geneticus probeert na te gaan of de adviesvrager uit vrije wil een erfelijkheidonderzoek wil ondergaan.

Het recht om bestaande informatie betreffende de gezondheid niet te ontvangen heeft bij de erfelijkheidsadvisering speciaal gewicht. Met name bij voorspellend onderzoek kan het niet ontvangen van informatie van groot belang zijn voor de adviesvrager in verband met de invulling en perceptie van zijn leven. Het goed hulpverlenerschap vereist dat in ieder geval bij voorspellend onderzoek de adviesvrager wordt gewezen op het feit dat hij gebruik kan maken van zijn recht op niet weten. Indien het besluit om een erfelijkheidsonderzoek te ondergaan weloverwogen is genomen, mag men verwachten dat de adviesvrager niet snel op zijn besluit om de uitslag te vernemen zal terugkomen. Bij onverwachte bevindingen is er sprake van een andere situatie. Voorafgaand aan het erfelijkheidsonderzoek dient duidelijk op de mogelijkheid van onverwachte bevindingen te worden gewezen, zodat de adviesvrager aan kan geven of hij hiervan op de hoogte wil worden gesteld. Indien uit het erfelijkheidsonderzoek blijkt dat er inderdaad sprake is van onverwachte bevindingen, vereist de zorgvuldigheid dat nogmaals aan de adviesvrager gevraagd wordt of hij hieromtrent geïnformeerd wenst te worden.

Heeft de klinisch geneticus ook de plicht om de adviesvrager op zijn recht op niet weten te wijzen? Gesteld is dat het goed hulpverlenerschap vereist dat hier in het geval van voorspellend onderzoek op wordt gewezen en dat wordt besproken of de adviesvrager volledig geinformeerd wil worden over de resultaten. Bij voorspellend onderzoek betreft de uitslag het risico op een aandoening in de (nabije) toekomst bij de adviesvrager of een bloedverwant. Het feit dat dergelijk onderzoek om gezondheidsredenen uitgesteld kan worden, alsmede de mogelijke gevolgen ervan voor zowel de adviesvrager als familieleden, maken dat de klinisch geneticus als 
goed hulpverlener erop dient te wijzen dat de adviesvrager niet verplicht is om het erfelijkheidsonderzoek te ondergaan on ook niet verplicht is de informatie die uit het onderzoek komt te ontvangen.

Het recht om bestaande informatie niet te ontvangen kan de adviesvrager ertoe doen besluiten dat hij voorafgaand aan het erfelijkheidsonderzoek geen inlichtingen wil ontvangen. Het is echter aan de klinisch geneticus om te bepalen of het niet verstrekken van inlichtingen voorafgaand aan het erfelijkheidsonderzoek in overeenstemming is met zijn goed hulpverlenerschap.

Indien gebruikmaking van het recht om bepaalde inlichtingen niet te ontvangen leidt tot kennelijk ernstig nadeel voor de adviesvrager of voor anderen, worden de bedoelde inlichtingen alsnog verstrekt aan de adviesvrager. Met name twee situaties zijn hierbij denkbaar. Ten eerste de situatie waarin de adviesvrager vérgaande maatregelen en handelingen overweegt te treffen en verrichten, uitgaande van de onterechte veronderstelling dat hij in de toekomst zal gaan lijden aan een ernstige erfelijke ziekte. Ten tweede de situatie waarin de adviesvrager heeft aangegeven niet te willen worden ingelicht over onverwachte bevindingen, maar op grond van zijn persoonlijke omstandigheden aangenomen mag worden dat hij over de onverwachte bevinding wel geïformeerd wil worden.

In paragraaf 6.6 stond het recht op niet weten van kinderen en ongeborenen centraal. Aanleiding hiervoor was het feit dat dit recht kan botsen met het recht op informatie van de ouders. Kinderen kunnen geen recht op weten uitoefenen op het moment dat dit recht in het geding is. Daarom wordt hiervoor de term rights-in-trust of anticiperend autonomie recht gebezigd. Voor ongeborenen geldt hetzelfde. Bovendien zijn zij geen drager van rechten en plichten. Wel kan men spreken van beschermwaardige belangen waardoor er een zekere reflex-werking toekomt aan het recht op niet weten voor de geboorte.

Wanneer ouders bij hun kind een erfelijkheidsonderzoek willen laten verrichten is het altijd het belang van de ouders en het kind bij weten dat moet worden afgewogen tegen het belang van het kind bij niet weten. Het is een overweging die ouders als goede vertegenwoordigers dienen te maken, waarbij het belang van het kind voorop staat. Dit belang kan strijdig zijn met dat van de ouders. Daarnaast bevat het goed hulpverlenerschap ook de eigen verantwoordelijkheid van de klinisch geneticus voor de bescherming van de belangen van het kind. De vraag wanneer erfelijkheidsonderzoek in het belang van het kind is, hangt voornamelijk af van de mogelijkheden tot primaire en/of secundaire preventie. Bovendien zal de vraag of het onderzoek kan worden uitgesteld aan de orde moeten komen. Richtlijnen kunnen een steun zijn bij de concrete beantwoording door de klinisch geneticus van de vraag of een verzoek tot een erfelijkheidsonderzoek verenigbaar is met het goed hulpverlenerschap. Het verdient daarom aanbeveling dat de beroepsgroep deze opstelt.

Het te beschermen belang dat de ongeborene heeft om in de toekomst verschoond te blijven van bepaalde informatie kan beschermd worden door bij prenataal onderzoek 
alleen te informeren over het feit of de vrucht al dan niet aangedaan is en niet over dragerschap van een recessieve mutatie of een gebalanceerde translocatie. Gezien de afwezigheid van gezondheidsredenen om geinformeerd te worden over dragerschap en de aanwezigheid van het belang om zelf in de toekomst een keuze te kunnen maken, is hier een restrictief beleid gerechtvaardigd. Een additioneel argument vormen hier de mogelijk negatieve effecten van aangetoond dragerschap.

Het te beschermen belang dat de ongeborene heeft om in de toekomst verschoond te blijven van bepaalde informatie kan daarnaast beschermd worden door het stellen van voorwaarden aan de toegang tot prenatale diagnostiek. Verdedigd is de stelling dat indien ouders verzocken om een prenataal onderzoek naar later in het leven optredende onbehandelbare andoeningen, terwijl de keus om het kind geboren te laten worden reeds gemaakt is door de aanstaande ouders, de klinisch geneticus verplicht is, op grond van zijn goed hulpverlenerschap, om aan te geven dat het belang van de ouders bij een dergelijk verzoek minder zwaar weegt dan het belang van de ongeborene om in de toekomst zelf te kunnen beslissen of hij wil weten of zich in de toekomst een onbehandelbare ziekte zal openbaren. Wanneer de ouders volharden in hun verzoek, rest de klinisch geneticus de mogelijkheid om het verzoek op grond van zijn professionele standaard te weigeren. Daarnaast is betoogd dat de beschikbare genetische technieken niet mogen worden aangewend om te selecteren tegen normale kenmerken of gezondheid.

Het feit tot slot dat uit prenataal erfelijkheidsonderzoek of uit erfelijkheidonderzoek bij kinderen informatie kan worden gegenereerd die van belang kan zijn wanneer het kind 16 jaar of ouder is, rechtvaardigt dat er in dergelijke situaties sprake is van een recht op weten. Dit impliceert een bewaarplicht voor de klinisch geneticus.

In het volgende hoofdstuk zal de inhoud en de omvang van de geheimhoudingsplicht van de klinisch geneticus worden onderzocht. De situatie waarin ten gevolge van de geheimhoudingsplicht familieleden niet geïnformeerd kunnen worden en de situatie waarin ten gevolge van de geheimhoudingsplicht geen erfelijkheidsonderzoek bij de adviesvrager verricht kan worden zullen worden besproken. In beide situaties kan de klinisch geneticus zich in een conflict van plichten bevinden. De criteria waaraan voldaan moet zijn alvorens de klinisch geneticus zonder toestemming tot informeren mag overgaan, zullen daarbij aan de orde komen. 



\section{ERFELIJKHEIDSADVISERING EN GEHEIMHOUDING}

\subsection{Inleiding}

In de voorgaande hoofdstukken zijn aan de orde geweest: het recht op informatie, de therapeutische exceptie, het toestemmingsvereiste, het recht op weten en het recht op niet weten. In dit hoofdstuk wordt aandacht besteed aan de geheimhoudingsplicht. In de volgende paragraaf wordt kort ingegaan op de algemene inhoud van de geheimhoudingsplicht. Vervolgens wordt deze nader uitgewerkt voor de relatie adviesvrager-klinisch geneticus. Bij erfelijkheidsadvisering spelen structureel belangen van familieleden van de adviesvrager mee. Alvorens verder in te gaan op de geheimhoudingsplicht wordt eerst aandacht besteed aan de wijze waarop familieleden benaderd zouden moeten worden wanneer erfelijkheidsinformatie voor hen relevant kan zijn. Vervolgens zullen de situaties aan de orde komen waarin de geheimhoudingsplicht leidt tot het niet kunnen informeren van familieleden of het niet kunnen verrichten van erfelijkheidsonderzoek bij de adviesvrager. Het conflict van plichten wordt besproken als een mogelijkheid om de geheimhoudingsplicht op te heffen. Tevens wordt ingegaan op alternatieven voor het conflict van plichten.

\subsection{De geheimhoudingsplicht}

Het doel van de geheimhoudingsplicht is primair: het ervoor zorgen dat de patiënt zich zonder vrees dat hij zichzelf daardoor zou schaden in verband met het moeten prijsgeven van gevoelige gegevens, zich tot een hulpverlener kan wenden. Er dienen zo min mogelijk belemmeringen te zijn bij het aangaan van een behandelingsovereenkomst met een hulpverlener. Bovendien dient voorkomen te worden dat patiënten zich gedrongen voelen bepaalde gevoelige informatie achter te houden. Daarnaast dient de geheimhouding ook een individueel privacybelang. ${ }^{1}$ De patiënt heeft er recht op dat zijn gegevens geheim worden gehouden. De geheimhoudingsplicht van de hulpverlener is daarom een geheimhoudingsrecht van de patiënt. Het geheim behoort hem toe en wordt bewaard door de hulpverlener door te zwijgen. Door de geheimhoudingsplicht wordt de persoonlijke levenssfeer en het daarin besloten persoonlijk geheim van de patiënt beschermd. ${ }^{2}$ Het uitgangspunt bij het gebruik van medische gegevens is dat ze slechts mogen worden gebruikt voor het doel waarvoor ze zijn verstrekt. Het belang van de geheimhouding is, zoals opgemerkt, niet alleen een individueel belang. Het is in het algemeen belang dat de vrije toegang tot de gezondheidszorg wordt beschermd. Patiënten moeten, zonder angst voor schending van de geheimhoudingsplicht, naar een hulpverlener kunnen gaan en hem vertrouwelijke informatie kunnen verschaffen. ${ }^{3}$

Gevers 1995, p. 7.

De Brauw 1988, p. 9.

Leenen 2000, p. 222. 
De geheimhoudingsplicht van de hulpverlener is onder meer-1 geregeld in artikel 7:457 BW:

1. "Onverminderd het in artikel 448, lid 3, tweede volzin, bepaalde draagt de hulpverlener zorg, dat aan anderen dan de patiënt geen inlichtingen over de patiënt dan wel inzage in of afschrift van de bescheiden, bedoeld in artikel 454, worden verstrekt dan met toestemming van de patiënt. Indien verstrekking plaatsvindt, geschiedt deze slechts voor zover daardoor de persoonlijke levenssfeer van een ander niet wordt geschaad. De verstrekking kan geschieden zonder inachtneming van de beperkingen, bedoeld in de voorgaande volzinnen, indien het bij of krachtens de wet bepaalde daartoe verplicht.

2. Onder anderen dan de patiënt zijn niet begrepen degenen die rechtstreeks betrokken zijn bij de uitvoering van de behandelingsovereenkomst en degene die optreedt als vervanger van de hulpverlener, voor zover de verstrekking noodzakelijk is voor de door hen in dat kader te verrichten werkzaamheden.

3. Daaronder zijn evenmin begrepen degenen wier toestemming terzake van de uitvoering van de behandelingsovereenkomst op grond van de artikelen 450 en 456 is vereist. Indien de hulpverlener door inlichtingen over de patiënt dan wel inzage in of afschrift van de bescheiden te verstrekken niet geacht kan worden de zorg van goed hulpverlener in acht te nemen, laat hij zulks achterwege."

De hoofdregel luidt dat de hulpverlener geen mededelingen aan derden mag doen over gegevens omtrent de patiënt. Dit geldt ook voor een ziekenhuis of andere instelling wanneer zij als hulpverlener optreden. Onder anderen zijn niet begrepen degenen die rechtstreeks betrokken zijn bij de uitvoering van de behandelingsovereenkomst alsmede de vertegenwoordigers van de patiënt. Een uitzondering kan gemaakt worden wanneer de patiënt hiervoor toestemming geeft.

De geheimhoudingsplicht is ook in het straf-en bestuursrecht geregeld. Artikel 272 lid 1 van het Wetboek van Strafrecht stelt: “Hij die enig geheim waarvan hij weet of redelijkerwijs moet vermoeden dat hij uit hoofde van ambt, beroep of wettelijk voorschrift dan wel vroeger ambt of beroep verplicht is het te bewaren, opzettelijk schendt, wordt gestraft met gevangenisstraf van te hoogste een jaar of geldboete van de vierde categorie." In het Wetboek van Strafvordering wordt in artikel 218 het verschoningsrecht geregeld: "Van het geven van getuigenis of van het beantwoorden van bepaalde vragen kunnen zich ook verschoonen zij die uit hoofde van hun stand, hun beroep of hun ambt tot geheimhouding verplicht zijn, doch alleen omtrent hetgeen waarvan de wetenschap aan hen als zoodanig is toevertrouwd." Artikel 8:33 lid 3 Algemene wet bestuursrecht verklaart van artikel 191 de leden 2 en 4 van het Wetboek van burgerlijke rechtsvordering van toepassing dat een verschoningsrecht toekent in lid 2, onder b aan: "zij die tot geheimhouding verplicht zijn uit hoofde van hun ambt, beroep of betrekking omtrent hetgeen hun in die hoedanigheid is toevertrouwd." Ook de Wet op de beroepen in de individuele gezondheidszorg regelt het beroepsgeheim. Artikel 88 luidt: "Een ieder is verplicht geheimhouding in acht te nemen ten opzichte van al datgene wat hem bij het uitoefenen van zijn beroep op het gebied van de individuele gezondheidszorg als geheim is toevertrouwd, of wat daarbij als geheim te zijner kennis is gekomen of wat daarbij te zijner kennis is gekomen en waarvan hij het vertrouwelijke karakter moest begrijpen." Mits vallend onder het tuchtrecht kan het ten onrechte doorbreken van de geheimhoudingsplicht een reden zijn voor een tuchtrechtelijke maatregel. 
Volgens het eerste lid van artikel 7:457 BW mag in dat geval aan anderen wel informatie worden verstrekt. Een tweede uitzondering is te vinden in artikel 7:448 lid $3 \mathrm{BW}$, war de therapeutische exceptie is geregeld: de hulpverlener mag op grond daarvan aan een ander dan de patiënt inlichtingen verstrekken. Een derde uitzondering is gelegen in het feit dat wet- of regelgeving de hulpverlener er soms toe verplichten om gegevens te verstrekken. En voorbeeld hiervan is de Infectieziektenwet. Een vierde uitzondering is aan de orde wanneer de hulpverlener op grond van overmacht zich genoodzaakt ziet zijn geheimhoudingsplicht te doorbreken. ${ }^{5}$ Deze uitzondering wordt in de volgende paragraaf besproken.6

\subsection{Erfelijkheidsadvisering en de geheimhoudingsplicht}

Eén van de specifieke kenmerken van erfelijkheidsinformatie is dat deze informatie, behalve voor de adviesvrager, ook van belang kan zijn voor bloedverwanten van de adviesvrager. Door middel van het aantonen van een erfelijke ziekte of een genetische afwijking die leidt of kan leiden tot een erfelijke ziekte, bij de adviesvrager of zijn nageslacht, kan het risico voor bloedverwanten op dezelfde erfelijke ziekte worden vastgesteld.

Het uitgangspunt is dat ten opzichte van niemand de geheimhoudingsplicht mag worden doorbroken, tenzij met toestemming van de adviesvrager? Ook in de erfelijkheidsrichtlijnen wordt dit uitgangspunt gehanteerd:

"Ieder heeft het recht zelf te beslissen of zijn erfelijkheidsgegevens en lichaamsmateriaal worden verstrekt aan anderen dan degenen die beroepsmatig rechtstreeks bij het aktuele erfelijkheidsonderzoek zijn betrokken."s

\subsubsection{Het benaderen van familieleden}

Erfelijkheidsinformatie die verkregen wordt door middel van een erfelijkheidsonderzoek kan ook van belang zijn voor familieleden van de adviesvrager. 9 In de erfelijkheidsrichtlijnen wordt hierover het volgende gesteld:

$5 \quad$ Sluijters 1999 , p. 425-426 en Kamerstukken II 1989/90, 21 561, nr.3, p. 38-40.

6 Voor een beschouwing over de toekomst van de geheimhoudingsplicht: Dute 1995, p. 79-89.

7 Met betrekking tot de verwerking van persoonsgegevens betreffende erfelijke eigenschappen wordt hetzelfde uitgangspunt gehanteerd. In artikel 21 lid $4 \mathrm{Wbp}$ is geregeld dat deze slechts mogen worden verwerkt voor zover deze verwerking plaatsvindt met betrekking tot de betrokkene bij wie de betreffende gegevens zijn verkregen.

s Vereniging voor Gezondheidsrecht 1991, uitgangspunt 3.4.

9 Dit is bijvoorbeeld anders wanneer het informatie betreft over een bij de adviesvrager nieuw ontstane mutatie. Een dergelijke mutatie kan wel van belang zijn voor het nageslacht van de adviesvrager. 
"Als de arts vindt dat bepaalde informatie aan familieleden niet onthouden kan worden, bespreekt hij dit met de cliënt. Hij verzoekt de cliënt de betrokken familieleden te informeren. Als de client de arts vraagt dit voor hem te doen, voldoet de arts aan dat verzoek."10

De klinisch geneticus kan met - en wanneer hij zich in een conflict van plichten bevindt zonder ${ }^{11}$ - toestemming van de adviesvrager familieleden van de adviesvrager inlichten over erfelijkheidsinformatie die voor hen relevant kan zijn.

Mag de klinisch geneticus familieleden inlichten?

Alvorens in te gaan op de vraag op welke wijze dit zou moeten geschieden, dient eerst de vraag aan de orde te komen of de klinisch geneticus wel gerechtigd is om, met of zonder toestemming van de adviesvrager, familieleden ongevraagd te informeren. ${ }^{12}$ Het betreft informatie die grote gevolgen kan hebben voor die familieleden, zonder dat zij in de gelegenheid zijn om te beslissen of zij geïnformeerd willen worden. De keus om wel of niet geïnformeerd te worden kan niet besproken worden zonder dat men weet dát er informatie beschikbaar is. Met andere woorden: familieleden kunnen hun recht op niet weten niet volledig uitoefenen. $\mathrm{Zij}$ kunnen alleen aangeven, op de hoogte gesteld van het feit dat er erfelijkheidsinformatie beschikbaar is, dat zij niet verder geïnformeerd willen worden. Welk belang prevaleert: het mogelijk belang bij erfelijkheidsinformatie of het mogelijk belang bij het verschoond blijven van erfelijkheidsinformatie? Deze vraag speelt alleen wanneer familieleden niet op de hoogte zijn van het feit dat erfelijkheidsinformatie beschikbaar kan komen die voor hen van belang kan zijn. Indien zij door de adviesvrager hiervan wel op de hoogte zijn gebracht, kunnen zij alvorens erfelijkheidsinformatie tot stand wordt gebracht, reeds aangeven of zij op de hoogte willen worden gebracht van de aanwezigheid van een verhoogd risico op een erfelijke aandoening. Wanneer familieleden er niet van op de hoogte zijn dat er erfelijkheidsinformatie is die voor hen van belang kan zijn, verdient het om de volgende redenen de voorkeur de familieleden in kennis te stellen van het feit dat er erfelijkheidsinformatie beschikbaar is die voor hen van belang kan zijn en dat zij daar desgewenst van op de hoogte kunnen worden gesteld.13

Ten eerste wordt informatie tot stand gebracht die mogelijk grote gevolgen heeft voor het leven van familieleden. Zelfbeschikking in de betekenis dat mensen zelf

ing voor Gezondheidsrecht1991, richtlijn A 7.

Zie hiervoor de volgende paragraaf.

Kuitert beantwoordt deze vraag ontkennend: "Het is niet geoorloofd een ander mens op te zadelen met problemen waar hij niet om heeft gevraagd." Kuitert 1989, p. 180.

Markenstein, Gevers en Roscam Abbing noemen het meedelen aan familieleden dat er relevante informatie beschikbaar is een mogelijkheid om het maken van een keuze door de betrokkenen zelf te bevorderen. Deze mededeling is mijns inziens geen optie, maar de enige aanvaardbare manier om enerzijds aan familieleden kenbaar te maken dat er relevante erfelijkheidsinformatie beschikbaar is en anderzijds het recht op niet weten zo veel mogelijk te beschermen, door hen in staat te stellen zelf de keuze te maken of zij willen weten om welke informatie het gaat. Markenstein, Gevers en Roscam Abbing 1999, p. 49-50. 
keuzes maken die het beste bij hun situatie past, vereist dat zij kunnen beschikken over informatie die voor hen relevant is bij het maken van beslissingen over bijvoorbeeld het krijgen van kinderen en het kiezen voor een bepaalde carrière. Zonder deze informatie zijn geïnformeerde keuzes, gerelateerd aan de gezondheid en het welzijn, voor deze familieleden niet mogelijk. De ongevraagde wetenschap dat erfelijkheidsinformatie beschikbaar is leidt weliswaar in eerste instantie tot een beperking van de zelfbeschikking, maar resulteert, door de vergroting van de opties, uiteindelijk tot een situatie waarin geinformeerd wordt beschikt. ${ }^{14}$

Daarbij dient er wel voor gewaakt te worden dat er niet een schril contrast ontstaat tussen enerzijds de benadering van onwetende familieleden en anderzijds de zorgvuldigheid van de erfelijkheidsadvisering voorafgaand aan de beslissing om erfelijkheidsonderzoek te laten verrichten. Een zelfde zorgvuldige handelwijze is ook geboden bij de beslissing een onwetend familielid al dan niet op de hoogte te stellen en de eventuele erfelijkheidsadvisering die daarop volgt. ${ }^{15}$ Een familielid dat door de adviesvrager of de klinisch geneticus wordt geinformeerd omtrent de aanwezigheid van een verhoogd risico op of de aanwezigheid van een erfelijke ziekte, wordt als het ware uitgenodigd een erfelijkheidsonderzoek te ondergaan. Dit maakt dat de klinisch geneticus er extra voor moet waken dat de uiteindelijke keuze om een erfelijkheidsonderzoek te laten verrichten een autonome, vrije en geinformeerde keuze is.

Ten tweede wordt in onze maatschappij een goede gezondheid als zeer belangrijk ervaren. De Commissie DNA-diagnostiek van de Gezondheidsraad merkt op dat:

"als er een mogelijkheid bestaat om ziekteverschijnselen te voorkómen, uit te stellen of te beperken, zal voor velen zelfs een geringe risicoverhoging voldoende aanleiding zijn een DNA-test te vragen." 16

Dit leidt tot de veronderstelling dat erfelijkheidsinformatie door veel mensen als voor hen relevante informatie zal worden beschouwd en dat zij op de hoogte willen worden gesteld van het feit dat er informatie beschikbaar is.

Familieleden kunnen ook ongevraagd worden geïnformeerd wanneer ten behoeve van de adviesvrager familiegegevens worden opgevraagd. Indien zij niet op de

1. Husted 1996, p. 58. Na deze opvatting te hebben beschreven, bestrijdt de auteur deze opvatting: "One could instead argue that in many cases what were initially very valuable options for the person to choose (for one set of reasons) or not to choose (for a different set of reasons) were being closed due to the disclosure. (...) she or he may now be struggling for moral survival. (...) a life of morally forced choices." De wetenschap dat er erfelijkheidsinformatie beschikbaar is kan bij een goede erfelijkheidsadvisering nooit leiden tot moreel geforceerde keuzes. Het is wel mogelijk dat het familielid niet op de wetenschap zit te wachten dat er erfelijkheidsinformatie beschikbaar is. Dat is het belang dat afgewogen moet worden tegen het belang om hiervan wel op de hoogte te worden gesteld.

15 Markenstein, Gevers en Roscam Abbing 1999, p. 47.

16 Gezondheidsraad 1998, p. 102. 
hoogte waren of zich niet realiseerden dat er mogelijk een erfelijke aandoening in de familie voorkomt, betekent het vragen van toestemming voor het opvragen van familiegegevens dat zij hier ongevraagd mee worden geconfronteerd. Daar staat tegenover dat de erfelijkheidsinformatie warmee ze worden geconfronteerd ook voor deze familieleden van belang kan zijn. Ook in deze situaties is voorzichtigheid geboden. Het recht op een persoonlijke levenssfeer dient zo veel mogelijk te worden gerespecteerd. ${ }^{17}$

\section{Wanne'r mogen verwanten worten ingelicht?}

$\mathrm{Nu}$ de vraag beantwoord is of de klinisch geneticus familieleden op de hoogte mag stellen, ${ }^{1 s}$ dienen de vragen wanneer dit mag en hoe dit zou moeten gebeuren beantwoord te worden. Eerst de vraag wanneer dit zou mogen. In de literatuur wordt hierover opgemerkt:

"Het is duidelijk, dat de hulpverlener zich het best kan laten leiden door hetgeen een redelijk persoon zou willen weten (analoog aan art. 7:448 lid 2 BW betreffende aan de patiënt te verstrekken informatie)."19

Het wettelijk uitwerken van deze norm lijkt hen weinig zinvol. Zij achten het belangrijk dat de professie zich bezint op de vraag bij welke vormen van erfelijkheidsonderzoek de voordelen van bepaalde relevante gegevens aan familieleden voor hen zozeer opwegen tegen de nadelen, dat voor wel informeren moet worden gekozen.

Leenen constateert dat er geen andere mogelijkheid is dan te aanvaarden dat familieleden kunnen worden geïformeerd over de beschikbaarheid van gegevens. Hij noemt geen criterium. Hij stelt wel dat informeren kan worden nagelaten indien moet worden verwacht dat de informatie het familielid schade toe zal brengen. ${ }^{20}$ Wanneer moet worden verwacht dat de informatie het familielid schade zal toebrengen, zal het informeren moeten worden nagelaten. De veronderstelling dat de erfelijkheidsinformatie beschouwd zal worden als relevante informatie die het familielid zal willen ontvangen, die het informeren rechtvaardigt, is in dergelijke

17 Gezondheidsraad 1989, p. 100-101.

18 De vraag of een klinisch geneticus onder omstandigheden familieleden op de hoogte moet stellen is in hoofdstuk 5 aan de orde geweest. Daar is vastgesteld dat de klinisch geneticus geen waarschuwingsplicht heeft ten opzichte van bloedverwanten van de adviesvrager.

19 Markenstein, Gevers en Roscam Abbing 1999, p. 49. In zijn preadvies uit 1987 komt Gevers tot een conclusie van dezelfde strekking: "De arts zal hier de weg moeten kiezen waarbij aan de mogelijkheid tot zelfbeschikking het meeste recht wordt gedaan en dic informatie verstrekken die voor hen relevant is en waarvan redelijkerwijs mag worden aangenomen, dat zij die - indien voor de keus gesteld - zouden willen ontvangen". Gevers 1987, p. 38. In omgekeerde zin De Wert: "(..) hij dient daarvan af te zien wanneer redelijkerwijze moet worden aangenomen dat de verwanten, indien voor de keus gesteld, de betreffende informatie niet zouden willen ontvangen." De Wert, XVI Ethische aspecten, hoofdstuk 1, paragraaf 1.3 . 
situaties niet juist. In dezelfde zin stelt Gevers dat van het verstrekken van op zichzelf belangrijke inlichtingen zou moeten worden afgezien, indien er gegronde redenen zijn om aan te nemen dat de betreffende informatie niet gewenst wordt of voor het familielid meer schade dan baat zou opleveren. ${ }^{21}$ De norm is dus het redelijke familiolid, met rumte voor feitelijke omstandigheden die ander licht op dit uitgangspunt kumnen werpen.

De Commissie DNA-diagnostiek van de Gezondheidsraad merkt op dat het soms duidelijk zal zijn dat familieleden er een aanzienlijk belang bij hebben om voor een mogelijk genetisch risico gewaarschuwd te worden, met name wanneer het om een aandoening gaat met ernstige gevolgen, terwijl kennis van het risico één of meer reële handelingsopties biedt. $\mathrm{Zij}$ wijst er echter op dat het hierbij steeds meer om multifactoriële aandoeningen zal gaan. Bij multifactoriële aandoeningen zal het juist niet altijd duidelijk zijn of familieleden belang hebben bij erfelijkheidsinformatie. Omdat dergelijk onderzoek bovendien ook steeds vaker buiten de klinisch genetische centra zal platsvinden, is het volgens de Commissie noodzakelijk dat er binnen de betreffende specialismen in samenspraak met klinisch genetici duidelijke richtlijnen worden ontwikkeld. Enerzijds kumnen deze richtlijnen steun bieden bij het maken van een zorgvuldige afweging en anderzijds kunnen zij te grote verschillen in het handelen van hulpverleners voorkomen. ${ }^{22}$

Het belang van duidelijke richtlijnen is groot, mede gezien de toename van crfelijkheidsonderzoek naar multifactoriële aandoeningen en het feit dat dergelijk onderzoek plaatsvindt buiten de klinisch genetische centra. De norm voor hulpverleners om zich te laten leiden door hetgeen een redelijk persoon zou willen weten, lijkt onder deze omstandigheden niet meer dan een uitgangspunt te kunnen vormen.

Op welke wijze moeten verwanten worden ingelicht?

Wanneer het besluit genomen is om één of meerdere bloedverwanten in te lichten omtrent de aanwezigheid van erfelijkheidsinformatie, moet nog besloten worden hoe deze verwanten het beste kunnen worden ingelicht. Er zijn verschillende mogelijkheden. De adviesvrager kan mondeling of schriftelijk zijn familieleden inlichten. Een andere mogelijkheid is dat de klinisch geneticus dit doet. Hij kan dit mondeling of schriftelijk doen, maar kan ook de huisarts of een vertrouwensarts hierbij inschakelen. Welke wijze is te prefereren?

Van belang bij de beantwoording van deze vraag is het feit dat de klinisch geneticus geen behandelingsovereenkomst heeft met de familieleden voor wie de erfelijkheidsinformatie relevant is. Het verdient om die reden de voorkeur dat de adviesvrager zijn familieleden informeert. Dit is in overeenstemming met de erfelijkheidsrichtlijn die aan het begin van deze paragraaf is aangehaald. Gevers is van mening dat de klinisch geneticus zich er in zo'n geval wel van dient te

\footnotetext{
21 Gevers 1987 , p. 38-39.

22 Gezondheidsraad 1998, p. 105.
} 
vergewissen dat de informatie op een adequate manier is overgebracht. ${ }^{23}$ Hij gaat verder niet in op de wijze waarop dit zou moeten gebeuren. Het ligt voor de hand om te veronderstellen dat hij ervan uitgaat dat de klinisch geneticus dit afstemt met de adviesvrager, aangezien de klinisch geneticus niet beschikt over de adressen van de desbetreffende verwanten. Een principieel bezwaar is bovendien gelegen in het recht op respect voor de persoonlijke levenssfeer van de familieleden van de adviesvrager. De door Gevers gestelde eis dat de geneticus zich ervan dient vergewissen dat de informatie op adequate wijze is overgebracht, is mijns inziens niet haalbaar. Het informeren bij de adviesvrager of hij zijn familieleden heeft geïnformeerd kan niet de zekerheid geven dat familieleden op adequate wijze zijn geïformeerd. De eis zou daarom moeten worden gematigd. De klinisch geneticus dient redelijke inspanningen te verrichten om ervoor te zorgen dat familieleden door de adviesvrager worden ingelicht. Of de inspanningen redelijk zijn zal afhangen van de belangen die er voor verwanten op het spel staan. Indien de belangen groot zijn en de klinisch geneticus bijvoorbeeld geen familieleden terugziet, terwijl het een grote familie betreft waardoor hij aanneemt dat in ieder geval een aantal familieleden zich voor een erfelijkheidsadvies tot een klinisch geneticus zal wenden, kan dit voor hem een aanleiding zijn om nogmaals bij de adviesvrager te informeren of het inlichten van zijn verwanten goed is verlopen. De inspanningen zullen er echter voornamelijk uit bestaan dat de klinisch geneticus ten eerste tijdens de erfelijkheidsadvisering het belang van de informatie voor familieleden duidelijk makt en ten tweede de adviesvrager helpt met het informeren van zijn familieleden wanneer hij daar om verzoekt.

De erfelijkheidsrichtlijnen stellen dat de klinisch geneticus de familieleden moet informeren wanneer de adviesvrager dit vraagt. Een adviesvrager kan goede redenen hebben om wel toestemming te verlenen om zijn familieleden in te lichten, maar het informeren zelf niet op zich te willen nemen. Een slechte relatie met familieleden kan hiervan de oorzaak zijn, maar ook kan de belasting te groot te zijn wanneer de adviesvrager zelf slecht nieuws heeft gekregen naar aanleiding van het erfelijkheidsonderzoek dat hij heeft laten verrichten. Bovendien heeft de adviesvrager recht op privacy. ${ }^{24} \mathrm{Hulp}$ in enigerlei vorm van de klinisch geneticus is dan geboden. De klinisch geneticus is ook degene die heeft gewezen op het mogelijk belang van familieleden bij de erfelijkheidsinformatie. Hierbij dient men echter steeds zoveel mogelijk te streven naar het informeren van familieleden via de adviesvrager. Hij is degene die een relatie heeft met zijn familieleden. Een mogelijkheid is dat de klinisch geneticus een brief opstelt die de adviesvrager verstrekt aan zijn familieleden. Een brief is voor de klinisch geneticus een goede mogelijkheid om ervoor te zorgen dat de informatie die wordt overgebracht medisch

23

\section{Gevers 1987, p. 39.}

Ten Kate 1980, p. 159-161. Ten Kate noemt verder nog als redenen voor de adviesvrager om zelf de familie niet te willen informeren het feit dat men het betreffende familielid soms niet persoonlijk kent en ten tweede is het vaak binnen de familie taboe om de mogelijkheid van een erfelijke genese ter sprake te brengen omdat het onderwerp door de aard van de handicap of de verwachte reactie van de betrokkene te delicaat is om het inlichten aan de adviesvrager over te laten. 
juist is. Wanneer de klinisch geneticus de familieleden zou informeren kan dit bedreigender zijn dan wanneer de adviesvrager dit doet. Het gevaar bestaat dat wanneer de klinisch geneticus aangeeft dat erfelijkheidsinformatie beschikbaar is, dit de indruk zou kunnen wekken dat het onverstandig, of misschien zelfs onverantwoord, is om van dergelijke informatie niet op de hoogte te willen worden gesteld. Het is immers ongebruikelijk om persoonlijk door een hulpverlener, buiten het bestaan van een behandelingsovereenkomst, ongevraagd op een medisch risico te worden gewezen.

Het bovenstaande geldt ook in de situatie warin familieleden toestemming moet worden gevraagd voor het opvragen van hun gegevens. Ook hier is de adviesvrager de eerst aangewezen persoon om zijn familieleden te benaderen. ${ }^{25}$

\section{Inlichten vin de huisarts?}

Het inlichten van familieleden, met of zonder toestemming van de adviesvrager, kan ook door de huisarts van het betreffende familielid worden gedaan. Eén van de eisen voor de aanvaardbaarheid van een conflict van plichten ${ }^{26}$ is dat de gegevens alleen aan de behandelend arts van het familielid worden verstrekt. ${ }^{27} \mathrm{Bij}$ erfelijkheidsadvisering zal dit veelal de huisarts van het familielid betreffen. Het informeren van de huisarts levert, wanneer dit zonder toestemming van de adviesvrager gebeurt, en hij niet rechtstreeks betrokken is bij de uitvoering van de behandelingsovereenkomst, op grond van artikel 7:457 lid 1 en $2 \mathrm{BW}$, een schending van de geheimhoudingsplicht op. Bij erfelijkheidsadvisering zal het vaak om gevoelige informatie gaan. Het betrekken van een andere hulpverlener bij de behandelingsovereenkomst dient alleen te geschieden wanneer er een wettelijk voorschrift, zoals in het geval van de therapeutische exceptie, is of wanneer dit om medische redenen geïndiceerd is. Dit laat echter onverlet dat de klinisch geneticus goede redenen moet hebben om een andere hulpverlener erbij te betrekken en hem te informeren. Een goede reden is bijvoorbeeld aanwezig indien de adviesvrager het betreffende familielid niet zelf wil informeren, de geneticus telefonisch informeren niet in overeenstemming acht met zijn goed hulpverlenerschap en het betreffende familielid ver weg woont. Onder die omstandigheden is het verdedigbaar om het informeren aan een andere arts over te laten.

\section{De erfelijke andoening vermelden?}

Als familieleden op de hoogte worden gebracht van het feit dat er erfelijkheidsinformatie bestaat die voor hen relevant kan zijn, moet daarbij worden aangegeven welke aandoening het betreft? Indien de adviesvrager zijn familieleden inlicht, is het aan hem om te bepalen hoeveel informatie hij verstrekt aan familieleden. De klinisch geneticus en de adviesvrager kunnen hierover overleggen. De klinisch geneticus kan erop wijzen dat familieleden recht hebben op respect voor

\section{Gezondheidsraad 1989, p. 100-101.}

26 In de volgende paragraaf wordt ingegaan op het conflict van plichten.

27 Leenen 2000, p. 84. Sluijters heeft voorgesteld om ook de beslissing om de geheimhoudingsplicht te doorbreken over te laten aan een vertrouwensarts. Sluijters 1977, p. 174. 
de persoonlijke levenssfeer en wellicht niet geïformeerd willen worden. Zeker wanneer een familielid in het geheel niet bekend is met de betreffende aandoening, is voorzichtigheid op zijn plaats. In een dergelijke situatie is het alleen informeren over het feit dat er erfelijkheidsinformatie beschikbaar is, meer voor de hand liggend. Dit is ook het geval indien de adviesvrager de klinisch geneticus verzoekt om familieleden te informeren. De klinisch geneticus heeft geen enkele relatie met die familieleden en kan derhalve niet inschatten of zij geïformeerd willen worden. Op dic manier wordt het meest recht gedaan aan het recht op niet weten van verwanten.

Het recht op geheimhouding van de adviesorager

Tot slot nog een opmerking over het recht op geheimhouding van de adviesvrager. Wanneer familieleden wordt gevraagd gegevens te verstrekken ten behoeve van de adviesvrager, is het wanneer het familielid hierom vraagt onvermijdelijk dat daardoor ook gegevens betreffende de adviesvrager bekend worden. De Gezondheidsraad merkt hierover op:

"Voor zover het mogelijk is de familie te benaderen zonder aan te geven voor wie de gegevens nodig zijn, verdient dit de voorkeur." 28

Deze benadering is te verdedigen, mits wel duidelijk wordt gemaakt voor welk doel de gegevens worden opgevraagd. Indien het familielid wil weten voor welk familielid gegevens worden opgevraagd, zal de klinisch geneticus genoodzaakt zijn dit te vertellen. Het familielid moet in staat worden gesteld een gënformeerde toestemming te geven. Gevers merkt hierover op dat de regels van het beroepsgeheim geen ruimte laten om het verlangen van de adviesvrager naar absolute discretie te laten prevaleren boven het recht van verwanten om in het verstrekken van gegevens aan derden gekend te worden. ${ }^{29}$ Indien de adviesvrager onder geen omstandigheid wil dat zijn identiteit wordt prijsgegeven is de consequentie dat verdere erfelijkheidsadvisering aan de adviesvrager waarschijnlijk onmogelijk wordt. Dit dient alvorens de klinisch geneticus een familielid benadert te worden besproken met de adviesvrager, zodat hij de mogelijke consequentie van zijn standpunt overziet.

\section{Een plicht tot informeren?}

Hiervoor waren de vragen aan de orde of het inlichten van familieleden geoorloofd is en op welke wijze dit zou moeten gebeuren. In hoofdstuk 5 is reeds de vraag aan de orde geweest óf en zo ja, onder welke omstandigheden op de klinisch geneticus een plicht tot informeren zou rusten. Daar is betoogd dat geen algemene waarschuwingsplicht aangenomen kan worden voor klinisch genetici jegens familieleden van de adviesvrager. Een juridische plicht voor de klinisch geneticus tot informeren zou wel aanwezig kumnen zijn wanneer het om een ernstige behandelbare ziekte gaat en de geneticus weet dat de adviesvrager de familie niet inlicht. 
7.3.2 De situatie warin ten gevolge van de geheimhoudingsplicht familieleden niet geinformeerd kumnen worden

Ondanks het grote individuele en algemeen belang van het beroepsgeheim is het niet absoluut. Doorbreking ervan is enerzijds mogelijk op grond van een wettelijk voorschrift en anderzijds op grond van een conflict van plichten. Wanneer er geen wettelijke grond is om zijn zwijgplicht te doorbreken, maar de klinisch geneticus in een noodtoestand verkeert in de zin van een conflict van plichten, kan een doorbreking van de zwijgplicht gerechtvaardigd zijn. In dat geval kan de klinisch geneticus zich rechtens beroepen op artikel 40 Wetboek van Strafrecht:

\section{"Niet strafbaar is hij die cen feit begaat waartoe hij door overmacht is gedrongen."}

Artikel 40 WvSr ontneemt de strafbaarheid aan het doorbreken van de zwijgplicht wanneer de klinisch geneticus kan aantonen dat hij in een noodsituatie verkeert doordat hij zich gedrongen voelt aan een hoger belang dan door de norm van de zwijgplicht wordt beschermd voorrang te moeten verlenen. ${ }^{30}$ De geheimhoudingsplicht kan in het geding komen wanneer een adviesvrager weigert erfelijkheidsinformatie aan familieleden door te geven die daar belang bij hebben. Dit belang kan gelegen zijn in het feit dat het een ernstige ziekte betreft die behandeld kan worden. Een ander belang kan in de procreatieve leeftijd van het familielid gelegen zijn. Daartegenover staat het belang van de adviesvrager bij geheimhouding van de erfelijkheidsinformatie. Een slechte of geen relatie met familieleden kan voor hem de reden zijn om de informatie geheim te houden. Bedacht moet worden dat het hier om gevoelige informatie gaat. Bij een conflict van plichten zal de rechter in het algemeen marginaal toetsen: niet de vraag of de klinisch geneticus juist heeft gehandeld is aan de orde, maar de vraag of hij in redelijkheid en met een goede afweging van de aan de orde zijnde belangen heeft kunnen komen tot zijn beslissing om zijn geheimhoudingsplicht te schenden. ${ }^{31}$

\section{Criteria bij een conflict van plichten}

Wanneer kan er sprake zijn van een conflict van plichten? In de Memorie van Toelichting bij artikel 7:457 BW wordt aangegeven dat een uitzondering op de geheimhoudingsplicht kan worden aangenomen wanneer de risico's voor de familie zo onmiddellijk en zo evident zijn en de mogelijkheden om die risico's af te wenden zodanig reëel zijn, dat niet-nakoming van artikel 7:457 lid 1 BW geacht kan worden te berusten op overmacht. Benadrukt wordt dat in een dergelijke situatie een conflict van plichten niet gemakkelijk mag worden aangenomen: het betreft hoogst uitzonderlijke situaties. ${ }^{32}$ In de erfelijkheidsrichtlijnen worden de volgende criteria gehanteerd:

30 Naar de mening van Kuitert kan er nooit sprake zijn van een doorbreking van de geheimhoudingsplicht op grond van een conflict van plichten tenzij de volksgezondheid door het vasthouden aan de zwijgplicht in gevaar zou komen. Kuitert 1989, p. 182.

31 Leenen 2000, p. 84-85 en p. 234-235. Zie ook CMT 28 september 1972, NJ 1973, 270.

32 Kamerstukken II 1989/90, 21561 , nr. 3, p. 40. 
"Als de cliënt de betrokken familieleden zelf niet wil informeren en ook aan de arts geen toestemming geeft om dat te doen, mag de arts alleen in de volgende situatie tot informeren overgaan:

- alles is geprobeerd om toestemming van de cliënt te krijgen,

- de arts verkeert in gewetensnoot door te \%wijgen,

- er is geen andere weg om het probleem op te lossen,

- het niet-informeren levert voor het betrokken familielid emstige schade op, en

- het is vrijwel zeker dat door het informeren die schade kan worden voorkómen of beperkt." 33

Leenen voegt hier nog de proportionaliteitseis aan toe: er mag niet meer informatie worden verstrekt dan voor de diagnose en/of behandeling van het familielid noodzakelijk is en ook voor het overige moet de persoonlijke levenssfeer van de adviesvrager zo min mogelijk geschaad worden. Ook de Gezondheidsraad stelt deze eisen. ${ }^{34}$ Een ander verschil met de erfelijkheidsrichtlijnen is dat Leenen spreekt over het naar alle warschijnlijkheid voorkomen van ernstige schade en dat de erfelijkheidsrichtlijnen en de Gezondheidsraad eisen dat het vrijwel zeker is dat door het informeren de schade wordt beperkt of voorkómen. De Gezondheidsraad stelt bovendien dat het niet schenden van de geheimhoudingsplicht waarschijnlijk ernstige schade én ernstigleed met zich moet brengen. ${ }^{35}$

Welke criteria moeten nu worden gehanteerd wanneer de klinisch geneticus zich in een conflict van plichten bevindt? De erfelijkheidsrichtlijnen, Leenen en de Gezondheidsraad stellen dat ten eerste alles in het werk moet zijn gesteld om toestemming van de adviesvrager te verkrijgen. De term alles is moeilijk te objectiveren. Bovendien gaat deze eis ver. Moet een klinisch geneticus de adviesvrager 5 keer proberen te overreden of 10 keer? Het begrip redelijke inspanningen dat in de internationale literatuur wordt gehanteerd, heeft dit nadeel niet, omdat het beter te objectiveren is. ${ }^{36}$ Bovendien kan de rechter bij de bepaling of de klinisch geneticus redelijke inspanningen heeft verricht om de adviesvrager tot medewerking te bewegen, rekening houden met de omstandigheden van het geval.

33 Vereniging voor Gezondheidsrecht, richtlijn A 7. Internationaal worden er vergelijkbare criteria gehanteerd. Fletcher, Berg en Tranøy noemen deze criteria "widely accepted principles and practices". Fletcher, Berg en Tranøy 1985, p. 199-205. Zie ook President's Commission for the Study of Ethical Problems in Medicine and Biomedical and Behavioral Research 1983, p. 44-45.

34 Gezondheidsraad 1989, p. 105-106. Sutorius neemt deze criteria over. Niet als criteria die de geheimhoudingsplicht zouden kunnen opheffen, maar als belangrijke bakens, die de geneticus behulpzaam kunnen zijn bij afwegingsperikelen voorafgaand aan een erfelijkheidsonderzoek. Sutorius 1993, p. 173. Zie hierover de volgende paragraaf.

35 Gezondheidsraad 1989, p. 105-106.

36 Fletcher, Berg en Tranoy en de President's Commission for the Study of Ethical Problems in Medicine and Biomedical and Behavioral Research spreken over reasonable efforts. Fletcher, Berg en Tranøy 1985, pag. 201 en President's Commission for the Study of Ethical Problems in Medicine and Biomedical and Behavioral Research 1983, p. 44. Ook Gevers sluit zich aan bij de voorwaarden uit de internationale literatuur. Gevers 1987, p. 34. 
Bepaald kan worden of hij in dít geval, rekening houdend met alle omstandigheden, zoals bijvoorbeeld de redenen die de adviesvrager heeft om zijn familie niet in te lichten, redelijke inspanningen heeft verricht om de adviesvrager te overreden.

Ten tweede de eis dat de geneticus door het handhaven van de geheimhoudingsplicht in gewetensnood moet verkeren. Deze eis is noodzakelijk om van een conflict van plichten te kunnen spreken.

Ten derde de eis dat er geen andere weg is om het probleem op te lossen dan via doorbreking van het geheim. Dit subsidiariteitsvereiste is een algemene eis die aan elke doorbreking van een plicht, om aan een andere plicht te voldoen, wordt gesteld. Leenen stelt daarbij nog als eis dat het onderzoek of de behandeling niet zonder de informatie kan worden uitgevoerd. Deze eis kan echter ook worden gelezen in de algemene eis dat er geen andere weg is om het probleem op te lossen dan doorbreking van het geheim.

Ten vierde de eis dat het niet-informeren ernstige schade oplevert voor het betrokken familielid en dat het vrijwel zeker is dat door het informeren die schade kan worden voorkómen of beperkt. De Gezondheidsraad spreekt over waarschijnlijke ernstige schade én ernstig leed en dat het vrijwel zeker moet zijn dat de familie de införmatie zal gebruiken, zodat de schade wordt voorkomen of beperkt.

Wat te denken van deze verschillende formuleringen? De eis van de erfelijkheidsrichtlijnen, dat het niet informeren ernstige schade oplevert, is te strikt. Indien het betrokken familielid geen drager is van een mutatie die tot een ernstige erfelijk ziekte leidt, treedt er bij niet informeren geen ernstige schade op. Dit geldt eveneens wanneer het betrokken familielid wel drager is van een mutatie, maar deze mutatie bij het betrokken familielid niet tot een ernstige erfelijke ziekte leidt. ${ }^{37}$ Ook de door Leenen gestelde eis dat door te informeren naar alle waarschijnlijkheid schade wordt voorkomen en de eis van de Gezondheidsraad dat het niet schenden van de geheimhoudingsplicht waarschijnlijk ernstige schade en ernstig leed met zich meebrengen, is te strikt. Het risico op een erfelijke ziekte bij een familielid is maximaal $50 \%$. Bij een risico van $50 \%$ kan men niet stellen dat het niet informeren waarschijnlijk of naar alle waarschijnlijkheid ernstige schade met zich meebrengt. De eis dat het niet informeren van het betrokken familielid een hoog risico op ernstige schade met zich meebrengt, verdient mijns inziens de voorkeur. ${ }^{38}$ Daarbij ga ik ervan uit dat een risico van $50 \%$ op ernstige schade in ieder geval een hoog risico is. De eis dat de schade kan en zal worden voorkomen of beperkt is cruciaal. Indien preventieve maatregelen schade niet kunnen voorkomen of beperken, zal geen

${ }_{37} \quad$ Hierbij ga ik ervan uit dat de ernstige schade gelegen is in het lijden aan een emstige erfelijke ziekte en niet in de wetenschap dat men daar een verhoogd risico op heeft. Door de eis te stellen dat niet informeren waarschijnlijk ernstige schade en ernstig leed toebrengt, lijkt de Gezondheidsraad ervan uit te gaan dat de ernstige schade ook gelegen kan zijn in de wetenschap dat men een verhoogd risico heeft op een erfelijke ziekte.

$3 s \quad$ Zie ook De Wert 1999, p. 254. 
sprake zijn van een conflict van plichten omdat de klinisch geneticus geen plicht zal voelen om leed te voorkomen wanneer dit niet mogelijk is. Dit geldt eveneens voor de situatie waarin op voorhand duidelijk is dat het familielid de schade niet zal voorkomen of beperken.

Ten vijfde de proportionaliteitseis: er wordt niet meer informatie verstrekt dan nodig is ter voorkoming van ernstige schade en ook voor het overige wordt de persoonlijke levenssfeer van de adviesvrager zo min mogelijk aangetast. Deze eis wordt niet gesteld in de erfelijkheidsrichtlijnen. Het is echter, evenals het subsidiariteitsvereiste, een algemene eis die aan ieder conflict van plichten wordt gesteld. Uit de eis dat niet meer informatie wordt verstrekt dan noodzakelijk is, volgt mijns inziens tevens de eis dat de informatie niet aan meer personen wordt verstrekt dan noodzakelijk is. Indien mogelijk (wanneer de klinisch geneticus beschikt over voldoende persoonsgegevens) dient het betrokken familielid rechtstreeks geïnformeerd te worden.

Ten zesde de eis dat de dreigende gezondheidsschade op korte termijn te verwachten is. Deze eis is niet te vinden in de genoemde literatuur, maar wordt gesteld door De Wert. Als aan alle hierboven genoemde eisen is voldaan, kan desondanks geen sprake zijn van een terechte doorbreking van de zwijgplicht wanneer het risico op een erfelijke aandoening in de tijd ver verwijderd is. Wanneer het risico vervolgens nabij is, kan de klinisch geneticus, wanneer een nieuwe poging om toestemming te krijgen van de adviesvrager mislukt is, het familielid inlichten. ${ }^{39}$ Overigens moet een en ander mijns inziens wel bezien worden in het licht van het moment waarop preventieve maatregelen kunnen worden genomen. De eis luidt dan dat de dreigende gezondheidsschade op korte termijn te verwachten dan wel dat deze op lange termijn te verwachten is, maar dat het medisch gezien zinvol is om op korte termijn preventieve maatregelen te nemen.

Tot slot de eis dat de adviesvrager op de hoogte wordt gesteld van het feit dat de klinisch geneticus zijn geheimhoudingsplicht gaat doorbreken. ${ }^{40}$ Het goed en met name zorgvuldig hulpverlenerschap brengt met zich mee dat de adviesvrager op de hoogte is van het feit dat informatie wordt doorgegeven aan een familielid. Het is ten slotte zijn recht op geheimhouding dat wordt geschonden. 


\subsubsection{Alternatieven voor een conflict van plichten?}

Bij erfelijkheidsinformatie zijn de belangen van familieleden structureel in het geding. Biedt de rechtvaardigingsgrond van artikel 40 van het Wetboek van Strafrecht wel voldoende bescherming? De Gezondheidsraad wijst een wettelijke regeling ter vervanging van de constructie waarin de klinisch geneticus een beroep moet doen op een conflict van plichten af. Hij stelt terecht dat conflicten van plichten niet in wettelijke regels zijn te vangen ${ }^{* 1}$ Deze zijn immers per definitie algemeen en zouden onvoldoende recht doen aan de omstandigheden van elke specifieke situatie.

Daarnaast stelt de Raad dat formalisering het gevaar met zich meebrengt dat de uitzondering een regel wordt.22 Dit gevaar lijkt niet irreëel. Wanneer het onder omstandigheden informeren van familieleden een recht wordt, in plaats van een strafbaar feit waaraan op grond van artikel $40 \mathrm{WvSr}$ de wederrechtelijkheid kan worden ontnomen, kan dit leiden tot het sneller aannemen van omstandigheden die het inlichten van bloedverwanten rechtvaardigen. Dit terwijl de oplossing via het conflict van plichten benadrukt dat aan de belangen van familieleden onder omstandigheden recht wordt gedaan, maar dat dit beperkt blijft tot uitzonderingssituaties omdat het primat ligt bij het recht op geheimhouding van de adviesvrager. Bovendien is er, gezien het feit dat jurisprudentie terzake ontbreekt, geen reden om aan te nemen dat, ondanks de structurele belangen van familieleden en de toenemende mogelijkheden om erfelijke aandoeningen op te sporen, een klinisch geneticus zich regelmatig in een conflict van plichten bevindt. 43

\section{Voorwaardelijke toegang?}

Een andere mogelijkheid om een conflict van plichten te vermijden is om de toegang tot erfelijkheidsonderzoek afhankelijk te maken van de bereidheid om familieleden over relevante informatie zo nodig in te lichten. Sutorius stelt voor om in het kader van erfelijkheidsonderzoek van meer complexe aard een modelovereenkomst op te stellen waarin de klinisch geneticus en de adviesvrager, en zo mogelijk de bloedverwanten, hun afspraken over de te volgen informatiestrategie hebben neergelegd. Indien de klinisch geneticus en de adviesvrager er niet in slagen om tot afspraken over het informatiebeleid te komen, moet worden aangenomen dat er onvoldoende basis bestaat om de erfelijkheidsadvisering te continueren, aldus Sutorius. De criteria waaraan voldaan moet zijn wil de klinisch geneticus op grond van een conflict van plichten, tot doorbreking van zijn geheimhoudingsplicht overgaan, blijven belangrijke bakens, die de klinisch geneticus behulpzaam kunnen

$41 \quad$ Zie ook Sutorius 1993, p. 174: "Een noodsituatie behoort nu cenmaal uitzondering te blijven, terwijl regelgeving de normen stelt voor een groot aantal gevallen."

+2 Gezondheidsraad 1989, p. 107.

43 Sutorius daarentegen vreest dat de klinisch geneticus regelmatig voorbij zal gaan aan de weigering van cen adviesvrager om toestemming te geven voor het gebruik of de overdracht van erfelijkheidsgegevens. Het zoeken van de oplossing via het conflict van plichten, waardoor de geheimhoudingplicht formeel blijft bestaan, maakt het bezwaar van de rechtsonzekerheid minder problematisch, maar het gevaar van een op langere termijn optredende vertrouwensbreuk tussen de geneticus en de adviesvrager blijft onverminderd bestaan, aldus Sutorius. Sutorius 1993, p. 172-173. 
zijn bij afwegingsperikelen vooraf." De President's Commission zegt hierover het volgende:

\begin{abstract}
"Making access to the test conditional upon prior agreement to disclose information may be justifiable. (...) Consequently, a decision to require consent to disclosure must take into account the harm that might be done or the benefits that might be foregone if some individuals chose not to participate." 15
\end{abstract}

De toegang tot de hulpverlening afhankelijk maken van de bereidheid om de belangen van familieleden te dienen, is in strijd met het recht op gezondheidszorg. Op grond van dit recht heeft de overheid de zorg voor de beschikbaarheid van de noodzakelijke gezondheidsvoorzieningen. Het stellen van voorwaarden brengt de vrije toegang tot gezondheidsvoorzieningen in gevaar. Indien dit adviesvragers af zou schrikken en ertoe zou leiden dat zij zich niet tot een klinisch geneticus wenden, zou een dergelijk beleid tevens contraproductief werken. De relevantie informatie komt niet tot stand, zodat adviesvragers noch diens familieleden ervan op de hoogte geraken. Het is ook niet nodig om dergelijke beperkende voorwaarden te stellen omdat de hulpverlener met een beroep op een conflict van plichten alsnog familieleden in kan lichten. ${ }^{46}$ Bovendien kan de adviesvrager op zijn belofte om zijn familieleden erfelijkheidsinformatie te verschaffen, altijd terugkomen. ${ }^{77}$ Dit betekent echter niet dat de klinisch geneticus voorafgaand aan het erfelijkheidsonderzoek niet op het mogelijk belang van de uitslag van het erfelijkheidsonderzoek voor familieleden moet wijzen en op het feit dat wanneer hij zich in een conflict van plichten zou bevinden, hij familieleden mogelijkerwijs zonder toestemming van de adviesvrager zal informeren. Afgezien van het feit dat dit onder de informatieplicht van de klinisch geneticus valt, wordt door het vooraf informeren van de adviesvrager hierover, hem toch een zekere keuzemogelijkheid gelaten. Indien de adviesvrager zich a priori onder geen beding zou kumnen verenigen met de mogelijkheid dat familieleden worden geinformeerd, kan hij van het erfelijkheidsonderzoek afzien. ${ }^{4}$

Artikel 7:452 BW stelt dat de patiënt de hulpverlener naar beste weten de inlichtingen en de medewerking geeft die deze redelijkerwijs voor het uitvoeren van de overeenkomst behoeft. Zou op grond van dit artikel kunnen worden gesteld dat de adviesvrager zijn medewerking moet geven bij het inlichten van familieleden omdat de klinisch geneticus deze voor het uitvoeren van de overeenkomst behoeft? In redelijkheid is niet vol te houden dat de medewerking bij het inlichten van familieleden redelijkerwijs nodig is om de behandelingsovereenkomst uit te voeren. Van de adviesvrager wordt verwacht dat hij zich naar vermogen inspant. ${ }^{49}$ Deze

4 Sutorius 1993, p. 173.

45 President's Commission for the Study of Ethical Problems in Medicine and Biomedical and Behavioral Research 1983, p. 43-44.

46 Zie ook Gevers 1987, p. 30.

47 Zie ook Gezondheidsraad 1989, p. 107, Markenstein, Gevers en Roscam Abbing 1999, p. 47 en Gevers 1987, p. 30.

48 Gevers 1987, p. 30.

49 Kamerstukken II 1989/90, 21 561, nr. 3, pag. 33. 
inspanningsverplichting is echter vastgelegd opdat de hulpverlener in staat wordt gesteld om zijn patiënt zo goed mogelijk te onderzoeken en behandelen en over zijn gezondheidstoestand te informeren en niet om medewerking aan het inlichten van familieleden af te dwingen. Het informeren van familieleden is geen onderdeel van de behandelingsovereenkomst.

\section{Erfelijkheidsinformatie frmiliebezit?}

Een laatste mogelijkheid die in de literatuur is geopperd is om bij erfelijkheidsadvisering niet vast te houden aan de geheimhoudingsplicht. Erfelijkheidsinformatie is in deze opvatting te zien als een familiebezit. Dit zou betekenen, aldus de Gezondheidsraad dat familieleden via de klinisch geneticus onbelemmerd zouden kunnen beschikken over de aanwezige informatie. ${ }^{50}$ Zo verdedigt Skene bijvoorbeeld, in tegenstelling tot het in de Verenigde Staten, maar ook in Nederland, gangbare legal model, het medical model.51 Over het medical model zegt hij het volgende:

"On this model, people would not have the ultimate right to "control" their information and the use of their tissue taken for genetic testing (...); and doctors will have a special role in providing and imparting genetic information that may appear contrary to their traditionl obligation to maintain patient confidentiality. (...) The advantages of the medical/familial model are that it takes full account of the factual circumstances of providing genetic advice and developing a family pedigree. Its primary focus is on health promotion. Many people, both doctors and patients, support sharing information within families. It is more flexible (though critics may say paternalistic). It avoids the problems that arise from characterising tissue as property and makes tissue more readily available for later access by family members and researchers." 52

In Nederland is deze opvatting door Ten Kate verdedigd. ${ }^{53} \mathrm{Hij}$ komt tot de conclusie dat:

"gezien het belang van een adequate counseling de behandelend arts van familieleden dient te spreken, terwijl de genetisch counselor, gezien het belang van het beroepsgeheim, zoveel als verantwoord is, dient te zuijgen. Deze conclusie wordt ondersteund door de stellingen dat 1 . personen een recht kunnen doen laten gelden op de diagnostische informatie die over familieleden bestaat, en dat 2 . de genetic

50 Gezondheidsraad 1989, p. 107-108.

51 Skene 1998, p. 1-41. Het medical model dat Skene verdedigt is afkomstig uit de Guidelines on Ethical Aspects of Risk Assessment, Genetic Testing and Genetic Registers in Relation to Cancer van de Anti-Cancer Council of Victoria, Cancer Genetic Ethics Committee, Ethics and Familial Cancers. Deze richtlijnen zijn overgenomen door the Australian Cancer Network on the recommendation of the National Health and Medical Research Council als nationale richtlijnen in Australia. Skene 1998, noot 1 op p. 1 en addendum op p. 41.

52 Skene 1998, p. 24 en 34-35.

53 Ten Kate 1976, p. 49-55. 
counselor een uitzonderingspositie inneemt die in zekere zin vergelijkbaar is met die van de vertrouwensarts." 5.4

Erfelijkheidsgegevens zouden in zijn visie dus familiebezit worden in die zin dat de geheimhoudingsplicht van de behandelend arts van familieleden niet zou gelden ten aanzien van de klinisch geneticus. Voor zover mogelijk heeft de klinisch geneticus deze geheimhoudingsplicht wel ten opzichte van de adviesvrager. Het betoog van Ten Kate gat over de situatie waarin ten behoeve van de adviesvrager gegevens over familieleden nodig zijn. De situatie waarin de klinisch geneticus tegen de wil van de adviesvrager familieleden wil informeren over een verhoogd risico op een erfelijke aandoening, wordt niet besproken. Omdat zijn conclusie wordt ondersteund door de stelling dat personen een recht kunnen doen laten gelden op de diagnostische informatie die over familieleden bestaat, neem ik aan dat Ten Kate ook in de laatstgenoemde situatie uitgaat van een recht van de klinisch geneticus om familieleden hierover te informeren.

De opvatting dat erfelijkheidsinformatie als familiebezit zou moeten worden beschouwd wordt in de literatuur verworpen.55 Tegen de opvatting zijn zowel principiële als praktische bezwaren aan te voeren. Ten eerste rechtvaardigt het belang bij erfelijkheidsinformatie geen dergelijke vérgaande inbreuk op zowel het zelfbeschikkingsrecht en het recht op respect voor de persoonlijke levenssfeer als het recht op geheimhouding. In hoofdstuk 5 is reeds opgemerkt dat de aanwezigheid van een bloedband niet het intieme en persoonlijke karakter van de informatie wegneemt. ${ }^{56}$ Familieleden kunnen totale vreemden voor elkaar zijn. ${ }^{57}$ Bovendien kan de erfelijkheidsinformatie juist binnen de familieverhoudingen een zeer gevoelig karakter hebben. ${ }^{58} \mathrm{Er}$ is geen principieel verschil tussen de bescherming van de privacy jegens derden en jegens familieleden. In de gezondheidszorg wordt de bescherming van medische informatie betreffende de patiënt, en zeker van gevoelige informatie, 59 van groot belang geacht. Het recht op privacy is mede aanleiding

\section{Ten Kate 1976 , p. 54.}

55 Zie hiervoor bijvoorbeeld Gevers 1987, p. $32-34$ en Sutorius 1993, p. 172-173.

56 In gelijke zin Sutorius wanneer hij stelt dat het in onze samenleving nog maar de vraag is of de familie nog wel kan gelden als unit of confidentiality. Hij stelt zich de vraag of loutere verwantschap op zichzelf voldoende grondslag vormt voor een te creëren familiegcheim. Sutorius 1993, p. 172.

57 Zie ook Gevers die opmerkt dat bloedverwanten in beginsel derden zijn die in veel gevallen ook feitelijk en psychologisch buiten de privé-sfeer van de betrokkene staan. Gevers 1987, p. 33.

58 Gevers 1987, p. 33-34.

59 Zie bijvoorbeeld EHRM 25 februari 1997, NJ 1999, 516. Hier oordeelde het Hof met betrekking tot de bescherming van medische gegevens: "(..) the Court will take into account that the protection of personal data, not least medical data, is of fundamental importance to a person's enjoyment of his or her right to respect for private and family life as guaranteed by Article 8 of the Convention (art. 8). (...) The above considerations are especially valid as regards protection of the confidentiality of information about a person's HIV infection. The disclosure of such data may dramatically affect his or her 
geweest tot verdere regeling van patiëntenrechten. ${ }^{60}$ De hulpverlener heeft een geheimhoudingsplicht die tijdens en na het leven van de patiënt van kracht is. Ook ten opzichte van derden is informatie uit erfelijkheidsonderzoek beschermd in die zin dat geen melding hoeft te worden gemaakt van reeds ondergaan erfelijkheidsonderzoek bij het aangaan van verzekeringen en arbeidsrelaties. Het niet bieden van deze vérgaande bescherming ten opzichte van familieleden zou strijdig zijn met genoemde uitgangspunten.

Ten tweede zou het opheffen van de geheimhoudingsplicht ten opzichte van familieleden van de adviesvrager tot een barrière kunnen leiden voor wat betreft het laten verrichten van erfelijkheidsonderzoek.61 Het recht om zelf te beslissen om al dan niet een erfelijkheidsonderzoek te ondergaan wordt door deze mogelijkheid uitgehold. Tegenover het recht wordt een drempel geplaatst die de vrije toegang belemmert. Een drempel die, afhankelijk van de gevoeligheid van de informatie en de aard van de verhouding met familieleden, in de praktijk te hoog kan blijken te zijn.

Ten derde is er, wanneer de erfelijkheidsinformatie aan meer familieleden bekend is, geen controle op de geheimhouding van gegevens ten opzichte van derden. Familieleden kunnen deze informatie buiten de familiekring verspreiden. ${ }^{62}$ Gezien de groeiende mogelijkheden om erfelijkheidsinformatie te genereren is dit gevaar reëel. ${ }^{63} \mathrm{Op}$ die manier kan erfelijkheidsinformatie ook buiten de familiekring bekend worden en wordt het recht op geheimhouding ook buiten de familiekring uitgehold. Gezien de aard van de informatie is dit een onaanvaardbaar gevolg. De bescherming van erfelijkheidsinformatie ten opzichte van derden bij het aangaan van verzekeringen en arbeidsrelaties zou hierdoor zelfs in gevaar kunnen komen. Daamaast zou de vertrouwelijkheid van de niet specifiek de erfelijkheid betreffende informatie in gevaar kunnen komen. Bij bijvoorbeeld een inzagerecht in het dossier zouden familieleden op de hoogte raken van persoonlijke gegevens. Aan dit bezwaar zou tegemoet gekomen kunnen worden door familieleden geen inzagerecht te verlenen, maar een recht om op verzoek door de klinisch geneticus geinformeerd te worden. Hierbij kan echter ook de niet specifiek de erfelijkheid betreffende informatie bekend worden. Bij een conflict van plichten kan dit aanleiding zijn voor de klinisch geneticus om zijn geheimhoudingsplicht zwaarder te laten wegen. Bij een recht op erfelijkheidsinformatie van familieleden is er geen ruimte voor een afweging.

Ten slotte twee praktische bezwaren die de afbakening betreffen. Hoe zou ten eerste de kring van bloedverwanten moeten worden afgebakend? Zou de

private and family life, as well as social and employment situation, by exposing him or her to opprobium and the risk of ostracism."

(6) Kamerstukken II 1990/91, 21 561, nr. 6, p. 2-3.

61 Zie ook Leenen 2000, p. 85 en Gezondheidsraad 1989, p. 107-108.

62 Zie ook Gezondheidsraad 1989, p. 107-108.

63 Sutorius en Gevers wijzen er daarbij op dat van steeds meer ziekten genetische factoren zullen worden onderkend. Gevers 1987, p. 34 en Sutorius 1993, p. 172. 
geheimhoudingsplicht evenmin moeten gelden ten opzichte van (gegevens van) neven en nichten of zelfs achterneven en -nichten? Bovendien kan ook het risico voor eerstegraads bloedverwanten zéér laag zijn. Zou het recht om familieleden in te lichten of het recht van familieleden om ingelicht te worden dan onverminderd moeten gelden of moet dit recht gerelateerd worden aan de omvang van het belang van familieleden? Ten tweede is de inbreuk op het geheim nauwelijks in te perken. Ten Kate geeft aan dat voor de erfelijkheidsadvisering "alle diagnostische informatie genetisch relevant is, ook die betreffende niet erfelijke aandoeningen". ${ }^{6.4}$

Deze bezwaren tegen de opvatting dat erfelijkheidsinformatie als familiebezit moet worden gezien, laten onverlet dat er situaties kunnen bestaan, waarin de kennis van erfelijkheidsinformatie bij familieleden ernstige gezondheidsschade kan voorkómen. In dergelijke situaties kan de klinisch geneticus zich echter op het conflict van plichten beroepen. Dit geldt ook voor de situatie waarin erfelijkheidsinformatie nodig is ten behoeve van een erfelijkheidsadvies aan de adviesvrager. In de volgende paragraaf wordt hierop ingegaan.

\subsubsection{De situatie waarin ten gevolge van de geheimhoudingsplicht geen erfelijkheidsonderzoek bij de adviesvrager verricht kan worden}

Hiervoor is ingegaan op de situatie waarin de klinisch geneticus op grond van zijn geheimhoudingsplicht familieleden niet kan informeren over mogelijke risico's op een erfelijke aandoening. Aangegeven is dat wanneer aan een aantal criteria is voldaan, de klinisch geneticus met een beroep op een conflict van plichten familieleden zonder toestemming van de adviesvrager kan informeren. In deze paragraaf is de situatie aan de orde waarin er ten behoeve van de adviesvrager geen erfelijkheidsonderzoek kan worden verricht, en er dus geen diagnose ${ }^{65}$ kan worden vastgesteld, omdat de vereiste medewerking van een familielid ontbreekt.

Familiegegevens zijn bij erfelijkheidsadvisering van cruciaal belang. Ten Kate geeft aan dat de klinisch geneticus voor het bepalen van het genetisch risico behoefte heeft aan verschillende soorten informatie:

- "informatie over de familiestructuur (de 'stamboom');

- informatie over de precieze aard van de aandoening(en) waarvoor het risico moet worden bepaald;

- informatie over de plaats van de aangedane personen in de stamboom; en

- informatie over de (in de literatuur of elders) bestaande kennis met betrekking tot het erfelijkheidspatroon of empirische herhalingsrisico's." 66

of Ten Kate 1976, p. 52. Zie ook Ten Kate 1980, p. 159-161.

65 Onder diagnose wordt in deze paragraaf ook begrepen: het vaststellen van dragerschap van een mutatie of chromosomale afwijking die bij de adviesvrager zelf of bij diens nageslacht tot een verhoogd risico op een erfelijke aandoening of tot een erfelijke aandoening leidt. 
Met name voor wat betreft de informatie over de precieze aard van de aandoening(en) waarvoor het risico moet worden bepaald is medewerking van éen of meerdere familieleden vaak noodzakelijk. Ongericht onderzoek om afwijkingen in het DNA of aan de chromosomen vast te stellen is of onmogelijk óf om praktische redenen weinig zinvol. Daarom wordt gericht onderzoek gedaan, waarbij de diagnose bij een familielid richtinggevend is. Ten Kate wijst er echter ook op dat de wetenschap dat een bepaald familielid niet aangedaan is, ook relevante informatie voor de klinisch geneticus kan opleveren. Dit is met name het geval wanneer uit de familiesituatie conclusies moeten worden getrokken ten aanzien van het erfelijkheidspatroon of ten aanzien van de hoogte van het risico van de adviesvrager op de familiaire aandoening. Zo is de kans op dragerschap voor de moeder van een zoontje met de spierdystrofie van Duchenne afhankelijk van het aantal zoons en broers dat de ziekte niet heeft. ${ }^{67}$

Het is ook mogelijk dat er erfelijkheidsonderzoek bij de adviesvrager verricht wordt, zonder dat er onderzoek nodig is bij een familielid dat reeds lijdt of heeft geleden aan de aandoening. Een voorbeeld hięrvan is erfelijkheidsonderzoek naar de ziekte van Huntington. Deze ziekte wordt, indien aanwezig, altijd veroorzaakt door dezelfde genmutatie. Ook in dit soort situaties zal de klinisch geneticus echter gegevens van familieleden op willen vragen zodat eerst de familieanamnese kan worden geverifieerd, alvorens er onderzoek wordt verricht bij de adviesvrager.

Indien een familielid geen toestemming geeft om zijn gegevens te gebruiken ten behoeve van de erfelijkheidsadvisering aan de adviesvrager, kan er geen diagnose worden gesteld bij de adviesvrager. Door de weigering van een familielid om zijn gegevens te verstrekken, kan de klinisch geneticus zelfs in een positie komen te verkeren waarin hij niet de waarheid tegen de adviesvrager kan spreken. Dit is het geval wanneer het betreffende familielid zich voorheen als adviesvrager voor een erfelijkheidsadvies tot hem heeft gericht. Een juridische oplossing is er niet voor dit probleem, aldus Leenen. De klinisch geneticus zal in zo'n situatie op zorgvuldige wijze moeten proberen de minst schadelijke gedragslijn te vinden. ${ }^{68}$

Zijn er uitzonderingen op de geheimhoudingsplicht te maken wanneer de gegevens van het familielid voor de adviesvrager van belang zijn? Gevers zegt hierover:

"Het verstrekken van gegevens door hun behandelend arts aan de genetisch adviseur is volgens de regels van het beroepsgeheim dan hooguit nog in bijzondere gevallen mogelijk, nl. wanneer die gegevens voor een juiste diagnose doorslaggevend zijn en het vaststellen van cen diagnose voor de adviesvrager zo belangrijk is, dat het beroepsgeheim tegenover familieleden hierbij ten achter mag worden gesteld. Huisarts en genetisch counselor zullen hierover overleg moeten plegen, (...) en in voorkomende gevallen een beroep op het conflict van plichten moeten doen."69

\footnotetext{
67 Ten Kate 1980, p. 159-160.

is Leenen 2000, p. 85.

69 Gevers 1987, p. 31.
} 
Ook Leenen geeft aan dat een conflict van plichten aanwezig kan zijn wanneer een familielid weigert om toestemming te geven voor het verstrekken van zijn gegevens ten behoeve van de adviesvrager. ${ }^{70}$ In de literatuur wordt echter niet de vraag gesteld of hiervoor wel dezelfde criteria zouden moeten gelden als die in de vorige paragraaf zijn besproken, terwijl er wel sprake is van een andere situatie. De adviesvrager wil immers een erfelijkheidsonderzoek ondergaan ondat hij of zijn nageslacht mogelijk aan een erfelijke aandoening zal gaan lijden. Hij is dus op de hoogte van een mogelijk risico. De criteria dat er redelijke inspanningen zijn verricht om toestemming te krijgen van de adviesvrager, dat de klinisch geneticus in gewetensnood moet verkeren en dat er is voldaan aan het subsidiariteitsvereiste gelden uiteraard onverkort. Ook de proportionaliteitseis, de eis dat de dreigende schade op korte termijn te verwachten is en de eis dat, in dit geval, het familielid op de hoogte wordt gesteld van het feit dat de klinisch geneticus de informatie aan de adviesvrager doorgeeft, zijn hier van toepassing.

Het vierde criterium stelde dat het niet informeren van het betrokken familielid een hoog risico op ernstige schade met zich meebracht en dat het vrijwel zeker was dat door het informeren die schade kon worden voorkómen of beperkt. Ten eerste zou hier in plaats van familielid, adviesvrager moeten worden gelezen. Ten tweede is het de vraag of het niet informeren van de adviesvrager een hoog risico op ernstige schade met zich meebrengt. De adviesvrager weet immers dat hij een verhoogd risico loopt op een erfelijke aandoening bij zichzelf of bij zijn nageslacht. De erfelijkheidsinformatie dient ter vaststelling van het exacte risico. Door de wetenschap van de adviesvrager dat hij risico loopt, zijn er voor hem mogelijkheden om het risico te reduceren. Het probleem is echter gelegen in de vaak weinig aantrekkelijke mogelijkheden voor de adviesvrager om het risico te reduceren. Indien bijvoorbeeld ten gevolge van het ontbreken van informatie over de specifieke mutatie die binnen een familie een erfelijke aandoening veroorzaakt het exacte risico niet vastgesteld kan worden, dan zou hel ontbreken van de wetenschap of de adviesvrager drager is van deze mutatie ertoe kunnen leiden dat er van een zwangerschap wordt afgezien on op die manier het risico tot nul te reduceren op nageslacht met de erfelijke aandoening. Dit zal voor veel adviesvragers een onbevredigende mogelijkheid zijn. In de situatie waarin de klinisch geneticus familieleden op de hoogte brengt van het feit dat erfelijkheidsinformatie beschikbaar is en daarmee ernstige schade probeert te voorkómen of verminderen, zullen de bezwaren van de adviesvrager zich waarschijnlijk richten op het feit dat hij niet wil dat familieleden weten dát er sprake is van een erfelijke aandoening. In de situatie die hier aan de orde is, is reeds bekend dat er (mogelijk) een erfelijke aandoening in de familie speelt. In zo'n situatie is de schending van de privacy bij de bekendmaking van de specifieke mutatie minder groot dan bij de bekendmaking van het feit dat er mogelijk een erfelijke aandoening in de familie speelt. Daartegenover staat het belang van de adviesvrager bij de wetenschap hoe groot het risico is dat hij of zijn nageslacht aan de betreffende erfelijke aandoening zal gaan leiden. Indien het belang van de adviesvrager in een specifieke situatie, na afweging van alle omstandigheden van het geval, beduidend groter is, is de klinisch geneticus

Leenen 2000, p. 85 , noot 45 . 
gerechtigd zijn geheimhoudingsplicht te doorbreken. Bij de omstandigheden van het geval zullen aan de zijde van de adviesvrager de (on)mogelijkheden om het risico op de erfelijke aandoening te reduceren de doorslag geven bij de beslissing van de klinisch geneticus. Aan de zijde van het familielid zullen zijn redenen om de gegevens niet te willen verstrekken van belang zijn. Ik zou daarom het volgende criterium willen voorstellen: het niet informeren van de adviesvrager leidt ertoe dat de resterende mogelijkheden voor hem om het risico op een erfelijke aandoening te reduceren in een onredelijke verhouding staan tot de schending van de privacy van het familielid door voor erfelijkheidsonderzoek gebruik te maken van de specifieke mutatie die bij het familielid is angetoond.

Indien de klinisch geneticus op grond van een conflict van plichten toch de gegevens van een familielid gebruikt, kan dit alleen wanneer hij zelf toegang tot deze gegevens heeft, dus in het geval dat het betreffende familielid zich voorheen als adviesvrager tot hem heeft gericht. Wanneer een andere hulpverlener de klinisch geneticus de gegevens van het betreffende familielid zou laten inzien, is die andere hulpverlener degene die zijn geheimhoudingsplicht schendt.

\section{Geheimhoudingsplicht un de dood}

Hoe dient te worden gehandeld wanneer het familielid van wie gegevens nodig zijn, overleden is? De geheimhoudingsplicht van de hulpverlener geldt ook na het overlijden van zijn patiënt. De behandelend arts bij wie ten behoeve van de adviesvrager gegevens worden opgevraagd is in beginsel op grond van zijn geheimhoudingsplicht niet gerechtigd deze gegevens te verstrekken. Ook de nabestaanden kunnen niet beschikken over deze gegevens. ${ }^{71}$ Ook hier is de ratio dat de patiënt zich zonder vrees dat hij zichzelf daardoor zou schaden in verband met het moeten prijsgeven van gevoelige gegevens, zich tot een hulpverlener kan wenden. Bovendien is er ook een individueel privacybelang.

Een uitzondering op de geheimhoudingsplicht is aanwezig wanneer de adviesvrager, bij leven uiteraard, toestemming heeft gegeven voor het verstrekken van zijn gegevens. De toestemming geldt alleen wanneer deze uitdrukkelijk is gegeven en voor zover er geen redenen van algemeen belang zijn die zich daartegen verzetten. ${ }^{72}$ Ploem noemt nog de eis dat de toestemming specifiek is. ${ }^{73}$ Voor de erfelijkheidsadvisering is deze eis met name van belang omdat duidelijk moet zijn of, wanneer de adviesvrager aan bepaalde familieleden toestemming heeft verleend om na zijn dood zijn gegevens in te zien, de adviesvrager ook aan het familielid in kwestie hiervoor toestemming heeft gegeven. Het is daarom allereerst van belang dat een klinisch geneticus wanneer daartoe aanleiding is, aan een adviesvrager over wie erfelijke gegevens worden vastgelegd, vraagt of hij toestemming geeft om na zijn overlijden zijn gegevens te gebruiken ten behoeve van erfelijkheidsadvisering aan

7 Dit uitgangspunt wordt al lange tijd aanvaard. Zie bijvoorbeeld Hazewinkel-Suringa 1959 , p. 95. Zie voor een meer recente beschouwing Ploem 1999, p. 489-499.

2 Gevers 1990, p. 172.

i3 Ploem 1999, p. 493. 
bloedverwanten en zo ja, aan welke bloedverwanten. Schriftelijke toestemming hiervoor van de adviesvrager is hierbij aangewezen.

Wanneer deze toestemming niet is gevraagd, maar er voor bloedverwanten een dringend belang in het geding is, ${ }^{74}$ dan is er geen andere weg dan het werken met de juridische fictie dat de overleden persoon in het belang van zijn familieleden toestemming zou hebben willen geven, tenzij anders moet worden aangenomen. ${ }^{75}$ Daarbij moet overwogen worden of de gegevens erg privacygevoelig zijn en of er conflicten tussen de betreffende familieleden bestonden. Tevens dient de doorbreking van het geheim tot een minimum beperkt te blijven; alleen die gegevens die nodig zijn voor diagnostiek mogen worden verstrekt. ${ }^{76}$

Indien moet worden aangenomen dat de overledene geen toestemming gegeven zou hebben voor het verstrekken van zijn gegevens, kan de klinisch geneticus alleen wanneer hij zich in een conflict van plichten bevindt, gerechtigd zijn gegevens van de overledene te gebruiken. ${ }^{77}$ In dat geval dient voldaan te zijn aan de eerder besproken criteria, voor zover toepasbaar op de situatie waarin de adviesvrager is overleden. Bij twee eisen levert de toepasbaarheid problemen op. Ten eerste de eis dat de klinisch geneticus zich redelijke inspanningen moet hebben getroost om toestemming te krijgen van de adviesvrager is. Wel kunnen, indien daar sprake van is geweest, in de overweging betrokken worden de inspanningen die de klinisch geneticus heeft verricht toen de adviesvrager nog leefde en de redenen die de adviesvrager had om destijds geen toestemming te willen verlenen om zijn familieleden zijn gegevens te verstrekken of de redenen die hij had om aan te geven dat hij niet wilde dat na zijn overlijden zijn gegevens zouden worden verstrekt. Ten tweede de eis dat de klinisch geneticus de adviesvrager op de hoogte stelt van het feit dat hij zijn geheimhoudingsplicht gaat doorbreken. Deze eis kan vanzelfsprekend niet gesteld worden.

De Groot spreekt over een rechtmatig belang. De Groot 2000, p. 1146-1148.

Zie bijvoorbeeld Pr. Rb. Alkmaar 14 januari 1999, TvGr 2000, 23. Leenen merkt op dat uit de rechtspraak blijkt dat de rechter behalve aan de veronderstelde toestemming, ook wel toetst aan het criterium of nabestaande zulke zwaarwegende belangen hebben dat het beroepsgeheim hiervoor mag wijken. Leenen 2000, p. 228. De Groot merkt hierover op: "Men ontkomt niet aan de indruk dat de toestemming soms gemakkelijk wordt verondersteld wanneer het belang van de derde bij het verkrijgen van de informatie voldoende zwaarwegend is (...) betekent dit in feite niet dat het accent van de (veronderstelde) toestemming verschuift naar de legitimiteit van de belangen van de nabestaanden?" De Groot 2000, p. 1146. Van Wijmen (annotatie HR 20 april 2001, NJ 2001,600 ) werkt de criteria op grond waarvan de geheimhoudingsplicht na overlijden mag worden doorbroken nader uit. Wanneer er geen aanwijzingen zijn te vinden omtrent hetgeen de patiënt in een hypothetische situatie waarschijnlijk zou hebben gewenst, wordt ook wel voor een normatieve benadering gekozen: er wordt dan uitgegaan van hoe een redelijk handelend patient zou hebben gehandeld. Zie bijvoorbeeld Pr. Rb Breda 5 januari 2000, TvGr 2000, 24. 


\subsection{Samenvatting}

In dit hoofdstuk is de geheimhoudingsplicht besproken. De geheimhoudingsplicht is onder meer geregeld in artikel 7:457 BW. De geheimhoudingsplicht zorgt ervoor dat de patiënt zich zonder vrees dat hij zichzelf daardoor zou schaden in verband met het moeten prijsgeven van gevoelige gegevens, zich tot een hulpverlener kan wenden. Door de geheimhoudingsplicht wordt de persoonlijke levenssfeer en het daarin besloten persoonlijk geheim van de patiënt beschermd. De patiënt heeft er recht op dat zijn gegevens geheim worden gehouden.

Eén van de specifieke kenmerken van erfelijkheidsinformatie is dat deze informatie, behalve voor de adviesvrager, ook van belang kan zijn voor bloedverwanten van de adviesvrager. Door middel van het aantonen van een erfelijke ziekte of een genetische afwijking die leidt of kan leiden tot een erfelijke ziekte, bij de adviesvrager of zijn nageslacht, kan het risico voor bloedverwanten op dezelfde erfelijke ziekte worden vastgesteld. Naast een mogelijk belang bij erfelijkheidsinformatie voor familieleden staat een mogelijk belang om niet te worden ingelicht. Daarom is de vraag gesteld of een klinisch geneticus überhaupt gerechtigd is om familieleden in te lichten. Uitgaande van de veronderstelling dat erfelijkheidsinformatie door veel mensen als voor hen relevante informatie zal worden beschouwd en dat zij op de hoogte willen worden gesteld van het feit dat er informatie beschikbaar is, is deze vraag bevestigend beantwoord. Mede gezien de toename van erfelijkheidsonderzoek naar multifactoriële aandoeningen en het plaatsvinden van dergelijk onderzoek buiten de klinisch genetische centra zal de vraag wanneer dit zou moeten gebeuren door de beroepsgroep moeten worden beantwoord door middel van richtlijnen. Het inlichten van familieleden dient door de adviesvrager zelf te gebeuren.

Ondanks het grote individuele en algemene belang van het beroepsgeheim is het niet absoluut. Doorbreking ervan is enerzijds mogelijk op grond van een wettelijk voorschrift en anderzijds op grond van een conflict van plichten. Wanneer er geen wettelijke grond is om zijn zwijgplicht te doorbreken, maar de klinisch geneticus in een noodtoestand verkeert in de zin van een conflict van plichten, kan een doorbreking van de zwijgplicht gerechtvaardigd zijn. In dat geval kan de klinisch geneticus zich rechtens beroepen op artikel 40 Wetboek van Strafrecht. Daarbij dienen de volgende criteria te worden gehanteerd:

- redelijke inspanningen zijn verricht om toestemming van de adviesvrager te verkrijgen;

- door het handhaven van de geheimhoudingsplicht verkeert de klinisch geneticus in gewetensnood;

- er is geen andere weg om het probleem op te lossen dan via doorbreking van het geheim;

- het niet informeren van het betrokken familielid brengt een hoog risico op ernstige schade met zich mee en het is vrijwel zeker dat door het informeren die schade kan en zal worden voorkómen of beperkt; 
- er wordt niet meer informatie verstrekt dan nodig is ter voorkoming van ernstige schade en ook voor het overige wordt de persoonlijke levenssfeer van de adviesvrager zo min mogelijk aangetast;

- de dreigende gezondheidsschade is op korte termijn te verwachten of op lange termijn met dien verstande dat het medisch gezien zinvol is om op korte termijn preventieve matregelen te nemen;

- de adviesvrager wordt op de hoogte gesteld van het feit dat de klinisch geneticus zijn geheimhoudingsplicht gaat doorbreken.

Zijn er gezien de structurele belangen van familieleden bij de erfelijkheidsinformatie waarover een adviesvrager beschikt, geschiktere alternatieven voor het huidige conflict van plichten? Een wettelijke regeling ter vervanging van de constructie waarin de klinisch geneticus een beroep moet doen op een conflict van plichten is weinig aantrekkelijk. Conflicten van plichten zijn niet in wettelijke regels te vangen. Bovendien houdt formalisering het gevaar in zich dat de uitzondering regel wordt. Een andere mogelijkheid om een conflict van plichten te vermijden is om de toegang tot erfelijkheidsonderzoek afhankelijk te maken van de bereidheid om familieleden over relevante informatie zo nodig in te lichten. De toegang tot de hulpverlening afhankelijk maken van de bereidheid om de belangen van familieleden te dienen, is echter in strijd met het recht op gezondheidszorg. Bovendien zou deze voorwaardelijke toegang adviesvragers af kunnen schrikken en daardoor contraproductief werken. Een laatste mogelijkheid die in de literatuur is geopperd, is om de geheimhoudingsplicht bij erfelijkheidsonderzoek niet van toepassing te laten zijn ten aanzien van familieleden van de adviesvrager. Erfelijkheidsinformatie is in deze opvatting een soort familiebezit. Er zijn verschillende bezwaren tegen deze opvatting. Ten eerste rechtvaardigt het belang bij erfelijkheidsinformatie geen dergelijke vérgaande inbreuk op het zelfbeschikkingsrecht, het recht op privacy alsmede het recht op geheimhouding. Ten tweede zou het opheffen van de geheimhoudingsplicht ten opzichte van familieleden van de adviesvrager tot een barrière kunnen leiden voor wat betreft het laten verrichten van een erfelijkheidsonderzoek. Ten slotte is er geen controle op de geheimhouding van gegevens buiten de familiekring.

In de laatste paragraaf is de situatie aan de orde geweest waarin er ten behoeve van de adviesvrager geen erfelijkheidsonderzoek kan worden verricht, en er dus geen diagnose kan worden vastgesteld, omdat de vereiste medewerking van een familielid ontbreekt. Onderzocht is of er in het geval er sprake is van een conflict van plichten dezelfde criteria kunnen worden gehanteerd als in de situatie waarin een klinisch geneticus familieleden van de adviesvrager niet in kan lichten omtrent hun risico op een erfelijke aandoening. Geconcludeerd is dat de eis dat het niet informeren van het betrokken familielid een hoog risico op ernstige schade met zich meebrengt en dat het vrijwel zeker is dat door het informeren die schade kan worden voorkómen of beperkt, in deze situatie niet toepasbaar is. Daarom is het volgende criterium voorgesteld: het niet informeren van de adviesvrager leidt ertoe dat de resterende mogelijkheden voor hem om het risico op een erfelijke aandoening te reduceren in een onredelijke verhouding staan tot de schending van de privacy van het familielid 
door voor erfelijkheidsonderzoek gebruik te maken van de specifieke genmutatie die bij het familielid is aangetoond.

Hoe dient te worden gehandeld wanneer het familielid van wie gegevens nodig zijn, overleden is? De geheimhoudingsplicht van de hulpverlener geldt ook na het overlijden van zijn patiënt. Een uitzondering op de geheimhoudingsplicht is aanwezig wanneer de adviesvrager, bij leven uiteraard, toestemming heeft gegeven voor het verstrekken van zijn gegevens. Wanneer deze toestemming niet is gevraagd, maar er voor bloedverwanten een dringend belang in het geding is, dan is er geen andere weg dan het werken met de juridische fictie dat de overleden betrokkenen in het belang van zijn familieleden toestemming zou hebben willen geven, tenzij anders moet worden aangenomen.

In de volgende drie hoofdstukken zullen de resultaten van het empirische onderzoek besproken worden. In hoofdstuk $8 \mathrm{komt}$ aan de orde hoe er in de praktijk van de klinisch genetische centra wordt omgegaan met en hoe er wordt gedacht over het recht op informatie, de therapeutische exceptie en het toestemmingsvereiste. 



\section{ERFELIJKHEIDSADVISERING, INFORMATIE EN TOESTEMMING IN DE PRAKTIJK}

\subsection{Inleiding}

Het recht op informatie en het toestemmingsvereiste vormen cen belangrijk onderdeel van de behandelingsovereenkomst. Eerst na een geïformeerde toestemming van de adviesvrager kan er een erfelijkheidsonderzoek worden verricht. In dit hoofdstuk staat de wijze centraal waarop aan het recht op informatie en het toestemmingsvereiste in de praktijk van de erfelijkheidsadvisering inhoud wordt gegeven. In paragraaf 8.2 wordt een korte beschrijving gegeven van de houding van klinisch genetici ten opzichte van patiëntenrechten en de erfelijkheidsadvisering. Paragraaf 8.3 gaat in op de wijze waarop in de praktijk wordt omgegaan met en gedacht wordt over de informatieplicht. Hierbij komt tevens het perspectief van adviesvragers aan de orde. In paragraaf 8.4 wordt beschreven hoe klinisch genetici omgaan met de therapeutische exceptie. De vraag of erfelijkheidsadvisering non-directicf van aard is, komt in paragraaf 8.5 aan de orde. Paragraal 8.6 beschrijft hoe klinisch genetici invulling geven aan het toestemmingsvereiste. Elke paragraaf wordt afgesloten met een beschouwing waarin wordt gekeken hoe de gegeven beschrijving van het onderwerp zich verhoudt tot de juridische invulling daarvan. Het hoofdstuk wordt afgesloten met een slotbeschouwing waarin de volgende vragen worden beantwoord:

- Zijn klinisch genetici op de hoogte van het recht op informatie, het toestemmingsvereiste en de therapeutische exceptie?

- Delen klinisch genetici de uitgangspunten van de juridische invulling van deze rechten?

- Worden deze rechten toegepast conform de juridische invulling die daaraan is gegeven?

- Wat zijn daarbij de knelpunten en dilemma's en hoe zijn deze eventueel op te lossen?

\subsection{Houding klinisch genetici ten opzichte van patiëntenrechten}

Alle geïnterviewde klinisch genetici zijn in beginsel positief over het feit dat steeds meer rechten van patiënten wettelijk zijn geregeld. Bovendien past het volgens hen in de huidige samenleving.

"Het hoort bij deze tijd. Het is een maatschappelijk verschijnsel."

Patiënten zijn mondiger en zelfbewuster en in die lijn zijn patiëntenrechten ontwikkeld. De Wgbo is als term bekend en van de inhoud is men globaal op de hoogte. De finesses en de achtergronden zijn niet altijd even duidelijk. De Wgbo 
regelt volgens klinisch genetici wat al zo zou moeten zijn. Het belang van de Wgbo voor de klinische genetica wordt door een geneticus als volgt omschreven.

"Dat is bij uitstek in ons vakgebied een heel belangrijke wet ondat we zulke essentiële onderzoeken doen. Daarom stellen we al van oudsher heel bewust dat we geen erfelijkheidsonderzoek verrichten voordat de mensen goed geinformeerd zijn, want we hebben het niet over het heden en het simpel bepalen van een bloedgehalte, maar we hebben het over families en over generaties."

Als positieve aspecten worden vaak genoemd de duidelijkheid en eenduidigheid voor zowel patiënten als artsen. Patiënten genieten bescherming op een specialistisch, voor hen onbekend, vlak. Voor genetici is het duidelijker dan voorheen aan welke verplichtingen ze moeten voldoen. De Wgbo maakt het voor onderzoeksgerichte specialisten die de patiëntenzorg ook willen gebruiken voor het doen van onderzoek, minder gemakkelijk om het belang van de patiënt uit het oog te verliezen omdat veel beter moet worden uitgelegd waarom men dingen doet. Wat valk wordt benadrukt is dat er in de praktijk voor de geneticus nauwelijks iets veranderd is. In de klinische genetica werden adviesvragers reeds uitvoerig geïnformeerd. Voor de invoering in 1995 van de Wgbo werkte men al in overeenstemming met de belangrijkste wettelijke bepalingen. De Wgbo is volgens klinisch genetici daarom eerder een consolidatie van de bestaande praktijk.

De wettelijke bescherming die de Wgbo adviesvragers biedt, vindt men soms theoretisch. De regeling staan soms ver af van de praktijk. De patiënt is er niet van op de hoogte en is er niet mondiger door geworden. Ook wordt genoemd dat patiëntenrechten een beetje doorschieten in de zin dat het de werkbaarheid in gevaar zou kunnen brengen.

Uit het KNMG-onderzoek uit 1998 en de Wgbo-evaluatie uit 2000 is gebleken dat artsen ambivalente gevoelens hebben over de Wgbo.' Helderheid over de rechten van de patiënt en de plichten van de arts staan tegenover nadelen als verzakelijking en juridisering van de arts-patiëntrelatie. Klinisch genetici lijken positiever te staan tegenover de Wgbo. De positieve aspecten worden benadrukt evenals het feit dat men reeds conform de belangrijkste bepalingen uit de Wgbo werkte, voordat deze werd ingevoerd. Ze beschouwen hun vak ook als toonaangevend op het gebied van de omgang met en de informatieverstrekking aan de adviesvragers.

"Ik denk dat wij relatief weinig klachten hebben gekregen in verhouding tot andere disciplines, omdat dit vakgebied eigenlijk toonaangevend is geweest in verhouding tot alle andere specialismen als het gaat om goede voorlichting aan mensen geven, zodat ze zelf hun besluiten kunnen nemen en goed begrijpen waar het over gaat."

\section{Beschourving}

De grondhouding van klinisch genetici ten opzichte van patiëntenrechten is positief. $\mathrm{Ze}$ beschouwen hun vak als toonaangevend voor wat betreft de informatieverstrekking aan adviesvragers. In de volgende paragraaf, waar het recht

De Haes e.a. 1998, p. 31. Dute 2000, p. 113-114. 
op informatie aan de orde is, zal ook blijken dat adviesvragers uitgebreid geïformeerd worden, en dat met name het feit dat hier ruim de tijd voor wordt genomen zeer door adviesvragers gewaardeerd wordt.

De negatieve aspecten die worden genoemd lijken gebaseerd op een verkeerde interpretatie van de inhoud en het doel van de Wgbo. Zo lijkt de opvatting dat de regeling soms ver van de praktijk afstaat en theoretisch is, te veronderstellen dat de Wgbo bestaat uit een starre regeling van de rechten en plichten van zowel de patiënt als de hulpverlener, die geen recht kan doen aan de complexe praktijk. De Wgbo is echter een kaderwet die algemene rechten en plichten omschrijft, maar de concrete invulling daarvan aan de praktijk overlaat. Door open normen als het goed hulpverlenerschap en de eis dat de hulpverlener zich bij het informeren van de patiënt laat leiden door hetgeen deze redelijkerwijze dient te weten, kan recht worden gedaan aan de specifieke omstandigheden van elke afzonderlijke situatie.

Het gevaar dat de Wgbo de werkbaarheid in gevaar zou brengen, lijkt niet aanwezig. Klinisch genetici geven immers zelf aan dat de Wgbo een consolidatie is van de bestaande praktijk. Het voldoen aan de informatieplicht kost tijd, maar deze tijd wordt ook voor adviesvragers genomen.

\subsection{Het recht op informatie}

In deze paragraaf wordt beschreven hoe in de praktijk invulling wordt gegeven aan het recht op informatie. Achtereenvolgens komt aan de orde: het informeren bij erfelijkheidsadvisering, het bespreken van de consequenties voor familieleden, onverwachte bevindingen, de wijze van informeren over de uitslag en ten slotte het recht op informatie versus het recht op niet weten.

\subsubsection{Het informeren bij erfelijkheidsadvisering}

Elk eerste gesprek start met de vraag naar de reden van de komst van de adviesvrager en het tekenen van de stamboom. Ook wanneer de stamboom via familieleden voor de geneticus al bekend is, wordt toch de stamboom opgemaakt. De geheimhoudingsplicht van de klinisch geneticus noopt hem hiertoe. Het is voor de klinisch geneticus tevens een mogelijkheid om te inventariseren wat de adviesvrager reeds weet over het mogelijke erfelijkheidsprobleem en hoe het contact met de familieleden is die de geneticus reeds eerder hebben geconsulteerd. Het is overigens niet zo dat adviesvragers altijd met een vraag naar erfelijkheidsonderzoek naar het klinisch genetisch centrum komen. Het kan zijn dat een adviesvrager voor een informatief gesprek komt en wil weten wat hem te wachten staat met betrekking tot een bepaalde aandoening. Ook is het mogelijk dat hij is doorverwezen en eigenlijk zelf geen erfelijkheidsvraag heeft. Hij is dan bijvoorbeeld verwezen door een specialist omdat die een vraag heeft. 
Sommige klinisch genetische centra sturen voor een eerste gesprek formulieren naar de adviesvrager warop deze de familie in kaart kan brengen.

\begin{abstract}
"Als er bijvoorbeeld een aanmelding is van een erfelijke vorm van borstkanker, dan krijgen mensen thuis al formulieren toegestuurd. Deze zijn bedoeld om de familie alvast in kaart te brengen omdat dat gewoon handig is. Op die manier bewerkstellig je dat de mensen thuis al goed hebben nagedacht over wie in de familie borstkanker had, de geboortedata, in welk ziekenhuis en door welke specialist familieleden zijn behandeld. Als je dat pas bij het eerste gesprek vraagt zeggen ze: 'had ik dat maar geweten, dan had ik het opgezocht'."
\end{abstract}

Deze benadering heeft als voordeel dat het erfelijkheidsonderzoek wordt bespoedigd. Adviesvragers weten vaak niet dat de hele stamboom bij cen eerste gesprek wordt getekend en stellen tijdens een eerste gesprek wel eens dat wanneer ze geweten hadden dat dit belangrijk was, ze van te voren in de familie navraag zouden hebben gedaan.

"Ik vond eigenlijk dat ze van tevoren een formulier hadden moeten meesturen waar bepaalde vragen opstaan, zodat je bij de familie al navraag kunt doen. Er wordt heel veel over de familie gevraagd en vaak weet je dat op zo'n moment helemaal niet."

\title{
Beschonzuing
}

De vraag is echter of deze werkwijze niet te onderzoeksgericht is. Er wordt vanuit gegaan dat adviesvragers onderzoek willen laten doen naar hun risico op een bepaalde aandoening of dat adviesvragers een diagnose willen horen. Het is mogelijk dat adviesvragers geen hulpvraag hebben, maar doorverwezen zijn, en bij nader inzien willen afzien van een erfelijkheidsonderzoek. De mogelijkheid bestaat ook dat ze voor een informatief gesprek komen. Een vrijblijvend informatief gesprek wordt echter onlogisch als er door de adviesvragers veel voorwerk is gedaan gericht op erfelijkheidsonderzoek. Een dergelijke werkwijze is daarom niet aan te bevelen.

Het verdere verloop van het gesprek is voor een groot deel afhankelijk van de vraagstelling. De vraagstellingen kunnen in twee groepen worden ingedeeld: enerzijds vragen naar voorspellend erfelijkheidsonderzoek en anderzijds vragen naar een diagnostisch erfelijkheidsonderzoek.

\subsubsection{Informatie bij voorspellend onderzoek naar aandoeningen bij de adviesvrager}

Voorspellend onderzoek wordt verricht naar monogene en multifactoriële aandoeningen die leiden of kunnen leiden tot een aandoening bij de adviesvrager. Het verloop van de erfelijkheidsadvisering hangt bij dergelijk onderzoek af van het feit of er reeds een mutatie in de familie bekend is en de adviesvrager hiervan afweet.

\section{De mutatie is bekend}

De mutatie die tot een aandoening leidt of kan leiden, kan om twee redenen bekend zijn. Ten eerste omdat de aandoening altijd wordt veroorzaakt door dezelfde genmutatie. In dat geval is er geen onderzoek nodig bij een familielid dat reeds lijdt, of heeft geleden, aan de aandoening. Een voorbeeld hiervan is de ziekte van 
Huntington. De ziekte wordt, indien aanwezig, altijd veroorzaakt door dezelfde genmutatie. Er is dus geen sprake van verschillende mutaties die deze aandoening veroorzaken of van een erfelijke en een niet erfelijke vorm van de ziekte. Om het risico op de ziekte te bepalen wordt informatie ingewonnen bij hulpverleners die familieleden hebben behandeld, zodat zeker is dat bij een familielid de diagnose Huntington is gesteld. De mutatie kan ook bekend zijn omdat reeds erfelijkheidsonderzoek is verricht bij een ander familielid en daarbij de mutatie is aangetoond. Indien de familiesituatie bekend is kan het risico op de mutatie berekend worden en houdt, indien de adviesvrager hiertoe besluit, het onderzoek in dat gericht naar één mutatie wordt gezocht.

\section{De mutatie is niet bekend}

Het is ook mogelijk dat de mutatie niet bekend is. Wanneer de aandoening waar de erfelijkheidsvraag zich op richt, niet door één specifieke genmutatie wordt veroorzaakt, zal eerst de mutatie die binnen een familie tot een erfelijke aandoening leidt, moeten worden aangetoond bij een familielid dat lijdt aan de betreffende aandoening. Is er nog geen erfelijkheidsonderzoek in de familie verricht, de mutatie is dus niet bekend, dan moet eerst de vraag beantwoord worden of de aandoening in de familie überhaupt erfelijk, of mogelijk erfelijk, is. Een voorbeeld van een aandoening waarvan ook een niet-erfelijke variant bestaat, is borstkanker. Wordt deze vraag bevestigend beantwoord, dan zal een familielid benaderd worden, dat lijdt of heeft geleden aan de betreffende aandoening, met de vraag of hij mee wil werken aan genetisch onderzoek waarbij gekeken wordt of de familiaire mutatie gevonden kan worden. Deze persoon wordt de indexpatiënt genoemd. Pas wanneer bij de indexpatiënt een mutatie wordt gevonden, kan bij de adviesvrager naar deze mutatie worden gezocht. Het niet aantonen van een mutatie bij de indexpatient, makt onderzoek bij de adviesvrager onmogelijk. Het vermoeden van een erfelijke vorm van de aandoening in de familie kan echter blijven bestaan, bijvoorbeeld wanneer bepaalde typen tumoren bij meerdere familieleden in meerdere generaties voorkomen. Het niet aantonen van een mutatie bij de indexpatiënt betekent in deze situatie dat het in de betreffende familie een mogelijk erfelijke vorm van een aandoening betreft waarvan de mutatie (nog) niet is aangetoond.

Het is ook mogelijk dat een mutatie zowel in de familie als bij de geneticus bekend is, omdat een ander familielid of enkele familieleden dit hebben laten onderzoeken, maar dat de adviesvrager niet van deze gegevens op de hoogte is. In hoofdstuk 10, alwaar de geheimhoudingsplicht wordt besproken, komt deze situatie verder aan de orde.

Bepalend voor de informatieverstrekking aan de adviesvrager is de ervaring met en de kennis die men heeft van de aandoening waar de erfelijkheidsvraag zich op richt en het overervingspatroon daarvan. Indien de erfelijke aandoening en de mutatie in de familie reeds bekend zijn, zijn adviesvragers meestal op de hoogte van hun risico op de erfelijke aanleg voor de betreffende aandoening en weten ze door de familieverhalen ook enigszins wat erfelijkheidsadvisering inhoudt. Ook hebben ze de ziekte van dichtbij meegemaakt. 
Wanneer een adviesvrager met de vraag komt of de in de familie voorkomende aandoening erfelijk zou kunnen zijn, wordt eerst veel aandacht besteed aan medischtechnische aspecten van de mogelijkheden en onmogelijkheden van erfelijkheidsonderzoek. Vervolgens wordt het risico op de erfelijke aanleg berekend, ervan uitgaande dat de aandoening erfelijk is. De gevolgen voor bloedverwanten bij een gebleken erfelijke aanleg worden besproken, alsmede de eventuele medische handelingsopties die een adviesvrager heeft wanneer er sprake is van een erfelijke aanleg. Bij de vraag ten slotte of en waarom men door wil gaan met het voorspellend erfelijkheidsonderzoek wordt uitgebreid stil gestaan. In de meeste gevallen wordt vervolgens informatie opgevraagd van familieleden om te kunnen achterhalen of werkelijk sprake is of was van de aandoening waar de adviesvrager een voorspellend erfelijkheidsonderzoek naar wil laten verrichten en wordt de adviesvrager gevraagd contact op te nemen met een eerstegraads familielid dat aan de aandoening lijdt of heeft geleden, zodat een afspraak gemaakt kan worden met dat familielid. Tijdens een volgend gesprek met de adviesvrager worden de resultaten besproken van opgevraagde gegevens en van eventueel bloedonderzoek dat verricht is bij een aangedaan familielid. Ook wordt er dan stil gestaan bij de vraag waarom de adviesvrager voorspellend onderzoek wil ondergaan. De mogelijke gevolgen van het erfelijkheidsonderzoek bij het aangaan van verzekeringen en hypotheken worden genoemd en er wordt stil gestaan bij de eventuele medische handelingsopties die een adviesvrager heeft bij een ongunstige uitslag. Ook de gevolgen voor familieleden worden nogmaals aan de orde gesteld. Ten slotte wordt er, wanneer een adviesvrager besluit dat hij wil weten of hij de erfelijke aanleg heeft, bloed afgenomen dat opgestuurd wordt voor een erfelijkheidsonderzoek.

Als reeds een mutatie in de familie bekend is, of wanneer het een aandoening betreft die altijd wordt veroorzaakt door dezelfde genmutatie, kan het risico op de erfelijke aanleg tijdens een eerste gesprek berekend worden. Wel is, in het geval van een familiaire mutatie, nodig dat een familielid waarbij de erfelijke aanleg is vastgesteld toestemming geeft dat zijn gegevens worden gebruikt, zodat gericht naar de mutatie kan worden gezocht. De overige aspecten van de erfelijkheidsadvisering zijn gelijk aan hetgeen hierboven is beschreven.

Een enkele keer komt het voor dat het erfelijkheidsonderzoek reeds na één gesprek wordt ingezet. Dit is het geval wanneer een adviesvrager aangeeft goed op de hoogte te zijn van hetgeen het onderzoek inhoudt en aangeeft dat hij weloverwogen besloten heeft om het erfelijkheidsonderzoek te laten verrichten. Dit zal het geval zijn bij adviesvragers waar de erfelijke ziekte al geruime tijd in de familie voorkomt. In die situaties groeien adviesvragers vaak naar een erfelijkheidsonderzoek toe. Op het moment dat er een afspraak wordt gemaakt voor een gesprek is de keuze om een erfelijkheidsonderzoek te laten verrichten al gemaakt.

Het aanwezig zijn van een erfelijke ziekte in de familie brengt risico's op een erfelijke ziekte voor verschillende familieleden met zich mee. In de praktijk komt het voor dat familieleden tegelijk willen worden geïnformeerd wanneer zij een voorspellend erfelijkheidsonderzoek willen ondergaan en ook tegelijk de uitslag willen horen. Aan het eerste verzoek wordt meestal gehoor gegeven. De uitslag van voorspellend 
erfelijkheidsonderzoek wordt zelden of nooit aan meer dan één adviesvrager tegelijk gegeven. Adviesvragers hebben hier begrip voor.

"De dokter wilde de uitslagen niet tegelijk geven en daar hebben we ook alle begrip voor. Hij zei toen dat als je te horen krijgt dat je geen draagster bent, dan kun je nog geen vijf minuten blij zijn. Als je apart gaat, dan kan ieder het ook even een eigen plaatsje geven, het eventjes zelf laten bezinken."

Alle centra werken bij voorspellend onderzoek naar het risico op een aandoening bij de adviesvrager met maatschappelijk werkenden of psychologen om de advisering op psychosociaal gebied te ondersteunen. Het verschilt per centrum of zij de adviesvragers apart spreken dan wel samen met de klinisch geneticus de adviesvragers zien. In een enkel centrum wordt de psychosociale ondersteuning deels door de genetisch consulent verricht.

Bij voorspellend erfelijkheidsonderzoek werkt men dus volgens een min of meer vaste werkwijze. Deze kan protocollair vastgelegd zijn, zowel voor een bepaalde groep aandoeningen als voor een specifieke aandoening. Zo bestaan er protocollen voor erfelijke tumoren en voor de ziekte van Huntington. De ernst van veel ziektes, alsmede de gevolgen die een erfelijkheidsonderzoek voor zowel de adviesvrager als familieleden kan hebben, maakt dat bij de erfelijkheidsadvisering zeer uitvoerig stil wordt gestaan bij het feit of de adviesvrager zeker weet dat hij wil weten of hij de erfelijke aanleg voor de ziekte heeft alsmede of hij de gevolgen overziet. In sommige centra is protocollair vastgelegd dat de adviesvrager, bij voorspellend onderzoek naar een aandoening bij de adviesvrager zelf, schriftelijk moet motiveren waarom hij wil weten of hij gendrager is.

"Ze moeten ook cen briefje maken waarin ze aangeven waarom ze wel of niet getest willen worden. Voornamelijk waarom ze wel getest willen worden, zodat mensen erover na moeten denken."

\subsubsection{Informatie bij voorspellend onderzoek om het risico op een aandoening voor nageslacht of andere bloedverwuanten vast te stellen}

Naast voorspellend onderzoek om de risico's op een aandoening bij de adviesvrager vast te stellen, wordt ook voorspellend onderzoek verricht om de risico's voor nageslacht of andere bloedverwanten van de adviesvrager op een aandoening vast te kunnen stellen. Het betreft onderzoek naar dragerschap van een autosomaal of geslachtsgebonden recessief gen, of een chromosomale afwijking. Indien een vrouw twee of meer miskramen heeft gehad of wanneer de zwangerschap heeft geleid tot een vroeggeboorte waarbij de vrucht dood ter wereld is gekomen of kort na de geboorte overleden is, wordt bij de ouders onderzoek gedaan naar een chromosomale afwijking die de miskramen of de vroeggeboorte kan verklaren. Onderzoek naar een recessief gen wordt verricht wanneer een aandoening bij een familielid hier aanleiding toe geeft, dan wel wanneer bij de partner van de adviesvrager reeds bekend is dat hij drager is van een mutatie die bij nageslacht kan leiden tot een autosomaal recessieve afwijking. 
De adviesvrager krijgt informatie over het onderzoek en de mogelijke uitkomsten. Bij een erfelijkheidsvraag naar dit type onderzoek wordt sterk benadrukt dat de uitkomst van het onderzoek geen consequenties heeft voor de eigen gezondheid. Het onderzoek is dus alleen voorspellend in die zin dat het aangeeft hoe groot het risico is voor anderen, met name voor nageslacht van de adviesvrager, dat zij zullen gaan lijden aan een erfelijke aandoening.

\subsubsection{Informatie bij diagnostisch onderzoek}

Diagnostisch erfelijkheidsonderzoek betreft onderzoek waarbij door middel van genetisch onderzoek wordt vastgesteld, of geprobeerd wordt vast te stellen, of de adviesvrager, of diens kind(eren) of bloedverwanten, lijden aan een erfelijke of aangeboren aandoening. Een aantal categorieën is te onderscheiden. In het eerste geval is de aanleiding dat de adviesvrager zelf een aandoening heeft die nog niet exact gediagnosticeerd is en waarvan hij, of zijn behandelend arts, vermoedt dat deze erfelijk zou kunnen zijn. Een tweede, belangrijke, categorie is die waarin diagnostisch onderzoek wordt verricht bij (verstandelijk) gehandicapten op verzoek van diens familieleden. In het verleden is vaak geen exacte diagnose gesteld en is geen oorzaak voor de handicap gevonden. Wanneer broers of zussen of andere familieleden van de gehandicapte adviesvrager een kinderwens hebben, kan de vraag actueel worden of de betreffende handicap erfelijk is. Ten slotte kunnen ouders vragen hebben over de mogelijke erfelijkheid van een aandoening bij hun kind(eren).

Het onderzoek bij gehandicapten naar een mogelijk erfelijke of aangeboren aandoening verloopt in alle centra volgens een min of meer vast patroon. Gevraagd wordt naar de ontwikkeling van de gehandicapte, vanaf de zwangerschap van de moeder tot het heden, waarbij zonodig gegevens worden opgevraagd. Vervolgens vindt een lichamelijk onderzoek plaats. Hierbij wordt ook naar minieme uiterlijke afwijkingen gezocht. Ten slotte worden de handen, voeten, het gezicht en de gehandicapte in zijn geheel op de foto gezet. Deze foto's worden in het teamoverleg getoond zodat gezamenlijk kan worden gezocht naar een verklaring voor de problemen. Wanneer dit nog niet verricht is, wordt in de regel bloedonderzoek gedaan naar chromosoomafwijkingen of wordt specifiek DNA-onderzoek aangevraagd. De informatie die tijdens het gesprek wordt gegeven bestaat enerzijds uit informatie omtrent het hoe en waarom van het stamboomonderzoek, het lichamelijk onderzoek en eventueel het bloedonderzoek en anderzijds uit informatie omtrent de verwachte resultaten van het onderzoek. Wanneer een diagnose is gesteld wordt ingegaan op de risico's voor overige familieleden en/of nageslacht op de erfelijke of aangeboren aandoening.

De informatieverstrekking bij onderzoek dat plaatsvindt om een aandoening exact te diagnosticeren, betreft het erfelijkheidsonderzoek zelf en spitst zich verder toe op de consequenties voor famulieleden en nageslacht wanneer vastgesteld wordt dat het een erfelijke aandoening betreft. De behandeling van de aandoening wordt overgelaten aan de behandelend arts. 


\section{Beleoing adviesvragers}

Adviesvragers geven aan dat zij uitgebreid geïnformeerd zijn door de klinisch geneticus. Ook uit de geobserveerde gesprekken werd duidelijk dat adviesvragers uitgebreid worden geinformeerd. Voor hen is naast het feit dat men inhoudelijk adequat geïnformeerd wordt, vooral de wijze waarop dit gebeurt van belang.

"Een goede uitleg en ook heel rustig. Dat vond ik het allerfijnste. Je werd helemaal op je gemak gesteld en ze nam de tijd voor je en zat niet op de klok te kijken voor het volgende gesprek. We zeiden na een tijd: 'nou, we zitten er al lang, er zal wel een stel zitten te wachten.' Toen zei ze: 'nee, ik reserveer altijd heel veel tijd voor de eerste gesprekken, trouwens voor alle gesprekken'. Dat vond ik zo fijn. Ze liet helemaal niet merken dat we op moesten schieten. Dat vond ik echt fijn. Heel héél rustig, ze praatte heel fijn."

"We hadden echt zoiets van: dit is dus heel anders dan die ziekenhuizen waar je normaal komt. Hij nam gewoon alle tijd voor ons. Hij liet ons ons verhaal doen. Hij had ook zijn verhaal. We konden alle vragen stellen die we wilden. Dat vond ik dus wel heel fijn, want het is toch een syndroom en ik had er nog nooit van gehoord."

"Veel aandacht, tijd genoeg, begrip en alle medewerking werd toegezegd die maar nodig is."

Adviesvragers die voor het eerst naar het klinisch genetisch centrum gaan en geen familieleden hebben die reeds een erfelijkheidsadvies hebben gekregen, althans voor zover bij hen bekend, geven aan dat zij niet wisten wat voor informatie en onderzoek zij konden verwachten. Adviesvragers bij wie er reeds jaren een erfelijke ziekte in de familie speelt gaven daarentegen aan, dat zij van tevoren wisten wat zij konden verwachten van de erfelijkheidsadvisering.

\section{Beschourving}

Uit bovenstaande beschrijving blijkt dat de adviesvrager uitgebreid wordt geinformeerd en dat de informatieverstrekking zich meestal over verschillende gesprekken uitstrekt. Bepalend hierbij is de ervaring met en de kennis die de adviesvrager heeft van de aandoening waar de erfelijkheidsvraag zich op richt, alsmede inzicht in en kennis van de (on)mogelijkheden om door middel van erfelijkheidsonderzoek informatie te vergaren.

In hoofdstuk 4 is aangegeven dat de adviesvrager, behalve over de in artikel 7:448 lid 1 en 2 BW genoemde punten ook geïnformeerd moet worden over de eventuele vereiste medewerking van bloedverwanten aan een erfelijkheidsonderzoek en over het mogelijke belang van de uitslag daarvan voor die bloedverwanten. Daarnaast valt informatie over de maatschappelijke gevolgen van een erfelijkheidsonderzoek, zoals informatie over de mogelijke gevolgen voor verzekeringen en hypotheken, onder de informatieplicht. Beide aspecten van de informatieplicht komen tijdens de erfelijkheidsadvisering aan bod.

In sommige centra moeten adviesvragers schriftelijk aangeven waarom ze wel of niet een voorspellend onderzoek willen ondergaan. In hoofdstuk 4 is aangegeven dat de 
klinisch geneticus zich ervan moet vergewissen dat de adviesvrager de informatie heeft begrepen. Het motiveren door de adviesvrager van de beslissing een erfelijkheidsonderzoek te willen ondergaan, is voor de klinisch geneticus een manier om na te gaan of het besluit van de adviesvrager is gebaseerd op juiste veronderstellingen en daarom een verantwoorde invulling van zijn informatieplicht.

Indien adviesvragers verzoeken om reeds bij een eerste gesprek bloed af te nemen, wordt aan zo'n verzoek voldaan als blijkt dat de adviesvrager er blijk van geeft reeds op de hoogte te zijn van de (meeste) relevante informatie en voor het eerste gesprek reeds weloverwogen besloten heeft een erfelijkheidsonderzoek te willen ondergaan. Onder deze omstandigheden lijkt het verantwoord om al bij een eerste gesprek het erfelijkheidsonderzoek in gang te zetten. Een bedenktijd van enkele weken op advies van de geneticus nadat de adviesvrager er zelf reeds jaren over nagedacht heeft, is haast een patemalistisch advies. Hier past wel een relativering bij. Het is mogelijk dat er al jaren een ziekte in de familie voorkomt zonder dat de erfelijkheid daarvan was aangetoond. Het bericht dat er een mutatie is gevonden en dat dus een gericht erfelijkheidsonderzoek mogelijk is, kan leiden tot overhaaste reacties, zonder dat rustig is overwogen of men verder wil leven met zekerheid omtrent het al dan niet aanwezig zijn van een bepaalde mutatie. Een klinisch geneticus staat als hulpverlener in iedere situatie opnieuw voor de opdracht om zich ervan te vergewissen dat het besluit van een adviesvrager om erfelijkheidsonderzoek te ondergaan, een weloverwogen besluit is. Indien adviesvragers voor het eerste gesprek telefonisch aangeven dat zij tijdens het eerste gesprek reeds geprikt willen worden, verdient het om die reden aanbeveling om aan te geven dat dit tijdens het eerste gesprek zal worden bekeken. In de loop van het gesprek zal het voor de geneticus duidelijk worden of hij hier gehoor aan kan geven.

Het verzoek van sommige adviesvragers om gezamenlijk te worden geinformeerd over een erfelijkheidsonderzoek alsmede over de uitslag, is begrijpelijk. Familieleden hebben vaak steun aan elkaar en de medische informatie en het risico op de erfelijke ziekte is vaak hetzelfde. Anderzijds is elke situatie uniek. Het apart spreken van elke adviesvrager kan aan het licht brengen dat een adviesvrager geen erfelijkheidsonderzoek wil ondergaan, maar dit niet kenbaar durft te maken aan bijvoorbeeld zijn broers en zussen. Ook andere relevante aspecten kunnen onderbelicht blijven wanneer meerdere familieleden tegelijk worden geadviseerd. Hier zal de geneticus op grond van zijn ervaring moeten bepalen op welke manier hij het beste de zorg van een goed hulpverlener in acht kan nemen. In hoofdstuk 4 is opgemerkt dat het goed hulpverlenerschap impliceert dat zeker bij voorspellend onderzoek de uitslag daarvan aan elke adviesvrager separaat verstrekt wordt. De praktijk is hiermee in overeenstemming.

Voor adviesvragers blijken vooral aspecten van belang te zijn die niet door de Wgbo worden geregeld, zoals het feit dat er genoeg tijd wordt uitgetrokken voor een gesprek, het feit dat er begrip en aandacht is voor de situatie van de adviesvrager en de opstelling van de klinisch geneticus. Anderzijds zou men kunnen beargumenteren dat de klinisch geneticus niet aan de voorwaarden van artikel 7:448 BW lid 1 en 2 kan voldoen wanneer voldoende tijd en aandacht voor de adviesvrager ontbreken. De 
klinisch geneticus moet zich ervan vergewissen dat de adviesvrager de informatie voldoende heeft begrepen. Dit brengt met zich mee dat hij alleen aan de hoge eisen die aan de informatieplicht worden gesteld kan voldoen indien de vaak complexe en grote hoeveelheid informatie duidelijk wordt verstrekt en er ruimte is om deze informatie te herhalen en om vragen te beantwoorden van de adviesvrager. Ook het informeren over de mogelijke gevolgen en consequenties van de keuze om een erfelijkheidsonderzoek te ondergaan vergen grote inspanning aan de zijde van de geneticus. Ook de zorg van een goed hulpverlener brengt met zich mee dat de klinisch geneticus voorwaarden schept om te kunnen voldoen aan de informatieplicht.

\subsubsection{Het bespreke'n van de consequenties voor familieleden}

Adviesvragers wordt in principe altijd meegedeeld dat de uitslag van een erfelijkheidsonderzoek ook gevolgen kan hebben voor hun familieleden. Tevens wordt besproken dat bij een ongunstige uitslag familieleden bij voorkeur ingelicht moeten worden. Hiermee wordt beoogd dat adviesvragers bij een ongunstige uitslag niet verrast zijn door en schrikken van de consequenties van de uitslag. De gevolgen voor familieleden worden overigens niet altijd in dezelfde mate benadrukt. Het is afhankelijk van de inschatting van de omvang van de mogelijke gevolgen voor familieleden. Bij voorspellend onderzoek zijn de gevolgen vaak groter dan bij diagnostisch onderzoek. Genetici geven aan dat voor de meeste adviesvragers de mogelijke consequenties voor familieleden geen verrassing zijn.

"Ze weten wel dat hier in tegenstelling tot bij andere specialisten niet alleen het individu centraal staat, maar toch ook de familie. Ik denk dat dat het grote verschil is."

Het is grotendeels afhankelijk van de vraag in hoeverre de mogelijk erfelijke aandoening reeds in de familie bekend is. Wanneer nog uitgezocht moet worden wat er überhaupt aan de hand is, kan het een verrassing zijn. Vaak wordt wel bij de gevolgen voor de kinderen en eventueel hun kinderen stilgestaan. Adviesvragers realiseren zich echter niet altijd dat de uitslag voor de hele familie consequenties kan hebben. Bij de gevolgen voor kinderen en de broers en zussen staat men stil, maar verdere familie wordt dan vergeten.

Het komt een enkele keer voor dat mensen geen erfelijkheidsonderzoek willen laten verrichten omdat het onderzoek consequenties kan hebben voor familieleden. Ze willen als het ware niet de hele familie over zich heen hebben of familieleden ongerust maken. Soms komt een adviesvrager alsnog terug voor onderzoek wanneer de mogelijke consequenties van een erfelijkheidsonderzoek met familieleden zijn besproken.

Adviesvragers ondergaan een erfelijkheidsonderzoek niet altijd of niet primair voor zichzelf. Men ondergaat het vaak mede voor de kinderen, zodat de kinderen bij een gunstige uitslag weten dat ze zelf en hun nageslacht geen drager kunnen zijn en dus geen erfelijkheidsonderzoek hoeven ondergaan. Er zijn ook adviesvragers die een 
erfelijkheidsonderzoek op verzoek ondergaan omdat het van belang is bij een familielid een diagnose rond te krijgen. De consequenties voor familieleden zijn in die situaties dus de aanleiding om het onderzoek te ondergaan.

Aangezien een erfelijke aanleg een hele familie treft, komt het voor dat er soms onderzoek wordt gedaan voor een adviesvrager die daar eigenlijk minder belang bij heeft dan een ander familielid dat geen erfelijkheidsonderzoek laat verrichten. Zoals een echtpaar met een kinderwens dat wil weten of het feit dat een nichtje een bepaalde verstandelijke handicap heeft, consequenties heeft voor hun kinderen, terwijl het nichtje of haar ouders daarover eigenlijk geen vragen hebben. In situaties waarbij een familielid een verstandelijke handicap heeft of een aangeboren afwijking, is lang niet altijd de medische oorzaak daarvan bekend en vergt het veel onderzoek om deze, indien mogelijk, vast te stellen. Bovendien is het meestal aannemelijk dat het risico lager is voor de verdere familieleden dan voor de ouders. De vraag dringt zich dan op hoe ver men in zo'n geval moet gaan met het onderzoeken van risico's op het krijgen van kinderen met een verstandelijke handicap of een aangeboren afwijking. Formeel is dan sprake van een indicatie voor een erfelijkheidsonderzoek, maar er worden door klinisch genetici vragen gesteld bij de wenselijkheid ervan.

"Ik vind het ver gaan om voor een ver familielid van alles overhoop te halen en allerlei onderzoek te verordonneren. Moet je nou alles uit de kast halen voor zo'n afgeleide vraagsteller?"

\section{Beschourwing}

Het aangeven dat de uitslag van een erfelijkheidsonderzoek consequenties kan hebben voor familieleden van de adviesvrager is een onderdeel van de informatieplicht van de klinisch geneticus. Door zich bewust te zijn van de consequenties, alsmede de mogelijke belangen van familieleden bij de informatie die door het erfelijkheidsonderzoek wordt gegenereerd, weet de adviesvrager waar hij mee instemt. Alleen na het afwegen van alle relevante informatie kan hij een weloverwogen keuze maken. De mogelijke consequenties voor familieleden vormen een enkele keer de reden om geen erfelijkheidsonderzoek te ondergaan.

In de situatie waarin een adviesvrager een erfelijkheidsadvies vraagt omdat hij een ver familielid heeft met een verstandelijke handicap of een aangeboren afwijking doet zich de situatie voor dat de consequenties van een erfelijkheidsonderzoek voor een ander familielid waarschijnlijk groter zijn dan voor de adviesvrager. Voor de klinisch geneticus kan dit lastig zijn. Dit kan en moet hij echter kenbaar maken aan de adviesvrager bij het informeren over de consequenties van het onderzoek voor de adviesvrager zelf en voor zijn familieleden. Hij zal aan moeten geven dat het herhalingsrisico voor nageslacht van de adviesvrager zonder nadere informatie niet met zekerheid vast te stellen is, maar dat het waarschijnlijk laag is. Na afweging van de mogelijkheden en met name de onmogelijkheden om de erfelijkheidsvraag te beantwoorden is het, wanneer er sprake is van een medische indicatie, echter wel aan de adviesvrager om te besluiten of hij de erfelijkheidsadvisering wil continueren. 


\title{
8.3.3 Onverwachte bevindingen
}

Het is mogelijk dat bij erfelijkheidsonderzoek op onverwachte bevindingen wordt gestuit. Dit zal voornamelijk aan de orde zijn bij het doornemen van de familieanamnese en bij het verrichten van chromosomenonderzoek en incidenteel bij DNA-onderzoek. Door het vaak op een specifieke mutatie gerichte erfelijkheidsonderzoek doen onverwachte bevindingen zich bij erfelijkheidsadvisering niet vaak voor.

"Wij gaan juist heel gericht op jacht naar dingen en dat genereert eigenlijk nooit iets heel onverwachts dat hele andere implicaties heeft dan wat mensen hadden gevraagd. Chromosomenonderzoek is misschien wel eens een uitzondering."

Het meedelen van onverwachte bevindingen en met name de wijze waarop dit moet worden aangepakt is voor klinisch genetici niet gemakkelijk.

\begin{abstract}
"Wat ik moeilijk vind is de vraag in hoeverre je mag aankaarten dat je icts anders hebt ontdekt, waarvan jij weet dat het erfelijk kan zijn, terwijl de mensen daar niet voor komen. In hoeverre breng je dat ter sprake of breng je het überhaupt wel ter sprake. Wanneer je vraagt of de mensen er vragen over hebben, kweek je al onrust. Ik denk dat je het eigenlijk wel ter sprake moet brengen, maar het is niet de eerste vraag van die mensen geweest. Ik denk dat je mensen die informatie niet mag onthouden. Het moeilijkste is het tijdstip waarop je het aankaart en het kunnen inschatten of mensen er open voor staan. Je weet niet of ze er ooit over nagedacht hebben."
\end{abstract}

Een praktijkvoorbeeld laat zien dat onverwachte bevindingen tot voor de klinisch geneticus lastige situaties kunnen leiden.

\begin{abstract}
"Een man kwam met een vraag naar dragerschap voor taaislijmziekte - CF - omdat een zusje een kind had gekregen met die ziekte. Die man wilde zich laten testen, omdat hij zelf kinderen wilde op termijn en wilde weten hoe groot de kans was dat hij een kind kreeg met CF. We hebben die test bij die meneer uitgevoerd en hebben daar inderdaad dragerschap voor CF aangetoond, samen met een andere afwijking die in deze combinatie beschreven is bij mannen met vruchtbaarheidsproblemen. Het ging dus om informatie waar die man helemaal niet om vroeg en die kreeg ik via deze uitslag voor mijn neus. Wij hebben uiteindelijk besloten om het wel te vertellen. Wij vonden dat we dat die man wel moesten vertellen, omdat we die informatie hadden. Het kan ook niet dat zij straks aan kinderen willen beginnen en de hele mallemolen van technieken ingestuurd worden, en dat ze er dan uiteindelijk na lang zoeken misschien een keer achterkomen dat dit speelt, terwijl wij dat al weten. Ik denk dat dat toch te essentiële informatie is om in zo'n situatie achter te houden, hoewel het niet iets is waar hij om gevraagd heeft. Ik heb gezegd dat we dit als toevalsbevinding erbij gevonden hebben en dat het vaker is beschreven bij dit probleem. Ik heb eigenlijk niet gevraagd of hij het wilde horen. Ik heb het gewoon verteld en niet gevraagd of hij het wilde weten."
\end{abstract}

\section{Beschoutwing}

Onverwachte bevindingen zullen, zij het niet vaak, bij de erfelijkheidsadvisering vóórkomen. In hoofdstuk 4 is aangegeven dat medische informatie altijd aan de adviesvrager behoort te worden meegedeeld. De wijze waarop de geneticus dit in 
individuele situaties invult zal voornamelijk afhangen van het soort bevinding. Het aangeven dat ex een onverwachte bevinding uit het onderzoek is gekomen en dat het te maken heeft met de vruchtbaarheid en dan vervolgens de vraag: 'Wilt u dit weten?' is gekunsteld. Zeker wanneer de adviesvrager aangeeft dat hij een kinderwens heeft. In andere situaties zou het wel van goede zorg kunnen getuigen wanneer de geneticus aangeeft dat mogelijk een andere erfelijke aandoening speelt en vervolgens vraagt of de adviesvrager hier meer over wil weten. De geneticus zal hierbij een inschatting moeten maken van het juiste tijdstip en de beste manier om de boodschap mee te delen.

\subsubsection{De wijze wan informeren over de witslag}

Uitslagen van erfelijkheidsonderzoek, zowel diagnostisch als voorspellend, worden in principe altijd op het klinisch genetisch centrum gegeven. Het schriftelijk of telefonisch doorgeven van de uitslag gebeurt voornamelijk op verzoek van de adviesvrager en in principe alleen wanneer het geen voorspellend onderzoek naar een aandoening bij de adviesvrager zelf betreft. Na afloop van de erfelijkheidsadvisering krijgt de adviesvrager een brief thuisgestuurd waarin in begrijpelijke taal wordt samengevat hetgeen tijdens de advisering besproken is. De brief gaat tevens in kopie naar de huisarts en eventueel naar de betrokken behandelende specialisten. Het kan ook zo zijn dat de huisarts en betrokken specialisten een professionele brief ontvangen die inhoudelijk op hetzelfde neerkomt. Impliciet wordt aangenomen dat adviesvragers dit weten. Het wordt dan ook niet altijd gezegd. Soms echter wordt adviesvragers gevraagd of de huisarts en andere specialisten op de hoogte mogen worden gesteld. Dit betreft ernstige ziektes, voornamelijk de ziekte van Huntington. Daarbij komt het voor dat adviesvragers er voor kiezen dat de huisarts en betrokken specialisten niet worden ingelicht.

\section{Beschouwing}

Het informeren over de uitslag van zowel voorspellend als diagnostisch onderzoek wordt in de regel gegeven tijdens een gesprek tussen de klinisch geneticus en de adviesvrager. In hoofdstuk 4 is gesteld dat het goed hulpverlenerschap impliceert dat naarmate de gevolgen van het onderzock ingrijpender kunnen zijn, het sterk af te raden is om de uitslag dáárvan telefonisch te geven. Dit komt overeen met het gebruik in de praktijk om de uitslag van een voorspellend onderzock naar een aandoening bij de adviesvrager zelf, niet door middel van een telefoongesprek mede te delen.

Het vragen van toestemming aan adviesvragers voor het informeren van de huisarts en andere specialisten bij ernstige ziektes is een vorm van goed hulpverlenerschap. In hoofdstuk 4 bleek dat bij de ziekte van Huntington niet alle adviesvragers het op prijs stellen wanneer de huisarts over hun voorspellend onderzoek wordt geïformeerd. 


\title{
8.3.5 Het recht op informativ versus het recht op niet weten
}

Een adviesvrager heeft recht op informatie. Dit recht kan echter botsen met de wens van een familielid om verschoond te blijven van erfelijkheidsinformatie. Dit probleem doet zich bijvoorbeeld voor wanneer een adviesvrager wil laten onderzoeken of hij drager is van een mutatie die tot dezelfde erfelijke ziekte leidt of kan leiden als waaraan één van zijn grootouders lijdt of heeft geleden.2 Gebleken dragerschap bij de adviesvrager toont aan dat de ouder die tevens zoon of dochter is van de grootouder, ook drager moet zijn van de mutatie die tot de erfelijke ziekte lijdt. Indien deze ouder niet wil weten of hij drager is, maar de adviesvrager wel, ontstaat er een impasse die men tracht te doorbreken door naar consensus te streven tussen ouder en kind over het al dan niet laten verrichten van een erfelijkheidsonderzoek. Genetici geven aan hier vaak succesvol in te zijn.

"Wat heel vaak gebeurt als je het allemaal zo bespreekt, is dat het meestal toch zo draait dat die ouder er toch bij betrokken raakt en zich inderdaad laat testen. Wat ook gebeurt is dat de ouder dan nee zegt in de hoop dat wij dan ook nee zeggen en dat het allemaal bij het oude blijft. Maar dat op het moment dat die ouder hoort dat er toch bloed is afgenomen, de ouder op dat moment zegt: 'als het nu toch echt gaat gebeuren, wil ik het toch eigenlijk eerst zelf weten.'"

Genetici zijn zich bewust van het feit dat het verrichten van een erfelijkheidsonderzoek bij alleen de adviesvrager en niet bij de ouder in de familie tot moeilijke situaties kan leiden. Het is in hun ogen een illusie om te denken dat de ouder in onwetendheid kan blijven verkeren wanneer de adviesvrager een erfelijkheidsonderzoek heeft laten verrichten.

\begin{abstract}
"Wij als dokters vinden dat het een heel moeilijk probleem is waar je die adviesvragers mee naar huis stuurt. Wij zien ons zelf hier soms ook wat meer als de dokter van de familie die gewoon probeert mee te denken voor de gehele familie. Hoe moeten we hier dan mee verder? Straks komen ze wel met dat kleine kind op de verjaardag van opa. Dat zijn moeilijke situaties."
\end{abstract}

"De reactie is dan vaak: 'Ja, maar dan vertel ik het hem gewoon niet'. Ik zeg dan dat dat zo niet werkt. Het is onmogelijk om zo'n uitslag uiteindelijk voor je te houden. Uit de lengte of uit de breedte, dat komt een keer uit."

Klinisch genetici geven aan dat ze het recht op informatie van de adviesvrager, zowel bij behandelbare als onbehandelbare aandoeningen, in het algemeen zwaarder vinden wegen dan de wens van de ouder om van deze informatie verschoond te blijven.

2 Deze situatie komt ook voor bij voorspellend erfelijkheidsonderzoek bij een adviesvrager die een eeneige tweelingbroer of -zus heeft. Naar deze situatie is tijdens de interviews echter niet gevraagd. 
"Ik vind wel dat het recht van een twintigjarige zwaarder weegt. Iemand van twintig heeft nog zoveel levensbeslissingen voor zich: carrière, huwelijk, het stichten van een gezin. Dat zijn stappen die cen oudere al gemaakt heeft."

\section{Beschourwing}

In hoofdstuk 4 is aangegeven dat vanuit juridisch oogpunt het belang van de adviesvrager zal moeten prevaleren, maar dat in concrete situaties met name de redenen van de adviesvrager om te willen weten en van de ouder om niet te willen weten, van belang zijn. Relevante factoren bij het maken van een afweging zijn de persoonlijke omstandigheden en de psychische draagkracht van zowel de adviesvrager als de ouder en de kans dat de ouder ongewild op de hoogte raakt van een ongunstige uitslag van het erfelijkheidsonderzoek dat bij de adviesvrager is verricht.

Klinisch genetici geven aan naar consensus te streven tussen ouder en kind, mede vanuit de overtuiging dat het een illusie is dat de ouder niet van de uitslag van een erfelijkheidsonderzoek bij het kind op de hoogte zal geraken. Als reden om uiteindelijk het belang van het kind te laten prevaleren worden de nog te nemen levensbeslissingen van het kind genoemd. Naast de in hoofdstuk 4 genoemde relevante factoren, is ook deze factor, gezien het feit dat de uitslag van een erfelijkheidsonderzoek diep kan ingrijpen in het leven van de adviesvrager en hij zijn levensbeslissingen waarschijnlijk zal laten afhangen van de uitslag ervan, van belang. Gezien de belangen die de ouder kan hebben bij niet weten, is het op voorhand $z$ waarder laten wegen van de belangen van het kind, echter niet goed te verdedigen. In elke situatie zullen de belangen van zowel de ouder als kind moeten worden gewogen.

\subsection{De therapeutische exceptie}

Van de therapeutische exceptie wordt in de praktijk weinig gebruik gemaakt. ${ }^{3}$ Wanneer genetici wordt gevraagd of ze in de praktijk wel eens informatie niet geven blijkt dat hetgeen men onder informatie niet geven verstaat niet samenvalt met de wettelijke omschrijving van de therapeutische exceptie. Zo wordt bijvoorbeeld gesteld dat niet alle mogelijke risico's worden verteld. Ook wordt ingegaan op het feit dat met de adviesvrager stil wordt gestaan bij de vraag of hij wel wil weten of hij een erfelijke aanleg heeft en dat soms in overleg wordt besloten dat het op dat moment voor de adviesvrager niet het juiste moment is om erfelijkheidsonderzoek te laten verrichten. Het op grond van de geheimhoudingsplicht niet kunnen vertellen dat enkele familieleden van de adviesvrager al bekend zijn bij de geneticus en dat hij soms al weet wat het risico voor de adviesvrager is op een bepaalde aandoening

Uit de evaluatie van de Wgbo blijkt dat ook andere hulpverleners weinig gebruik maken van de mogelijkheid om informatie achter te houden. Er zou zelfs sprake zijn van een afnemende tendens. De belangrijkste reden om gebruik te maken van de therapeutische exceptie blijkt de psychische labiliteit van de patiënt te zijn. Dute 2000 , p. 85 . 
wordt ook gezien als het achterhouden van informatie. Men benadrukt dat nooit een zogenaamde echte uitslag wordt achtergehouden. Hiermee wordt bedoeld een op papier gestelde, door het laboratorium verzonden chromosomen- of een DNAuitslag.

In de praktijk kunnen er verschillende redenen zijn om informatie voorlopig niet mee te delen. Een eerste reden is het ontbreken van enig vermoeden aan de zijde van de adviesvrager dat er een aandoening in het spel is. In zo'n geval wordt een klinische diagnose niet onmiddellijk uitgesproken. De geneticus uit wel zijn bezorgdheid en verricht een bloedonderzoek om vervolgens de uitslag daarvan in een volgend gesprek te bespreken. Het volgende voorbeeld maakt dit duidelijk.

"Het gebeurt nog wel eens dat wij een kind zien met aangeboren afwijkingen of een ontwikkelingsachterstand die wordt verwezen door de kinderarts naar ons en dat je merkt aan de ouders dat ze zich helemaal geen zorgen maken om het kind. Dan zeggen ze: 'we zien ook wel dat hij traag is, maar ik was vroeger ook helemaal niet snel', of: 'we vinden helemaal niet dat hij er gek uitziet, want opa had ook van die oren en die zag er ook zo uit'. Dan is er dus geen enkel begrip, geen enkel ziekte-inzicht. Soms gebeurt het dat je op dat moment de diagnose al hebt, dat je ziet en weet dat het een klassiek syndroom is. Dan kan het gebeuren dat als je de mensen voor de eerste keer ziet, je dat niet zegt. Je zoekt een omweg. Je zegt: 'ik maak me samen met de kinderarts toch wel zorgen om uw kind, mar ik zie u nu pas voor het eerst, dus ik wil u graag over drie of zes maanden nog een keer zien. Dan kan ik het kind nog eens bekijken. Dan kan ik ondertussen in de boeken toch nog eens kijken of er misschien toch niet een oorzaak zou kunnen zijn voor wat er met uw kind aan de hand is, want ik maak me toch zorgen'. Of je zegt dat je nog een bloed- of een DNA-onderzoek wilt doen, zodat dat je een volgende keer kunt zeggen dat je in het bloed gevonden hebt dat het kind aan een syndroom leidt."

Een tweede reden om informatie op een later tijdstip te geven is gelegen in het feit dat de klinische diagnose niet voorkwam uit de erfelijkheidsvraag, maar uit de anamnese en het uiterlijk van de adviesvrager. Ook hier wordt vaak bevestigend onderzoek gebruikt om het stellen van de diagnose uit te stellen. Meestal wordt de adviesvrager verteld dat een aandoening wordt vermoed, maar dat men het nog niet zeker weet en dat verder onderzoek noodzakelijk is. Strikt genomen klopt dit ook. De reden hierachter is dat de geneticus de adviesvrager niet wil overvallen met een aandoening waarvan hij het bestaan bij zichzelf waarschijnlijk niet vermoedt, omdat hij met een geheel andere vraag is gekomen.

Een derde reden om informatie achter te houden is een onduidelijke uitslag. Wanneer de uitslag voor de geneticus zelf onduidelijk is, wordt er soms voor gekozen om niet alle mogelijkheden te bespreken alvorens er meer duidelijkheid is. De geneticus stelt zich dan wat terughoudend op omdat hij het prematuur vindt om alle mogelijkheden uitgebreid door te spreken en het gevoel heeft er geen goed aan te doen door alle opties op tafel te leggen. De rechtvaardiging hiervoor wordt gezocht in het feit dat het geen definitieve keuze is om informatie achter te houden. De adviesvrager krijgt later te horen wat er aan de hand is. 
Indien uit onderzoek bij toeval blijkt dat de adviesvrager niet het biologische kind is van zijn vader wordt dit in het algemeen niet meegedeeld. Dit kan enige creativiteit vragen van de klinisch geneticus bij het meedelen van de uitslag.

Om verschillende redenen komt de therapeutische exceptie in de klinische genetica weinig voor. Bij diagnostisch onderzoek is een adviesvrager veelal lange tijd op zoek naar een medische oorzaak en een naam voor de afwijking cq. problemen. De diagnose zal niet bestaan uit het constateren van een levensbedreigende ziekte zodat om die reden niet te verwachten is dat de adviesvrager de uitslag niet aankan. Diagnostisch onderzoek in de zwangerschap kan wel slecht nieuws genereren. Bij de erfelijkheidsadvisering wordt hierop echter nadrukkelijk gewezen, zodat aanstaande ouders hier rekening mee kunnen houden. Er is in de prakijk dan ook geen reden om een slechte uitslag achter te houden. Hier komt nog bij dat ouders na een slechte uitslag bij prenataal onderzoek de mogelijkheid openstaat om voor een abortus provocatus te kiezen. Het achterhouden van de uitslag zou hen deze optie ontnemen.

Bij voorspellend erfelijkheidsonderzoek, met name onderzoek naar een aandoening bij de adviesvrager zelf, wordt alvorens erfelijkheidsonderzoek wordt verricht besproken of het onderzoek voor de adviesvrager op dat moment een juiste stap is en of er voldoende draagvlak is te zijner tijd voor de uitslag. Dit leidt in de praktijk soms tot het besluit van de adviesvrager om geen erfelijkheidsonderzoek te laten verrichten. Bij voorspellend onderzoek is er medisch gezien ook geen reden om het niet uit te stellen. De uitgebreide erfelijkheidsadvisering voorafgaand aan presymptomatisch onderzoek voorkomt situaties waarin een geneticus meent informatie achter te moeten houden omdat er onvoldoende draagkracht is bij de adviesvrager. Of een adviesvrager daadwerkelijk een uitslag, en met name een slechte uitslag, goed kan verwerken is hiermee niet gezegd. Een andere reden waarom bij presymptomatisch onderzoek niet snel informatie zal worden achtergehouden is het feit dat dergelijk onderzoek een eenduidige uitslag kent en vrijwel nooit onverwachte bevindingen met zich mee brengt. Indien de mutatie bekend is, wordt er gericht naar gezocht en is de uitslag positief of negatief. De adviesvrager heeft de erfelijke aanleg wel of niet.

Ten slotte strookt het niet informeren van de adviesvrager niet met de beroepsethiek van genetici, die gekenmerkt wordt door een grote nadruk op het zelfbeschikkingsrecht. Het betreft informatie die grote gevolgen voor zowel de adviesvrager als zijn familieleden kan hebben.

"Ik kan me niet voorstellen dat je als klinisch geneticus dingen niet vertelt. Juist omdat je het belang van de autonomie en het zelfbeschikkingsrecht van de patiënt zo hoog in het vaandel hebt staan."

Aan de wettelijke eis om een collega te raadplegen alvorens de therapeutische exceptie toe te passen, wordt vrijwel altijd voldaan. De reden hiervoor is het vaste gebruik om over moeilijke casus met collegae te overleggen. 


\section{Beschourving}

De redenen die worden gegeven voor het gebruik van de therapeutische exceptie zijn allemaal gronden om informatie later te geven, niet om die volledig te onthouden. De eerstgenoemde reden was het ontbreken van elk ziekte-inzicht bij de ouders. Van belang hierbij lijkt dat de ouders niet echt een erfelijkheidsvraag hebben. Ze zijn door de kinderarts naar de klinisch geneticus verwezen zonder goed te beseffen dat de geneticus mogelijk een syndroom vaststelt bij hun kind. Dit verklaart de terughoudendheid van de klinisch geneticus. Het rechtvaardigt deze echter niet, tenzij het meedelen van de diagnose kennelijk ernstig nadeel voor de adviesvrager oplevert. Gezien de strikte wijze waarop dit volgens de Memorie van Toelichting dient te worden geïnterpreteerd, zal dit niet snel het geval zijn. Zeker niet wanneer ouders pas na maanden weer terug worden gezien.

Een tweede reden blijkt in de praktijk te zijn de situatie waarin op klinische gronden een diagnose wordt vermoed of kan worden gesteld terwijl de erfelijkheidsvraag zich daar niet op richt. Het verschil met de vorige reden is dat hier niet om de informatie wordt gevraagd. Het zijn voor de adviesvrager onverwachte bevindingen, waarover geen afspraken gemaakt konden worden voor wat betreft het wel of niet meedelen daarvan. Dit zal geen reden opleveren om de informatie hierover achter te houden, wel om die informatie met beleid aan de adviesvrager te verstrekken. Dit kan inhouden dat deze eerst in een volgend gesprek wordt meegedeeld.

De derde reden die werd gegeven was de situatie waarin er sprake is van een onduidelijke uitslag. In de Memorie van Toelichting wordt opgemerkt dat het in onzekerheid verkeren omtrent de prognose onvoldoende is voor een beroep op de therapeutische exceptie. "Ook deze onzekerheid zal op passende wijze aan de patiënt moeten worden meegedeeld." ${ }^{4}$ Wanneer onzekerheid omtrent de prognose geen grond oplevert voor de toepassing van de therapeutische exceptie, zal dit evenmin zo zijn voor wat betreft een onduidelijke uitslag. De klinisch geneticus zal de adviesvrager moeten informeren over deze onzekerheid en de mogelijke opties. De adviesvrager moet weten wat mogelijke uitkomsten van het erfelijkheidsonderzoek zullen zijn. Dit zal uiteraard op passende wijze moeten gebeuren. Het informeren over de mogelijkheden houdt niet in dat deze tot in detail moeten worden besproken.

Zoals in hoofdstuk 4 beargumenteerd, valt het geleidelijk en gefaseerd informeren van een adviesvrager niet onder de therapeutische exceptie, maar is het een invulling van het goed hulpverlenerschap. In de praktijk wordt vaak geleidelijk en gefaseerd informatie verstrekt aan ouders van een pasgeboren baby met een aangeboren afwijking. Afgezien van het feit dat vaak niet valt te voorspellen hoe het kind zich in de toekomst zal ontwikkelen, wordt het als onverantwoord medisch handelen gezien wanneer alle mogelijke ontwikkelingsproblemen van het kind in zo'n vroeg stadium al worden geschetst. In onderstaande casus werden er twee uitslagen in één gesprek gegeven. Het niet informeren werd door de geneticus gezien als het achterhouden van 
informatie. Het niet geven van twee uitslagen in éen gesprek is echter ook een manier van geleidelijk informeren.

"Ik heb een keer meegemaakt dat mensen voor twee dingen kwamen. Het ene was een dragerschapsonderzoek naar borstkanker. Het andere was een onderzoek naar de oor\%aken van de aangeboren afwijkingen van cen kindje dat ze hadden gehad. In principe is toen afgesproken om beide vragen te scheiden, maar toen de mensen voor het tweede gesprek kwamen over dat kindje had ik inmiddels de uitslag al van het DNA-onderzoek gekregen, waarvoor ze eigenlijk een andere afspraak zouden krijgen. Die uitslag was slecht, die mevrouw was drager en had een hoog risico op borstkanker, zestig tot vijfentachtig procent. Het kwam ontzettend veel voor in haar familie. Er was een hele hoge penetrantie. Ik heb verteld dat ik de uitslag had en dat we daar een afspraak over zouden maken, maar dat ze het ook op dat moment mochten horen. Ze wilden het gelijk horen, maar waren daar achteraf toch boos over. Maar ik zat wel met een uitslag waarop ze me achteraf, als er bijvoorbeeld in die tussenperiode iets gebeurd was, hadden kunnen aanspreken dat ik die informatie toen al wel had. Ik wilde haar toch zo snel mogelijk een screeningsadvies geven. Het was toch meer bedoeld ter bescherming van de patiënt, maar zij vatte het dus helemaal anders op. Je kan het niet altijd precies goed doen zoals de patiënt het zou willen. Ik vind bovendien ook dat je een uitslag bewust zou achterhouden door op zo'n moment niet aan te geven dat je de uitslag hebt."

Het apart behandelen van verschillende erfelijkheidsvragen kan gezien worden als geleidelijk en gefaseerd informeren. Het goed hulpverlenerschap bracht voor de geneticus met zich mee dat de twee uitslagen op verschillende tijdstippen zouden worden gegeven. Het betrof twee verschillende vragen waar onderzoek naar werd gedaan. In bovenstaande casus zijn twee uitslagen in één gesprek gegeven omdat de geneticus geen informatie wilde achterhouden en het bovendien om gezondheidsredenen van belang was om de uitslag reeds te geven. Het goed hulpverlenerschap vereist echter een zorgvuldiger aanpak die inhoudt dat de uitslagen in aparte gesprekken worden meegedeeld zodat een zorgvuldige begeleiding mogelijk is. Het zou zelf de professionele verantwoordelijkheid van de klinisch geneticus kunnen worden genoemd. Het niet vertellen van een uitslag omdat de adviesvragers voor een andere uitslag komen is dan ook geen informatie achterhouden. Ze komen immers voor andere informatie. Het meedelen van de tweede uitslag om gezondheidsreden is in dit geval niet een doorslaggevend argument. Het zal niet zo zijn geweest dat de afspraak voor de tweede uitslag pas maanden later was gepland. Aan een andere adviesvrager wordt een dergelijke uitslag evenmin om gezondheidsredenen eerder doorgegeven.

Ongetwijfeld zal de klinisch geneticus hier ook het zelfbeschikkingsrecht van de adviesvrager op het oog hebben gehad. Op grond van zijn zelfbeschikkingsrecht heeft een adviesvrager recht op informatie en zijn de uitzonderingen daarop beperkt. Ook hier valt een zekere spanning te bespeuren tussen de professionele verantwoordelijkheid van de geneticus en het zelfbeschikkingsrecht van de adviesvrager. Enerzijds de verantwoordelijkheid om het informatieproces medisch verantwoord te laten verlopen, dat wil zeggen: de informatie doseren zodat de adviesvrager de gelegenheid krijgt de informatie te verwerken. Anderzijds concrete 
informatie niet willen achterhouden die voor de adviesvrager van vitaal belang is, te weten de omvang van het risico op erfelijke borstkanker.

Zoals uit de redenen die worden aangegeven voor het gebruik van de therapeutische exceptie blijkt, is in de praktijk het verschil tussen enerzijds het geleidelijk en gefaseerd informeren en anderzijds het toepassen van de therapeutische exceptie niet altijd helder. De omstandigheden zullen vaak doorslaggevend zijn. Als uitgangspunt kan worden gesteld dat informatie niet te snel achter gehouden mag worden, ook niet wanneer dit slechts van korte duur is. Vermoedens en onduidelijkheden moeten binnen zekere grenzen meegedeeld worden. Het maken van duidelijke afspraken over de manier waarop onduidelijke bevindingen zullen worden meegedeeld, maakt dat er daarna ook geen reden zal zijn om informatie achter te houden.

\subsection{Een non-directieve houding?}

Genetici geven aan samen met de adviesvrager tot een besluit te willen komen dat voor de adviesvrager zelf de juiste keuze is. De reden hiervoor is dat men zich medeverantwoordelijk voelt voor een bepaalde keuze.

"We hebben minstens één en soms twee gesprekken voordat de bloedafname voor DNA-onderzoek gebeurt. In die gesprekken kijk je waarom ze dat onderzoek willen en of je voor jezelf als maatschappelijk werker en klinisch geneticus de indruk hebt dat dat voor hen een goede keus is; dat we iets goeds doen."

Een adviesvrager geeft aan de non-directieve houding van de klinisch geneticus te waarderen.

"Hij greep niet in, hij vertelde het verhaal en alle consequenties. Hij bekeek het van alle kanten en vroeg onder andere: 'wil je het dan wel doen of wil je het niet'. Van alle kanten werd dat verhaal belicht en ik vind dat hij het heel tactisch en heel duidelijk deed. Het was adviserend. Het was niet beinvloedend. Dit is ook onderzoek dat je helemaal zelf moet willen."

De actieve inbreng van de klinisch geneticus bij de besluitvorming kan betekenen dat een erfelijkheidsonderzoek wordt afgeraden.

"Ik zeg dan: 'als ik u nou zo hoor, de situatie waar u nu inzit, dan vraag ik me af of dit het moment is in uw leven om dit onderzoek te gaan doen. $U$ zou er ook nog over na kurnen denken of het een tijd uitstellen.' In veel gevallen gaan mensen daar ook op in en zeggen ze: 'nu u dat zo zegt heeft u eigenlijk wel gelijk. Laten we er nog eens rustig over nadenken, we bellen over een jaar wel terug."'

"Ik zag een meisje van achttien en die wilde dragerschapsonderzoek. Ze zat net voor haar examens en toen hebben we in gezamenlijk overleg besloten om gewoon nog te wachten met het onderzoek. Het zou zo af kunnen leiden van wat op dat moment belangrijk voor haar was. Ik vind het wel heel moeilijk hoor." 


\section{Beschonzing}

In hoofdstuk 4 is verdedigd dat het moral education model van Arras een invulling geeft aan het concept van non-directiviteit die het meest recht doet aan het doel van de erfelijkheidsadvisering, te weten de adviesvrager een geinformeerde en weloverwogen keuze te laten maken die het beste bij hem past. Bij dit model worden de morele aspecten van de verschillende keuzemogelijkheden die een adviesvrager heeft door de geneticus aan de orde gesteld, maar wordt de keuze aan de adviesvrager gelaten. Door de verschillende morele aspecten aan de orde te stellen heeft de adviesvrager inzicht in hetgeen waarvoor hij kiest.

Uit bovenstaande citaten komt het beeld naar voren dat in veel gevallen het dialogisch model wordt gehanteerd, waarbij soms ongevraagde adviezen worden gegeven. In het dialogische model proberen de geneticus en de adviesvrager in een dialoog gezamenlijk tot een besluit te komen omtrent het wel of niet ondergaan van een erfelijkheidsonderzoek dat het beste bij de opvattingen en overtuigingen van de adviesvrager past. De hierboven weergegeven citaten illustreren dat de klinisch geneticus streeft naar een besluit waarvan hij denkt dat dit het beste voor de adviesvrager zou zijn.

Een gevaar van dit dialogische model schuilt in het feit dat de klinisch geneticus bewust of onbewust toch zijn eigen waarden probeert op te leggen aan de adviesvrager, waardoor er een soort onderhandelingssituatie ontstaat. In het hierboven aangehaalde citaat waarin de klinisch geneticus en het meisje van 18 gezamenlijk besloten om het onderzoek uit te stellen, geeft de klinisch geneticus aan dat hij het wel heel moeilijk vond. Hij lijkt hiermee te bedoelen dat hij niet weet of hier nu een grens is overschreden of niet.

De klinisch geneticus zal zich hier bij ieder gesprek bewust moeten zijn van het feit dat de keus om wel of geen erfelijkheidsonderzoek te ondergaan uiteindelijk aan de adviesvrager is. Het hoeft geen gezamenlijk besluit te zijn. Het expliciteren van zijn rol en vooral de grenzen daarvan aan de adviesvrager, zouden hierbij behulpzaam kumnen zijn. Hij kan als hulpverlener niet verder gaan dan het verstrekken van informatie en het aan de orde stellen van de verschillende morele gezichtspunten, ook al voelt hij zich medeverantwoordelijk voor een bepaalde keuze.

\subsection{Het toestemmingsvereiste}

Tijdens de erfelijkheidsadvisering wordt toestemming gevraagd aan de adviesvrager alvorens er een erfelijkheidsonderzoek wordt verricht. Daarnaast wordt er, indien nodig, toestemming aan familieleden gevraagd om medewerking te verlenen aan het erfelijkheidsonderzoek van de adviesvrager. Ten slotte wordt er in sommige situaties toestemming gevraagd om verder onderzoek te doen wanneer de erfelijkheidsvraag vooralsnog niet beantwoord kan worden. De genoemde situaties worden hieronder besproken. 


\subsubsection{Toestemming van de ndviesvrager}

De adviesvrager geeft alvorens er een erfelijkheidsonderzoek wordt verricht, toestemming hiervoor. Bij een erfelijkheidsvraag die een diagnostisch erfelijkheidsonderzoek vereist, wordt door de klinisch geneticus uitgelegd welke handelingen hij moet verrichten om de vraag te kunnen beantwoorden. Meestal wordt door instemmend te knikken daar vervolgens toestemming voor gegeven. Bij voorspellend erfelijkheidsonderzoek wordt voornamelijk stil gestaan bij de vraag waarom de adviesvrager dit onderzoek wil ondergaan. Vervolgens geeft de adviesvrager meestal expliciet toestemming.

Door sommige centra wordt er bij voorspellend onderzoek naar een aandoening bij de adviesvrager schriftelijk toestemming gevraagd. Op die manier hopen klinisch genetici, indien nodig, te kunnen bewijzen welke informatie is gegeven én dat de adviesvrager heeft ingestemd met een erfelijkheidsonderzoek. Het feit dat de adviesvager daardoor min of meer gedwongen wordt nogmaals goed na te denken over het voorspellend erfelijkheidsonderzoek dat hij wil laten verrichten, wordt gezien als een positief neveneffect.

"Bij voorspellend DNA-onderzock laten we de adviesvragers een formulier ondertekenen waarin staat aangegeven wat we met ze besproken hebben. Dat is nuttig. Los van het gemoedelijke heen en weer praten wordt dan op een gegeven moment hetgeen besproken is zwart op wit gesteld. Het is voor mij het schriftelijke bewijs dat ik dat daadwerkelijk verteld heb en dat zwart op wit staat dat de adviesvrager inderdaad een crfelijkheidsonderzoek wil. Adviesvragers zitten er best even naar te kijken want het is wel heel officieel. Maar laat ze daar maar even goed bij stil staan. Dat is sowieso de teneur van het hele gesprek. Weet waar je aan begint, je kunt het maar één keer doen."

Bij een diagnostisch onderzoek naar de oorzaak van een (verstandelijke) handicap worden vaak dia's gemaakt die worden gebruikt voor intern overleg en onderwijs. Hiervoor wordt, in tegenstelling tot vroeger, meestal expliciet toestemming gevraagd aan de adviesvrager.

"Dia's zijn in feite onderdeel van het medisch dossier, net als wanneer je röntgenfoto's makkt. Alleen is het nog veel privacygevoeliger, omdat je daar mensen op kan herkennen. Vroeger zeiden we: 'ik moet nog even wat dia's van je maken.' Nu zeg je: 'ik wil graag dia's maken. Vindt $u$ dat goed, want die hebben we nodig bij de patiëntenbespreking om zo maximaal mogelijk het antwoord te kunnen vinden. Daarna gaan die dia's in het archief. Vindt $u$ het goed dat we ze ook gebruiken voor colleges en verpleegkundigenonderwijs?'"

\section{Beschouwing}

In hoofdstuk 4 is gesteld dat bij erfelijkheidsonderzoek geen ruimte is voor veronderstelde toestemming. Er dient altijd expliciet toestemming door de adviesvrager gegeven te worden. Hiervoor is aangegeven dat in de praktijk van de erfelijkheidsadvisering de toestemming niet wordt verondersteld. 
Bij voorspellend erfelijkheidsonderzoek wordt door sommige centra schriftelijke toestemming van de adviesvrager verlangd. Het neveneffect van deze toestemming die in een rechtszaak als een bewijsstuk zou kunnen dienen, is volgens klinisch genetici dat adviesvragers hierdoor hun keuze om een erfelijkheidsonderzoek te ondergaan nog eens goed overwegen. In paragraaf 8.3.1 is opgemerkt dat het motiveren door de adviesvrager van de beslissing om een erfelijkheidsonderzoek te willen ondergaan voor de klinisch geneticus een manier is om na te gaan of de adviesvrager de verstrekte informatie heeft begrepen. Wanneer een adviesvrager een formulier ondertekent waarin staat aangegeven wat er besproken is, zou ook dit een aanwijzing kunnen zijn voor de klinisch geneticus dat de adviesvrager de informatie begrepen heeft en een geinformeerde toestemming geeft.

Gezien de aard van de handeling, het vastleggen van fysieke kenmerken van de adviesvrager, is ook voor wat betreft het maken van foto's of dia's voor veronderstelde toestemming geen ruimte. Bovendien dient het doel van de handeling duidelijk te zijn. Dit is vaak tweeledig. Ten eerste wordt door middel van overleg met collegae getracht een diagnose te stellen. Ten tweede kunnen foto's en dia's ten behoeve van het onderwijs gebruikt worden. In tegenstelling tot vroeger wordt hier door de klinisch geneticus nu toestemming gevraagd.

\subsubsection{Toestemming van familieleden}

Wanneer er, alvorens erfelijkheidsonderzoek kan worden verricht, gegevens over familieleden opgevraagd moeten worden, worden hiervoor na een eerste gesprek toestemmingsformulieren aan de adviesvrager meegegeven. In sommige centra krijgen adviesvragers reeds voor zij voor een eerste gesprek naar het klinisch genetisch centrum komen formulieren thuisgestuurd om de familie in kaart te brengen en/of formulieren die familieleden kunnen tekenen om toestemming te verlenen voor het opvragen van gegevens. Ook van de adviesvrager zelf worden soms, al dan niet voor hun komst, gegevens opgevraagd.

"Je maakt een afspraak, maar in de tussentijd vraag je of ze alvast wat gegevens over de familie op een rij willen zetten en toestemmingsformulieren willen regelen. Je vraagt gegevens op, je maakt alvast een stamboom en als ze komen, dan weet je al ongeveer waar het over gaat."

\section{Beschouwing}

In paragraaf 8.3.1 van dit hoofdstuk is ingegaan op de vraag of bovenstaande werkwijze niet te onderzoeksgericht is. Er wordt reeds vanuit gegaan dat een adviesvrager een erfelijkheidsonderzoek wil laten verrichten. Een tweede kritiekpunt betreft het feit dat zowel de adviesvrager als de familieleden geen geïnformeerde toestemming kunnen geven. In hoofdstuk 4 is beschreven dat de toestemming niet verder kan reiken dan waarover de door de klinisch geneticus gegeven informatie zich heeft uitgestrekt. Zonder deze informatie van de klinisch geneticus is de toestemming van de adviesvrager voor het opvragen van gegevens niet rechtsgeldig. Dit geldt tevens voor het vragen van toestemming van familieleden voor het 
opvragen van hum gegevens. Het toestemming vragen overlaten aan de adviesvrager die zelf nog niet geïnformeerd is door de klinisch geneticus getuigt bovendien niet van goed hulpverlenerschap. Het is daarom aan te bevelen om de anamnese van de adviesvrager en zijn familie pas na een eerste gesprek in kaart te brengen. Indien de adviesvrager na een eerste gesprek zelf toestemming geeft voor het opvragen van zijn gegevens, weet hij waarvoor hij toestemming geeft. Hij kan bovendien zijn familieleden uitleggen waarom hun toestemming nodig is voor het opvragen van gegevens. Overigens is dit niet altijd mogelijk. Met name bij zwangere vrouwen kan het noodzakelijk zijn om snel gegevens ter beschikking te hebben en daarom worden deze vaak voor het eerste gesprek opgevraagd.

\subsubsection{Toestemming voor het verrichten van nader onderzoek}

Voor een eerste gesprek tussen een klinisch geneticus en een adviesvrager wordt altijd ruim de tijd genomen. Meestal duren deze gesprekken een uur. De duur van de gehele erfelijkheidsadvisering is variabel en vaak afhankelijk van praktische omstandigheden, zoals de tijd die het opvragen van gegevens in beslag neemt en de duur van het laboratoriumonderzoek. Naast praktische omstandigheden bepaalt de verplichte bedenktijd bij het voorspellend onderzoek naar een aandoening bij de adviesvrager zelf de duur van de erfelijkheidsadvisering. Gezien de ingrijpende aard van het onderzoek wordt in principe pas bij een tweede gesprek onderzoek verricht zodat adviesvragers hetgeen ze in een eerste gesprek te horen hebben gekregen rustig kumnen verwerken en vervolgens een beslissing kunnen nemen. Uitzonderingen zijn de gesprekken waarin een adviesvrager duidelijk maakt dat hij zijn beslissing reeds heeft genomen op basis van alle relevante informatie.

Wanneer het niet lukt om de erfelijkheidsadvisering binnen afzienbare tijd af te ronden, wordt de erfelijkheidsadvisering soms voorlopig afgerond. Dit is bijvoorbeeld het geval bij DNA-onderzoek naar een zeldzame aandoening. Het laboratoriumonderzoek kan dan meer dan een jaar in beslag nemen. In een dergelijk geval wordt er een voorlopige verslag aan de adviesvrager verstrekt met de opmerking dat er weer contact zal worden opgenomen wanneer de definitieve uitslag van het onderzoek er is.

Wanneer de uitslag van een erfelijkheidsonderzoek pas na lange tijd bekend wordt, blijkt dat adviesvragers de uitslag alsnog graag willen horen, ook al verwachten ze geen uitslag meer.

"Mensen verwachten dat niet meer, maar ze zijn wel nog steeds bezig met kanker in de familie. Het wordt over het algemeen dan heel positief ervaren dat er toch iets mogelijk is. Ze vergeten het toch niet zo gauw hoor. Het wordt ervaren als iets belangrijks in hun leven."

In dergelijke gevallen worden mensen meestal door middel van een briefje geinformeerd dat er een uitslag bekend is en dat ze contact kunnen opnemen met het 
klinisch genetisch centrum indien ze deze willen horen zodat ze nogmaals de keuze kunnen maken of ze het willen weten of niet.

Het komt ook voor dat een erfelijkheidsonderzoek geen mutatie oplevert, maar dat men gezien de technische ontwikkelingen verwacht in de nabije toekomst een gerichter erfelijkheidsonderzoek te kunnen verrichten waarbij wellicht een mutatie wordt gevonden. Sommige centra vragen voorafgaand aan het erfelijkheidsonderzoek schriftelijke toestemming om door te mogen zoeken naar een mutatie wanneer het initiële erfelijkheidsonderzoek geen mutatie heeft opgeleverd. Tevens wordt dan vastgelegd dat de adviesvrager aangeeft in de toekomst hierover te willen worden geinformeerd zodra dit van belang kan zijn voor de adviesvrager of voor zijn familieleden. Ook in die situaties wordt, wanneer er een mutatie wordt gevonden, de adviesvrager door middel van een briefje geïnformeerd dat er een uitslag bekend is en dat hij contact op kan nemen met het klinisch genetisch centrum indien hij deze wil horen. Andere centra raden adviesvragers aan om jaarlijks te bellen met de vraag of het technisch inmiddels mogelijk is om een mutatie op te sporen.

\section{Beschouruing}

De uitslag van een erfelijkheidsonderzoek kan soms eerst na een lange periode bekend worden. Het gebruik om adviesvragers door middel van een briefje te informeren over het feit dat er een uitslag is, laat aan adviesvragers nogmaals de keuze of ze de uitslag willen weten of niet. Het geven van de uitslag door middel van een brief zou niet getuigen van goed hulpverlenerschap. De keuze om een erfelijkheidsonderzoek te laten verrichten en over de uitslag geinformeerd te worden, was gebaseerd op de informatie die de klinisch geneticus in het verleden heeft gegeven over de aard van het onderzoek en de mogelijke consequenties daarvan. Gezien de lange tijd die kan verstrijken tussen de oorspronkelijke toestemming en de uiteindelijke uitslag van het erfelijkheidsonderzoek staat niet vast dat de adviesvrager op het moment dat de uitslag beschikbaar is nog steeds geinformeerd wil worden over de uitslag. Door de adviesvrager opnieuw de keuze te laten maken, wordt in de praktijk van de erfelijkheidsadvisering het meest recht gedaan aan het zelfbeschikkingsrecht van de adviesvrager in de vorm van een keuze tussen wel en niet weten.

\subsection{Slotbeschouwing}

In deze slotbeschouwing staan de volgende vragen centraal:

- Zijn klinisch genetici op de hoogte van het recht op informatie, het toestemmingsvereiste en de therapeutische exceptie?

- Delen klinisch genetici de uitgangspunten van de juridische invulling van deze rechten?

- Worden deze rechten toegepast conform de juridische invulling die daaraan is gegeven? 
- Wat zijn daarbij de knelpunten en dilemma's en hoe zijn deze eventueel op te lossen?

Zijn klinisch genetici op de hoogte van hun informatieplicht? Het antwoord op deze vraag is bevestigend, gezien de grote hoeveelheid informatie die aan adviesvragers wordt verstrekt. Ook het feit dat adviesvragers moeten toestemmen in een erfelijkheidsonderzoek is bekend. Adviesvragers wordt mondeling, dan wel schriftelijk toestemming gevraagd voor een erfelijkheidsonderzoek. De therapeutische exceptie is daarentegen nauwelijks bekend bij klinisch genetici. Dit geldt zowel voor de term als voor de inhoud van artikel 7:448 lid 3 BW.

De tweede vraag luidde of de uitgangspunten van het recht op informatie, het toestemmingsvereiste en de therapeutische exceptie door klinisch genetici worden gedeeld. Door de adviesvrager uitgebreid te informeren en stil te staan bij de vraag of en waarom de adviesvrager een erfelijkheidsonderzoek wil ondergaan geven klinisch genetici er blijk van dat het volgens hen de adviesvrager is die na afweging van alle voor hem relevante informatie, toe moet stemmen in een erfelijkheidsonderzoek. Door middel van de therapeutische exceptie is een mogelijkheid geschapen om in uitzonderingsgevallen geen informatie te verstrekken. Ondanks het feit dat klinisch genetici nauwelijks bekend zijn met dit artikel, maken zij er, conform de bedoeling van de wetgever, spaarzaam gebruik van, blijkend uit het feit dat zij aangeven alle hen bekende informatie aan de adviesvrager mede te delen.

Worden het recht op informatie, de therapeutische exceptie en het toestemmingsvereiste toegepast conform de juridische invulling die hieraan is gegeven en wat zijn daarbij de knelpunten? Ten eerste het recht op informatie. In paragraaf 8.3 .1 bleek dat adviesvragers tijdens verschillende gesprekken uitgebreid geinformeerd worden door de klinisch geneticus. Het betreft hierbij zowel medische informatie als informatie over de mogelijke persoonlijke en maatschappelijke gevolgen van een erfelijkheidsonderzoek. Ook de mogelijke consequenties voor familieleden worden met de adviesvrager besproken. De hoeveelheid informatie die wordt verstrekt bleek voornamelijk afhankelijk te zijn van de voorkennis omtrent de erfelijke aandoening waar de erfelijkheidsvraag zich op richt en de (on)mogelijkheden om door middel van erfelijkheidsonderzoek de vraag te beantwoorden. Voor adviesvragers blijken met name begrip, aandacht en het feit dat er veel tijd voor hen wordt uitgetrokken van belang te zijn. Het feit dat hier in hun ogen aan voldaan was, werd als uitermate positief ervaren.

De klinisch geneticus krijgt in de praktijk regelmatig het verzoek om zijn informatieplicht anders in te vullen dan hij gewoon is te doen. Voorbeelden hiervan zijn het informeren van verschillende adviesvragers tegelijkertijd, de voorinformatie tot één gesprek te beperken en het informeren van de adviesvrager door middel van een telefoongesprek. In dergelijke situaties zal de klinisch geneticus telkens moeten nagaan of het voldoen aan deze verzoeken in overeenstemming is met zijn goed hulpverlenerschap. 
Het informeren over onverwachte bevindingen is lastig voor klinisch genetici. Zeker wanneer de mogelijkheid van onverwachte bevindingen niet voorafgaand aan het erfelijkheidsonderzoek met de adviesvrager is besproken, vergt het informeren hierover een behoedzame aanpak. De erfelijkheidsvraag was niet op deze bevindingen gericht en voor de klinisch geneticus speelt daarom altijd de vraag of de adviesvrager deze informatie wel wil weten.

Wordt de therapeutische exceptie toegepast conform de juridische invulling die hieraan is gegeven? Over de therapeutische exceptie is in hoofdstuk 4 opgemerkt dat er bij erfelijkheidsadvisering weinig ruimte is voor het gebruik van de therapeutische exceptie. Dit geldt zeker indien het niet het tijdelijk niet verstrekken van inlichtingen betreft. De praktijk toont dat er weinig gebruik wordt gemaakt van de therapeutische exceptie en dat wanneer dit gebeurt het alleen het tijdelijk niet verstrekken van inlichtingen betreft. In de situaties waarin de therapeutische exceptie wordt toegepast blijkt dat er vaak geen sprake is van een kennelijk ernstig nadeel. Wel bleek dat door het vaste gebruik om met collegae te overleggen aan de consultatieplicht wordt voldaan.

De praktijk van de erfelijkheidsadvisering laat zien dat het verschil tussen de therapeutische exceptie en het geleidelijk en gefaseerd informeren niet altijd duidelijk is. De klinisch geneticus ziet zich geregeld voor de vraag gesteld of hij in een bepaalde situatie informatie achterhoudt en daarmee de therapeutische exceptie toepast of dat hij de adviesvrager op een verantwoorde manier informeert door dit geleidelijk en gefaseerd te doen.

Voor wat betreft de wijze waarop wordt geinformeerd is het uitgangspunt dat de erfelijkheidsadvisering non-directief van aard is. In hoofdstuk vier is verdedigd dat het moral education model van Arras, dat non-directief is voor wat betreft de keuze van de adviesvrager, het meest recht doet aan zijn zelfbeschikkingsrecht. In de praktijk van de erfelijkheidsadvisering lijkt echter het dialogische model gevolgd te worden. In dit model trachten de klinisch geneticus en de adviesvrager gezamenlijk tot een besluit te komen.

Tot slot het toestemmingsvereiste. Uit paragraaf 8.6 bleek dat adviesvragers toestemming geven voordat er een erfelijkheidsonderzoek wordt verricht. Ook voor het maken van foto's en dia's wordt toestemming gevraagd. Het schriftelijk toestemming verlenen op verzoek van de klinisch geneticus komt bij voorspellend erfelijkheidsonderzoek soms voor. Het voordeel hiervan zou kunnen zijn dat de adviesvrager zijn keuze goed overweegt en een geïnformeerde toestemming geeft.

Het vragen van toestemming van de adviesvrager en zijn familieleden voor het opvragen van gegevens, alvórens er een gesprek heeft plaatsgevonden, levert een ongeïnformeerde en dus rechtsongeldige toestemming op.

Het wederom toestemming vragen om geïnformeerd te worden over de uitslag van een erfelijkheidsonderzoek als deze pas na lange tijd bekend wordt, getuigt van goed 
hulpverlenerschap. Door de adviesvrager opnieuw de keuze te laten maken, wordt in de praktijk van de erfelijkheidsadvisering het meest recht gedaan aan het zelfbeschikkingsrecht van de adviesvrager in de vorm van een keuze tussen wel of niet weten.

In het volgende hoofdstuk wordt ingegaan op de wijze waarop het recht op niet weten in de praktijk van de erfelijkheidsadvisering gestalte krijgt. Aan de orde komt hoe adviesvragers worden geinformeerd over hun recht op niet weten en hoe hier gebruik van wordt gemaakt. Ook de situatie waarin een adviesvrager aangeeft wel een erfelijkheidsonderzoek te willen ondergaan, maar daar vooraf geen informatie over te willen ontvangen, wordt besproken. Tot slot wordt ingegaan op een tweetal praktijkcasus waarbij het recht op niet weten van kinderen en ongeborenen een rol speelt. 



\section{ERFELIJKHEIDSADVISERING EN HET RECHT OP NIET WETEN IN DE PRAKTIJK}

\subsection{Inleiding}

Het recht op niet weten is een belangrijk recht. Het is gebaseerd op het recht op eerbiediging van de persoonlijke levenssfeer. Het betekent voor de erfelijkheidsadvisering dat een adviesvrager zelf beslist of hij door middel van een erfelijkheidsonderzoek informatie tot stand wil laten komen en ook het recht heeft om na een erfelijkheidsonderzoek te besluiten om geen inlichtingen te willen ontvangen. Dit onderstreept het belang van de door de klinisch geneticus te verstrekken informatie, zodat een adviesvrager hiertoe weloverwogen kan besluiten. In dit hoofdstuk staat centraal hoe door klinisch genetici wordt omgegaan met het recht op niet weten. In paragraaf 9.2 wordt beschreven hoe adviesvragers worden geïnformeerd over hun recht op niet weten. Paragraaf 9.3 gaat in op de situaties waarin de adviesvrager gebruik maakt van zijn recht om geen erfelijkheidsonderzoek te ondergaan alsmede zijn recht om na het onderzoek af te zien van verdere inlichtingen. Het komt echter ook voor dat een adviesvrager aangeeft wel een erfelijkheidsonderzoek te willen ondergaan, maar daar vooraf geen informatie over wil ontvangen. Hieraan wordt in paragraaf 9.4 aandacht besteed. Paragraaf 9.5 behandelt een tweetal praktijkcasus waarbij het recht op niet weten van kinderen en ongeborenen een rol speelt. Elke paragraaf wordt afgesloten met een beschouwing waarin wordt gekeken hoe de gegeven beschrijving van het onderwerp zich verhoudt tot de juridische invulling daarvan. Het hoofdstuk wordt afgesloten met een slotbeschouwing waarin de volgende vragen worden beantwoord:

- Zijn klinisch genetici op de hoogte van het feit dat de adviesvrager een recht op niet weten heeft?

- Delen klinisch genetici de uitgangspunten van de juridische invulling van dit recht?

- Wordt het recht op niet weten toegepast conform de juridische invulling die daaraan is gegeven?

- Wat zijn daarbij de knelpunten en dilemma's en hoe zijn deze eventueel op te lossen?

\subsection{Het informeren over het recht op niet weten}

De klinisch geneticus informeert de adviesvrager in de praktijk op twee manieren over het recht op niet weten. Enerzijds door aan te geven dat een erfelijkheidsonderzoek vrijwillig is en dat adviesvragers voor zichzelf moeten afwegen of zij datgene dat onderzocht kan worden ook daadwerkelijk willen weten. Anderzijds door concreet aan te geven dat een adviesvrager te allen tijde kan besluiten niet geïformeerd te willen worden over de uitslag van het erfelijkheidsonderzoek. Het eerste aspect wordt met name benadrukt wanneer bij de 
klinisch geneticus het gevoel ontstaat dat de adviesvrager een bepaalde uitslag niet aankan of niet echt achter het onderzoek staat.

\begin{abstract}
"In situaties waar je merkt aan de patiënt dat hij niet echt voldoende draagkracht heeft om ook het resultaat te horen of dat hij zich gestuurd of gebonden voelt, benadruk je nog een keer extra dat alle keuzevrijheid, alle beslissingsvrijheid aan hem of haar is. Ilij heeft het recht het onderzock heiemaal niet in gang te laten zetten. Dus hij mag best voor een informatief gesprek komen en is niet verplicht het bijbehorende laboratoriumonderzoek te laten doen."
\end{abstract}

Daarnaast wordt aangegeven dat de mogelijkheden en vooral de onmogelijkheden van erfelijkheidsonderzoek worden benadrukt wanneer bij adviesvragers hierover onjuiste veronderstellingen leven.

"Ik moet reggen dat mensen toch vaak met een bepaald idee komen, ook als ze verwezen zijn. We vragen eigenlijk ook altijd wat ze er zelf van denken. Vaak stuit je wel op veronderstellingen die mensen hebben over wat wij doen, die niet helemaal juist zijn. Bijvoorbeeld als er net een televisieprogramma is uitgezonden. Dat is een poosje geleden gebeurd over borstkanker. Sommige mensen zeiden dan al na vijf minuten: "ik wil best wel hieraan meewerken, maar ik wil niet mijn borsten eraf laten halen". Dan begin je dus eigenlijk helemaal bij nul door gewoon uit te leggen dat het een informatief gesprek is en dat ze ermee kunnen doen wat ze zelf willen."

Het tweede aspect, te weten het aangeven dat een adviesvrager altijd kan besluiten de uitslag niet te willen ontvangen, is bij voorspellend erfelijkheidsonderzoek een vast onderdeel van de erfelijkheidsadvisering. Ook na de blocdafname worden adviesvragers er in principe nogmaals op gewezen dat zij het recht behouden niet over de uitslag geïformeerd te worden.

\begin{abstract}
"Wanneer we het bloed afgenomen hebben is er altijd een periode tot de uitslag er is. Die varieert van zes weken tot drie maanden. Wat we altijd zeggen is dat als zij zich in die weken bedenken en toch de uitslag niet willen weten, dat ze hun besluit kunnen herroepen. Dan wordt de procedure gestopt en het materiaal vernietigd. Als het echt gebeurt, is het lastig. Je hoopt dat het niet gebeurt, maar op zich mogen de mensen dat doen. Het kan toch dat ze te impulsief zijn geweest en zich toch te gemakkelijk hebben laten leiden door de omstandigheden. Bijvoorbeeld in de zin van: nu kan het, nu ben ik hier, laat ik het nu maar doen, en dat ze als ze thuis zijn spijt hebben."
\end{abstract}

Als het besluit om een voorspellend erfelijkheidsonderzoek te ondergaan genomen is, wordt niet in alle gevallen nogmaals op de mogelijkheid gewezen om de uitslag niet te vernemen. Sommige genetici geven aan het onlogisch te vinden om na de uitgebreide erfelijkheidsadvisering die voorafgegaan is aan het besluit van de adviesvrager om een erfelijkheidsonderzoek te laten verrichten, wederom aan te geven dat men niet over de uitslag geïnformeerd hoeft te worden. Bovendien zijn sommige genetici van mening dat een kwalitatief goede erfelijkheidsadvisering voorkomt dat adviesvragers besluiten niet geinformeerd te willen worden over de uitslag van een onderzoek en dat om die reden het recht op niet weten niet expliciet benoemd hoeft te worden. 
"Voordat je dat bloed afneemt probeer je heel erg duidelijk te krijgen of iemand ook echt wil of niet. Daar ligt een groot deel van het werk bij presymptomatische diagnostiek; om daar bij de gesprekken heel duidelijk op in te gaan. Ik moet zeggen dat het in veel gevallen gewoon heel duidelijk is dat mensen het echt willen. Terwijl wij dan een uur bezig zijn om aan te geven dat er ook negatieve kanten aan zitten en dat het belangrijk is om je te realiseren wat het allemaal voor jezelf inhoudt. In die gevallen zeg ik niet: 'als $u$ de uitslag niet zou willen weten dan kunt u altijd bellen.' Maar heel soms merk je dat er twijfel is en dan zou je dat kunnen noemen. Maar ik moet je eerlijk zeggen; op het moment dat er twijfel is, zal ik dat onderzoek niet in gang zetten. Dus je probeert het van tevoren goed in te schatten. Ik zeg het dus niet expliciet. Als ik ook maar enige aarzeling merk of ik merk dat mensen er niet goed over na hebben gedacht, dan zal ik ze bedenktijd geven voordat ik het onderzoek inzet. Daar ligt bij mij het zwaartepunt; van tevoren heel duidelijk en zeker weten dat iemand het wil. Ik denk dat dat logischer is dan snel bloed af te nemen en tegen mensen te zeggen: 'Je mag je altijd terugtrekken.' Dat doen mensen ook minder snel, denk ik. Dan hebben ze van die redeneringen van: als je A hebt gezegd, moet je ook B zeggen."

Voor wat betreft het informeren over het recht op niet weten bij voorspellend onderzoek kan een onderscheid gemaakt worden tussen enerzijds onderzoek dat een aandoening of een risico daarop bij de adviesvrager zelf voorspelt en anderzijds onderzoek dat alleen voorspellend is in de zin dat het risico's voor nageslacht op een erfelijke aandoening vaststelt.

"Bij dragerschapsonderzoek is dat net weer anders. Dan willen mensen weten of ze drager zijn en dan wordt er niet meer uitvoerig gezegd: 'weet u dat wel zeker? U kunt er ook voor kiezen om dat niet te weten.' Er wordt wel zijdelings over gepraat. Er wordt stilgestaan bij wat het betekent om drager te zijn, bij wat de adviesvrager eraan heeft om dat straks te weten en bij de consequenties voor de kinderwens wanneer de partners allebei drager zijn. Als adviesvragers niet voor moeilijke keuzes willen komen te staan, dan moeten ze het onderzoek nu niet doen. Daar wordt wel wat over gepraat, maar niet zeer uitgebreid en expliciet, zoals bij Huntington en kanker wel gebeurt."

Hoewel adviesvragers ook bij diagnostisch erfelijkheidsonderzoek kunnen besluiten het onderzoek niet voort te zetten, komt het recht op niet weten bij dit type onderzoek tijdens de erfelijkheidsadvisering meestal niet expliciet aan de orde.

"Het ligt anders. Het is minder belastend, minder beladen."

\section{Beschourwing}

De praktijk laat zien dat het recht op weten en het recht op niet weten nauw met elkaar zijn verweven. Bij voorspellend erfelijkheidsonderzoek wordt de adviesvrager er in principe op gewezen dat hij kan besluiten om geen erfelijkheidsonderzoek te laten verrichten, of om na een verricht onderzoek geen inlichtingen te willen ontvangen. Daar staat de visie tegenover dat het niet nodig is om het recht op niet weten te expliciteren wanneer daar een goede erfelijkheidsadvisering aan voorafgaat. Het is duidelijk dat de kwaliteit van de erfelijkheidsadvisering voorafgaand aan een erfelijkheidsonderzoek en het besluit van adviesvragers na afloop daarvan om de uitslag niet te willen weten, voor de klinisch geneticus nauw met elkaar 
samenhangen. Wanneer voorafgaand aan een erfelijkheidsonderzoek een adviesvrager uitgebreid is geinformeerd en hij op basis van alle relevante informatie weloverwogen besloten heeft dat hij wil weten wat zijn risico is op een bepaalde erfelijke aandoening, dan vinden sommige klinisch genetici dat ze mogen aannemen dat de adviesvrager niet op zijn besluit terug zal komen.

De praktijk laat echter zien dat het ondanks een zorgvuldige en uitgebreide erfelijkheidsadvisering voorkomt dat mensen zich na een erfelijkheidsonderzoek bedenken en besluiten de uitslag niet te willen weten. In hoofdstuk 6 is de vraag aan de orde geweest of de klinisch geneticus de plicht heeft om de adviesvrager op zijn recht op niet weten te wijzen. Daar is opgemerkt dat het bij diagnostisch erfelijkheidsonderzoek minder voor de hand ligt om de adviesvrager erop te wijzen dat hij ook het recht heeft om informatie niet te ontvangen. Een adviesvrager komt immers met een klacht en hoopt dat deze gediagnostiseerd kan worden. Een dergelijke hulpvraag verschilt niet wezenlijk van die in andere patiënthulpverlenerrelaties. De vraag of men het wel wil weten speelt hier nauwelijks. Bij voorspellend onderzoek daarentegen werd wel een plicht hiertoe aanwezig geacht. Het feit dat dergelijk onderzoek om gezondheidsredenen uitgesteld kan worden, alsmede de mogelijke gevolgen ervan voor zowel de adviesvrager als diens familieleden, maken dat de klinisch geneticus op grond van zijn goed hulpverlenerschap de adviesvrager duidelijk moet maken dat hij zich te allen tijde kan bedenken en moet bespreken of de adviesvrager volledig wil worden geïnformeerd over de uitslag. Het feit dat de praktijk laat zien dat een zorgvuldige en uitgebreide erfelijkheidsadvisering niet altijd kan voorkomen dat adviesvragers besluiten de uitslag niet te willen weten, vormt een extra argument om bij voorspellend erfelijkheidsonderzoek de eis te stellen dat de adviesvrager expliciet op zijn recht op niet weten wordt gewezen. Een geneticus merkte op dat adviesvragers soms redeneren in de trant van, als je A zegt, moet je ook B zeggen. Het duidelijk maken dat $B$ niet op $A$ hoeft te volgen, kan voorkómen dat een adviesvrager niet durft aan te geven dat hij een uitslag niet wil weten. Het is wellicht niet logisch dat een adviesvrager zich alsnog bedenkt, maar een besluit van de adviesvrager hoeft voor de klinisch geneticus ook niet logisch te zijn. Aan het einde van dit hoofdstuk wordt hier nog op teruggekomen.

\subsection{Het besluit om niet te willen weten}

Het besluit om geen erfelijkheidsonderzoek te ondergann komt geregeld voor. Het betreft dan voornamelijk voorspellend erfelijkheidsonderzoek. Bij diagnostisch erfelijkheidsonderzoek is het nauwelijks aan de orde. Indien het aan de orde is, speelt niet het feit dat mensen niet geïnformeerd willen worden een rol, maar juist het feit dat adviesvragers verwachten dat ze niet geïnformeerd kunnen worden, in de zin dat er een diagnose gesteld kan worden.

Bij voorspellend erfelijkheidsonderzoek gaat het voornamelijk om adviesvragers die mogelijk een verhoogd risico hebben op een erfelijke aandoening. Binnen deze groep bedenkt een aantal zich na een paar maanden. Men heeft alle informatie laten 
bezinken en komt terug op het oorspronkelijke voornemen een erfelijkheidsonderzoek te ondergaan. Een aantal genetici geeft aan dat voor sommige adviesvragers de vraag of het laten verrichten van cen voorspellend erfelijkheidsonderzoek voor hen wel de juiste keuze is, pas concreet wordt en beter bespreekbaar is ná een bloedafname. Binnen die groep is het aantal adviesvragers dat zich bedenkt nadat het onderzoek in gang is gezet relatief groot. Daarnaast zijn het vooral de genetici zelf die, bij twijfel over de vraag of de adviesvrager de informatie en de mogelijke consequenties van een erfelijkheidsonderzoek begrijpt, een afwachtende houding aannemen.

"Er zijn ook heel veel mensen die zeggen dat ze wel willen, maar dat ik dan zelf denk: moet het wel, denk er nog even over na. Soms houdt de maatschappelijk werker het een bectje af. We zijn toch ook wel vrij veel met afhouden bezig omdat er soms mensen tegenover je komen zitten die zeggen: 'ik kom voor een genonderzoek.' Dan denk je: wat cen gekke vraag. Onze maatschappij is zo ingericht dat mensen niet zeggen: 'ik maak me zorgen over dit of dat,' maar: 'ik wil een genonderzoek.' Wanneer je dan die vertaalslag hebt gegeven en hebt uitgelegd waar het nu om gaat, dan blijkt dat het soms toch niet zinnig is om een DNA-onderzoek te doen."

Het besluit om nadat een erfelijkheidsonderzoek in gang is gezet de uitslag niet te willen horen komt weinig voor. Genetici geven, zoals opgemerkt, aan dat een kwalitatief goede erfelijkheidsadvisering voorkomt dat adviesvragers besluiten niet geïnformeerd te willen worden over de uitslag van een erfelijkheidsonderzoek. Dat neemt niet weg dat adviesvragers zich soms toch bedenken. Hoe wordt hiermee omgegaan? Een dergelijke keuze wordt gerespecteerd, aldus de klinisch genetici. Het is een recht van de adviesvrager om aan te geven dat hij van verdere informatie afziet. Het respect voor de keuze van de adviesvrager wordt daarbij soms ondersteund door de overtuiging dat weten niet per definitie voordelen heeft.

"Dat is dan toch de keus van die persoon. Als die nooit gekomen was, was het hetzelfde geweest en, ja, we zijn niet zaligmakend."

"Dat is niet moeilijk. Helemaal niet. Dit is sowieso onderzoek waarbij je niet weet of je goed of slecht doet als je die uitslag hebt. Dus als mensen dat dan niet willen weten; prima."

Het feit dat de keuze wordt gerespecteerd, betekent niet dat het voor een geneticus gemakkelijk is, zeker niet wanneer de uitslag al binnen is. Bij voorspellend onderzoek is impliciet en expliciet stilgestaan bij de vraag of de adviesvrager wil weten of hij zal gaan lijden aan een erfelijke aandoening of wat zijn risico daarop is. Indien een adviesvrager vervolgens besluit zich terug te trekken uit het onderzoek, is dit voor de klinisch geneticus een onverwachte wending. Genetici geven aan dat ze wel proberen de reden van het besluit van de adviesvrager te achterhalen. Het voornaamste argument hiervoor is dat het niet logisch is dat adviesvragers zich bedenken.

"Het is belangrijk te achterhalen waarom iemand het nu ineens niet wil weten, want je gaat zeker bij het soort uitslagen dat een hoog risico op dragerschap met zich mee kan brengen juist al heel uitvoerig op alles in, voordat je een onderzoek inzet. Je gaat zo'n 
hele procedure door en als ij of de patient de geringste twijfel heeft, dan doe je het onder\%oek niet. Je zet het toch alleen maar in als je daar beide volledig achter staat en met name de patiënt natuurlijk."

Genetici ervaren het als hun plicht om na te gaan of de beslissing om de uitslag van een erfelijkheidsonderzoek niet te willen weten niet op onjuiste veronderstellingen is gebaseerd. Daarom wordt altijd contact gezocht met de adviesvrager om de reden van zijn besluit te achterhalen.

\begin{abstract}
" $\mathrm{k}$ zou niet redeneren: de patient wil het niet weten dus het dossier kan het archief in. In $z o$ 'n situatie zou ik wel de plicht voelen om het probleem op te lossen. Het is natuurlijk wel een probleem. Over de autonomie van patiënten zijn vaak discussies. Mensen zijn natuurlijk heel vaak bang. Ik vind dat je niet te gauw moet zeggen dat het een autonome beslissing van de patiënt is, want autonoom betekent dat je het overziet. Je moet wel iets verder kijken dan wat iemand z.egt."
\end{abstract}

Zijn er ook situaties denkbaar waarin de keuze van de adviesvrager niet wordt gerespecteerd? Genetici geven aan dat het respecteren van de wens om de uitslag niet te willen horen vooral moeilijk is wanneer het een goede uitslag betreft en de adviesvrager op grond van zijn onwetendheid preventieve maatregelen neemt, zoals jaarlijkse controles. Dit wordt echter gezien als een consequentie van een te respecteren besiuit. Iets anders is het wanneer er een slechte uitslag is en er effectieve preventieve maatregelen voorhanden zijn. Dit is echter een situatie die in de praktijk niet aan de orde is.

"Als jemand expliciet zegt dat hij het niet wil weten, dan zou er echt een sterk tegengesteld belang moeten zijn voor iemand om die uitslag wel te weten. Dat zou bijvoorbeeld zo kunnen zijn als die adviesvrager een zickte heeft waar écht wat aan te doen is als hij het weet. Dan heb je het recht om door dat recht op niet weten heen te breken. En dan overheerst het punt dat je niet wil schaden. Maar bij veel aandoeningen is dat niet zo. Bij Huntington, en zelfs bij erfelijke borstkanker, is het de vraag of mensen er beter aan toe zijn met uitslag dan zonder uitslag."

De wijze waarop adviesvragers gebruik maken van hun recht op niet weten varieert. Sommigen schrijven een brief, anderen geven telefonisch door dat ze niet geïnformeerd willen worden. Het komt zelden voor dat mensen tijdens het uitslaggesprek aangeven niet geïnformeerd te willen worden.

Hoe wordt met een uitslag omgegaan wanneer deze reeds in het bezit is van de klinisch geneticus, terwijl de adviesvrager aangegeven heeft er geen kennis van te willen nemen? Meestal wordt met de adviesvrager overlegd. De uitslag kan vernietigd worden of in het dossier bewaard blijven. In het laatste geval wordt de uitslag dan in een envelop in het dossier bewaard zodat de uitslag niet automatisch bij het openen van het dossier bekend wordt. Soms wordt in overleg met de adviesvrager besloten de uitslag op een nader te bepalen tijdstip, bijvoorbeeld 1 jaar na dato, te vernietigen. Sommige genetici hebben de gewoonte de uitslag te bewaren. 
"lk doe de envelop in de status en daar komt niemand achter. Die envelop blijft bewaard. Als mensen daar later op tertg willen komen en het toch wel willen weten; prima. Maar dan hoef je niet meer die hele procedure in; bloed prikken en het onderzoek doorlopen. Dan heb je die uitslag al."

\section{Beschoutwing}

De praktijk laat zien dat adviesvragers regelmatig besluiten geen erfelijkheidsonderzoek te ondergaan. Bij voorspellend erfelijkheidsonderzoek naar een mutatie die bij de adviesvrager zelf tot een erfelijke ziekte kan leiden, moet een bedenktijd voorkómen dat het besluit om een erfelijkheidsonderzoek te laten verrichten een overhaaste beslissing is. Klinisch genetici geven bovendien aan dat ze een afwachtende houding aannemen wanneer ze zich afvragen of adviesvragers weten waar ze aan beginnen. In hoofdstuk 6 is opgemerkt dat de adviesvrager zelf, na het ontvangen van de vóórinformatie van de klinisch geneticus, de afweging maakt of hij door middel van een erfelijkheidsonderzoek informatie tot stand wil laten komen. In hoofdstuk 4 is gesteld dat naarmate de informatie van groter gewicht is, de hulpverlener zich meer moeite moet getroosten om deze goed over te dragen en zich ervan te verzekeren, dat zij door de adviesvrager is begrepen. Het gewicht van de informatie en de mogelijke gevolgen rechtvaardigen hoge eisen voor wat betreft de informatieplicht van de klinisch geneticus. Voor het recht op niet weten betekent dit dat wordt stilgestaan bij de vraag of en, zo ja, waarom de adviesvrager het erfelijkheidsonderzoek wil ondergaan, zodat de adviesvrager uiteindelijk een weloverwogen keuze kan maken. De moeite die genetici zich getroosten bestaat dus uit een voorgeschreven bedenktijd om de adviesvrager in staat te stellen een weloverwogen keuze te maken en een afwachtende houding wanneer er twijfel bestaat over het feit of de informatie en de mogelijke consequenties van een erfelijkheidsonderzoek worden begrepen. Het recht op niet weten in de zin dat er geen informatie tot stand wordt gebracht, wordt dus gerespecteerd. Ten eerste wordt ruim de gelegenheid geboden om te besluiten geen onderzoek te laten verrichten. Ten tweede wordt bij twijfel aan volledig begrip een afwachtende houding aangenomen. Ten derde lijkt de overtuiging te leven dat weten niet per definitie beter is dat niet weten.

Indien een erfelijkheidsonderzoek in gang is gezet, en de adviesvrager besluit de uitslag niet te willen weten, wordt dit volgens klinisch genetici gerespecteerd. Het wordt daarbij wel als een plicht ervaren om na te gaan of het een weloverwogen beslissing betreft die op juiste veronderstellingen is gebaseerd, zeker wanneer de klinisch geneticus reeds beschikt over de uitslag. In hoofdstuk 6 is de vraag gesteld of de klinisch geneticus naar de motivatie van de adviesvrager mag vragen, indien hij te kennen geeft dat hij terugkomt op zijn besluit om de uitslag van het reeds ondergane erfelijkheidsonderzoek te vernemen. De wet stelt immers geen eisen wanneer de adviesvrager besluit gebruik te maken van zijn recht op niet weten. Aan de informatieplicht uit artikel 7:448 lid 1 en 2 BW wordt echter de eis gesteld dat de hulpverlener zich ervan vergewist dat de patiënt de informatie begrepen heeft. ${ }^{1}$ Het proces van de erfelijkheidsadvisering is erop gericht de adviesvrager in staat te 
stellen de voor hem juiste keuze te maken, gebaseerd op alle relevante informatie, morele gezichtspunten en inzicht in de mogelijke gevolgen. In dat licht bezien getuigt het van goed hulpverlenerschap indien de klinisch geneticus de adviesvrager naar zijn redenen vraagt wanneer hij onverwacht mededeelt dat hij de uitslag niet wil horen. Op die manier kan de geneticus zich ervan vergewissen dat ook de keuze om de uitslag niet te willen horen een weloverwogen keuze is die op de juiste informatie gebaseerd is. Het is mogelijk dat de adviesvrager de verstrekte informatie verkeerd begrepen heeft en op grond daarvan heeft besloten de uitslag niet te willen horen, terwijl hij deze wel had willen weten wanneer hij van de juiste informatie was uitgegaan. Dit kan overigens nooit tot een verplichte verantwoording leiden. Indien de adviesvrager zijn keuze niet wenst toe te lichten, zal de klinisch geneticus deze moeten respecteren. De plicht die de klinisch genetici ervaren is dus ook juridisch als een plicht te beschouwen.

Klinisch genetici geven aan het recht op niet weten te respecteren. Er zijn omstandigheden te bedenken waarin dit niet het geval zou zijn, al zullen deze zich zelden tot nooit voordoen, omdat er weinig situaties zijn waarin het nadeel zo evident is dat er van kennelijk ernstig nadeel gesproken kan worden. Het hypothetische geval wordt genoemd waarin de adviesvrager een ziekte zal krijgen waarbij preventieve maatregelen duidelijk effect sorteren. Het belang bij niet weten dat niet opweegt tegen het kennelijk ernstig nadeel dat het besluit om geen inlichtingen te ontvangen voor de adviesvrager met zich mee zou brengen, wordt hierbij verwoord als het recht hebben om door het recht op niet weten heen te breken omdat het niet willen schaden overheerst. In hoofdstuk 6 is opgemerkt dat het feit alleen dat een ziekte behandelbaar is, niet een uitzondering op artikel 7:449 BW rechtvaardigt. De adviesvrager is immers voorafgaand aan het onderzoek hierover uitgebreid geïnformeerd en aangenomen mag worden dat de adviesvrager met deze mogelijkheid rekening heeft gehouden en de mogelijke consequenties van zijn keuze overziet.

Als een adviesvrager te kennen geeft de uitslag van een erfelijkheidsonderzoek niet te willen weten wordt er meestal overlegd met de adviesvrager wat er met de uitslag moet gebeuren. Dit doet het meeste recht aan het recht van de adviesvrager om zelf te beslissen wat met de informatie omtrent zijn gezondheidstoestand gebeurt. Het verdient daarom aanbeveling dat dit overleg altijd plaatsvindt. Het nadeel van het vernietigen van de uitslag is uiteraard dat indien de adviesvrager terugkomt op zijn besluit, het onderzoek zal moeten worden overgedaan. Dit is echter een consequentie van zijn keuzevrijheid die de adviesvrager zal moeten aanvaarden.

\subsection{Een erfelijkheidsonderzoek zonder vooraf geïnformeerd te zijn}

Een adviesvrager heeft het recht om, wanneer hij dit te kennen geeft, geen inlichtingen te ontvangen. Hiervóór is gebleken dat adviesvragers enerzijds van dit recht gebruik maken door geen erfelijkheidsonderzoek te ondergaan en anderzijds door niet over de uitslag van een onderzoek geïformeerd te willen worden. Het komt echter ook voor dat een adviesvrager wel een erfelijkheidsonderzoek wil laten 
verrichten en daarvan de uitslag ook wil vernemen, maar dat hij voorafgaand aan het erfelijkheidsonderzoek niet geinformeerd wil worden. De volgende praktijkcasus kan dit verduidelijken:

Mevrouw $X$ neemt contact op met een klinisch geneticus en geeft aan dat zij zwanger is. Zij heeft een hoog risico op een kind met een ernstige erfelijke aandoening. Op grond daarvan komt zij in aanmerking voor prenatale diagnostiek. Ze geeft aan dit onderzoek te willen ondergaan. Ze wil van te voren echter niet gë̈nformeerd worden.

Meneer $Y$ neemt telefonisch contact op met een klinisch genetisch centrum. Iij heeft zojuist gehoord dat hij een risico heeft van vijftig procent op de aanleg voor de ziekte van Huntington. Hij wil dat zijn bloed zo spoedig mogelijk wordt onderzocht op de aanwezigheid van de mutatie die tot de ziekte leidt. Hij wil door de huisarts geprikt worden en hij wil ook de uitslag via de huisarts horen.

In de praktijk leidt dit soort verzoeken voor klinisch genetici tot moeilijke situaties. Enerzijds is er geen sprake van volledige erfelijkheidsadvisering omdat de adviesvrager vooraf niet is geinformeerd door de geneticus. Anderzijds is er sprake van een medische indicatie voor het desbetreffende erfelijkheidsonderzoek en wil de geneticus zijn adviesvrager dit onderzoek niet onthouden. Dergelijke verzoeken worden binnen een centrum uitgebreid besproken en per situatie wordt bepaald hoe zal worden gehandeld.

\section{Beschouwing}

Bovenstaande casus toont een dilemma waar de Wgbo niet op heeft geanticipeerd. In hoofdstuk 6 is opgemerkt dat artikel 7:449 BW waarin is geregeld dat een adviesvrager niet verplicht is inlichtingen te ontvangen wanneer hij zulks wenst, bedoeld is om een patiënt de gelegenheid te geven om te besluiten dat hij niet geinformeerd wil worden over een uitslag. Kan een adviesvrager zich in dit soort casus daarom nog wel beroepen op een recht op niet weten? Wanneer een adviesvrager besluit voorafgaand aan een erfelijkheidsonderzoek geen inlichtingen te willen ontvangen, betekent dit dat hij geen weloverwogen beslissing heeft genomen in die zin dat hij niet alle inlichtingen heeft ontvangen die hem in staat stellen een weloverwogen geinformeerde beslissing te nemen. Ondanks het feit dat ervan uit mag worden gegaan dat de adviesvrager in ieder geval die inlichtingen wenst te ontvangen die nodig zijn voor het maken van een weloverwogen beslissing is er geen juridische eis dat de adviesvrager die informatie ook ontvangt. De klinisch geneticus kan zich hier wel op het standpunt stellen dat het verrichten van een erfelijkheidsonderzoek zonder het verstrekken van de vóórinformatie strijdig is met de zorg van een goed hulpverlener. Deze norm onderstreept de normen en ervaringen van de beroepsgroep alsmede de eigen professionele verantwoordelijkheid van de klinisch geneticus. De norm van artikel 7:453 BW houdt volgens de regering verband met alle normen met betrekking tot behoorlijke hulpverlening.? De beroepsgroep zal hier met betrekking tot de verschillende soorten erfelijkheidsonderzoek moeten bepalen of het onderzoek ook zonder de 
vóórinformatie verricht kan worden, met ruimte voor de omstandigheden van elke afzonderlijke situatie. Criteria die hierbij gehanteerd kunnen worden zijn de verstrekkendheid van de mogelijke consequenties van het onderzoek en de kennis hieromtrent bij de adviesvrager. Hiermee kan een $u$ vrangt, wij draaien beleid worden voorkomen. Toch bestaat er hier een zekere spanning met artikel 7:449 BW. De hulpverlener mag niet besluiten om op grond van de opvattingen binnen zijn beroepsgroep, bepaalde patiëntenrechten uit de Wgbo te negeren. ${ }^{3}$ Van de Wgbobepalingen kan niet ten nadele van de patiënt worden afgeweken. Evenmin zal in elke situatie gesteld kunnen worden dat het niet ontvangen van de vóórinformatie kennelijk ernstig nadeel voor de adviesvrager zal opleveren. Toch behoort de invulling van het goed hulpverlenerschap door de beroepsgroep mijns inziens hier de beslissende stem te hebben. Het recht om geen inlichtingen te ontvangen is een belangrijk recht dat een onderdeel is van het recht op weten en is afgeleid van het recht op privacy. Uit de wetgeschiedenis en de literatuur blijkt echter dat het artikel bedoeld is om een patiënt de gelegenheid te geven een uitslag niet te ontvangen. Bovendien zou het verrichte erfelijkheidsonderzoek zonder toestemming zijn verricht wanneer deze niet voorafgegaan zou zijn door volledige informatie.

Indien het niet vooraf geinformeerd willen worden wel als een onderdeel van het recht op niet weten zou worden gezien, zal een uitzondering op het recht om geen inlichtingen te ontvangen aanwezig kunnen zijn wanneer het belang dat de patiënt daarbij heeft niet opweegt tegen het kennelijk ernstig nadeel dat daaruit voor hem kan voortvloeien. Op grond van deze uitzondering kan besloten worden om een adviesvrager bepaalde inlichtingen toch te verstrekken alvorens een erfelijkheidsonderzoek te verrichten.

Ten slotte het verzoek van de man uit de tweede casus om de uitslag van het erfelijkheidsonderzoek via de huisarts de vernemen. Moet een klinisch geneticus hierop ingaan? Een belangrijk argument om dat niet te doen is mijns inziens gelegen in het feit dat erfelijkheidsadvisering van complexe aard een functie is die op grond van de Regeling Klinisch Genetisch Onderzoek en Erfelijkheidsadvisering alleen door de Stichtingen voor Klinische Genetica mag worden uitgevoerd. ${ }^{4}$ Het meedelen van de uitslag door de huisarts is daarmee in strijd. Zeker bij een voorspellend erfelijkheidsonderzoek naar een onbehandelbare aandoening, waarbij de erfelijkheidsadvisering complex is, is het van belang deze door een klinisch genetisch centrum te laten uitvoeren.

$3 \quad$ Legemaate 1995, p. 15.

4 Deze regeling is tot stand gekomen omdat de door de klinisch genetische centra verrichte functies vallen onder de vergunningsregeling die is gebaseerd op artikel 2 van de Wet bijzondere medische verrichtingen (Wbmv). 


\title{
9.5 Het recht op niet weten van kinderen en ongeborenen
}

In de praktijk wordt geen voorspellend onderzoek verricht bij kinderen. Hierop wordt een uitzondering gemaakt wanneer de aanleg reeds op kinderleeftijd tot uiting kan komen en/of wanneer preventieve maatregelen reeds op kinderleeftijd genomen kunnen worden. In de praktijk blijkt de instelling van ouders een uitzondering op dit uitgangspunt op te kunnen leveren.

\begin{abstract}
"Wij doen ook bijna geen onderzoek meer bij minderjarigen. Recentelijk kwam er een vader met een zoontje met Duchenne en die wilde het DNA van zijn zoontje laten testen om die mutatie te vinden. Hij wilde dat alleen maar om zijn dochter te kunnen onderzoeken. Maar die dochter is wel twaalf en zit in de brugklas. We doen deze onderzoeken bij minderjarigen bijna nooit meer. Soms wel, maar dan doen we er moeilijk over. Deze vader is ook bij de huisarts geweest om er nog eens over te praten en om een lang verhaal kort te maken heb ik vorige week wel die dochter laten prikken. Ik denk dat dat soms kan. Soms doen we het wel. Dit was een Turks gezin, waar die instelling van de ouders toch wat anders is. Wat meer paternalistisch dan tegenwoordig de meeste Nederlandse ouders. Maar ik denk dat je daar flexibel in moet kunnen zijn. Als je maar goed weet waar je mee bezig bent."
\end{abstract}

\section{Beschouwing}

In deze casus spelen twee belangen. Enerzijds het belang van de vader om geïnformeerd te worden over het feit of zijn dochter wel of geen draagster is en anderzijds het belang van de dochter om zelf te zijner tijd te kunnen beslissen of zij wil weten of zij draagster is of niet en dus zelf te kunnen beslissen over het ondergaan van een erfelijkheidsonderzoek. In hoofdstuk 6 is verdedigd dat bij de vraag of ouders een voorspellend onderzoek bij hun kind moeten laten verrichten het belang van het kind voorop staat. Ouders dienen daarbij als goede vertegenwoordigers te handelen. Naast deze verantwoordelijkheid van de ouders, rust op de klinisch geneticus op grond van zijn goed hulpverlenerschap de verantwoordelijkheid om de belangen van het kind te beschermen. In deze casus betreft het erfelijkheidsonderzoek naar een mutatie die bij de dochter niet tot symptomen zal leiden. Er is met andere woorden geen gezondheidsbelang aanwezig om dit onderzoek te verrichten. Het zal alleen in de toekomst voor de dochter van belang kunnen zijn, wanneer zij een kinderwens zou hebben. Het feit dat de ouders een paternalistische instelling hebben doet niet af aan het feit dat de belangen van de dochter voorop dienen te staan. In deze casus is het belang van het kind strijdig met het belang van de vader. De vader kan in dit geval zijn rol als goede vertegenwoordiger niet vervullen. Het goed hulpverlenerschap vereist hier dat het verzoek om een erfelijkheidsonderzoek niet wordt gehonoreerd door de klinisch geneticus.

Daarnaast was in bovenstaande casus mede de toestemming van de dochter en de moeder vereist alvorens een erfelijkheidsonderzoek verricht had kunnen worden. Voor kinderen van 12 tot 16 geldt, zoals in hoofdstuk 6 beschreven, de dubbele toestemmingseis. Voor verrichtingen ter uitvoering van de 
behandelingsovereenkomst, in casu het erfelijkheidsonderzoek, is dan zowel toestemming van het kind als van beide ouders vereist.

\section{Erfelijkheidsonderzock bij ongebore'nen}

In hoofdstuk 6 is aandacht besteed aan de toegang tot erfelijkheidsonderzoek. Daar werd gesteld dat het onjuist is om aan de toegang tot prenatale diagnostiek de eis te stellen dat ouders voornemens moeten zijn om bij cen ongunstige uitslag de vrucht te laten aborteren. Een nitzondering werd gevonden in later in het leven optredende ernstige onbehandelbare aandoeningen. Indien ouders de vrucht bij een negatieve uitslag bij voorbaat niet wensen te aborteren, hoeft geen onderzoek te worden verricht. Het toekomstige zelfbeschikkingsrecht van het toekomstige kind dient zwaarder te wegen dan het recht van de aanstaande ouders op het ontvangen van (mogelijk geruststellende) informatie. De praktijk laat hier en daar een ander beeld zien. In een aantal centra wordt echter geen prenatale diagnostiek verricht wanneer de aanstaande ouders alleen geinformeerd willen worden over het al dan niet aanwezig zijn van de erfelijke aanleg voor een ernstige onbehandelbare aandoening bij hun toekomstige kind en dus niet voornemens zijn om bij een ongunstige uitslag de vrucht te aborteren.

\section{Beschourving}

De eis dat een verzoek van toekomstige ouders tot prenataal onderzoek niet slechts wordt gedaan om geinformeerd te worden, is in principe een inbreuk op de grondslag en het doel van de erfelijkheidsadvisering. Het uitgangspunt dat de erfelijkheidsadvisering non-directief van aard is, heeft ten doel de adviesvrager in staat te stellen een vrije en geinformeerde keuze te maken. Het eerste uitgangspunt van de erfelijkheidsrichtlijnen luidt als volgt:

"leder heeft het recht zelf te beslissen of hij erfelijkheidsonderzoek ondergaat. (...) Dit uitgangspunt betekent tevens dat de arts aan het verrichten van erfelijkheidsonderzoek geen bijzondere voorwaarden mag stellen, zoals de bereidheid een abortus te ondergaan bij een gebleken positieve uitslag van prenataal onderzoek."

Verzoeken om prenatale diagnostiek zonder voornemens te zijn consequenties aan de uitslag te verbinden komen in de praktijk weinig voor. In hoofdstuk 6 is het volgende standpunt verdedigd. Indien ouders verzoeken om een prenataal onderzoek naar later in het leven optredende onbehandelbare aandoeningen, terwijl de keus om het kind geboren te laten worden reeds gemaakt is door de aanstaande ouders, is de klinisch geneticus verplicht, op grond van zijn goed hulpverlenerschap, om aan te geven dat het belang van de ouders bij een dergelijk verzoek minder zwaar weegt dan het toekomstige belang van het toekomstige kind om in de toekomst zelf te kunnen beslissen of het wil weten of zich in de toekomst een onbehandelbare ziekte zal openbaren. Wanneer de ouders volharden in hun verzoek, rest de klinisch geneticus de mogelijkheid om het verzoek op grond van zijn professionele standaard te weigeren. Sommige klinisch genetische centra werken, zoals opgemerkt, overeenkomstig dit standpunt en honoreren dergelijke verzoeken

$5 \quad$ Vereniging voor Gezondheidsrecht 1991, uitgangspunt 3.1. 
nict. Om het toekomstige recht op niet weten van het toekomstige kind zo goed mogelijk te beschermen, verdient het aanbeveling dat alle centra dergelijke verzoeken weigeren.

\subsection{Slotbeschouwing}

In deze slotbeschouwing staan de volgende vragen centraal:

- Zijn klinisch genetici op de hoogte van het feit dat de adviesvrager een recht op niet weten heeft?

- Delen klinisch genetici de uitgangspunten van de juridische invulling van dit recht?

- Wordt het recht op niet weten toegepast conform de juridische invulling die daaraan is gegeven?

- Wat zijn daarbij de knelpunten en dilemma's en hoe zijn deze eventueel op te lossen?

De eerste vraag luidde of klinisch genetici op de hoogte zijn van het feit dat de adviesvrager een recht op niet weten heeft. Een bevestigend antwoord op deze vraag kan worden afgeleid uit het feit dat adviesvragers bij voorspellend onderzoek naar een aandoening bij de adviesvrager zelf, meestal erop worden gewezen dat ze zich te allen tijde kunnen bedenken en kunnen besluiten geen verdere inlichtingen te willen ontvangen. Bovendien wordt bij erfelijkheidsonderzoek aangegeven dat adviesvragers voor zichzelf moeten afwegen of zij dit willen ondergaan.

De tweede vraag was of klinisch genetici de uitgangspunten van de juridische invulling delen. Het leidend rechtsbeginsel in de juridische hoofdstukken was het zelfbeschikkingsrecht van de adviesvrager. De adviesvrager heeft een recht op informatie en op basis van die informatie geeft hij al dan niet toestemming voor een erfelijkheidsonderzoek. Naast een recht op informatie heeft de adviesvrager echter ook een recht op niet weten. Bij erfelijkheidsadvisering is het de adviesvrager die uiteindelijk de keuze maakt of hij een erfelijkheidsonderzoek wil ondergaan. Ook deze vraag kan bevestigend beantwoord worden. Klinisch genetici benadrukken dat adviesvragers altijd alleen voor een informatief gesprek kunnen komen en dat het de keuze van de adviesvrager is of hij een erfelijkheidsonderzoek wil ondergaan. Het recht op niet weten vloeit volgens hen logisch voort uit het feit dat het de adviesvrager is die een keuze maakt.

De derde vraag luidde of het recht op niet weten ook wordt toegepast conform de juridische invulling die daaraan is gegeven. Het informeren over het recht op niet weten gebeurt, zoals reeds opgemerkt, in de praktijk op twee manieren. Enerzijds door concreet aan te geven dat een adviesvrager te allen tijde kan besluiten niet geïnformeerd te willen worden over de uitslag van het erfelijkheidsonderzoek. Anderzijds door aan te geven dat een erfelijkheidsonderzoek vrijwillig is en dat adviesvragers voor zichzelf moeten afwegen of zij datgene dat onderzocht kan worden ook daadwerkelijk willen weten. Uit de voorgaande paragrafen blijkt echter 
het volgende knelpunt. Het recht op niet weten van de adviesvrager wordt weliswaar gerespecteerd door de klinisch geneticus, maar hij heeft er moeite mee als de adviesvrager in zijn ogen irrationele besluiten neemt. Dit is uit het volgende af te leiden.

Ten eerste vinden sommige genetici het onlogisch om na uitgebreide erfelijkheidsadvisering die voorafgegaan is aan het besluit van de adviesvrager om een erfelijkheidsonderzoek te laten verrichten, wederom aan te geven dat hij nog altijd kan besluiten de uitslag van het onderzoek niet te vernemen. Om die reden wordt dit in de praktijk regelmatig nagelaten. Een standpunt dat een stap verdergaat is dat door een goede erfelijkheidsadvisering het überhaupt niet nodig is het recht op niet weten te benoemen. Alleen bij twijfel van de adviesvrager omtrent het laten verrichten van een erfelijkheidsonderzoek is hier aanleiding voor. Dit veronderstelt dat de kwaliteit van de erfelijkheidsadvisering van dien aard is dat een adviesvrager na een weloverwogen besluit om een erfelijkheidsonderzoek te ondergaan van dit recht geen gebruik zal maken. Hierbij wordt tevens een hoge mate van rationaliteit van de adviesvrager verwacht. Het komt echter voor dat adviesvragers, ondanks de volgens klinisch genetici kwalitatief hoogwaardige erfelijkheidsadvisering, de uitslag niet willen vernemen.

Ten tweede geven veel klinisch genetici aan dat ze er moeite mee hebben als een adviesvrager daadwerkelijk aangeeft de uitslag van zijn erfelijkheidsonderzoek niet te willen weten. Het recht op niet weten wordt erkend, maar men hoopt dat er na een erfelijkheidsonderzoek geen gebruikt van gemaakt wordt. Het is een onbevredigende situatie indien op het besluit om een erfelijkheidsonderzoek te ondergaan, het besluit volgt om toch de uitslag niet te willen weten. Gezien het feit dat voorafgaand aan het erfelijkheidsonderzoek uitvoerig aandacht wordt besteed aan de vraag of en waarom de adviesvrager wel wil weten dat hij een verhoogd risico heeft op een erfelijke aandoening of aan een erfelijke aandoening zal gaan lijden en het onderzoek alleen wordt verricht wanneer er bij de adviesvrager geen twijfel lijkt te bestaan, is een dergelijk besluit in de ogen van de klinisch geneticus irrationeel.

Ten derde blijkt dit uit het feit dat de meeste klinisch genetici het als hun plicht zien om na te gaan waarom een adviesvrager besloten heeft om de uitslag van een erfelijkheidsonderzoek niet te willen weten. Eerder is opgemerkt dat dit wordt gerechtvaardigd door het feit dat de klinisch geneticus zich ervan dient te vergewissen dat de adviesvrager de informatie heeft begrepen. Wanneer een beslissing van de adviesvrager in het licht van de voorafgegane erfelijkheidsadvisering irrationeel lijkt, ervaart de klinisch geneticus het als zijn plicht om na te gaan of de adviesvrager de informatie begrepen heeft, zodat hij zich ervan kan verzekeren dat het besluit vrijwillig genomen is en gebaseerd is op alle voor de adviesvrager relevante informatie. Uit het feit dat klinisch genetici het als een plicht zien om na te gaan waarom een adviesvrager besloten heeft geen verdere inlichtingen te willen ontvangen, blijkt echter wel dat men zich ervan gaat vergewissen of de adviesvrager de informatie begrepen heeft wanneer een besluit hen irrationeel voorkomt. 
Uit het bovenstaande blijkt dat klinisch genetici er moeite mee hebben wanneer een besluit van de adviesvrager in hun ogen irrationeel is. In de situatie waarin een adviesvrager wel een erfelijkheidsonderzoek wil ondergaan, maar hierover vooraf niet geinformeerd wil worden, speelt wederom de vraag of het besluit van de adviesvrager om voorafgaand aan een erfelijkheidsonderzoek geen inlichtingen te ontvangen, cen rationeel besluit is, alsmede of het dat zou moeten zijn. Het is in ieder geval niet gebaseerd op informatie omtrent het te verrichten onderzoek en de mogelijke consequenties ervan. Het kan wel zo zijn dat het besluit gebaseerd is op alle voor de adviesvrager relevante informatie. Bij de vraag of een verzoek om een erfelijkheidsonderzoek in dergelijke situaties gehonoreerd moet worden, spelen echter ook factoren als de professionele verantwoordelijkheid van de klinisch geneticus een rol. ${ }^{6}$ In deze situaties is het wederom de irrationeel gedrag vertonende adviesvrager die een voor klinisch genetici lastige situatie creëert.

Hoofdstuk 10 besteedt aandacht aan de geheimhoudingsplicht. Aan bod komen de wijze waarop familieleden worden geïformeerd, de wijze waarop de klinisch genetici omgaan met en denken over de geheimhoudingsplicht en het conflict van plichten alsmede de wijze waarop wordt gedacht over en omgegaan met de geheimhoudingsplicht na de dood.

Zie hiervoor hoofdstuk 6 en paragraaf 9.4 . 



\section{ERFELIJKHEIDSADVISERING EN GEHEIMHOUDING IN DE PRAKTIJK}

\subsection{Inleiding}

Bij erfelijkheidsadvisering spelen er structureel belangen van familieleden mee. Erfelijkheidsinformatie kan behalve voor de adviesvrager ook voor diens verwanten van belang zijn. Daarnaast is om de adviesvrager te kunnen adviseren vaak de medewerking van één of meer familieleden noodzakelijk. Indien de adviesvrager zijn familieleden niet wil informeren of familieleden geen informatie ter beschikking van de adviesvrager willen stellen, kan de klinisch geneticus voor een groot dilemma komen te staan. Enerzijds is hij gebonden aan zijn geheimhoudingsplicht en anderzijds wil hij de adviesvrager of diens familieleden inlichten omtrent mogelijke erfelijke risico's. In dit hoofdstuk is de geheimhoudingsplicht aan de orde. Paragraaf 10.2 beschrijft hoe familieleden over een mogelijk risico op een erfelijke aandoening worden geinformeerd. Paragraaf 10.3 gaat in op de consequenties van de geheimhoudingsplicht waar de klinisch geneticus in de praktijk van de erfelijkheidsadvisering mee wordt geconfronteerd. In paragraaf 10.4 wordt beschreven hoe klinisch genetici denken over en omgaan met het conflict van plichten. Hierbij zijn twee situaties aan de orde. Ten eerste de situatie waarin een familielid ten gevolge van de geheimhoudingsplicht van de klinisch geneticus niet over een mogelijk risico op een erfelijke afwijking kan worden geïnformeerd. Ten tweede de situatie waarin ten behoeve van de adviesvrager geen erfelijkheidsonderzoek kan worden verricht, omdat de vereiste medewerking van een familielid ontbreekt. Paragraaf 10.5 beschrijft hoe wordt gedacht over en omgegaan met de geheimhoudingsplicht na de dood van de adviesvrager of een familielid. Elke paragraaf wordt afgesloten met een beschouwing waarin wordt gekeken hoe de empirie zich verhoudt tot de juridische invulling daarvan. Het hoofdstuk wordt afgesloten met een slotbeschouwing waarin de volgende vragen worden beantwoord:

- Zijn klinisch genetici op de hoogte van het feit dat de adviesvrager recht heeft op geheimhouding van zijn gegevens?

- Delen klinisch genetici de uitgangspunten van de juridische invulling?

- Wordt de geheimhoudingsplicht toegepast conform de juridische invulling die daaraan is gegeven?

- Wat zijn de knelpunten en de dilemma's en hoe zijn deze eventueel op te lossen?

\subsection{Het benaderen van familieleden}

Familieleden worden niet door de klinisch geneticus zelf benaderd. Indien erfelijkheidsinformatie voor verwanten van de adviesvrager van belang zou kunnen zijn, wordt de adviesvrager hier door de geneticus op gewezen. Dit gebeurt, zoals reeds in hoofdstuk 8 aangegeven, al in een vroeg stadium van de erfelijkheidsadvisering. Op die manier is het voor de adviesvrager tijdens het 
uitslaggesprek geen verrassing dat de uitslag ook consequenties kan hebben voor bloedverwanten.

"De grootste fout zou zijn als je pas achteraf duidelijk maakt dat je misschien achter de rug van de adviesvrager om naar zijn familie zal gaan. Je geeft mensen dan niet de kans om te zeggen dat ze in dat geval helemaal geen onderzoek willen."

Het informeren van familieleden over een mogelijke risico op een erfelijke aandoening is voor de adviesvrager niet altijd een gemakkelijke taak. Bovendien bestaat aitijd de mogelijkheid dat de adviesvrager zegt zijn familieleden te zullen informeren, maar dit uiteindelijk niet doet.

"Wat je wel ziet is hoe mocilijk het is voor de eerste patiënt bij wie een aandoening is vastgesteld om informatie aan de familieleden te geven. Ik heb een vrouw gehad die overhoop lag met haar broers en zusters, maar uiteindelijk vond ze het toch wel belangrijk om het aan hen door te geven. Dat heeft ze dan ook wel gedaan, maar natuurlijk een beetje via via. Eén familielid werd ingelicht en een ander familielid, dat ze zelfs een keer op straat tegenkwam, werd niet ingelicht. Die moest het dan weer horen van die persoon die ze wel had ingelicht. Het feit dat wij patiënten hun familie laten inlichten stuit dus nog wel eens op problemen. Het gebeurt ook wel eens dat de informatie toch niet wordt doorgegeven. De afgelopen patiëntenbespreking hadden we daar een geval van. Een patiënte die draagster was van een bepaalde aandoening had dat niet doorgegeven aan haar familie. Toen kwam een dochter van haar zus, tien weken zwanger, met de vraag: 'er zit wat in mijn familie. Heeft dat voor mij nog consequenties?' En dat wil je eigenlijk niet op zo'n manier zeggen. Dat is toch wel vaak een dilemma; doen mensen dat wel goed, kunnen ze ermee omgaan, wat doe je ze aan. Ondanks dat vinden we tot nu toe dat de adviesvrager de verbindende schakel moet zijn."

De klinisch geneticus laat het informeren dus aan de adviesvrager over. De energie die erin gestoken wordt om adviesvragers hun familieleden te laten informeren verschilt per geneticus.

"Er wordt wel door de één meer en actiever op doorgegaan. Je kunt dat bewerken noemen; de eerste nee nemen we niet voor een nee. Na een half jaartje proberen we het nog eens een keer of nog eens een keer."

Soms lost het probleem zich vanzelf op. Dit is bijvoorbeeld het geval wanneer een familielid van de adviesvrager zich eigener beweging voor een erfelijkheidsadvies tot een klinisch geneticus wendt en dit familielid wel bereid is andere familieleden in te lichten. Indien de adviesvrager heeft aangegeven zijn familieleden te zullen informeren, maar de klinisch geneticus geen enkel familielid terugziet, is dit soms een reden om na te gaan of de adviesvrager zijn familieleden heeft geïnformeerd.

"Het nadeel is dat ik niet weet of mensen die familiebriefjes krijgen. Het kan best zijn dat iemand die zegt dat hij het aan al zijn familieleden zal vertellen, dat vervolgens niet doet. Dat komt wel eens een keertje voor en dat vind ik heel erg. We hebben het hier onlangs nog over gehad. Het zint ons niet. Wat we vermoedelijk weer gaan doen als de mankracht het toelaat is dat we de druk op de ketel iets verhogen doordat we bijvoorbeeld na een half jaar weer contact opnemen met de adviesvrager en zeggen: 
'weet u nog wat we onlangs besproken hebben over de familie? Kunnen we nog ergens mee helpen? Ileeft u nog vragen? Hoe is het gegaan?' Dat is toch een hele vriendelijke manier om even te kijken of het ergens geblokkeerd is. Natuurlijk kan iemand liegen en zeggen dat iedereen de informatie heeft terwijl dat niet het geval is. Dan houdt het op. Ik denk dat dat ongeveer de grens is tot waar wij bereid zijn te gaan. Daar ligt toch echt wel een grens. Je kunt moeilijk met een luidspreker op het dak familiefeesten af gaan rijden. We gaan iets meer druk op de ketel zetten dan vroeger, omdat we toch een paar schrijnende gevallen hebben gezien. Nu gaan we een beetje meer agent spelen op de vriendelijkste manier die we kunnen bedenken."

De belangrijkste reden om familieleden te informeren zijn de preventieve opties die familieleden ter beschikking staan wanneer blijkt dat zij zullen gaan lijden aan of een hoog risico hebben om te gaan lijden aan een erfelijke aandoening of indien zij een hoog risico hebben op nageslacht met een aandoening. Daarnaast kan wetenschappelijke interesse in de praktijk een reden zijn om nogmaals contact op te nemen met de adviesvrager, wanneer de klinisch geneticus niks van familieleden van de adviesvrager hoort.

"Ik kan het niet controleren. Wanneer je zelf wetenschappelijk geïnteresseerd bent, kun je nog wel eens een keertje opbellen en zeggen: 'ik heb maar niks gehoord, maar het is in uw familie toch eigenlijk heel erg belangrijk om dat gen te detecteren. Dat is niet alleen in uw belang, maar het is ook een algemeen belang. Moeten we aannemen dat uw familie niet van zins is? Heeft u reacties kunnen peilen?' Een tweede reden om nog eens te bellen is wanneer het een aandoening betreft waarvan je weet dat preventief ingrijpen mogelijk is. Dat zijn eigenlijk de twee situaties waarin ik toch wat agressiever ben, maar binnen de grenzen van het redelijke zou ik zeggen."

De klinisch geneticus ziet het informeren van familieleden dus als taak van de adviesvrager. Sommige centra geven adviesvragers als standaard een familiebrief mee die ze in de familie kunnen verspreiden. Andere centra werken alleen met een familiebrief wanneer de adviesvrager daarom vraagt. Genetici wijzen erop dat adviesvragers na afloop van de erfelijkheidsadvisering ook een samenvattende brief krijgen die ze gedeeltelijk zouden kunnen gebruiken om hun familieleden in te lichten. De familiebrieven zijn algemeen. Er worden in de regel geen namen in genoemd. Bovendien is de informatie over de erfelijke aandoening summier. De reden die hiervoor wordt aangegeven is dat men de inbreuk op de privacy zo gering mogelijk wil houden.

"Hele uitgebreide brieven die alles vertellen kunnen door sommige mensen zeer ongewenst worden gevonden. Het is een inbreuk op je privacy als jou ongevraagd wordt verteld dat jij risico loopt op iets. Het is met de beste bedoelingen gedaan, maar het is toch een inbreuk. Wij houden die inbreuk dus het liefst een beetje aan de kleine kant. Een kort briefje kun je gemakkelijker naast je neerleggen en vergeten dan een brief die meteen in alle details treedt."

Naast het feit dat een ongevraagde brief als een inbreuk op de privacy wordt gezien, geven genetici aan dat een familiebrief ook heel bedreigend kan zijn voor verwanten. 
Bovendien kumnen familieleden zich door de brief verplicht voelen om zich tot een klinisch geneticus te wenden.

"Ik heb het zelf cen paar keer gedaan en uit de reacties maak ik op dat het toch heel bedreigend is als zo'n brief ineens op je deurmat ligt. lk kreeg het gevoel dat mensen dachten dat ze moesten komen omdat de instantie zegt dat er onderzoek mogelijk is."

Genoemde nadelen maken dat familiebrieven niet een standaard gebruik zijn bij erfelijkheidsadvisering. Ze worden meestal op verzoek van de adviesvrager meegegeven. Deze kan bijvoorbeeld aangeven dat hij bang is dat sommige verwanten boos zullen worden wanneer hij ze mondeling informeert. Een andere reden kan zijn dat hij aangeeft het moeilijk te vinden alle informatie correct door te geven. Een geneticus geeft aan dat het werken met een familiebrief zijns inziens minder problematisch is wanneer het aandoeningen betreft die de desbetreffende persoon niet zelf kan krijgen.

"Maar bij de translocaties en bij dragerschap, waarbij het dus niet om mogelijke ziektes bij de persoon zelf gaat, vind ik het minder erg om zo'n algemene brief mee te geven. Ik vind het wat anders als het gaat om een aandoening die iemand zelf kan hebben. Wij hebben daar geen vaste richtlijnen voor. Ja, goed hulpverlenerschap, we proberen dat linksom of rechtsom zo te doen dat we later uit kunnen leggen waarom we het zo gedaan hebben."

De informatie in de familiebrieven is zoals opgemerkt summier. De aandoening waar desbetreffende familieleden mogelijk een verhoogd risico op lopen wordt wel in de brief genoemd. De reden hiervoor is het feit dat er onderzoek wordt aangeboden en dat je daarom aan moet geven wat voor soort onderzoek je aanbiedt. Dit argument geldt uiteraard alleen als er daadwerkelijk onderzoek wordt aangeboden in de brief. Niet elke klinisch geneticus biedt onderzoek aan in een familiebrief. De tweede reden heeft betrekking op gevoelens van onrust wanneer familieleden niet weten welke erfelijke aandoening het betreft.

\begin{abstract}
"We hebben wel overwogen om de aandoening niet te noemen, ook om de hoeveelheid informatic minimaal te houden in zo'n familiebrief, maar hebben dat niet doorgevoerd. Ik vind dat we niet heel veel informatie geven in die brief, maar wanneer je alleen zou aangeven dat men misschien een risico zou kunnen lopen op iets, dan zou de onrust nog veel groter kunnen zijn, dan wanneer je meteen benoemt wat er gaande is. Familieleden kunnen dan ook wat bewuster reageren. (...) Ik denk dat mensen anders gaan vragen: 'wat is dat dan? Welk risico loop ik dan?' Ze hebben zich dan al de gekste dingen in het hoofd gehaald, waar ze allemaal risico op zouden kunnen hebben. En dan komt het toch boven water. Uiteindelijk gaat iemand dan vertellen of schrijven waar het nu precies over gaat."
\end{abstract}

\title{
Beschouzving
}

De praktijk laat zien dat het voor een adviesvrager niet altijd gemakkelijk is om familieleden in te lichten over risico's op een erfelijke aandoening. Het uitgangspunt dat de adviesvrager zelf zijn familieleden moet inlichten, wordt door klinisch genetici echter onderschreven. In hoofdstuk 7 is dit uitgangspunt ook aan de orde geweest. 
Daar is gesteld dat de klinisch geneticus een behandelingsovereenkomst heeft met de adviesvrager en niet met diens familieleden. Het kan bovendien bedreigend zijn voor familieleden wanneer zij rechtstreeks door een klinisch geneticus zouden worden geinformeerd. Opgemerkt werd dat het gevaar bestaat dat wanneer de klinisch geneticus aangeeft dat er erfelijkheidsinformatie beschikbaar is, dit de indruk zou kunnen wekken dat het onverstandig, of misschien zelfs onverantwoord, is om van dergelijke informatie niet op de hoogte te willen worden gesteld. Klinisch genetici gaven aan dat wanneer er gewerkt wordt met een familiebrief dit bedreigend kan zijn en gezien kan worden als een verplichting om onderzoek te laten verrichten. Het betreft hier dus niet het rechtstreeks informeren door de klinisch geneticus, maar het informeren via een familiebrief die de adviesvrager verspreidt. Indien blijkt dat het informeren via een familiebrief bedreigend kan zijn voor familieleden, dan geldt dit des te meer voor het rechtstreeks informeren.

Over het werken met een familiebrief zijn de meningen verdeeld. In hoofdstuk 7 is aangegeven dat een klinisch geneticus door middel van een familiebrief kan helpen met het informeren van de adviesvrager. Hij is degene die wijst op het belang van de informatie en zal enige hulp aan moeten bieden wanneer de adviesvrager aangeeft om welke reden dan ook moeite te hebben met het informeren van zijn verwanten. Zoals hiervoor gebleken is, heeft een familiebrief ook nadelen. Ongevraagd een brief ontvangen wordt door sommige genetici als een inbreuk op de privacy van de verwanten van de adviesvrager gezien en kan bedreigend zijn voor verwanten. Het is echter aan de adviesvrager om familieleden op een verantwoorde manier te informeren. Het versturen van een familiebrief zonder bijvoorbeeld een telefonische aankondiging is wellicht geen elegante wijze van informeren. Zeker in die situaties waarin familieleden niet op de hoogte zijn van het feit dat er een erfelijke aandoening in de familie speelt. Dit neemt niet weg dat er van de klinisch geneticus, in de gevallen waarin hij met een familiebrief werkt, een zekere inspanning kan worden verwacht om de brief zo op te stellen dat de verstrekte informatie summier is en beperkt blijft tot de mededeling dat erfelijkheidsinformatie beschikbaar is over de familiaire aandoening die in de familie speelt.

In hoofdstuk 7 is opgemerkt dat wanneer een familielid in het geheel niet bekend is met de familiaire aandoening het meer voor de hand liggend is om alleen mee te delen dat erfelijkheidsinformatie beschikbaar is. Dit doet het meeste recht aan de persoonlijke levenssfeer van de familieleden en hun recht op niet weten. In de praktijk wordt de familiaire aandoening wel genoemd. Een eerste argument om deze wel te vermelden was het feit dat in de brief wordt aangegeven dat het mogelijk is om een erfelijkheidsonderzoek te laten verrichten en dat om die reden moet worden aangegeven welke mogelijk familiaire aandoening het betreft, zodat het familielid weet waarnaar erfelijkheidsonderzoek gedaan kan worden. Dit argument roept echter de vraag op of in een familiebrief wel onderzoek aangeboden zou moeten worden. Een dergelijke mededeling zou als een soort oproep om onderzoek te laten verrichten kunnen worden beschouwd. Het is wenselijker om aan te geven dat men zich voor meer informatie altijd tot een klinisch genetisch centrum kan wenden. Zo'n formulering legt minder druk op een familielid om gevolg te geven aan het aanbod. Het tweede argument was het feit dat alleen aangeven dat er informatie beschikbaar 
is, meer onrust kan oproepen dan wanneer in de brief de familiaire aandoening benoemd wordt en dat familieleden bewuster kunnen reageren op een brief die wel aangeeft om welke aandoening het draait. Daar staat echter tegenover dat familieleden, wanneer de aandoening niet vermeld is, nog de keuze hebben om te besluiten dat zij niet willen weten welke aandoening het betreft. Bovendien kunnen ze door één telefoontje naar de adviesvrager achterhalen om welke erfelijke aandoening het gaat.

Ten slotte de vraag hoe ver de geneticus zou moeten gaan in het benadrukken van het belang voor verwanten dat zij door de adviesvrager worden geïnformeerd alsmede de vraag of de klinisch geneticus mag controleren of verwanten daadwerkelijk zijn geinformeerd. In hoofdstuk 7 is opgemerkt dat de klinisch geneticus redelijke inspanningen dient te verrichten om ervoor te zorgen dat familieleden door de adviesvrager worden ingelicht. Het na een half jaar informeren bij de adviesvrager of hij familieleden heeft geïnformeerd en vragen of er nog hulp kan worden geboden, wanneer er aanzienlijke belangen voor familieleden mee gemoeid zijn, kan beschouwd worden als het verrichten van redelijke inspanningen. Dit zou ook door de genetisch consulente gedaan kunnen worden die zich bezighoudt met de nazorg van de erfelijkheidsadvisering. Het is wel van belang om goed voor ogen te houden waarom het belangrijk is dat familieleden worden geïnformeerd. Als de erfelijkheidsinformatie voor hen van belang kan zijn omdat er preventieve opties zijn, getuigt het van goed hulpverlenerschap om de adviesvrager hierover te benaderen met de vraag of hij zijn familieleden heeft geïnformeerd en of hij hulp nodig heeft. In de situatie waarin het belang groot is voor familieleden om geïformeerd te worden, kan de klinisch geneticus namelijk overwegen om op grond van een conflict van plichten de desbetreffende familieleden in te lichten tegen de wil van de adviesvrager. Dit kan hij echter eerst doen wanneer de adviesvrager aangeeft zijn familieleden niet te willen informeren en de klinisch geneticus redelijke inspanningen heeft verricht om de adviesvrager op andere gedachten te brengen. ${ }^{1}$ De situatie kan zich ook voordoen, zoals een klinisch geneticus eerder in deze paragraaf aangaf, dat een geneticus bij wetenschappelijke interesse in een bepaalde erfelijke aandoening een adviesvrager nogmaals benadert en wijst op het belang van informatie over de erfelijke aandoening voor familieleden. Wanneer in zo'n situatie, naast een algemeen belang, ook sprake is van een individueel belang voor de desbetreffende verwanten, is dit niet problematisch. De klinisch geneticus zal zich in dergelijke situaties wel altijd af moeten vragen of hij de adviesvrager ook in de situatie waarin geen wetenschappelijk belang zou meespelen, nogmaals zou hebben benaderd. Het wetenschappelijk belang mag geen zelfstandige rol spelen.

\subsection{De geheimhoudingsplicht}

Elke adviesvrager heeft recht op geheimhouding van zijn gegevens. Dit leidt ertoe dat verschillende familieleden zich afzonderlijk als adviesvrager met een erfelijkheidsvraag tot een klinisch geneticus kunnen wenden zonder dat de klinisch

De overige voorwaarden waaraan voldaan moet zijn staan beschreven in hoofdstuk 7 . 
geneticus kenbaar kan maken dat hij de medische achtergrond van de familie reeds kent. Het maken van een stamboom, terwijl deze voor de geneticus al bekend is, of het pretenderen dat men de familie niet kent en niks weet van de familiaire aandoening, kan lastig zijn.

"Ontzettend vervelend. Je zit soms wel heel erg te draaien. Officieel weet ik niets, dus zit ik dommetje te spelen en dat is een rotsituatie."

Ondanks het feit dat een klinisch geneticus zich in een lastige situatie kan bevinden, is er geen discussie over het feit dat het bij de geheimhoudingsplicht hoort om niet aan te geven dat men verschillende familieleden reeds kent en van bepaalde feiten op de hoogte is.

"Dat hoort bij de geheimhouding als arts en dat gaat soms heel ver. Dat we vandaag een mevrouw krijgen met een familiair probleem en morgen komt haar broer en als die het niet van elkaar weten, dan weten wij het ook niet. Dan maken we dezelfde stamboom weer opnieuw. We geven dezelfde toestemmingsformulieren voor familieleden mee. En dan komt er wel eens reactie uit de familie. Mensen die zeggen: 'die toestemming heb ik al gegeven.' En dan zeg ik: 'Ja mevrouw, dat weet ik, maar de mensen weten niet van elkaar dat ze komen.' En dat komt vaak wel goed over bij de mensen. Ze weten dan zeker dat ze hun vertrouwelijke informatie hier vertrouwelijk kunnen neerleggen. Soms is het heel open, zo van: 'gisteren was mijn zus nog hier.' Dan mag ik ook zeggen: 'ja, dat is zo.' Verder zeg ik dan weer niks. Ik heb daar persoonlijk geen moeite mee."

Er kan echter een problematische situatie ontstaan wanneer de klinisch geneticus op voorhand kan aangeven hoe groot het risico is dat de adviesvrager heeft op de erfelijke aandoening waar de vraag zich op richt. Hij wil enerzijds de adviesvrager informeren over de hoogte van het risico op een bepaalde aandoening, terwijl hij dit alleen kan doen door gebruikmaking van kennis die verkregen is uit onderzoek bij familieleden van de adviesvrager.

\footnotetext{
"lk kan een casus vertellen van de oncogenetica, waar in een familie een mutatie in één van de borstkankergenen gevonden werd. Het was een zeer uitgebreide familie met veel aangedane familieleden. Er kwam toen een mevrouw binnen waarvan ik de zus al had gezien, maar dat wist zij niet. Zij had geen contact met haar zus. Ik had ook andere familieleden al gezien, dus in feite kende ik de hele stamboom al en wist ik ook wie in de familie aangedaan was en wie niet, tenminste voorzover er onderzoek werd verricht. Ik neem dan de stamboom gewoon opnieuw op en doe dat op grond van wat zij mij vertelt. Alleen dat stukje komt in het dossier te staan, dus niet de dingen die ik van de andere familieleden weet. Maar op een gegeven moment moet ik natuurlijk tegen haar cen uitspraak doen over de omvang van haar risico op de mutatie. Dat werd lastig omdat ik in deze situatie wist dat ze een risico had van vijftig procent omdat ik de uitslagen van haar zus kende, maar dat mocht ik dus niet doorgeven en ook niet gebruiken. Ik wou haar echter wel goed informeren, dus heb ik gezegd: 'alle gegevens bij elkaar overziend en ervan uitgaande wie in de familie wat heeft gehad, is het zeer waarschijnlijk dat u een risico van vijftig procent heeft.' Zo probeer je er dan een beetje omheen te worstelen."
} 


\section{Beschomiving}

Gegeven de verwantschap tussen familieleden is het logisch dat wanneer binnen een familie mogelijk sprake is van een erfelijke aandoening, verschillende familieleden zich tot een klinisch geneticus wenden. Ondanks het feit dat dit tot lastige situaties kan leiden, wordt het belang van het recht op geheimhouding van elke adviesvrager terecht gerespecteerd. Bovenstaande casus, waarin voor de klinisch geneticus het risico op de mutatie die tot borstkanker kan leiden, bekend was doordat de zus van de adviesvrager reeds onderzoek had laten verrichten, laat echter zien dat de geheimhoudingsplicht kan botsen met de plicht om de adviesvrager goed te informeren. In deze casus moet de adviesvrager nog beslissen of hij een erfelijkheidsonderzoek wil laten verrichten. Voor het maken van deze keuze zal de omvang van het risico op de mutatie die tot borstkanker kan leiden, van groot belang zijn. Wanneer de klinisch geneticus niet op de hoogte was geweest van het feit dat bij de zus van de adviesvrager de mutatie was aangetoond, was het risico op de mutatie op voorhand mogelijk lager geweest, omdat in dat geval niet bekend was dat de zus van de adviesvrager drager is van de mutatie die een hoog risico geeft op borstkanker. De vraag die hier van belang is, is of in genoemde casus de geheimhoudingsplicht is geschonden. Artikel 7:457 lid 1 BW, eerste volzin, luidt:

"Onverminderd het in artikel 448, lid 3, tweede volzin, bepaalde draagt de hulpverlener zorg, dat aan anderen dan de patiënt geen inlichtingen over de patiënt dan wel inzage in of afschrift van de bescheiden, bedoeld in artikel 454, worden verstrekt dan met toestemming van de patiënt."

Op grond van de geheimhoudingsplicht is het dus niet toegestaan om inlichtingen over de adviesvrager, dan wel inzage in of afschrift van zijn bescheiden te verstrekken zonder toestemming van de adviesvrager. In de situatie die hier aan de orde is, heeft de klinisch geneticus gebruik gemaakt van erfelijkheidsinformatie over de zus, teneinde de andere zus adequat te kunnen informeren. Het recht op geheimhouding is hier dus geschonden. De klinisch geneticus heeft niet aangegeven dat op grond van het feit dat bij de zus de mutatie is aangetoond, het risico voor de adviesvrager $50 \%$ is. Om dit feit te verhullen, heeft de geneticus niet duidelijk aangegeven hoe hij het risico van $50 \%$ heeft berekend. De vraag is echter of dit wel onder de informatieplicht valt. Juist doordat de klinisch geneticus niet op de rekensom ingaat is hij in staat om de adviesvrager precies aan te geven wat de omvang van zijn risico is en tevens de privacy van de andere zus zoveel mogelijk te beschermen. Enerzijds is hier de geheimhoudingsplicht geschonden, maar anderzijds kan niet van een klinisch geneticus worden verwacht dat hij zijn hoofd leegmaakt en daardoor de adviesvrager niet op adequate wijze informeert. 


\title{
10.4 Het conflict van plichten
}

In hoofdstuk 7 is het conflict van plichten aan de orde geweest. Indien een klinisch geneticus in een noodtoestand verkeert in de zin van een conflict van plichten, kan een doorbreking van de zwijgplicht juridisch gerechtvaardigd zijn. Een conflict van plichten kan aan de orde zijn wanneer een familielid ten gevolge van de geheimhoudingsplicht van de klinisch geneticus niet over een mogelijk risico op een erfelijke afwijking kan worden geïnformeerd. Het kan echter ook aan de orde zijn wanneer ten behoeve van de adviesvrager geen erfelijkheidsonderzoek kan worden verricht, omdat de vereiste medewerking van een familielid ontbreekt. Beide situaties worden in deze paragraaf besproken.

\section{Het informeren van een familielid zonder toestemming van de adviesvrager}

Ten eerste de situatie waarin ten gevolge van de geheimhoudingsplicht een familielid van een adviesvrager niet kan worden geinformeerd. Een klinisch geneticus formuleert het dilemma als volgt.

\begin{abstract}
"Het zijn dan twee rechten die elkaar tegenspreken. Aan de ene kant heeft de adviesvrager het recht dat zijn gegevens niet worden doorgegeven aan de familie en aan de andere kant heeft de rest van de familie ook het recht op genetisch onderzock wat ten voordele van hun gezondheid is. Zeker als het om een emstige aandoening gaat die behandelbaar is."
\end{abstract}

Het informeren van een familielid zonder toestemming van de adviesvrager komt zelden voor. Klinisch genetici zijn van mening dat een familielid van een adviesvrager niet benaderd kan worden zonder toestemming en geven aan dat zij zich in een conflict van plichten zeer terughoudend zullen opstellen. Er zijn genetici die zich geen situaties kunnen voorstellen waarin zij tegen de wens van de adviesvrager in een familielid zouden informeren. Genetici die zich wel situaties zouden kunnen voorstellen waarin zij een familielid informeren zonder toestemming van de adviesvrager, geven aan dit te overwegen wanneer de erfelijke aandoening die in het geding is behandelbaar is of wanneer de prognose te verbeteren is wanneer de aandoening door periodiek onderzoek in een vroeg stadium wordt vastgesteld. Door alle genetici wordt overigens benadrukt dat $z i j$, alvorens tot informeren over te gaan, uitvoerig intern zouden overleggen. De erfelijke kankers worden genoemd als voorbeeld voor een situatie waarin $\mathrm{zij}$ wellicht, zonder toestemming van de adviesvrager, familieleden van de adviesvrager zouden informeren.

"Ik ben een dokter en eerlijk gezegd vind ik het erger dat iemand nodeloos dood gaat aan schildklierkanker op jonge leeftijd dan dat de privacy van iemand met voeten getreden wordt. Ik vind het allebei vreselijk, maar ik weet wel wat ik erger vind. Daarom heb ik dit beroep ook gekozen."

\footnotetext{
"Als er nog wat aan te doen is, is het voor jou direct van belang om te weten of je drager bent of niet. Een ander belang is dat degene die jij voor je hebt recht heeft op privacy. In dit geval denk ik, en de meeste mensen met mij, dat het belang van een broer of een zus die drager kan zijn groter is dan het recht op privacy van degene die voor je zit. Als het
} 
dan uiteindelijk niet wil lukken via degene die voor je zit, ben je denk ik als arts gerechtigd om die privacy te schenden."

Een geneticus geeft aan dat zijns inziens niet alleen bij behandelbare aandoeningen een conflict van plichten kan ontstaan.

"Een conflict van plichten kan ook bij risico's op ernstige aandoeningen ontstaan. Duchenne is een goed voorbeeld. Mensen kumnen daar draagster van zijn en dat is natuurlijk toch een hele ernstige aandoening. Ik kan me ook voorstellen dat je in zo'n soort situatie informeert, wanneer er dus een risico is voor nageslacht. Dat doe je dus niet alleen bij behandelbare aandoeningen. Dat is niet het enige criterium. Er zijn ook andere dingen belangrijk voor mensen dan dat ze ziek zijn en daarvoor behandeld kunnen worden. De kans op een kind met een aangeboren aandoening is misschien wel geen gezondheidsrisico, maar wel een risico voor je welzijn."

Situaties waarin een klinisch geneticus zich daadwerkelijk in een conflict van plichten bevindt, zijn zeldzaam. De verklaring die hiervoor wordt gegeven is gelegen in het feit dat de adviesvrager in de meeste gevallen wel is te overtuigen van het belang van de informatie voor familieleden.

"Het uitgangspunt is dat je het niet buiten de mensen zelf om probeert te doen. Je probeert het de mensen zelf te laten doen. Ik heb nog nooit meegemaakt dat dat uiteindelijk niet lukte. Uiteindelijk, moet ik wel zeggen. Soms zijn daar máánden energie, tijd en moeite voor nodig. Maar met enig tact en geduld kom je er wel."

De reden dat adviesvragers wel te overtuigen zijn van het belang van erfelijkheidsinformatie voor hun familieleden wordt door een geneticus gezocht in het feit dat er een selectie is van adviesvragers die zich tot een klinisch geneticus wenden.

"Ik heb ook wel eens gedacht dat er misschien een selectie is van mensen. Als je een patroon van ziekten in de familie hebt dan blijkt dat pas als die familie met elkaar spreekt. Als je tien broers en zussen hebt die met de grootste trammelant uit elkaar zijn gegaan, dan kom je er natuurlijk nooit achter dat drie of vier broers dezelfde ziekte hebben. Ik denk dat de families die wij in kaart brengen misschien wel per definitie families zijn die van elkaar weten wie wat heeft en die bij elkaar komen."

Wanneer een klinisch geneticus zonder toestemming van de adviesvrager familieleden zou willen inlichten, loopt hij altijd tegen het praktische probleem aan dat hij geen gegevens heeft van de familieleden in kwestie. Hij weet hooguit de naam van de huisarts wanneer de familie in kwestie, of althans de meeste familieleden, dezelfde huisarts hebben als de adviesvrager. De genetici geven ook aan dat wanneer ze tegen de wil van de adviesvrager familieleden zouden informeren, ze dit via de huisarts zouden doen.

"Ik zou dan de huisarts, van de broer of zus die van niks weet, vertellen wat in de familie van zijn patiënt zit. Ik zou dan zeggen: 'er komt iets voor, wat voor haar van belang is bijvoorbeeld erfelijke borstkanker - en ze zou daar drager van kunnen zijn. Als ze wil kan ze zich daarop na laten kijken. Zou u dat een keer met haar willen doorspreken, zodat ze in ieder geval weet dat het speelt.' Dan schuif je de verantwoordelijkheid weer 
een beetje af. Ik denk dat het een voordeel is dat die huisarts die vrouw kent. Het is, dat heb ik wel eens meegemaakt, erg onprettig om mensen zo maar thuis te bellen. Vreemde dokter, academisch ziekenhuis, dat is bedreigend voor mensen. Dan geef ik de voorkeur aan de huisarts die de mensen kent en het op een rustig moment kan bespreken."

Bij de klinisch genetici die zich gedwongen zagen hun geheimhoudingsplicht te schenden, is het informeren van de familieleden voor wie de informatie van belang kon zijn, ook in samenwerking met de huisarts gebeurd.

"Ik heb ook wel eens meegemaakt dat we wisten dat een adviesvrager het niet verder wilde doorgeven. Toen heb ik, omdat het toevallig gelokaliseerd was in één dorp, de vijf huisartsen uit dat dorp bijeen geroepen en uitgelegd hoe de situatie was. Ik heb toen gezegd: ' $u$ kent uw' dorp van haver tot gort. $U$ weet precies welke volgende familieleden voor het onderzock in aanmerking komen. Ik wil $\mathrm{u}$ dit meedelen. Het is $\mathrm{uw}$ verantwoordelijkheid nu om, wanneer u de betrokkenen tegenkomt op uw spreekuur of wanneer $u$ anderszins een gelegenheid kunt vinden, te informeren naar wat er verder nog in de familic voorkomt. Dan kunt u van die gelegenheid gebruik maken om aan te kaarten dat het misschien verstandig is om advies te gaan vragen.' Zo omzeil je dus een onwillig familielid. Dat doe je alleen maar wanneer de medische belangen voor die betrokken familieleden heel groot zijn. Zo'n huisarts zal dan moeten balanceren. (...) Dat is lastig. Dan moet je intuittief als huisarts te werk gaan. Ik kan dat als klinisch specialist niet doen, want ik heb per definitie geen recht om rechtstreeks contact met die persoon op te nemen."

"Ik heb één keer, tegen alle wettelijke bepalingen in, de huisarts van iemand gebeld en gezegd: 'die man behoort tot die familie. Ik weet via via dat u zijn huisarts bent. Die meneer is een neef van mensen die hier zijn en hij heeft een verhoogde kans op darmkanker. Hij zou eigenlijk onderzocht moeten worden. Ik weet alleen uit stamboomonderzoek dat hij bestaat en hoe hij heet en dat u zijn huisarts bent. Zou $u$ eens met hem willen gaan praten?' Dat is eigenlijk linke soep. Ik weet niet of ik het weer zou doen. Toen dacht ik: hoe moet dat nou? De familie zei dat hij verhuisd was en dat niemand meer contact met hem had. Toen vond ik het voor mijzelf niet te verkopen om te zeggen: niemand heeft contact met hem, dus dan moet die man maar bloot staan aan het risico. Dat is natuurlijk heel gek, omdat hij gewoon tien kilometer verderop woonde en de familie dacht: dat is te ver met de bus, daar houden we geen contact mee. Het is toch vreemd dat je dan op dit gebied niks kunt doen. In principe en zeker wettelijk mag ik dan niks doen. Kan ik niks doen. Die man was daar heel blij mee. Dat is dan zo iemand die kerstkaartjes stuurt om mij te bedanken. Kerstkaartjes krijg je alleen van patiënten waarvan je zelf denkt: had ik dat niet anders moeten doen."

Een geneticus die terugkijkt geeft aan hoe ingrijpend het rechtstreeks benaderen van een familielid is.

"Het is best moeilijk, want je weet soms dat er grote belangen van afhangen. Ik vind toch niet dat dat kan. Ik ben jong en idealistisch begonnen en ik heb wel eens gedacht: natuurlijk moet dat. Maar daar heb ik toch een keer zo mijn neus mee gestoten. Dat je bijvoorbeeld met goede bedoelingen de familie Van Dam opbelt en mevrouw Van Dam aan de lijn krijgt en dan blijkt het mevrouw Van Dam nummer twee te zijn, terwijl ik dacht dat het om de eerste ging. Je hoeft dat maar een paar keer te doen en dan bedenk je dat het eigenlijk gewoon niet kan. Dat grijpt zo intensief in in mensenlevens. Je moet het 
jezelf proberen voor te stellen. Je wordt op een goede dag door één of andere dokter van een jou niet bekend instituut gebeld met de mededeling: 'wij mocten toch eens met elkaar praten.' Dat kan niet, denk ik. Daar ligt voor mij nu de grens. Ik denk dat we wel wat gevoeliger worden voor formele argumenten en dat we vroeger veel meer geneigd waren om, doenerig als wij zijn, goed te doen."

Een manier ten slotte om te voorkomen dat een conflict van plichten ontstaat is de toegang tot erfelijkheidsonderzoek afhankelijk maken van de bereidheid om familieleden te informeren. Klinisch genetici zien niets in die mogelijkheid.

"Daar ben ik het absoluut niet mee eens. Ik denk dat je dan alle rechten van iemand op zorg aan het betreden bent."

\section{Beschouwing}

Het informeren van familieleden van de adviesvrager, tegen de wil van de adviesvrager, over een mogelijk hoog risico op een erfelijke aandoening, komt zelden voor. De verklaring hiervoor wordt gezocht in de redelijkheid van adviesvragers en het tact en geduld van de klinisch geneticus. Een conflict van plichten ontstaat volgens klinisch genetici wanneer een adviesvrager zijn familieleden niet wil informeren en het een aandoening betreft die te behandelen is of waarvan de prognose bij vroegtijdige opsporing te verbeteren is. Dit voldoet aan het criterium dat het niet informeren van het betrokken familielid een hoog risico op ernstige schade met zich meebrengt, welke schade kan en zal worden voorkomen of beperkt. Het is afhankelijk van de hoogte van het risico of ook het risico op een kind met een aangeboren aandoening aan dit criterium voldoet.

Het informeren van familieleden van de adviesvrager zonder zijn toestemming levert praktische problemen op. Op grond van de stamboom kan de klinisch geneticus bepalen welke familieleden een hoog risico lopen op een erfelijke aandoening. Hij beschikt echter niet over hun adressen of telefoonnummers. Klinisch genetici geven aan dat ze in zo'n situatie de huisarts van de familie zouden benaderen, ervan uitgaande dat die wel beschikt over adressen en telefoonnummers. Bovendien kent de huisarts de familie en kan hij een geschikt moment afwachten om hen te informeren, aldus klinisch genetici. Dit zou minder bedreigend zijn dan een vreemde dokter van een academisch ziekenhuis.

$\mathrm{Bij}$ het informeren via de huisarts zijn wel enkele kanttekeningen te plaatsen. Ten eerste wordt er vanuit gegaan dat de huisarts zijn patiënten goed kent. Er zullen echter ook patiënten zijn die zelden een gezondheidsprobleem hebben, waardoor ze geen of nauwelijks contact hebben met hun huisarts. Ten tweede levert het informeren van de huisarts een schending van de geheimhoudingsplicht op als hij niet rechtstreeks betrokken is bij de uitvoering van de behandelingsovereenkomst. In hoofdstuk 7 is opgemerkt dat uit de eis dat bij schending van de geheimhoudingsplicht op grond van een conflict van plichten niet meer informatie wordt verstrekt dan noodzakelijk is, tevens de eis volgt dat de informatie niet aan meer personen wordt verstrekt dan noodzakelijk is. Indien mogelijk (wanneer de klinisch geneticus beschikt over voldoende persoonsgegevens) dient het betrokken 
familielid rechtstreeks geinformeerd te worden. Het betreft vaak gevoelige informatie, die diep in kan grijpen in het leven van het familielid. Indien de klinisch geneticus niet beschikt over voldoende persoonsgegevens en hij toch familieleden wil informeren, zal hij zich voor die persoonsgegevens wel tot de huisarts van zijn adviesvrager moeten richten wanneer deze ook de huisarts van andere familieleden is. Dit impliceert echter nog niet dat dan ook de huisarts de familieleden moet informeren. Het is wel zo dat de huisarts dan inmiddels op de hoogte is van de situatie. Wanneer hij de desbetreffende familieleden kent, is hij in een dergelijke situatie wellicht de aangewezen persoon on de informatie over te brengen. De huisarts en de geneticus zullen hier samen de route moeten kiezen die hen het minst schadelijk voor de betreffende familieleden lijkt. Zoals klinisch genetici al aangaven, is deze manier van informeren waarschijnlijk minder bedreigend dan het informeren door de klinisch geneticus.

In beide genoemde casus waarin familieleden zonder toestemming van de adviesvrager zijn geïnformeerd, is dit via de huisarts gebeurd. Vooral de eerste casus illustreert dat de huisarts meer mogelijkheden heeft om familieleden op een informele wijze te informeren over een mogelijk risico op een erfelijke afwijking door te vragen of er nog ziektes voorkomen in de familie. Hij kan daardoor wellicht beter inschatten of een familielid wel geïnformeerd wil worden. Als de tijd het toelaat kan de huisarts wachten tot een familielid op het spreekuur verschijnt.

\section{Het informeren van de adviesvrager zonder toestemming van een familielid}

Ten tweede de situatie waarin ten behoeve van de adviesvrager geen erfelijkheidsonderzoek kan worden verricht, omdat de vereiste medewerking van een familielid ontbreekt. Bij veel erfelijke aandoeningen is het noodzakelijk om de specifieke mutatie te kennen die in een familie een erfelijke aandoening veroorzaakt, alvorens bij de adviesvrager een erfelijkheidsonderzoek kan worden verricht. Niet elke klinisch geneticus beschouwt het gebruik maken van de wetenschap welke specifieke mutatie het in een familie betreft zonder toestemming van de indexpersoon bij wie de mutatie is aangetroffen als een schending van de geheimhoudingsplicht. Wel worden dit soort situaties als problematisch ervaren.

"Het ging om een aandoening waarbij je wel wat te winnen hebt door te weten dat je drager kunt zijn. In die familie hebben we het lang geprobeerd met de ouderwetse methoden van screenend onderzoek aan te bieden. Op een goed moment wordt dan na jaren alsnog bij de eerste indexpatiënt de mutatie in het DNA gevonden. Dat betekent dat je met een simpel bloedtestje nu voor de rest van de familie een ja of een nee kunt krijgen. Moet je dan van die eerste persoon toestemming hebben om diens gegevens te gebruiken voor broers en zusters? Of mag je met cen stalen gezicht bloed afnemen van de broers en zusters en dat opsturen naar een laboratorium voor een uitslag? (...) Je hebt de specifieke mutatie van één aangeduid familielid nodig om bij de rest te weten waamaar je kijken moet. Dat vind ik een lastig punt; of je dan werkelijk van die eerste persoon die toestemming formeel moet hebben en hoever je daarmee moet gaan. De indexpatiënt geeft nu aan dat hij even niks met ons te maken wil hebben omdat hij nu die aandoening heeft en dat al vervelend genoeg vindt. (...) $\mathrm{Hij}$ wil dus eigenlijk niet nog eens cen update-gesprekje over die na jaren nagekomen uitslag. Zo gaat het vaak met dingen die in ontwikkeling zijn. Maar als hij dat niet wil, moet je hem dan nog wel laten 
rekenen voor toestemming? Of kın je dan zeggen: ik heb alles gedaan wat ik hieraan doen kon en ik ga gewoon die familie in, want die familieleden hebben allemaal belang bij deze nieuwe kennis. We hebben daar geen standaard beleid in. We proberen toch in elke situatie maar weer opnieuw te bedenken wat nu het meest aangewezen is. Ik heb in dit geval eerst an meneer een briefje geschreven met een soort ja-tenzij-voorstel, in de trant van: als ik niet voor een bepaalde datum van u hoor dat $u$ er bezwaar tegen heeft, dan ga ik toch weer contact met uw familieleden zoeken. Dat zijn wel allemaal mensen met wie wij eerder ook een formeel contact hebben gehad, dus dat maakt het dan weer makkelijker, denk ik. Aan de ene kant wordt het makkelijker, aan de andere kant betekent het ook dat je eigenlijk meer verantwoordelijkheid naar die mensen voelt. Je hebt er een arts-patiënt relatie mee gehad jaren geleden."

In de onderstaande casus is het familielid er duidelijk in dat ze geen gegevens wil verstrekken ten behoeve van erfelijkheidsonderzoek bij de adviesvrager.

"Het betrof een familie waarin een jongetje de spierziekte van Duchenne had. Dit is een geslachtsgebonden overervende aandoening. Bij het jongetje was de verantwoordelijke deletic in het Duchenne-gen door middel van DNA-onderzoek opgespoord. Zijn moeder wenste niet na te laten kijken of zij al dan niet draagster was. Vervolgens kwam een halfzus van deze moeder, die wel wilde weten of zij draagster was van deze aandoening. Aangezien de beide halfzussen niet on speaking terms waren, wilde de moeder van de patiënt de gegevens niet vrijgeven. Daarnaast zou het vinden van draagsterschap bij haar halfzus meteen duidelijk maken dat zij zelf ook draagster zou zijn. Aangezien ik zowel de patiënt en zijn ouders als deze halfzus gecounseld had in het verleden, was ik op de hoogte van het feit dat er een deletie gevonden was bij de patiënt. DNA-onderzoek bij onze nieuwe adviesvraagster, de halfzus dus, zou met zekerheid aan kunnen tonen of $z$ ij al dan niet draagster was van deze deletie. Ik heb enige malen uitgebreid telefonisch contact gehad met de ouders van de patiënt. $\mathrm{Zij}$ bleven bij hun weigering. Na overleg besloten we toch het bloed van onze nieuwe adviesvraagster te laten onderzoeken met de specifieke vraag naar de bekende deletie, met als motivering dat in dit geval het recht op weten prevaleerde boven het recht op niet weten. We hebben naar de patiënt toe gedaan alsof dat uiteindelijk niet nodig bleek te zijn, dus de patiënt, onze adviesvrager, weet niet dat we toch de gegevens van haar zus hebben gebruikt en die zus weet ook niet dat we de gegevens hebben gebruikt. Het is dus in feite iets waar je volgens de officiële regels niet legaal bezig bent, maar waarbij het belang voor de halfzus voor ons zo duidelijk zwaarder woog. Je brengt geen schade toe omdat beide zussen uiteindelijk toch niet wisten dat het gebruikt is. In de periode dat er gewacht werd op een uitslag, kwam er tenslotte toch bericht van de oorspronkelijke adviesvragers dat wij de gegevens mochten gebruiken."

\section{Beschouzving}

Als voor een onderzoek ten behoeve van een adviesvrager de vereiste medewerking van een familielid ontbreekt, is in bepaalde gevallen wegens de geheimhoudingsplicht geen erfelijkheidsonderzoek mogelijk. Dit is alleen anders wanneer de klinisch geneticus zich op een conflict van plichten zou beroepen en er daarbij voldaan is aan de in hoofdstuk 7 besproken criteria. Klinisch genetici zien het gebruik maken van de kennis omtrent de aard en/of de locatie van de mutatie die bij de 'indexpatiënt' een bepaalde erfelijke aandoening veroorzaakt of kan veroorzaken, niet altijd als een schending van het recht op geheimhouding van de indexpatiënt. In 
de eerder geciteerde casus geeft de geneticus aan dat hij het een lastig punt vindt of hij werkelijk van de indexpatiënt formeel toestemming moet hebben. Kennelijk is dit voor hem niet vanzelfsprekend. In plaats van toestemming te vragen voor het gebruik van de kennis omtrent de specifieke mutatie, schrijft hij de indexpatiënt een brief, waarin hij aangeeft dat de indexpatiënt zelf moet aangeven of hij bezwaar heeft tegen het feit dat van zijn gegevens gebruik wordt gemaakt.

Artikel 7:457 lid 1 BW bepaalt dat aan anderen dan de patiënt geen inlichtingen over de patiënt worden verstrekt. Het inlichten van de familieleden van de oorspronkelijke adviesvrager, de indexpatiënt, betekent dat ze op de hoogte worden gesteld van het feit dat bij de indexpatiënt de mutatie is gevonden die de familiaire afwijking veroorzaakt. Hiervoor is toestemming nodig van de indexpatiënt, want het betreffen inlichtingen over hem. Deze informatie valt wel dus wel onder de geheimhoudingsplicht. Ervan uitgaan dat de indexpatiënt er geen bezwaar tegen heeft dat inlichtingen worden verstrekt, tenzij hij bezwaar maakt, is niet gelijk aan het vragen van toestemming voor het verstrekken van inlichtingen. De klinisch geneticus had in de besproken casus beter een brief kunnen sturen waarin hij toestemming vroeg voor het verstrekken van inlichtingen.

In de casus waar onderzoek gedaan is naar dragerschap van de deletie die bij mannelijk nageslacht van de adviesvrager tot de ziekte van Duchenne kan leiden, is er een erfelijkheidsonderzoek verricht zonder dat de adviesvrager wist dat er voor dit onderzoek gegevens van haar zus zijn gebruikt. Aan de adviesvrager zijn dus formeel geen inlichtingen over haar zus verstrekt. Aan de klinisch geneticus zijn evenmin inlichtingen omtrent de zus verstrekt omdat de klinisch geneticus de erfelijkheidsadvisering bij de zus zelf heeft verricht. Het lijkt echter niet juist om wel een schending van de geheimhoudingsplicht aan te nemen wanneer een andere hulpverlener de klinisch geneticus tegen de wil van de zus had geïnformeerd en niet van schending te spreken wanneer er feitelijk geen sprake is van informeren omdat beide zussen zich tot dezelfde klinisch geneticus hebben gewend. Door dit feit is de klinisch geneticus reeds op de hoogte van de specifieke deletie. Formeel kan men wel over het verstrekken van inlichtingen zonder toestemming van de patiënt spreken: de klinisch geneticus heeft aan zichzelf inlichtingen verstrekt door de deletie op te zoeken in het dossier van de ene zus en daarvan ten behoeve van de andere zus gebruik te maken. Het is duidelijk dat het doel van de geheimhoudingsplicht, te weten het waarborgen dat de patiënt zich zonder vrees dat hij zichzelf daardoor zou schaden zich tot een hulpverlener kan wenden, niet bereikt wordt wanneer tegen de wil van een adviesvrager zijn gegevens worden gebruikt om onderzoek te doen bij een familielid die zich ook als adviesvrager tot een klinisch geneticus wendt. Bovendien neemt een klinisch geneticus niet de zorg van een goed hulpverlener in acht, en handelt hij niet in overeenstemming met de hem rustende verantwoordelijkheid, die voorvloeit uit de professionele standaard, als hij tegen de wil van een adviesvrager in, gebruik makkt van zijn gegevens, tenzij sprake is van overmacht.

Was er in deze casus sprake van overmacht, in de zin van een conflict van plichten? In hoofdstuk 7 zijn deze criteria aan de orde geweest. 
- Ten eerste moeten redelijke inspanningen zijn verricht om toestemming te krijgen van de adviesvrager. Hieraan lijkt voldaan te zijn, gezien het uitgebreide telefonische contact dat er enige malen is geweest.

- Ten tweede moet de klinisch geneticus in gewetensnood verkeren.

- Ten derde moet er geen andere weg zijn om het probleem op te lossen dan via doorbreking van het geheim. In deze casus is het alleen mogelijk om met kennis omtrent de locatie van de deletie onderzoek te doen bij de adviesvrager.

- Ten vierde mag er niet meer informatie worden verstrekt dan noodzakelijk.

- Ten vijfde de eis dat de dreigende schade op korte termijn te verwachten is of op lange termijn met dien verstande dat het medisch gezien zinvol is om op korte termijn preventieve maatregelen te nemen. De schade voor de adviesvrager bestaat eruit dat zij het risico loopt op nageslacht met de ziekte van Duchenne. Alleen wanneer zij binnen afzienbare tijd zwanger zou willen raken, lijkt aan deze eis voldaan te zijn.

- Ten zesde de eis dat het familielid op de hoogte wordt gesteld van het feit dat de klinisch geneticus de informatie aan de adviesvrager doorgeeft. Aan deze eis is niet voldaan. In hoofdstuk 7 is reeds gesteld dat het goed hulpverlenerschap met zich meebrengt dat de adviesvrager op de hoogte is van het feit dat zijn gegevens worden gebruikt ten behoeve van een familielid. Het is ten slotte zijn recht op geheimhouding dat wordt geschonden.

- De zevende eis die kan worden gesteld is dat het niet informeren van de adviesvrager ertoe leidt dat de resterende mogelijkheden voor hem om het risico op een erfelijke aandoening te reduceren in een onredelijke verhouding staan tot de schending van de privacy van het familielid door voor erfelijkheidsonderzoek gebruik te maken van de specifieke mutatie die bij het familielid is aangetoond. De mogelijkheden in deze casus om het risico op een zoon met de ziekte van Duchenne te reduceren tot nul bestaan enerzijds uit niet zwanger worden en anderzijds uit het aborteren van aangedane vruchten. Zijn deze mogelijkheden buitenproportioneel groot in vergelijking met de schending van de privacy van de zus die niet wil weten of zij zelf gendraagster is? Het is niet bekend of zij draagster is, aangezien de deletie ook spontaan kan zijn ontstaan bij haar zoontje. Het aantonen van de deletie bij haar zus, betekent automatisch dat zij gendraagster is. Op deze plaats is het onmogelijk om dieper op deze vraag in te gaan en deze te beantwoorden, aangezien te weinig bekend is over de motieven en argumenten van beide zussen om enerzijds wel en anderzijds niet te willen weten. Deze casus toont wel de complexiteit van zowel de genetica als van de juridische vraagstukken die kunnen ontstaan wanneer erfelijkheidsinformatie voor verschillende familieleden van belang kan zijn.

\subsection{De geheimhoudingsplicht na de dood}

In de situaties waarin het familielid van wie de klinisch geneticus gegevens wil opvragen ten behoeve van de adviesvrager, overleden is, is het in de praktijk gebruikelijk dat aan de partner of de kinderen van het overleden familielid 
toestemming wordt gevraagd voor het opvragen van de gegevens van het overleden familielid. Het komt ook voor dat een klinisch geneticus de gegevens van zijn overleden adviesvrager wil gebruiken ten behoeve van onderzoek bij een familielid die zich ook als adviesvrager aanmeldt.

\begin{abstract}
"Er werd onderzoek gestart bij een patiënte naar een kankerbeeld waarbij de meest verschillende vormen van kanker kunnen ontstaan. Pas jaren later kwam de uitslag en kon dus de erfelijke aanleg worden aangetoond. Inmiddels was die patiënte al overleden en degene voor wie de uitslag belangrijk zou zijn, de kinderen, konden we niet bereiken. Vervolgens kwam toevallig een andere tak van de familic binnen; een dochter van een mevrouw die ook tengevolge van kanker was overleden. Zij had ongeveer dezelfde vraag omdat er ook zoveel kanker in de familie voorkwam. Mag je dan de gegevens van deze eerste mevrouw, die inmiddels overleden was, gebruiken voor voorlichting en onderzoek bij degene die uiteindelijk voor counseling is binnengekomen? $\mathrm{Er}$ is toen heel veel moeite gedaan om met iemand contact op te nemen die het recht heeft om de gegevens van die mevrouw te mogen verstrekken of te mogen gebruiken. Die waren er gewoon niet meer. Ik heb hen met de grootste moeite niet kunnen bereiken. Toen hebben we de gegevens in overleg met de huisartsen van beide betrokken personen gebruikt. We hebben de gegevens wel gebruikt omdat we vonden dat het belangrijke medische informatie is die je niet achter moet houden."
\end{abstract}

In onderstaande casus is het inlichten van familieleden tegen de wil van de overleden patiënt aan de orde.

"Bij een overleden man vonden ze bij de obductie allerlei tumoren die bij een erfelijk kankerbeeld zouden kunnen passen. Deze meneer, een alcoholist met een vergrote lever, heeft zijn vriendin op zijn sterfbed laten zweren dat alles wat er medisch uit het nader onderzoek kwam geheim zou blijven voor zijn familie. Hij had de pest aan zijn familie. Na zijn dood werd ik benaderd door de internist die aangaf dat het een erfelijke kankerbeeld zou kunnen zijn. Dat kunnen we nakijken. Als dat zo is, is dat van groot belang voor familieleden. Het is nog niet bewezen, maar als het dat wel is, is het de vraag hoe we dat verder moeten aanpakken. Ik heb dus contact opgenomen met de huisarts van die overleden meneer en gezegd wat ons probleem is. Het kan zijn dat ik straks een uitslag heb, die potentiële consequenties heeft voor de familieleden. Hoe kunnen we die dan benaderen? Kent $u$ die familieleden? Daar heeft hij over nagedacht. Ons plan zou er heel goed op neer kunnen komen dat we inderdaad precies dat gaan doen wat die meneer niet goed vond. Wat het misschien makkelijker maakt, is dat die meneer er gewoon niet meer is. Ik weet niet of zo'n soort erfenis juridisch ook bestaat. Dat je kunt zeggen: 'ik wil niet dat na mijn dood mijn familieleden er wat aan hebben.' Het is geen geld dat ze erven, maar het is kennis die niet gegenereerd is door die meneer, maar door andere mensen. Hoe dan ook, wij gaan dit serieus afhandelen. Als het maar even kan zullen we proberen die familieleden at risk te benaderen. Dat had die meneer niet voorzien toen hij op zijn sterfbed zei: 'mijn familie gaat het geen bal aan wat er met mij aan de hand was.' Misschien dat als je met die vriendin zou praten, ze zou zeggen dat hij dat natuurlijk niet bedoelde. Dat het uiteraard geen probleem is. Dat ze zegt: 'ik ken ze allemaal en ik wil ze zelf wel opbellen.' Je maakt je misschien zorgen om niks, maar het gaat om het principe. Iemand wilde niet dat de rest van zijn familie wist hoe het met hem zat. Terwijl je dan iets vindt, waardoor je toch familieleden gaat inlichten. Je hoeft niet te zeggen dat hij een alcoholist was, maar wel dat hij een aandoening had die voor zijn familieleden van belang is." 
Uit een onderzoek van de KNMG onder haar leden blijkt dat veel artsen in een dergelijke situatie waarschijnlijk op dezelfde manier zouden handelen. Op de vraag of een arts in de situatie waarin van een overleden patiënt lichaamsmateriaal bewaard is gebleven, dat materiaal in het geval van een ernstige erfelijke ziekte aan de nabestaanden mag verstrekken ten behoeve van een erfelijkheidsonderzoek met het oog op mogelijke interventie bij die nabestaanden, antwoordde $80 \%$ van de 480 respondenten namelijk bevestigend. ${ }^{2}$

\section{Beschouwing}

Wanneer gegevens worden opgevraagd van een overleden familielid van de adviesvrager, wordt hiervoor toestemming gevraagd aan de partner of de kinderen van het overleden familielid. In hoofdstuk 7 is aangegeven dat de geheimhoudingsplicht van een hulpverlener ook na het overlijden van zijn patiënt geldt. Daarom is de behandelend arts bij wie ten behoeve van de adviesvrager gegevens worden opgevraagd in beginsel op grond van zijn geheimhoudingsplicht niet gerechtigd deze gegevens te verstrekken. Ook de nabestaanden kunnen niet beschikken over deze gegevens. Wanneer voor de adviesvrager een dringend belang in het geding is, kan met de juridische fictie worden gewerkt dat het overleden familielid in het belang van de adviesvrager toestemming zou hebben willen geven, tenzij anders moet worden aangenomen. Daarbij moet overwogen worden of de gegevens erg privacygevoelig zijn en of er conflicten tussen de betreffende familieleden bestonden.

Omdat nabestaanden niet kunnen beschikken over de gegevens van de overledene, zijn zij niet gerechtigd om toestemming te geven voor het opvragen van gegevens bij de hulpverlener die beschikt over gegevens van de overleden persoon. De hulpverlener zal zelf de afweging moeten maken of zijn overleden patiënt toestemming zou hebben willen geven voor het opvragen van zijn gegevens ten behoeve van de adviesvrager. In de hierboven beschreven casus waarin er veel moeite is gedaan om contact op te nemen met nabestaanden van de mevrouw waarbij een erfelijke aanleg voor een bepaald kankerbeeld was aangetoond, waren deze inspanningen juridisch gezien overbodig. De klinisch geneticus had zelf de afweging moeten maken of deze mevrouw er bezwaar tegen zou hebben gehad wanneer de gegevens waaruit de erfelijke aanleg blijkt, waren gebruikt om bij het familielid van deze overleden mevrouw, die zich inmiddels als adviesvrager tot de klinisch geneticus heeft gewend, onderzoek te doen naar dezelfde erfelijke aanleg. Overleg met de huisartsen van beide vrouwen is in deze casus niet aangewezen. De geheimhoudingsplicht van de klinisch geneticus geldt ook naar deze huisartsen. Zij zijn niet bij de behandelingsovereenkomst betrokken.

Indien moet worden aangenomen dat de overledene geen toestemming gegeven zou hebben voor het verstrekken van zijn gegevens, kan de klinisch geneticus alleen wanneer hij zich in een conflict van plichten bevindt, gerechtigd zijn gegevens van de overledene te gebruiken. Van belang hierbij zijn de redenen die hij had om aan te 
geven dat hij niet wilde dat na zijn overlijden zijn gegevens zouden worden verstrekt. In de casus waarin na obductie bleek dat de overleden man mogelijk aan kankerbeeld leed dat erfelijk is, gaf de man duidelijk aan dat zijn gegevens geheim moesten blijven voor zijn familieleden. De vraag is echter of hij deze mening ook zou zijn toegedaan wanneer hij wist dat het belang bij de informatie over de erfelijke kanker voor familieleden erg groot is. Indien de vriendin van de overleden man aangeeft dat de man geheim wilde houden dat hij alcoholist was, zou men kunnen werken met de fictie dat de overleden man, gezien het grote belang bij de informatie, toestemming zou hebben gegeven om deze informatie te verstrekken. Indien moet worden aangenomen dat dit niet zo is, kunnen familieleden alleen geïnformeerd worden op grond van een conflict van plichten. ${ }^{3}$ In deze casus is de klinisch geneticus overigens formeel niet de hulpverlener die zich in een conflict van plichten zou bevinden. Hij heeft geen behandelingsovereenkomst met de overleden man. Via de internist is hij nu wel betrokken bij de uitvoering van de behandelingsovereenkomst.

\subsection{Slotbeschouwing}

In deze slotbeschouwing zullen de volgende vragen worden beantwoord:

- Zijn klinisch genetici op de hoogte van het feit dat de adviesvrager recht heeft op geheimhouding van zijn gegevens?

- Delen klinisch genetici de uitgangspunten van de juridische invulling?

- Wordt de geheimhoudingsplicht toegepast conform de juridische invulling die daaraan is gegeven?

- Wat zijn de knelpunten en de dilemma's en hoe zijn deze eventueel op te lossen?

De klinisch geneticus weet dat hij aan anderen geen inlichtingen over de adviesvrager mag verstrekken, tenzij de adviesvrager hiervoor toestemming geeft. Het is klinisch genetici echter niet duidelijk of dit ook geldt wanneer voor een onderzoek ten behoeve van een adviesvrager gegevens van een familielid nodig zijn omtrent de aard en/of de locatie van een mutatie en de klinisch geneticus zelf reeds over deze gegevens beschikt omdat het familielid in het verleden bij dezelfde klinisch geneticus een erfelijkheidsonderzoek heeft laten verrichten. Er bestaat tevens onduidelijkheid omtrent de geheimhoudingsplicht wanneer een persoon overleden is. Soms wordt er ten onrechte vanuit gegaan dat voor het opvragen van gegevens van een overleden persoon toestemming moet worden gevraagd van een familielid. Klinisch genetici zijn dus niet steeds bekend met de gehele omvang van de geheimhoudingsplicht.

De vraag of klinisch genetici de uitgangspunten delen van de juridische invulling van de geheimhoudingsplicht, kan bevestigend worden beantwoord. Het doel van de geheimhoudingsplicht is tweeledig: enerzijds het ervoor zorgen dat de patiënt zich zonder vrees dat hij zichzelf daardoor zou schaden in verband met het moeten prijsgeven van gevoelige gegevens, tot een hulpverlener kan wenden en anderzijds

Zie hoofdstuk 7 voor de criteria waaraan bij een conflict van plichten voldaan moet zijn. 
om de persoonlijke levenssfeer van de adviesvrager te beschermen. Deze uitgangspunten worden onderschreven. Om die reden worden familieleden niet zonder toestemming van de adviesvrager geinformeerd tenzij er in een conflict van plichten een hoger belang is. Bovendien wordt, gezien het belang dat aan de geheimhoudingsplicht wordt gehecht, het niet als een knelpunt ervaren dat men soms ten opzichte van de adviesvrager moet veinzen de familie en de familiaire aandoening niet te kennen.

De laatste twee vragen luidden of de geheimhoudingsplicht wordt toegepast conform de juridische invulling die hieraan gegeven is en wat de knelpunten waren. Gezien het feit dat hiervoor werd geconcludeerd dat klinisch genetici niet altijd bekend zijn met de gehele omvang van de geheimhoudingsplicht, kan deze vraag niet geheel bevestigend worden beantwoord. Uit de voorgaande paragrafen kwamen de volgende knelpunten naar voren.

Het uitgangspunt dat de adviesvrager zelf de familieleden moet informeren wordt algemeen onderschreven. Klinisch genetici geven aan dat adviesvragers meestal wel te overtuigen zijn van het belang dat familieleden kunnen hebben bij informatie over een mogelijk risico op een erfelijke aandoening. Er ontstaat echter een spanning tussen enerzijds het belang van familieleden bij die informatie en anderzijds de geheimhoudingsplicht van de klinisch geneticus wanneer de adviesvrager in eerste instantie zijn familieleden niet wil inlichten of wanneer hij zegt dit te zullen doen, maar er twijfel ontstaat bij de klinisch geneticus of dit daadwerkelijk is gebeurd. Om het recht op geheimhouding van de adviesvrager niet te schenden, wordt soms veel moeite gedaan om de adviesvrager ertoe over te halen zijn familieleden wel in te lichten. Dit gebeurt met name indien familieleden een groot risico lopen op een erfelijke aandoening waarvoor hen preventieve opties ter beschikking staan.

De adviesvrager wordt bij het informeren van zijn familieleden soms, al dan niet op zijn verzoek, door de klinisch geneticus geholpen door middel van een familiebrief. Bij het ongevraagd informeren van een familielid moet altijd het mogelijke belang bij informatie worden afgewogen tegen het belang dat het familielid kan hebben bij niet weten. Genetici geven aan dat het een inbreuk op de privacy is als men ongevraagd wordt geïformeerd over erfelijkheidsrisico's. Deze inbreuk maakt dat de inhoud van een familiebrief summier dient te zijn. De vraag echter of een familiebrief niet op zich al het mogelijke belang bij niet weten schendt alsmede welke informatie in een brief zou mogen staan, blijkt in de praktijk een punt te zijn waarover de meningen uiteen lopen.

Het op grond van de geheimhoudingsplicht veinzen dat men de familie en de familiaire aandoening niet kent, kan lastig zijn voor de klinisch geneticus, maar wordt niet als een knelpunt ervaren. Dit wordt anders wanneer de geheimhoudingsplicht botst met de plicht en de drang van de klinisch geneticus om een adviesvrager op adequate manier te informeren. In een dergelijke situatie probeert men enerzijds de geheimhoudingsplicht niet te schenden door niet op de situatie van een familielid in te gaan en anderzijds door een zorgvuldige woordkeuze de adviesvrager toch adequat te informeren. 
Het conflict van plichten is de juridische benaming voor het knelpunt dat ontstaat wanneer de geheimhoudingsplicht botst met de plicht die klinisch genetici voelen om gezondheidsschade bij een familielid te voorkomen. De redenen die genetici aangeven om een familielid zonder toestemming van de adviesvrager te informeren lijken overeen te komen met het criterium dat het niet informeren van het betrokken familielid een hoog risico op ernstige schade met zich meebrengt, welke schade kan en zal worden voorkomen of beperkt. Klinisch genetici die zich in een conflict van plichten bevonden geven aan hoe ingrijpend het voor familieleden kan zijn om hen zonder toestemming van de adviesvrager te benaderen. Ze zijn van mening dat informeren via de huisarts in principe minder ingrijpend is omdat hij de familieleden kent. Bovendien doet zich het praktische probleem voor dat de klinisch geneticus geen adresgegevens heeft van familieleden. De eis luidt dat bij een conflict van plichten de informatie niet aan meer personen wordt verstrekt dan noodzakelijk is. De praktijk laat echter zien dat het informeren van andere personen soms om praktische redenen noodzakelijk is.

Ook in de situatie waarin er ten behoeve van de adviesvrager geen erfelijkheidsonderzoek kan worden verricht omdat de vereiste medewerking van een familielid ontbreekt, kan sprake zijn van een conflict van plichten. Er zijn immers twee conflicterende belangen, te weten het belang van de geheimhoudingsplicht en het belang van de adviesvrager om een erfelijkheidsonderzoek te laten verrichten. In paragraaf 10.5 is aangegeven dat niet alle genetici van mening zijn dat de geheimhoudingsplicht wordt geschonden wanneer zonder toestemming van het familielid gebruik wordt gemaakt van informatie omtrent de aard en/of de locatie van een mutatie. Op dit punt lopen recht en praktijk enigszins uiteen.

Ten slotte de geheimhoudingsplicht na de dood. Onder de meeste klinisch genetici leeft de overtuiging dat nabestaanden toestemming moeten geven voor het opvragen van de gegevens van de overledene. Om die reden wordt voor het opvragen van gegevens van een overledene veelal toestemming gevraagd aan diens nabestaanden. Hierbij doen zich situaties voor die klinisch genetici als een knelpunt ervaren, terwijl dit knelpunt er vanuit een juridisch perspectief niet is. In de casus waarin veel moeite is gedaan om de familie van de overleden adviesvrager toestemming te vragen om de gegevens van de overleden adviesvrager te gebruiken, terwijl dit niet lukte, ging men er ten onrechte vanuit dat de naaste familie van de adviesvrager na zijn dood over zijn gegevens beschikt.

De casus waarin de overleden man mogelijk had geleden aan een erfelijk kankerbeeld toont dat ook na de dood een conflict van plichten kan ontstaan. Bij leven had de man kenbaar gemaakt dat zijn gegevens geheim gehouden moesten worden. Het belang van familieleden om geïnformeerd te worden woog volgens de klinisch geneticus echter zwaarder dan de geheimhoudingsplicht. 


\section{CONCLUSIES EN AANBEVELINGEN}

\subsection{Inleiding}

In de hooldstukken 3 tot en met 7 is de vraag aan de orde geweest wat het juridisch kader is inzake informatie, toestemming en geheimhouding bij erfelijkheidsadvisering in de klinisch genetische centra. De vraag hoe hiermee in de praktijk van de erfelijkheidsadvisering in de klinisch genetische centra wordt omgegaan is in de hoofdstukken 8,9 en 10 behandeld. In dit laatste hoofdstuk wordt geconcludeerd wat het gewenste juridisch kader is voor informatie, toestemming en geheimhouding bij erfelijkheidsadvisering in de klinisch genetische centra. Daarbij wordt nagegaan of de uitwerking daarvan in de erfelijkheidsrichtlijnen van de Vereniging voor Gezondheidsrecht uit 1991 nog voldoet. Waar nodig worden voorstellen voor nieuwe richtlijnen gedaan. In paragraaf 11.6 zal de vraag worden beantwoord of de $W$ gbo als algemeen juridisch kader voldoet voor de regeling van informatie, toestemming en geheimhouding bij erfelijkheidsadvisering in de klinisch genetische centra. In de slotparagraaf wordt aandacht besteed aan de plaats van de erfelijkheidsadvisering in de klinisch genetische centra binnen de gezondheidszorg.

\subsection{Het recht op informatie en het toestemmingsvereiste}

\subsubsection{Het recht op informatie}

Het recht op informatie is een belangrijk recht. Een adviesvrager dient op basis van de door de klinisch geneticus verstrekte informatie een weloverwogen besluit te kunnen nemen ten aanzien van het al dan niet ondergaan van een erfelijkheidsonderzoek. Ten tweede dient de adviesvrager te weten welke conclusies de klinisch geneticus heeft kunnen trekken met betrekking tot zijn gezondheidstoestand. Ten derde draagt het verstrekken van duidelijke en begrijpelijke inlichtingen ertoe bij dat de adviesvrager optimaal kan meewerken aan de bevordering of het herstel van zijn gezondheidstoestand. De informatie moet zo veel mogelijk in voor de adviesvrager begrijpelijke bewoordingen worden gegeven, rekening houdend met zijn specifieke informatiebehoefte op grond van zijn persoonlijke omstandigheden. De klinisch geneticus moet zich ervan vergewissen dat de adviesvrager de informatie voldoende heeft begrepen.

\section{Hoge eisen ann de informatieplicht}

Voorspellend erfelijkheidsonderzoek is geen medisch noodzakelijk onderzoek. Het voorspellende karakter dient te worden benadrukt omdat juist dit het ondergaan van dergelijk onderzoek minder vanzelfsprekend maakt. Uit de jurisprudentie bleek dat bij medisch niet-noodzakelijk onderzoek hoge eisen worden gesteld aan de informatieplicht. Daarnaast rechtvaardigen de voorspellende aard van het onderzoek en de mogelijke gevolgen van het onderzoek voor zowel de adviesvrager als zijn 
familieleden het stellen van hoge eisen aan de informatieplicht bij de erfelijkheidsadvisering over voorspellend erfelijkheidsonderzoek.

In de praktijk is gebleken dat adviesvragers door de klinisch geneticus in verschillende gesprekken uitgebreid worden geinformeerd. Het betreft zowel medische informatie als informatie over de eventuele psychosociale en maatschappelijke gevolgen van een erfelijkheidsonderzoek. Ook de eventuele consequenties voor familieleden worden met de adviesvrager besproken. De hoeveelheid informatie die wordt verstrekt bleek voornamelijk afhankelijk te zijn van de aanwezige voorkennis omtrent de erfelijke aandoening waar de erfelijkheidsvraag zich op richt en van de (on)mogelijkheden om door middel van erfelijkheidsonderzoek de vraag te beantwoorden. Uit de evaluatie van de Wgbo kwam naar voren dat van de huisartsen en specialisten naar eigen zeggen $99 \%$ altijd of meestal hum patiënten informeert over de aard en het doel van het onderzoek of de behandeling. Daarnaast geeft $71 \%$ van de huisartsen en specialisten aan altijd of meestal hun patiënten te informeren over de te verwachten risico's en gevolgen van een onderzoek of behandeling.' Uit een nadere verdieping in panels bleek dat huisartsen kien zijn op het geven van informatie over welke uitwerking een bepaalde behandeling zal hebben op het dagelijks leven van hun patiënten. ${ }^{2}$ Ondanks het feit dat huisartsen ook de uitwerking van bepaalde behandelingen op het dagelijks leven van hun patiënten betrekken bij hun informatieverstrekking, lijkt het verschil tussen klinisch genetici en andere artsen voor wat betreft de informatieverstrekking voornamelijk te bestaan uit het feit dat klinisch genetici meer aandacht besteden aan het geven van informatie over de eventuele gevolgen van een onderzoek. Deze gevolgen betreffen in de klinisch genetica nadrukkelijk ook de gevolgen voor familieleden van de adviesvrager.

In onderhavig onderzoek gaven de geïnterviewde adviesvragers aan dat zij goed en uitgebreid zijn geïnformeerd. Dit bleek tevens uit de geobserveerde gesprekken. Voor hen bleken echter met name begrip, aandacht en het feit dat er veel tijd voor hen wordt uitgetrokken van belang te zijn. Het feit dat hier in hun ogen aan voldaan was, werd als uitermate positief ervaren. Van de patiënten, zo bleek uit de evaluatie van de Wgbo, gaf $71 \%$ aan door de huisarts veelal voldoende gelegenheid te krijgen om vragen te stellen. Bij de medisch specialisten lag dit percentage op $61 \%$. Bij zowel huisartsen als specialisten werd het door $70 \%$ van patiënten niet moeilijk gevonden om vragen te stellen. ${ }^{3}$ Het feit dat de interviews met de adviesvragers kwalitatief van aard waren makkt het niet goed mogelijk om de verschillende uitkomsten goed te vergelijken.

De klinisch geneticus krijgt in de praktijk regelmatig het verzoek om zijn informatieplicht anders in te vullen dan hij gewoon is te doen. Voorbeelden hiervan zijn het informeren van verschillende adviesvragers tegelijkertijd, de voorinformatie in het geheel niet te ontvangen of tot één gesprek te beperken en het informeren van

Dute 2000, p. 77.

Dute 2000, p. 82.

Dute 2000, p. 397. 
de adviesvrager door middel van een telefoongesprek. In dergelijke situaties zal de klinisch geneticus telkens moeten nagaan of het voldoen aan deze verzoeken in overeenstemming is met zijn goed hulpverlenerschap.

De klinisch geneticus is verplicht om eventuele onverwachte bevindingen aan de orde te stellen, alvorens een erfelijkheidsonderzoek wordt verricht. Met name bij het doornemen van de familieanamnese en bij chromosomenonderzoek kan meer erfelijkheidsinformatie worden gegenereerd dan waar de erfelijkheidsvraag op gericht was. Het vermelden van deze mogelijkheid hoort daarom tot de standaard te verstrekken informatie wamneer dergelijk onderzoek wordt verricht. Alleen dan is de adviesvrager zo goed mogelijk geïnformeerd en in staat op basis van die informatie keuzes te maken. Ook het recht op niet weten wordt beschermd wanneer de adviesvrager in de gelegenheid wordt gesteld aan te geven wat hij wel en niet wil weten. Het maken van duidelijke afspraken over de vraag of en hoe eventuele onverwachte bevindingen meegedeeld zullen worden, behoort bij dergelijk onderzoek ook tot de vóórinformatie. Dit geldt voor medische informatie en niet medische informatie die verband houdt met de gezondheidstoestand van de adviesvrager.

Het informeren over onverwachte bevindingen is problematisch voor klinisch genetici. De aard van de eventuele bevindingen is zeer divers en de kans op elke bevinding op zich is valak laag. Zeker wanneer de mogelijkheid van onverwachte bevindingen niet voorafgaand aan het erfelijkheidsonderzoek met de adviesvrager is besproken, vergt het informeren hierover een behoedzame aanpak. De erfelijkheidsvraag was niet op deze bevindingen gericht en voor de klinisch geneticus speelt daarom altijd de vraag of de adviesvrager van deze informatie wel op de hoogte wil worden gesteld.

\section{Conchusie en anbeveling}

Het recht op informatie is een veelomvattend recht. Aan de informatieplicht van de klinisch geneticus moeten hoge eisen worden gesteld. Op grond van het recht op informatie dient de klinisch geneticus adviesvragers uitgebreid te informeren. In de praktijk van de erfelijkheidsadvisering krijgt dit vorm door adviesvragers uitgebreid te informeren over zowel de medische aspecten als de mogelijke psychosociale en maatschappelijke gevolgen van erfelijkheidsonderzoek. Voor adviesvragers bleken met name begrip, aandacht en het feit dat er veel tijd voor hen wordt uitgetrokken van belang te zijn. Nader onderzoek naar de verschillende aspecten van de informatieplicht zou een meer gedetailleerd beeld op kunnen leveren van de wijze waarop in de praktijk wordt geïnformeerd.

In de erfelijkheidsrichtlijnen is de informatieplicht als volgt uitgewerkt:

"De arts licht de cliënt op duidelijke wijze, en desgevraagd schriftelijk, in over de aard en de inhoud van het onderzoek, over de mogelijke resultaten en gevolgen ervan en over de beschikbare alternatieven. (...) Voor zover voorzienbaar vertelt hij bovendien dat de medewerking van bloedverwanten gewenst is, en dat het onderzoek resultaten kan opleveren die voor die bloedverwanten van groot belang zijn." 
Op basis van de resultaten van dit onderzoek stel ik het volgende artikel voor:4

De klinisch geneticus licht de adviesvrager op duidelijke wijze, en desgevraagd schriftelijk, in over de conclusies die hij heeft kunnen trekken over zijn gezondheidstoestand, over de aard en de inhoud van een eventueel te ondergaan erfelijkheidsonderzoek, over de eventuele resultaten en gevolgen ervan en over ander onderzock dat in aanmerking komt, zodat de adviesvrager in staat is een weloverwogen keuze te maken. Indien voor een erfelijkheidsonderzoek medewerking van familieleden is vereist, geeft hij dit duidelijk aan. Onder de eventuele gevolgen van een erfelijkheidsonderzoek worden in ieder geval verstaan:

a. het feit dat de uitslag van een erfelijkheidsonderzoek van belang kan zijn voor familieleden en

b. het feit dat een erfelijkheidsonderzoek onverwachte bevindingen kan genereren.

De informatie moet in voor de adviesvrager begrijpelijke bewoordingen worden gegeven, rekening houdend met zijn specifieke informatiebehoefte op grond van zijn persoonlijke omstandigheden. De klinisch geneticus vergewist zich ervan dat de adviesvrager de informatie heeft begrepen.

\subsubsection{De therapeutische cxceptie}

Artikel 7:448 lid 3 BW regelt de therapeutische exceptie. Deze uitzondering op de informatieplicht zal niet snel aan de orde zijn wanneer de mogelijke bevindingen en gevolgen van een erfelijkheidsonderzoek met de adviesvrager uitvoerig zijn doorgenomen en sprake is van een weloverwogen besluit om een erfelijkheidsonderzoek te ondergaan. Dit ligt anders bij onverwachte bevindingen. Indien de klinisch geneticus in het geval van onverwachte bevindingen gegronde redenen heeft om aan te nemen dat de gevonden informatie kennelijk ernstig nadeel voor de adviesvrager op zou leveren, is er ruimte om de therapeutische exceptie toe te passen. Het is voorts van belang een onderscheid te maken tussen enerzijds de toepassing van de therapeutische exceptie en anderzijds het gedoseerd en gefaseerd informeren. Het goed hulpverlenerschap vereist dat relevante informatie op het juiste tijdstip aan de adviesvrager wordt verstrekt, zodat hij de informatie begrijpt.

Klinisch genetici maken weinig gebruik van de therapeutische exceptie. Indien zij dit wel doen, betreft het uitsluitend het tijdelijk niet verstrekken van inlichtingen. In de situaties waarin de therapeutische exceptie wordt toegepast blijkt dat er niet altijd sprake is van kennelijk ernstig nadeel. Wel bleek dat, door de gebruikelijke werkwijze om hierover met collegae te overleggen, aan de consultatieplicht wordt voldaan. In de praktijk is het verschil tussen de therapeutische exceptie en het geleidelijk en gefaseerd informeren niet altijd duidelijk. De klinisch geneticus ziet zich geregeld voor de vraag gesteld of hij in een bepaalde situatie informatie achterhoudt en of hij daarmee de therapeutische exceptie toepast, of dat hij de

4 In de voorgestelde richtlijnen wordt, anders dan in de erfelijkheidsrichtlijnen van de Vereniging voor Gezondheidsrecht gehanteerde term 'cliënt', gesproken over de adviesvrager. Dit omdat deze term in het gehele onderzoek wordt gehanteerd. 
adviesvrager op een verantwoorde manier informeert door dit geleidelijk en gefaseerd te doen. Ook de Wgbo-evaluatie laat zien dat er weinig gebruik wordt gemaakt van de therapeutische exceptie. Bovendien wordt het niet informeren ook door artsen veeleer in de sleutel van het 'timen' en 'doseren' van informatie gezet dan van het bewust achterwege laten van informatie vanwege te verwachten kennelijk ernstig nadeel. De hoeveelheid informatie die wordt verstrekt, wordt gerelateerd aan de toestand van de patiënt en ook aan datgene wat hij ermee kan. Aan de consultatieplicht wordt slechts door $10 \%$ van de artsen altijd voldaan. $47 \%$ consulteert soms een andere hulpverlener, $43 \%$ zegt dit nooit te doen. ${ }^{5}$

\section{Conclusie}

Voor de therapeutische exceptie is op theoretische gronden bij erfelijkheidsadvisering weinig ruimte. De praktijk is hiermee in overeenstemming: van de therapeutische exceptie wordt nauwelijks gebruik gemaakt. Wel is het zo dat wanneer er gebruik van wordt gemaakt, er niet altijd sprake is van kennelijk ernstig nadeel. Waarschijnlijk is onbekendheid met deze juridische eis hiervan de oorzaak. Daarnaast is het onderscheid tussen enerzijds de therapeutische exceptie en anderzijds het geleidelijk en gefaseerd informeren in de praktijk niet helder. Het goed hulpverlenerschap vereist dat relevante informatie op het juiste tijdstip wordt verstrekt en laat ruimte voor vragen van de adviesvrager. Relevante informatie is in ieder geval informatie over een onduidelijke uitslag. De klinisch geneticus zal de adviesvrager moeten informeren over deze onduidelijkheid en de mogelijke opties. De adviesvrager moet weten wat de eventuele uitkomsten van het erfelijkheidsonderzoek zullen zijn. Dit zal uiteraard op passende wijze moeten gebeuren. Het informeren over de mogelijkheden houdt niet in dat deze tot in detail moeten worden besproken.

In de erfelijkheidsrichtlijnen is de therapeutische exceptie als volgt uitgewerkt:

"Informatie die kennelijk ernstig nadeel voor de cliënt zou opleveren, wordt door de arts (nog) niet gegeven."

Op grond van het feit dat bovenstaande formulering niet aansluit op de formulering in de Wgbo en bovendien niets vermeldt over de consultatieplicht stel ik het volgende artikel voor:

De klinisch geneticus verstrekt geen informatie aan de adviesvrager indien deze voor de adviesvrager kennelijk ernstig nadeel oplevert. De klinisch geneticus verstrekt deze informatie alsnog zodra hiervan geen sprake meer is. Alvorens de klinisch geneticus besluit geen informatie te verstrekken raadpleegt hij hierover een collega.

5 Dute 2000, p. 85-88. 


\subsubsection{Non-directiviteit}

Het uitgangspunt van de erfelijkheidsadvisering is dat deze non-directief van aard is. In hoofdstuk 4 is voor wat betreft de wijze van informeren het moral education model van non-directiviteit verdedigd. Het moral education model van Arras, warbij de morele aspecten van de verschillende keuzemogelijkheden die een adviesvrager heeft door de geneticus aan de orde worden gesteld, maar de beslissing aan de adviesvrager is, doet het meeste recht aan het doel van de erfelijkheidsadvisering, te weten de adviesvrager een geinformeerde en weloverwogen keuze te laten maken die het beste bij hem past. Het zelfbeschikkingsrecht wordt een echt zelfbeschikkingsrecht wanneer de adviesvrager inzicht heeft in de eventuele consequenties van zijn keuze.

Op het moral education model is, voor wat betreft de non-directiviteit van de houding van de klinisch geneticus, een aantal uitzonderingen te maken. Zo kunnen in verband met de indicatiestelling eisen aan de toegang tot erfelijkheidsonderzoek worden gesteld. Bovendien kan niet van een klinisch geneticus verwacht worden dat hij zijn eigen normen en waarden niet ter sprake brengt wanneer hij ernstige morele bezwaren heeft tegen een bepaalde keuze van een adviesvrager. Ten slotte is ook het geven van een gevraagd advies aanvaardbaar, mits duidelijk is dat het hier de persoonlijke normen en waarden van de klinisch geneticus betreffen.

Het uitgangspunt dat de erfelijkheidsadvisering non-directief van aard is, wordt door klinisch genetici onderschreven. In de praktijk van de erfelijkheidsadvisering lijkt in veel gevallen het dialogische model gevolgd te worden. In dit model trachten de klinisch geneticus en de adviesvrager gezamenlijk tot een besluit te komen.

\section{Conclusie en anubeveling}

Met behulp van het moral education model wordt getracht de adviesvrager in staat te stellen hem een geïnormeerde en weloverwogen keuze te laten maken die het beste bij hem past. In de praktijk lijkt veelal het dialogische model gevolgd te worden. Of hiermee ook het uitgangspunt is verlaten dat de erfelijkheidsadvisering non-directief van aard moet zijn, hangt af van de definitie die wordt gehanteerd. Nader onderzoek naar de verschillende concepten van non-directiviteit is gewenst. Veel klinisch genetici geven aan samen met de adviesvrager tot een besluit te willen komen, waarbij men het gevoel wil hebben dat het voor de adviesvrager het juiste besluit is. Nader onderzoek naar de wijze waarop klinisch genetici en adviesvragers met elkaar communiceren, alsmede waarom dit zo gebeurt, zal moeten uitwijzen of en waarom het dialogische model in de praktijk wordt gevolgd.

In de erfelijkheidsrichtlijnen is de wijze van informeren als volgt uitgewerkt:

"De arts helpt de cliënt die om advies vraagt bij het nemen van persoonlijke beslissingen, door de mogelijke alternatieven en de voor- en nadelen daarvan met hem te bespreken. De arts laat de cliënt vrij in de keuze die hij maakt en respecteert die keuze." 
In de erfelijkheidsrichtlijnen wordt aangegeven dat de klinisch geneticus de mogelijke alternatieven en de voor- en nadelen moet bespreken. Dit volgt mijns inziens reeds uit de informatieplicht. Bovendien gaat het artikel niet in op de situaties waarin de klinisch geneticus ernstige bezwaren heeft of van hem een advies gevraagd wordt. Op basis van de resultaten van dit onderzoek stel ik daarom het volgende artikel voor:

De klinisch geneticus stelt de morele aspecten van de verschillende keuzemogelijkheden die de adviesvrager openstaan aan de orde, maar laat de adviesvrager zelf een keuze maken. Van een klinisch geneticus kan niet worden verwacht dat hij zijn eigen normen en waarden niet ter sprake brengt indien hij emstige morele bezwaren heeft tegen een bepaalde keuze van een adviesvrager. Het geven van een gevraagd advies is, mits duidelijk is dat het de persoonlijke normen en waarden van de klinisch geneticus betreffen, in overeenstemming met het goed hulpverlenerschap.

\subsubsection{Het toestemmingsvereiste}

Voor verrichtingen ter uitvoering van de behandelingsovereenkomst is de toestemming van de adviesvrager vereist. Voor de veronderstelde toestemming van de adviesvrager zal bij de erfelijkheidsadvisering weinig ruimte zijn. Dit geldt in ieder geval voor de beslissing om een voorspellend erfelijkheidsonderzoek te laten verrichten. Dergelijk onderzoek dient in overdrachtelijke zin als ingrijpend en invasief te worden beschouwd. Ook diagnostisch erfelijkheidsonderzoek dient als een ingrijpende verrichting te worden beschouwd.

In de praktijk van de erfelijkheidsadvisering wordt pas tot erfelijkheidsonderzoek overgegaan als toestemming is verleend door de adviesvrager. Ook voor het maken van foto's en dia's wordt toestemming gevraagd. Het schriftelijk toestemming verlenen op verzoek van de klinisch geneticus komt bij voorspellend erfelijkheidsonderzoek soms voor. Het voordeel hiervan kan zijn dat de adviesvrager zijn keuze nogmaals goed overweegt alvorens hij toestemming geeft. Uit de Wgboevaluatie bleek dat voor artsen een zwaar accent ligt op de informatieverstrekking. Het vragen van toestemming leeft voor hen niet zo, tenzij het gaat om ingrijpende verrichtingen die voor de patiënt allerlei gevolgen kunnen hebben. Zo geven chirurgen aan dat zij formeler met het vragen van toestemming omgaan naarmate het onderzoek of de behandeling zwaarder is en voor de patiënt meer consequenties en risico's met zich mee brengt of kan brengen. ${ }^{6}$ Gezien de mogelijk verstrekkende gevolgen van erfelijkheidsonderzoek, ligt het bij dergelijk onderzoek ook meer voor de hand dat klinisch genetici adviesvragers hiervoor altijd formeel toestemming vragen.

Het door een aantal klinisch genetische centra gehanteerde gebruik om toestemming te vragen van de adviesvrager en zijn familieleden voor het opvragen van gegevens,

$6 \quad$ Dute 2000, p. 91. 
alvorens er een gesprek heeft plaatsgevonden, levert een ongeïnformeerde toestemming op.

Het wederom toestemming vragen om geïnformeerd te worden over de uitslag van een erfelijkheidsonderzoek als deze pas na lange tijd bekend wordt, getuigt van goed hulpverlenerschap. Door de adviesvrager opnieuw de keuze te laten maken, wordt in de praktijk van de erfelijkheidsadvisering het meest recht gedaan aan het zelfbeschikkingsrecht van de adviesvrager in de vorm van een keuze tussen wel en niet weten.

\section{Conclusie en annbeveling}

Zonder een geïnformeerde toestemming van de adviesvrager wordt geen erfelijkheidsonderzoek verricht. Het vragen van toestemming aan de adviesvrager en diens familieleden voor het opvragen van gegevens voor het eerste gesprek, kan geen geïnformeerde toestemming worden genoemd. Het verdient daarom aanbeveling eerst bij een gesprek met de adviesvrager diens toestemming te vragen voor het opvragen van gegevens en hem toestemmingsformulieren mee te geven voor familieleden. Het gebruik om wederom toestemming te vragen aan de adviesvrager om geïformeerd te worden over de uitslag van een erfelijkheidsonderzoek als deze pas na lange tijd bekend wordt, getuigt van goed hulpverlenerschap.

In de erfelijkheidsrichtlijnen is het toestemmingsvereiste als volgt uitgewerkt:

"De arts vraagt de cliënt of hij instemt met het erfelijkheidsonderzoek"

"De arts beperkt het erfelijkheidsonderzoek tot onderzoek waarvoor de cliënt toestemming heeft gegeven."

Op basis van de resultaten van dit onderzoek stel ik het volgende artikel voor:

De klinisch geneticus verricht alleen dan een erfelijkheidsonderzoek, wanneer de adviesvrager hiervoor toestemming heeft gegeven. Niet voordat een gesprek met de adviesvrager heeft plaatsgevonden wordt, indien aangewezen, diens toestemming gevraagd voor het opvragen van zijn gegevens en/of die van zijn familieleden. Indien tussen het verrichten van een erfelijkheidsonderzoek en het bekend worden van een uitslag geruime tijd is verstreken vraagt de klinisch geneticus, alvorens de uitslag mede te delen, hiervoor toestemming.

\subsection{Het recht op weten}

Het recht op informatie riep de vraag op of er ook buiten de behandelingsovereenkomst van een dergelijk recht gesproken kan worden. De vraag of er een recht op weten bestaat is nauwelijks voorwerp van onderzoek geweest in de Nederlandse rechtsliteratuur. In hoofdstuk 5 is onderzocht of, en zo ja, onder welke omstandigheden, er sprake kan zijn van een recht om kennis te vergaren betreffende 
de eigen genetische constitutie. Het betrof daarbij zowel het recht om informatie betreffende de genetische constitutie door middel van het ondergaan van een erfelijkheidsonderzoek te vergaren, als het recht op kennisname van reeds bestaande informatie waarover een ander dan de hulpverlener in het kader van de behandelingsovereenkomst beschikt.

Het recht om informatie tot stand te brengen betreffende de genetische constitutie door middel van het ondergann van een erfelijkheidsonderzoek

Voor wat betreft het recht om informatie betreffende de genetische constitutie door middel van het ondergaan van een erfelijkheidsonderzoek te vergaren, is onderzocht of dit is af te leiden uit het recht op respect voor de persoonlijke levenssfeer. In Nederland wordt de zeggenschap van personen over de eigen gegevens via het privacybegrip niet erkend. Er is geen sprake van een zogenaamd informationeel zelfbeschikkingsrecht. Twee uitspraken van het EHRM lijken daarentegen, via de erkenning van positieve verplichtingen voor de overheid ter bescherming van het recht op privacy, wel een opening te bieden voor de erkenning van een recht om informatie tot stand te doen brengen over de eigen genetische constitutie. In de twee besproken uitspraken leverde een aantasting van het welzijn van het individu een schending van artikel 8 EVRM op. In de genoemde arresten gaat het echter om bestaande overlast respectievelijk bestaande informatie. De vraag was echter of er een recht is om informatie tot stand te brengen door middel van het afdwingen van de mogelijkheid om een erfelijkheidsonderzoek te ondergaan. Het is niet aannemelijk dat de overheid op grond van het recht op privacy, en daarvan afgeleid een recht op weten, verplicht zou kunnen worden om alle technisch mogelijke en wetenschappelijk verantwoorde erfelijkheidsonderzoeken beschikbaar te stellen. Specifieke omstandigheden zouden hier in individuele gevallen wellicht wel toe kunnen leiden. In zo'n geval zou aangetoond moeten worden dat de informatie van vitaal belang is voor het individu en dat het niet verkrijgen van de informatie een aantasting van het welzijn van het individu oplevert. Dit zou het geval kunnen zijn bij een verhoogd risico op een ernstige ziekte waarbij preventieve maatregelen effect kunnen sorteren wanneer deze tijdig worden getroffen.

Het recht op kennisname van reeds bestannde informatie betreffende de eigen genetische constitutie

Om de vraag te beantwoorden of er sprake is van een recht op kennisname van reeds bestaande informatie betreffende de eigen genetische constitutie is gekeken of de jurisprudentie hiervoor aanknopingspunten biedt. De jurisprudentie van de Hoge Raad en het Europese Hof voor de Rechten van de Mens erkent het grote belang van informatie betreffende afstamming, ontwikkeling en de eigen jeugd. Volgens de Hoge Raad omvat het algemene persoonlijkheidsrecht mede het recht om te weten van welke ouders men afstamt. Het belang dat men heeft bij het kennen van de genetische constitutie, althans het kennen van een onderdeel daarvan lijkt een minstens zo vitaal belang. Het maakt mijns inziens, net als de kennis van wie men afstamt, onderdeel uit van de identiteit. Het recht op kennisname van bestaande informatie betreffende de eigen genetische constitutie zou dan afgeleid kunnen worden uit het algemene persoonlijkheidsrecht dat onder andere ten grondslag ligt aan het recht op een persoonlijke levenssfeer. Dit is geen absoluut recht. Het zal 
afgewogen moeten worden tegen rechten en vrijheden van anderen, met name tegen het recht op respect voor de persoonlijke levenssfeer van een bloedverwant die over informatie beschikt die zowel relevant is voor de bloedverwant als voor degene die een recht op die informatie claimt. Doze uitkomst van deze afweging zal afhangen van de concrete omstandigheden van het geval. Van belang hierbij zijn het belang van de inbreuk op de privacy, de ernst van de inbreuk op de privacy en het subsidiariteitsbeginsel.

\section{E'n algemene warschuwingsplicht wan de klinisch geneticus jegens familieleden?}

Tevens is de vraag behandeld of de klinisch geneticus jegens familieleden van de adviesvrager een algemene waarschuwingsplicht, dan wel een waarschuwingsplicht onder specifieke omstandigheden, heeft. Van een algemene waarschuwingsplicht kan niet worden gesproken. Wel is het mogelijk dat onder omstandigheden op de klinisch geneticus een waarschuwingsplicht rust. Jurisprudentie waarin een dergelijke plicht voor een klinisch geneticus is erkend bestaat echter (nog) niet.

\section{Conclusie e'n anbeveling}

Het recht op weten is mede voorwerp van onderzoek geweest. Geconcludeerd is dat het niet aannemelijk is dat de overheid op grond van het recht op privacy, en daarvan afgeleid een recht op weten, verplicht zou kunnen worden om alle technisch mogelijk en wetenschappelijk verantwoorde erfelijkheidsonderzoeken aan te bieden. Specifieke omstandigheden zouden hier in individuele gevallen wellicht wel toe kunnen leiden.

Het recht op kennisname van bestaande informatie betreffende de eigen gerietische constitutie zou afgeleid kunnen worden uit het algemene persoonlijkheidsrecht dat onder andere ten grondslag ligt aan het recht op een persoonlijke levenssfeer. Dit is geen absoluut recht. Het zal afgewogen moeten worden tegen rechten en vrijheden van anderen. Het zal bij erfelijkheidsadvisering dus afgewogen moeten worden tegen het recht op een persoonlijke levenssfeer van een bloedverwant die over informatie beschikt die zowel relevant is voor de bloedverwant als voor degene die een recht op die informatie claimt. De uitkomst van deze weging zal afhangen van concrete omstandigheden. Wellicht zal toekomstige jurisprudentic meer handvatten bieden.

Een algemene waarschuwingsplicht van de klinisch geneticus jegens familieleden kan naar Nederlands recht niet worden aangenomen. Wellicht zal ook hier toekomstige jurisprudentie handvatten bieden voor specifieke situaties waarin deze plicht wel zou bestaan. Klinisch genetici zelf kunnen hierin ook een rol spelen door in een richtlijn aan te geven onder welke omstandigheden volgens haar een waarschuwingsplicht zou rusten op de klinisch geneticus jegens familieleden. ${ }^{7}$

7 In de "Beleidsnota De toepassing van genetica in de gezondheidszorg" geeft de minister aan dat zij het voor de praktijk nuttig acht wanneer het veld de situaties waarin de toepassing van het conflict van plichten met een beroep op overmacht aangewezen lijkt, nader zou concretiseren en inzichtelijk zou maken. Ministerie van 


\subsection{Het recht op niet weten}

Het recht op niet weten is voor de adviesvrager een belangrijk recht. Het is niet strijdig met zijn zelfbeschikkingsrecht. Ervan uitgaande dat alleen een adviesvrager zelf kan bepalen of het besluit om bepaalde informatie niet te willen ontvangen gebaseerd is op alle voor hem relevante informatie, is het besluit om geen informatie te willen ontvangen juíst een autonome keuze. Deze keuze hoeft niet rationeel te zijn in de ogen van anderen.

Klinisch genetici onderschrijven dit. Zij benadrukken dat adviesvragers altijd voor een informatief gesprek kunnen komen en dat het de keuze van de adviesvrager is of hij een erfelijkheidsonderzoek wil ondergaan. Het recht op niet weten vloeit volgens hen logisch voort uit het feit dat het de adviesvrager is die een keuze maakt.

Het recht op niet weten bestant uit drie aspecten

Het recht op niet weten bestaat uit drie aspecten. Ten eerste het recht om te bepalen of informatie tot stand wordt gebracht en daarmee het recht om zelf te beslissen omtrent het wel of niet ondergaan van een erfelijkheidsonderzoek. Ten tweede het recht om bestaande informatie niet te ontvangen. Dit aspect wordt geregeld in artikel 7:449 BW. Ten derde het recht om niet te weten of men een verhoogd risico loopt op een erfelijke aandoening. Het verschil met het tweede aspect is dat er geen adviesvraag is in het kader van een behandelingsovereenkomst. Dit aspect is in hoofdstuk 7 behandeld.

\section{Eerste aspect}

Het recht om zelf te bepalen of informatie betreffende de gezondheid tot stand wordt gebracht is af te leiden uit en wordt beschermd door het recht op respect voor de persoonlijke levenssfeer. Dit recht leidt ertoe dat niemand verplicht is een erfelijkheidsonderzoek te ondergaan. De adviesvrager moet hiermee zelf instemmen. Er kan zich evenwel een aantal situaties voordoen waarin de adviesvrager een zeker drang voelt om een erfelijkheidsonderzoek te ondergaan. Door de structurele aanwezigheid van belangen van verwanten bestaat het gevaar dat men tot een erfelijkheidonderzoek besluit uitsluitend of voornamelijk in het belang van anderen. Ook sociale druk kan aanleiding zijn voor een erfelijkheidsonderzoek. Het goed hulpverlenerschap brengt met zich mee dat de klinisch geneticus probeert na te gaan of de adviesvrager uit vrije wil een erfelijkheidsonderzoek wil ondergaan.

In de praktijk wordt het recht van de adviesvrager om zelf te bepalen of hij informatie betreffende de gezondheid tot stand wil brengen door klinisch genetici beschermd door aan te geven dat een erfelijkheidsonderzoek vrijwillig is en dat adviesvragers voor zichzelf moeten afwegen of $z \mathrm{ij}$ datgene dat onderzocht kan worden ook daadwerkelijk willen weten. Met name bij voorspellend erfelijkheidsonderzoek wordt hierbij stilgestaan.

Volksgezondheid, Welzijn en Sport 2000, p. 37. Zie over het conflict van plichten verder paragraaf 11.5 . 


\section{Tweede aspect}

Het recht om bestaande informatie betreffende de gezondheid niet te ontvangen is bij de erfelijkheidsadvisering van bijzonder belang. Met name bij voorspellend onderzoek kan het niet ontvangen van informatie van groot belang zijn voor de adviesvrager in verband met de invulling en perceptie van zijn leven. Het goed hulpverlenerschap vereist dat in ieder geval bij voorspellend onderzoek de adviesvrager wordt gewezen op het feit dat hij gebruik kan maken van zijn recht op niet weten. Indien het besluit om een erfelijkheidsonderzoek te ondergaan weloverwogen is genomen, mag men verwachten dat de adviesvrager niet snel op zijn besluit om de uitslag te vernemen zal terugkomen. Bij onverwachte bevindingen is er sprake van een andere situatie. Voorafgaand aan het erfelijkheidsonderzoek dient duidelijk op de mogelijkheid van onverwachte bevindingen te worden gewezen, zodat de adviesvrager aan kan geven of hij hiervan op de hoogte wil worden gesteld. Indien uit het erfelijkheidsonderzoek blijkt dat er inderdaad sprake is van onverwachte bevindingen, vereist de zorgvuldigheid dat nogmaals aan de adviesvrager gevraagd wordt of hij hieromtrent geinformeerd wenst te worden.

Het recht op niet weten kan de adviesvrager ertoe doen besluiten dat hij voorafgaand aan het erfelijkheidsonderzoek geen inlichtingen wil ontvangen. Het is echter aan de klinisch geneticus om te bepalen of het niet verstrekken van inlichtingen voorafgaand aan het erfelijkheidsonderzoek in overeenstemming is met zijn goed hulpverlenerschap.

In de praktijk worden adviesvragers bij voorspellend onderzoek door de meeste klinisch genetici gewezen op hun recht op niet weten. $\mathrm{Zij}$ doen dit door adviesvragers erop te wijzen dat men te allen tijde kan besluiten niet geinformeerd te willen worden over de uitslag van het erfelijkheidsonderzoek. Wel is gebleken dat klinisch genetici er moeite mee hebben indien adviesvragers in hun ogen irrationele besluiten nemen.

Ten eerste vinden sommige genetici het onlogisch om na uitgebreide erfelijkheidsadvisering die voorafgegaan is aan het besluit van de adviesvrager om een erfelijkheidsonderzoek te laten verrichten, wederom aan te geven dat de adviesvrager nog altijd kan besluiten de uitslag van het onderzoek niet te willen weten. Om die reden wordt dit in de praktijk regelmatig nagelaten. Een standpunt dat nog een stap verdergaat is dat door een goede erfelijkheidsadvisering het überhaupt niet nodig is het recht op niet weten te benoemen. Alleen bij twijfel van de adviesvrager omtrent het laten verrichten van een erfelijkheidsonderzoek is hier aanleiding voor. Dit veronderstelt dat de kwaliteit van de erfelijkheidsadvisering van dien aard is dat een adviesvrager na een weloverwogen besluit om een erfelijkheidsonderzoek te ondergaan van dit recht geen gebruik zal maken. Hierbij wordt tevens een hoge mate van rationaliteit van de adviesvrager verwacht. Het komt echter voor dat adviesvragers, ondanks de volgens klinisch genetici kwalitatief hoogwaardige erfelijkheidsadvisering, de uitslag niet willen vernemen.

Ten tweede geven veel klinisch genetici aan dat het lastig is wanneer een adviesvrager daadwerkelijk aangeeft de uitslag van zijn erfelijkheidsonderzoek niet 
te willen weten. Het recht op niet weten wordt enerzijds erkend, maar men hoopt dat er geen gebruik van wordt gemaakt. Het wordt als een onbevredigende situatie gezien wanneer op het besluit om een erfelijkheidsonderzoek te ondergaan, het besluit volgt om toch de uitslag niet te willen weten.

Ten derde blijkt dit uit het feit dat de meeste klinisch genetici het als hun plicht zien om na te gaan waarom een adviesvrager besloten heeft om de uitslag van een erfelijkheidsonderzoek niet te willen weten.

Uit de evaluatie van de Wgbo blijkt dat ook huisartsen en specialisten de reden willen achterhalen indien hun patiënt aangeeft niet geinformeerd te willen worden. Niet zelden blijkt dan dat de patiënt van overdreven of verkeerde veronderstellingen uitgaat. In die gevallen kan het toch geinformeerd worden voor de patiënt een opluchting zijn. ${ }^{8}$

\section{Conclusie}

Uit het bovenstaande blijkt dat klinisch genetici er moeite mee hebben wanneer een besluit van de adviesvrager in hun ogen irrationeel is. Dit leidt er echter niet toe dat het recht op niet weten van adviesvragers niet wordt gerespecteerd. Wel is het zo dat sommige klinisch genetici het recht op niet weten niet benoemen. Bij voorspellend onderzoek verdient het aanbeveling dit wel te doen. Het feit dat dergelijk onderzoek om gezondheidsredenen uitgesteld kan worden, alsmede de mogelijke gevolgen ervan voor zowel de adviesvrager als diens familieleden, maken dat de klinisch geneticus als goed hulpverlener erop dient te wijzen dat de adviesvrager niet verplicht is om het erfelijkheidsonderzoek te ondergaan en ook niet verplicht is de informatie die uit het onderzoek komt te ontvangen.

\section{Litzonderingen}

Indien gebruikmaking van het recht om bepaalde inlichtingen niet te ontvangen leidt tot kennelijk ernstig nadeel voor de adviesvrager of voor anderen, worden de bedoelde inlichtingen alsnog verstrekt aan de adviesvrager. Met name twee situaties zijn hierbij denkbaar. Ten eerste de situatie waarin de adviesvrager vérgaande matregelen en handelingen overweegt te treffen c.q. verrichten, uitgaande van de onterechte veronderstelling dat hij in de toekomst zal gaan lijden aan een ernstige erfelijke ziekte. Ten tweede de situatie waarin de adviesvrager heeft aangegeven niet te willen worden ingelicht over onverwachte bevindingen, maar op grond van zijn persoonlijke omstandigheden aangenomen mag worden dat hij over de betreffende onverwachte bevinding wel geïformeerd wil worden.

In de erfelijkheidsrichtlijnen is het recht op niet weten op adequate wijze geregeld:

"Ieder heeft het recht zelf te beslissen of hij erfelijkheidsonderzoek ondergaat."

"leder heeft het recht zelf te beslissen of hij over de uitkomsten van ondergaan erfelijkheidsonderzock geïnformeerd wil worden."

Dute 2000, p. 90. 
"De arts vraagt de cliënt of hij volledig geinformeerd wil worden over de resultaten van het erfelijkheidsonderzoek, ook over eventuele onverwachte bevindingen."

"Nadat het erfelijkheidsonderzoek is verricht informeert de arts de client over de resultaten ervan, voor zover deze heeft aangegeven inderdaad geïformeerd te willen worden. De arts informeert de cliënt alleen tegen diens wil, als het belang van de cliënt bij niet-weten niet opweegt tegen het nadeel dat daaruit voor hemzelf of anderen kan voortvloeien."

\section{Het recht op niet weten van kinderen en ongeborenen}

Het recht op niet weten van kinderen en ongeborenen is in hoofdstuk 6 aan de orde geweest. Aanleiding hiervoor was het feit dat dit recht kan botsen met het recht op informatie van de ouders. Kinderen kunnen van een recht op niet weten niet altijd gebruik maken op het moment dat dit recht in het geding is. Daarom is hiervoor de term rights-in-trust of anticiperend autonomierecht gebezigd. Voor ongeborenen geldt dat zij geen drager zijn van rechten en plichten. Wel kan men spreken van beschermwaardige belangen waardoor een zekere reflex-werking toekomt aan het recht op niet weten voor de geboorte.

Wanneer ouders bij hun kind een erfelijkheidsonderzoek willen laten verrichten is het altijd het belang van de ouders en het kind bij weten dat moet worden afgewogen tegen het belang van het kind bij niet weten. Het is een overweging die ouders als goede vertegenwoordigers dienen te maken, waarbij het belang van het kind voorop staat. Dit belang kan strijdig zijn met dat van de ouders. Daarnaast impliceert het goed hulpverlenerschap ook een eigen verantwoordelijkheid van de klinisch geneticus om de belangen van het kind te beschermen. De vraag wanneer erfelijkheidsonderzoek in het belang van het kind is, hangt voornamelijk af van de mogelijkheden tot primaire en/of secundaire preventie. Bovendien zal de vraag of het onderzoek kan worden uitgesteld aan de orde moeten komen. Richtlijnen kunnen een steun zijn bij de concrete beantwoording door de klinisch geneticus van de vraag of een verzoek tot een erfelijkheidsonderzoek verenigbaar is met het goed hulpverlenerschap.

Het te beschermen belang dat de ongeborene heeft om in de toekomst verschoond te blijven van bepaalde informatie kan beschermd worden door bij prenataal onderzoek alleen te informeren over het feit of de vrucht al dan niet aangedaan is en niet over dragerschap van een recessieve mutatie of een gebalanceerde translocatie. Gezien de afwezigheid van gezondheidsredenen om geinformeerd te worden over dragerschap en de aanwezigheid van het belang om zelf in de toekomst een keuze te kunnen maken, is hier een restrictief beleid gerechtvaardigd. Een additioneel argument vormen hier de mogelijk negatieve psychosociale effecten van aangetoond dragerschap.

Het te beschermen belang dat de ongeborene heeft om in de toekomst verschoond te blijven van bepaalde informatie kan daarnaast beschermd worden door het stellen van voorwaarden aan de toegang tot prenatale diagnostiek. Geconcludeerd is dat indien ouders verzoeken om een prenataal onderzoek naar later in het leven 
optredende onbehandelbare aandoeningen, terwijl de keus om het kind geboren te laten worden reeds gemakt is door de aanstaande ouders, de klinisch geneticus op grond van zijn goed hulpverlenerschap verplicht is om aan te geven dat het belang van de ouders bij een dergelijk verzoek minder zwaar weegt dan het belang van de ongeborene om in de toekomst zelf te kunnen beslissen of hij wil weten of zich in de toekomst een onbehandelbare ziekte zal openbaren. Wanneer de ouders volharden in hun verzoek, rest de klinisch geneticus de mogelijkheid om het verzoek op grond van zijn professionele standaard te weigeren. In de praktijk vindt dergelijk onderzoek ook slechts plaats wanneer toekomstige ouders voornemens zijn om bij een ongunstige uitslag de vrucht te aborteren. Geconcludeerd is dat het van groot belang is dat de beroepsgroep terzake richtlijnen opstelt. Daarnaast is aangegeven dat de beschikbare genetische technieken niet mogen worden aangewend om te selecteren tegen normale kenmerken of gezondheid.

Het feit tot slot dat uit prenataal erfelijkheidsonderzoek of uit erfelijkheidsonderzoek bij kinderen informatie kan worden gegenereerd die van belang kan zijn wanneer het kind 16 jaar of ouder is, rechtvaardigt dat er in dergelijke situaties sprake is van een recht op weten. Dit impliceert een bewaarplicht voor de klinisch geneticus.

\section{Conclusie en annbevelingen}

Ook kinderen hebben een recht op niet weten. Ongeborenen komt een zekere reflexwerking van het recht op niet weten toe. De vraag wanneer erfelijkheidsonderzoek in het belang van het kind is, hangt voornamelijk af van de mogelijkheden tot primaire en/of secundaire preventie. Bovendien zal de vraag of het onderzoek kan worden uitgesteld aan de orde moeten komen. Richtlijnen kunnen een steun zijn bij de concrete beantwoording door de klinisch geneticus van de vraag of een verzoek tot een erfelijkheidsonderzoek verenigbaar is met het goed hulpverlenerschap. Het verdient daarom aanbeveling dat de beroepsgroep deze opstelt. ${ }^{9}$

Het te beschermen belang dat de ongeborene heeft om in de toekomst verschoond te blijven van bepaalde informatie dient bij prenataal onderzoek beschermd te worden door alleen te informeren over het feit of de vrucht al dan niet aangedaan is en niet over dragerschap van een recessieve mutatie of een gebalanceerde translocatie. Het te beschermen belang dat de ongeborene heeft om in de toekomst verschoond te blijven van bepaalde informatie kan daarnaast beschermd worden door het stellen van voorwaarden aan de toegang tot prenatale diagnostiek.

Een adviesvrager van zestien jaar of ouder heeft recht op informatie over een eerder bij hem verricht (prenataal) erfelijkheidsonderzoek. Tevens heeft hij een recht op

9 In de "Beleidsnota De toepassing van genetica in de gezondheidszorg" is de minister dezelfde mening toegedaan. Zij zegt hierover: "Ik zal binnenkort de beroepsgroep verzoeken richtlijnen te formuleren over de vraag welk onderzoek, gelet op de voordelen voor het kind of de meerderjarige onbekwame, geacht kan worden in diens belang te zijn." Ministerie van Volksgezondheid, Welzijn en Sport 2000, p. 39. Aldus ook Kamerstukken II 2001/02, 27 543, nr. 5, p. 4. 
inzage in de gegevens die over hem zijn vastgelegd. Het verdient aanbeveling dit recht wettelijk vast te leggen. Op die manier is het afdwingbaar. ${ }^{10}$

In de erfelijkheidsrichtlijnen is het recht op niet weten van het ongeboren of jonge kind als volgt uitgewerkt:

"Voor ouders die kiezen voor erfelijkheidsonderzoek bij hun (ongeboren of jonge) kind zal het recht op niet-weten van het kind een extra punt van overweging kunnen vormen. Het gat dan immers om een beslissing die voor het kind (later) vergaande gevolgen kan hebben."

Op basis van de resultaten van dit onderzoek stel ik het volgende artikel voor:

Indien ouders bij hun kind een erfelijkheidsonderzoek willen laten verrichten is het altijd het belang van de ouders en het kind bij weten dat moet worden afgewogen tegen het belang van het kind bij niet weten. Het is een afweging die ouders als goede vertegenwoordigers dienen te maken, waarbij het belang van het kind voorop staat. Het goed hulpverlenerschap impliceert ook cen eigen verantwoordelijkheid van de klinisch geneticus voor de bescherming van de belangen van het kind.

Het te beschermen belang dat de ongeborene heeft om in de toekomst verschoond te blijven van bepaalde informatie dient bij prenataal onderzoek beschermd te worden door alleen te informeren over het feit of de vrucht al dan niet aangedaan is en niet over dragerschap van een recessieve mutatie of een gebalanceerde translocatie en anderzijds door geen prenatale diagnostick te verrichten wanneer de aanstaande ouders alleen geinformeerd willen worden over het al dan niet aanwezig zijn van de erfelijke aanleg voor een ernstige onbehandelbare aandoening bij hun toekomstige kind en nict voornemens zijn om bij een ongunstige uitslag de vrucht te aborteren.

Een adviesvrager van zestien jaar of ouder heeft recht op informatie over een eerder bij hem verricht (prenataal) erfelijkheidsonderzoek. Tevens heeft hij een recht op inzage in de gegevens die over hem zijn vastgelegd.

\subsection{De geheimhoudingsplicht}

De geheimhoudingsplicht is onder meer geregeld in artikel 7:457 BW. De geheimhoudingsplicht zorgt ervoor dat de adviesvrager zich zonder vrees dat hij zichzelf daardoor zou schaden in verband met het moeten prijsgeven van gevoelige gegevens, tot een hulpverlener kan wenden. Door de geheimhoudingsplicht wordt de persoonlijke levenssfeer en het daarin besloten persoonlijk geheim van de

10 In de "Beleidsnota De toepassing van genetica in de gezondheidszorg" geeft de minister aan dat zij het pleidooi in de gezondheidsrechtelijke literatuur onderschrijft om kinderen vanaf 16 jaar het recht te geven zich te informeren omtrent het bestaan van op hen betrekking hebbende eerder verzamelde genetische gegevens. Zij geeft aan de beroepsgroep te vragen hiervoor nadere praktijkregels op te stellen. Ministerie van Volksgezondheid, Welzijn en Sport 2000, p. 40. Aldus ook Kamerstukken II 2001/02, 27 543 , nr. 5, p. 4. 
adviesvrager beschermd. De adviesvrager heeft er recht op dat zijn gegevens geheim worden gehouden.

De klinisch geneticus weet dat hij aan anderen geen inlichtingen over de adviesvrager mag verstrekken, tenzij de adviesvrager hiervoor toestemming geeft. Het is klinisch genetici echter niet steeds duidelijk of dit ook geldt wanneer voor een onderzoek ten behoeve van een adviesvrager gegevens van een familielid nodig zijn omtrent de aard en/of de locatie van een mutatie en de klinisch geneticus zelf reeds over deze gegevens beschikt omdat het familielid in het verleden bij dezelfde klinisch geneticus een erfelijkheidsonderzoek heeft laten verrichten. Er bestaat tevens onduidelijkheid omtrent de geheimhoudingsplicht wanneer een persoon overleden is. Soms wordt er ten onrechte vanuit gegaan dat voor het opvragen van gegevens van een overleden persoon toestemming moet worden gevraagd van een familielid. Klinisch genetici zijn dus niet steeds bekend met de gehele omvang van de geheimhoudingsplicht. Dit komt overeen met de evaluatie van de Wgbo. Daar bleek dat huisartsen en specialisten globaal op de hoogte zijn van artikel 7:457 Wgbo. Parate of detaillistische kennis over de exacte inhoud van de regeling is niet aanwezig. ${ }^{11}$

Klinisch genetici onderschrijven de uitgangspunten van de geheimhoudingsplicht. Familieleden worden niet zonder toestemming van de adviesvrager geïformeerd tenzij er in een conflict van plichten een hoger belang is. Bovendien wordt, gezien het belang dat aan de geheimhoudingsplicht wordt gehecht, het niet als een groot knelpunt ervaren dat men soms ten opzichte van de adviesvrager moet veinzen dat men de familie en de familiaire aandoening niet kent. Uit de evaluatie van de Wgbo komt hetzelfde beeld naar voren. Huisartsen en specialisten onderschrijven breed de norm van vertrouwelijkheid van medische gegevens. Het voldoen aan deze norm wordt veelal gezien als een bij het beroep horende plicht. ${ }^{12}$

Wat door klinisch genetici als een knelpunt wordt ervaren is de situatie waarin de geheimhoudingsplicht botst met de plicht en de drang van de klinisch geneticus om een adviesvrager op adequate manier te informeren. In een dergelijke situatie probeert men enerzijds niet op de situatie van een familielid in te gaan en anderzijds door een zorgvuldige woordkeuze de adviesvrager toch adequat te informeren.

\section{Conclusie}

De precieze inhoud en omvang van de geheimhoudingsplicht is klinisch genetici niet duidelijk. Ter bescherming van de persoonlijke levenssfeer van adviesvragers en het publieke belang van een goede gezondheidszorg, zouden klinisch genetici beter op de hoogte moeten zijn van de omvang van de geheimhoudingsplicht.

\footnotetext{
11 Dute 2000, p. 253.

12 Dute 2000, p. 253 en p. 289.
} 
Mogen familieleden worden ingelicht?

Eén van de specifieke kenmerken van erfelijkheidsinformatie is dat deze informatie, behalve voor de adviesvrager, ook van belang kan zijn voor bloedverwanten van de adviesvrager. Door middel van het aantonen van een erfelijke ziekte of een genetische afwijking die leidt of kan leiden tot een erfelijke ziekte, bij de adviesvrager of zijn nageslacht, kan het risico voor bloedverwanten op dezelfde erfelijke ziekte worden vastgesteld. Naast een mogelijk belang bij erfelijkheidsinformatie voor familieleden staat een mogelijk belang om niet te worden ingelicht. Daarom is de vraag gesteld of een klinisch geneticus überhaupt gerechtigd is om familieleden in te lichten. Uitgaande van de veronderstelling dat erfelijkheidsinformatie door veel mensen als voor hen relevante informatie zal worden beschouwd en dat zij op de hoogte willen worden gesteld van het feit dat er informatie beschikbaar is, is deze vraag bevestigend beantwoord. Mede gezien de toename van erfelijkheidsonderzoek naar multifactoriële aandoeningen en het plaatsvinden van dergelijk onderzoek buiten de klinisch genetische centra zal de vraag wanneer dit zou moeten gebeuren door de beroepsgroep moeten worden beantwoord door middel van richtlijnen. Het inlichten van familieleden dient door de adviesvrager zelf te gebeuren.

Het uitgangspunt dat de adviesvrager zelf de familieleden moet informeren wordt door klinisch genetici algemeen onderschreven. Zij geven aan dat adviesvragers meestal te overtuigen zijn van het belang dat familieleden kunnen hebben bij informatie over een mogelijk risico op een erfelijke aandoening. Er ontstaat echter een spanning tussen enerzijds het belang van familieleden bij die informatie en anderzijds de geheimhoudingsplicht van de klinisch geneticus wanneer de adviesvrager zijn familieleden niet wil inlichten of wanneer hij zegt dit te zullen doen, maar er twijfel ontstaat bij de klinisch geneticus of dit daadwerkelijk is gebeurd. Om het recht op geheimhouding van de adviesvrager niet te schenden, wordt soms veel moeite gedaan om de adviesvrager te motiveren zijn familieleden wel in te lichten. Dit gebeurt met name indien familieleden een groot risico lopen op een erfelijke aandoening waarvoor hen preventieve opties ter beschikking staan.

De adviesvrager wordt bij het informeren van zijn familieleden soms, al dan niet op zijn verzoek, door de klinisch geneticus geholpen door middel van een familiebrief. Bij het ongevraagd informeren van een familielid moet altijd het mogelijke belang bij informatie worden afgewogen tegen het belang dat het familielid kan hebben bij niet weten. Genetici geven aan dat het een inbreuk op de privacy is wanneer men ongevraagd wordt geinformeerd over erfelijkheidsrisico's. Deze tegenstrijdige belangen tonen het belang van een summiere inhoud van een familiebrief. De vraag echter of een familiebrief niet op zich al een schending is van het mogelijke belang bij niet weten, alsmede de vraag welke informatie wel en welke niet in een brief zou mogen staan, blijkt in de praktijk een knelpunt te zijn waarover de meningen uiteen lopen.

\section{Conclusie en annbeveling}

Het uitgangspunt dat de adviesvrager zelf zijn familieleden moet informeren wordt door klinisch genetici algemeen onderschreven. Over de vraag op welke wijze een klinisch geneticus hierbij behulpzaam kan zijn alsmede welke informatie wel en niet 
in een eventuele familiebrief behoort te staan bestaat, zoals opgemerkt, onder klinisch genetici geen eenstemmigheid. Van de klinisch geneticus kan, in de gevallen waarin hij met een familiebrief werkt, een zekere inspanning worden verwacht om de brief zo op te stellen dat de verstrekte informatie summier is en beperkt blijft tot de mededeling dat erfelijkheidsinformatie beschikbaar is over de familiaire aandoening. Indien een familielid in het geheel niet bekend is met de familiaire aandoening ligt het, in tegenstelling tot het gebruik van de meeste klinisch genetici om de betreffende aandoening te noemen, meer voor de hand om alleen mee te delen dat er erfelijkheidsinformatie beschikbaar is. Dit doet het meeste recht aan de privacy van de familieleden en hun recht op niet weten. Om meer eenstemmigheid te bereiken over de wijze waarop familieleden moeten worden benaderd en geïnformeerd, verdient het aanbeveling om over het informeren van familieleden een landelijke richtlijn op te stellen waarbij de persoonlijke levenssfeer van familieleden en hun recht op niet weten het uitgangspunt vormen. Bovendien zal gezien de toename van erfelijkheidsonderzoek naar multifactoriële aandoeningen en het plaatsvinden van dergelijk onderzoek buiten de klinisch genetische centra ook de vraag wanneer dit zou moeten gebeuren door de beroepsgroep moeten worden beantwoord.

\section{Hef conflict van plichten}

Ondanks het grote individuele en algemene belang van het beroepsgeheim is dit niet absoluut. Doorbreking ervan is onder meer mogelijk op grond van een conflict van plichten. Om een beroep te kunnen doen op het conflict van plichten dient aan de volgende criteria te zijn voldaan:

- redelijke inspanningen zijn verricht om toestemming van de adviesvrager te verkrijgen;

- door het handhaven van de geheimhoudingsplicht verkeert de klinisch geneticus in gewetensnood;

- er is geen andere weg om het probleem op te lossen dan via doorbreking van het geheim;

- het niet informeren van het betrokken familielid brengt een hoog risico op ernstige schade met zich mee en het is vrijwel zeker dat door het informeren die schade kan en zal worden voorkómen of beperkt;

- er wordt niet meer informatie verstrekt dan nodig is ter voorkoming van ernstige schade en ook voor het overige wordt de persoonlijke levenssfeer van de adviesvrager zo min mogelijk aangetast;

- de dreigende gezondheidsschade is op korte termijn te verwachten of op lange termijn met dien verstande dat het medisch gezien zinvol is om op korte termijn preventieve maatregelen te nemen;

- de adviesvrager wordt op de hoogte gesteld van het feit dat de klinisch geneticus zijn geheimhoudingsplicht gaat doorbreken.

Het informeren van een familielid zonder toestemming van de adviesvrager komt zelden voor. De redenen die klinisch genetici aangeven om een familielid zonder toestemming van de adviesvrager te informeren lijken overeen te komen met het criterium dat het niet informeren van het betrokken familielid een hoog risico op 
ernstige schade met zich meebrengt, welke schade kan en zal worden voorkomen of beperkt. Klinisch genetici die zich in een conflict van plichten hebben bevonden, geven aan hoe ingrijpend het voor familieleden kan zijn om hen zonder toestemming van de adviesvrager te benaderen. Ze zijn van mening dat informeren via de huisarts minder ingrijpend is omdat hij de familieleden kent. Bovendien doet zich het praktische probleem voor dat de klinisch geneticus geen adresgegevens heeft van familieleden. In hoofdstuk 7 is geconcludeerd dat bij een conflict van plichten de informatie niet aan meer personen mag worden verstrekt dan noodzakelijk is. De praktijk laat echter zien dat het informeren van andere personen soms om praktische redenen noodzakelijk is. In de evaluatie van de Wgbo wordt opgemerkt dat er behoefte lijkt aan meer zicht op de mogelijkheid om een beroep op het conflict van plichten te doen. ${ }^{1.3}$ In de praktijk van de erfelijkheidsadvisering bestaat deze behoefte niet, gezien het feit dat het informeren van een familielid zonder toestemming van de adviesvrager zelden voorkomt.

\section{Alternatieven voor het conflict van plichten?}

De vraag is besproken of er, gezien de structurele belangen van familieleden bij de erfelijkheidsinformatic waarover een adviesvrager beschikt, geschiktere alternatieven zijn voor het huidige conflict van plichten. Een wettelijke regeling ter vervanging van de constructie waarin de klinisch geneticus een beroep moet doen op een conflict van plichten is weinig aantrekkelijk. Conflicten van plichten zijn niet in wettelijke regels te vangen. Bovendien houdt formalisering het gevaar in zich dat de uitzondering regel wordt.

Een andere mogelijkheid om een conflict van plichten te vermijden is om de toegang tot erfelijkheidsonderzoek afhankelijk te maken van de bereidheid om familieleden over relevante informatie zo nodig in te lichten. De toegang tot de hulpverlening afhankelijk maken van de bereidheid om de belangen van familieleden te dienen, is echter in strijd met het recht op gezondheidszorg. Bovendien zou deze voorwaardelijke toegang adviesvragers af kunnen schrikken en daardoor contraproductief werken. Ook klinisch genetici zien niets in deze mogelijkheid.

Een laatste mogelijkheid die in de literatuur is geopperd, is om de geheimhoudingsplicht ten aanzien van familieleden van de adviesvrager niet van toepassing te laten zijn bij erfelijkheidsonderzoek. Erfelijkheidsinformatie is in deze opvatting een soort familiebezit. Er zijn verschillende bezwaren tegen deze opvatting. Ten eerste rechtvaardigt het belang bij erfelijkheidsinformatie geen dergelijke vérgaande inbreuk op het zelfbeschikkingsrecht, het recht op privacy alsmede het recht op geheimhouding. Ten tweede zou het opheffen van de geheimhoudingsplicht ten opzichte van familieleden van de adviesvrager tot een barrière kunnen leiden voor wat betreft het laten verrichten van een erfelijkheidsonderzoek. Ten slotte is er het gevaar dat door toedoen van familieleden gegevens van de adviesvrager ook buiten de familiekring bekend worden. 
De situatie waarin er ten behoeve van de adviesvrager geen erfelijkheidsonderzoek kan worden verricht, ondat de vereiste medewerking van een familielid ontbreekt.

In hoofdstuk 7 is tevens de situatie aan de orde geweest warin ten behoeve van de adviesvrager geen erfelijkheidsonderzoek kan worden verricht, en dus geen diagnose kan worden gesteld, omdat de vereiste medewerking van een familielid ontbreekt. Onderzocht is of in het geval er sprake is van een conflict van plichten dezelfde criteria kumnen worden gehanteerd als in de situatie waarin een klinisch geneticus familieleden van de adviesvrager niet in kan lichten omtrent hun risico op een erfelijke aandoening. Geconcludeerd is dat de eis dat het niet informeren van het betrokken familielid een hoog risico op ernstige schade met zich meebrengt en dat het vrijwel zeker is dat door het informeren die schade kan worden voorkómen of beperkt, in deze situatie niet toepasbaar is. Daarom is het volgende criterium voorgesteld: het niet informeren van de adviesvrager leidt ertoe dat de resterende mogelijkheden voor hem om het risico op een erfelijke aandoening te reduceren in een onredelijke verhouding staan tot de schending van de privacy van het familielid door voor erfelijkheidsonderzoek gebruik te maken van de specifieke mutatie die bij het familielid is angetoond.

Niet alle genetici zijn van mening dat de geheimhoudingsplicht wordt geschonden wanneer zonder toestemming van het familielid gebruik wordt gemaakt van de informatie omtrent de aard en/of de locatie van een mutatie. Op dit punt lopen recht en praktijk enigszins uiteen.

\section{De geheimhoudingsplicht na de dood}

De geheimhoudingsplicht van de klinisch geneticus geldt ook na het overlijden van de adviesvrager. Een uitzondering op de geheimhoudingsplicht is aanwezig wanneer de adviesvrager, bij leven uiteraard, toestemming heeft gegeven voor het verstrekken van zijn gegevens. Wanneer deze toestemming niet is gevraagd, maar voor bloedverwanten een dringend belang in het geding is, dan is er geen andere weg dan het werken met de juridische fictie dat de overleden adviesvrager in het belang van zijn familieleden toestemming zou hebben willen geven, tenzij anders moet worden aangenomen.

Onder de meeste klinisch genetici leeft de overtuiging dat nabestaanden toestemming moeten geven alvorens de gegevens van de overledene kunnen worden opgevraagd. Om die reden wordt voor het opvragen van gegevens van een overledene veelal toestemming gevraagd aan zijn nabestaanden. Hierbij doen zich situaties voor die klinisch genetici als een knelpunt ervaren, terwijl dit knelpunt er vanuit een juridisch perspectief niet is. Een voorbeeld is de situatie waarin nabestaanden niet of alleen met heel veel moeite getraceerd kunnen worden.

In de Wgbo-evaluatie wordt opgemerkt dat de ontwikkeling van richtlijnen gewenst lijkt waar het verzoeken om gegevensverstrekking betreft nadat de patiënt overleden is: 
"Niet altijd is duidelijk, wanneer in zulke gevallen op veronderstelde toestemming kan worden teruggevallen, resp. in hoeverre er ruimte is voor een belangenafweging los van het concept van veronderstelde toestemming." ${ }^{14}$ De verdere ontwikkeling van richtlijnen wordt daarom aanbevolen. ${ }^{1.5}$

Voor de praktijk van de erfelijkheidsadvisering is hier geen aanleiding voor. Indien de adviesvrager bij leven geen toestemming is gevraagd voor het opvragen van gegevens, kan, indien er een dringend belang is voor familieleden, de toestemming in beginsel worden verondersteld. Indien anders moet worden aangenomen, bevindt de klinisch geneticus zich in een conflict van plichten.

\section{Conclusie en aanbeveling}

Het conflict van plichten maakt het mogelijk de geheimhoudingsplicht te doorbreken. Een geschikt juridisch alternatief voor het conflict van plichten is er niet. Dit is echter niet problematisch, gezien het feit dat in de praktijk nauwelijks gebruik wordt gemaakt van deze juridische figuur. Bovendien lijken de redenen die klinisch genetici aangeven om een familielid zonder toestemming van de adviesvrager te informeren overeen te komen met het criterium dat het niet informeren van het betrokken familielid een hoog risico op ernstige schade met zich meebrengt, welke schade kan worden voorkomen of beperkt. Niet alle klinisch genetici zijn echter van mening dat de geheimhoudingsplicht wordt geschonden wanneer zonder toestemming van het familielid gebruik wordt gemaakt van zijn informatie. Het zonder toestemming van een familielid gebruik maken van zijn gegevens valt wel degelijk onder de geheimhoudingsplicht. Eerder in deze paragraaf is reeds opgemerkt dat klinisch genetici beter op de hoogte zouden moeten zijn van de onvang van de geheimhoudingsplicht.

In de erfelijkheidsrichtlijnen is de geheimhoudingsplicht als volgt uitgewerkt:

"Ieder heeft het recht zelf te beslissen of zijn erfelijkheidsgegevens en lichaamsmateriaal worden verstrekt aan anderen dan degenen die beroepsmatig rechtstreeks bij het aktuele erfelijkheidsonderzoek zijn betrokken."

"Als de arts vindt dat bepaalde informatie aan familieleden niet onthouden kan worden, bespreekt hij dit met de cliënt. Hij verzoekt de cliënt de betrokken familicleden te informeren. Als de cliënt de arts vraagt dit voor hem te doen, voldoet de arts aan dat verzoek."

"Als de cliënt de betrokken familieleden zelf niet wil informeren en ook aan de arts geen toestemming geeft om dat te doen, mag de arts alleen in de volgende situatie tot informeren overgaan:

- alles is geprobeerd om toestemming van de cliënt te krijgen,

- de arts verkeert in gewetensnood door te zwijgen,

- er is geen andere weg om het probleem op te lossen,

- het niet-informeren levert voor het betrokken familielid ernstige schade op, en

$14 \quad$ Dute 2000, p. 287.

15 Dute 2000, p. 292. 
- het is vrijwel zeker dat door het informeren die schade kan worden voorkómen of beperkt."

Op basis van de resultaten van dit onderzoek stel ik het volgende artikel voor:

De klinisch geneticus draagt er zorg voor, dat aan anderen dan de adviesvrager geen inlichtingen over de adviesvrager worden verstrekt dan met toestemming van de adviesvrager. Indien verstrekking plaatsvindt, geschiedt deze slechts voor zover daardoor de persoonlijke levenssfeer van een ander niet wordt geschaad. Onder anderen dan de adviesvrager zijn niet begrepen degenen die rechtstreeks betrokken zijn bij de uitvoering van de behandelingsovereenkomst en degene die optreedt als vervanger van de hulpverlener, voor zover de verstrekking noodzakelijk is voor de door hen in dat kader te verrichten werkzaamheden.

Indien de klinisch geneticus vindt dat bepaalde erfelijkheidsinformatie niet aan familieleden onthouden kan worden, bespreekt hij dit met de adviesvrager. Dit doet hij in een zo vroeg mogelijk stadium van de erfelijkheidsadvisering. Hij verzoekt de adviesvrager zelf zijn familieleden te informeren. Op verzoek van de adviesvrager kan de klinisch geneticus hem hierbij ondersteunen.

Indien de adviesvrager de desbetreffende familieleden zelf niet wil informeren en ook aan de klinisch geneticus geen toestemming geeft om dat te doen, mag de klinisch geneticus alleen in de volgende situatie tot informeren overgaan:

- redelijke inspanningen zijn verricht om toestemming van de adviesvrager te verkrijgen;

- door het handhaven van de geheimhoudingsplicht verkeert de klinisch geneticus in gewetensnood;

- er is geen andere weg om het probleem op te lossen dan via doorbreking van het geheim;

- het niet informeren van het betrokken familielid brengt een hoog risico op ernstige schade met zich mee en het is vrijwel zeker dat door het informeren die schade kan en zal worden voorkómen of beperkt;

- er wordt niet meer informatie verstrekt dan nodig is ter voorkoming van ernstige schade en ook voor het overige wordt de persoonlijke levenssfeer van de adviesvrager zo min mogelijk aangetast;

- de dreigende gezondheidsschade is op korte termijn te verwachten of op lange termijn met dien verstande dat het medisch gezien zinvol is om op korte termijn preventieve maatregelen te nemen;

- de adviesvrager wordt op de hoogte gesteld van het feit dat de klinisch geneticus zijn geheimhoudingsplicht gaat doorbreken.

Indien ten behoeve van de adviesvrager geen erfelijkheidsonderzoek kan worden verricht, en er dus geen diagnose kan worden gesteld omdat de vereiste medewerking van een familielid ontbreekt, dient het vierde criterium te worden vervangen door het volgende criterium:

- het niet informeren van de adviesvrager leidt ertoe dat de resterende mogelijkheden voor hem om het risico op een erfelijke aandoening te reduceren in een onredelijke verhouding staan tot de schending van de privacy van het familielid door voor erfelijkheidsonderzoek gebruik te maken van de mutatie die bij het familielid is aangetoond. 
Indien gegevens worden opgevraagd van een overleden adviesvrager, verstrekt de klinisch geneticus deze wanneer de adviesvrager, bij leven, toestemming heeft gegeven voor het verstrekken van zijn gegevens. Wanneer dece toestemming niet is gevraagd, maar er voor bloedverwanten cen dringend belang in het geding is, dan mag de klinisch geneticus ervan uitgaan dat de overleden adviesvrager in het belang van zijn familieleden toestemming zou hebben willen geven, tenzij anders moet worden aangenomen.

\subsection{De Wgbo of een status aparte voor de overeenkomst tussen klinisch geneticus en adviesvrager?}

In de inleiding is de vraag gesteld of de Wgbo een geschikt juridisch kader is voor de relatie tussen de klinisch geneticus en de adviesvrager of dat deze relatie een aparte juridische status vereist. Deze vraag kan nu op grond van het voorgaande als volgt worden beantwoord.

Aan de informatieplicht van de klinisch geneticus kunnen hoge eisen worden gesteld. In artikel 7:448 lid 1 en 2 BW is het recht op informatie echter adequat geregeld. Uit de algemene formulering van artikel 7:448 lid 1 en 2 BW kan de plicht voor klinisch genetici worden afgeleid om te informeren over de kenmerken van erfelijkheidsonderzoek, zoals het feit dat een erfelijkheidsonderzoek van belang kan zijn voor familieleden van de adviesvrager, alsmede het feit dat een erfelijkheidsonderzoek grote gevolgen kan hebben voor de adviesvrager.

Voor de therapeutische exceptie is bij erfelijkheidsadvisering weinig ruimte. Er is echter geen aanleiding deze bepaling niet van toepassing te laten zijn op de behandelingsovereenkomst tussen de klinisch geneticus en de adviesvrager.

Het toestemmingsvereiste uit artikel 7:450 lid $1 \mathrm{BW}$ is eenduidig: voor verrichtingen ter uitvoering van een behandelingsovereenkomst is de toestemming van de patiënt vereist. De uitwerking die hieraan in paragraaf 11.2 .4 is gegeven, te weten het eerst bij een gesprek toestemming vragen voor het opvragen van gegevens en het vragen van toestemming voor het mededelen van een uitslag indien het erfelijkheidsonderzoek geruime tijd in beslag heeft genomen, is afgeleid uit het feit dat een adviesvrager alleen na adequate informatie een rechtsgeldige toestemming kan geven.

Het recht op niet weten, zoals dat in artikel 7:449 BW is geregeld, is ook geschikt voor de relatie tussen de klinisch geneticus en de adviesvrager. Het is bij de erfelijkheidsadvisering wel van belang dat de klinisch geneticus de adviesvrager op dit recht wijst, zodat deze hiervan op de hoogte is.

Het belang van het (jonge) kind bij niet weten wordt in de Wgbo voldoende beschermd door enerzijds de eis in artikel 7:465 lid 5 BW dat ouders gehouden zijn jegens hun kind de zorg van goede vertegenwoordigers te betrachten. Anderzijds 
door artikel 7:465 lid 4 BW, waarin is geregeld dat de hulpverlener zijn verplichtingen jegens de wettelijke vertegenwoordigers van de patiënt niet hoeft na te komen wanneer deze nakoming niet verenigbaar is met de zorg van een goed hulpverlener.

In de Wgbo is niets geregeld over het te beschermen belang van het ongeboren kind om in de toekomst verschoond te blijven van informatie omtrent dragerschap van een recessieve mutatie of een gebalanceerde translocatie. De Wgbo is hiervoor ook niet het geschikte kader. De Wgbo stipuleert rechten en plichten van hulpverleners en patiënten. Het ongeboren kind is geen rechtssubject. Het voorgestelde artikel voor de nieuwe erfelijkheidsrichtlijnen kan de belangen van het ongeboren kind wel beschermen.

Het informatie- en inzagerecht voor adviesvragers van zestien jaar of ouder, bij wie eerder een (prenataal) erfelijkheidsonderzoek is verricht, alsmede de informatieplicht van de klinisch geneticus, zou, gezien de afdwingbaarheid van een wettelijke regeling, in de $\mathrm{Wgbo}$ vastgelegd moeten worden.

De Wgbo regelt de geheimhoudingsplicht in artikel 7:457 BW. Deze regeling voldoet tevens voor de erfelijkheidsadvisering. De voor de erfelijkheidsadvisering uitgewerkte criteria die bij een conflict van plichten gehanteerd dienen te worden zijn opgenomen in de voorgestelde modelbepaling.

De uitwerking in de voorgestelde modelbepaling betreffende het opvragen van gegevens van een overleden adviesvrager is een toespitsing op de erfelijkheidsadvisering van de algemene, niet in de Wgbo geregelde, doctrine.

\section{Conclusie}

De Wgbo is, indien het recht op informatie, de therapeutische exceptie, het toestemmingsvereiste, het recht op niet weten en de geheimhoudingsplicht op een adequate en verantwoorde wijze worden geinterpreteerd en toegepast, als algemeen juridisch kader ook geschikt voor de behandelingsovereenkomst tussen de klinisch geneticus en de adviesvrager. De voorgestelde richtlijnen zijn bedoeld als nadere invulling van de genoemde rechten en plichten uit de Wgbo voor de praktijk van de erfelijkheidsadvisering.

Het adequaat en verantwoord interpreteren en toepassen van het juridisch kader legt wel een grote verantwoordelijkheid op de schouders van de individuele klinisch geneticus. Het juridisch kader is, ook als het is aangevuld met richtlijnen, globaal van karakter. In veel situaties is de zorg van een goed hulpverlener het enige juridische houvast voor de klinisch geneticus. In dergelijke situaties zijn het met name de sensibiliteit en de ervaring van de klinisch geneticus die de invulling van het goed hulpverlenerschap vorm geven. Klinisch genetische centra werken ook met protocollen. Zo is voor bepaalde aandoeningen uitgewerkt welke informatie wordt gegeven en welke procedure wordt gevolgd. Ook zijn er protocollen voor een bepaald type vragen, zoals vragen naar voorspellend onderzoek bij de adviesvrager 
zelf. Ook deze protocollen laten echter onverlet dat in veel situaties de klinisch geneticus bij de vraag hoe te handelen aangewezen is op zijn sensibiliteit en ervaring.

Overigens geven klinisch genetici er blijk van zich bewust te zijn van het belang van patiëntenrechten. Met name het belang van het recht op informatie, het toestemmingsvereiste, het recht op niet weten en het recht op geheimhouding worden onderkend. Dit bewustzijn bleek uit de kritische houding van klinisch genetici ten opzichte van hun vak, uit de wijze waarop genoemde rechten vorm krijgen in de praktijk, alsmede uit de wijze waarop hierover wordt gedacht. Dit doet vermoeden dat de praktijk van de erfelijkheidsadvisering model kan staan voor de wijze waarop in de praktijk met patiëntenrechten dient te worden omgegaan.

De conclusie uit het voorafgaande luidt dat de Wgbo, indien het recht op informatie, de therapeutische exceptie, het toestemmingsvereiste, het recht op niet weten en de geheimhoudingsplicht op een adequate en verantwoorde wijze worden geïnterpreteerd en toegepast, als algemeen juridisch kader ook geschikt is voor de behandelingsovereenkomst tussen de klinisch geneticus en de adviesvrager. Dit komt overeen met de functie van de wet. In de Memorie van Toelichting is destijds aangegeven dat slechts enkele centrale elementen van de relatie patiënt-hulpverlener in de wet zijn vastgelegd, hetgeen een nadere invulling door betrokken partijen impliceert. De rechten en plichten zijn abstract geformuleerd. Onderkend wordt dat er een zekere behoefte bestaat aan standaardisering in welke behoefte kan worden voorzien door richtlijnen. ${ }^{16}$ De hierboven voorgestelde richtlijnen zouden in deze behoefte kumnen voorzien. ${ }^{17}$

\subsection{Erfelijkheidsadvisering in de toekomst}

Erfelijkheidsadvisering in de klinisch genetische centra was het onderwerp van dit onderzoek. In hoofdstuk 1 is opgemerkt dat erfelijkheidsinformatie een aantal specifieke kenmerken heeft, waardoor de relatie adviesvrager-klinisch geneticus in enkele opzichten afwijkt van de reguliere patiënt-hulpverlener relatie. De volgende kenmerken zijn daarbij genoemd. Ten eerste dat voor het verwerven van gegevens in het kader van erfelijkheidsonderzoek vaak informatie over bloed-en aanverwanten

Kamerstukken II 1989/90, 21561, nr. 3, p. 8.

17 Markenstein, Gevers en Roscam Abbing stellen bovendien dat regulering op het terrein van vroege opsporing, en dus ook op het terrein van voorspellend erfelijkheidsonderzoek, primair zal moeten plaatsvinden via algemene regelgeving. Hiervoor worden twee argumenten gegeven. Ten eerste zal de kwaliteit van de rechtsbescherming die kan worden geboden eerst en voornamelijk afhangen van de kwaliteit van de gezondheidswetgeving in algemene $z$ in. Dit omdat vroege opsporing zich maar gedeeltelijk laat losmaken uit de reguliere hulpverlening. Ten tweede wordt gewezen op het feit dat wanneer nieuwe technologieën nieuwe uitdagingen met zich mee brengen, het doorgaans doelmatiger is te investeren in een betere toepassing of aanpassing van algemene regelgeving dan het tot stand brengen van specifieke regelingeving op ad hoc basis. Markenstein, Gevers en Roscam Abbing 1999, p. 89. Zie ook Gevers 2001, p. 12-18. 
is vereist. Ten tweede dat erfelijkheidsinformatie niet alleen van belang kan zijn voor de adviesvrager zelf, maar ook voor zijn bloed- en aanverwanten. Ten derde dat erfelijkheidsinformatie een duurzaam en (althans gedurende een aantal generaties) vaak onveranderlijk karakter heeft. Ten vierde dat erfelijkheidsinformatie een voorspellende waarde heeft. Dit onveranderlijke karakter en de voorspellende waarde van erfelijkheidsinformatie kunnen grote gevolgen hebben voor het leven van de adviesvrager en diens naasten.

Deze kenmerken hebben niet geleid tot de conclusie dat voor de behandelingsovereenkomst tussen een klinisch geneticus en een adviesvrager een separaat juridisch kader moet worden gevormd. Wel is het recht op informatie, de therapeutische exceptie, het toestemmingsvereiste, het recht op niet weten en de geheimhoudingsplicht uitgewerkt in richtlijnen voor de erfelijkheidsadvisering in de klinische genetica. Is dit kader echter ook geschikt om in de nabije toekomst de erfelijkheidsadvisering te reguleren?

De geneeskunde lijkt op weg naar een nieuw paradigma: van een klinische curatieve geneeskunde naar een voorspellende geneeskunde, waarin de geneeskunde meer een proces wordt van het genereren van individuele gezondheidsinformatie. Hierbij zullen medische interventies vaker bestaan uit het verrichten van onderzoek bij gezonde personen, gevolgd door een advies op basis van individuele risicofactoren. Advisering neemt dan de plaats in van behandeling. ${ }^{18}$

Door de toenemende mogelijkheden tot vroege opsporing van erfelijk bepaalde risicofactoren zal in de toekomst waarschijnlijk veel informatie gegenereerd kunnen worden over verhoogde risico's op het krijgen van meer gangbare aandoeningen. Dit in tegenstelling tot de meer zeldzame, monogene ziekten waarvan ook voor de ontwikkelingen van DNA-diagnostiek het erfelijk karakter bekend was door het familiair voorkomen ervan. ${ }^{19}$ Juridisch is hierbij de vraag belangrijk hoe deze toenemende technologische mogelijkheden zullen worden gereguleerd. Welke rol moet bijvoorbeeld de medisch-professionele standaard hierbij spelen?20 De huidige organisatie van de DNA-diagnostiek is niet voldoende toegesneden op de toenemende vraag en het zich uitbreidende indicatiegebied met alle consequenties die dit met zich meebrengt voor behandeling en preventie. De klinisch genetische centra kunnen zowel kwantitatief als kwalitatief in de toekomst niet aan deze vraag voldoen, aldus de Commissie DNA-diagnostiek van de Gezondheidsraad. De Commissie concludeert dat het DNA-onderzoek bij algemeen voorkomende multifactoriële ziekten meer ingebed zal moeten worden in de klinische praktijk, waar ook de indicatiestelling, de behandeling en de follow-up plaatsvindt. ${ }^{21} \mathrm{Naast}$ de verwachte toenemende vraag naar DNA-diagnostiek, zal volgens de minister ook het feit dat mede dankzij de informatietechnologie veel klinisch genetisch onderzoek

18 Gevers 1999, p. 36. Zie ook Dute 2000, p. 35.

19 Gevers 2001, p. 16. Zie ook Galjaard 1997, p. 2432-2437.

20 Gevers 2001, p. 16. Gevers wijst ook op de rol van de ziektekostenwetgeving en de wetgeving inzake bijzondere medische verrichtingen. 
vereenvoudigd zal kunnen worden, ertoe bijdragen dat in de toekomst meer klinisch genetisch onderzoek buiten de klinisch genetische centra en buiten de academische ziekenhuizen plaatsvindt.22 De Commissie DNA-diagnostiek en de minister verwachten verder dat de eerstelijns gezondheidszorg geconfronteerd zal worden met vele vragen van patiënten en gezonde personen omtrent hum erfelijke risico's en de consequenties daarvan. De advisering hierover zal in veel gevallen tot de taak van de huisartsen of speciaal opgeleide paramedici gaan behoren. ${ }^{23}$

De vraag of het juridisch kader ook geschikt zal zijn voor toepassing buiten de klinisch genetische centra, laat zich moeilijk op voorhand beantwoorden. De hiervoor aangestipte veranderingen zullen zich voordoen binnen de context van de medische hulpverlening. Of het juridisch kader ook in de toekomst geschikt zal zijn hangt mede af van ontwikkelingen in de maatschappelijke en juridische context. Voor wat betreft de maatschappelijke context kan gedacht worden aan een verzakelijking van de zorgverlening, demografische veranderingen, assertievere, beter geinformeerde hulpvragers en aan veranderende opvattingen, bijvoorbeeld over het belang van privacy tegenover het belang om geïnformeerd te worden over erfelijkheidsrisico's. Bij ontwikkelingen in de juridische context kan gedacht worden aan het ontstaan van een claimcultuur. Wellicht wordt in de toekomst in het recht een algemene waarschuwingsplicht aangenomen van een hulpverlener jegens familieleden van een adviesvrager. ${ }^{2 \cdot 4}$

Het recht op informatie, de therapeutische exceptie, het toestemmingsvereiste, het recht op niet weten en de geheimhoudingsplicht zijn essentiële patiëntenrechten die alle zijn af te leiden uit het zelfbeschikkingsrecht. Deze rechten zullen ook toekomstige hulpverleningsrelaties reguleren. De interpretatie en de toepassing

22 Ministerie van Volksgezondheid, Welzijn en Sport 2000, p. 51.

23 Gezondheidsraad 1998, p. 134, Ministeric van Volksgezondheid, Welzijn en Sport 2000, p. 51 . In cen brief aan de Tweede Kamer heeft de minister aangegeven dat een nicuwe taakverdeling zal worden opgenomen in het nieuwe planningsbesluit dat in mei 2002 gereed moet zijn. In haar visie, en dit is tevens de visie van de Gezondheidsraad, zou dit kunnen gebeuren "binnen een netwerk, waarbinnen de vergunninghoudende academische ziekenhuizen als kenniscentra een centrale plaats innemen en waarbij andere ziekenhuizen en laboratoria op basis van heldere afspraken over werkwijze, protocol en indicatiestelling nauw met die kenniscentra samenwerken. (...) Binnen en buiten de academische ziekenhuizen zal de toepassing van het klinisch genetisch onderzock en erfelijkheidsadvisering (inclusief het voor en natraject) dienen plaats te vinden op basis van landelijke richtlijnen en protocollen, kwaliteitsboeken e.d." Kamerstukken II 2001/02, 27 543, nr. 5, p. 7.

24 Dute 2000, p. 34-35. De Stichting Toekomstscenario's Gezondheidszorg heeft voor wat betreft voorspellende geneeskunde een viertal toekomstscenario's ontworpen. In elk van deze scenario's wordt een beeld van de mogelijke situatie in het jaar 2010 geschetst, waarbij zowel voor de maatschappij als geheel als voor de gezondheidszorg sociale, culturele, economische en ethische aspecten aan bod komen. Met name de snelheid van de technologische ontwikkelingen alsmede de mate waarin burgers gebruik zullen willen maken van kennis over gezondheidsrisico's zullen volgens de Stichting bepalend zijn voor de situatie in 2010.Stichting Toekomstscenario's Gezondheidszorg 1999. 
ervan zullen waarschijnlijk wel veranderen. Het groeiend vermogen om gezondheidsrisico's te identificeren zal betekenen dat de informatieplicht van de hulpverlener zich in de toekomst meer zal concentreren op het omschrijven van risico's en het adviseren over preventieve maatregelen dan op het informeren over aard en doel van een behandeling. Dit betekent dat de nadruk meer op de bescherming van het recht op respect voor een persoonlijke levenssfeer dan op de bescherming van de lichamelijke integriteit zal komen te liggen. Het recht op niet weten zal bij onderzoek naar de aanwezigheid van risicofactoren naar verwachting een meer prominente plaats krijgen. Het stelt de adviesvrager voor de vraag of hij daadwerkelijk wil weten of hij een verhoogd risico heeft op één of bepaalde aandoeningen. Voor de veronderstelde toestemming is bij dergelijke afwegingen geen plaats. Het belang van de geheimhoudingsplicht ten slotte, wordt algemeen onderschreven. Het privacybelang dat hiermee gediend wordt, moet echter steeds afgewogen worden tegen het belang van het verstrekken van informatie aan anderen dan de adviesvrager. Het is de vraag hoe dit belang in de toekomst zal worden gewogen wanneer een erfelijkheidsonderzoek, meer nog dan nu, informatie genereert over gezondheidsrisico's van bloedverwanten van de adviesvrager. In de toekomst zal moeten blijken of ook in hulpverleningsrelaties dezelfde zorgvuldigheid zal worden toegepast als in de klinisch genetische centra.

Eén ding kan met zekerheid gesteld worden: het in acht nemen van de zorg van een goed hulpverlener is in de praktijk van de erfelijkheidsadvisering elke dag opnieuw een uitdaging. Het juridisch kader, bestaande uit het recht op informatie, de therapeutische exceptie, het toestemmingsvereiste, het recht op niet weten en de geheimhoudingsplicht, die geregeld zijn in de Wgbo en in- en aangevuld worden in een voorgestelde modelregeling, kan alleen in abstractie vormgeven aan de relatie tussen een klinisch geneticus en een adviesvrager. Zij zullen hier samen op basis van onderling vertrouwen concreet invulling aan moeten geven. 



\section{INFORMATIE, TOESTEMMING EN GEHEIMHOUDING BIJ ERFELIJKHEIDSADVISERING. EEN GEZONDHEIDSRECHTELIJK ONDERZOEK}

\section{Samenvatting}

In hoofdstuk 1 is het onderwerp van deze studie verkend. De centrale vraag van deze studie is: wat is het gewenste juridisch kader voor informatie, toestemming en geheimhouding bij erfelijkheidsadvisering in de klinisch genetische centra? Het gaat er in deze studie om een kader uit te werken waarin de toepassing van genetische kennis door de klinisch geneticus gestalte kan krijgen. Om hiertoe te kunnen komen twee deelvragen aan de orde, te weten:

- wat is het juridisch kader inzake informatie, toestemming en geheimhouding bij erfelijkheidsadvisering in de klinische genetische centra?

- hoe wordt in de praktijk van de erfelijkheidsadvisering binnen de klinisch genetische centra met (knelpunten en dilemma's rond) informatie, toestemming en geheimhouding omgegaan?

Het doel van deze studic is om een bijdrage te leveren aan verantwoorde zorg in de klinisch genetische centra. Voor klinisch genetici zou de winst kunnen zijn dat er meer duidelijkheid is in de vorm van een op hum situatie toegesneden invulling van de algemene verplichtingen voor hulpverleners zoals deze zijn neergelegd in de Wgbo. Voor adviesvragers kan meer duidelijkheid voor de hulpverlening een patiëntvriendelijkere zorgverlening bewerkstelligen. Het nader uitwerken en toespitsen van de behandelingsovereenkomst tussen klinisch genetici en adviesvragers bevordert bovendien de rechtsgelijkheid en rechtszekerheid. Het kan wellicht mede dienen als voorbeeld voor vergelijkbare hulpverleningssituaties.

In hoofdstuk 2 zijn de in dit onderzoek gehanteerde uitgangspunten en methoden verantwoord. De uitgangspunten van het juridisch betoog en de wijze waarop dit zich verhoudt tot het empirisch onderzoek zijn beschreven. Verder is ingegaan op de wijze waarop het empirisch onderzoek is uitgevoerd. Ten eerste is de keus voor kwalitatief onderzoek verantwoord. Ten tweede is de dataverzameling aan de orde geweest. In subparagrafen is aangegeven hoe de interviews en observatie zijn opgezet. Ten derde is de reikwijdte en representativiteit van het empirisch onderzoek beschreven. Ten slotte is ingegaan op de analyse van de verzamelde data.

In hoofdstuk 3 is het zelfbeschikkingsrecht van de adviesvrager aan de orde. Het wordt gezien als een rechtsbeginsel dat ten grondslag ligt aan het patiëntenrecht. Kenmerkend voor een rechtsbeginsel is dat de precieze inhoud niet exact is aan te geven, dat deze in de tijd verandert en afhangt van de omstandigheden. Wel zijn er grenzen aan te stellen. Met name het feit dat het zelfbeschikkingsrecht van de adviesvrager wordt begrensd door hetzelfde recht van zijn verwanten is voor de erfelijkheidsadvisering van belang. Of en wanneer een inbreuk op het zelfbeschikkingsrecht van een adviesvrager toelaatbaar is, is afhankelijk van 
verschillende factoren. Een belangrijke factor daarbij is de kans dat de erfelijke aandoening tot gezondheidsschade zal leiden alsmede de mogelijkheden om deze schade te voorkómen of te reduceren. In dit hoofdstuk is ook aandacht besteed aan de bredere maatschappelijke context waarin adviesvragers hun zelfbeschikkingsrecht uitoefenen. De klinisch geneticus dient zich van deze context bewust te zijn, zodat hij de adviesvrager zo goed mogelijk kan begeleiden bij het maken van een keuze om een erfelijkheidsonderzoek te ondergaan en eventueel bij het interpreteren van de uitslag daarvan.

In hoofdstuk 4 is het goed hulpverlenerschap, het recht op informatie, de therapeutische exceptie, het beginsel van de non-directieve erfelijkheidsadvisering en het toestemmingsvereiste besproken. Het goed hulpverlenerschap is éen van de kernbepalingen van de Wgbo. Het in acht nemen van de zorg van een goed hulpverlener is een algemene formulering die in concrete situaties invulling behoeft.

Het recht op informatie is geregeld in artikel 448 lid 1 en 2 BW. Een adviesvrager dient op basis van de verstrekte informatie een weloverwogen besluit te kunnen nemen ten aanzien van het eventueel ondergaan van een crfelijkheidsonderzoek. Erfelijkheidsonderzoek kan bestaan uit diagnostisch en uit voorspellend onderzoek. Voorspellend erfelijkheidsonderzoek is geen medisch noodzakelijk onderzoek. Het voorspellende karakter ervan dient te worden benadrukt omdat juist dit karakter het ondergaan van dergelijk onderzoek minder vanzelfsprekend maakt. Uit de jurisprudentie blijkt dat bij medisch niet-noodzakelijk onderzoek hoge eisen worden gesteld aan de informatieplicht. Daarnaast rechtvaardigen de voorspellende aard van het onderzoek en de mogelijke gevolgen van het onderzoek voor zowel de adviesvrager als zijn familieleden het stellen van hoge eisen aan de informatieplicht bij de erfelijkheidsadvisering over voorspellend onderzoek. De klinisch geneticus is verplicht om de mogelijkheid van onverwachte bevindingen aan de orde te stellen, alvorens een erfelijkheidsonderzoek wordt verricht. Het is daarom van groot belang om voorafgaand aan een erfelijkheidsonderzoek zo duidelijk mogelijke afspraken te maken over de vraag of en hoe eventuele onverwachte bevindingen meegedeeld zullen worden.

Artikel 7:448 lid 3 BW regelt de therapeutische exceptie. Deze uitzondering op de informatieplicht zal niet snel aan de orde zijn wanneer de mogelijke bevindingen en gevolgen van een erfelijkheidsonderzoek met de adviesvrager uitvoerig zijn doorgenomen en er sprake is van een weloverwogen besluit om een erfelijkheidsonderzoek te ondergaan. Dit ligt anders bij onverwachte bevindingen. Indien de klinisch geneticus in het geval van onverwachte bevindingen gegronde redenen heeft om aan te nemen dat de gevonden informatie kennelijk ernstig nadeel voor de adviesvrager op zou leveren, is er ruimte om de therapeutische exceptie toe te passen. Het is voorts van belang een onderscheid te maken tussen enerzijds de toepassing van de therapeutische exceptie en het gedoseerd en gefaseerd informeren. Het goed hulpverlenerschap vereist dat relevante informatie op het juiste tijdstip aan de adviesvrager wordt verstrekt, zodat hij de informatie begrijpt. 
Het uitgangspunt van de erfelijkheidsadvisering is dat deze non-directief van aard is. Het moral education model van Arras is verdedigd. Dit model, waarbij de morele aspecten van de verschillende keuzemogelijkheden die een adviesvrager heeft door de greneticus aan de orde worden gesteld, maar de keuze aan de adviesvrager is, doet het meeste recht aan het doel van de erfelijkheidsadvisering, te weten de adviesvrager een geïformeerde en weloverwogen keuze te laten maken die het beste bij hem past. Het recht op informatie is hiermee niet beperkt tot alleen de medisch-genetische informatie, zonder dat de eis van non-directieve erfelijkheidsadvisering wordt verlaten. De keuze is immers nog altijd aan de adviesvrager.

Ten slotte is het toestemmingsvereiste besproken. Voor verrichtingen ter uitvoering van de behandelingsovereenkomst is de toestemming van de adviesvrager vereist. Voor de veronderstelde toestemming van de adviesvrager is bij de erfelijkheidsadvisering geen ruimte.

In hoofdstuk 5 is het recht op weten behandeld. Bekeken is of, en zo ja, in welke omstandigheden, er sprake kan zijn van een recht om kennis te vergaren betreffende de eigen genetische constitutie. Het betreft daarbij zowel het recht om informatie betreffende de genetische constitutie door middel van het ondergaan van een erfelijkheidsonderzoek te vergaren als het recht op kennisname van reeds bestaande informatie waarover een ander dan de hulpverlener in het kader van de behandelingsovereenkomst beschikt. Voor wat betreft het recht om informatie betreffende de genetische constitutie door middel van het ondergaan van een erfelijkheidsonderzoek te vergaren, is het is niet aannemelijk dat de overheid op grond van het recht op privacy, en daarvan afgeleid een recht op weten, verplicht zou kunnen worden om alle technische mogelijke en wetenschappelijk verantwoorde erfelijkheidsonderzoeken aan te bieden. Specifieke omstandigheden zouden hier in individuele gevallen wellicht wel toe kunnen leiden. In zo'n geval zou aangetoond moeten worden dat de informatie van vitaal belang is voor het individu en dat het niet verkrijgen van de informatie een aantasting van het welzijn van het individu oplevert. Het recht op kennisname van bestaande informatie betreffende de eigen genetische constitutie zou afgeleid kunnen worden uit het algemene persoonlijkheidsrecht dat onder andere ten grondslag ligt aan het recht op een persoonlijke levenssfeer. Dit is geen absoluut recht en zal dus afgewogen moeten worden tegen rechten en vrijheden van anderen. De uitkomst van deze afweging zal afhangen van de concrete omstandigheden van het geval. Van belang hierbij zijn het belang dat gediend is met de inbreuk op de privacy, de ernst van de inbreuk op de privacy en het subsidiariteitsbeginsel. Bij het belang dat gediend is met de inbreuk op de privacy zullen mijns inziens met name het risico op een erfelijke aandoening en de mogelijkheid om preventieve matregelen te nemen, een rol spelen.

In hoofdstuk 6 staat het recht op niet weten centraal. Het recht om zelf te bepalen of informatie betreffende de gezondheid tot stand wordt gebracht is af te leiden uit en wordt beschermd door het recht op respect voor de persoonlijke levenssfeer. Dit recht leidt ertoe dat niemand verplicht is een erfelijkheidsonderzoek te ondergaan. Het recht om bestaande informatie betreffende de gezondheid niet te ontvangen 
heeft bij de erfelijkheidsadvisering speciaal gewicht. Met name bij voorspellend onderzoek kan het niet ontvangen van informatie van groot belang zijn voor de adviesvrager in verband met de invulling en perceptie van zijn leven. Het goed hulpverlenerschap vereist dat in ieder geval bij voorspellend onderzoek de adviesvrager wordt gewezen op het feit dat hij gebruik kan maken van zijn recht op niet weten. Indien het besluit om een erfelijkheidsonderzoek te ondergaan weloverwogen is genomen, mag men verwachten dat de adviesvrager niet snel op zijn besluit om de uitslag te vernemen zal terugkomen. Bij onverwachte bevindingen is er sprake van een andere situatie. Voorafgand aan het erfelijkheidsonderzoek dient duidelijk op deze mogelijkheid te worden gewezen, zodat de adviesvrager aan kan geven of hij hiervan op de hoogte wil worden gesteld. Het recht om bestaande informatie niet te ontvangen kan de adviesvrager ertoe doen besluiten dat hij voorafgaand aan het erfelijkheidsonderzoek geen inlichtingen wil ontvangen. Het is echter aan de klinisch geneticus te bepalen of het niet verstrekken van inlichtingen voorafgaand aan het erfelijkheidsonderzock in overeenstemming is met zijn goed hulpverlenerschap.

Tevens is het recht op niet weten van kinderen en ongeborenen aan de orde geweest. Wanneer ouders bij hun kind een erfelijkheidsonderzoek willen laten verrichten is het altijd het belang van de ouders en het kind bij weten dat moet worden afgewogen tegen het belang van het kind bij niet weten. Het is een overweging die ouders als goede vertegenwoordigers dienen te maken, waarbij het belang van het kind voorop staat. Dit belang kan strijdig zijn met dat van de ouders. Daarnaast bevat het goed hulpverlenerschap ook de eigen verantwoordelijkheid van de klinisch geneticus voor het beschermen van de belangen van het kind. De vraag wanneer erfelijkheidsonderzoek in het belang van het kind is, hangt voornamelijk af van de mogelijkheden tot primaire en/of secundaire preventie. Bovendien zal de vraag of het onderzoek kan worden uitgesteld aan de orde moeten komen. Richtlijnen kunnen een steun zijn bij de concrete beantwoording door de klinisch geneticus van de vraag of een verzoek tot een erfelijkheidsonderzoek verenigbaar is met het goed hulpverlenerschap. Het te beschermen belang dat de ongeborene heeft om in de toekomst verschoond te blijven van bepaalde informatie kan beschermd worden door bij prenataal onderzoek alleen te informeren over het feit of de vrucht al dan niet aangedaan is en niet over dragerschap van een recessieve mutatie of een gebalanceerde translocatie.

In hoofdstuk 7 is de geheimhoudingsplicht besproken. De geheimhoudingsplicht is onder meer geregeld in artikel 7:457 BW. Indien er sprake is van een conflict van plichten kan de klinisch geneticus zich rechtens beroepen op artikel 40 Wetboek van Strafrecht. Daarbij dienen de volgende criteria te worden gehanteerd:

- redelijke inspanningen zijn verricht om toestemming van de adviesvrager te verkrijgen;

- door het handhaven van de geheimhoudingsplicht verkeert de klinisch geneticus in gewetensnood;

- er is geen andere weg om het probleem op te lossen dan via doorbreking van het geheim; 
- het niet informeren van het betrokken familielid brengt cen hoog risico op ernstige schade met zich mee en het is vrijwel zeker dat door het informeren die schade kan en zal worden voorkómen of beperkt;

- er wordt niet meer informatie verstrekt dan nodig is ter voorkoming van ernstige schade en ook voor het overige wordt de persoonlijke levenssfeer van de adviesvrager zo min mogelijk aangetast;

- de dreigende gezondheidsschade is op korte termijn te verwachten of op lange termijn met dien verstande dat het medisch gezien zinvol is om op korte termijn preventieve maatregelen te nemen;

- de adviesvrager wordt op de hoogte gesteld van het feit dat de klinisch geneticus zijn geheimhoudingsplicht gaat doorbreken.

In de situatie waarin er ten behoeve van de adviesvrager geen erfelijkheidsonderzoek kan worden verricht, en er dus geen diagnose kan worden gesteld vastgesteld, omdat de vereiste medewerking van een familielid ontbreekt, is onderzocht of er in het geval er sprake is van een conflict van plichten dezelfde criteria kunnen worden gehanteerd als in de situatie waarin een klinisch geneticus familieleden van de adviesvrager niet in kan lichten omtrent hun risico op een erfelijke aandoening. Geconcludeerd is dat de eis dat het niet informeren van het betrokken familielid een hoog risico op ernstige schade met zich meebrengt en dat het vrijwel zeker is dat door het informeren die schade kan worden voorkómen of beperkt, in deze situatie niet toepasbaar is. Daarom is het volgende criterium voorgesteld: het niet informeren van de adviesvrager leidt ertoe dat de resterende mogelijkheden voor hem om het risico op een erfelijke aandoening te reduceren in een onredelijke verhouding staan tot de schending van de privacy van het familielid door voor erfelijkheidsonderzoek gebruik te maken van de specifieke genmutatie die bij het familielid is aangetoond.

In hoofdstuk 8 is onderzocht of het recht op informatie, de therapeutische exceptie en het toestemmingsvereiste toegepast worden conform de juridische invulling die hieraan is gegeven en wat daarbij de knelpunten zijn. Gebleken is dat adviesvragers tijdens verschillende gesprekken uitgebreid geinformeerd worden door de klinisch geneticus. Het betreft hierbij zowel medische informatie als informatie over de mogelijke persoonlijke en maatschappelijke gevolgen van een erfelijkheidsonderzoek. Ook de mogelijke consequenties voor familieleden worden met de adviesvrager besproken. De hoeveelheid informatie die wordt verstrekt bleek voornamelijk afhankelijk te zijn van de voorkennis omtrent de erfelijke aandoening waar de erfelijkheidsvraag zich op richt en de (on)mogelijkheden om door middel van erfelijkheidsonderzoek de vraag te beantwoorden. Voor adviesvragers blijken met name begrip, aandacht en het feit dat er veel tijd voor hen wordt uitgetrokken van belang te zijn. Het feit dat hier in hun ogen aan voldaan is, wordt als uitermate positief ervaren. De klinisch geneticus krijgt in de praktijk regelmatig het verzoek om zijn informatieplicht anders in te vullen dan hij gewoon is te doen. In dergelijke situaties zal de klinisch geneticus telkens moeten nagaan of het voldoen aan deze verzoeken in overeenstemming is met zijn goed hulpverlenerschap. Het informeren over onverwachte bevindingen is lastig voor klinisch genetici. 
De praktijk toont dat er weinig gebruik wordt gemaakt van de therapeutische exceptie en dat wanneer dit gebeurt het alleen het tijdelijk niet verstrekken van inlichtingen betreft. In de situaties waarin de therapeutische exceptie wordt toegepast blijkt dat er vaak geen sprake is van een kennelijk ernstig nadeel. Wel bleek dat door het vaste gebruik om met collegae te overleggen aan de consultatieplicht wordt voldaan. De praktijk van de erfelijkheidsadvisering laat zien dat het verschil tussen de therapeutische exceptie en het geleidelijk en gefaseerd informeren niet altijd duidelijk is. De klinisch geneticus ziet zich geregeld voor de vraag gesteld of hij in een bepaalde situatie informatie achterhoudt en daarmee de therapeutische exceptie toepast of dat hij de adviesvrager op een verantwoorde manier informeert door dit geleidelijk en gefaseerd te doen.

Voor wat betreft de wijze waarop wordt geinformeerd is het uitgangspunt dat de erfelijkheidsadvisering non-directief van aard is. In de praktijk van de erfelijkheidsadvisering lijkt, in tegenstelling tot het verdedigde model van Arras, het dialogische model gevolgd te worden. In het dialogische model trachten de klinisch geneticus en de adviesvrager gezamenlijk tot een besluit te komen.

Adviesvragers geven toestemming voordat er een erfelijkheidsonderzoek wordt verricht. Ook voor het maken van foto's en dia's wordt toestemming gevraagd. Het schriftelijk toestemming verlenen op verzoek van de klinisch geneticus kom bij voorspellend erfelijkheidsonderzoek soms voor. Het vragen van toestemming van de adviesvrager en zijn familieleden voor het opvragen van gegevens, alvórens er een gesprek heeft plaatsgevonden, levert een ongeïnformeerde toestemming op. Het wederom toestemming vragen om geïnformeerd te worden over de uitslag van een erfelijkheidsonderzoek als deze pas na lange tijd bekend wordt, getuigt van goed hulpverlenerschap. Door de adviesvrager opnieuw de keuze te laten maken, wordt in de praktijk van de erfelijkheidsadvisering het meest recht gedaan aan het zelfbeschikkingsrecht van de adviesvrager in de vorm van een keuze tussen wel en niet weten.

In hoofdstuk 9 is onderzocht of het recht op niet weten wordt toegepast conform de juridische invulling die daaraan is gegeven en wat daarbij de knelpunten zijn. Het informeren over het recht op niet weten gebeurt in de praktijk op twee manieren. Enerzijds door concreet aan te geven dat een adviesvrager te allen tijde kan besluiten niet geïnformeerd te willen worden over de uitslag van het erfelijkheidsonderzoek. Anderzijds door aan te geven dat een erfelijkheidsonderzoek vrijwillig is en dat adviesvragers voor zichzelf moeten afwegen of zij datgene dat onderzocht kan worden ook daadwerkelijk willen weten. Daarbij blijkt dat het recht op niet weten van de adviesvrager weliswaar wordt gerespecteerd door de klinisch geneticus, maar dat hij er moeite mee heeft als de adviesvrager in zijn ogen irrationele besluiten neemt.

In hoofdstuk 10 is onderzocht of de geheimhoudingsplicht wordt toegepast conform de juridische invulling die hieraan gegeven is en wat de knelpunten zijn. Het uitgangspunt dat de adviesvrager zelf de familieleden moet informeren wordt algemeen onderschreven. Klinisch genetici geven aan dat adviesvragers meestal wel 
te overtuigen zijn van het belang dat familieleden kunnen hebben bij informatie over een mogelijk risico op een erfelijke aandoening. Er ontstaat echter een spanning ussen enerzijds het belang van familieleden bij die informatie en anderzijds de geheimhoudingsplicht van de klinisch geneticus wanneer de adviesvrager in eerste instantie zijn familieleden niet wil inlichten of wanneer hij zegt dit te zullen doen, maar er twijfel ontstaat bij de klinisch geneticus of dit daadwerkelijk is gebeurd. Om het recht op geheimhouding van de adviesvrager niet te schenden, wordt soms veel moeite gedaan om de adviesvrager ertoe over te halen zijn familieleden wel in te lichten. Dit gebeurt met name indien familieleden een groot risico lopen op een erfelijke aandoening waarvoor preventieve opties ter beschikking staan. De adviesvrager wordt bij het informeren van zijn familieleden soms, al dan niet op zijn verzoek, door de klinisch geneticus geholpen door middel van een familiebrief. Bij het ongevraagd informeren van een familielid moet altijd het mogelijke belang bij informatie worden afgewogen tegen het belang dat het familielid kan hebben bij niet weten. Genetici geven aan dat het een inbreuk op de privacy is als men ongevraagd wordt geïnformeerd over erfelijkheidsrisico's. Deze inbreuk maakt dat de inhoud van een familiebrief summier dient te zijn. De vraag echter of een familiebrief niet op zich al het mogelijke belang bij niet weten schendt alsmede welke informatie in een brief zou mogen staan, blijkt in de praktijk een punt te zijn waarover de meningen uiteen lopen.

De redenen die genetici aangeven om een familielid zonder toestemming van de adviesvrager te informeren lijken overeen te komen met het criterium dat het niet informeren van het betrokken familielid een hoog risico op ernstige schade met zich meebrengt, welke schade kan en zal worden voorkomen of beperkt. Klinisch genetici die zich in een conflict van plichten bevonden geven aan hoe ingrijpend het voor familieleden kan zijn om hen zonder toestemming van de adviesvrager te benaderen. Ze zijn van mening dat informeren via de huisarts in principe minder ingrijpend is omdat hij de familieleden kent. Bovendien doet zich het praktische probleem voor dat de klinisch geneticus geen adresgegevens heeft van familieleden. De eis luidt dat bij een conflict van plichten de informatie niet aan meer personen wordt verstrekt dan noodzakelijk is. De praktijk laat echter zien dat het informeren van andere personen soms om praktische redenen noodzakelijk is. Niet alle klinisch genetici zijn van mening dat de geheimhoudingsplicht wordt geschonden wanneer zonder toestemming van het familielid gebruik wordt gemaakt van informatie omtrent de aard en/of de locatie van een mutatie.

Onder een aantal klinisch genetici leeft de overtuiging dat nabestaanden toestemming moeten geven voor het opvragen van de gegevens van de overledene. Om die reden wordt voor het opvragen van gegevens van een overledene veelal toestemming gevraagd aan diens nabestaanden. Hierbij doen zich situaties voor die klinisch genetici als een knelpunt ervaren, terwijl dit knelpunt er vanuit een juridisch perspectief niet is.

In hoofdstuk 11 is geconcludeerd wat het gewenste juridisch kader is voor informatie, toestemming en geheimhouding bij erfelijkheidsadvisering in de klinisch genetische centra. Hiertoe zijn voorstellen voor richtlijnen gedaan, die bedoeld zijn als nadere 
invulling op genoemde rechten en plichten uit de Wgbo voor de praktijk van de erfelijkheidsadvisering. Ten slotte is de conclusie getrokken dat de Wgbo, indien het recht op informatie, de therapeutische exceptie, het toestemmingsvereiste, het recht op niet weten en de geheimhoudingsplicht op een adequate en verantwoorde wijze worden geïnterpreteerd en toegepast, als algemeen juridisch kader ook geschikt is voor de behandelingsovereenkomst tussen de klinisch geneticus en de adviesvrager. 


\section{INFORMATION, CONSENT AND CONFIDENTIALITY IN GENETIC COUNSELING . A HEALTH LAW STUDY}

\section{Summary}

In chapter 1 the subject of this study is explored. The central question of this study is: what is the desired legal framework for information, consent and confidentiality in genetic counseling in centres of clinical genetics? The object of this study is to develop a framework in which the application of the genetic knowledge of the clinical geneticist can take shape. In order to do so, two main questions are explored:

- what are the requirements of the legal framework when it comes to information, consent and confidentiality in genetic counseling in centres of clinical genetics?

- in which way do centres of clinical genetics deal with (problems and dilemmas in matters of) information, consent and confidentiality in the actual practice of genetic counseling?

The objective of this study is to make a contribution to good care in the centres of clinical genetics. The benefit to clinical geneticists could be improved clarity, in the sense that the general duties of health care providers as stated in the Civil Code provisions on the medical treatment contract are made explicit for the specific setting of genetic counseling. For those who ask for counseling, the clients, this improved clarity could bring about a more client-friendly care. Exploration and elaboration of the provisions on the medical treatment contract in the genetic counseling setting, would improve equality of justice and legal security for both the geneticist and the client. Possibly, it could also provide an example to be followed in related health care settings.

Chapter 2 describes, and accounts for, the basic assumptions and the methods employed in this study. A description is given of the basic assumptions of the legal discourse and its relation to the empirical research that has been done. The way in which the empirical research was carried out is described as well. In the first place, the decision to opt for qualitative research is accounted for. Secondly, the way in which data were gathered is described. In subsections the way in which the interviews and observations were set up is indicated. Thirdly, the scope and representativity of the empirical research are described. Finally, the analysis of the gathered data is looked into.

In chapter 3 the subject is the right of self-determination of the client who asks for genetic counseling. The right of self-determination is seen as the principle of law that forms the foundation of the rights of patients. One of the characteristics of a principle of law is that the precise content of the principle cannot be defined: the content changes over time and is dependent on circumstances. Some boundaries can be indicated. In particular, it is important that the client's right of self-determination is limited by the right of self-determination of his relatives. A number of factors determine if and when a breach of the right of self-determination of a client is 
admissible. A major factor in this respect is the probability that a genetic disorder will lead to health damage in conjunction with the possibility, or impossibility, of prevention or reduction of this damage. In this chapter the right of self-determination will be reviewed in the broader social context in which clients ask for counseling. The clinical geneticist should be aware of this context in order to be able to counsel, in the best possible way, on the decision whether or not to undergo genetic testing, and, possibly, on how to interpret the results of testing.

Chapter 4 is about the concept of good care providership, the right to information, the therapeutic exception, the principle of non-directivity in genetic counseling and the requirement of consent. The principle of good care providership is one of the central provisions of the Civil Code provisions on the medical treatment contract. Good care providership is a general phrase which needs fleshing for the specific setting.

The right to information is described in the Civil Code, Book 7, article 448 paragraphs 1 and 2. The client seeking information should be given information in order to enable him to reach a well-considered decision about whether or not to undergo genetic testing. Genetic testing can be diagnostic or predictive. In predictive testing, a medical indication is absent. The predictive character has to be emphasized because it is this predictive element that makes the testing less self-evident. Jurisprudence shows that the care provider's obligation to inform has to conform to higher standards for testing when there is no medical indication. The predictive character of the testing and its possible consequences, both to the client and to his relations, justify the higher standards for the obligation to inform when it comes to genetic counseling on predictive testing. Before the actual testing takes place, the clinical geneticist is obliged to go into the possibility of unexpected findings. It is of great importance that an agreement is reached beforehand, as explicitly and clearly as possible, about the question in what way unexpected findings will be reported, or not.

Article 7:448 paragraph 3 of the Civil Code contains the therapeutic exception. This departure from the general rule of information is not easily invoked when possible findings and consequences of genetic testing have been discussed thoroughly with the client beforehand, and the client has been able to take this into account in his decision to undergo testing. Things can be different when there are unexpected findings. When the clinical geneticist has well-founded reasons to assume that the unexpected findings will manifestly cause serious harm to the client, there is room to make use of the therapeutic exception. It is important to differentiate between the use of the therapeutic exception on the one hand and of giving information phased, in stages, on the other hand. Good care providership requires that the right amount and degree of information is given to the client at the right time, to enable him to comprehend the information.

The basic principle of genetic counseling is its non-directivity. The moral education model of Arras is advocated. In this model the moral aspects of the different options the client has, are put forward by the geneticist, but the decision is the client's. This model is the one most in line with the objective of genetic counseling, which is to 
allow the client, who is well-informed, to make the well-considered choice that suits him best. The right to information is therefore not limited to the strictly medical genetic information; but the requirement of non-directivity remains. The choice remains up to the client.

Finally the requirement of informed consent is discussed. To carry out any procedure based on the medical treatment contract, the client's consent is necessary. There is no room for a presumption of consent of the client in genetic counseling.

In chapter 5 the right to know is discussed. The question is if a person has a right to gather knowledge about his own genetic constitution, and if so, under which circumstances. On the one hand there is the right to information on the genetic constitution that requires genetic testing, and on the other hand there is the right to gather information that is already available to someone other than the care provider in the context of the medical treatment contract.

In regard to the right of a person to gather information on his genetic constitution by way of testing, it is unlikely that the authorities, on the basis of the right to privacy and the related right to know, will be obliged to offer every genetic test that is technically possible and scientifically acceptable. Certain circumstances could lead to a right to know in individual cases. In such a case it would have to be clear that the information is of vital interest to the individual and that his not knowing constitutes a breach in his well-being. A person's right to know existing information on his own genetic constitution could be derived from the general personality right that forms the basis of the right to privacy, amongst others. This, however, is not an absolute right: it will have to be weighed against the rights and freedoms of others. The outcome of this weighing process depends on the actual circumstances of the case. Factors in the weighing are the interest that is served by the breach of privacy, the nature of the breach of the right to privacy en the principle of subsidiarity. When assessing the interest that is served by the breach of privacy, the risk of a genetic disorder and the existence or absence of preventive measures will, in my view, have to be taken into account particularly.

The central issue in chapter 6 is the right not to be informed. The right to determine whether information on an individual's health is to be disclosed or brought into existence can be traced to, and is protected by, the right to respect for privacy. This right implies that no-one can be obliged to undergo genetic testing. A person's right not to receive existing information about his health is especially important in genetic counseling. This is particularly the case with predictive testing. Not having to receive information can be of major importance to the client in his perception of life and the way he chooses to lead it. Good care providership obliges the care provider to inform the client that the client can exercise his right not to be informed, especially in cases of predictive testing. When a well-considered decision has been taken to undergo genetic testing, it is not very likely that the client will go back on his decision to hear the results. When it comes to unexpected findings, the situation is different. Before the actual genetic testing is done, the possibility of unexpected findings has to be discussed, in order to allow the client to state whether he wants to be informed 
should there be unexpected findings. Sometimes, a client decides he does not want any information prior to the genetic testing, based on the right not to be informed. It is up to the clinical geneticist to decide whether it is in accordance with his duty to provide good care not to give any information prior to testing.

The right not to be informed in cases of children and the unborn is discussed as well. When parents want their child to undergo genetic testing, the interest of the parents and the child to be informed has to be weighed against the interest of the child not to be informed. The parents have to take their decision on testing as good representatives of the child, and the interest of the child has to prevail. This interest may conflict with that of the parents. Good care providership includes a responsibility of the clinical geneticist to protect the interests of the child. The answer to the question whether genetic testing is in the interest of the child, depends primarily on the existence or absence of primary and/or secondary prevention. Apart from this, the possibility of testing at some later date has to be considered. Guidelines can support the clinical geneticist when he has to decide whether an actual demand for genetic testing is in accordance with the concept of good care providership. The interest of an unborn child not to have to know certain information at some future date can be protected by giving limited information after prenatal testing: about existing or impending disorders of the foetus, but not about whether he is a carrier of a recessive mutation or a balanced translocation.

Confidentiality is considered in chapter 7 . One of the regulations on confidentiality is article 7:457 of the Civil Code. In a case of conflict of duties, the clinical geneticist can refer to article 40 of the Criminal Code. The following criteria apply:

- reasonable efforts have been taken to acquire the consent of the client;

- having to maintain confidentiality brings the clinical geneticist in a moral dilemma;

- there is no solution to this dilemma but a breach of confidentiality;

- not informing the relative brings a high probability of risk of serious harm and it is almost a certainty that this harm can be prevented or limited by the disclosure of the information;

- only the information necessary to prevent or limit the risk of serious harm is given, and no more than is necessary for that purpose. The privacy of the client is breached as little as possible;

- the threat of health damage is to be expected in the short term, or in the long term, in which case it has to be advisable, on medical grounds, to start with prevention measures in the short term;

- the client is informed that the clinical geneticist is about to breach his confidentiality.

The situation in which genetic testing is not possible, and therefore no diagnosis can be made, because a previously tested relative is unwilling to cooperate, has been considered. The question is posed whether the above-mentioned criteria of conflict of duties that apply in the situation in which a clinical geneticist is unable to inform the relatives of a client of their risk of an genetic disorder, apply in this situation also. 
It is concluded that the requirement of high risk of serious harm which can be prevented or limited by giving information, is not present in this situation. Therefore the following criterion is proposed: not informing the client, leads to his having only restricted options to limit the risk of a genetic disorder, which is unreasonable in comparison with the breach of privacy of the relative by using the specific genetic mutation found in the genetic testing of the relative.

In chapter 8 the question has been considered whether the application of the right to information, the therapeutic exception and the requirement of informed consent in actual practice conforms to the legal requirements, and the main problems in the practice of genetic counseling are reviewed. As it turns out, clients who ask for genetic counseling are, in a number of talks, informed extensively by the clinical geneticist. Information is given on medical aspects as well as on possible personal and societal consequences of genetic testing. Possible consequences for relatives are discussed with the client also.

The amount of information is determined mainly by the extent of the client's previous knowledge about the genetic disorder in question and the possibility, or impossibility, to give an answer the actual question about the genetic disorder in genetic counseling. For the client the main important aspects of genetic counseling are that the clinical geneticist is understanding, attentive, and takes enough time. This generally being the case, counseling is viewed by the client as a very positive experience.

The clinical geneticist in actual practice is often asked to give information in a way that differs from his standard way of giving information. In situations like these, the clinical geneticist will have to decide, case by case, whether the request is compatible with his duty of good care providership. Having to give information about unexpected findings is seen as difficult by clinical geneticists.

In practice, little use is made of the therapeutic exception. When it is used it is often a matter of not giving the information outright, but in stages. The situations in which the therapeutic exception is applied, often do not conform to the requirement of manifestly serious harm. Before making use of the therapeutic exception the clinical geneticist consults his colleagues, as the law requires him to do. The practice in genetic counseling demonstrates that the line between the therapeutic exception and giving information in stages is often not a clear one. The clinical geneticist often is in doubt whether by withholding information in a certain situation he is making use of the therapeutic exception or whether he is in fact giving the information gradually, in a controlled way.

As to the way in which information is given, the starting-point is the non-directivity of genetic counseling. In the actual practice of genetic counseling the dialogical model is used, contrary to the model advocated by Arras. In the dialogical model the clinical geneticist and the client try to reach a shared conclusion. 
Clients give their consent before the actual testing is carried out. Consent is asked separately for the taking of photographs and slides. Occasionally, consent is confirmed in writing before predictive testing, at the request of the clinical geneticist. Consent of the client, or his relatives, given before consultation has taken place, is uninformed consent and as such not valid. A good care provider renews the request for consent to receive information when the results of testing only become available after a long time. By giving the client another opportunity to decide, the clinical geneticist shows respect for the right of self-determination of the client in his choice to be informed or not.

Chapter 9 is concerned with the question whether the right not to be informed in the practice of genetic counseling conforms to the legal requirements, and with the dilemmas that surround it in practice. In practice, information to the client about the right not to be informed is given in two ways: it is stated explicitly that the clients is free to decide, whenever he wants, that he does not want to be informed about the results of his tests. In addition to this, it is emphasized that genetic testing is voluntary and that the client has to decide for himself if he wants the tests that can be done, to be carried out. The clinical geneticist respects the right of the client not to be informed, but it appears that he often finds it hard to deal with a client when, in the eyes of the clinical geneticist, the client takes irrational decisions.

In chapter 10 confidentiality in actual practice is compared to the legal concept, and relevant dilemmas are discussed. The starting-point, that it is the client who informs his relatives, is generally accepted. Clinical geneticists indicate that clients usually can be convinced of the interest of relatives when it comes to information about the possible risks of a genetic disorder. There is a tension between the interest of relatives to be informed, on the one hand, and the duty of confidentiality of the clinical geneticist on the other hand, in cases when the client, at first, refuses to inform his relatives, or says he will inform his relatives but the clinical geneticist has reason to doubt whether the information has in fact been given. In order to respect the right of the client to confidentiality, a great deal of trouble is sometimes taken to convince the client that he really should inform his relatives. This is particularly the case when relatives run a great risk of a genetic disorder for which preventive options exist. The client is sometimes, at his request or otherwise, helped by the clinical geneticist with the family letter to his relatives. Before unsolicited information is given to a relative, the possible interest to be informed always has to weighed against the interest the relative can have not to be informed. Geneticists indicate that they see unsolicited information about hereditary disorders given to a relative as an invasion of the relative's right not to be informed. Because of this invasion of privacy, the family letter should contain summary information only. The question remains whether a family letter in itself does not constitute an invasion of the right not to be informed. Opinions differ in practice as to which information should be given in the family letter.

The reasons geneticists give to inform a relative without the consent of the client seem to comply with the criterion that without the information the relative in question would run a high risk of serious harm, and this harm can be prevented or 
limited. Clinical geneticists in a conflict of duties state that it can be very difficult for relatives when they are confronted with information without the consent of the client. Giving information to relatives through their general practitioner is seen in principle by geneticists as less difficult because the general practitioner knows the relatives involved. A practical problem is that the clinical geneticist does not know the addresses of the relatives. The law requires the geneticist in a conflict of duties not to inform any person other than the client unless this is absolutely necessary. In practice, it is occasionally necessary to inform others for practical reasons. Not all clinical geneticists agree that it is a breach of confidentiality when information about the nature and/or the location of a mutation is used without the consent of the relative.

A number of clinical geneticists is convinced that the consent of descendants of a deceased client is needed to be able to give information about the deceased. Therefore, before information is asked about someone deceased, the consent of his relatives is usually sought. In this respect the clinical geneticists experience a dilemma where, from a legal perspective, none exists.

In chapter 11 a conclusion is formulated about the desired legal framework for information, consent and confidentiality in genetic counseling in clinical genetic centres. A guideline is proposed in order to clarify the relevant rights and duties of the Civil Code provisions on the medical treatment contract for the practice of genetic counseling. Finally, when the right to information, the therapeutic exception, the requirement of informed consent, the right not to be informed and the right to confidentiality are interpreted adequately and responsibly, the conclusion is that the Civil Code is a suitable legal framework for the treatment contract between the clinical geneticist and the client. 



\section{GERAADPLEEGDE LITERATUUR}

Andrews e.a. 1994

L.B. Andrews e.a. (red.), Assessing genetic risks, Implications for health and social policy, Washington D.C.: National Academy Press 1994, p. 10.

\section{Arras 1990}

J.D. Arras, 'AIDS and Reproductive Decisions: Having Children in Fear and Trembling', The Milbank Qunterly 1990, p. 353-382.

Ball, Tyler en Harper 1994

D. Ball, A. Tyler en P. Harper, 'Predictive testing of adults and children', in: A. Clarke (red.), Genetic combelling, Practice and priciples, London and New York: Routledge 1994, p. 63-94.

Beauchamp en Childress 1994

T.L. Beauchamp en J.F. Childress, Principles of Biomedical Ethics, New York/Oxford: Oxford University Press 1994.

\section{Bertaux 1983}

D. Bertaux (red.), Biography and society: the life history approach in the social sciences, Beverly Hills: Sage Publications 1983.

Bleiker e.a. 1997

E.M.A. Bleiker e.a., 'Genetic counseling for hereditary cancer: A pilot study on experiences of patients and family members', Patient Education and Counseling 199732 , p. 107-116.

Bloch e.a. 1992

M. Bloch e.a., 'Predictive Testing for Huntington Disease in Canada: The Experience of Those Receiving an Increased Risk', American Journal of Medical Genetics 1992, p. 499-507.

Blok en Vedder 2000

P. Blok en A. Vedder, 'Privacy in ontwikkeling', in: J.E.J. Prins en J.M.A. Berkvens (red.), Privacyregulering in theorie en praktijk, Deventer: Kluwer 2000 p. 5-31.

Bolt 1997

I. Bolt, Goede raad, Over autonomie en goede redenen in de praktijk van de genetische counseling, Amsterdam 1997.

\section{Botkin 1995}

J.R. Botkin, 'Fetal Privacy and Confidentiality', Hastings Center Report 1995-5, p. 32-39. 


\section{Callens 1995}

S. Callens, Goed geregeld? Het gebruik van medische gegevens voor onderzoek, Antwerpen/Apeldoorn: Maklu 1995.

Capron 1973

A.M. Capron, 'Legal rights and moral rights', in: B. Hilton e.a. (red.), Ethical issues in human genetics, Genetic Combeling and the Use of Genetic Knowledge, New YorkLondon: Plenum Press 1973, p. 221-244.

Christiaens 1988

M. Christiaens, 'Medische voorlichting en (mis)vorming', Medisch Contact 1988, p. 846-848.

Cokelaere en Craeynest 1998

M. Cokelaere en P. Craeynest, Onze genen: handboek menselijke erfelijkheid, Leuven/Amersfoort: Acco 1998.

Copley e.a. 1995

T.T. Copley e.a., 'Are We All of One Mind? Clinicians' and Patients' Opinions Regarding the Development of a Service Protocol for Predictive Testing for Huntington disease', American Joumal of Medical Genetics 1995-58, p. 59-69.

Davis 1997

D.S. Davis, 'Genetic Dilemmas and the Child's Right to an Open Future', Hastings Center Report 1997-27, p. 7-15.

De Brauw 1988

P.J.W. de Brauw (red.), Medisch beroepsgeheim, Baarn:Ambo 1988.

De Groot 2000

G.R.J. de Groot, 'Zwijgen als het graf, Beroepsgeheim na de dood alleen bij uitzondering doorbreken', Medisch Contact 2000, p. 1146-1148.

De Haes e.a. 1998

J.C.J.M. de Haes e.a., De uitvoering van de informed consent vereiste in Nederlandse ziekenhuizen, KNMG-Project 'Informed consent', nr. IC-5, Utrecht: KNMG 1998.

De Jong, Bottema en Van de Vathorst 1999

E. de Jong, R. Bottema en S. van de Vathorst, 'Wet of geweten?, KNMG-ledenpanel over beroepsgeheim en conflict van plichten', Medisch Contact 1999, p. 1430-1433.

Dekkers 1979

F. Dekkers, De patient en het recht op informatie, Alphen aan den Rijn: Samson Uitgeverij 1979. 
De Vries 1995

G. de Vries, De ontwikkeling van wetenschap, Een inleiding in de wetenschapsfilosofie, Groningen: Wolters-Noordhoff 1995.

De Wert (XVI Ethische aspecten)

G.M.W.R. de Wert, 'XVI Ethische aspecten', in: H.A.M.J. ten Have e.a. (red.), Ethiek en recht in de gezondheidszorg, Deventer: Kluwer.

De Wert 1999

G.M.W.R. de Wert, Met het oog op de toekomst. Voortplantingstechnologie, erfelijkheidsonderzoek en ethick, Rotterdam 1999.

De Wert 1998

G.M.W.R. de Wert, 'Ethics of predictive DNA-testing for hereditary breast and ovarian cancer', Patient Education and Counseling 1998-35, p. 43-52.

Dierickx 1999

K. Dierickx, Genetisch gezond? Ethische en sociale aspecten van genetische tests en screenings, Antwerpen-Groningen: Intersentia 1999.

Dudok de Wit 1997

A.C. Dudok de Wit, To know or not to know, The Psychological Implications of Presymptomatic DNA Testing for Autosomal Dominant Inheritable Late Onset Disorders, 1997.

Dute 1998

J.C.J. Dute, 'Informatie over prenataal gevonden dragerschap, een juridisch commentaar', Tijdschrift voor Gezondheid en Ethiek 1998-8, p. 24-28.

Dute 1995

J.C.J. Dute, 'The future of medical confidentiality', in: P. Ippel e.a. (red.), Privacy disputed, Den Haag: SDU 1995, p. 79-89.

Dute 1994

J.C.J. Dute, De wetgeving ter bestrijding van infectiezickten, Nijmegen: Ars Aequi Libri 1994.

Dute e.a. 2000

J.C.J. Dute e.a. (red.), Evaluatie Wet op de geneeskundige behandelingsovereenkomst, Den Haag 2000.

Emanuel en Emanuel 1992

E.J. Emanuel en L.L. Emanuel, 'Four Models of the Physician-Patient Pelationship', JAMA 1992, p. 2221-2226. 


\section{Engberts 1997}

D.B. Engberts, Me't Permissie, morele argumentaties inzake het toestemmingsbeginsel bij de totstandkoming zan de Wel Geneeskundige Behandelings-Overeenkomst, Deventer: Kluwer 1997.

\section{Enst en Schwartz 1962}

M.L. Ernst en A.U. Schwartz, The right to be let alone, Westport: Greenwood Press 1962.

European Community Huntington's Disease Collaborative Stydy Group 1993

European Community Huntington's Disease Collaborative Stydy Group, 'Ethical and social issues in presymptomatic testing for Huntington's disease. A European Community collaborative study', Journal of Medical Genetics 1993, p. 1028-1035.

Feinberg 1980

J. Feinberg, 'The child's right to an open future', in: W. Aiken en M. LaFollette (red.), Whose child? Children's rights, parental authority, and state power, Totowa: Littlefield adams \& Co. 1980, p. 124-153.

Fletcher, Berg en Tranøy 1985

J.C. Fletcher, K. Berg en K.E. Tranøy, 'Ethical aspects of medical genetics, A proposal for guidelines in genetic counseling, prenatal diagnosis and screening', Clinical Genetics 1985, p. 199-205.

\section{Fried 1984}

C. Fried, 'Privacy, a moral analysis', in: F.D.Schoeman (red.), Philosophical dimensions of privacy, an anthology, Cambridge: Cambridge University Press 1984, p. 203-222.

Galjaard 1997

H. Galjaard, 'Toekomstige ontwikkelingen in het erfelijkheidsonderzoek. 1. Technologische mogelijkheden', Nederlands Tijdschrift voor Geneeskunde 1997, p. 24322437.

\section{Gevers 2001}

J.K.M. Gevers, 'Genetica en voorspellend medisch onderzoek', Tijdschrift voor Gezondlitidsrecht 2001, p. 12-18.

Gevers 1999

J.K.M. Gevers, 'Predictieve geneeskunde als uitdaging voor het recht', in: F.C.B. van Wijmen (red.), Privantrecht in de $21^{\circ}$ eenw, Blik in de medische praktijk in de $21^{e}$ eenw, Kluwer 1999, p. 33-49.

\section{Gevers 1996}

J.K.M. Gevers, Voorspellend medisch onderzoek; rechtsbescherming, Preadvies Vereniging voor Gezondheidsrecht, Utrecht 1996. 
Gevers 1995

J.K.M. Gevers, 'Inhoud en ontwikkeling van het medisch beroepsgeheim', in: F. de Graaf en C. Lameer (red.), Medisch beroepsgeheim onder druk, Houten/Diegem: Bohn Stafleu Van Loghum 1995, p. 6-14.

Gevers 1994

J.K.M. Gevers, 'De Bioethiek Conventie; kanttekeningen bij een ontwerp-verdrag van de Raad van Europa', Tijdschrift voor Gezondheidsrecht 1994, p. 456-464.

Gevers 1990

J.K.M. Gevers, 'Rechtsbescherming na de dood', in: J.K.M. Gevers en J.H. Hubben (red.), Grenzen aan de zorg; zorgen ann de grens, Alphen aan den Rijn: Samson H.D. Tjeenk Willink 1990, p. 172.

Gevers 1989

J.K.M. Gevers, 'Erfelijkheidsonderzoek en mensenrechten in het bijzonder het recht op bescherming van de persoonlijke levenssfeer', in: Stichting NJCM-Boekerij, Erfelijkheidsonderzock en mensenrechten, Leiden 1989, p. 17-24.

Gevers 1987.

J.K.M. Gevers, Juridische aspecten van erfelijkheidsonderzoek en -advies, Preadvies Vereniging voor Gezondheidsrecht, Utrecht: Vereniging voor Gezondheidsrecht 1987.

Gevers en Van Aalst 1998

J.K.M. Gevers en A. van Aalst, De rechter en het medisch handelen, Deventer: Kluwer 1998.

Gezondheidsraad 2001

Gezondheidsraad, prenatale screening: Downsyndroom, neuralebuisdefecten, routineechoscopie, Den Haag 2001.

Gezondheidsraad 1999

Gezondheidsraad, Klinisch-genetisch onderzoek en erfelijkheidsadvisering; nadere advisering voor een nieuwe planningsregeling, Den Haag 1999.

Gezondheidsraad 1998

Gezondheidsraad, DNA-dingnostiek, Rijswijk 1998.

Gezondheidsraad 1989

Gezondheidsraad, Erfelijkheid: wetenschap en mantschappij: Over de mogelijkheden en grenzen van erfelijkheidsdiagnostiek en gentherapie, Den Haag 1989.

Gezondheidsraad 1986

Gezondheidsraad, Grenzen zan de gezondheidszorg, Den Haag 1986. 
Gezondheidsraad 1980

Gezondheidsraad, Advies inzake ethiek van de erfelijkheidsadvisering. Den Haag 1980.

Gezondheidsraad 1977

Gezondheidsraad, Advies inzake genetic counseling, Rijswijk 1977.

Hazewinkel-Suringa 1959

D. Hazewinkel-Suringa, De doolhof van het beroepsgeheim, Haarlem: H.D. Tjeenk Willink 1959.

Horstman, De Vries en Haveman 1999

K. Horstman, G.H. de Vries en O. Haveman, Gezondheidspolitiek in een risico-cultuur, burgerschap in het tijdperk van de voorspellende geneeskunde, Maastricht/Amsterdam 1999.

Hugginns e.a. 1992

M. Hugginns e.a., 'Predictive testing for Huntington disease in Canada: adverse effects and unexpected results in those receiving a decreased risk', American Journal of Medical Genetics 1992, p. 508-515.

Hulst 1995

E.H. Hulst, Het recht van de patient op informatie: de juridische stand van zaken, KNMG Projekt 'Informed Consent', nr. IC-2, Utrecht: KNMG 1995.

\section{Husted 1996}

J. Husted, 'Autonomy and a right not to know', in: R. Chadwick, M. Levitt en D. Shickle, The right to know and the right not to know, Aldershot: Avebury 1996, p. 58.

International Huntington Association and the World Federation of Neurology Research Group on Huntington's Chorea 1994

International Huntington Association and the World Federation of Neurology Research Group on Huntington's Chorea, 'Guidelines for the molecular genetics predictive test in Huntington's disease', Journal of Medical Genetics 1994, p. 555-559.

Ippel 1994

P. Ippel, 'Gezondheidsrecht en gezondheidsethiek', in: W. van der Burg en P. Ippel (red.), De Sinmese tweeling, recht en moranl in de biomedische praktijk, Assen: Van Gorcum 1994, p. 39.

Jochemsen 1999

H. Jochemsen, 'Een mens is meer dan zijn genen alleen', in: M. van Zwieten en A. Kalden (red.), Ons gescreende lichaam, kansen en risico's van de genetica, Balans 1999.

Kasdorp 1988

J.P. Kasdorp, Grenzen aan het recht op gezondheidszorg, Preadvies Vereniging voor Gezondheidsrecht, Utrecht 1988. 
Kastelein 1995

W.R. Kastelein, 'Informatieplicht en toestemmingsvereiste, hoe ver moet de dokter gaan?', Medisch Contact 1995, p. 336-339.

Katz 1984

J. Katz, The Silent World of Doctor and Patient, New York: The Free Press 1984.

Kelk 1990

C. Kelk, 'Rechtsbeginselen en het Gezondheidsrecht', Tijdschrift voor Gezondheidsrecht 1990, p. 111.

Kessler 1988

S. Kessler, 'Invited Essay on the Psychological Aspects of Genetic Counseling. V. Preselection: A Family Coping Strategy in Huntington Disease', American Joumal of Medical Genetics 1988, p. 617-621.

KNMG 1998

KNMG, Achtergrondstudie Commissie Medische Ethiek, Artsen en Genen, Het gebruik van genetische kennis in de medische praktijk, Utrecht 1998.

Kuitenbrouwer 1991

F. Kuitenbrouwer, Het recht om net rust gelaten te worden, over privacy, Amsterdam: Balans 1991.

Kuitert 1989

H.M. Kuitert, Mag alles wat kan? Ethiek en medisch handelen, Baarn: Ten Have 1989.

Lagro-Janssen en Van Wijmen 1998

A.L.M. Lagro-Janssen en F.C.B. van Wijmen, 'Informeren is zilver, verzwijgen is goud? Informatieplicht en therapeutische exceptie volgens de WGBO', Huisarts en wetenschap 1998, p. 603-606.

Lannfelt e.a. 1995

L. Lannfelt e.a., 'Genetic Counseling in a Swedish Alzheimer Family with Amyloid Precursor Protein Mutation', American Joumal of Human Genetics 1995, p. 332-335.

Leenen 2000

H.J.J. Leenen (bewerkt door J.K.M. Gevers en H.J.J. Leenen), Handboek Gezondheidsrecht. Deel 1: Rechten van mensen in de gezondheidszorg, Houten/Diegem: Bohn Stafleu Van Loghum 2000.

Leenen 1995

H.J.J. Leenen, 'Recht op gezondheidszorg, overheid en stelsel van ziektekostenverzekering', Tijdschrift voor gezondheidsrecht 1995, p. 396-406. 


\section{Leenen 1994}

H.J.J. Leenen, 'A declaration on the Promotion of Patients' Rights in Europe', in: Tijdschrift voor Gezondheidsrecht 1994, p. 275-281.

\section{Leenen 1978}

H.J.J. Leenen, Rechten wan mensen in de gezondheidszorg, een gezondheidsrechtelijke studie, Alphen aan den Rijn/Brussel: Samson Uitgeverij 1978.

\section{Legemaate 1997}

J. Legemaate, 'Het recht van de patiënt op informatie, mede in relatie tot de dossierplicht van de arts', Advocatenblad 1997, p. 202-207.

\section{Legemaate 1995}

J. Legemaate, 'De zorg van een goed hulpverlener, in relatie tot de professionele standaard', in: J. Legemaate (red.), De Wgbo: van tekst naar toepassing, Houten/Diemen: Bohn Stafleu Van Loghum 1995, p. 14-16.

\section{Legemaate 1994}

J. Legemaate, Goed recht, De betekenis en de gevolgen van het recht voor de praktijk van de hulpverlening, Preadvies Vereniging voor Gezondheidsrecht, Utrecht 1994.

\section{Leschot 1997}

N.J. Leschot, 'Organisatie en beleid van prenatale diagnostiek in Nederland', in: H. Brandenburg (red.), Prenatale diagnostiek, Houten/Diegem: Bohn Stafleu Van Loghum 1997, p. 121-133.

\section{Leschot en Brunner 1998}

N.J. Leschot en H.G. Brunner, 'Klinische genetica in de praktijk', in: N.J. Leschot en H.G. Brunner (red.), Klinische genetica in de praktijk, Maarssen: Elsevier/Bunge 1998, p. 1-2.

\section{Liebaers en Hamel 1999}

Liebaers en Hamel, 'Erfelijkheidsadvisering', in: J.C. Pronk e.a. (red.), Leerboek medische genetica, Maarssen: Elsevier/Bunge 1999, p. 287-293

\section{Maeijer 1968}

J.M.M. Maeijer, 'De juridische relatie tussen geneesheer en patiënt', in: De geneesheer en het recht, Deventer: Kluwer 1968.

Mannens en De Boer 1999

Mannens en De Boer, 'Basisprincipes', in: J.C. Pronk e.a. (red.), Leerboek medische genetica, Maarssen: Elsevier/Bunge 1999, p. 31-56.

Markenstein, Gevers en Roscam Abbing 1999

L.F. Markenstein, J.K.M. Gevers en H.D.C. Roscam Abbing, Vroege opsporing en recht op (niet) weten; een verkennend onderzoek, Utrecht/Amsterdam 1999. 
Marley 1966

L.N. Marley, 'Enige raakpunten tussen medische praktijk en het leerstuk der aansprakelijkheid', in: Schuld en verontschuldiging in de medische praktijk, Roermond: Romein 1966.

Maso en Smaling 1998

I. Maso en A. Smaling, Kualitatief onderzoek: praktijk en theorie, Amsterdam: Boom 1998.

Maso en Smaling 1990

I. Maso en A. Smaling, 'Objectiviteit in kwalitatief onderzoek: een overzicht', in: I. Maso en A. Smaling (red.), Objectiviteit in kwalitatief onderzoek, Meppel/Amsterdam: Boom 1990, p. 13.

Mill (1859) 1989

J.S. Mill, Over vrijheid, Meppel/Amsterdam: Boom 1989 (On liberty 1859, vertaald door W.E. Krul).

Ministerie van Volksgezondheid, Welzijn en Sport 2000

Ministerie van Volksgezondheid, Welzijn en Sport, Beleidsnota De toepassing van genetica in de gezondheidszorg, Den Haag 2000.

Nabben en Van de Luytgaarden 1996

P.F.P. Nabben en H.J.L.M. van de Luytgaarden, De ultieme vrijheid, Een rechtstheoretische analyse van het recht op privacy, Deventer: Kluwer 1996.

Nance 1993

W.E. Nance, 'Parables', in: D.M. Bartels, B.S. LeRoy en A.L. Caplan (red.), Prescribing Our Future: Ethical Challenges in Genetic Counseling, New York: Aldine De Gruyter 1993.

Nationale Raad voor de Volksgezondheid 1994

Nationale Raad voor de Volksgezondheid, Juridisch-ethisch beoordelingskader preventie, Advies over de juridisch-ethische principes bij de beoordeling van programmatische preventie, Zoetermeer 1994.

Nationale Raad voor de Volksgezondheid 1987

Nationale Raad voor de Volksgezondheid, Advies geneeskundige behandelingsovereenkomst 1987.

Nationale Raad voor de Volksgezondheid 1986

Nationale Raad voor de Volksgezondheid, Advies grenzen van de zorg, Zoetermeer 1986. 


\section{Nelis 1998}

A. Nelis, DNA-diagnostiek in Nederland: een regime-analyse van de ontwikkeling van de klinische genetion en DNA-dingnostische tests, 1970-1997, Enschede: Twente University Press 1998.

Nuffield Council on Bioethics 1993

Nuffield Council on Bioethics, Genetic screening, ethical issues, London: Nuffield Council on Bioethics 1993.

Nys 2002

H. Nys, 'Het recht op weten en niet-weten bij genetische diagnostiek', in: J.C.J. Dute, J.K.M. Gevers en G.R.J. de Groot (red.), Omzien naar de toekomst, 35 jaar preadviezen Vereniging voor Gezondheidsrecht, Houten/Diegem: Bohn Stafleu van Loghum 2002, p. 263-277.

\section{Nys 1998}

I- Nys (red.), De Conventie Mensenrechten en Biogeneeskunde van de Raad van Europa; inhoud en gevolgen voor patienten en hulpverleners, Antwerpen-Groningen: Intersentia rechtswetenschappen 1998.

Ost 1986

D.E. Ost, The Joumal of Medicine and Philosophy 1986, p. 279-284.

\section{Ost 1984}

D.E. Ost, 'The 'right' not to know', The Journal of Medicine and Philosophy 1984, p. 301312.

\section{Ploem 1999}

M.C. Ploem, 'Een zorgvuldige omgang met medische gegevens na de dood', Tijdschrift voor Gezondheidsrecht 1999, p. 489-499.

President's Commission for the Study of Ethical Problems in Medicine and Biomedical and Behavioral Research 1983

President's Commission for the Study of Ethical Problems in Medicine and Biomedical and Behavioral Research, Screening and Connseling for Genetic Conditions, The Ethical, Social, and Legal Implications of Genetic Screening, Counseling, and Education Programs, Washington D.C.: U.S. Government Printing Office 1983.

Raad van Europa 1997

Raad van Europa, Recommendation No. R (97) 5 on the protection of medical data, 1997.

Raad van Europa 1992

Raad van Europa, Recommendation No. $R$ (92) 3 of the committee of ministers to member states on genetic testing and screening for health care purposes, 1992. 
Rachels 1984

J. Rachels, 'Why privacy is important', in: F.D.Schoeman (red.), Philosophical dimensions of privacy, an anthology, Cambridge: Cambridge University Press 1984, p. 290-299.

Rang 1973

J.F. Rang, Patiëntenrecht, Leiden: Stafleu's wetenschappelijke uitgeversmaatschappij 1973.

Ratzan 1985

A. Ratzan, 'Unsollicited medical opinion', Joumal of Medicine and Philosophy 1985, p. 147-162.

Ravenschlag 1992

I. Ravenschlag, Het recht op niet weten, meer dan een quidproquo, Amsterdam: Thesis Publishers 1992.

Report of a Working Party of the Clinical Genetics Society 1994

Report of a Working Party of the Clinical Genetics Society, 'Clinical practice in medical genetics, The genetic testing of children', Journal of Medical Genetics 1994, p. 785-797

Roscam Abbing 1995

H.D.C. Roscam Abbing, 'Recht op informatie en het toestemmingsvereiste', in: J. Legemaate (red.), De Wgbo: van tekst naar toepassing, Houten/Diemen: Bohn Stafleu Van Loghum 1995, p. 21-33.

Roscam Abbing 1994a

H.D.C. Roscam Abbing, 'Artikel 8: recht op privéleven' in: J.K.M. Gevers (red.), Het EVRM en de gezondheidszorg, Nijmegen: Ars Aequi Libri 1994, p. 107.

Roscam Abbing 1994b

H.D.C. Roscam Abbing, 'Een Europese catalogus voor rechten van de patiënt', Tijdschrift voor Gezondheidsrecht 1994, p. 313-314.

Roscam Abbing 1994c

H.D.C. Roscam Abbing, Beslissen door de patiënt, Houten/Zaventem: Bohn Stafleu Van Loghum 1994.

Roscam Abbing 1986

H.D.C. Roscam Abbing, 'Genetische manipulatie', in: J.K.M. Gevers en H.J.J. Leenen (red.), Rechtsvragen rond voortplanting en erfelijkheid, Deventer: Kluwer 1986, hoofdstuk 8 . 
Rutten e.a. 1998

M.P.M.H. Rutten e.a., De huidige 'n tockomstige organisatio an klinisch genetisch onderaek in Nederland, Rotterdam: Erasmus Universiteit Rotterdam 1998.

Scheltens 1981

D.F. Scheltens, Mens 'n mensenrechte'n, Alphen aan den Rijn/Brussel: Samson Uitgeverij 1981.

Sharpe 1993

N. Sharpe, 'Presymptomatic testing for Huntington disease: is there a duty to test those under the age of eighteen years?', American Joumal of Medical Genetics 1993, p. 250-253.

\section{Skene 1998}

L. Skene, 'Patients' rights or family responsibilities? Two approaches to genetic testing', Medical Law Revie'te 1998-6, p. 1-41.

Sluijters 1985

B. Sluijters, Geknipt verband, Deventer: Kluwer1985.

Sluijters 1977

B. Sluijters, 'De arts en het belangenconflict', in: Quid iuris, Deventer: Kluwer 1977, p. 174.

Sluijters e.a. 1999

B. Sluijters e.a. (red.), Gezondheidsrecht, Tekst en Commentaar, Deventer: Kluwer 1999.

\section{Sluijters en Biesaart 1995}

B. Sluijters en M.C.I.H. Biesaart, De geneeskundige behandelingsovereenkomst na invoering van de WGBO, Zwolle: W.E.J. Tjeenk Willink 1995.

Smaling 1990

A. Smaling, 'Objectiviteit en rolneming', in: I. Maso en A. Smaling (red.), Objectiviteit in kwalitaticf onderzoek, Meppel/Amsterdam: Boom 1990, p. 33-35.

Stichting Toekomstscenario's Gezondheidszorg 1999.

Stichting Toekomstscenario's Gezondheidszorg, Toekomstscenario's voorspellende geneeskunde, Den Haag: Rathenau Instituut 1999.

\section{Strasser 1986}

M. Strasser, 'Mill and the right to remain uninformed', The Joumal of Medicine and Philosophy 1986, p. 265-278.

Sutorius 1993

E.Ph.R. Sutorius, Manipuleren met leven. Preadvies Nederlandse Juristen-Vereniging, Zwolle: W.E.J. Tjeenk Willink 1993. 
Swanborn 1990

P.G. Swanborn, 'Objectiviteit: een poging tot duidelijkheid', in: I. Maso en A. Smaling (red.), Objectiviteit in kwalitatief onderzoek, Meppel/Amsterdam: Boom 1990, p. 53-59.

\section{Ten Have 1999}

H. ten Have, 'Gezondheid is geen doel op zich', in: M. van Zwieten en A. Kalden (red.), Ons gescreende lichanm, kansen e'n risico's oan de genetica, Balans 1999.

Ten Have, ter Meulen en Van Leeuwen 1998

H.A.M.J. ten Have, R.H.J. ter Meulen en E. van Leeuwen, Medische ethiek, Houten/Diegem: Bohn Stafleu Van Loghum 1998.

Ten Kate 1998

L.P. ten Kate, 'Informatie over prenataal gevonden dragerschap, een medisch commentaar', Tijdschrift voor Gezondheid en Ethiek, 1998-8, pag. 24-28.

Ten Kate 1980

L.P. ten Kate, 'De informatiebehoefte van de medisch geneticus', Medisch Contact 1980, p. $159-161$.

Ten Kate 1976

L.P. ten Kate, 'Spreken en zwijgen over familieleden, Medisch beroepsgeim en erfelijkheidsadvisering', Metamedica 1976-55, p. 49-55.

The American Society of Human Genetics Board of Directors and The American College of Medical Genetics Board of Directors 1995

The American Society of Human Genetics Board of Directors and The American College of Medical Genetics Board of Directors, 'ASHG/ACMG Report, Points to Consider: Ethical, Legal and Psycosocial Implications of Genetic Testing in Children and Adolescents', American Joumal of Human Genetics 1995, p. 1233-1241.

Tibben 2000

A. Tibben, Van vrees naar hoop, erfelijke newrodegeneratieve ziekten opnieutu bezien, Leiden 2000.

Tibben 1993

A. Tibben, What is Knowledge But Grieving?, On psychological effects of presymptomatic DNA-testing for Huntington's disease, 1993.

Tibben e.a. 1997

A. Tibben e.a., 'Three-year follow-up after presymptomatic testing for Huntington's disease in tested individuals and partners', Health Psychology 1997-16, p. 20-35.

Tibben e.a. 1990

A. Tibben e.a., 'Testing for Huntington's disease with support for all parties', Lancet 1990, p. 335-553. 


\section{Tijmstra 1999}

Tj. Tijmstra, 'Leed voorkomen heeft een prijs', in: M. van Zwieten en A. Kalden (red.), Ons gescreende lichan, kansen en risico's ian de genetica, Balans 1999.

\section{Tijmstra 1997}

Tj. Tijmstra, 'Kennis maakt verantwoordelijk, in welke beslissituatie mogen mensen worden geplaatst?', Medisch Contact, 1997, p. 1578-1581.

\section{Tijmstra en Bajema 1990}

Tj. Tijmstra en C. Bajema, 'Je zult die ene maar zijn; risicobeleving en keuzegedrag rond medische technologie', Nederlands Tijdschrift voor Geneeskunde 1990, p. 18841885.

\section{Van de Kamp (XVI Vakinhoudelijke aspecten)}

J.J.P. van de Kamp, 'XVI Vakinhoudelijke aspecten', in: H.A.M.J. ten Have e.a. (red.), Ethick en recht in de gezondheidszorg, Deventer: Kluwer.

\section{Van der Burg en Oevermans 1994}

W. van der Burg en H. Oevermans, 'Grondrechten in het gezondheidsrecht' in: W. van der Burg en P. Ippel (red.), De Siamese tweeling, recht en moranl in de biomedische praktijk, Assen: Van Gorcum 1994, pag. 187-202.

Van der Mijn 1990

W.B. van der Mijn, 'Rechtvaardigheid; een kwestie van ieder het zijne geven', Tijdschrift voor Gezondheidsrecht 1990, p. 122.

Van der Voort, Grundmeijer en Hendrick 1995

H.P.M. van der Voort, H.G.L.M. Grundmeijer en J.M.A. Hendrick, 'NHG-NIPOenquête, Huisarts en zinvol handelen', Huisarts en Wetenschap 1995, p. 351-354.

\section{Van der Weele 1987}

C. van der Weele, 'Genen beter maken: Is de medische genetica eugenetisch?', Tijdschrift voor Gezondheid en Politiek 1987, p. 36-43.

\section{Van Lomwel en Van Veen 1999}

A.B. Van Lomwel en E-B. van Veen, De WGBO, de betekenis voor de hulpverleners in de gezondheidszorg, Lelystad: Koninklijke Vermande 1999.

Van Wijmen 1996

F.C.B. van Wijmen, Goed patiëntschap als spiegelbeeld van verantwoorde zorg, Deventer: Kluwer 1996.

Van Wijmen 1995

F.C.B. van Wijmen, 'Vertrouwen en verantwoorde zorg. Bij de inwerkingtreding van de WGBO', Medisch Contact 1995, p. 411-412. 
Van Zuuren 1996

F.J. van Zuuren, 'Neutraliteit in de praktijk van genetische counseling', Tijdschrift woor geneeskunde en ethiek 1996, p. 77-81.

Vereniging van Stichtingen Klinische Genetica i.o. en Zorgverzekeraars Nederland 1995

Vereniging van Stichtingen Klinische Genetica i.o. en Zorgverzekeraars Nederland, Overeenkomst Klinische Genetica in Nederland anno 1996, indicaties en machtigingen, 1995.

Vereniging voor Gezondheidsrecht 1991

Vereniging voor Gezondheidsrecht, 'Richtlijnen Vereniging voor Gezondheidsrecht. Wat mag en moet bij erfelijkheidsonderzoek?', Tijdschrift voor Gezondheidsrecht 1991, p. $481-488$.

Verhey 1992

L.F.M. Verhey, Horizontale werking van grondrechten, in het bijzonder wan het recht op privacy, Zwolle: W.E.J. Tjeenk Willink 1992.

\section{Visser 't Hooft 1979}

H.Ph. Visser 't Hooft, 'Het mensbeeld in het gezondheidsrecht', Tijdscirrift voor Gezondheidsrecht 1979, p. 181-189.

VSOP 2001

VSOP, De VSOP vijf jnar in beeld, 1995-2000, activiteiten, beleid en ontwikkelingen, Soestdijk 2001.

Wertz, Fanos en Reilly 1994

D.C. Wertz, J.H. Fanos en Ph.R. Reilly, 'Genetic Testing for Children and Adolescents, Who decides?', IAMA 1994, p. 875-881.

\section{Wester 1995}

F. Wester, Strategieën voor kzualitatief onderzoek, Bussum: Coutinho 1995.

\section{White 1999}

M.T. White, 'Making responsible choices: an interpretive ethic for genetic decisionmaking', Hastings Center Report 1999-29, p. 14-21.

Widdershoven 2000

G.A.M. Widdershoven, Ethiek in de kliniek, Hedendaagse benaderingen in de gezondheidsethiek, Maastricht: Boom 2000. 
Yarborough, Scott en Dixon 1989

M. Yarborough, J.A. Scott en L.K. Dixon, 'The role of beneficence in clinical genetics: non-directive counseling reconsidered', Theoretical Medicine 1989, p. 139-149.

Ziekenfondsraad 1986

Ziekenfondsraad, Grenzen aan de groei van het verstrekkingenpakket, Amstelveen 1986. 


\section{Curriculum Vitae}

Wendy Kieboom werd op 23 oktober 1973 geboren te Raamsdonk. In 1992 behaalde zij het VWO diploma aan het Dongemond College te Raamsdonksveer. Datzelfde jaar startte zij met de studie Rechtsgeleerdheid aan de Universiteit Leiden, met als afstudeerrichting Strafrecht. In augustus 1997 behaalde zij haar doctoraalexamen. Van september 1997 tot en met januari 1998 was zij werkzaam als juridisch medewerker bij de Pensioen- en Uitkeringsraad in Leiden. In februari 1998 begon zij aan de Faculteit der Gezondheidswetenschappen van de Universiteit Maastricht als onderzoeker in opleiding bij de sectie Gezondheidsrecht aan het in dit proefschrift beschreven promotieonderzoek, onder de leiding van prof. mr. F.C.B. van Wijmen en mr. dr. J.C.J. Dute. Sinds juni 2002 is zij werkzaam als jurist bij het academisch ziekenhuis Maastricht, onder meer als ambtelijk secretaris van de Medisch Ethische Commissie van het azM en de Universiteit Maastricht. 